This report was prepared as an account of work sponsored by the United States Government. Neither Research and Development Administ States Energy their employes subcontractors, or the any of their contractors, warranty, express or impled, or ass, makes any liability or responsibility for the accuracy, any legal or usefuiness of any information, apparatus, proteness process disclosed, or represents that its use would or

PROCEEDINGS OF THE CONFERENCE ON

DECONTAMINATION AND DECOMMISSIONING (D\&D)

OF ERDA FACILITIES

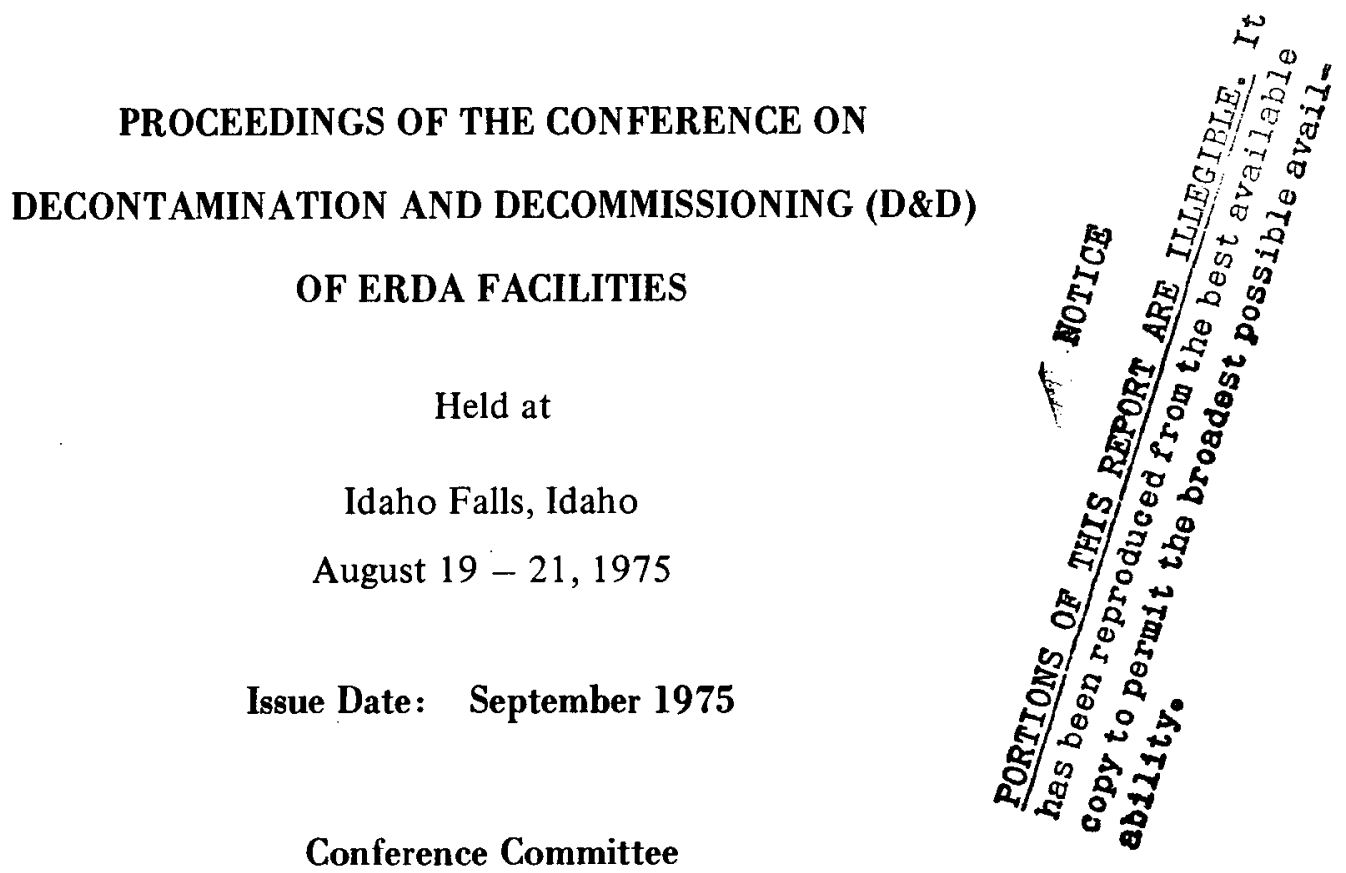

George Wehmann, Director Office of Waste Management

ERDA-ID Conference Chairman

Ron M. Nelson, Office of Waste Management

ERDA-ID

John C. Commander, Projects Branch Manager

Aerojet Nuclear Company

W. W. (Bud) Hickman, Waste Management Program Division Manager

Aerojet Nuclear Company

\title{
Sponsored by
}

U.S. Energy Research and Development Administration

and

Aerojet Nuclear Company

Waste Management Program Division 


\section{DISCLAIMER}

This report was prepared as an account of work sponsored by an agency of the United States Government. Neither the United States Government nor any agency Thereof, nor any of their employees, makes any warranty, express or implied, or assumes any legal liability or responsibility for the accuracy, completeness, or usefulness of any information, apparatus, product, or process disclosed, or represents that its use would not infringe privately owned rights. Reference herein to any specific commercial product, process, or service by trade name, trademark, manufacturer, or otherwise does not necessarily constitute or imply its endorsement, recommendation, or favoring by the United States Government or any agency thereof. The views and opinions of authors expressed herein do not necessarily state or reflect those of the United States Government or any agency thereof. 


\section{DISCLAIMER}

Portions of this document may be illegible in electronic image products. Images are produced from the best available original document. 
-

•

- 


\section{CONTENTS}

SESSION I

WELCOMING REMARKS AND CONFERENCE OBJECTIVES

WELCOMING REMARKS by $\mathrm{C}$. Wayne Bills, Assistant Manager, Production and Technical Support, U. S. Energy Research

Development Administration, Idaho Operations . . . . . . . .

OPENING REMARKS by Fred H. Tingey, Assistant General

Manager, Programs, Aerojet Nuclear Company . . . . . . . . . . . 4

SESSION II

DECONTAMINATION AND DECOMMISSIONING (D\&D) POLICY

Chairman: Ron M. Nelson, Office of Waste Management, U. S. Energy Research Development Administration, Idaho Operations

DECONTAMINATION AND DECOMMISSIONING POLICY AND PROGRAMS by Harold Glauberman, Division of Environmental Control

Technology, U. S. Energy Research Development Administration . . .

RADIOLOGICAL SURVEILLANCE OF ERDA EXCESS REAL PROPERTY by Robert E. Allen, Process Facilities Safety Branch, Division of Operational Safety, U. S. Energy Research Development Administration .......................... 15

ERDA SAFETY PRACTICES INVOLVING DISPOSAL OF CONTAMINATED REAL PROPERTY by E. K. Loop, Chief, Process Facilities Safety Branch, Division of Operational Safety, U. S. Energy Research

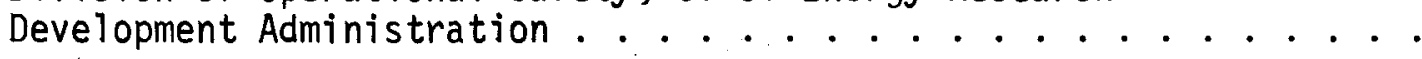

STATUS OF ANSI STANDARDS ON DECOMMISSIONING OF NUCLEAR REPROCESSING FACILITIES by H. B. Graham, Holifield Nationa? Laboratory . . . . . . . . . . . . . . . . .

* PROPOSED GUIDELINES FOR DECONTAMINATION AND DISPOSAL OF CONTAMINATED REAL PROPERTY by Robert E. Allen, Process Facilities Safety Branch, Division of Operational Safety, U. S. Energy Research Development Administration ......... 
* EXPERIENCE WITH D\&D OF LICENSED FACILITIES by Peter B. Erickson and George Lear, Division of Reactor Licensing, U. S. Energy

Research Development Administration . . . . . . . . . . . . .

* ALTERNATIVE FOR REACTOR DECOMMISSIONINg by Peter B. Erickson and George Lear, Division of Reactor Licensing, U. S. Energy

Research Development Administration . . . . . . . . . . . . .

* CURRENT NRC REGULATIONS AND GUIDES FOR DECOMMISSIONING LICENSED

REACTORS by Peter B. Erickson and George Lear, Division of

Reactor Licensing, U. S. Energy Research Development

Administration ......................

DEVELOPMENT OF DISPOSITION CRITERIA DERIVATION METHODOLOGY FOR COMMERCIAL FUEL CYCLE FACILITIES by D. A. Waite and C. E. Jenkins, Environmental Evaluations Division, Pacific Northwest Laboratories . . . . . . . . . . . . . . . . . .

\section{SESSION III}

\section{DECONTAMINATION AND DECOMMISSIONING (D\&D) EXPERIENCE \\ Chairman: J. C. Commander, Projects Branch Manager, Aerojet Nuclear Company.}

DECONTAMINATION AND DECOMMISSIONING OF LICENSED FUEL

REPROCESSING PLANTS by Richard B. Chitwood, Division of

Materials and Fuel Cycle Facility Licensing, U. S. Nuclear

Regutatory Commission ....................

TECHNOLOGY FOR DISMANTLING LARGE RADIOACTIVE STRUCTURAL

COMPONENTS by Robert Blumberg, Holifield National Laboratory . . . .

ELK RIVER REACTOR DISMANTLING by B. J. Davis, Safety Division

U. S. Energy Research Development Administration . . . . . . . .

PROGRAM PLAN FOR REMOVAL OF THE MATERIALS TEST REACTOR

OVERHEAD WORKING RESERVOIR by Ben C. Lunis, Aerojet Nuclear

Company. . . . . . . . . . . . . . . . . . . . . . . . . . .

DECONTAMINATION AND DISPOSITION OF HALLAM AND PIQUA REACTORS

by W. F. Heine, Program Manager and B. F. Ureda, Project

Manager, D\&D Program, Atomics International . . . . . . . . .

DECONTAMINATION OF A HIGHLY RADIOACTIVE CHEMIC.AL PROCESSING

FACILITY by $P$. R. Moore, E. I. du Pont de Nemours and

Company, Savannah River Plant . . . . . . . . . . . . . . . .

Three topies combined into one paper for publication. 
DISPOSITION OF TA-33-21, A PLUTONIUM CONTAMINATED EXPERIMENTAL

FACILITY by E. J. Cox, R. Garde and A. M. Valentine,

Los Alamos Scientific Laboratory . . . . . . . . . . . . . .

SEPARATIONS CANYON DECONTAMINATION FACILITIES by J. H. Hershey,

E. I. du Pont de Nemours and Company, Savannah River Plant . . . . .

A SUMMARY REVIEW OF MOUND LABORATORY'S EXPERIENCE IN D\&D OF RADIOACTIVE FACILITIES, 1949 - 1973 by J. M. Garner

and W. P. Davis, Mound Laboratory . . . . . . . . . . . .

THE DECOMMISSIONING OF THE FISSION PRODUCT DEVELOPMENT

LABORATORY AT HOLIFIELD NATIONAL LABORATORY by R. W. Schaich,

Holifield National Laboratory . . . . . . . . . . . .

DECONTAMINATION AND DECOMMISSIONING EXPERIENCE AT EXPERIMENTAL

BREEDER REACTOR NO. I by E. W. Kenda 71 , Aerojet Nuclear

Company ....................

PROCESSING EBR-I NaK TO PRODUCE A STORABLE SOLID by

R. R. Hammer and L. C. Lewis, Allied Chemical Corporation . . . .

DISMANTLING AN ALPHA-CONTAMINATED FACILITY by R. D. Caldwel1 and R. M. Harper, E. I. du Pont de Nemours and Company,

Savannah River Plant . . . . . . . . . . . . . . . . . .

DEMOLITION OF BUILDING 12, AN OLD PLUTONIUM FILTER FACILITY by

E. L. Christensen, R. Garde and A. M. Valentine, Los Alamos

Scientific Laboratory . . . . . . . . . . . . . . .

SESSION IV

DECONTAMINATION AND DECOMMISSIONING (D\&D) OF FUTURE PROJECTS

Chairman: W. W. Hickman, Waste Management Program Division Manager, Aerojet Nuclear Company

PROGRAM PLAN FOR DECONTAMINATION AND DECOMMISSIONING THE. MATERIALS TESTING REACTOR AT THE INEL by Thomas $F$. Jones, Aerojet Nuclear Company . . . . . . . . . . . . . . . . .

PNL STUDIES OF D\&D AT HANFORD by K.. M. Harmon, Manager Hanford Waste Management Programs, Pacific Northwest Laboratories . . . . . . . . . . . . . . . . . . .

DESIGN FEATURES FOR DECONTAMINATION IN NEW PLUTONIUM FACILITIES

by K. J. Frieberg, Dow Chemical Corporation . . . . . . . . . . .

WASTE MANAGEMENT AND SAFETY CONSIDERATIONS FOR FUTURE LASL

D\&D PROJECTS by A. M. Valentine and J. L. Warren, Los Alamos

Scientific Laboratory . . . . . . . . . . . . . . . 
THE HOT FUEL EXAMINATION FACILITY/SOUTH REFURBISHMENT PROGRAM

by L. Larsen and C. C. Miles, Argonne National Laboratory . . . . .

PREPARATION FOR DECONTAMINATION AND DISPOSITION OF THE SCDIUM REACTOR EXPERIMENT (SRE) AND OTHER ERDA FACILITIES AT AI by W. F. Heine, Program Manager and A.W. Graves, Project Manager, Engineering, Atomics International . . . . . . . .

A DECOMMISSIONING PLAN FOR THE HEAVY WATER COMPONENTS TEST REACTOR by F. R. Field,E. I. du Pont de Nemours and Company, Savannah River Plant. . . . . . . . . . . . . . . . .

SUMMARY REPORT OF SOIL REMOVAL PERLIMINARY EXCAVATIONS by

C. E. Wickland, Rockwell International, Rocky Flats Division....

DISPOSAL OF PERSONAL PROPERTY FROM ERDA FACILITIES BEING

DECOMMISSIONED by John D. French, Division of Procurement,

U. S. Energy Research and Development Administration.......

LIST OF ATTENDEES . . . . . . . . . . . . . . . . 509 
C. Wayne Bills, Assistant Manager, Production

and Technical Support, U. S. Energy Research

Development Administration, Idaho Operations

Good morning. It's a pleasure to welcome you to this conference on behalf of the Energy Research and Development Administration.

Such a good turnout for a D\&D meeting is evidence to me that the nuclear industry is reaching the years of its maturity. Please note that I said maturity and not old age. The reason I mention it is to point out that not so many years ago there wasn't all this much interest in decontamination and decommissioning of facilities. . because most nuclear facilities were relatively new and in use. But gradually, more and more of the older facilities are being shut down permanently. And, of course, that's where you people come in.

Before I say anything further about D\&D, let me take a few minutes to tell you a little about the Idaho National Engineering Laboratory . . . for the benefit of those who are not familiar with our programs.

Until just a year ago the INEL was called the National Reactor Testing Station. . which pretty well described its mission during the first 25 years. But in recent years, the role of the Station evolved more towards engineering research and development. And so the name was changed to reflect more accurately the expanding activities being carried out here to meet the nation's energy research and development needs.

The Site... as we call it here . . was established by the AEC in 1949 as a center where nuclear reactors and allied facilities could be built and operated, primarily to support the Commission's reactor development programs. When the first reactor was completed here in 1951, plans called for constructing possibly 10 reactors over the next 15 years. Actually, 40 were built here during that period. As of today, 51 reactors have been built at the Laboratory . . more of them and more different kinds of them than have been built anywhere else in the 
world. And 17 of those reactors are still operating or operable. All the others have been phased out after completing their missions.

This might make you conclude that we have a tremendous backlog of D\&D. But I should point out that most of the original reactor buildings . . . with a few exceptions . . have been modified over the years to accept follow-on reactor experiments. So we do not have 34 empty buildings sitting around on the desert awaiting D\&D. Instead, there are less than half a dozen candidates. Although the laboratory's contributions to nuclear technology have been far too numerous to list in detail, I would like to mention that three of the world's major power reactor concepts were prototyped here in Idaho. I refer, of course, to the pressurized water reactor, boiling water reactor, and liquid metal cooled fast breeder. We're also proud that the first prototypes of a nuclear submarine reactor and navy surface ship reactor were also built and operated here. In addition, we have made important contributions to fuel processing technology. And we developed the first plant-scale, continuous process for solidifying highly radioactive waste liquids.. . back in 1963.

At present, the laboratory's facilities and expertise are being used to further six of the nation's highest priority energy R\&D programs . . . water reactor safety testing . . materials and fuels development for water-cooled reactors . . naval propulsion.. reactor fuels processing and waste management. . materials and fuels testing for the liquid metal cooled breeder reactor . . and geothermal electrical and space heating applications.

Something over 6,000 people are employed at the laboratory . . mostly employees of ERDA's four operating contractors . . Aerojet Nuclear Company . . Allied Chemical Corporation . . Argonne National Laboratory . . and Westinghouse.

Now that you fully understand the INEL . . let's talk about D\&D. I would like to note that there were several pretty large D\&D efforts before 
EBR-1. Of course, the decon work in the Pacific was a very complete task . . and latest reports of results in places like Bikini Atoll have demonstrated that even "worst case" contamination can be made habitable by the proper techniques.

One of the largest decon efforts ever undertaken at INEL was . . of course. . In connection with the SL-1 accident back in 1961. In the months following that accident, the entire facility... . including the reactor and its building . . was removed and buried. Many thousands of manhours were involved in that work as well as in removing or stabilizing the relatively small amount of exterior contamination.

I know you are particularly interested in learning more about the fine job Aerojet Nuclear Company performed in that regard on EBR-1. There is obviously a difference between recovery from an accident and the planned approach to $D \& D$ that you will be stressing in your conference this week. And we have learned much, too, in the past 15 years that should make our efforts easier, safer, and less expensive. One thing we can do today is to avoid relying on manpower to the extent that was necessary for the SL-1 recovery and clean-up . . . by taking advantage of the better equipment and techniques now at our disposal.

Then, too, and with the advantage of experience, today we are designing facilities with $D \& D$ in mind . . something that was not done in the early days of our industry. This foresight will undoubtedly make the task far easier and less expensive when current facilities are ready for retirement.

Let me close with the hope that your time here will prove to be a good investment both for yourselves and your employers . . and that in the years ahead you will find good use for the matters that will be discussed during this conference. 
WELCOMING REMARKS

by

Fred H. Tingey, Assistant General Manager, Programs Aerojet Nuclear Company

On behalf of $\mathrm{Dr}$. Leeper and the 2300 employees of Aerojet Nuclear Company it is my pleasure to welcome you to Idaho Falls and the Idaho National Engineering Laboratory. First, I would like to introduce you to Aerojet Nuclear Company.

Aerojet Nuclear Company (ANC) is the prime operating contractor to the Energy Research and Development Administration (ERDA) at the Idaho National Engineering Laboratory (INEL). It is a research and engineering oriented company serving a variety of customers having as a common goal energy resource development. In addition to the usual support services provided all contractors on site, one of the basic functions ANC performs at INEL is the development of analytical capability, computer codes, and relevant experimental data by which the safety of commercial power reactors can be determined. Modeling simulation studies and experiment design and analysis utilizing complex reactor systems are ANC's major strengths and form an integral part of its total systems approach. With the installation of the sodium loop in the ETR and the proposed gas loop this technology and expertise can now be extended to other than water reactor systems.

In addition to operating research reactors, ANC operates material test reactors which provide unique test environment for the development of improved reactor fuel and structural components.

Alternate non-nuclear sources of energy are also being developed by ANC. The first phase of a significant Geothermal effort has been recently completed at Raft River with the drilling of two Geothermal wells. Both the electric 
and non-electric potential of the Raft River site will be explored. In addition, a joint ERDA- State of Idaho heating project for several state office buildings in Boise is being managed by ANC.

Finally, ANC recognizes in INEL the opportunity for controlled environmental research through the designation of INEL as an environmental park. Environmental data and test results collected for over 25 years as part of a comprehensive reactor site management program provides an exciting new research potential.

The Company, incorporated in Idaho in 1971, is a wholly owned subsidiary of Aerojet-General Corporation, which is a subsidlary of the General Tire and Rubber Company. ANC had 2,693 employees as of June 30, 1975.

With regard to your meeting, it is particularly significant to me at least that this conference, which I understand is the first of this type, is held here at INEL inasmuch as this has been and continues to have the largest concentration of nuclear reactors in the world. It also seems significant to me that the extensive D\&D effort before ERDA has already begun with the recent transfer of EBR I to the National Parks Service and the initial D\&D effort on the MTR. I understand you will hear more about these efforts as the conference proceeds. You will note from your program that 14 reactor facilities at INEL are now candidates for D\&D.

It is apparent that the future of the nuclear industry depends in large measure on public acceptance of the processes and procedures incidental thereto. Waste Management by no means is the least among these which is commanding considerable attention. D\&D of excess facilities is a significant part of Waste Management. Thus, I commend you for your interest and attention to this problem and trust that the information and experiences you gain here will be beneficial to you as you focus on $D \& D$ in your respective areas of responsibility. Thank you! 


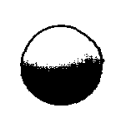

$\bullet$

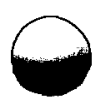


02659

DECONTAMINATION AND DECOMMISSIONING

POLICY AND PROGRAMS

by:

H. Glauberman

Division of Environmental Control Technology

U. S. Energy Research and Development Administration Washington, D. C. 20545

In this presentation, I intend to review the policies, objectives, and the program structure for the management of surplus radioactively contaminated ERDA facilities.

Prior to September 1973, decontamination and decommissioning responsibilities for surplus contaminated facilities in the AEC (now ERDA) were not assigned to any specific program division. Consequently, there was no administrative procedure or mechanism for establishing decontamination priorities and budgeting for these facilities. In September 1973, the General Manager in a memorandum to Heads of Divisions, Headquarters, and Managers of Field offices announced that the Division of Waste Management and Transportation (now abolished) was to assume the responsibility for planning, budgeting, and program implementation for al1 AEC facilities (including buildings, equipment and land) which could meet all of the following criteria: (1) the facilities are radioactively contaminated to the extent that they cannot be occupied or dismantled without health physics controls; (2) the facilities are excess to the identifiable needs of any AEC program; and (3) the facilities are clearly definable by site map coordinates or other means. The intent of this policy statement was to centralize the substantial resources required for an orderly and 
effective disposition of surplus facilities. This policy is still in effect under ERDA and the responsibility is now assigned to the Division of Environmental Control Technology (ECT). Approximately 200 facilities which meet the criteria are assigned to ECT, and an additional 60 facilities are expected to become excess by FY 1980 . Policies and guidelines for decontamination and decommissioning of excess real property are also contained in WASH-1202 (73), "P1an for the Management of AEC-Generated Radioactive Waste." The policy statements that have been included are:

1. New AEC facilities shall be designed and operated to maximize the probability that they can be converted to other beneficial uses, with a minimum of restrictions, when no longer useful for their original purpose.

2. Existing AEC facilities originally designed to permit eventual decontamination and conversion to other uses shall be operated during the remainder of their original programs so as to facilitate such decontamination and conversion.

3. Existing AEC facilities where design and operation have made eventual conversion to other uses impractical shall be operated during the remainder of their original programs so as to minimize the needs for post-shutdown surveillance and maintenance, and to facilitate possible continuing AEC use. 
4. All operational plans shall consider the needs for eventual decontamination and decommissioning, to a degree of detail consistent with the estimated remaining useful life of the facility. For facilities determined to be excess, plans shall be maintained to protect employees and the public from potential hazards from the facilities. Further, decontamination and decommissioning plans shall be developed and carried out consistent with the possibilities of conversion to other beneficial uses, the possibilities of reducing surveillance and maintenance needs, the degree of effort required for decontamination, and the interactions with continuing AEC activities, if any, on the same general site.

5. During the last few years of operation of a specific facility or site scheduled to become excess or shut down, the program division has the prime responsibility for planning and budgeting for the decontamination and decommissioning as part of the remaining operation and final shutdown plan. Particular emphasis should be placed on budgeting sufficiently far in advance so that knowledgeable people can remain available. It is my understanding that WASH-1202 will be updated in the near future as an ERDA plan by the Nuclear Fue1 Cycle and Production Division and will continue to include general decontamination and decommissioning policy. Additional policies and requirements related to decontamination and decommissioning are contained in the following 
ERDA issuances: ERDAM 5301, "Real Estate Management," which provides for disposal of contaminated real property; PMI 109-45.50, "Excess and Surplus Radioactively Contaminated Personal Property," which provides for the utilization and disposal outside of ERDA of excess and surplus contaminated personal property; ERDAM 6301 and Appendix 6301, "General Design Criteria," which includes requirements to consider decontamination and decommissioning in initial design of facilities; and ERDA Appendix 110I, Part III and IV, which provides for transfer of items to other ERDA offices and Federal agencies. I will not go into the specific implementation details of these ERDA issuances since for the most part they will be addressed by other speakers on the agenda.

The objectives of the management of surplus contaminated facilities program are to:

1. Provide surveillance and maintenance of excess facilities assigned to. ECT until disposition is undertaken.

2. Develop technology for safe and economic decontamination and disposition of radioactively contaminated facilities, equipment and metals.

3. Establish plans, priorities, and budgets for disposition of excess facilities, assigned to ECT.

4. Reduce potential for environmental contamination and need for perpetual surveillance and maintenance. 
5. Reduce the inventory of ERDA excess radioactively contaminated facilities, to the greatest extent practical.

I now want to briefly review our program for the management of surplus contaminated facilities to meet these objectives. The program is divided into four categories: surveillance, planning, disposition, and research and development methods.

The numerous shutdown surplus contaminated facilities require routine surveillance and periodic maintenance to insure a safe condition prior to the undertaking of disposition actions. Surveillance and maintenance is being provided for surplus facilities at the Idaho National Engineering Laboratory (INEL), Hanford, Oak Ridge National Laboratory (ORNL), Savannah River, Argonne National Laboratory, and a few other sites. Surveillance of these facilities will be continued until they have been decontaminated to safe levels or some other disposition actions have been completed.

The relatively high funding required for disposition of surplus contaminated facilities dictates careful and extensive planning. Planning efforts were started in FY 1975 at Hanford, INEL, and ORNL and are continuing in FY 1976. The Hanford site contains the largest number and variety of types of contaminated facilities considered surplus at the present time, therefore, the major planning effort is related to this site. The main objectives of the planning studies are to establish methods, costs, priorities, and the identification of necessary research and development for the disposition of the current 
inventory of surplus facilities. These planning studies should permit establishing long-range plans at these sites by the end of FY 1977.

Disposition activities are under way on some of the surplus contaminated facilities, but a large number of these facilities will continue to be held under safe surveillance in FY 1976, pending assignment of priorities and available funding in future budgets. A number of disposition actions have been completed in the past year and are listed below along with the responsible Field office/contractor and associated cost.

Facility

E1k River Reactor

EBR-I Complex

MTR-Working Resevoir

Kinetics Experiment

Water Boiler

Hot Cave-Bldg. 003

Plutonium Experimenta1

Facility $(\mathrm{TA}-33-21)$
Field office/Contractor

$\mathrm{CH} /$ United Power Association/ $\$ 6,200,000$ Gulf United

ID/Aerojet Nuclear Corp.

ID/Aerojet Nuclear Corp.

SAN/Atomics Internationa 1

SAN/Atomics Internationa1

AL/ IAASL

Disposition actions that are currently in progress include the

Nuclear Rocket Development Station (NRDS) at Nevada and the Sodium

Reactor Experiment and former space reactor facilities at Santa Susana, California. The initial effort at NRDS has been concentrated on preparing and packaging the Rover and Tory II-c fuel which contains approximately $2,500 \mathrm{Kgs}$ of 93 percent enriched uranium, valued at 
$\$ 25$ million for shipment to Idaho for reprocessing. The Tory II-c reactor disassembly is expected to be completed in FY 1976 and all fuel packaging and shipping completed in FY 1977. Further decontamination efforts necessary to accomplish a safe and orderly disposition of all facilities at NRDS will require significant costs and efforts over several years.

The decontamination and disposition of the Sodium Reactor Experiment and other space reactor facilities at Santa Susana were started by Atomics International in FY 1975 and will be continued in FY 1976. The dismantling and disposition of the SRE is currently scheduled for completion in FY 1978 and the remaining space facilities by FY 1979. Experience gained at the Elk River Reactor dismantling relative to the plasma arc torch cutting and the use of explosive techniques will be applied to the SRE task. Based on our five-year projections, a number of new disposition activities are planned for startup in FY 1977, however, these are subject to upcoming budgetary reviews and Congressional approval.

The decontamination and disposition research and development program is developing new or improved technology needed to minimize restrictions on the future use of radioactively contaminated buildings, equipment and metals when they are no longer required by current programs. Emphasis is being placed on the need to develop methods for decontamination and disposition of equipment, buildings, volume reduction of contaminated process equipment, and the resource recovery . 
of contaminated metals. Smelting experiments have been initiated and methods for separating the radioactivity in the molten stage are being investigated. The contractors presently involved in these studies are Atlantic Richfield Hanford Co., National Lead of Ohio and Argonne Nationa1 Laboratory.

The ARHCO program objective is to develop and demonstrate processes for consolidating contaminated equipment or other metal components to achieve decontamination and significant bulk volume reduction. The NLO program relates to the disposal and/or recovery of metals contaminated with enriched uranium while the program at ANL is limited to plutonium contamination of metals and equipment.

I have not gone into the nuts and bolts of specific programs since a number of the papers that are scheduled for presentation during the remainder of this meeting will do so.

In conclusion, I would like to point out that the management of surplus contaminated facilities has gotten off to a relatively good start considering that the budget for this activity has grown from less than one-half million in FY 1973 to about $\$ 6.4$ million in FY 1976. However, in order to meet our ultimate objective for the approximately 200 surplus facilities, it is obvious that the disposition of radioactively contaminated facilities is an expensive undertaking and will take several decades to complete. In addition, it will be necessary to have a firm commitment and support to establish some minimum level of annual funding so as to permit cost effective planning and proper utilization of experienced personnel. 
02660

RADIOLOGICAL SURVEILLANCE OF ERDA EXCESS REAL PROPERTY

Robert E. Allen

Process Facilities Safety Branch

Division of Operational Safety

\section{ABSTRACT}

This paper discusses the problems associated with the resurvey of the radiological condition of previously excessed real property that was associated with radioactivity and provides guidance toward expediting future decontamination and disposition actions of real property currently considered as excess to ERDA program needs.

This is a two-part program; the resurvey of previously excessed real property and the radiological survey and evaluation of real property proposed for excessing actions. Early in 1974 a survey was made at each AEC field office to identify all previously excessed real or related personal property that had been involved with radioactive materials. This survey was directed toward the identification of those sites or facilities where the decontamination efforts were not fully documented or where a review of the radiological condition reports indicate the desirability of obtaining additional data to verify the current radiological condition of the property.

The survey identified about 100 sites or facilities involved with radioactivity that were excessed by the Manhattan Project and the AEC between 1943 and 1974 . The radiological records of most of those identified were found to adequately document the radioactivity associated with the property at the time of its disposal, and those levels of radioactive contamination remaining should present no further potential problems. This survey also brought out some discrepancies and anomolies in several past decontamination and disposal actions. Some of these can be characterized as 
the lack of a final radiological condition survey report or the radiological condition report developed at the time of the excessing action indicates levels of radioactivity remaining that should be reassessed in the light of present day practices.

During the Manhattan Project days and the 1940's and 1950 's, there were a number of activities conducted at various facilities involving radioactivity that we can find no records of any decontamination efforts. These facilities were very probably decontaminated, however the records have not been located. All of these facilities and sites must be surveyed to some extent to establish an official record of their condition. It is expected that some of these facilities no longer exist; hence, no survey can be made.

In summary, this program is directed toward developing a comprehensive radiological condition survey record of all real property no longer under the control of ERDA that was utilized for work involving radioactivity.

Some will require rather extensive surveys and others may require only a simple examination. A preliminary examination of each facility or site will be necessary to determine the extent of further radiological documentation necessary.

Should any of the proposed radiological surveys indicate a need for remedial actions, this information will be provided to the Division of Environmental Control Technology for appropriate action.

In the second part of this program relating to current excess disposal actions, there are administrative problems which are arising with real property which is not clearly defined as falling under the requirements of ERDAM 5301. Examples of these areas are: real property that has been leased by ERDA, or facilities constructed by ERDA on real property not owned by the Government. 
Uniform procedures for review and evaluation of all types of disposal actions involving real property that has been associated with radioactivity should involve the following basic requirements:

1. The existing radiological condition and past radiological operational records of the site or facility must be known and reviewed.

2. A detailed plan for decontamination of the property must be developed which will:

a. identify the methods by which the radioactivity will be removed and disposed of.

b. include an indication of methods proposed to achieve radioactivity levels that are as low as practicable.

c. include proposed radiological decontamination criteria based upon an analysis of those levels of radioactivity that are as low as technically and economically feasible for that site or facility.

d. include an estimate of the radiation dose commitment to future users of the property after decontamination to the proposed decontamination levels.

3. Upon completion of the decontamination action, a final radiological condition report documenting the levels of radioactivity remaining at the site or facility must be prepared, including a radiation certification clearance signed by the ERDA organization conducting the decontamination action. These are essentially the same procedures contained in ERDAM 5301. 
$\bullet$

$\bullet$

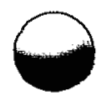




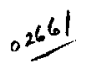

ERDA SAFETY PRACTICES INVOLVING DISPOSAL

OF CONTAMINATED REAL PROPERTY

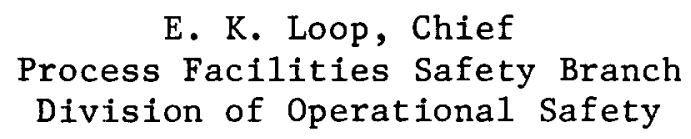

ERDA has a policy of protecting the public from radiological hazards arising from their operations. For that reason, we are implementing procedures designed to assure that real property being considered for excess disposal is free of radiological hazards that might have unfavorable impact on the public, and also to make all reasonable efforts to remove contamination levels to as low as technically and economically feasible. The specific procedures for excess disposal are outlined in the Property Management Handbook, ERDAM 5301. Although these procedures apply specifically to property being reported to GSA for excess disposal, the intent of these guidelines with respect to the safety aspects is used to establish the procedures and requirements for other property actions. This includes not only ERDA owned real property but any real property utilized for ERDA activities under loan agreement, lease, rental, or other contractual arrangements.

Recently there have been actions where property has been made available for public access, an example being the EBR-I Complex, where we request these same procedures be applied.

The procedures in ERDAM 5301 provide, among other things, for a decontamination and cleanup plan "designed to achieve a range of levels down to lowest practicable and, for each plan, provide estimated costs and risk analyses of the potential radiation exposure to man through direct and indirect pathways." Questions frequently are raised during ERDA reviews regarding decontamination plans when the plan does not adequately define the proposed actions. We must assure that the plan provides for cleanup to safe and acceptable levels, and that these levels will also represent ALAP. 
With regard to establishing safe levels, we are involved in the development of health related guides and standards that may be used in the excess disposal actions. At this time it is not practical to establish a single table or criteria that would be sufficient to meet the objectives of ALAP for each and every disposal action. However, we are making some progress in the development of radiological levels below which one can find reasonable assurance that health considerations become subordinate to the goals of ALAP and environmental significance. Our ultimate intent is to develop health related upper limit guidelines for soil contaminants in real property, plus surface contaminants and induced activity in related personal property.

The first effort for developing health related guidelines for plutonium contamination in soils was undertaken by Mr. Jack Healy of LASL. Mr. Healy's analysis of health risks associated with plutonium soil contaminants is presently under review by ERDA and ERDA contractor staff preliminary to being incorporated as an interim ERDA guideline. OS is involved in this effort.

Mr. Healy has also undertaken the development of a mathematical model which calculates the radiation dose to individuals in the proximity of contaminated objects. The model considers many pathways of exposure, including ingestion and inhalation. This highly quantitative approach to establishing contamination limits for beta-gamma emitters should be useful for special site analyses.

The problems of disposal of materials and equipment containing induced radioactivity has been given consideration by Brookhaven National Laboratory. A proposal has been made for BNL to develop induced radioactivity limits for unrestricted release of materials and to develop techniques to insure representative sampling and quantitative analyses of the radioactivity in the materials. 
The American Nuclear Standards Institute, with ERDA participation, has developed a surface contamination concensus standard which is presently undergoing national letter ballot action.

In the excessing or relinquishing controls of real property utilized for ERDA activities, it may become necessary to place restrictions of some type on future use of that property by private or public users. An example of this is the Tatum Dome Test Site near Hattisburg, Mississippi, where the Federal Government retains the exclusive right to regulate and control access to the subsurface of the real property below the depth of mean sea level which is some 400 feet at that location. This is an example of a disposal action where uncontrolled public access and use of the surface to a depth of some 400 feet is permitted. This was a unique situation; however, it points out the need for an individual case-by-case review of each disposal action.

There are approximately 200 radioactively contaminated sites or facilities which have been identified as excess to current ERDA program needs. Not all of these will be decontaminated for unrestricted use, but some will be decontaminated to levels that will permit other industrial uses by ERDA or by other qualified users of the property.

In summary, we must assure the implementation of ERDA procedures regarding radiological hazards relating to real property being considered for release from ERDA control. This is to assure that it will not result in a health hazard from a radiological safety standpoint, and that the principles of ALAP are applied. We are also involved in the development of health effect guidelines for real property disposal, and we must assure that any restrictions on the use of real property are identified in those instances where unrestricted use is not practical. 
$\bullet$

$\bullet$

$\ominus$ 
$02^{262}$

Status of ANSI Standards on Decommissioning

of Nuclear Reprocessing Facilities

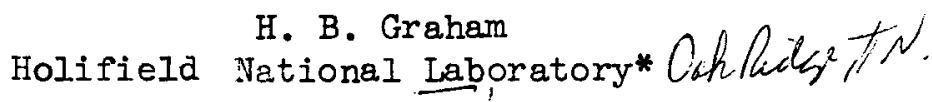

Preparation of the American National Standard "Design Objectives for Decommissioning of Nuclear Reprocessing Facilities" was industry's attempt at interpreting 10CFR, Part 50, Appendix F for the designer of nuclear reprocessing facilities. Appendix F states in part that "a design objective for reprocessing plants shall be to facilitate decontamination and removal of all significant radioactive waste at the time the facility is permanently decommissioned." This is what the subcomittee has attempted to do.

The first problem was the definition for decommissioning. Defining "decomissioning" as used in this standard was difficult. Each member of the subcomittee had a different idea of decommissioning. A definition of decommissioning evolved as "the planned and orderly execution of a program taken by a nuclear facility licensed to achieve a substantial and permanent improvement in the status of a shutdown facility which includes: (I) decontamination of the structure and equipment; (2) removal of sources of radioactivity; (3) return of the site to such a condition that it may be safely returned to unrestricted surface use; (4) maintenance under the minimum surveillance required: for the protection of public health and safety for a specified time where it is shown to be technically and/or economically infeasible to decontaminate *Operated by the Union Carbide Corporation for the Energy Research
and Development Administration. 
to levels acceptable for unrestricted use."

The area of minimum surveillance created more discussion than anything else. The first thing that comes to mind of the licensee is abandonment of the facility. Let someone else maintain surveillance of this facility in perpetuity. Corporate entities have finite lives. Only governmental agencies survive the ages. Most of the privately owned nuclear reprocessing facilities have a provision in their state charter which allows the licensee to transfer title to the property to their respective state body for continued surveillance and monitoring of the site boundaries.

Does the final ownership of the property affect the-design? It really does not. The protection of the public health and safety is the prime consideration in all cases. Achlevement of this objective is the ultimate design, regardless of ownership.

The state of the art under present-technology is entombment for much of the facility-a monument for posterity. There are all kinds of ramifications to that statement, none particularly acceptable. The degree to which a facility would be completely dismantled would depend on a cost-risk-benefit analysis, where the cost/risk is the cost in dollars plus the expense to personnel in carrying out the decontamination activities, and the benefit is the reduction of the risk to the general public and residual radioactivity in the facility.

During the design phase of the plant project, the levels of radiological contamination expected to be present at the time of decommissioning shall be evaluated, and the general procedures and equipment to be used to decontaminate the affected area shall be identified. Special design features necessary to permit the proposed decontamination 
to be carried out safely are to be incorporated in the facility at the time of construction.

Prior to decommissioning, detailed studies shall be made to identify the locations, types, quantities, and associated hazards of radioactive materials and reactive chemicals which are or may be present in the facility. To the extent practicable, the locations, types, quantities, and associated hazards of radioactive materials and reactive chemicals remaining after decontamination shall be identified and documented.

Where the owner has deactivated or shut down one process facility but continues to operate on the same site or builds another operating plant on the same site, this deactivation of the facility, even if it involves abandonment in place, is not decommissioning in the context of this standard. Deactivation can be partial or can involve complete shutdown of the process operation. Even where total plant shutdown is part of deactivation, the plant owner has complete control of the functions or activities remaining on site and retains the complete responsibility for surveillance of the deactivated facility to assure public health and safety. Generally, where a process or plant facility becomes either technologically obsolete or deteriorated to such a degree that renovation is economically infeasible, the owner will build another facility encompassing advanced technology within the same site boundaries. There are several reasons for such a decision: (I) the site has already obtained the necessary approvals for this similar work; (2) the environmental statement would require less effort during preparation; (3) utilities, roads, manpower, waste discharge, and all the other support facilities are already present; and (4) community acceptance of the plant operation is present. It is not necessary to prove your value to the community. 
Many of the problems existing during the original PSAR and FSAR presentations have resolved themselves. Since the plant is a going concern, the hectic days of the original construction are replaced by a more orderly organization during the new construction and operation. This is not to say that all headaches are resolved. If not eliminated, they are at least reduced to a more manageable proposition.

The first task undertaken by this subcommittee was the preparation of an ANSI Standard, "General Design Criteria for Nuclear Reprocessing Facilities" -N101.3 - 1972, which included a section on decommissioning. Time will not permit a discussion of all the dryruns and obstacles encountered by the subcomittee in their deliberations. When a standard is prepared for a subject that has never been tackled previously, and a sensitive subject at that, all kinds of problems appear. A simple a thing as the title required hours of discussion and, in fact, three revisions before it was finalized. Actually, it was the same title that we started with in the beginning. The U.S. Nuclear Regulatory Commission, formerly the U.S. Atomic Energy Commission-Regulatory Branch, provided guidance for much of the standard. They were in the process of preparing 10CFR, Part 50, Appendix Q covering the same subject. Many of their recommendations are included. Their regulation was issued a year after our standard became available for public use. Incidently, NCR failed to endorse the standard because their Appendix $Q$ had the force of law and our standard, like any ANSI Standard, is used on a voluntary basis. Our subcommittee members were perturbed to say the. least. They had worked hard and spent their time and their company's money preparing this standard. They deserved recognition for their efforts.

The present standard may have the same fate. NCR will be preparing another Appendix to Part 50 after results from their contract with PNL 
are obtained. This study was consummated to provide NCR with a costbenefit-risk analysis resulting from decommissioning of a nuclear reprocessing facility. This information is unavailable but vitally important to them before attempting to formulate national policy. The subcommittee feels that with present technology, abandonment with entombment of the highly radioactive parts of the plant is the only economically feasible alternative to decomissioning of nuclear fuel reprocessing facilities. This study will put a dollar figure on each step involved with decomissioning. This will include returning the site to its original condition on one end of the spectrum to a minimal decontamination and entombment of certain equipment and facilities with periodic surveillance held to a minimum on the other.

All potentially hazardous facilities would be made inaccessible to casual visitors. This would not prevent deliberate action on someone's part to gain access to these entombed facilities. It would be the intent of the designer to design a facility by which the complete facility could be decontaminated to de minimus levels. De minimus level is defined as that level of contamination acceptable for unrestricted use or release. In this case, release means to the general public.

In the preparation of this standard, a review of a 1971 report by Eurochemic, entitled "The Shutdown of Reprocessing Facilities Results of Preliminary Studies on the Installations Belonging to Eurochemic," was made to provide the subcommittee with possible pertinent information from an independent study. Their report concluded that the extent to which complete dismantling is required depends on the local conditions and on the nature of the activities foresen for the ultimate use of the site. In their case, these considerations led to a proposal for the total 
dismantling of the Eurochemic Facilities and for sending the solid waste offsite for their final disposition.

The study was primarily concerned with the definition of the state in which the Eurochemic facilities might be abandoned without posing problems either for the safety of the environment or for the carry out, on the same site, of possible future industrial activities of a nonnuclear character. In addition, the study included decontamination and the dismantling of the installations, the treatment of the resulting residues, and the transportation of these solid wastes to some permanent disposal site.

The study concluded that dismantlement of a facility of the type of Eurochemic, which handles large quantities of irradiated fuel elements in solution, is technically possible. Nonetheless, we are speaking of a difficult undertaking, full of risks, which necessitates putting to work large efforts whose financial magnitude should not be underestimated.

It was this last statement that the industrial members on the subcommittee could see more vividly. When you mention risks and financial objectives of untold magnitude, they retrench to the most conservative position. In this study they were talking about a force of 40 to 50 people working 3 to 4 years dismantling the Eurochemic facilities. The facilities in the U.S. have a larger capacity, shorter-cooled material, and higher-burnup fuels to reprocess. The thesis that a nuclear fuel reprocessing facility should be designed so that it could be completely dismantled some 40 years in the future was entirely unacceptable. It was not practical. With the high-level concentration of radioactivity and contamination in certain parts of the facility, decontamination and removal of all activity would be most difficult. After ERDA's study by PNL is completed, a better position can be taken on the subject. Some place between the two extremes is industry's position. 


\title{
PROPOSED GUIDELINES FOR DECONTAMINATION AND DISPOSAL. OF CONTAMINATED REAL PROPERTY
}

\author{
R. E. Allen \\ Process Facilities Safety Branch \\ Division of Operational Safety
}

\begin{abstract}
Proposed draft Guidelines for the Safe Disposition of Contaminated Real or Related Personal Property were recently transmitted to the ERDA safety directors or their equivalent in all ERDA field organizations. The major comments received were informally discussed. While a detailed analysis of all comments has not been completed, all comments received were of a positive nature.
\end{abstract}

One significant comment made by several people was that these guidelines should be expanded to cover other hazardous materials as well as radioactivity. This suggestion warrants consideration in view of the diversified nature of the work now being conducted throughout the ERDA complex. 
DECOMMISSIONING AND DECONTAMINATION OF LICENSED REACTOR FACILITIES

AND

DEMONSTRATION NUCLEAR POWER PLANTS

By: George Lear and Peter B. Erickson

U. S. Nuclear Regulatory Commission

Division of Reactor Licensing

Washington, D. C. 20555

\begin{abstract}
Decommissioning of 1 icensed reactors and demonstration nuclear power plants has been accomplished by "mothballing" (protective storage), "entombment" and dismantling or a combination of these three alternatives. The alternative selected by a licensee seems to be primarily based on cost. A licensee must, however, show that the decommissioning process provides adequate protection of the health and safety of the public and no adverse impact on the environment. To date the NRC has approved each of the alternatives in the decommissioning of different facilities. The decommissioning of small research reactors has been accomplished primarily by dismantling. Licensed nuclear power plants, however, have been decommissioned primarily by being placed in a mothballed state in which they continue to retain a reactor license and the associated licensee responsibilities.
\end{abstract}




\section{Decommissioning and Decontamination of Licensed}

\section{Reactor Facilities and Demonstration Nuclear Power Plants}

\section{Introduction}

Since 1960,5 licensed nuclear power plants, 4 demonstration nuclear power plants, 6 licensed test reactors, 28 licensed research reactors and 22 licensed critical facilities have been or are in the process of being decommissioned. The experience gained in these decommissioning actions has been factored into the present Nuclear Regulatory Commission (NRC) requirements for reactor decommissioning.

This paper will list and discuss the current NRC regulations and guides and will examine decommissioning alternatives that are acceptable to the NRC. Examples of specific reactor facilities will be discussed with respect to the decommissioning alternatives.

Since this paper has been prepared for presentation at a conference which includes representatives from the Energy Research and Development Administration (ERDA), ERDA contractors, the Nuclear Regulatory Commission, and others, it has been tailored to present information which we hope will be useful to a11.

\section{Summary}

Reactor decommissioning has been accomplished by "mothballing" (protective storage), "entombment" and "dismantling" or a combination of these three alternatives. The alternative selected by a licensee seems to be primarily based on cost considerations. To-date the NRC has approved cases employing each of the alternatives for the decommissioning on the basis of adequate protection of the health and safety of the public. 
Small research reactors have usually been dismantled in contrast to licensed test or power reactors that have usually been mothballed. For licensed test and power reactors, the licensee preference has been and will probably continue to be to place them in some form of protective storage (mothballed, mothballed with partial entombment, or mothballed with partial dismantlement). Three nuclear power demonstration plants have been entombed as a decommissioning alternative.

Current Regulations and Guides for Decommissioning of Licensed Reactors

Regulations applicable to licensed reactor decommissioning are described in the Code of Federal Regulations Title 10. Title 10 CFR Part $50 \$ 50.82$; "Application for termination of 1icenses" provides rules by which a licensee may make application to the NRC for authorization to dismantle a reactor facility and terminate its license upon satisfactory completion of dismantlement. Title 10 CFR Part $50 \$ 50.59$, "Authorization of Changes, tests and experiments" and \$50.90, "Application for amendment of license or construction permit" provides the rules by which a licensee may amend his license to attain a "possession only" status. This state of a facility license results from NRC approval of deletion of requirements in the facility Technical Specifications that are applicable to reactor operations. Title 10 CFR Part 20, "Standards For Protection Against Radiation" establishes procedura1 requirements and the radioactivity concentration limits for release of radioactive material to the environment.

Title 10 CFR Part 51 §1.5, "Requirement for Environmental Impact Statements, Negative Declaration and Impact Appraisals" requires the 
preparation of either an environmental impact statement or a negative declaration for license amendments or orders authorizing the dismantling or decommissioning of nuclear power or test reactors. An environmental impact appraisal must be prepared to support the negative declaration. Negative declarations and environmental impact appraisals have been prepared by the NRC staff for dismantling and other decommissioning actions involving licensed reactors as required by Title 10 CFR Part $51 \S 51.5$.

Title 10 CFR Part $50 \$ 50.33$ "Contents of applications; general information" requires that an applicant for a license show financial ability (a) to operate the plant and (b) to cover the cost of permanently shutting down the facility and maintaining it in a safe condition, i.e., meet decommissioning costs.

Regulatory Guide 1.86* "Termination of Operating Licenses for Nuclear Reactors" describes conditions and procedures considered acceptable by the NRC staff for each decommissioning alternative. Published in 1974, this guide has been distributed to utilities and other organizations that possess facility operating licenses.

The conditions and procedures required by the NRC for each decommissioning alternative are discussed in the following paragraphs.

\footnotetext{
*Regulatory Guides are issued to describe and make available to the public methods acceptable to the NRC staff, of implementing specific parts of the Commission's regulations, to delineate techniques used by the staff in evaluating specific problems or postulated accidents, or to provide guidance to applicants. Regulatory Guides are not substitutes for regulations and compliance with them is not required. Methods and solutions different from those set out in the guides will be acceptable if they provide a basis for the findings requisite to the issuance or continuance of a permit or license by the Commission.
} 
Requirements for Mothballing

Mothballing is the process of placing a facility in protective storage. The facility may be left intact except that a11 reactor fuel, radioactive fluids and radioactive wastes such as ion exchange resins, contaminated scrap materials and contaminated chemicals are removed. The existing license is amended to a "possession on $1 y$ " status and if not amended in the future continues in effect indefinitely. The "possession only" license is a reactor facility license that permits a licensee to possess the facility but prohibits operation of the facility as a nuclear reactor.

Access control must be provided at the mothballed facility to prevent inadvertent exposure of employees or members of the public. In addition to proper posting of radiation areas in accordance with $10 \mathrm{CFR}$ Part 20, multiple locked barriers should be used to make it difficult for an unauthorized person to gain access to any area which is not acceptable for unrestricted access (Table 1).

To further minimize the possibility of significant exposure to intruders, areas above $5 \mathrm{mR} / \mathrm{hr}$ should be made accessible only by the deliberate cutting of welded closures or the disassembly and removal of substantial structures and/or shielding material.

In addition, a means must be provided to indicate to designated personnel when a physical barrier is penetrated. The physical barriers must be inspected at least quarterly to determine that they are intact and to detect any evidence of attempts by unauthorized persons to enter the facility. If the licensee prefers, he may use full time company representatives to control access to the facility instead of the concept 
which requires physical barriers and intrusion alarm systems. The NRC has accepted various combinations of the above access control measures for licensees that have elected to use the mothballing alternative for decommissioning. Other specific examples are to be discussed later.

In addition to access control requirements, the licensee is required to perform periodic inspections, facility radiation surveys and environmental sampling at the mothballed facility.

Quarterly facility radiation surveys and sampling are required to determine whether there is any radioactive material being released through the containment barriers of the facility. Surveys and sampling should be.performed along the most probable path by which radioactive material stored in the containment region could be transported to the outer regions of the facility and/or to the environment.

Environmental radiation surveys should be performed at least semiannually to verify that no significant amounts of radioactivity have been released to the environment. Samples such as soil, vegetation and water should be taken from locations for which statistical data has been established during reactor operations.

An annual report to the NRC is required for mothballed licensed facilities. The report describes the results of inspections, environmental sampling and facility radiation surveys and provides an evaluation of the performance of the access control and radiation surveillance measures. Requirements for Entombment

Entombment consists of removing all fuel assemblies, radioactive fluids and wastes followed by the sealing of remaining radioactive material 
within a structure integral with the biological shield. A program of inspection, facility radiation surveys and environmental sampling is required for a licensed facility that has been entombed. However, these services are expected to be maintained at a level lower in cost and extent than that required for the first discussed alternative of mothballing. By comparison with mothballing, the entombment of the facility will also permit some relaxation of required access control measures because physical access to the "sealed" residual radioactivity would be made very difficult.

To date, entombment has not been selected by licensees as their method of decommissioning but it has been used in the past for some demonstration power plants that were owned by the AEC (now ERDA). Dismantling and Termination of License

Dismantling is defined as removal of all fuel, radioactive fluids and waste, and all radioactive structures. Surface contamination levels have been established in Regulatory Guide 1.86 (Table 1) which must be met prior to termination of the facility license. In addition to meeting the surface contamination levels, the acceptability of the presence of materials which have been made radioactive by neutron activation would be evaluated on a case-by-case basis prior to termination of the license. In general however, all significantly activated components, such as the reactor structural components near the core, would have to be removed to meet the surface contamination limits (Table 1). The NRC is considering the development of specific guidance with respect to activated materials in conjunction with a revision of Regulatory Guide 1.86 and the development of new and revised rules (regulations) on reactor decommissioning. 
Experience in Decommissioning and Decontamination of Licensed Reactors and Nuclear Power Demonstration Plants

A list of the 15 licensed power and test reactors and nuclear power demonstration plants that have been decommissioned or are now in the process of being decommissioned is shown in Table 2. The decommissioning alternative selected and the present license status for each reactor is also shown. Table 2 does not include the 1icensed research reactors and critical facilities that have been decommissioned but of the fifty facilities in these two categories that have been or are being decommissioned, all but four have been or will be totally dismantled with their licenses terminated; these four facilities will retain a "possession-only" type license for an indefinite period while in the mothballed status. Table 2 shows that, to-date, all but one of the 11 licensees with power or test reactors have chosen mothballing as the alternative for decommissioning.

One factor that influences a licensee's choice of a decommissioning alternative is cost. The cost of dismantling the Elk River Nuclear Demonstration Plant was approximately $\$ 6,000,000$ as compared to the $\$ 500,000$ cost of mothballing the Saxton test reactor. A cost of $\$ 10,000$ per year for continued access control and surveillance at the Saxton facility is required, however, as compared to no access control and surveillance costs at the E1k River site.

The cost of total dismantlement of the Saxton reactor may have been more than that of Elk River because of the higher radioactive inventory of the pressure vessel at Saxton. The radioactivity inventory of the pressure vessel at E1k River was less than 10,000 curies at the time of 
decommissioning as compared to the inventory for the Saxton pressure vessel of over $1,000,000$ curies at the time of its decommissioning.

A consideration for mothballing by licensees is that it allows a certain degree of flexibility. Some licensees, such as the Saxton facility licensee, have indicated that they may dismantle the facility in 40 or 50 years when most of the activity that has penetrating radiation will have decayed. At that time, the isotope Nickel 63, with a 92 year half-life, will be the most prominent radioactive isotope; however, Nickel 63 is a low energy beta emitter and its direct radiation hazard would be much easier to cope with in dismantling of the facility. Research reactors may be temporarily placed in a mothball status while awaiting sale of the reactor components for reuse at another site. Table 3 shows the differences in access control at the ten licensed facilities that have been or are being decommissioned by mothballing. This list includes all licensed power and test reactors that have been decommissioned or are now involved in decommissioning. All of these reactors except Fermi 1 and Peach Bottom 1 have completed the process of being converted to the protective storage status. Mothballing of the Fermi facility is essentially complete. Peach Bottom 1 is now in an early phase of decommissioning. Mothballed facilities continue indefinitely to be licensed under a "possession only" reactor licenses until they are dismantled. Dismantling may be an inexpensive process of simply making the facility unusable as a reactor (to satisfy the legal requirements of Title 10 CFR Part 50.82) if the radioactivity has decayed to levels such that the facility can be released for unrestricted access. Mothballed facilities that are not 1icensed under a "possession only" reactor 
facility license are the SEFOR facility, which is licensed under a byproduct materials license with the State of Arkansas, and the CarolinasVirginia Tube Reactor and Path-finder, both of which have NRC byproduct materials licenses. A state byproduct materials license may be issued in "Agreement States" in accordance with authority granted by 10 CFR Part 150 "Exemptions and Continued Regulatory Authority in Agreement States". An NRC byproduct materials license may be issued in accordance with $10 \mathrm{CFR}$ Part 30 "Rules of General Applicability to Licensing of Byproduct Material".

Figure 3 shows that most mothballed reactors use full-time security personnel to provide access control at the facility rather than use the passive technique available via intrusion alarms. In many cases this use of full-time security personnel is not a large cost at decommissioned nuclear power plants, because these costs may be shared with operating nuclear power plants in the immediate area which independently require full-time security personnel.

As previously discussed, most research reactor licensees have chosen to totally dismantle their facilities and to seek a termination of their license as the preferred decommissioning alternative. Most of them, however, have as a first step converted their license to possession-only status for the period of time preceding dismantling and disposal of the facility. This possession-only status has lasted for a period of months to more than a year while the licensees have made arrangments for sale or disposal of the reactor components. The University of Wyoming, for instance, maintained their L-77 reactor in a possession-only status for a period of 17 months until they were able to donate the reactor components to another university. 
Entombment has been used for three nuclear power demonstration plants (Hallam, Piqua, and Bonus). In each case, an analysis was performed which demonstrated that any release of radioactivity from the entombed facility to the environment would be well below permissible concentrations for unrestricted areas as set forth in 10 CFR Part 20. Provisions were also made at the facilities to assure that the entombed structures would not be inadvertently uncovered in the future. Notification and appropriate descriptions were placed in land title records to notify any future owners of the property that entry into the contained volumes would require prior licensing action or other specific Federal government approval. 
TABLE I

ACCEPTABLE SURFACE CONTAMINATION LEVELS

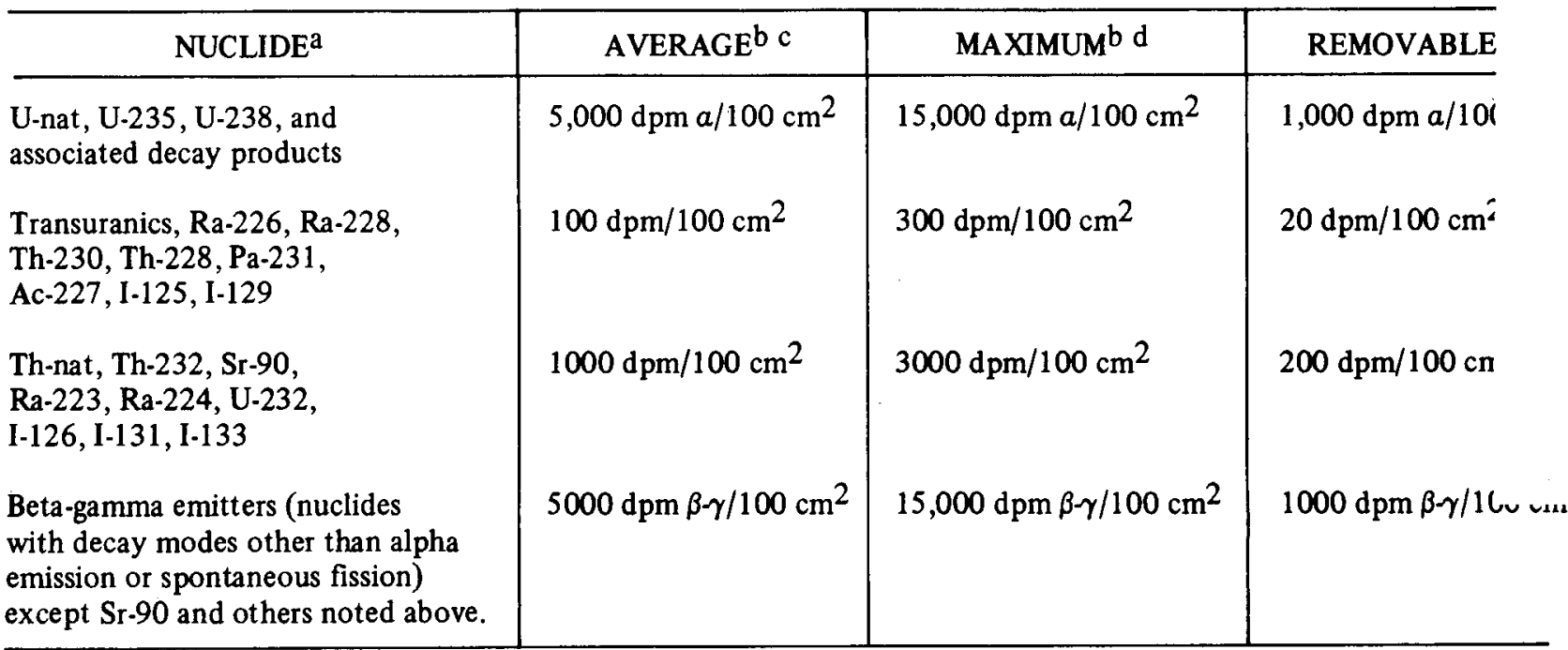

\footnotetext{
Where surface contamination by both alpha- and beta-gamma-emitting nuclides exists, the limits established for alpha- and beta-gamma-emitting nuclides should apply independently.

${ }^{b}$ As used in this table, dpm (disintegrations per minute) means the rate of emission by radioactive material as determined by correcting the counts per minute observed by an appropriate detector for background, efficiency, and geometric factors associated with the instrumentation.

cMeasurements of average contaminant should not be averaged over more than 1 square meter. For objects of less surface area, the average should be derived for each such object.

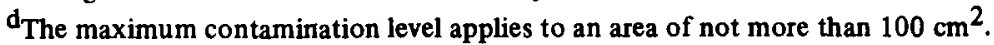

The amount of removable radioactive material per $100 \mathrm{~cm}^{2}$ of surface area should be determined by wiping that area with dry filter or soft absorbent paper, applying moderate pressure, and assessing the amount of radioactive material on the wipe with an appropriate instrument of known efficiency. When removable contamination on objects of less surface area is determined, the pertinent levels should be reduced proportionally and the entire surface should be wiped.
}

*Extract from Regulatory Guide 1.86, "Termination of Operating Licenses for Nuclear Reactors." 
TABLE 2

Decommissioning Alternatives Used For Power, Demonstration and Test Reactors

\begin{tabular}{|c|c|c|c|}
\hline Reactor & $\begin{array}{l}\text { Decommissioning } \\
\text { Mode Selected }\end{array}$ & $\begin{array}{l}\text { Present Status } \\
\text { of License }\end{array}$ & Location \\
\hline \multicolumn{4}{|c|}{ Licensed Power Reactors } \\
\hline VBWR & Mothballed & Possession Only ${ }^{1)}$ & $\begin{array}{l}\text { Alameda Co. } \\
\text { Calif. }\end{array}$ \\
\hline Fermi 1 & Mothballed & Possession Only & Monroe Co., Mich. \\
\hline CVTR & Mothballed & Byproduct $\mathrm{NRC}^{2)}$ & $\begin{array}{l}\text { Parr } \\
\text { South Carolina }\end{array}$ \\
\hline $\begin{array}{l}\text { Peach } \\
\text { Bottom } 1\end{array}$ & Mothballed & Possession Only & York Co., PA. \\
\hline Pathfinder & $\begin{array}{l}\text { Conversion and } \\
\text { Mothballing }\end{array}$ & Byproduct NRC & $\begin{array}{ll}\text { Sioux Falls } \\
\text { South Dakota }\end{array}$ \\
\hline \multicolumn{4}{|c|}{ Licensed Test Reactors } \\
\hline Saxton & Mothballed & Possession Only. & Saxton PA \\
\hline SEFOR & Mothballed & $\begin{array}{l}\text { Byproduct State of } \\
\text { Arkansas } 3 \text { ) }\end{array}$ & $\begin{array}{l}\text { Strickler } \\
\text { Arkansas }\end{array}$ \\
\hline $\begin{array}{l}\text { Westinghouse } \\
\text { Test Reactor }\end{array}$ & Mothballed & Possession Only & Waltz Mil1, PA. \\
\hline $\begin{array}{l}\text { NASA } \\
\text { Plumbrook }\end{array}$ & Mothballed & Possession On1y & Sandusky, Ohio \\
\hline GE EVESR & Mothballed & Possession On1y & $\begin{array}{l}\text { Alameda Co., } \\
\text { Calif. }\end{array}$ \\
\hline $\mathrm{B} \& \mathrm{~W}$ & $\begin{array}{l}\text { Dismantled except } \\
\text { for some concrete } \\
\text { structures }\end{array}$ & Byproduct NRC & $\begin{array}{l}\text { Lynchburg } \\
\text { Virginia }\end{array}$ \\
\hline \multicolumn{4}{|c|}{$\begin{array}{l}\text { 1) "possession only" license is a reactor facility license that } \\
\text { permits possession of the facility but prohibits operation. }\end{array}$} \\
\hline \multicolumn{4}{|c|}{$\begin{array}{l}\text { 2) A "Byproduct NRC" license is a license issued in accordance with } \\
10 \text { CFR Part } 30 .\end{array}$} \\
\hline \multicolumn{4}{|c|}{$\begin{array}{l}\text { 3) A "Byproduct License" may be issued by an agreement state in } \\
\text { accordance with authority granted by } 10 \mathrm{CFR} \text { Part } 150 \text {. }\end{array}$} \\
\hline
\end{tabular}


TABLE 2 (Continued)

Demonstration Power Plants (Government Owned)

Hallam Entombed Hallam, Neb.

\begin{tabular}{llll}
\hline Piqua & Entombed & $"$ & Piqua, Ohio \\
\hline Elk River & Dismantled & $"$ & $\begin{array}{l}\text { E1k River } \\
\text { Minn. }\end{array}$ \\
\hline Bonus & Entombed & $"$ & Puerto Rico \\
\hline
\end{tabular}

4) "Operating Authorization" for a government owned reactor operated by a utility may be terminated in accordance with requirements of 10 CFR Part 115. 
TABLE 3

Access Control At Reactor Facilities In Mothball Status

\begin{tabular}{|c|c|c|}
\hline Reactor & Intrusion Monitoring & $\begin{array}{l}\text { Physical Barriers In } \\
\text { Addition to Normal Shielding }\end{array}$ \\
\hline VBWR & $24 \mathrm{Hr}$. Security Personnel & Locked doors, security fence \\
\hline Fermi 1 & $24 \mathrm{Hr}$. Security Personnel & Locked doors, security fence \\
\hline CVTR & Periodic Surveillance & $\begin{array}{l}\text { Welded closures, locked access } \\
\text { doors, security fence }\end{array}$ \\
\hline Peach Bottom & $24 \mathrm{Hr}$. Security Personnel & To be established \\
\hline Pathfinder & $24 \mathrm{Hr}$. Security Personne1 & $\begin{array}{l}\text { Welded closures, security } \\
\text { fence }\end{array}$ \\
\hline Saxton & Intrusion Alarm System & $\begin{array}{l}\text { Locked Access Doors, } \\
\text { security fence }\end{array}$ \\
\hline SEFOR & Intrusion Alarm System & $\begin{array}{l}\text { Welded closures, security } \\
\text { fence, locked doors }\end{array}$ \\
\hline WTR & $24 \mathrm{Hr}$. Security Personnel & Locked doors, security fence \\
\hline Plumbrook & $24 \mathrm{Hr}$. Security Personnel & Locked doors, security fence \\
\hline GE EVESR & $24 \mathrm{Hr}$. Security Personnel & Locked doors, security fence \\
\hline
\end{tabular}




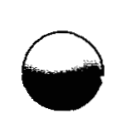

$\bullet$

- 


\author{
DEVELOPMENT OF DISPOSITION CRITERIA DERIVATION \\ METHODOLOGY FOR COMMERCIAL FUEL CYCLE FACILITIES* \\ by \\ D. A. WAITE \\ and \\ C. E. JENKINS
}

\title{
Abstract
}

A technique for deriving disposition criteria for the release and use of nuclear facilities has been developed. The criteria 1) are based on a consistent system of rationale, 2) give quantitative guidance on acceptable levels for release of nuclear facilities, 3) are applicable to all of the identified use restriction categories and 4) are adaptable to different types of nuclear facilities. Rationale for the derivation methodology and criteria acceptability standards are discussed. The derivation mechanism is developed and applied to a plutonium fuel fabrication facility. Present and future extension of the technique is indicated.

\section{INTRODUCTION}

This report discusses the development and definition of acceptable criteria for release and use of nuclear sites and/or facilities under specified use restriction categories--disposition criteria. Disposition criteria were developed to facilitate decision-making regarding disposition al ternatives (see Figure 1).

To develop these disposition criteria, existing guidance was reviewed, philosophy and objectives were identified, and mechanisms were developed and applied to a generic mixed oxide fuel fabrication plant.

* This paper is based on work performed under U.S. Nuclear Regulatory Commission Contract No. 300A00839. 


\section{STATEMENT OF PROBLEM}

Useful disposition criteria must 1) be based on a consistent system of rationale, 2) give quantitative guidance on acceptable levels for site or facility usage, 3 ) be applicable to all of the use restriction categories, and 4) be adaptable to other types of nuclear facilities.

In order to determine if existing guidance on acceptable criteria for release met these requirements, an extensive literature search was conducted. This review revealed that existing criteria for release for plutonium and other transuranics were inadequate but could be used as one factor in determining the acceptability of derived disposition criteria.

\section{PHILOSOPHY AND OBJECTIVES}

The basic guiding philosophy for the disposition criteria development is that once radiological protection parameters are quantified, the resulting degree of protection level will be met in every category. That is, under no circumstance will offsite population exposures exceed those specified at the unrestricted use level. Where higher residual contamination levels are allowable, prevention of increased exposure potential will be maintained through use restrictions specified for each use category. The objectives are to provide a rationale and methodology that are consistent and adaptable, yet provide definitive technically based numerical guidance for acceptable criteria for release.

Acceptability of numerical guidance derived through this methodology is determined by analysis on the bases of 1) detectability in the field by portable instrumentation, 2) dose commitment potential to individuals or populations, 3) by comparison with previously suggested guidance as shown in Figure 1 for plutonium.

The collective function of these assessment parameters is to establish an acceptable contamination level range for each use category. The requirement that specified contamination levels must be detectable in the field with portable instrumentation provides a simple means of establishing an upper limit for the unrestricted use category. Limitation of dose commitment 
potential to individuals or populations, practically interpreted, also provides an upper bound to the unrestricted use category. This same dose value also is considered in deriving upper bounds for other use categories. The practicality of derived disposition criteria numbers is assessed by comparison with the previously suggested guidance offered in Figure 1.

Economic feasibility will affect the decontamination and decommissioning of specific sites and facilities, but this factor was not allowed to influence the establishment of acceptable disposition criteria.

\section{USE RESTRICTION CATEGORIES}

Use restriction categories for the disposition criteria development methodology began as 1) restricted, 2) conditional and 3) unrestricted. As investigation progressed, the conditional category was subdivided into a) conditional uses needing continuing surveillance and b) those not requiring such surveillance.

The restricted use category denotes the limitation of the facility to "nuclear use only." Thus, occuptational exposure is allowed via the restricted use category specification while involuntary exposure to populations is limited to the unrestricted category level.

Conditional use categories were assessed on the basis of practical limitations affecting the availability of toxic materials by manipulation of active exposure pathways by either surveillance or nonsurveillance modes. For instance, restricting the availability of contamination by either restricting the use of drinking water or by physically restricting access of the contamination to the atmosphere would necessitate the active involvement of radiological monitoring personnel at the facility site and in its adjacent environment.

Conditional-nonsurveillance use is defined as the use of statutory law to 1 imit 1 and usage or to block significant exposure pathways; for instance, city zoning laws restricting agricultural use, drilling water wells, etc. Governmental maintenance commitments may also be involved, such as those associated with present day low-level radioactive waste surface burial. 
The unrestricted use category denotes release of site and facility for unconditional access and use by the public.

\section{MECHANISMS}

In determining the appropriate use category of a specific site or facility, the site characteristics must be compared to technically based numerical guidance.

To aid in visualization of the derivation process, a matrix with use restriction category rows and contaminated medium columns was constructed (see Figure 2). The first number selected would be in column 1--row 1 (surface contamination--unrestricted use) which is based on detectability and serves as the easiest attainable upper bound number to the unrestricted use category. Assessment on basis of other criteria is discussed subsequently. Surface contamination guidance is intended to be used on any surfaces where such field measurements are feasible. Activity/mass contamination levels are intended to be applied to bulk materials such as water, soil, etc. Because of radical differences in availability factors or release fractions of smearable and nonsmearable surface contamination, appropriate levels are specified for each of these circumstances for each use category.

Figure 2 was organized in such a way that a comparable activity/mass contamination level appears across from each surface contamination value. An activity/mass value consistent with the row 1--column 1 number is selected by reading the number on the right axis with the same ordinant as the selected surface contamination value. This activity/mass value is entered into row 1--column 2 .

Before values for row 2 can be derived, row 1 values (unrestricted use) must be examined on the basis of dose commitment potential to individuals or populations. If the calculated potential exposure exceeds established dose standards, a reduction in row 1 values is necessary. Therefore, development of more sensitive detection instrumentation is required to satisfy all acceptability criteria. If the calculated dose potentials are within existing standards, doses resulting from row 1 concentration values would serve as the basis for calculating remaining release criteria. 
Results of the dose calculation will also identify critical pathways. The relative importance of components of these pathways can be used to indicate which pathway adjustments can be made to restrict dose potential to unrestricted use levels.

The dose reduction which can be achieved by pathway restrictions is taken advantage of to equivalently increase acceptable concentration levels in row 2 (conditional use--nonsurveillance). The fact that more effective pathway restrictions are usually possible with active surveillance than without surveillance is incorporated into the derivation of values for row 3 (conditional use--surveillance). As a result, surveillance values may be higher than nonsurveillance without violating the unrestricted dose level criteria.

Since the restricted.use category is defined as "nuclear use only," occupational exposure standards are used to determine the row 4 upper 1 imits.

\section{PLUTONIUM FACILITY DISPOSITION CRITERIA}

The derivation process for the generic plutonium fuel fabrication plant was begun by setting up the matrix and selecting a number in row 1--column 1 based on detectability in the field by portable instrumentation (see Figure 3). On this basis a number of $220 \mathrm{dpm} / 100 \mathrm{~cm}^{2}$ fixed contamination was selected. A comparison of this value with Figure 1 shows this value (equivalent to $10 \mathrm{nCi} / \mathrm{m}^{2}$ ) to be the interface between materials contaminated (by definition) with plutonium and materials not contaminated. A smearable contamination level two orders of magnitude more restrictive was also selected for unrestricted use surface contamination on the basis of greater release fraction potential.

Figure 1 shows a value for contamination activity per unit mass of $10 \mathrm{pCi} / \mathrm{g}$ approximately equivalent to $10 \mathrm{nCi} / \mathrm{m}^{2}$. This value was included in row 1--column 2 (activity/mass concentration--unrestricted use) (see Figure 3 ). The relationship of this number to relevant detection levels and to occupational and nonoccupational standards can be seen in Figure 1 . 
Inclusion of a total inventory limit was originally considered, but integration of the recommended surface contamination level over the approximately $4 \times 10^{5} \mathrm{ft}^{2}$ of facility surface in the reference plutonium fuel fabrication plant yielded a number for the total inventory of slightly less than $1 \mathrm{mCi}$ plutonium. This quantity of plutonium could not be realistically determined for the purpose of site use restriction category selection purposes. Therefore, this column was dropped from the matrix.

Procedures used to insure conservatism included, for plutonium, ageing the fuel mixture for 15 years to increase the dose potential because of ${ }^{241} \mathrm{Am}$ ingrowth and also to approximate the midpoint of plant life. Two plutonium isotopic mixtures representing different burnup fuel were analyzed to establish a bracket of recognizable potential hazards. The resultant reference mixtures which were used as the basis for the derivation of the criteria being discussed are shown in Table 1.

TABLE 1. Plutonium Reference Mixture

$\begin{array}{ccc}\text { Radionuclide } & \text { Wt\%-Mixture 1 } & \text { Wt\%-Mixture 2 } \\ 238 \mathrm{Pu} & 1.9 & 2.1 \\ 239 \mathrm{Pu} & 63 & 51 \\ 240 \mathrm{Pu} & 19 & 25 \\ 241 \mathrm{Pu} & 5.2 & 6.6 \\ 242 \mathrm{Pu} & 3.8 & 7.8 \\ 241 \mathrm{Am} & 6.8 & 6.8\end{array}$

Since the basic guiding philosophy for the disposition criteria development has been stated to be that once radiological protection parameters are quantified, the resulting degree of protection level will be met in every use category and every facility type, the "relative hazard indices" (RHI) were established for these reference plutonium mixtures for future comparisons. Methods and index values described by Morgan ${ }^{(1)}$ were used. A tabulation of the hazard index calculations for the reference plutonium mixtures is shown in Table 2. 
TABLE 2

\begin{tabular}{|c|c|c|c|c|c|}
\hline Radionuclides & $\underline{W t} \%$ & & RHI & Total & \\
\hline \multicolumn{6}{|l|}{ Mixture I } \\
\hline${ }^{238} \mathrm{Pu}$ & 1.9 & $x$ & 152 & $=288.8$ & \\
\hline${ }^{239} \mathrm{Pu}$ & 63 & $x$ & 1.04 & $=65.52$ & \\
\hline${ }^{240} \mathrm{Pu}$ & 19 & $x$ & 3.84 & 72.96 & \\
\hline${ }^{241} \mathrm{Pu}$ & 5.2 & $x$ & 3.23 & 16.796 & \\
\hline${ }^{242} \mathrm{Pu}$ & 3.8 & $x$ & 0.0621 & 0.236 & \\
\hline${ }^{241} \mathrm{Am}$ & 6.8 & & 15.9 & $=108.12$ & \\
\hline & & & & 552.432 & $\div 100=5.52 \mathrm{RHI}$ for mixture \\
\hline
\end{tabular}

Mixture II

${ }^{238} \mathrm{Pu}$
$239 \mathrm{Pu}$
$240 \mathrm{Pu}$
${ }^{241} \mathrm{Pu}$
$242 \mathrm{Pu}$
$241 \mathrm{Am}$

$$
\begin{aligned}
2.1 \times 152 & =319.2 \\
5.1 \times 1.04 & =53.04 \\
25 \times 3.84 & =96 \\
6.6 \times 3.23 & =21.32 \\
7.8 \times 0.0621 & =0.48 \\
6.8 \times 15.9 & =\frac{108.12}{598.16} \div 100=5.98 \mathrm{RHI} \text { for mixture }
\end{aligned}
$$

An examination of relevant dose calculations indicates that within the restrictions appropriate to the conditional use--nonsurveillance category a factor of at least 10 can be expected. Another factor of 10 can be expected under the surveillance condition. As a result, values in rows 2 and 3 are one and two orders of magnitude greater than those specified for unrestricted use. However, in no case were these calculated doses found to be the most limiting of the acceptability criteria.

The upper bounds indicated in row 3 serve also as the lower bounds for the restricted use category values. Upper bounds for this category must be established on the basis of specific comparisons of contamination conditions with occupational dose standards. 
The relationships of all values shown in Figure 3 are graphically illustrated in Figure 1.

\section{DISPOSITION CRITERIA FOR OTHER FACILITIES}

Based on the previously discussed philosophy that once radiological protection parameters are quantified, the resulting degree of protection will be met in every use category for all facility types, the plutonium disposition criteria tabulated in Figure 3 can be related to criteria for other nuclear facilities. Scaling adjustments necessary to make the plutonium facility criteria achieve this consistent degree of protection for the other facilities can be made on the basis of two methods: dose calculations or relative hazard indices. In using the relative hazard index method the RHI for the new contamination radionuclide is calculated. The plutonium numbers in Figure 3 are then raised or lowered in reverse proportion to the ratio of the new radioelement mixture RHI to the plutonium index. The latter method is feasible because previous calculations have shown airborne transport to be the critical exposure pathway for most decommissioned facilities of most types. Since this criteria derivation method is still evolving, both methods of derivation are being pursued until it is clear that both methods are applicable.

\section{SUMMARY}

A technique for deriving disposition criteria which 1) are based on a consistent system of rationale, 2) give quantitative guidance on acceptable levels for release of nuclear facilities, 3) are applicable to all of the identified use restriction categories and 4) are adaptable to other types of nuclear facilities has been developed. Initial testing of the technique was carried out on a plutonium fuel fabrication facility. To date, it has also been applied to a chemical reprocessing plant with all techniques and assumptions appearing to be consistent regardless of facility type. Application to other fuel cycle facilities is underway. 


\section{REFERENCE}

1. K. Z. Morgan, W. S. Snyder and M. R. Ford, "Relative Hazard of Various Radioactive Materials," Health Physics, Vol. 10, pp. 151-169, 1964.

\section{FIGURES}

1. Plutonium Action Levels

2. Basic Disposition Criteria Matrix

3. Disposition Criteria Matrix 


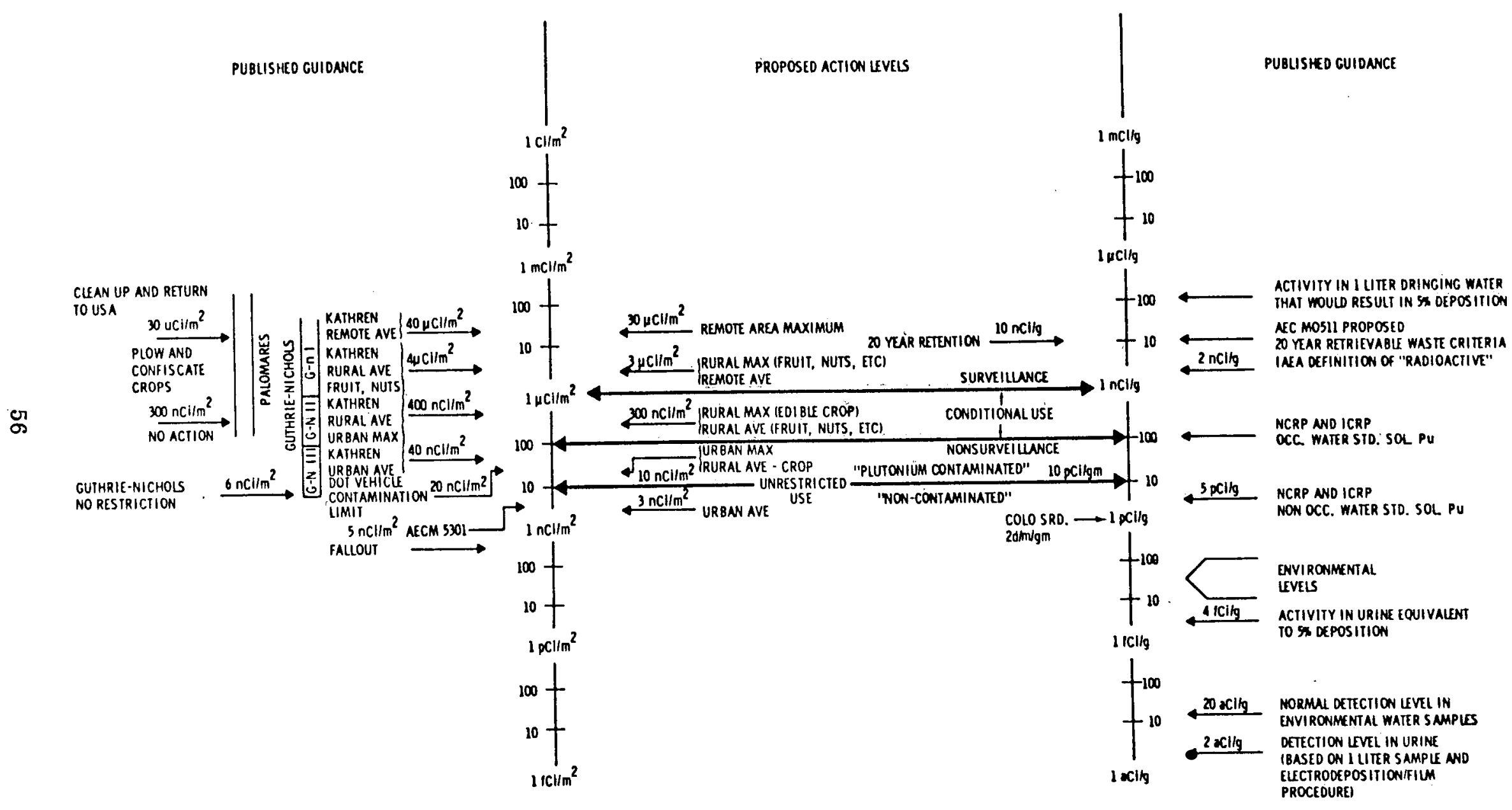

FIGURE 1. Plutonium Action Levels 


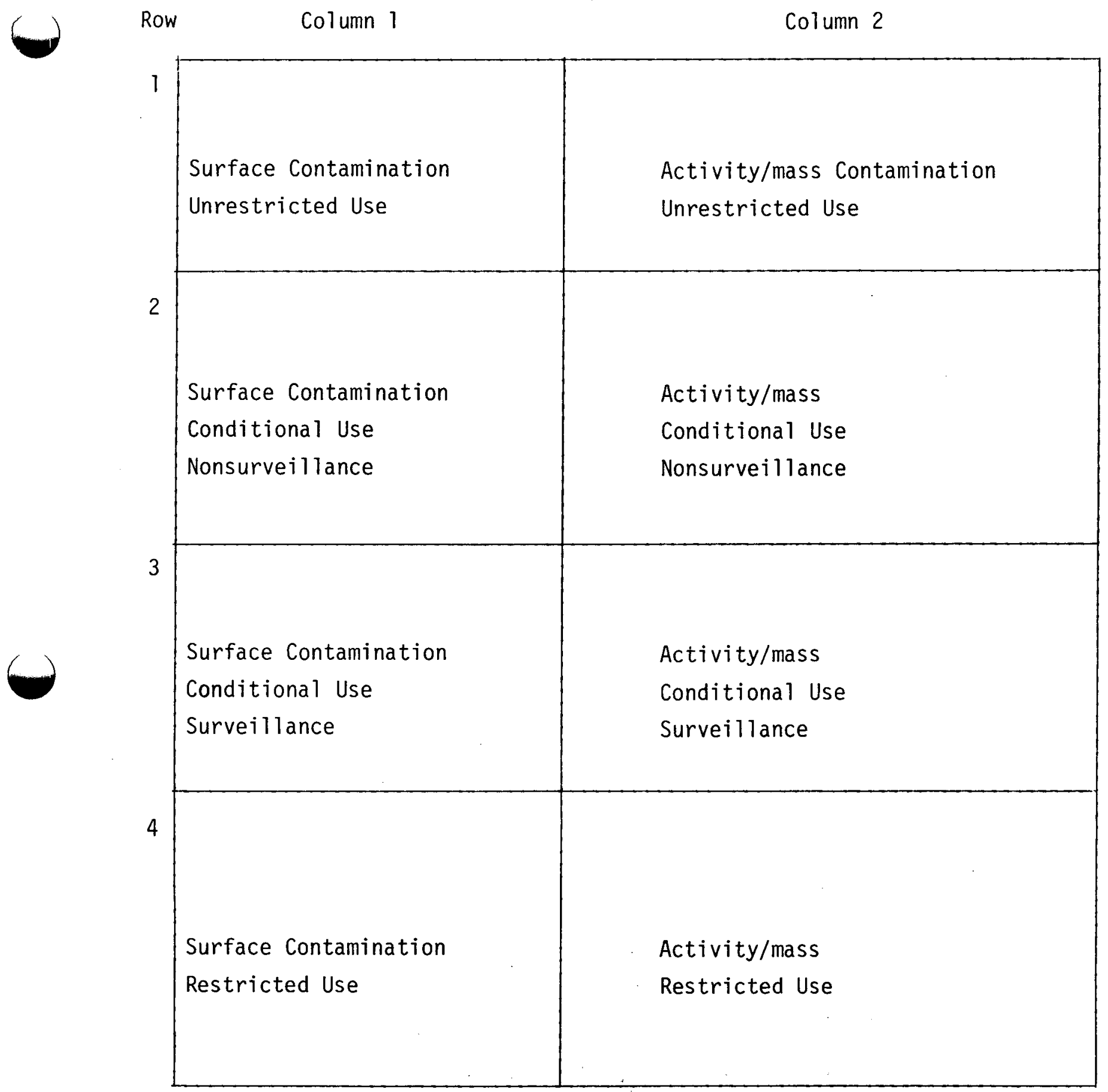

FIGURE 2. Basic Dispostion Criteria Matrix 


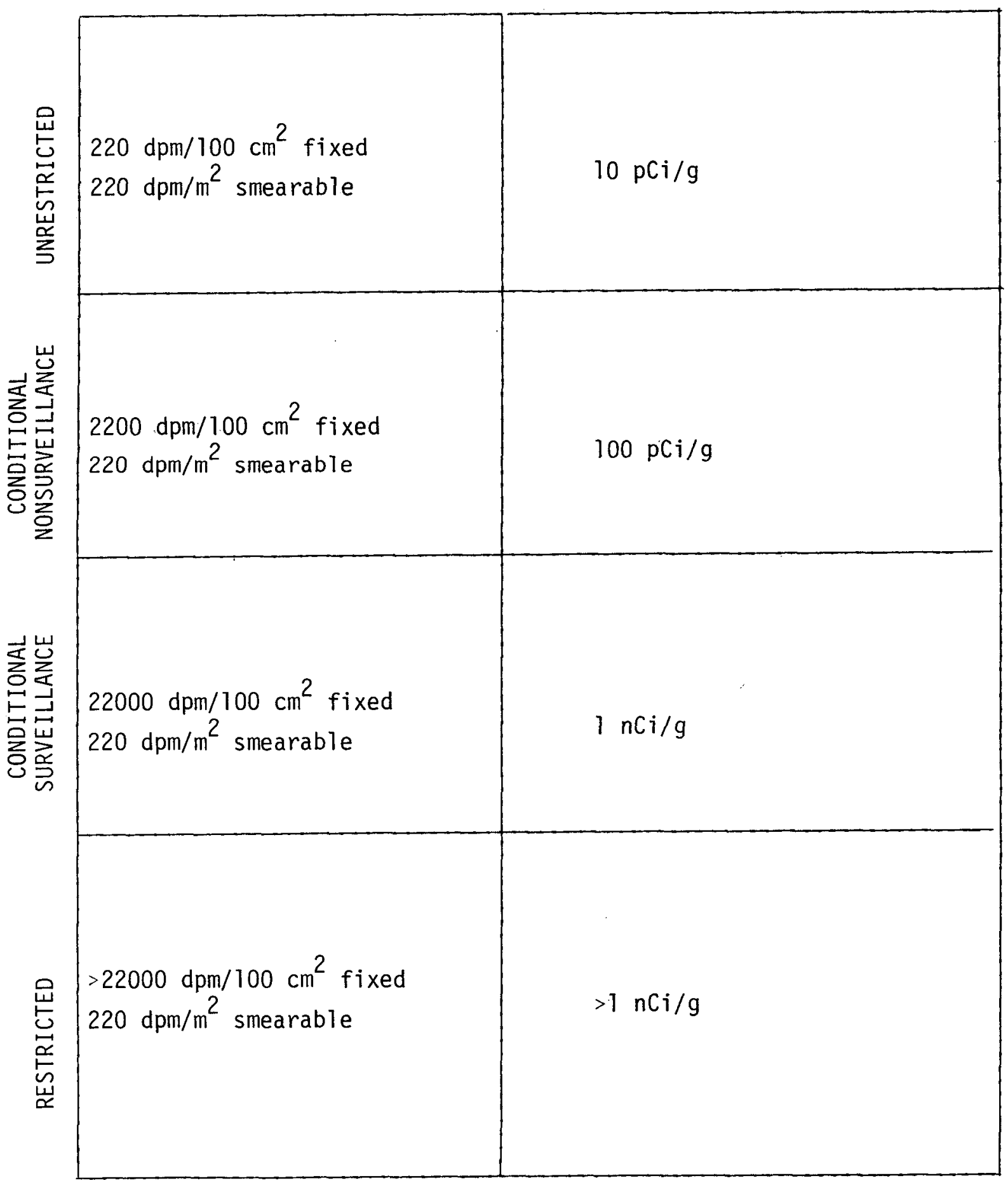

FIGURE 3. Disposition Criteria Matrix 


\title{
$0266^{5}$ \\ DECONTAMINATION AND DECOMMISSIONING OF LICENSED \\ FUEL REPROCESSING PLANTS
}

\begin{abstract}
by
Richard B. Chitwood

Division of Materials and Fuel Cycle Facility Licensing

U. S. Nuclear Regulatory Commission
\end{abstract}


DECONTAMINATION AND DECOMMISSIONING OF LICENSED

FUEL REPROCESSING PLANTS

\section{Introduction}

Although a number of ERDA reprocessing facilities and pilot-plants have been decontaminated and then converted to other radiochemical uses or laid away under surveillance, no existing fuel reprocessing plant has been decommissioned completely. Moreover, there is limited operating experience related to licensed commercial fuel reprocessing plants. However, early in the growth of the nuclear fuel cycle, the Nuclear Regulatory Commission (NRC) considered prospective problems relevant to future obsolescence of nuclear facilities, particularly fuel reprocessing plants. This is reflected in NRC policy, stated in Appendix F to 10 CFR Part 50 of the Commission's regulations, which established among other things that "...a design objective for fuel reprocessing plants shall be to facilitate decontamination and removal of all significant radioactive wastes at the time the facility is permanently decommissioned." Furthermore, this is reflected in our safety and environmental impact reviews wherein, to ensure that prospective contamination of facilities and the environs will be as low as can be reasonably attained, careful consideration is given to facility design and operating procedures. In addition, the Commission has committed to develop criteria for the extent of decontamination to be required upon decommissioning of fuel reprocessing facilities prior to termination of the license. In short, our objectives are to minimize the contamination of facilities and the site, to require that plants be designed to facilitate later decontamination for 
decommissioning, and to require that at termination of the license, the site be left in a condition which relies on a minimum of perpetual surveillance for continued protection of the health and safety of the public.

This morning, Pete Erickson discussed NRC regulations and guides related to decommissioning licensed reactors. In general, much of what he discussed and the regulations he referred to also apply to fuel reprocessing plants licensed pursuant to 10 CFR Part 50 and other Commission regulations. Several speakers that follow me will talk about experiences and plans for decontaminating and decommissioning radioactive facilities which, in general, are related to decommissioning future licensed reprocessing plants.

Appendix $F$ to 10 CFR Part 50

At the present time the NRC is developing criteria for the decommissioning of reprocessing plants. Some guidance on this subject may be found in Appendix F, 10 CFR 50, which states:

1. A requirement that all high-level wastes be transferred to a Federal repository before the plant is retired from operational status.

2. A design objective requiring that reprocessing plants shall be designed to facilitate decontamination and removal of all significant radioactive wastes at the time the facility is permanently decommissioned. 
3. A requirement that applicants proposing to operate fuel reprocessing plants, in submitting information concerning financial qualifications, shall include information enabling the Commission to determine whether the applicant is financially qualified, among other things, to provide for the removal and disposal of radioactive wastes during operation and upon decommissioning of the facility..

4. A statement that criteria for the extent of decontamination to be required upon decommissioning and license termination will be developed by the Commission in consultation with competent groups and that opportunity will be afforded for public comment before such criteria are made effective.

Design Criteria for Decommissioning Nuclear Fuel Reprocessing P1ants (N300-1974)

A standard sponsored by American National Standards Committee N46 has been drafted (but not yet approved), titled "Design Criteria for Decommissioning Nuclear Fuel Reprocessing Plants (N300 - 1974)." This draft standard proposes criteria to be incorporated into the design of reprocessing plants to facilitate the future decommissioning of such plants, as well as criteria for the conduct of the decommissioning operation. In summary, the objectives of the decommissioning operation are to (a) decontaminate the structure and equipment, to the extent practicable, (b) to remove sources of radioactivity or to render them inaccessible, and (c) to return the site to such a condition that it may safely be returned to unrestricted use, 
or so it may be maintained under the minimum surveillance as required for the protection of public health and safety.

This draft standard generally proposes that various features should be included in the design of reprocessing plants to assist in decommissioning, as follows: The fuel storage pool should be designed to permit decontamination or should be designed to permit covering with a sealed closure. Process equipment should be designed to permit decontamination and/or removal. The cell structure containing the process equipment should be designed to permit decontamination and sealing. All onsite waste storage systems should be designed in such a way that stored radioactive material can be removed safely at the time of decommissioning. Stacks, filters and auxiliary equipment should be designed to minimize the problems of decontamination or removal. Prior to decommissioning a detailed study should be made to identify the location, types, quantities and associated hazards of the radioactive materials and reactive chemicals that may be present.

The draft standard also provides for various operations to be done during decommissioning, as follows: The fuel is to be removed from the fuel storage pool and the pool decontaminated to the extent possible. If required, the pool should be filled in and sealed. In-cell equipment should be decontaminated and removed, or decontaminated to a level that will permit it to be left in place. The cell structure shall be evaluated for adequacy in both confinement and shielding. Windows and other penetrations 
should be permanently sealed. Liquid waste should be removed and the tanks decontaminated to the extent practicable. Lines and piping to waste tanks should be flushed, drained and protected against accidental excavation. Auxiliary equipment should be decontaminated to acceptable levels or made inaccessible. High-level solid wastes should be removed and the storage areas decontaminated and sealed. Low-level waste burial trenches sha1l be identified and covered to assure that there is no radiation hazard to the public. Surveillance should be provided after decommissioning to assure that barriers to radioactive material remain intact, to confirm that the contamination level within the site remains at an acceptably low level, and to determine that no activities which might impair the barriers' have been initiated on the site.

In general, the requirements proposed for termination of operations of a reprocessing plant are similar to those for a nuclear reactor; but, the latter are not fully applicable because of differences in the type and quantity of radioactive wastes produced, and the differences in the way radionuclides are retained in the equipment after shutdown. A large part of the radioactivity associated with reactor structural components is that induced by neutron irradiation. Induced activity cannot be removed by the decontamination procedures used in fuel reprocessing plants. Reprocessing plant equipment becomes highly contaminated by deposition of fission products and actinide elements on surfaces in contact with the process media. However, surface contamination can be removed or substantially reduced by decontamination methods. 


\section{Decontamination Experience}

The technology associated with the decontamination of reprocessing plants and reactors is available today. For example, experience has been obtained at $\mathrm{HNL}$ (formerly ORNL) in numerous pilot plant programs, involving systems for the reprocessing of irradiated fuel, in which complete systems have been decontaminated, equipment disassembled, and the remaining site prepared for direct installation of equipment for the next pilot demonstration.

The Metal Recovery Plant at HNL, which operated for a nine-year period, employed all of the unit operations common to reprocessing plants. These unit operations consisted of irradiated fuel storage and handling, dissolution, solvent extraction, evaporation, ion-exchange, and product polishing. Upon its shutdown in 1959, the facility was decontaminated with mineral acids and left in a standby condition. Since that time, there has been no detectable release of the residual activity to the environs.

Similarly, facilities at Hanford have been successfully decontaminated and laid away; but, not decommissioned completely. However, current commercial fuel reprocessing plants are more complex, and thus may be more difficult to decontaminate and decommission.

\section{Decommissioning Alternatives}

Recognizing that decontamination may be possible at some future date or that some other action may be required to decommission nuclear fuel 
reprocessing plants, four possible means of accomplishing decommissioning are apparent:

a. Mothballing the Facility. This can be accomplished by decontaminating to a practical point where radioactivity could not be released to the environs by natural means. After decontamination, all openings would be sealed. The commitment of resources would be the chemicals used in decontaminants, water, labor, energy, the disposal of the liquid waste generated at a Federal repository committing additional land, and any transportation hazards involved. It would not preclude the possible recommissioning of the facility at some future date if advancements in technology warranted. Surveillance would be required.

b. Entombment. Entombment would involve filling cells, waste tanks, etc., with concrete or other suitable materials. Decontamination would be done to the extent that economics indicated the desirability for reducing the volume to be filled with concrete or other suitable materials. Entombment would be final insofar as future options regarding the facility are concerned. Surveillance would be required.

c. Decontamination and Removal of Equipment to a Burial Ground. This involves the same commitment as mothballing, plus the labor and energy expended for equipment removal, plus additional 1 and for burial either onsite or at a Federal repository. This would allow recommissioning the facility at some future date if advancements in technology warranted. Surveillance would be required. 
d. Dismantling. The complete dismantling of the facility is probably possible at a price, which must be balanced against the risks to the public and the costs for perpetual surveillance inherent in the above alternatives.

Thus, in selecting one of the above alternatives, one must balance the environmental benefits in relation to costs, including exposure to personnel during the decontamination and decommissioning operation, and one must attempt to answer these questions:

1. What is the status of the plant when the decision is made to decommission or cease operation?

2. To what level must the plant be decontaminated?

3. Does the initial plant design incorporate systems that will enhance system decontamination - that is, can all surfaces be contacted with decontaminants at the proper conditions?

4. To what use will the site be put following decommissioning?

5. Are there current regulatory criteria that have applicability to reprocessing plant decommissioning, and what are the ultimate storage requirements for the numerous diversified wastes that will be generated?

Disposal of Radioactive Wastes

In general, currently proposed commercial fuel reprocessing plants, such as the Barnwell Nuclear Fuel Plant, do not rely on the environment for safe confinement of radioactivity. That is, the plant is designed with 
multiple barriers to preclude the release of radioactivity to soil or ground water. Moreover, it is intended that the high-level radioactive : liquid wastes, in accordance with Appendix F to 10 CFR Part 50, will be? converted to a solid form and transferred to a Federal repository. Furthermore, the Commission is considering the amendment of its regula- $\cdots$ tions in 10 CFR Part 20, "Standards for Protection Against Radiation," to prohibit the disposal by burial in soil of transuranium elements. For the most part, transuranic wastes would be required to be transferred to a Federal repository for storage of such wastes as soon as practicable $;$ but within five years after its generation. In this regard, ERDA is developing specifications, requirements, and charges for three genera1 * categories of radioactive waste: high-level radioactive waste, as defined in Appendix F to 10 CFR Part 50; high-gamma transuranic wastes; and, low-gamma transuranic wastes; which will be published at some later date as separate Miscellaneous Notices. The following proposed ERDA definitions apply to the latter two categories of waste:

High-Gamma Transuranium-Contaminated Solid Waste - Waste that requires special shielding for radiation exposure control during transportation, handling, storage, or retrieval, and meets the definition of solid radioactive waste. Examples consist of scraps or remnants of original fuel element cladding known as "hulls" and other transuranium-contaminated metallic scraps, equipment and solid materials, resulting from reactor and fuel reprocessing operations, that emit high-gamma radiation but are not presently classified as high-level waste. 
Low-Gamma Transuranium-Contaminated Solid Waste - Waste that can be handled, packaged, stored and retrieved without shielding and without accumulation of significant doses of direct radiation and meets the definition intent of solid radioactive wastes. Examples are expendable material such as absorbent tissues, clothing, gloves, plastic bags, sludges, solidified waste, and equipment originating in plutonium processing and fabrication facilities. Package radiation dose rates must be limited to a maximum of $500 \mathrm{mrem} / \mathrm{hr}$ at contact with the surface, and the maximum from each package must not exceed $30 \mathrm{mrem} / \mathrm{hr}$ at 3 feet. The shipper must certify that the ingrowth of more active daughter products will not cause radiation levels to exceed the above limits during handling, shipping, and retrievable storage.

I'm sure it wouldn't surprise anyone here if I were to suggest that most, if not all, of the contaminated waste generated as a result of the decontamination and decommissioning of a fuel reprocessing plant would fall into one or another of these three categories. And, like a dog chasing its tail, some of the systems for handing the contaminated waste may have to be disposed of in a like manner.

\section{Summary and Conclusion}

In summary, at this point in time, NRC is in the process of developing guidance for decommissioning nuclear fuel reprocessing plants. The problem is complex since several related considerations must be taken into account regarding the decommissioning a specific fuel reprocessing plant, 
including: the planned future use of the site in relation to the condition of the plant and site at that time; a balancing of the long-term risk to the environment in relation to the occupational exposure risk and costs associated with the alternative modes for retiring the facility; and, the required disposal of the contaminated waste generated by decontamination and decommissioning operations. As I have indicated, it appears to me that the care and effort given during initial design to planning for the eventual decommissioning could substantially reduce the problems and costs of terminating operations, which otherwise are likely to increase significantly with the contaminated condition of facilities and the site, and the needs for perpetual surveillance.

In general, our philosophy is that the plant as well as the waste storage areas must be left in such a condition that no casual action by man or animals could result in significant exposure to radiation. 


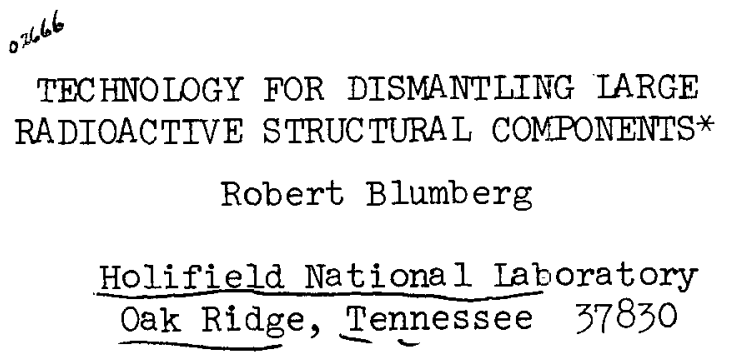

The dismantling of the ERR (Elk River Reactor) was completed successfully and safely in september, 1974. This $58 \mathrm{MW}(\mathrm{t})$, boiling water reactor was removed down to its foundations, and all of the radioactive material was shipped in suitable containers to licensed burial grounds. The most difficult and the unique part of this effort was the cutting up and removal of the radioactive structural parts, namely the inner thermal shield, the pressure vessel, and the outer thermal shield. The tools and techniques for this operation were designed, developed, and fabricated at the Oak Ridge National Laboratory. This development provides the nuclear industry with a viable alternative to entombment and surveillance for decommissioning reactors. This paper describes the technology used, and comments on its application to larger, more radioactive systems.

* Research sponsored by the Energy Research and Development Administration under contract with the Union Carbide CorporationNuclear Division. 


\section{INTRODUCTION}

The Elk River Reactor (ERR) was a $58 \mathrm{MW}(t)$ boiling water reactor, Owned by Energy Research and Development Administration (ERDA) and operated by the United Power Association. It was shut down in 1968 after operating intermittently for three years. It was dismantled during the period from August 1971 to September 1974. A comprehensive description of the overall dismantling operation is given in Reference 1. The unique and difficult part of that operation was to cut up the large, highly radioactive structural components into pieces and transfer them into shipping casks. Almost all of the 10,000 $\mathrm{Ci}$ inventory was located in these structural components. The basic tool that

was developed and used for this purpose was a remotely operated, underwater plasma torch.

The purpose of this paper is two fold: to present some details of the plasma torch technology used at the ERR, and to comment on some of the problems of applying this technology to typical power reactors at the end-of-life decommissioning. It is hoped that this information will prove helpful to those involved with making decisions in this area.

\section{Description of the Equipment}

The technology that was developed by ERDA specifically for the ERR makes it possible to cut remotely, automatically, and under water, with a plasma torch. Cuts of $11 / 2$ in. thick stainless steel were made under water on the inner thermal shield. The pressure vessel, which was $31 / 8$ in. thick carbon steel with a 0.109 in. stainless steel overlay, was 
cut in air. The outer thermal shield, consisting of carbon steel and lead, was cut with an oxy-acetylene torch in air. These vessels were approximately $7 \mathrm{ft}$ in diameter and had contact readings of 1500,250 , and $1 \mathrm{R} /$ hour, respectively. All of the equipment performed reliably and accurately. It was rugged, easy to learn to operate, and did not require lengthy set-up times.

The hardware components of this system consist of the plasma equipment, the manipulator, the control package, and an assortment of long handled mechanical tools. There are also a number of "software" items such as operating procedures, personnel training, plasma process parameters, etc. that are required. The plasma equipment consists of the torch, torch hoses, cables, power supplies, cutting gases, and accessories that are available from the welding equipment industry. The Linde PT-7 plasma torch was used because it had the highest capacity rating of any torch on the market. For this application a number of minor modifications to this hardware as purchased are required. The torch is shown under water in Fig. 1.

The torch is mounted on and moved by a manipulator. This is a special purpose, moderately sophisticated, one of a kind device. Its design was heavily influenced by the accuracy and rigidity requirements of the plasma cutting process. It weighs almost $4000 \mathrm{lbs}$ and is $28 \mathrm{ft}$ long. It has a $20 \mathrm{ft}$ travel vertically and rotates $390^{\circ}$. In the radial direction the torch is forced outward to bear against the 
metal to be cut, or it is completely withdrawn. Two arms, or torch holders, are used, one driven hydraulically for underwater work and an electrically driven arm for in-air cutting. The design of each arm reflects the criteria imposed by the cutting situation.

A control system controls the position and movement of the manipulator (thereby the torch), all of the cutting process parameters and a special sequence of operations. The panel shown in Fig. 2, which houses the controls, is located in an area remote from the manipulator and torch but connected by a bundle of hoses and power and signal wires. Included in this bundle are the following; air to keep water out of the torch, torch cooling water, nitrogen cutting gas, argon starting gas, d-c power to the torch, and to the drive motors, tachometer and position potentiometer signals, etc.

The cutting equipment is augmented with long handled tools for supporting and moving the cut segments and various other functions. Specially designed platforms, stands, and tool supports are also required and maintenance provisions have to be considered. In addition to the mechanical hardware, it is necessary to test the components both separately and assembled and to develop by trial and error the cutting parameters that would give the most satisfactory results. The development work of this type for ERR was done on small samples wherever possible.

With the equipment described and the general techniques used at the ERR, the Sodium Reactor Experiment (SRE) near Ios Angeles will also be dismantled. Atomics Intemational (AI) has acquired from ORNL, 
the control panel, which was salvaged from the ERR operation, and all of the drawings of the manipulator. The radioactive parts of the reactor will be removed, the building decontaminated, and responsibility for the site will be transferred from ERDA to AI. The work is scheduled for completion late in 1978.

Comments and Observations on Using the Plasma Torch Technique

It has been shown that dismantling is feasible and practical for small reactors that have not operated for long times. Is it feasible, safe, and practical to use the same technique on a large reactor at the end of its service life?

The two items that strongly influence this question are the increased thicknesses of the various vessels and the increased radiation levels. Modern carbon steel pressure vessels are in the range of 9 in. thick with a 0.25 in. stainless steel overlay. Thermal shields are 2.75 in. thick stainless steel. Cutting these metal thicknesses with the underwater plasma torch has not been demonstrated. Further it is expected that all of these structures would have unusual geometries such as at penetrations, reinformcements, attachments, etc. A development program would be required to demonstrate the ability to cut these thicknesses and special geometries.

The increased radiation levels, however, are the major concern. These levels can be from $10^{3}$ to $10^{5}$ times that encountered at the ERR. Costs of shipping and operations would be strongly influenced by the total curie inventory. Protection of the operating crew would be extremely difficult. The necessary techniques have not been demonstrated 
and need to be developed. The procedure used at the ERR was first to cut up and remove the reactor intemals from inside the pressure vessel, using water shielding. Then the inner thermal shield was cut under water by the plasma arc. Thus, with water shielding, the most radioactive components were handled in a straightforward way. From this point on, the cutting was done in air. Although the most radicactive components had already been removed there were higher levels of radiation during this latter operation and consequently higher crew exposures. This experience suggests to the author that the critical points to be evaluated are the radiation levels that exist at the time when there is no longer water shielding available. The time honored means to overcome the above problem, i.e., remote operations and more shielding, translate into increased costs.

In the area of waste management the record at the ERR was quite satisfactory. Established health physics field techniques and equipment were used in controlling contamination and in monitoring a wide range of environmental situations. Also there was close cooperation with the dismantling operations group in controlling potential contamination produced by the plasma-arc process. The underwater cutting produced very little airborne contamination while frequent changes of the HEPA filters in the exhaust system were required for in-air cutting.

The reservations stated above can be summed up as follows:

1. The technique cannot be applied in a rubber stamp fashion to any given reactor or radioactive system.

2. To establish whether this method is feasible for use on any specific situation it is suggested that as a minimum, an engineering 
effort is required that would consist of three parts: (a) a thorough analysis of the curie inventory and the resultant radiation levels in the plant, (b) a preliminary plan of action similar in content and detail to the Activity Specifications ${ }^{1}$ used at the ERR and (c) a cost estimate. Details of this effort are suggested in Table 1.

3. Further development of the technique is necessary to demonstrate the capability of cutting the increased thicknesses of large pressure vessels and components. Development efforts beyond the absolute minimum requirements may lead to new dismantling technqiues that would make the process easier and cheaper.

To sum up, the underwater plasma arc technology, holds promise in the field of decommissioning, but should be applied with caution, solid engineering, planning, and forethought. 
Table 1. Proposed engineering analysis to establish the feasibility for using plasma torch dismantling.

Item

1.0 Ana lysis of radiation

1.1 Curie inventories

1.2 Resultant radiation levels

1.3 Shielding for operations

1.4 Shielding for shipping

2.0 Plan of action

2. I Genera 1 procedure

2.2 Cutting operations

2.3 Contamination control and environmental protection

2.4 Transfer operations

2.5 Shipping

2.6 Development required

2.7 Alterations to the building

2.8 Special problems

3.0 Cost estimate

3.1 Site alteration

3.2 Development

3.3 Equipment

3.4 Operations - Labor

3.5 Operations - Materials

3.6 etc.
Estimated Effort

(manyears)

1.5

.2

Total $\overline{2 *}$

* over a 6 month time span 


\section{REFERENCES}

1. United Power Association, Elk River, Minn. "Final Elk River

Reactor Program Report" CO0-651-93, September, 1974, revised November 1974.

2. J. F. Nemec, R. M. Beckers, and R. Blumberg, "Radioactive Operations in the Dismantling of the Elk River Reactor" Proceedings of the American Nuclear Society, 19th Annual Meeting, Chicago, Illinois, June 1973. 


\section{FIGURES}

Figure 1. Plasma-arc torch in the underwater development tank.

Figure 2. Plasma torch manipulator control panel. 


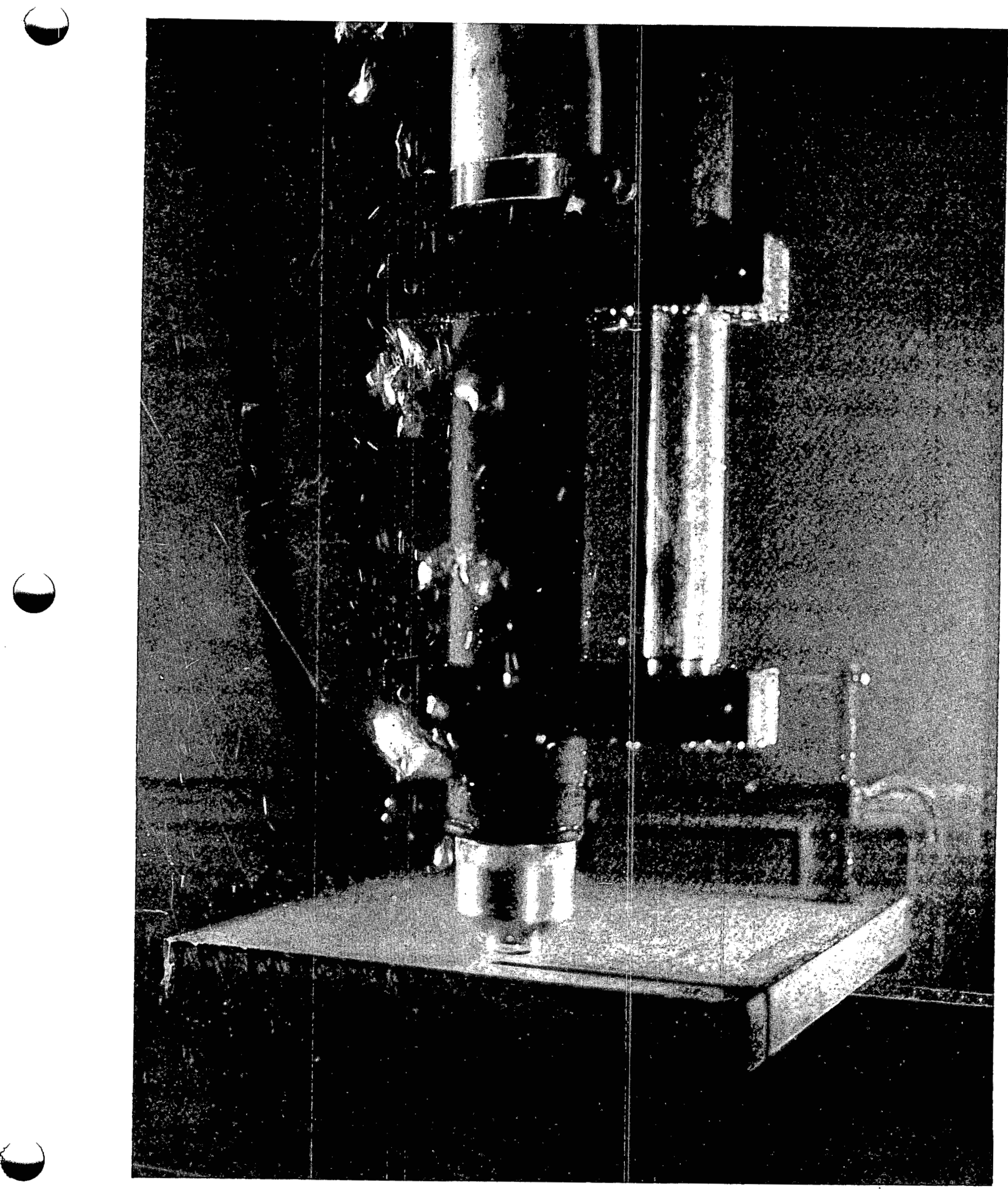

Figure 1 


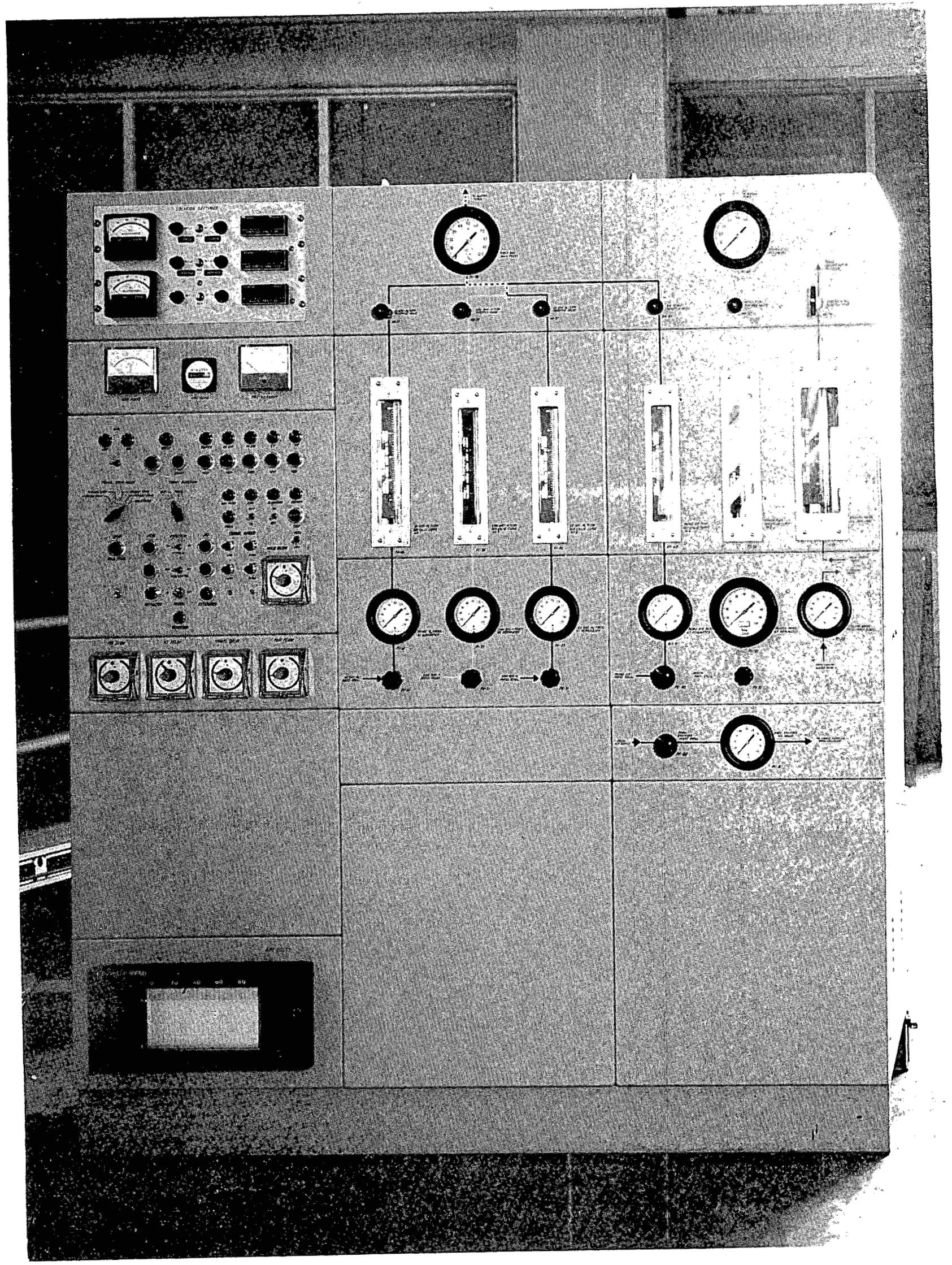

$\ominus$ 图: :

00

$a^{2}+202004$

$4+32$ or $y 9$

$=$ te eqe

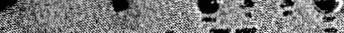

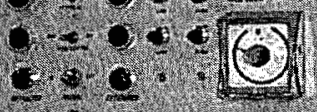

000000

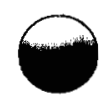

[อ][0]

$\rightarrow-0=0$

- 
ELK RIVER REACTOR DISMANTLING

Bobby J. Davis, Health Physicist Safety Division

U. S. Energy Research and Development Administration Chicago Operations office

9800 South Cass Avenue

Argonne, Illinois 60439

\begin{abstract}
$\underline{\text { ABSTRACT }}$
The Elk River Reactor (ERR) was constructed by the AEC on land leased from the United Power Association (UPA). Upon expiration of the operating term of the contract, UPA waived its option to purchase the reactor. Pursuant to the terms of the contract and lease, the AEC had the obligation to make the site usable without danger to the public health and safety. Final agreement specified that the ERR would be dismantled and removed with the exception of the underground portion of the Reactor Building. The underground portion was to be left in place and any resulting cavities filled with earth and rubble. The dismantling program was carried out in three overlapping phases as follows:
\end{abstract}

1. The Planning Phase which included the preliminary planning and selection of the dismantling approach.

2. The Dismantling Phase which included all work performed to remove the reactor facility and restore the site to its pre-reactor condition, and

3. The Closeout Phase which included the final site survey and efforts necessary to terminate the AEC license and contract.

of particular interest was the use of a remotely operated plasma cutting torch to section the pressure vessel internals, the pressure vessel and the outer thermal shield, the use of explosives in removal of the biological shield and the method of establishment of the criteria for material disposal. 


\section{INTRODUCTION}

The Elk River Reactor (ERR), a $58 \mathrm{MW}(\mathrm{th})$, indirect-cycle, natural circulation, boiling water reactor was constructed by Allis-Chalmers under an Atomic Energy Commission (AEC) contract and was operated by the United Power Association (UPA) of E1k River, Minnesota, under contract to the Commission. The reactor was constructed adjacent to an existing conventional steam electrical plant on land owned by UPA and leased to the AEC (Figure 1).

Initial reactor criticality was achieved on November 19, 1962, with power operation commencing on July 13, 1964. The plant was commercially operated by UPA until final shutdown on January 31,1968 , resulting in a total of $53,000 \mathrm{MWD}_{\text {th }}$ of power.

Upon expiration of the operating term of the contract, UPA waived its option to purchase the plant. Pursuant to the terms of the contract and lease, the AEC had the obligation to make the site usable without danger to the public health and safety. The final agreement between UPA and the AEC specified that the ERR would be dismantled and removed approximately to grade with the exception of the underground portion of the reactor building which would be completely removed and that the resulting cavities would be filled with earth and rubble.

Physical dismantling began in June 1972 and was completed in July 1974 . Upon completion of the dismantling operation, the site was returned to 
approximately the condition which existed prior to the installation of the reactor with all vestiges of the reactor plant having been removed (except for portions of subgrade foundations). The final radiation survey of the site produced no evidence of radiation levels in excess of normal background. No license or other authorization is required and no continuation of radiological monitoring is necessary.

\section{GENERAL SUMMARY}

The ERR dismantling program was carried out in three overlapping phases which can be identified as follows:

A. Planning Phase - This included the preliminary planning and the selection of the dismantling approach with analyses of feasibility and cost. Scoping documents describing the general dismantling sequence were prepared including, the Elk River Reactor Dismantling Environmental Statement, the Elk River Reactor Dismantling Plan, eleven Activity Specifications, and twenty-one Detailed Working Procedures.

B. Dismantling Phase - This phase included all work performed to remove the ERR facility and restore the site. Minor revisions were made to the methods developed in the planning phase to accommodate existing field conditions.

C. Facility Closeout Phase - This phase included those activities necessary to terminate the "Possession Only" authorization and the AEC contract. These activities included preparation of a Final Radiation Survey Report and Final Program Report.

The responsibilities of the major participants in the dismantling program are outlined below: 
A. United Power Association Responsibility

UPA performed the authorized dismantling activities retaining full responsibility for all of the work including safety. UPA identified and retained approval controls over those portions of the AEC Dismantling Plan and Activity Specifications which might have endangered the integrity of UPA's steam electric generating facilities.

To provide assurance that UPA management was carrying out its responsibilities for the protection of the public, plant personnel and property from any attendant hazards during these operations, a Safety Review Committee was appointed by UPA and acted as an independent advisory group to UPA management, and as such, provided independent safety review of activities during the ERR dismantling program.

B. Gulf United Nuclear Fuels Corporation (GU) Responsibility GU prepared and recommended an AEC Dismantling P1an and Activity Specifications for review and comment by all participants. It also provided UPA and the AEC, as requested, engineering services, safety committee participation and other services and support for the dismantling both on and off-site.

C. Atomic Energy Commission Responsibility

1. Chicago Operations office (CH)

a. $\mathrm{CH}$ was responsible for all contract activities including safety and the management of the dismantling including the administration of the UPA and GU contracts. $\mathrm{CH}$ provided official notice to UPA and GU of AEC approvals for the Dismantling Plan, Activity Specifications, safety, con- 
struction and subcontracts and other actions requiring AEC approva1.

b. The CH-ERR Site Representative (AEC Representative) provided UPA and GU with official AEC approval of Detailed Working Procedures and such other actions under a) above which were specifically delegated to him, monitored the work, and assisted participants in the dismantling effort.*

2. Division of Waste Management and Transportation (WMT)* WMT provided programmatic and technical responsibility for the work.

III. PROGRAM PLANNING

For planning purposes the dismantling was divided into eleven major tasks as follows:

A. Facility and site preparation.

B. Removal of equipment and systems exterior to the biological shield not required to support other dismantling activities.

C. Removal of the coal-fired superheater and associated systems.

D. Removal of the superheater and a portion of the service building connecting the reactor building with the UPA Steam Plant facility.

E. Removal of the pressure vessel internals.

F. Removal of the pressure vessel and segmentation of the outer thermal shield.

G. Remova1 of the outer thermal shield and all radioactive or contaminated structures.

* Originally, these activities were the responsibility of the Division of Reactor Development and Technology. 
H. Removal of the reactor building and all remaining non-contaminated equipment contained therein.

I. Removal of miscellaneous equipment.

J. Disposal of all government-owned property.

K. Program closeout including final radiation survey and program reports.

The documentation required for each major task consisted of an Activity Specification which provided a general scope including sequencing, health and safety considerations, and a conceptual design for special tooling. Each Activity Specification was supported by engineering studies to scope or justify the activity and contained technical guidelines for the preparation of Detailed Working Procedures. The Detailed Working Procedures were prepared immediately prior to the implementation of a particular task and included a step-by-step removal approach, tooling requirements, and a discussion of radiological and industrial safety requirements.

The general dismantling sequence evolving from the planning may be divided into three distinct but overlapping stages: 1) Removal of the most highly radioactive components including the reactor internals, pressure vessel, etc; 2) Removal of plant systems and equipment outside the biological shield containing low levels of radioactive contamination; and 3) Removal of noncontaminated structures.

The second and third stages were in general accomplished using conventional demolition techniques and will not be addressed further. Only those activities concerned with the removal, packaging, and disposal of the most 
highly radioactive components (Tasks $\mathrm{E}$ and $\mathrm{F}$ noted above) and other contaminated structures (Task G above) will be discussed.

IV. Removal and Disposal of Pressure Vessel Internals, Pressure Vessel and Segmentation of the Outer Thermal Shield

The removal of reactor internals (shown schematically in Figure 2) involved handling highly radioactive components. The calculated inventory of radioactivity and the contact radiation levels of these components are given in Figure 3.

A. Equipment

With the exception of the equipment used to segment: the inner thermal shield, pressure vessel, and outer thermal shield, the equipment used was typical of long-handled special purpose equipment used at most reactor installations.

The equipment used to remotely segment the inner thermal shield, pressure vessel and outer thermal shield consisted of a system of inter-related parts which can be describea as follows:

1. A cutting torch system which consisted of all the usual equipment required for operating a commercial plasma or oxy-acetylene torch.

2. A manipulator which carried the torch through the required range of travel, provided structural strength for torch rigidity, and provided accurate control of torch speed and torch-to-work distance.

3. A system which provided remote control of the manipulator and the cutting process. 
4. Segment handling tools.

5. Other miscellaneous equipment including a contamination control system, manipulator storage stand, support platform, and lower radial bearing.

The testing and development work required to bring the plasma and oxy-acetylene cutting process to the desired level of readiness involved three different testing programs: a) bench scale tests, b) full scale mockup tests of the complete manipulator and plasma torch system, and c) separate tests of the in-air cutting procedures.

The data obtained from this testing program established all of the parameters for both underwater and in-air plasma arc cutting including voltage, amperage, torch-to-work distance, nozzle size, gas flow, travel speed, and starting conditions.

A preliminary testing program for segmentation of the outer thermal shield indicated that the plasma torch technique was not feasible for this operation since cutting was required in areas containing lead. Therefore, an additional development effort was conducted which resulted in an oxy-acetylene torch system which could be mounted on the original manipulator.

B. Removal

The upper stainless steel control rod guide and shroud assembly was the first internal component to be removed. It was mechanically attached to the lower shroud assembly with tackwelded machine screws. 
The upper shroud was separated from the lower shroud by use of a hydraulic bolt shearing tool. After detachment, the shroud was transferred in-air from the reactor vessel to the fuel element storage well (FESW) and placed on an underwater cutting platform where a commercially available sheet metal nibbler, modified for both underwater and remote operation was used to segment the shroud into suitable sizes for loading into two shielded cask liners (Figure 4).

The lower zircoloy control rod guide and shroud assembly was separated from the shroud support plate by shearing 36 stainless steel cap screws. After detachment, the lower shroud was transferred in-air to the FESW where it was segmented and packaged in the same manner as the upper shroud.

Detaching the shroud and core support plate from the support stand was relatively simple as it only required the removal of four captive bolts using a long-handled socket tool. After detachment, the plate was lifted, moved through the fuel transfer canal to the FESW and loaded directly into a shielded cask liner.

The core support stand was attached to the pressure vessel with four captive bolts which were removed using a long-handled socket too1. The stand was then transferred in-air to the FESW for underwater loading into a shielded cask liner. 
The feedwater distribution ring and four shadow shields were fastened to the inner thermal shield with bolts which were removed using an air-operated impact wrench. The shadow shields were loaded underwater directly into a shielded cask liner located in the bottom of the pressure vesse1. The feedwater distribution ring was removed in four segments and transferred in-air to a cask liner located in the FESW.

A commercially available hand-held plasma arc cutting torch was used to segment the stainless steel steam baffle while a remotely operated plasma torch was used to segment the inner thermal shield (Figure 5). This latter component was a 1-inch thick, type 304 stainless steel cylinder approximately 81 -inches I.D. and 12-feet high. A11 cutting was done underwater within a containment enclosure formed by the side walls of the reactor cavity. All penetrations into the cavity were sealed and a metal cover called a contamination control envelope was placed over the cavity. The containment enclosure had a separate exhaust fan and filtering system containing a prefilter and a high efficiency particulate filter capable of removing most of the airborne contamination generated during cutting operations. After segmentation of the inner thermal shield, the contamination control envelope was removed and the segments were transferred to the FESW for underwater loading into a cask liner.

The next major task was removal of the pressure vessel. The vessel was an 84-inch I.D. cylinder approximately 25-feet in height with 
3-inch carbon steel walls and a 0.1-inch, type 304 stainless steel inner cladding. The pressure vessel was segmented using the plasma torch equipment described previously with modifications to the torch and torch arm. Cutting was performed in-air within the containment enclosure with the vessel water level maintained slightly below the cut elevation. The upper six-foot section of the vessel including the vessel flange was removed as one piece, (Figure 6), sealed with metal plates and shipped as its own container. The remainder of the vessel was cut into 19 segments. The segments were transferred in-air to cask liners either located on the main operating floor or in the FESW (Figure 7).

The outer thermal shield consisted of a 3-inch annulus of lead sandwiched between two 3/4-inch carbon steel plates and was approximately 15-1/2 feet in height and 8-1/2 feet in diameter. It had been fabricated in three $120^{\circ}$ sections and assembled onsite utilizing 3-inch thick welded carbon steel joints.

Since the temperatures generated by the plasma torch would cause significant lead vaporization, it was necessary that an oxy-acetylene torch system which operated at a lower temperature be used for segmentation of the outer thermal shield. The torch system was mounted on the plasma torch manipulator and operated from a remote location outside the containment enclosure. The geometry of the cutting in this case was more complex than for either the inner thermal shield or the pressure vesse1. Approximately 300 cuts were required of six 
different types; namely, (1) 3/4-inch plate with lead backing, (2) lead melting, (3) stainless steel cooling tubes, (4) 3/4-inch plate with concrete backing, (5) 5-1/2-inch carbon steel plate with concrete backing and (6) severing of stainless steel cooling coil penetrations. The cutting pattern resulted in six large segments which were transferred in-air to shipping containers (Figure 8) located on the basement floor of the reactor building.

V. Removal and Disposal of Radioactive and Contaminated Materials from the

\section{Biological Shield and Reactor Building}

A. Description of Structures

An isometric view of the ERR biological shield (B/S) and fuel element storage well is shown in Figure 9. This structure was approximately 45-feet high with a maximum thickness of 9-feet and was composed of 3,500 psi (minimum) concrete reinforced with $\# 9$ rebar located at a depth of approximately 4-inches from all exposed surfaces on a 12-inch by 12 -inch vertical and horizontal grid with additional reinforcement at various elevations.

The operating floors in the reactor building consisted of the subbasement floor which contained the building sump and liquid waste processing equipment, the basement, the intermediate floor, and the main floor, each of which was reinforced with 16 and $\# 9$ rebars on 12-inch centers.

B. Remova1 Methods

The following criteria were considered in selecting a removal method for the concrete and associated steel structures: 
1. Confinement of the reactor building could not be breached until all radioactive material had been removed or adequately contained.

2. The removal method had to lend itself to control of airborne and surface contamination.

3. The spread of contamination outside of the reactor cavity during removal of the interior portion of the cavity had to be minimized.

4. The removal method could not affect operation of the UPA fossilfired electrical generation plant.

5. Radiation exposure to dismantling personnel had to be minimized.

6. The size and weight of removed materials had to be controlled to meet shipping and burial criteria.

Experience during the dismantling indicated that both flame cutting and thermal lance techniques were not feasible due to the generation of large quantities of toxic gases and smoke.

Drilling and rock-jacking were feasible for the removal of concrete walls up to a maximum thickness of 2-feet; however, the time required made these methods uneconomical. Rock-jacking is also not an effective method for the removal of thick, heavily reinforced concrete structures such as the $\mathrm{B} / \mathrm{S}$. Other methods including the use of a demolition ball and wall sawing were considered. In both cases, tests carried out indicated that these techniques were not feasible from a time or production standpoint.

The use of explosives for removal of the B/S and FESW was only con- 
sidered after all other techniques had proved unsuccessful. The main concerns in using explosives were the control of airborne contamination and the assurance that vibrations generated by the blasting would not disrupt the operation of the turbine generators in the UPA Steam Plant. Consequently, a testing program which consisted of loading progressively larger charges in the upper portion of the $\mathrm{B} / \mathrm{S}$ and measuring the vibrations and dust levels resulting from their detonation was made. The results of these tests indicated that a maximum charge weight per delay of $1-1 / 4$ lbs. could be used without producing vibrations in excess of those normally seen during startup of the turbine generators and that airborne contamination could be controlled using blasting mats and a localized fog spray system.

\section{Operations}

Al1 blasting operations were under the direct control of a qualified explosives engineer. In addition, a Detailed Working Procedure was written to assure administrative control of the blasting operations. This procedure provided a general removal sequence and specified the radiological and industrial safety criteria to be used during the blasting.

In general, two types of drill patterns were used. The first pattern consisted of $1 / 2$ to 5 -foot deep boreholes with burdens of $1-1 / 3$ to 1-1/2 feet and spacings of $1-1 / 2$ to 3 feet depending upon the reinforcing rod pattern and location. This pattern was then usually loaded with conventional cartride type dynamites. 
The second type of drill pattern involved boreholes 12 to 16 feet in depth with burdens of 8 to 18 -inches and fairly wide spacings of $2-1 / 2$ to 5 -feet. The smaller burden and larger spacings were used to remove reinforcing rod mats located 4-inches from exposed surfaces. Removal of these rod mats provided good relief to the next row of production holes which were drilled using larger burdens and smaller spacings. Both vertical and horizontal holes were used and they were normally loaded with several strands of detonating cord.

The maximum blast fired inside the reactor building was $1-1 / 4$ lbs. per delay on 20 delays.

No air blast pressure damage occurred during the blasting operations conducted within the sealed reactor building. Outside noise levels were minimal although some blasts could be faintly heard approximately 300 feet from the blast site.

All blasts were monitored using accelerometers mounted on the turbine generator pedestals in the UPA Steam Plant. In addition, a portable seismograph was used to monitor vibrations at various locations on the reactor site. During blasting, no vibrations were produced which exceeded the normal startup vibrations of the UPA Steam Plant turbine generators.

D. Remova1 Sequence

Radiation surveys performed prior to the beginning of major demolition work indicated that the following structures contained sufficient 
radioactive contamination to require their removal under existing radiation procedures:

1. B/S and FESW

2. Main, intermediate, and basement floors

3. Subbasement floor (contaminated to a depth of approximately 6-inches)

Contamination also existed at isolated areas including portions of the reactor building inner concrete liner. The general sequence of demolition proceeded from the top of the B/S downward. Attempts were made to identify all radioactive or contaminated material and remove it as the demolition proceeded toward the subbasement.

The first structure to be removed using explosives was the portion of the $\mathrm{B} / \mathrm{S}$ extending from elevation $947 \mathrm{ft} .6$ in. to elevation $938 \mathrm{ft} .0$ in. The majority of concrete in this area was noncontaminated; however, surface contamination resulting from reactor operations (fuel transfer, other dismantling activities), did exist at elevation $947 \mathrm{ft} .6 \mathrm{in}$. and on the inner and outer surfaces of the reactor cavity.

The next structure to be removed was the main floor at elevation $938 \mathrm{ft}$. 0 in. Various removal methods were considered including wall sawing techniques. However, it was found that the most efficient method for removal of the floor consisted of using a jackhammer to expose the rebar on a given floor area supported by a floor beam. 
After the rebar was exposed and a crane attached to the floor slab, the ends of the support beam were cut using explosives. The rebar was then cut and the floor slab removed and prepared for shipment.

The next stage of demolition consisted of removal of the entire B/S and FESW structure from elevation $938 \mathrm{ft} .0$ in. to elevation $923 \mathrm{ft} .0$ in. Although radioactive contamination existing in this area was higher than in the upper portion of the $\mathrm{B} / \mathrm{S}$, the possibility of an airborne contamination problem was still minimal and therefore, the major concern during this phase was efficiently removing the materia1.

The next phase of $B / S$ removal consisted of the removal of the relatively highly radioactive portion of the $\mathrm{B} / \mathrm{S}$ extending from elevation $923 \mathrm{ft} .0 \mathrm{in}$. to $903 \mathrm{ft}$. 0 in. In this particular phase, contamination control was the prime consideration and therefore, all blasting operations proceeded from inside the reactor cavity outward (Figure 10) with an appropriate seal over the top of the cavity at elevation $923 \mathrm{ft} .0$ in. Starting with the inner ring of reinforcing rods, progressively larger rings were removed. Excellent control of debris and dusts was exercised and no significant airborne contamination problems were encountered.

The final phase of work consisted of removal of the remaining $B / S$ and FESW structure, the intermediate and basement floors and removal of approximately 6-inches of the subbasement floor (Figures 11 and 12). 
In general, these activities were carried out using methods similar to those used for the previous work.

E. Material Disposal

For obvious economic reasons, it was desirable to dispose of as much demolition debris as possible in local landfills. Because there were no burial facilities for radioactive materials in the State of Minnesota, a lack of disposal standards for activated materials, and because of existing adverse public reaction to the nuclear industry from certain sectors, great pains were taken to insure that no radioactivity above background, remained in the structures that were disposed of in Minnesota. For these reasons, the term "detectable reactor originated radioactivity" or DROR was specified contractually and defined for this project. It should be emphasized that DROR as defined below is unique to the ERR project, it is a one-time requirement, and there is no intent to suggest a guideline for future decommissioning actions or to supercede guidelines issued by the Nuclear Regulatory Commission. The term DROR was applicable only to demolition rubble that was to be left in the State of Minnesota and was defined procedurally by a special sampling and analytical method. Briefly the sampling technique involved removal of at least 50 pounds of surface concrete in situ from a predetermined sampling area of approximately $200 \mathrm{ft}^{2}$ or less (Figure 13). If the concrete were in the form of rubble, sufficient 50 pound random samples were taken to represent $1 \%$ of the total weight of the rubble sampled. Samples were analyzed by gamma spectrometric analysis with a large volume (4-inch $\mathrm{x} 5$-inch) NaI(T1) crystal. Normal background radiation levels in concrete were 
determined with a number of samples taken at the site but outside of the reactor building. For the two radionuclides most often observed in structural materials ${ }^{137} \mathrm{Cs}$ and ${ }^{60} \mathrm{Co}--$ the minimum detectable activity at the two-sigma level was estimated to be 0.12 and $0.04 \mathrm{pCi} / \mathrm{gm}$, respectively. If a sample of concrete did not contain these concentrations, the concrete was judged to be free of detectable reactor originated radioactivity and was disposed of at a sanitary landfill near the ERR site.

VI. Radiological Conditions and Personne1 Exposure

In spite of the attention given during dismantling to remote or underwater operations, the use of temporary radiation shielding and other safeguards, significant radiation exposure was received by those engaged in dismantling activities. The greatest portion of this exposure was received during almost constant work in low level radiation fields, varying between 5 and $15 \mathrm{mR} / \mathrm{hr}$.

During dismantling, a total of 75 rem of whole body penetrating exposure was received by approximately 100 people connected with the dismantling project. The average whole body exposure was about 0.8 rem while the maximum total exposure received by any workman was about $4.5 \mathrm{rem}$.

Dismantling operations required the expenditure of approximately 12 rem of personnel exposure for removal of the reactor internals, 45 rem for removal of the pressure vessel and outer thermal shield, 12 rem for removal of the biological shield, and 6 rem for removal of systems external to the biological shield. 
Internal deposition of radioactive material in personnel was estimated periodically with a whole body counter. The radionuclides identified by whole body counter examination were exclusively ${ }^{137} \mathrm{Cs}$ and ${ }^{60} \mathrm{Co}$. No internal deposition exceeded $1 \%$ of a maximum permissible body burden even though airborne levels of radioactivity were significant at times. This may be attributed to detailed preplanning, training, and the liberal use of various types of respiratory protective equipment.

\section{Program Costs}

The total project cost (including $\$ 418,000$ of technical support services provided by Gulf United Nuclear Fuels Corporation under a separate prime contract with $\mathrm{AEC}$ ) was $\$ 6.148$ million. A summary of costs by major tasks (exclusive of technical support services) is shown in Figure 14. 
1. Final E1k River Reactor Program Report, C00-651-93, September 1974, Revised November 1974.

2. Final Report of the Safety Review Committee for Decommission and Dismantling of the United Power Association's Elk River Reactor, dated July 26, 1974.

3. Final Elk River Reactor Site Survey, Results and Summary, C00-651-92, Ju1y 23, 1974 
1. E1k River Reactor Plant

2. Pressure Vessel Internals and Outer Thermal Shield

3. Reactor Internals Radiation Levels and Radioactive Inventory

4. Segmentation of Shroud

5. Installation of Plasma Torch Manipulator

6. Upper Pressure Vesse1 Section

7. Pressure Vessel Segment Transfer

8. Outer Thermal Shield Concrete Shipping Vault

9. Isometric Section of the Biological Shield and Fuel Element Storage Well

10. Explosive Removal of Biological Shield Concrete

11. Removal of Subbasement Wa11s

12. Explosive Scarfing of Subbasement Floor and Walls

13. Wall Sampling for Detectable Reactor Originated Radioactivity

14. Project Costs 


\section{C}

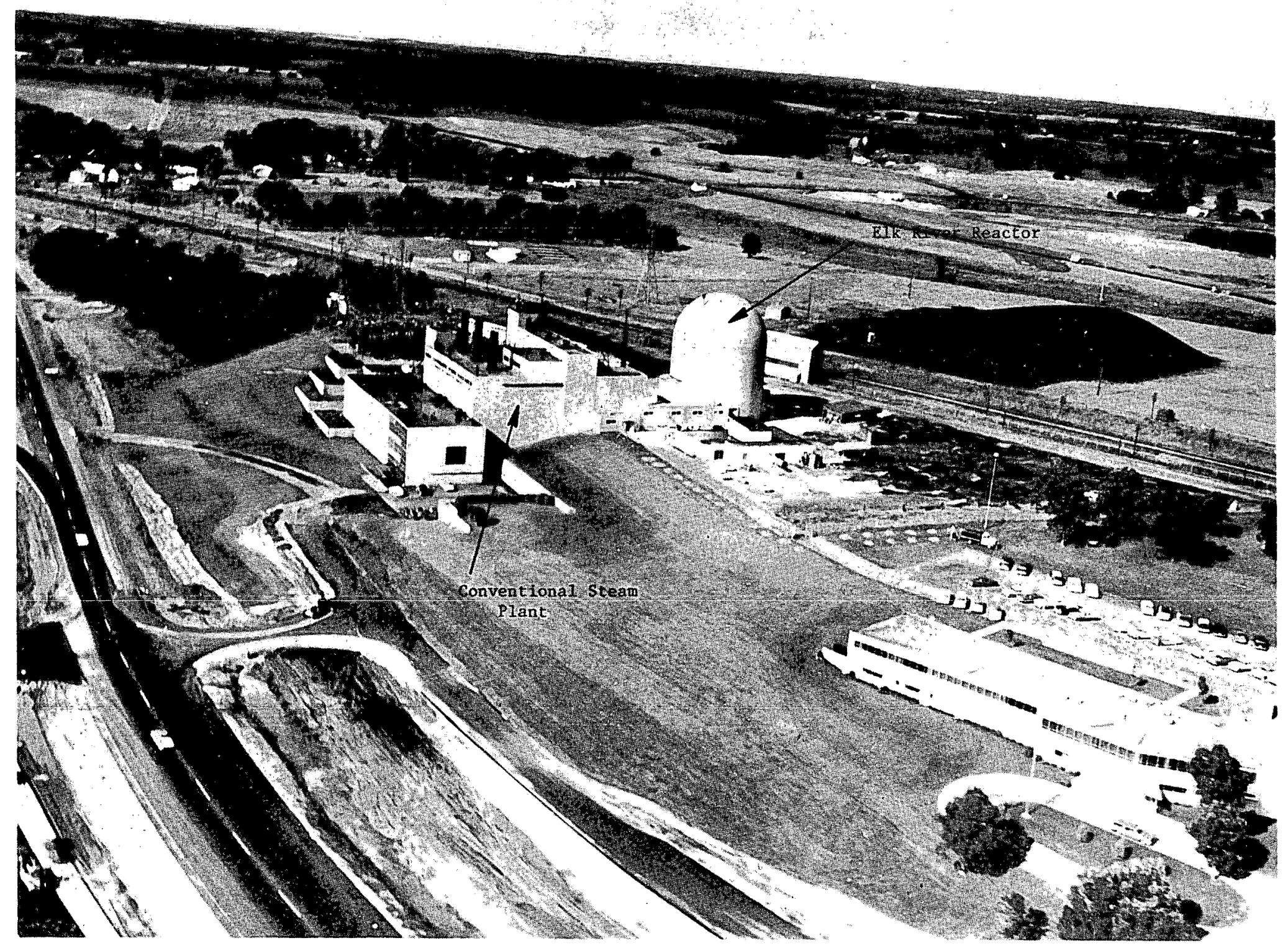

Figure 1

E1k River Reactor Plant 
FIGURE 2

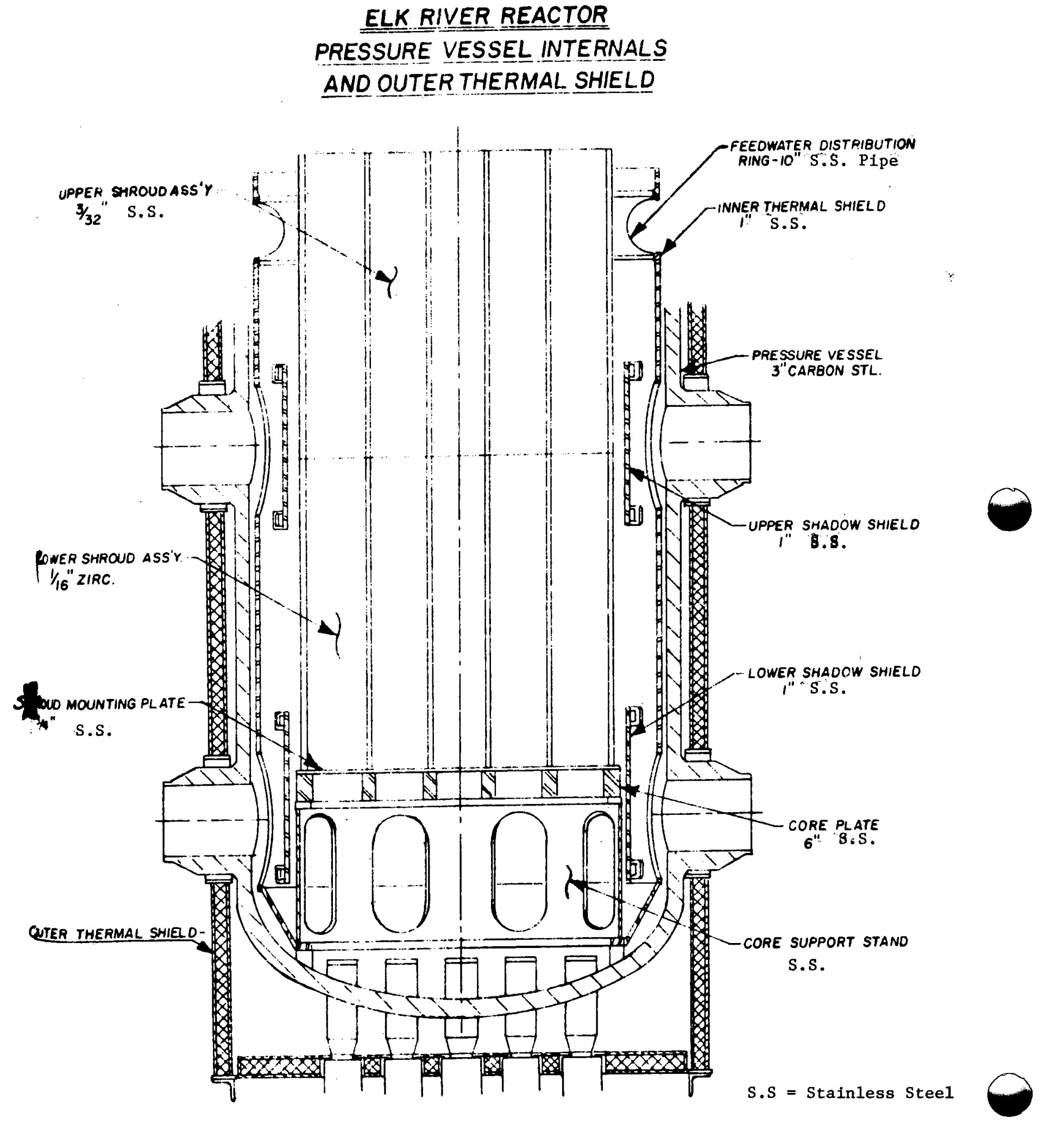


Figure 3

\section{REACTOR INTERNALS RADIATION LEVELS AND RADIOACTIVE INVENTORY}

COMPONENT

S. S. SHROUD

ZIRCALOY SHROUD

CORE \& SHROUD PLATES

CORE SUPPORT STAND

INNER THERMAL SHIELD

SHADOW SHIELDS

FEEDWATER DISTRIBUTION

RING
MAXIMUM CONTACT

RADIATION LEVEL, R/hr

2800

175

8000

150

1000

3000

60
INVENTORY

(CURIES)

770

35

2370

100

3090

2330

75 


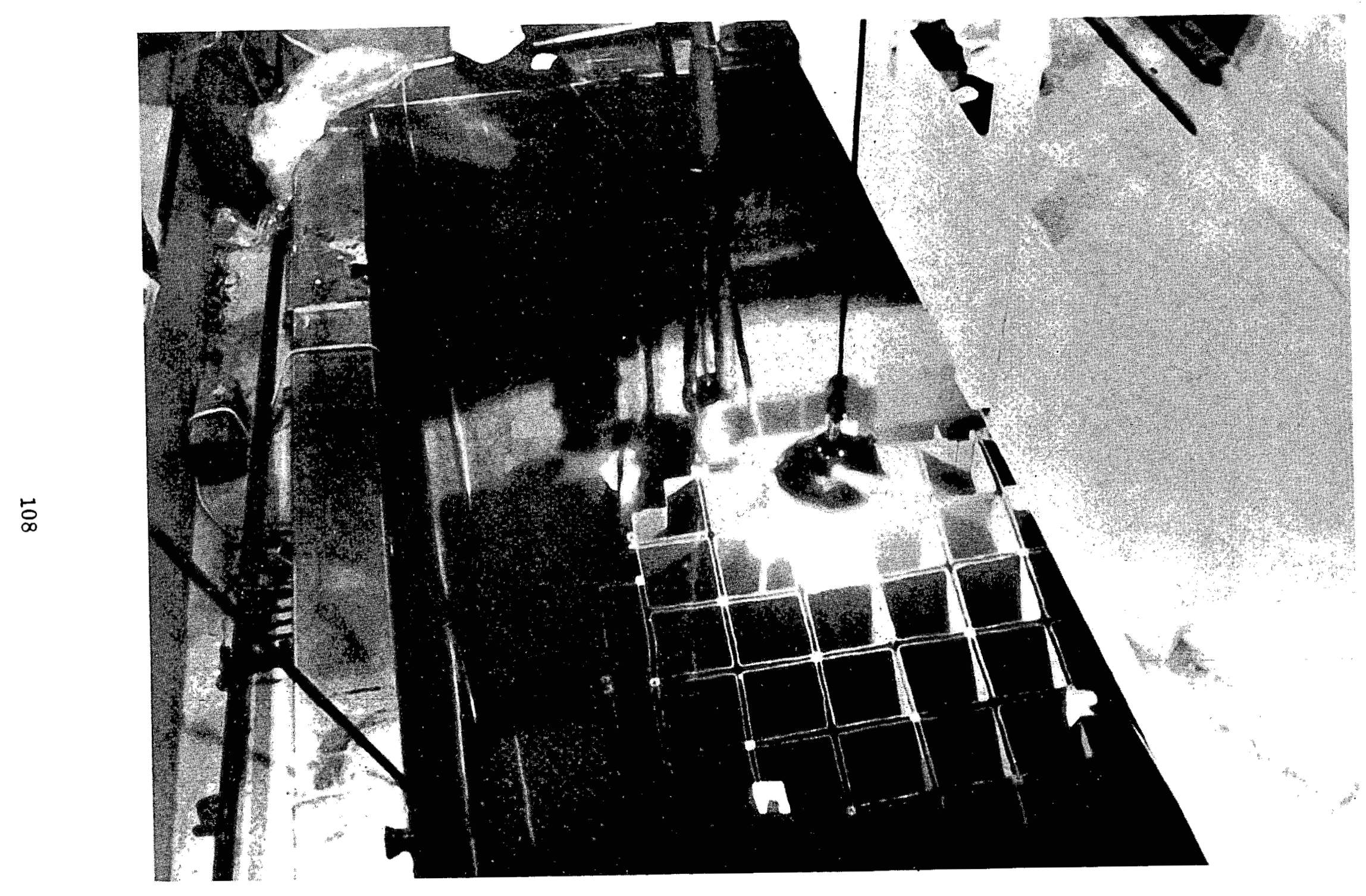

Figure 4

Segmentation of Shroud 


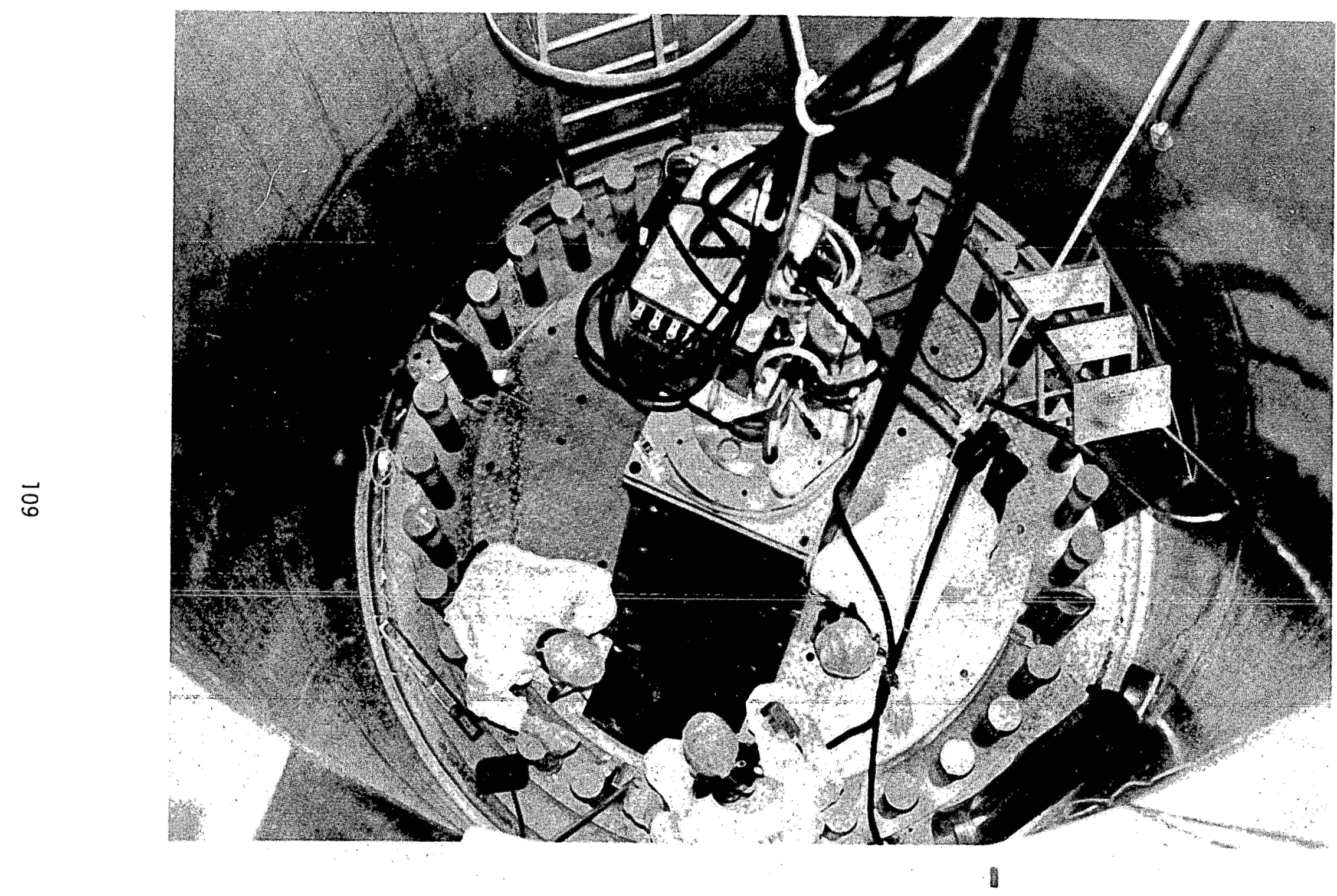

Figure 5

Installation of Plasma Torch 


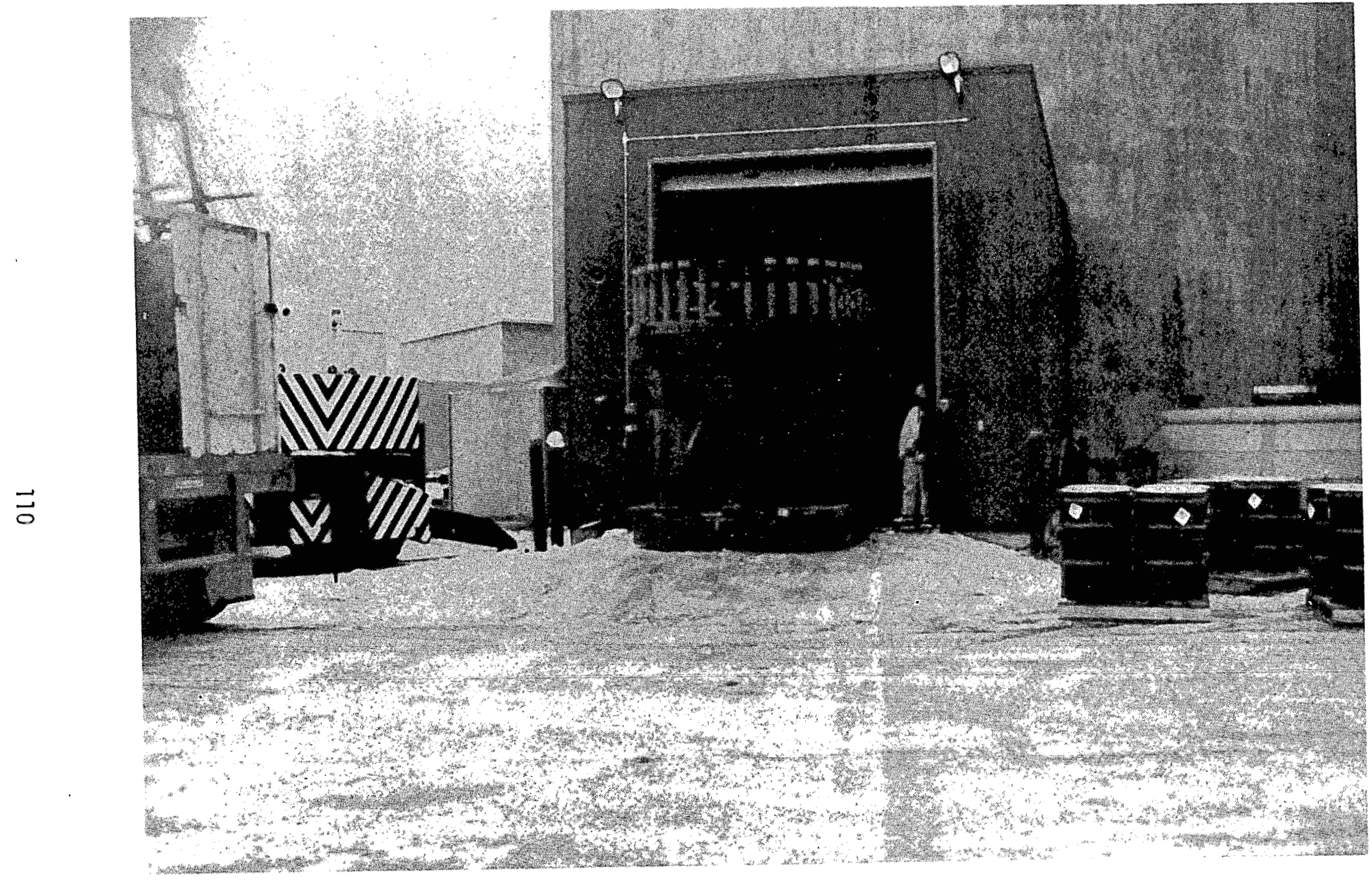

Figure 6

Upper Pressure Vessel Section 
$\begin{array}{lll}\text { C } & \text { C } & \text { C }\end{array}$

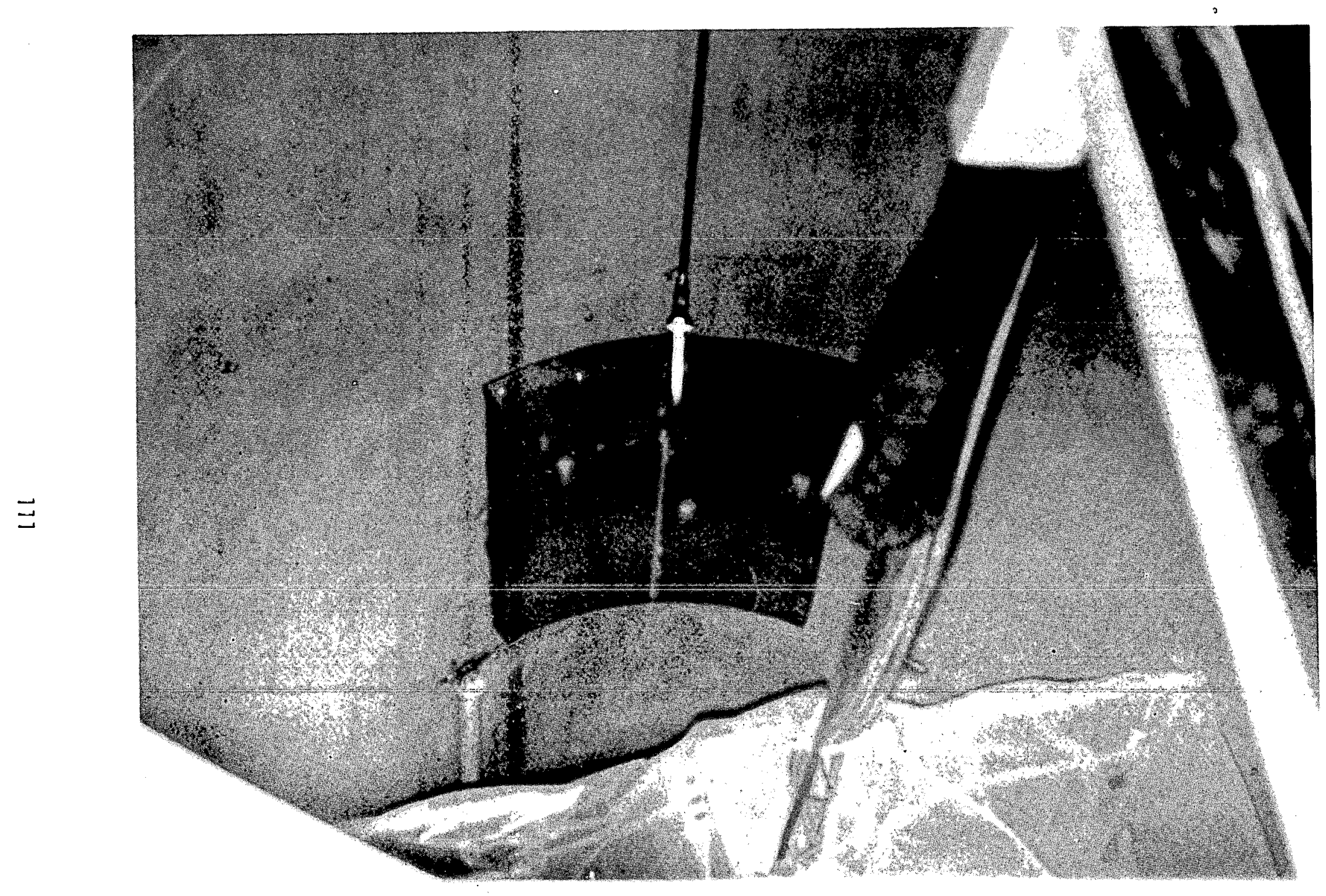

Figure 7

Pressure Vessel Segment Transfer 


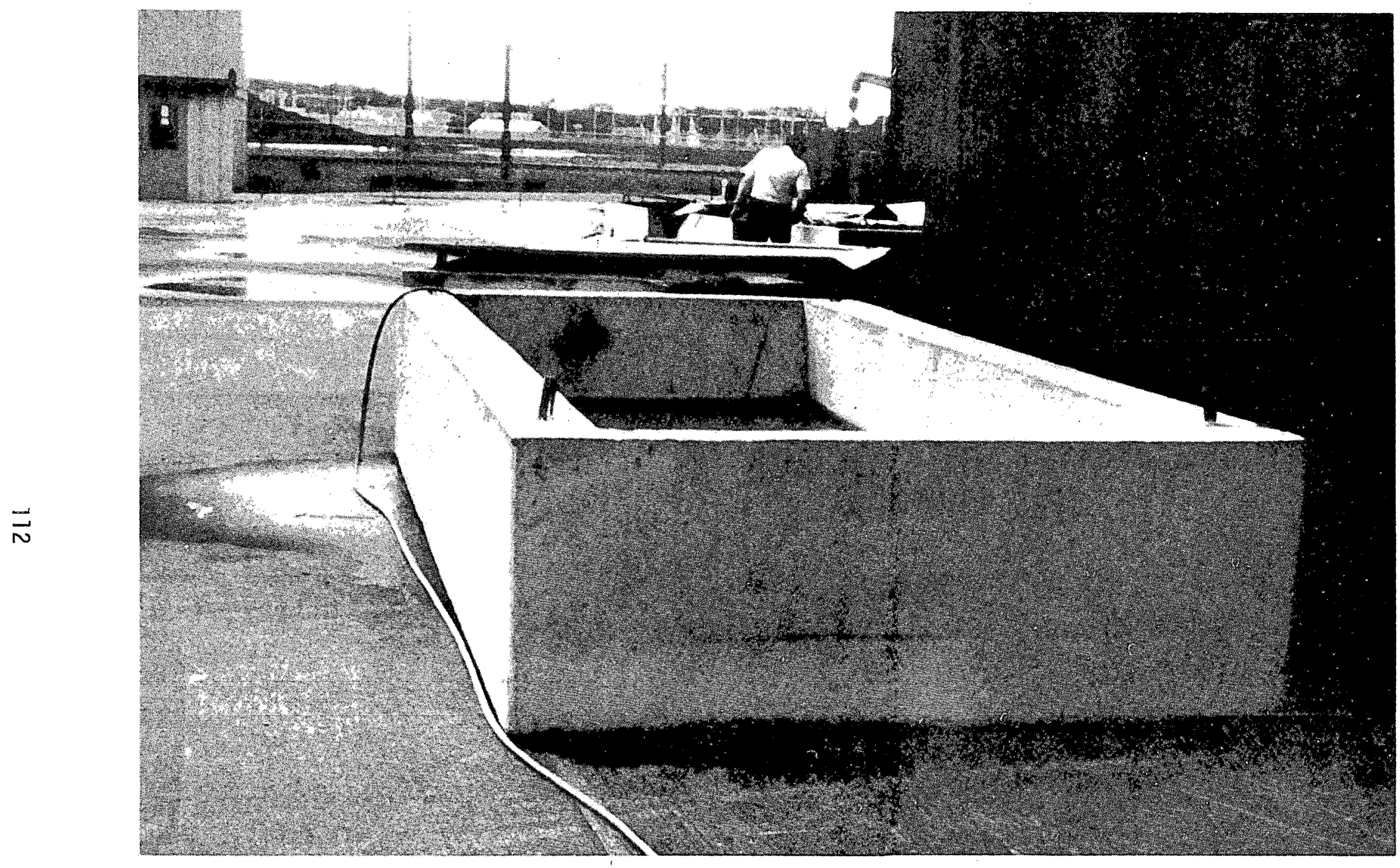

Figure 8

Outer Thermal Shield Concrete Shipping Vault 
FIGURE 9
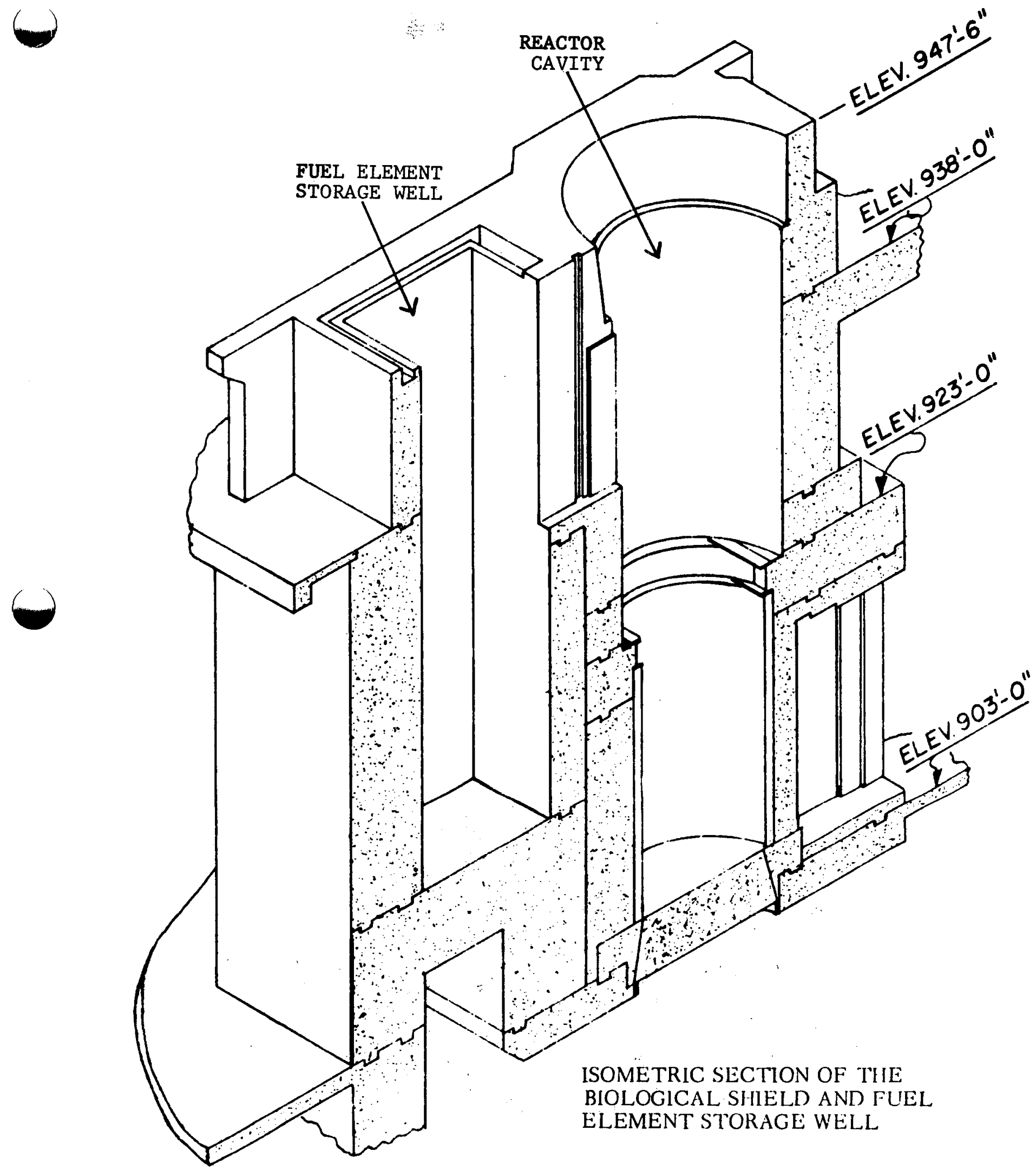


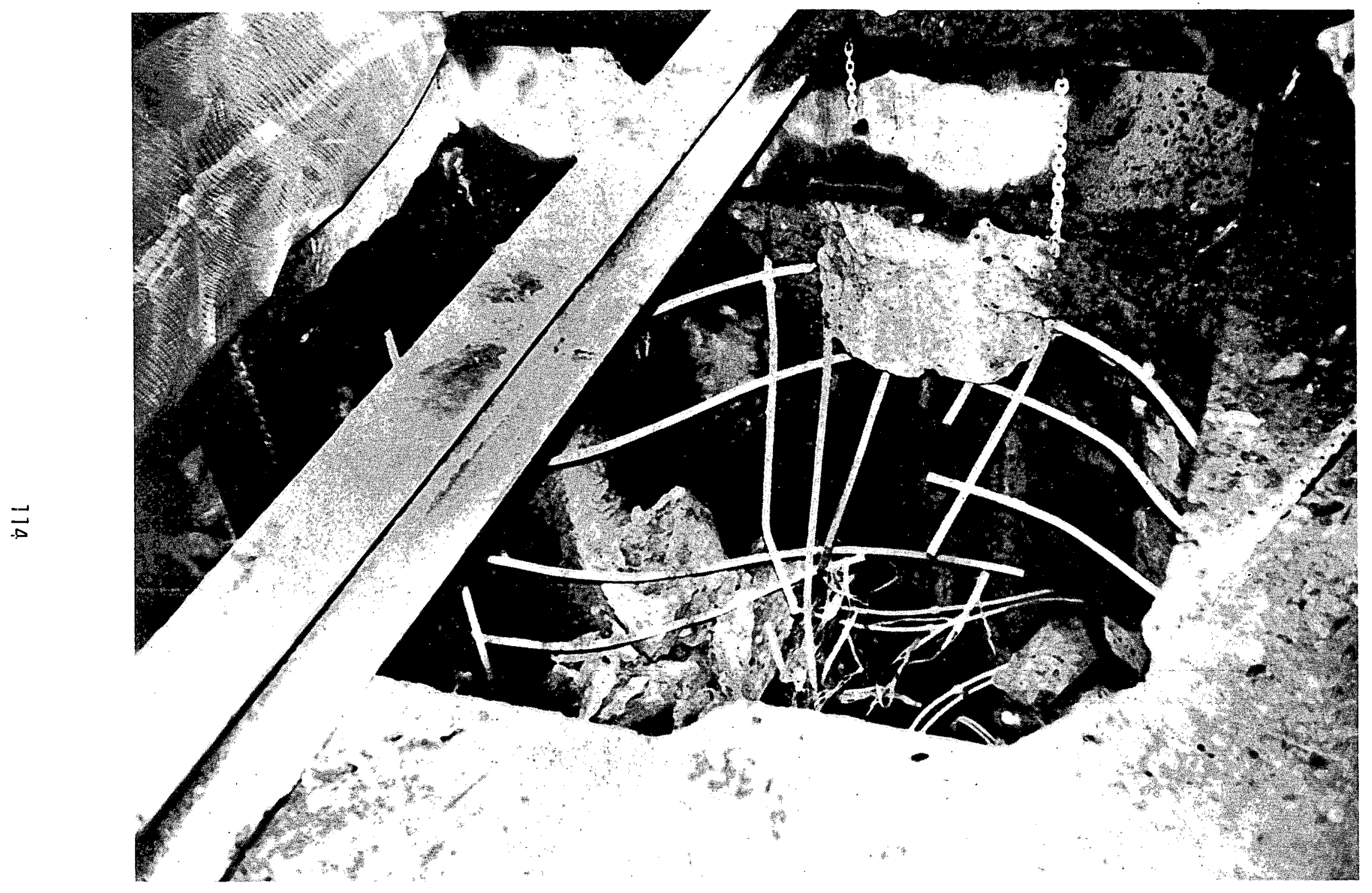

Figure 10

Explosive Removal of Biological Shield Concrete 


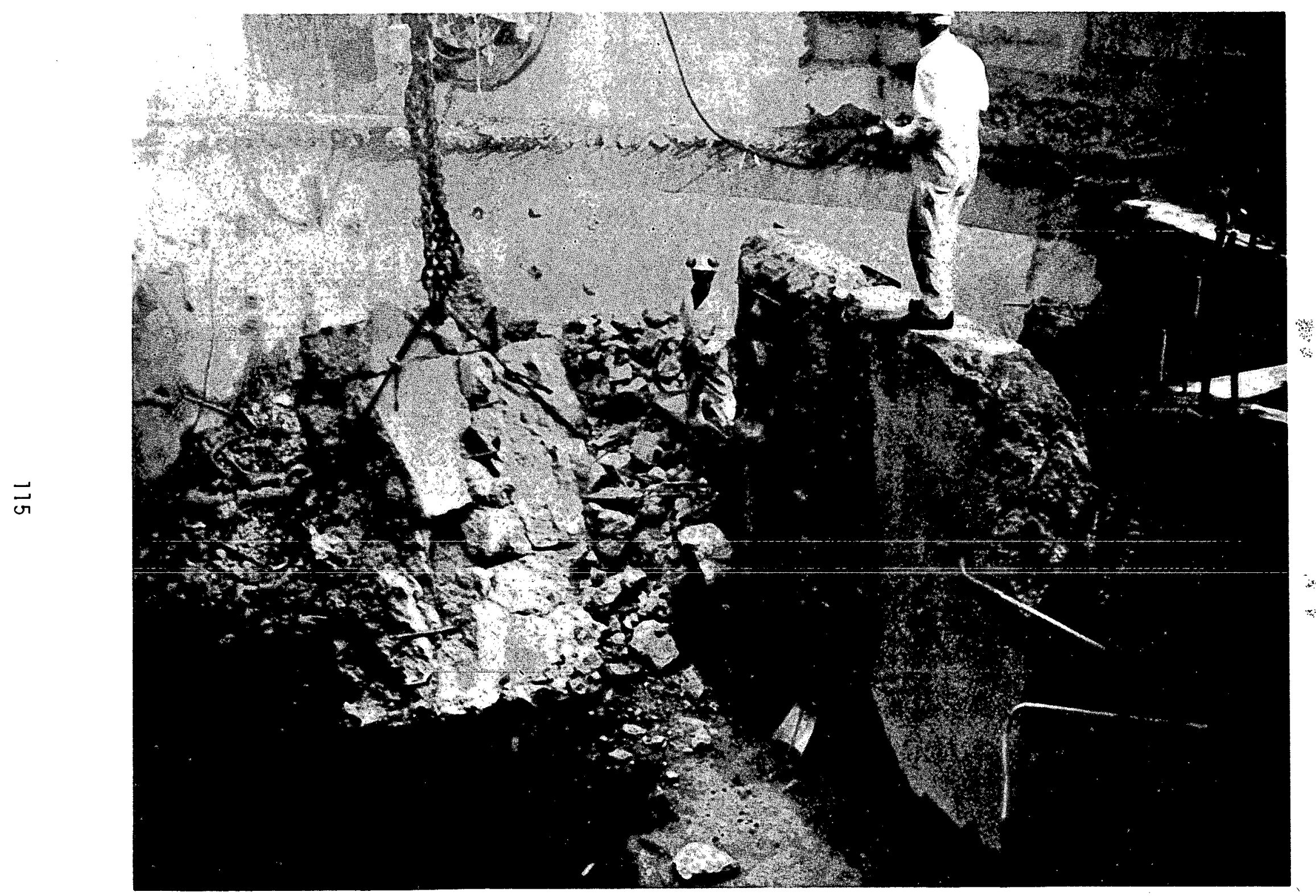

Figure 11

Removal of Subbasement Walls 


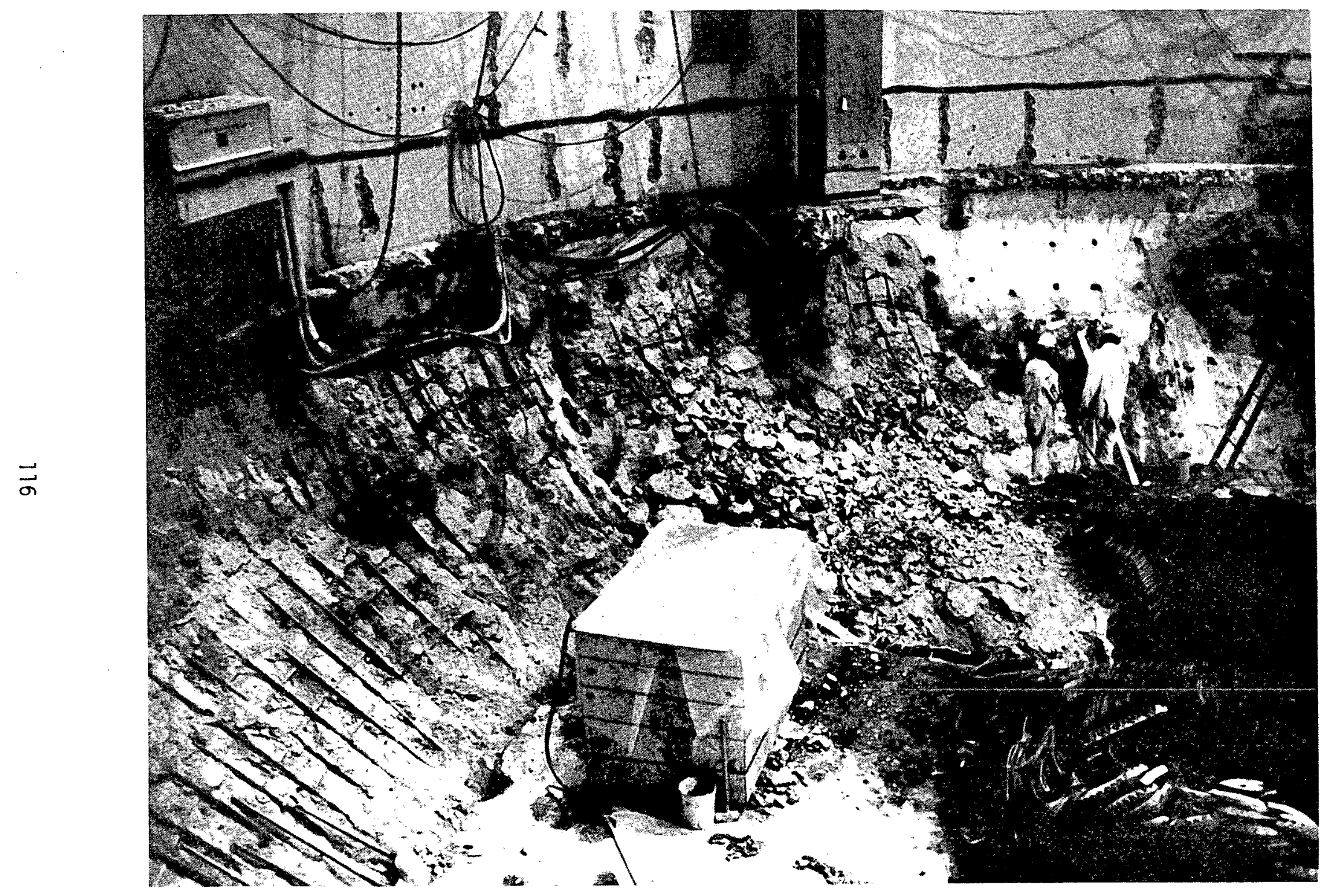

Figure 12

Explosive Scarfing of Subbasement Floor and Walls 
c

\section{C}

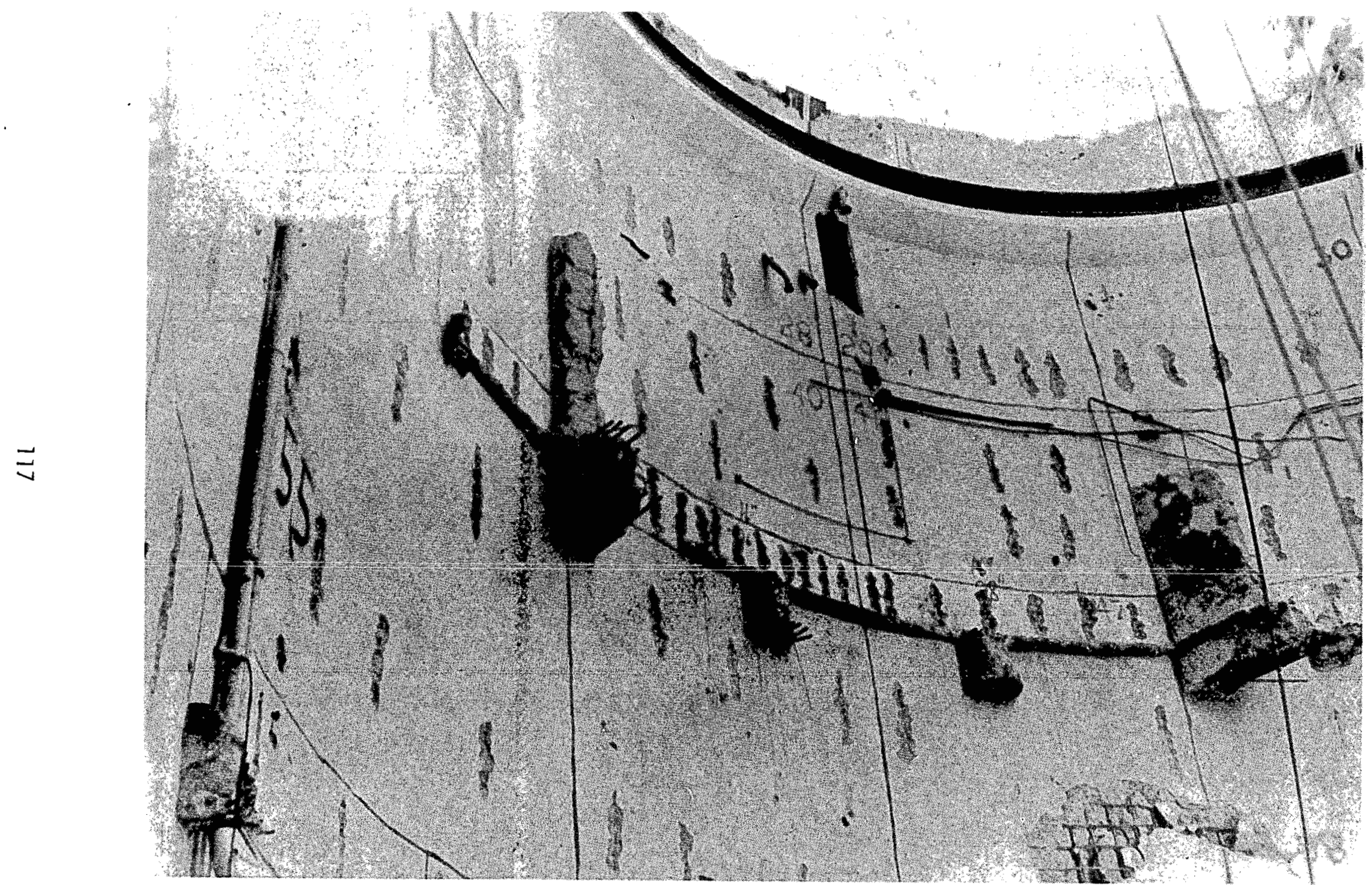

Figure 13

Wa11 Sampling for Detectable

Reactor Originated Radioactivity 
Figure 14

\section{PROJECT COSTS}

ACTIVITY SPECIFICATION NO.

1. Final Facility Plans

2. Removal of Piping \& Equipment from Containment

3. Removal of Superheater $\&$ Superheater Building

4. Removal of Passageway $\&$ Equipment

5. Removal and Disposa1 of Vessel Internals

6. Removal and Disposal of Pressure Vessel

7. Removal and Disposal of Biological Shield

8. Remova1 of Containment Building \& Structure

9. Removal of Miscellaneous Equipment

10. Material Disposal

11. Facility Closeout

TOTAL
ACTUAL OR

EST IMATED

ACTUAL COST

$\$ 460,372$

301,736

86,988

67,987

785,110

$1,057,337$

$1,233,969$

391,468

19

$1,248,888$

103,901

$\$ 5,737,775$ 


\author{
PROGRAM PLAN \\ FOR \\ REMOVAL OF THE MATERIALS TEST REACTOR \\ OVERHEAD WORKING RESERVOIR
}

\begin{abstract}
This paper covers the salient features of the removal of an excessed contaminated facility, the Materials Test Reactor (MTR) Overhead Working Reservoir (OWR) from the Test Reactor Area (TRA) to the Radioactive Waste Management Complex (RWMC) at the Idaho National Engineering Laboratory (INEL). The 125 ton OWR was an overhead 160,000 gallon capacity tank approximately 193 feet high which supplied cooling water to the MTR. Radiation at ground level beneath the tank was $5 \mathrm{mR} / \mathrm{hr}$ and approximately $800 \mathrm{mR} / \mathrm{hr}$ at the exterior surface of the tank. Sources ranging from 3 $\mathrm{R} / \mathrm{hr}$ to in excess of $500 \mathrm{R} / \mathrm{hr}$ exist within the tank. The tank interior is contaminated with uranium, plutonium and miscellaneous fission products. The OWR was lowered to ground level with the use of explosive cutters. Dismantling, decontamination and disposal was performed by Aerojet Nuclear Company (ANC) maintenance forces.
\end{abstract}

Ben C. Lunis

Aerojet Nuclear Company

Idaho Falls, Idaho 83401




\section{INTRODUCTION}

During August, 1973, the AEC-Idaho Operations Office (now ERDA-ID) requested Aerojet Nuclear Company (ANC) to assume the responsibility for carrying out ERDA's Decontamination and Decommissioning (D\&D) program for excess contaminated facilities at the Idaho National Engineering Laboratory (INEL). The MTR Overhead Working Reservoir (OWR) at the Test Reactor Area is one of the INEL facilities meeting the estabilished criteria for D\&D work and is the first phase of the D\&D of the MTR complex. The program called for the total removal and disposal of the OWR.

This paper presents a review of the Program Plan which was prepared by ANC and a brief summary of the execution of the work of that program. 


\section{GENERAL DESCRIPTION}

Figure 1 locates the Test Reactor (TRA) and the RWMC, approximately 11 miles to the south, in the southern portion of the INEL site in south east Idaho. The facilities making up the MTR complex including the OWR at TRA are shown in figure 2.

The OWR, as shown on the left in figure 3 , is a stainless steel clad insulated water storage tank, 32 feet in diameter and approximately 46 feet tall, supported on four 30 inch diameter legs with intermediate structural supports giving a total overall height of 193 feet. Tank wa11 thicknesses range from 5/16 inches at the bottom to $3 / 16$ inches at the top. The insulated inlet and outlet lines are 30 inches in diameter, providing primary cooling water to the MTR when it was in operation. An 18 inch stainless steel clad overflow line is attached to one leg. Caged ladders and a catwalk provide for access to the tank exterior and interior. A floating roof, similar to a large pie pan with pie shape segments included, is lodged within the tank approximately at the spring line.

The interior surfaces of the OWR became radioactively contaminated during its active service by particulate material which was carried with the MTR primary cooling water and was deposited in varying concentrations on the tank interior. 
The program scope included: removal of security fence around a 60 foot square area; removal and replacement of area fencing and overhead electrical service; preparation of an impact area; spraying the interior of the tank with a contamination fixative; preparatory work on the structure; explosive release of the structure; sectioning the piping and support structure; removal of contaminated material to the RWMC; surplusing non-contaminated items; and clean up and restoration of the area. Removal of underground supports and piping are not included in this program but will be a part of the future MTR D\&D work.

\section{D\&D PROBLEMS}

Contamination within the tank and radiation fields averaging approximately $600 \mathrm{mR} / \mathrm{hr}$ at the exterior of the tank portion of the OWR, point sources exceeding $500 \mathrm{R} / \mathrm{hr}$ within the tank and the height of the structure placed various restraints upon the removal of the OWR. Process buildings and utility services within 85 feet of the OWR further limited removal methods. Operation of the nearby Advanced Test Reactor during removal activities further restricted project execution. Additionaliy, the demolition method to be selected had to fit the funding and schedule limitations previously established for FY-1975. 
The program plan to remove the MTR OWR was proposed in ANC Schedule 189C ID 3606 A, entitled. "Decontamination and Decommissioning of the MTR Working Reservoir" and was funded in FY-1975.

\section{PROJECT MANAGEMENT}

As Project Manager, ANC was responsible for the planning and direction of the project, including assembly of the task force required to accomplish the work. Key personnel from ANC were structured into a task force to prepare the Program Plan, D\&D procedures, activity specifications, safety and environmental reports and to execute the removal of the physical structure.

The expertise and services of Mr. K. G. Anderson, an explosives engineer active in the dismantling of the Elk River Reactor, was also utilized.

\section{ALTERNATE CONSIDERATIONS}

Many different removal methods were considered. Included were crane rigging, tilting, controlled fall, explosive release, helicopter or helium balloon. lifts and jacking. Deferral of the removal work to allow further decay of the fission products was also viewed. Initially, ANC personnel prepared a lump sum subcontract package for the lowering of the OWR tank section and support structure using large mobile cranes. Bids ranging upwards from $\$ 236,000$ were received and rejected due to funding limitations. The subcontract package was modified and reissued. The new low bid of $\$ 194,700$ was rejected since total project funding was 1 imited to $\$ 105,000$. Except for the explosive release method, the other removal alternates were evaluated and rejected as being unsafe, too costly, limited by equipment availability or impractical. The explosive release method was chosen as the safest method with the least potential radiation exposures to personnel which still met budget limitations. 
REMOVAL PLAN

A security fence around the OWR was removed from the 60 feet square area. A 40 feet $\times 60$ feet impact area directly to the north of the OWR was prepared by removing the security fence and overhead utility services in the immediate area. Plastic sheets were placed over the impact area to facilitate removal of fission product contamination and activation particles in the event the OWR ruptured at impact allowing spillage to occur. Truck loads of soft soil were placed over the plastic sheets in a dimpled fashion resembling plastic egg trays. Additional plastic sheets were placed over the soil and rigging cables were positioned over the plastic to accommodate load rigging after the OWR explosive release. Fire hose fog nozzles were placed on the sides of the impact area to provide a fine water spray over the OWR tank body in the event the tank ruptured and contamination was released. A contamination fixative, TURCO 5580G, was pumped to the tank and remotely sprayed inside the tank to fix the contamination. Sections of the inlet, outlet and overflow pipes were removed to permit an engineered release of the OWR. (see figure 4). Cuts into these contaminated pipes were made with mechanical cutters (Wheller-Fein milling saw) through urethane foam which was injected between two balloons within the pipes to control contamination. Mechanical cuts were made in the support legs (see figure 4) to facilitate utilization of flexible lineal shaped charge (FLSC) explosives. (see figure 5 for a view of the FLSC). Charges were placed in redundancy to assure proper removal of leg sections to control the direction of the fall. The charges were activated at night and the structure impacted the ground exactly as predetermined. (see special effects photograph in fig. 6). See figure 7 for a view of the FLSC cut in one of the 30 inch legs. Note the courseness of the preparatory notching flame cut as compared to the smooth FLSC cut.

The pre-release preparations were successful since the tank did not repture and contamination releases were insignificant. 
After the successful release of the OWR, the piping and support structure members were cut into sections. The noncontaminated items were disposed of as surplus material and the contaminated material was removed to the Radioactive Waste Management Complex (RWMC) at INEL. Openings into the tank were sealed with plastic and TURCO $5580 \mathrm{G}$ was sprayed over suspect external areas of the tank body to fix contamination. Two cranes were used to $1 \mathrm{ift}$ the approximate 45 ton tank onto a 100 ton lowboy trailer (see figure 10). The tank was secured and hauled to the RWMC for pit disposal. Soil bearing contamination was removed from the OWR site and disposed at the RWMC. The area was cleaned up and restored as required with the project work being essentially completed as scheduled on June 30, 1975. 
SUMMARY OF PROGRAM STATUS

The project work was satisfactorily accomplished in a very safe manner without exceeding allowable radiation exposures to the personnel involved. The OWR impacted the ground in the predetermined position. No damage occurred to underground utility services directly under the tank body impact area. The seismic sensing system at the Advanced Test Reactor was not activated by the impact. No air blast or ground shock damage occurred to adjacent structures. The tank did not rupture and contamination release was insignificant. The project was completed within budget limitations. 


\section{FIGURES}

1. INEL Site map.

2. Test Reactor Area Plot Plan.

3. The Overhead Working Reservoir prior to removal.

4. View of the OWR showing removed sections of the inlet and outlet pipes and the notches cut into the legs to facilitate explosive cuts.

5. View of a portion of the flexible lineal shaped charges (FLSC).

6. Special effects photograph of the release of the OWR at night.

7. View of the FLSC cut in one leg section.

8. Overhead view of the OWR on the ground.

9. View of the OWR on the ground.

10. View of the OWR tank section being loaded for transportation. 


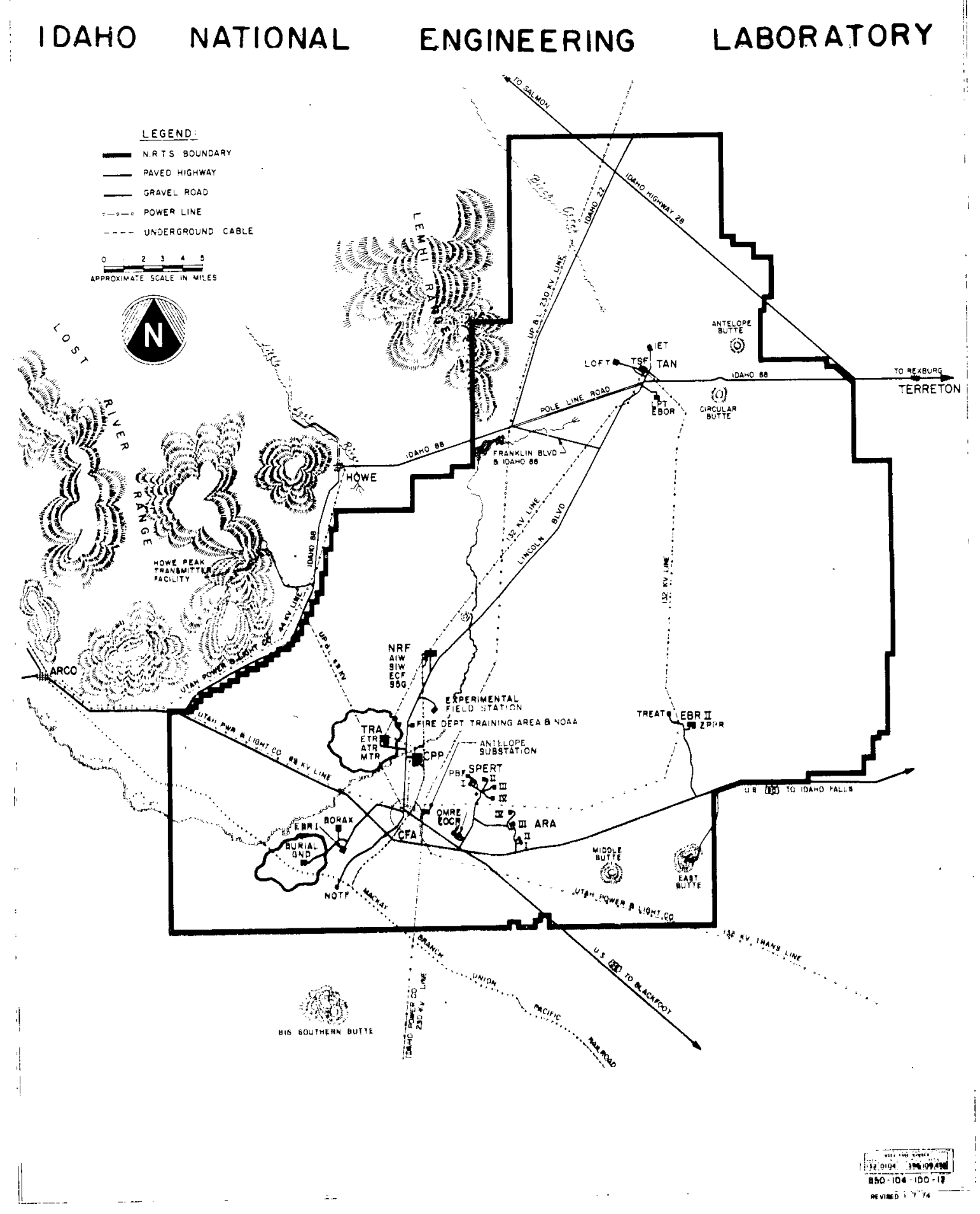

FIGURE I 
C

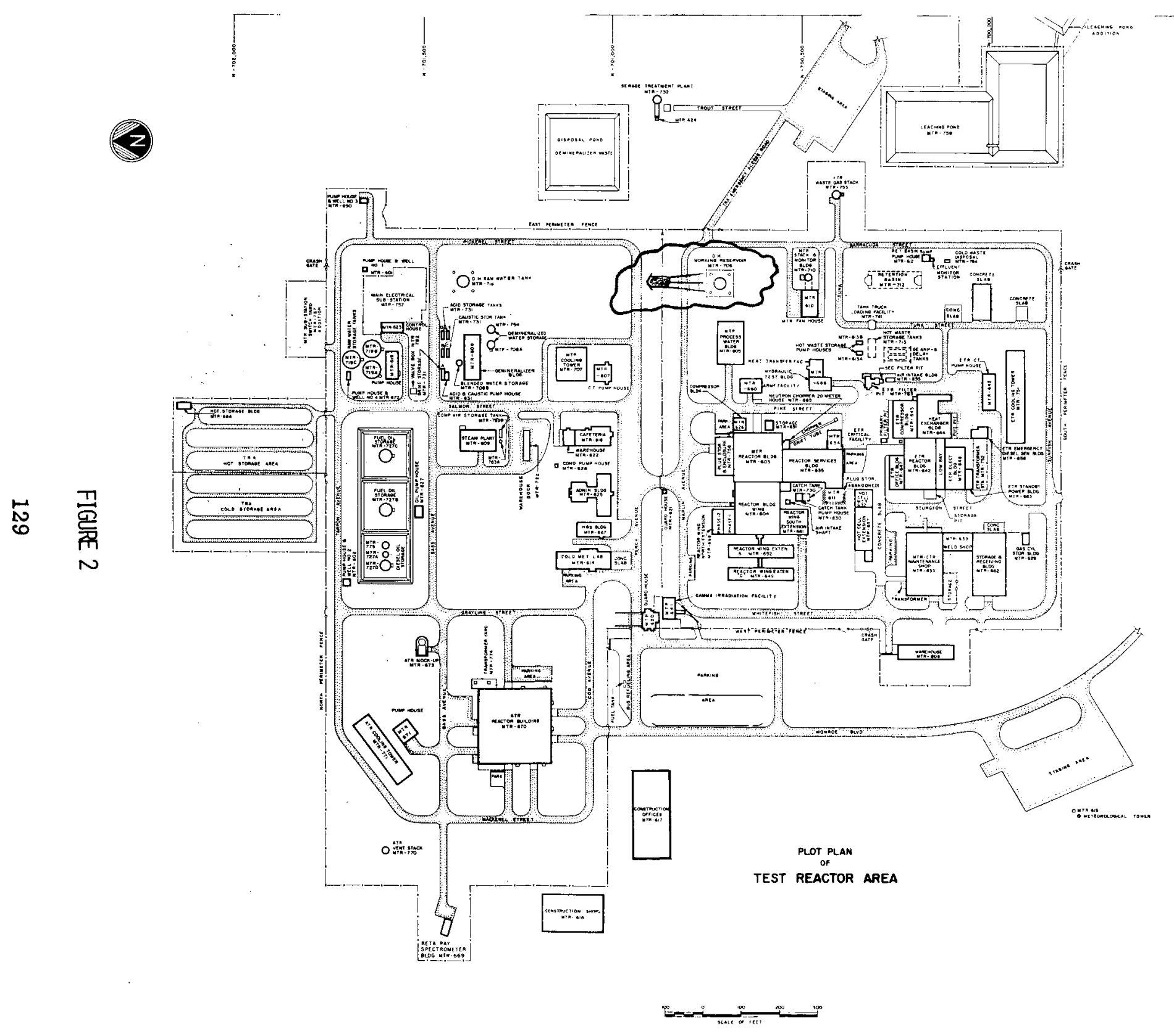




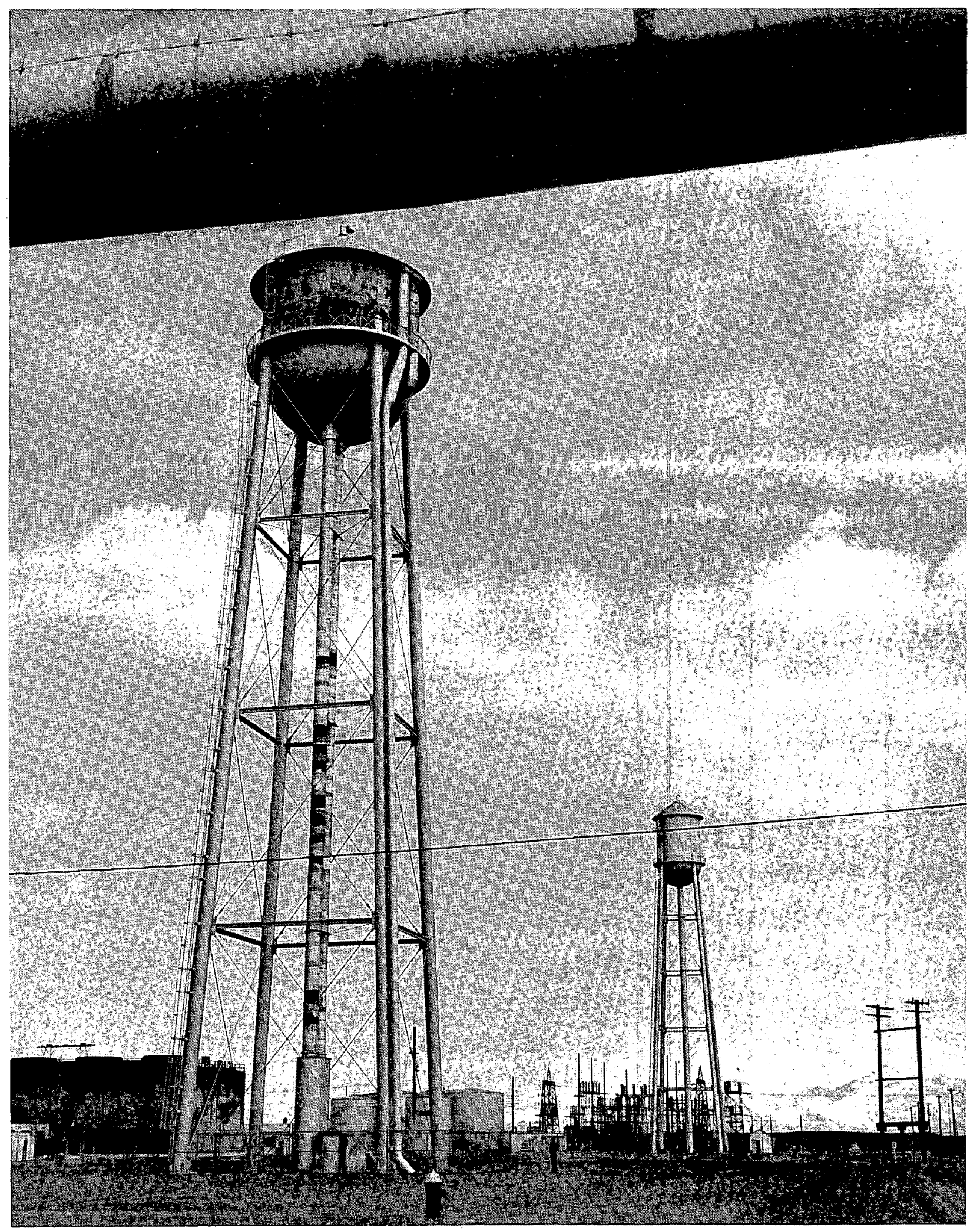

FIGURE 3 


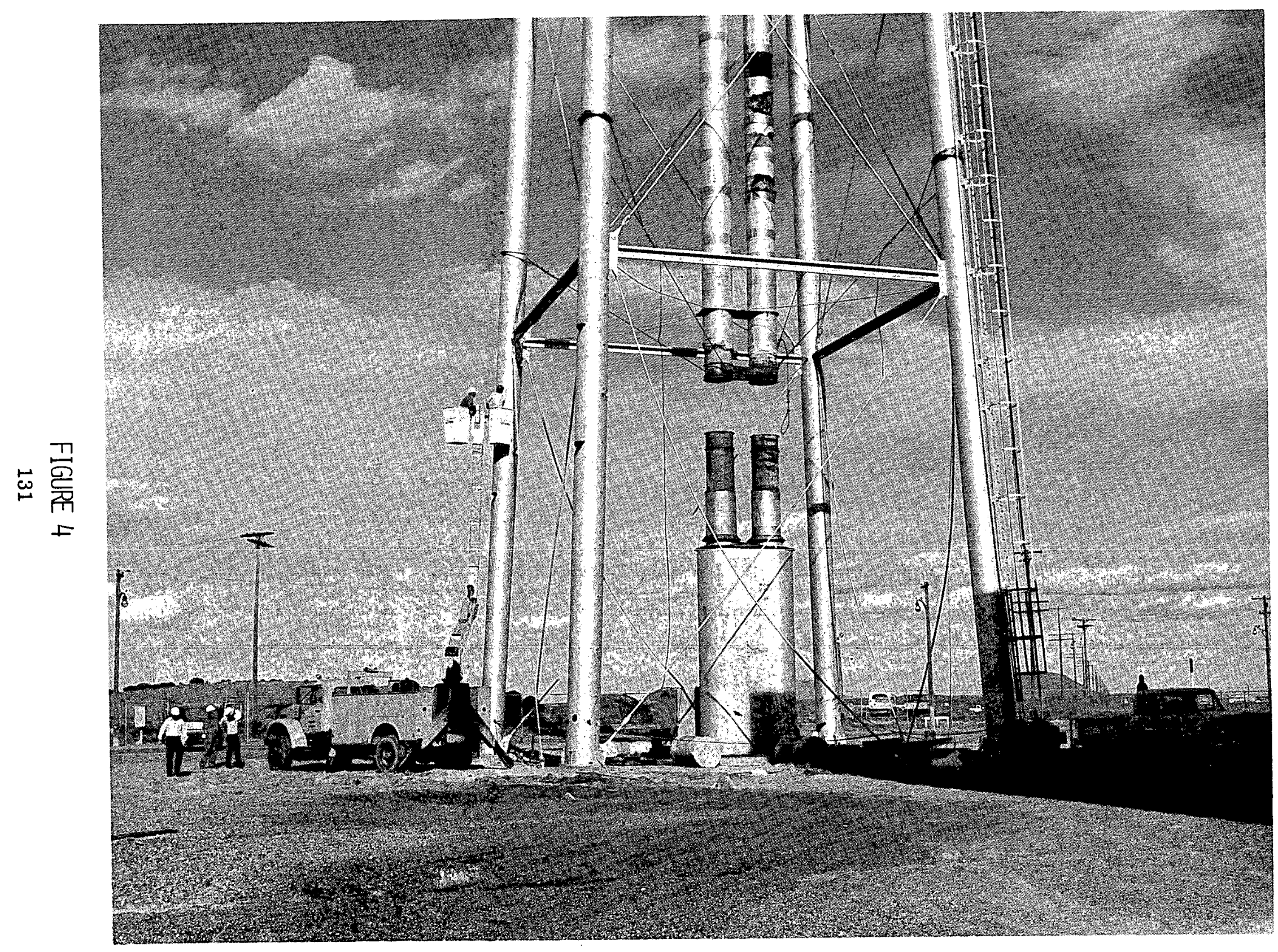




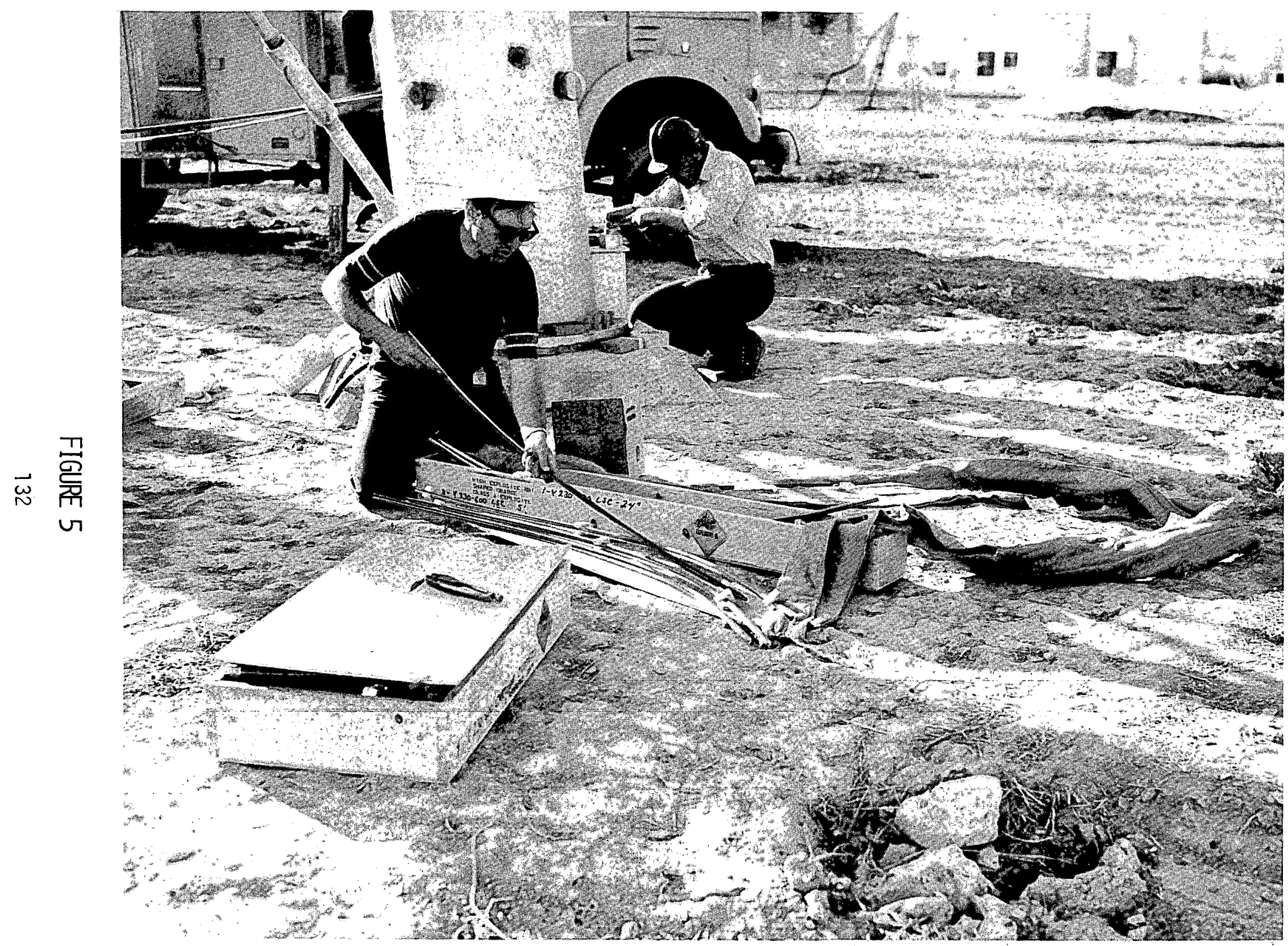




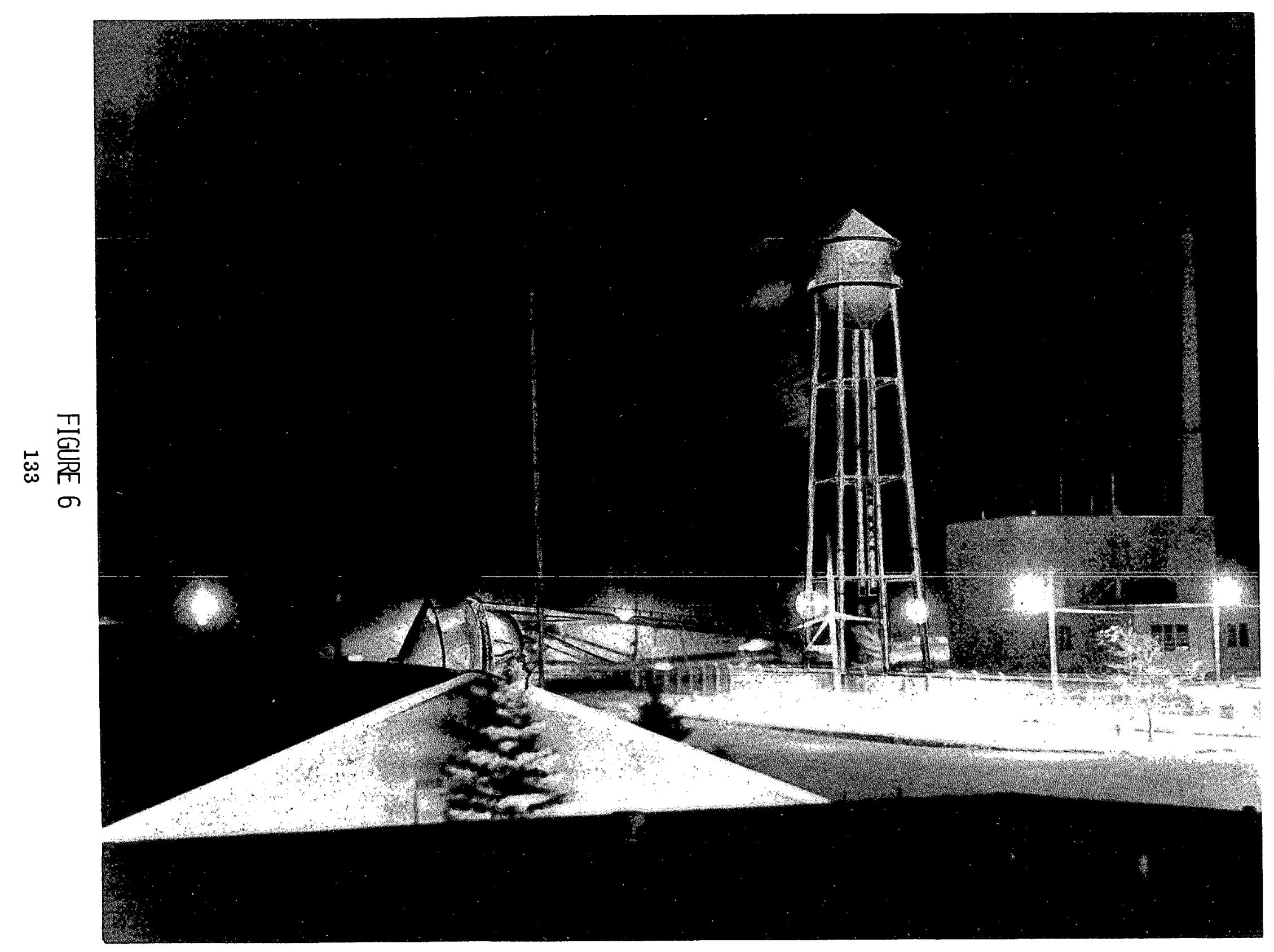




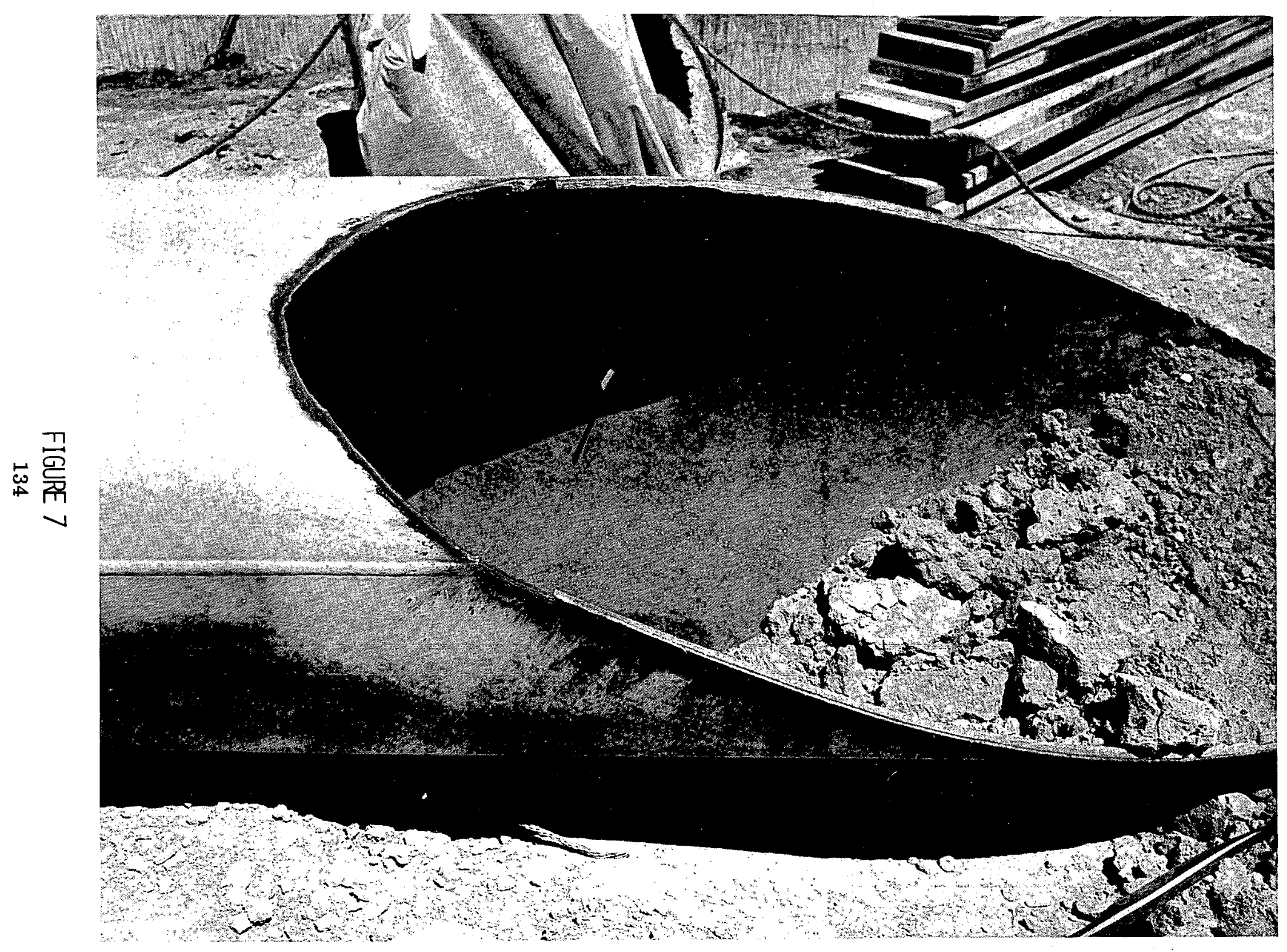




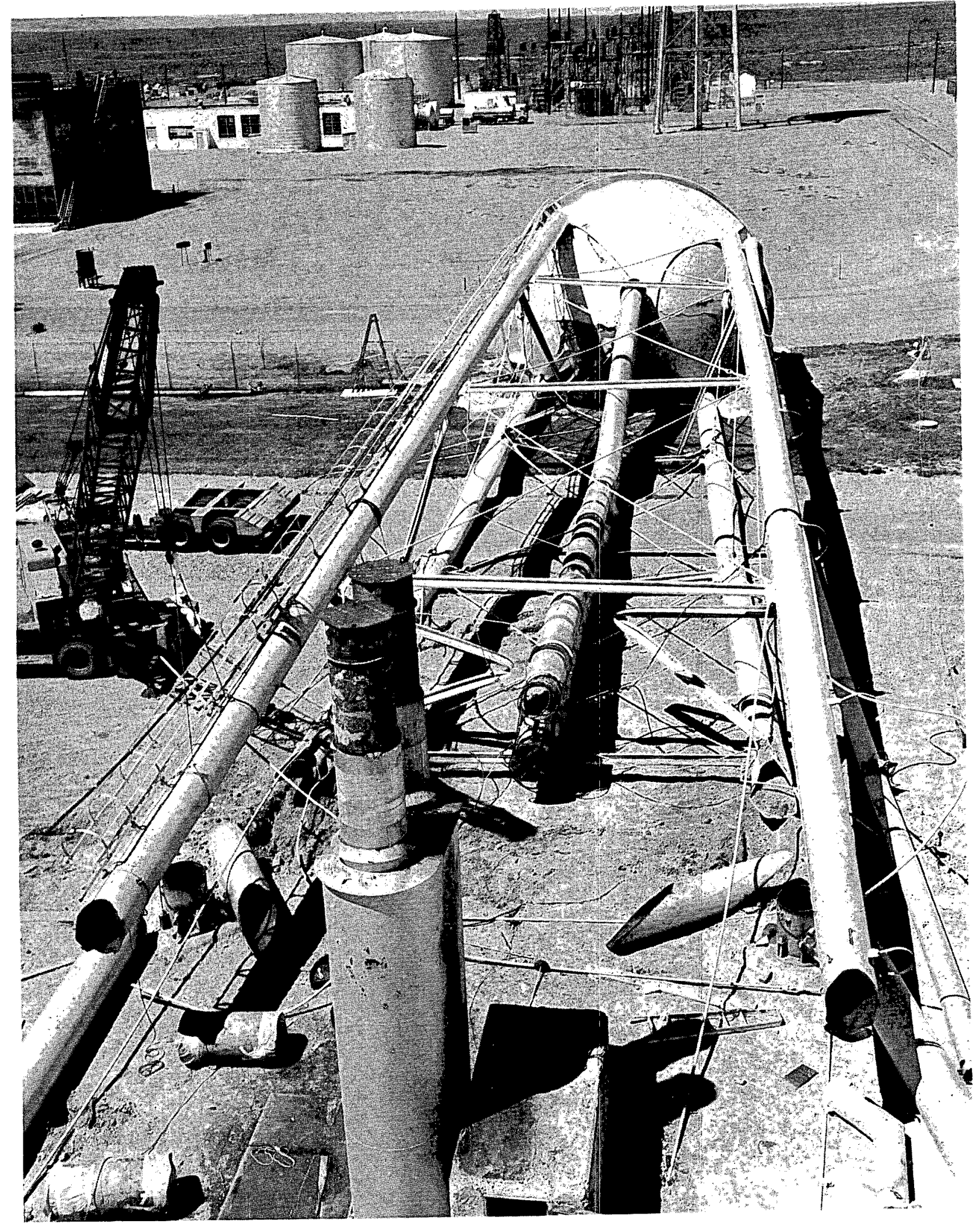

FIGURE 8 


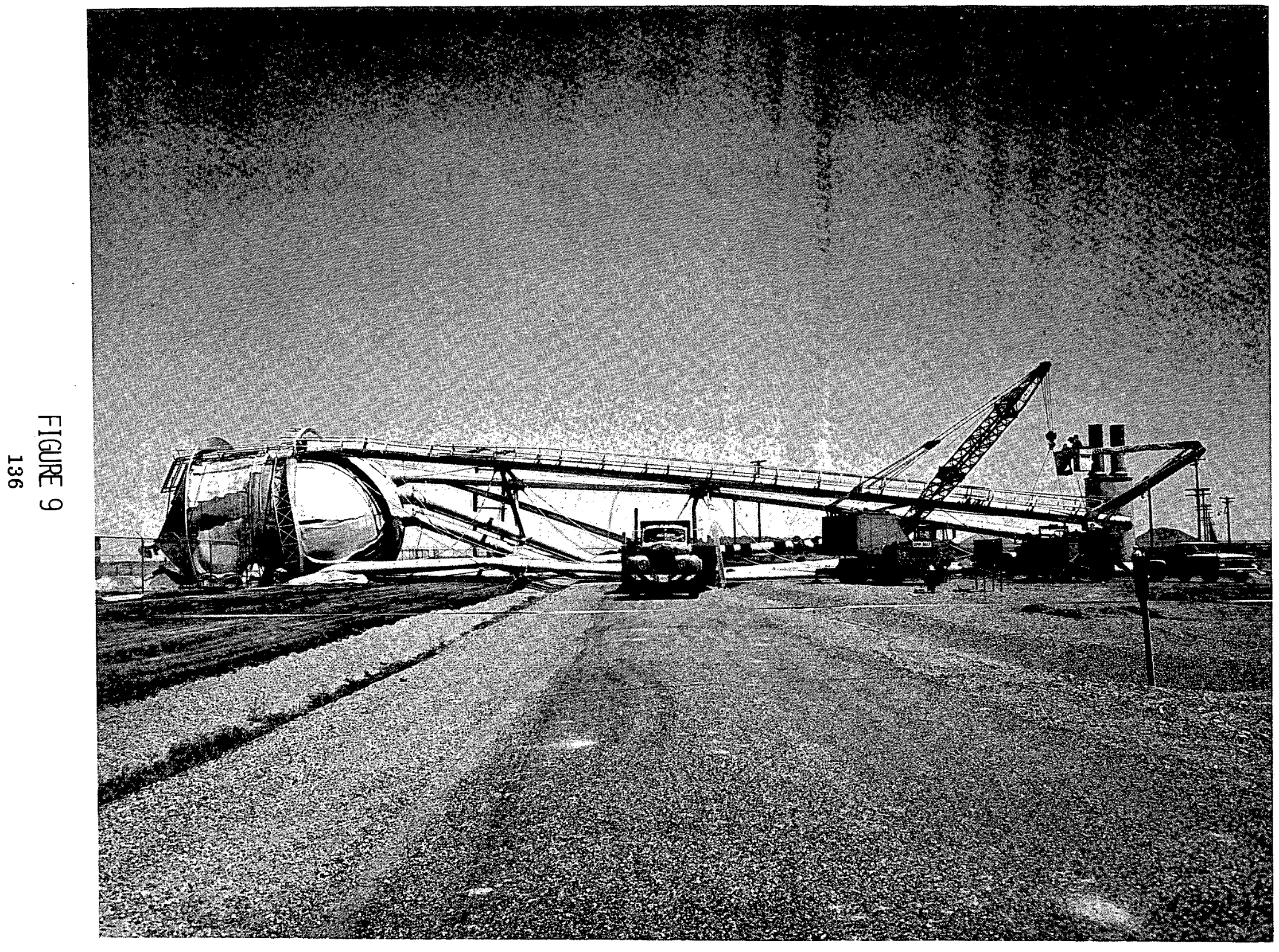


C

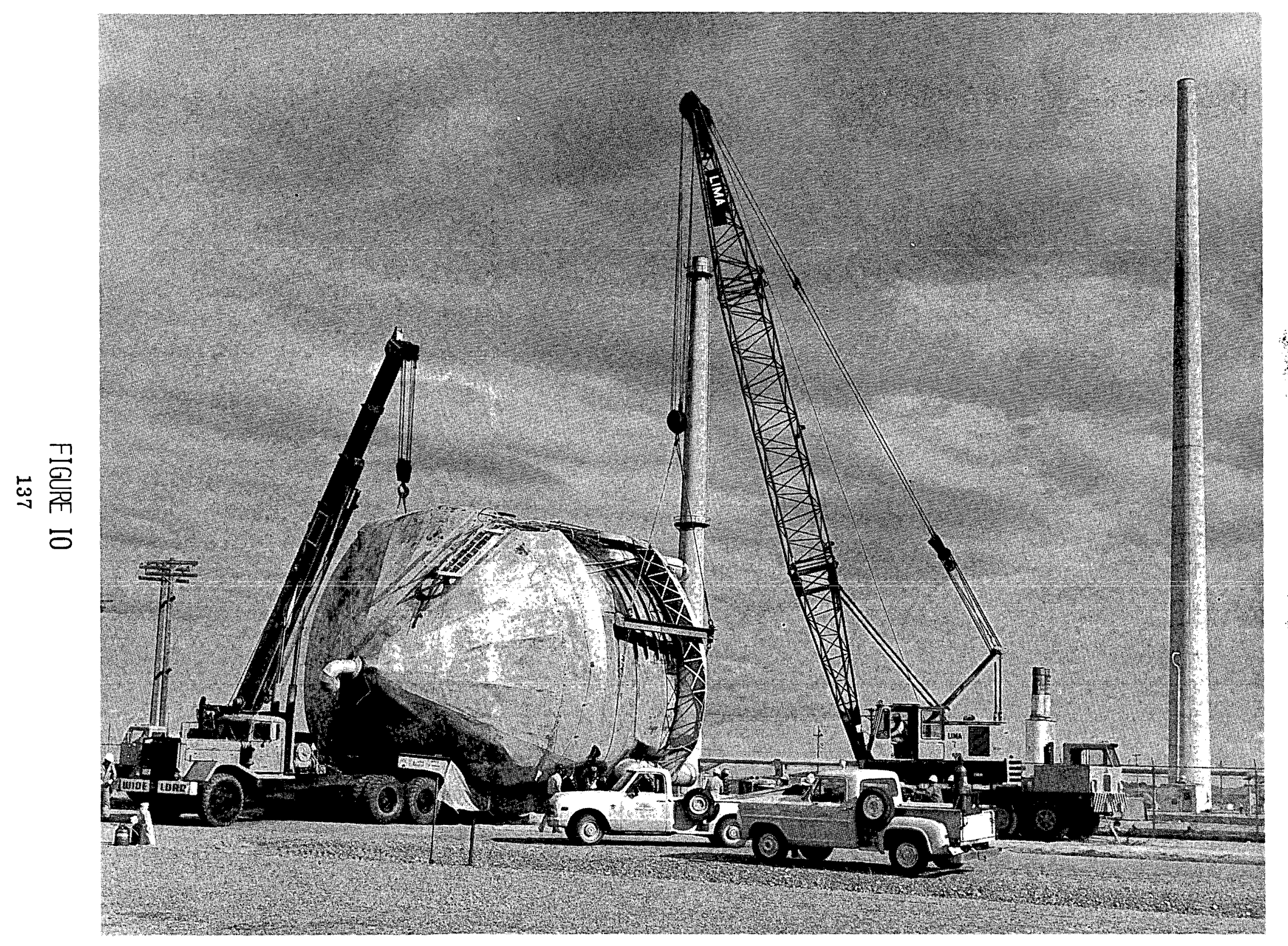




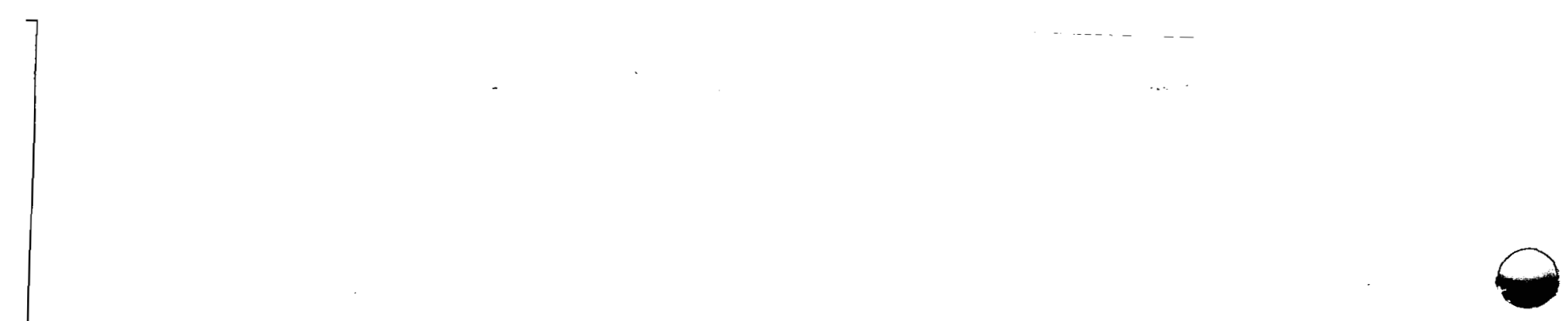

$\bullet$

$\bullet$ 
Title:

DECONTAMINATION \& DISPOSITION OF HALLAM \& PIQUA REACTORS

Author(s): W. F. Heine

Program Manager

D\&D Program

B. F. Ureda

Project Manager

Dismantling Activities

D\&D Program

Atomics Internationa]

8900 De Soto Avenue

Canoga Park, Cal ifornia 91304

Abstract: The Hallam Nuclear Power Facility, a sodium cooled, graphite moderated, 256 Mwt power reactor, went critical in 1962, was shut down as a result of moderator problems in 1964, and was decommissioned in 1969. The Piqua Nuclear Power Facility, an organic cooled, 45 Mwt power reactor went critical in 1963, was shut down in 1966 because of coolant problems, and was decommissioned in 1969.

Fuel, coolant, and support systems of both reactors were removed from the site. The reactor vessels are entombed at their sites. Remaining systems at Hallam were sealed in the underground vaults were then covered with six feet of earth. The Piqua vessel is sealed in the concrete reactor containment building. The state of Nebraska is responsible for monitoring the site which contained $3 \times 10^{5}$ curies in 1969. The Piqua site was purchased by the U.S. Government and then leased to the City of Piqua. The remaining radioactivity at Piqua also was $2.6 \times 10^{5}$ curies. 
Hallam

The sodium-cooled graphite-moderated reactor (256 Mwt) in Hallam, Nebraska Nuclear Power Facility was shut down in September 1964. Figure 1 shows the facility during operation. The major elements of the facility were: The reactor, a primary sodium system, intermediate heat exchangers, a secondary sodium system, steam generator, and turbine generator. Decommissioning began in JuTy 1966 and was completed in August 1969. The general requirements established by the AEC included the following:

1. Remove all fuel from the site

2. Remove all bulk sodium

3. Chemically inert the residual sodium

4. Dispose of a11 radioactive residues

5. Prevent release of contamination from and physical access to any subsurface volumes by permanently sealing all floor-level penetrations.

In meeting these requirements, Atomics International, in conjunction with the Utility (Consumers Public Power), prepared: 1) a retirement plan, 2) activity specifications which delineated the discrete retirement tasks, and 3 ) the detailed working procedures. Preparation of this documentation was supported by extensive engineering studies and safety analyses. A supplement to the HNPF Safeguards Analys is was compiled and upon acceptance, the AEC-DRL issued a deactivation order. 
Unirradiated fuel was packaged and returned to AI. Irradiated fuel was canistered and shipped to Savannah River using two specially designed shipping casks. Each cask had a capacity of six fuel elements. The casks were mounted on railroad cars.

Bulk secondary sodium was removed from the site in the three fill tanks and shipped to AI. The five tanks of radioactive primary sodium were shipped to Hanford, Washington by special train. The primary sodium was slightly radioactive (7 curies in the 550,000 1b. shipment).

Residual sodium in the reactor vessel was passivated using a nitrogen steam mixture. The resulting sodium hydroxide was dried and the reactor vessel purged with nitrogen and sealed.

Disposition of radioactive residues was handled routinely by following the procedures established for plant operation. Decontamination of system components, primarily removal of radioactive sodium, was accomplished in a sodium cleaning facility erected for this purpose. Components that could not be cleaned satisfactorily were packaged and shipped for burial.

Radioactive components and materials remaining at the site are sealed in the underground vaults of the remaining structure. The reactor vessels and the reactor internals constitute the major radioactivity remaining at the site. An estimated 300,000 curies were sealed in the reactor and the underground vaults. Two $1 / 2$ in. thick steel plates were welded over the reactor vessel and the reactor area. After weld sealing all penetrations into the isolation structure, which is the remaining underground volume, its surface was first covered with tar, then 2 feet of dirt, a continuous $40 \mathrm{mil}$ plastic film, and finally 4 more feet of dirt. 
The finished grade is shown in Figure 2. The large concrete structure in the background is the intermediate heat exchanger vaults. The heat exchangers have been removed. Removal of the massive concrete 7 foot thick walls was economically prohibitive.

Fuel handling and shipping was performed by the Utility. A construction contractor, under the direction of the Utilities' Health and Safety Administration and staff removed the system components and sealed the reactor and vaults. A demolition contractor removed the nonradioactive above-grade structures.

A final status report (2) ahd safety analysis of the remaining structures was prepared. The State of Nebraska has jurisdiction over the site and periodically monitors the site. Water from the wells on the periphery of the property is analyzed. The Utility is responsible for the property and is currently generating power at the site. Facility drawings, reports, analyses, and photographs relating to the buried structures have been sealed in capsules and placed in two locations. One capsule was placed in the concrete wall of the intermediate heat exchanger and the other was welded to the reactor cover plate. 
Piqua

The organic cooled, 45 Mwt reactor in Piqua, Ohio was shut down in January 1966. Figure 1 shows an aerial view of the plant. Decommissioning began in December 1967 and was completed in February 1969. The general requirements for the retirement of the Piqua Nuclear Facility were:

1. Reactor core components, fuel and other radioactive materials will be shipped off site in accordance with the existing procedures. (The organic coolant had been disposed of by burning.)

2. Reactor vessel, thermal shield, grid plates, and support barrels will remain in place. Penetrations into the reactor complex will be plugged.

3. Reactor vessel will be filled with dry sand and top shield plug will be welded in place.

4. Reactor complex will be sealed with a waterproof barrier and a concrete cover. See Figure 2 .

5. Contaminated piping and equipment inside the reactor building will be removed or decontaminated.

6. Reactor building will be converted into a warehouse. The heating and ventilation systems fire protection system, utilities and waste systems will be retained.

(1)

A retirement plan, work specifications, and detailed procedures were prepared. An Evaluation of the Residual Radionuclides Study and a Retirement Safety Analys is were conducted and reports prepared. 
Pre and post dismantlement surveys were made for radioactive contamination in the PNPF facilities. The results of a survey conducted in 1968 before initiating the retirement showed very low levels. This was due to the minimal transfer of radioactive materials on the organic coolant and the long (2-year) period since operation. Radioisotope totals ranged from $1.28 \times 10^{-3} \mu$ $\mathrm{ci} / \mathrm{ml}$ to $9.2 \times 10^{-2} \mu \mathrm{ci} / \mathrm{ml}$ for PNPF residues and fluids. Contamination survey of PNPF surfaces ranged from $180 \mu \mathrm{Ci}$ (aqueous waste tank) to $85.74 \mu \mathrm{Ci}$ (spent fuel pool). A final survey for radioactive contamination showed a maximum of $.57 \mathrm{p} \mathrm{Ci/g}$ alpha, $1.15 \mathrm{p} \mathrm{Ci} / \mathrm{g}$ Beta-gamma for fluids and residues.

For plant surfaces, less than $1 \mathrm{dpm} / 100 \mathrm{~cm}^{2}$ alpha and $0.8 \mathrm{~m}$ $\mathrm{rod} / \mathrm{hr}$ field Beta-gamma; $65 \mathrm{dpm} / 100 \mathrm{~cm}^{2}$ removal Beta-gamma maximums were measured. The total radioactivity of significant radionuclides sealed in the facility in 1969 was $2.6 \times 10^{5}$ curies.

The PNPF retirement activities were performed by City of Piqua operations personnel. AI provided engineering and safety support, and Batelle Memorial Institute provided consulting services to the City of Piqua. The AEC administered and managed the project.

Nuclear fuel was shipped off site, the coolant was burned, and the contaminated piping and equipment inside the reactor building were removed or decontaminated. The reactor vessel, the concrete shielding, and reactor vessel materials were left in place, and sealed with a waterproof barrier and a concrete slab.

Detailed records and information relating to the retirement of PNPF were placed in sealed metal boxes at the site. After review of the retirement safety analyses termination of the 
operating authorization was granted by DRL. Title to the land occupied by the reactor and auxiliary buildings was transferred to the U. S. Government. The site and buildings were then leased to the City of Piqua. 


\section{REFERENCES}

(1) "Hallam Nuclear Power Facility Retirement Program Summary", AI-AEC-12709, June 1969.

(2) "Retirement of the Piqua Nuclear Power Facility", AI-AEC-12832, April 1970. 


\section{LIST OF FIGURES}

Figure 1. HNPF Reactor Building

Figure 2. Final HNPF Retirement Configuration

Figure 3. Aerial View of PNPF

Figure 4. PNPF Reactor Complex Showing Regions of

Radioactive Materials 

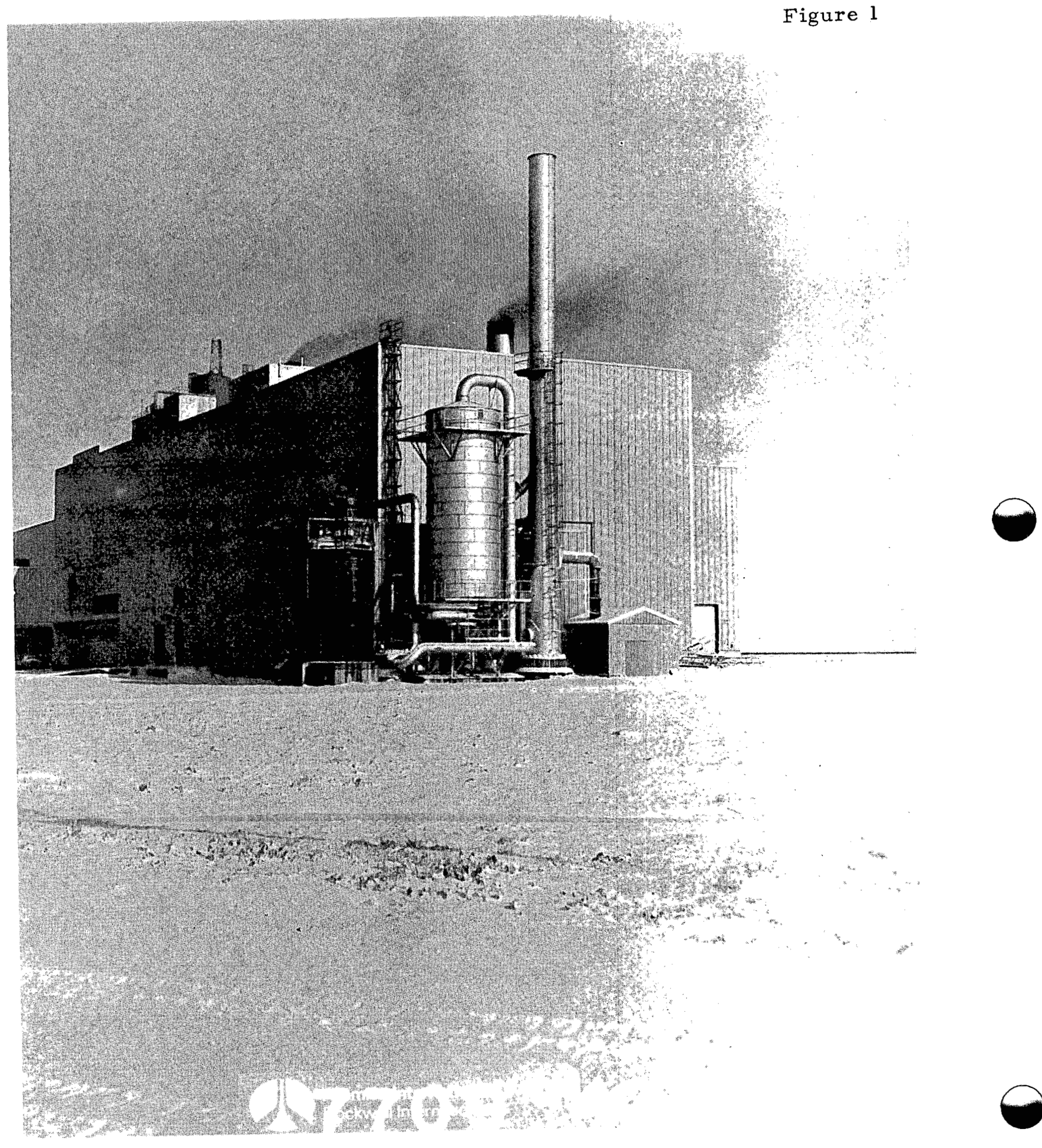


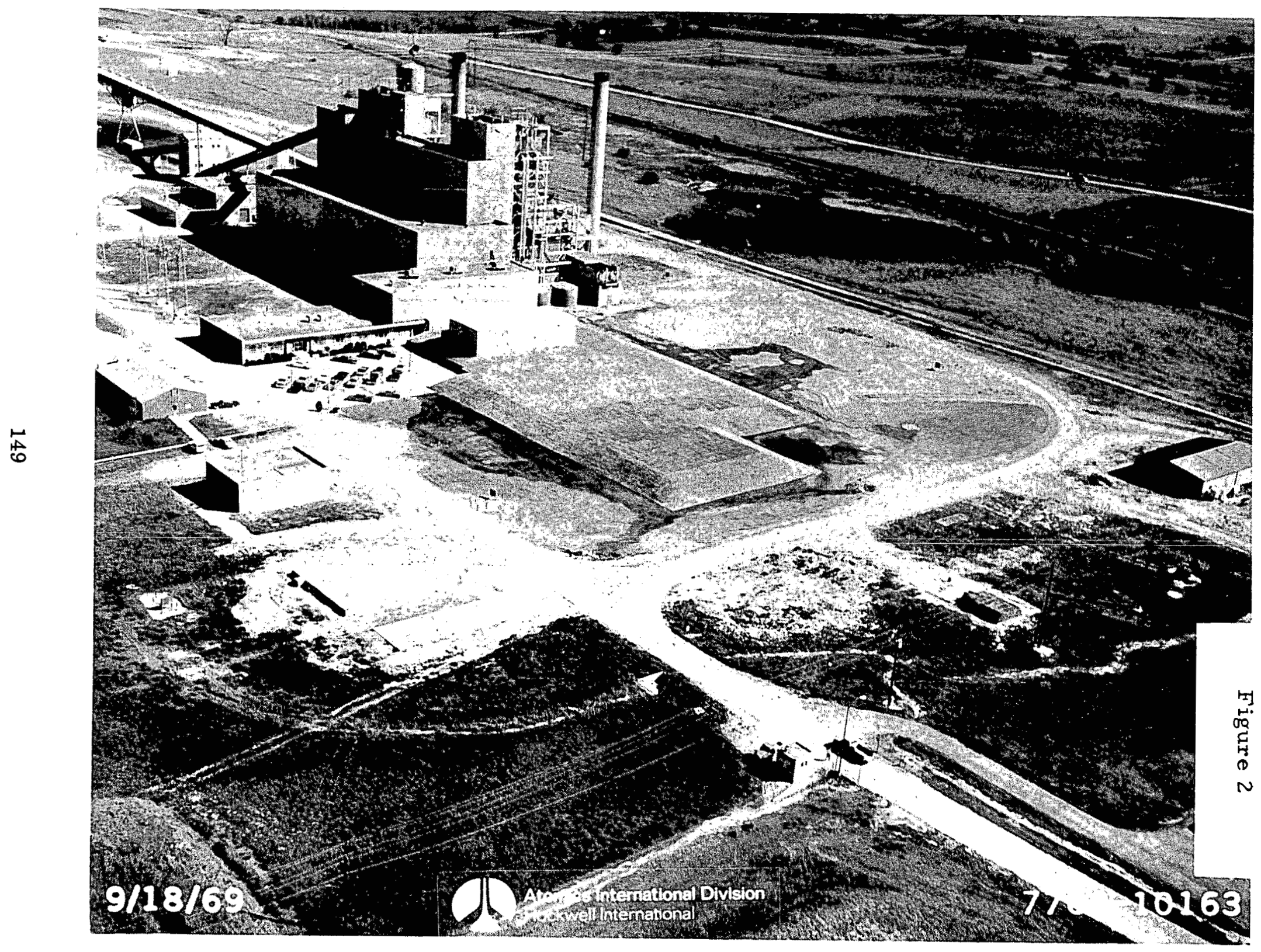




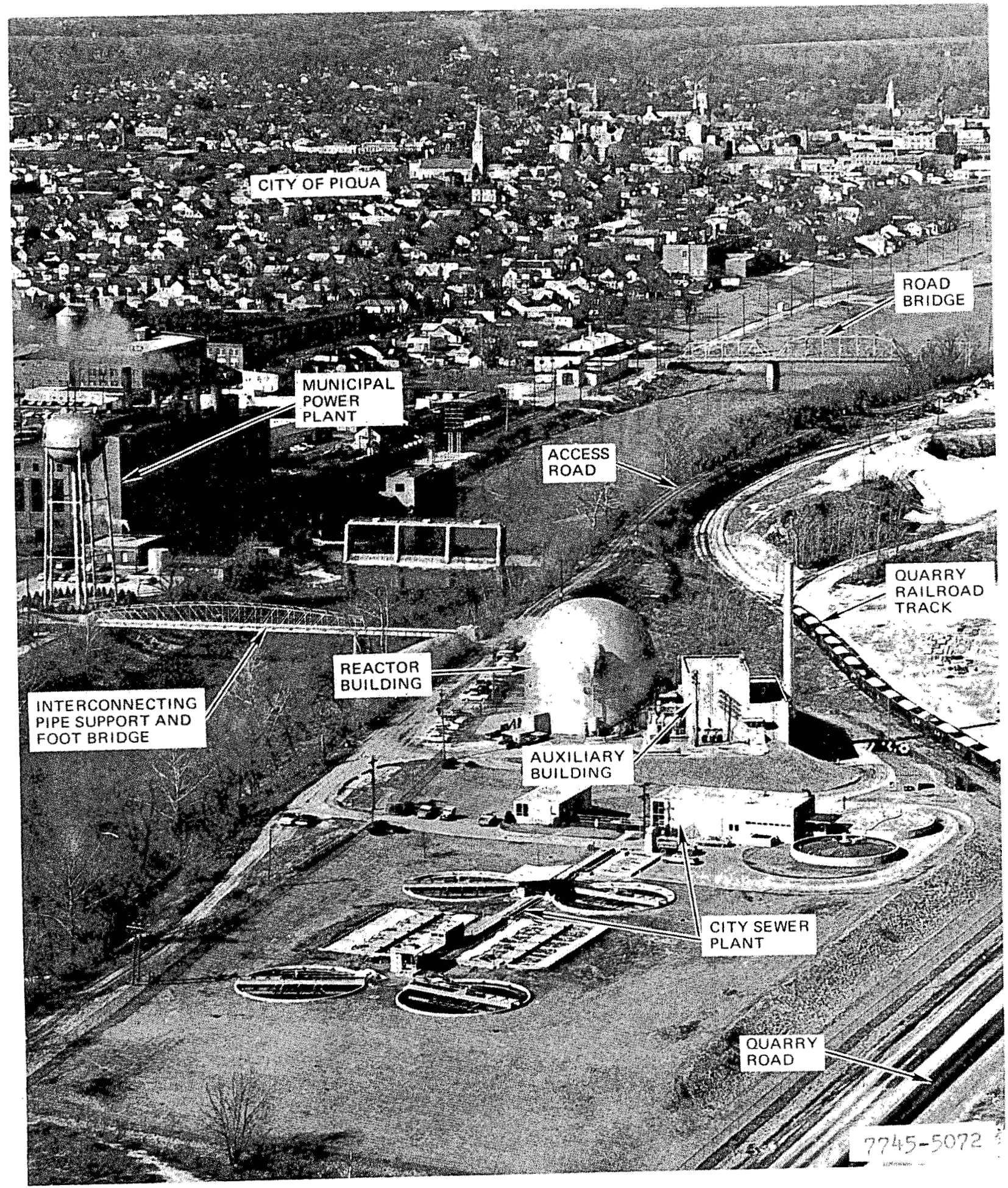


Figure 4

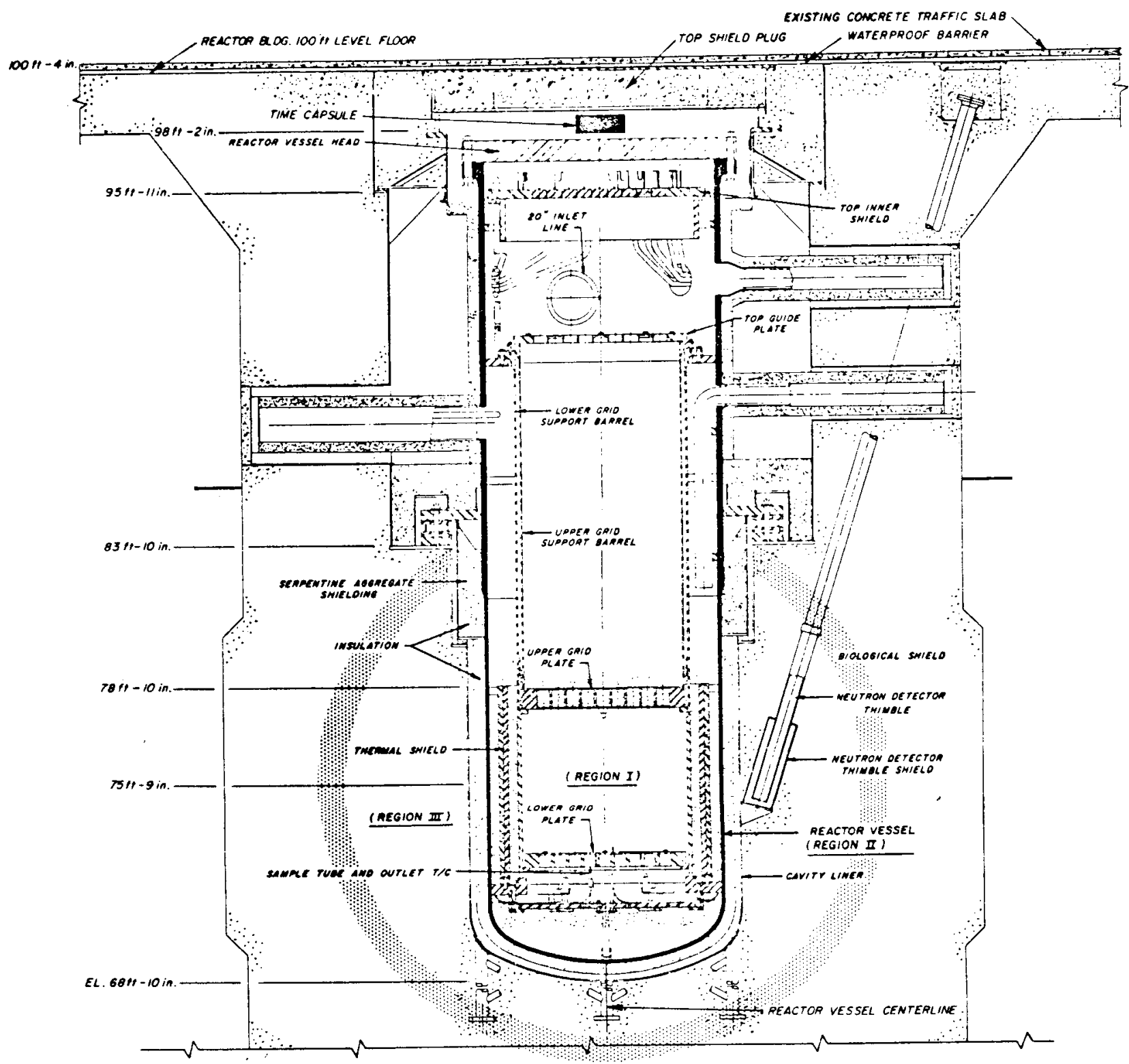

PNPF Reactor Complex Showing Regions of Radioactive Materials 


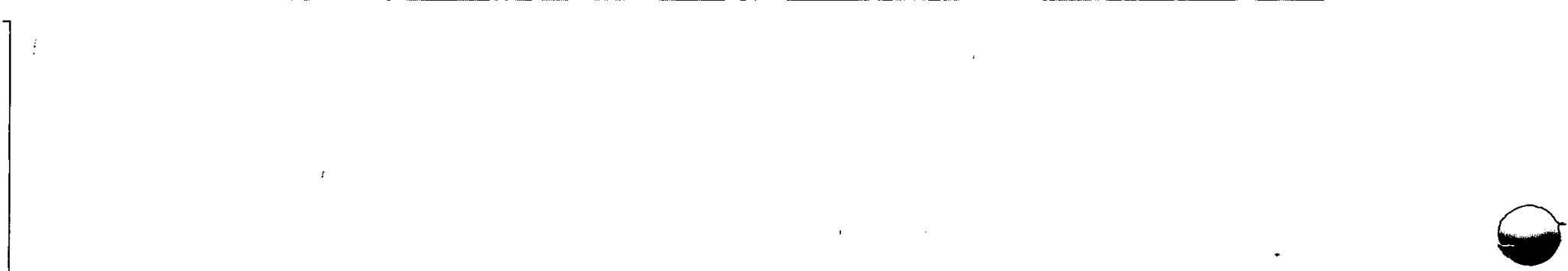

$\bullet$

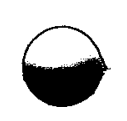




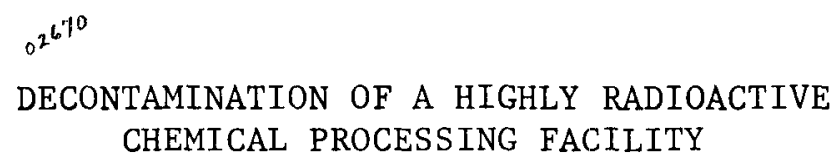

ABSTRACT

Five modules of the highly radioactively contaminated "hot canyon" in one of the chemical processing plants for irradiated fuel at Savannah River Plant were successfully decontaminated for installation of a new process. Decontamination was completed in about one year at a cost of about $\$ 150,000$. The various techniques employed, equipment used, and the overall job plan are described.

\section{BACKGROUND}

Building 221-F, typical of two "canyon-type" chemical processing plants at the Savannah River Plant, was completed in 1954 for processing irradiated fuel elements as part of the production cycle for ${ }^{239} \mathrm{Pu}$. The building is of steel reinforced concrete, about 800 feet long $\times 120$ feet wide $\times 70$ feet high (figure 1 ). Chemical processing is carried out in stainless steel equipment in two canyons, referred to as hot and warm. Each canyon is about 600 feet long, 15 feet wide, and 25 feet deep below the cell covers. One canyon is located on each side of the building, and the center section between the two canyons includes servicing areas, offices, control rooms, etc., on four separate levels. The walls of the hot canyon are of 5-1/2-foot-thick steel-reinforced concrete for shielding the high levels of radiation. The warm canyon, with lower levels of radiation, has 2-1/2-foot-thick walls. The canyons are maintained at a negative air pressure with respect to the rest of the building. The canyon exhaust air is filtered by a sand filter prior to dis- 
charge to the environs.

Canyon processing equipment is installed in modules arranged in a repetitive pattern for pipe transfer routes, instrumentation, and required services. Equipment includes tanks, evaporators, dissolvers, centrifuges, mixer-settlers, and centrifugal contactors which are handled remotely by overhead bridge cranes employing hoists, impact wrenches, and special tools. Observation in the hot canyon is by periscopes installed on the crane and viewed from a heavily shielded cab. The warm canyon can be observed directly, using binoculars if required, from the shielded crane cab (figure 2).

After "hot" processing began in 1954, personnel did not enter the hot canyon until 1971 when entry was made in connection with the work described here. Fixed radiation levels up to 1000 rads are encountered in the hot canyon after billions of curies of fission product activity have been processed. Maintenance of equipment is done remotely. Although pipe jumpers and equipment are now routinely decontaminated for direct maintenance, several years were required to develop methods for recovering failed equipment.

When the need for a new, relatively small multipurpose facility (employing master-slave manipulators and bulk shield windows) for processing highly radioactive materials became apparent in 1969 , consideration was directed toward using part of the north end of the hot canyon in Building 221-F because equipment in this space was no longer needed and functions could be reassigned to other canyon equipment (figure 3). Design studies showed that the new facility could be economically installed in the last five modules in the north end of the Building 221-F hot canyon provided that this portion of the canyon could be decontaminated to levels that would permit construction personnel to work directly in the canyon. A goal of a general 
radiation level of $25 \mathrm{mR}$ and no appreciable smearable or airborne contamination was established for this decontamination effort. DECONTAMINATION

Overal1 Plan

The plan developed for this decontamination effort included (1) removal of the former processing equipment, (2) remote deçontamination of canyon walls and floor using the hot canyon crane, (3) isolation of the five modules to be cleaned from the rest of the canyon, (4) penetration of the 5-1/2-foot-thick wall for personnel entry, (5) direct decontamination as required - e.g., chipping out contaminated concrete, and (6) concrete replacement and painting. Work started in February 1970 and was completed in February 1971 (figure 4).

Remote Phase

Four tanks and associated pipe jumpers located in modules 17.4, 18.1, 18.2, and 18.3 were all extensively flushed and relocated. After the tanks were removed, remote decontamination of the canyon walls, floor, and all other surfaces began; this work continued from March through July 1970. A "Tigar Jet"* suspended from the crane sprayed hot solutions $\left(80^{\circ} \mathrm{C}\right)$ of water, $10 \%$ nitric acid, $10 \%$ caustic, and $10 \%$ nitric acid with hydroxylanine acid sulfate through rotating spray nozzles at a pressure of 135 psig. An 8-inch-diameter hole was core drilled through the wall in module 18.4 for radiation surveys and observation. A grid system of radiation levels was used to record the progress of the job so the "Tigar Jet" could be positioned where needed to reduce radiation levels. Piping embedded in the concrete walls was flushed using a special manifold to flush several pipes simultaneously. All flushing and spray solutions

* "Tigar Jet' tank scrubber, model $M$, manufactured by Vic Jet, Inc., 114 Forrest Avenue, Narberth, Pennsylvania. 
(approximately 200,000, gallons) were collected in the section 17 and 18 sumps and moved to waste evaporators for concentration and disposal. Radiation levels were reduced from the initial levels of 230 rads maximum and 68 rads average to 1.3 rads maximum and $500 \mathrm{mrads}$ average (table 1). Another 8-inch hole was core drilled in the wall in module 18.2 for additional radiation surveys and direct observation. Lights were installed in the canyon to provide better visibility. During July 1970, in preparation for personnel entry into the canyon, a 2-1/2-foot-thick steel reinforced concrete shielding wall was installed between modules 17.3 and 17.4. This installation served to isolate the portion of the canyon being cleaned from the rest of the canyon where normal Purex processing continued.

Personnel Entry and Direct Decontamination Phase

Penetration of the 5-1/2-foot-thick steel-reinforced concrete hot canyon wall was accomplished by core drilling techniques. Except for the 8-inch-diameter holes used for special observation, all holes were 4 inches in diameter. A total of eight "windows" were cut to accommodate the master-slave manipulators and bulk shield windows required for the new process. About 100 4-inch-diameter holes were drilled to outline each window, and the block of concrete thus cut out was hydraulically pushed into the canyon for removal. Each block weighed approximately 25 tons and was removed using the hot canyon crane. The total of 4-inch hole length drilled was about one mile. Diamond tip core drills were used. After the first window was opened to the canyon, an air lock was set up and personnel wearing air-supplied plastic suits entered the canyon and continued with direct decontamination using a high pressure jet nozzle. The high pressure system was the "Water Blaster"* which was operated at 4500 psig

* American Water Blaster model WBG-110, manufactured by American Water Blaster Company, PO Box 55343, Houston, Texas 77055. 
using a hand-held jet lance. Jackhammers were used to chip out contaminated concrete. Localized areas of contamination (or "hot spots") were cleaned by hand or by the high pressure jet. Conditions continued to improve gradually and, by February 1971, working times increased to greater than 8 hr per day. After the area was painted, the need for respiratory protection was eliminated. The final radiation level averaged about $20 \mathrm{mR}$ per $\mathrm{hr}$, with no smearable or airborne contamination (figure 5). During the work, no contamination was spread to the clean work area in the center section of the building and no personnel were overexposed to radiation.

CONCLUSIONS

In conclusion, the following achievements were demonstrated:

- Decontamination of a highly radioactive contaminated canyon-type chemical processing facility.

- Remote spraying of water, acid, and caustic to effectively reduce initial high radiation levels.

o Penetration of thick reinforced concrete walls by diamond-tipped core drills.

- Direct decontamination by personnel to remove localized areas and hot spots in the final phase.

- Removal of concrete surfaces by chipping, and refinishing and painting to fix any remaining contamination for the desired optimum conditions. 
Figure 1. Separations Building

Figure 2. Separations Building Cross Section

Figure 3. Separations Building Hot Canyon, Sections 17 \& 18

Figure 4. Decontamination Schedule

Figure 5. Finished Cell 
IABLE 1. DECONTAMINATION OF HOT CANYON*

\begin{tabular}{|l|c|c|}
\hline & \multicolumn{2}{|c|}{$\begin{array}{l}\text { RADIATION LEVELS } \\
\text { IN CANYON (rad/hr) }\end{array}$} \\
\cline { 2 - 4 } & AVERAGE & MAXIMUM \\
\hline BEFORE EQUIPMENT REMOVAL & 68 & 230 \\
AFTER EQUIPMENT REMOVAL & 1.5 & 3.8 \\
AFTER MANUAL DECONTAMINATION & 0.50 & 1.3 \\
\hline
\end{tabular}

* overall dF $=3.4 \times 10^{3}$ 


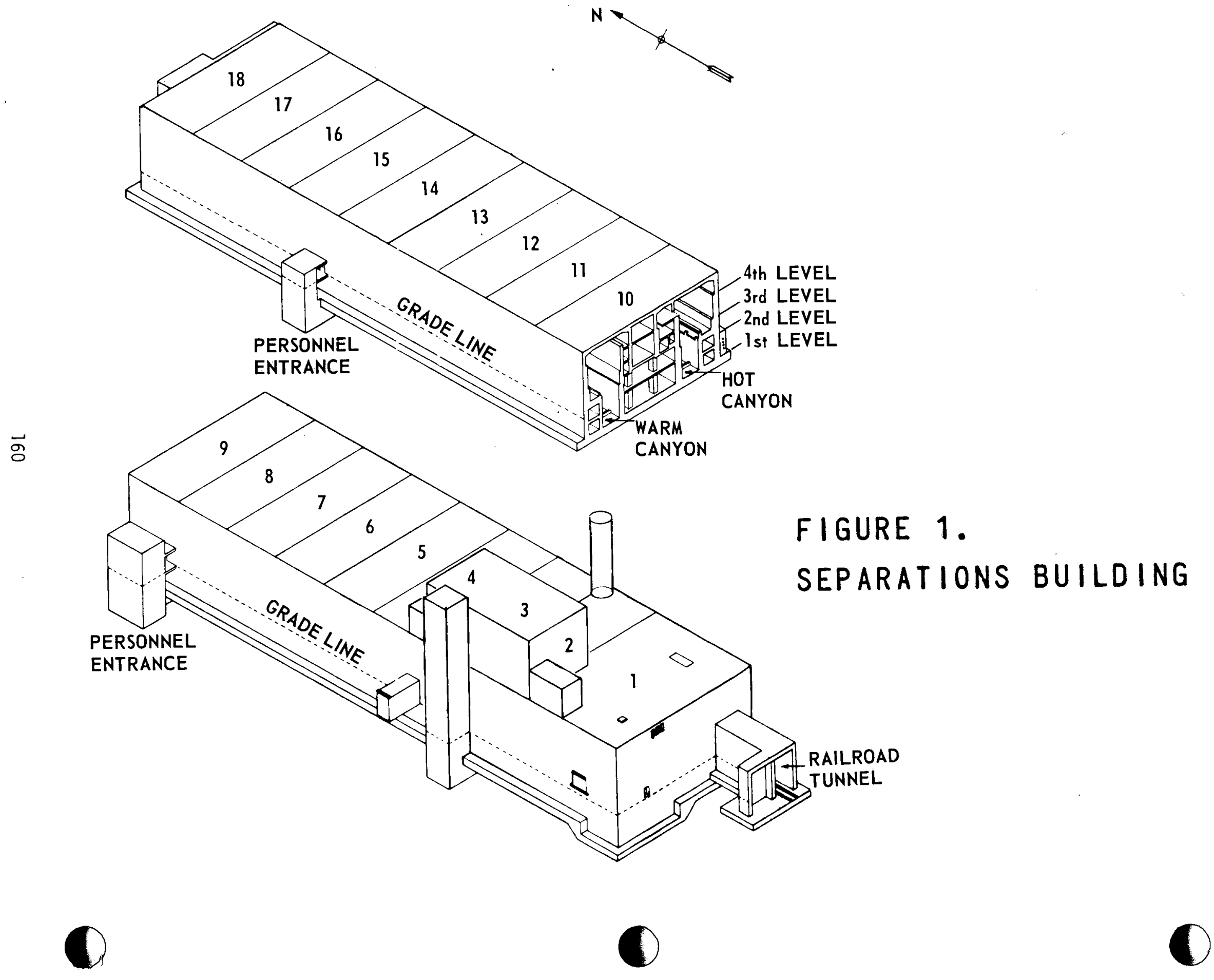


FIGURE 2. SEPARATIONS BUILDING CROSS SECTION

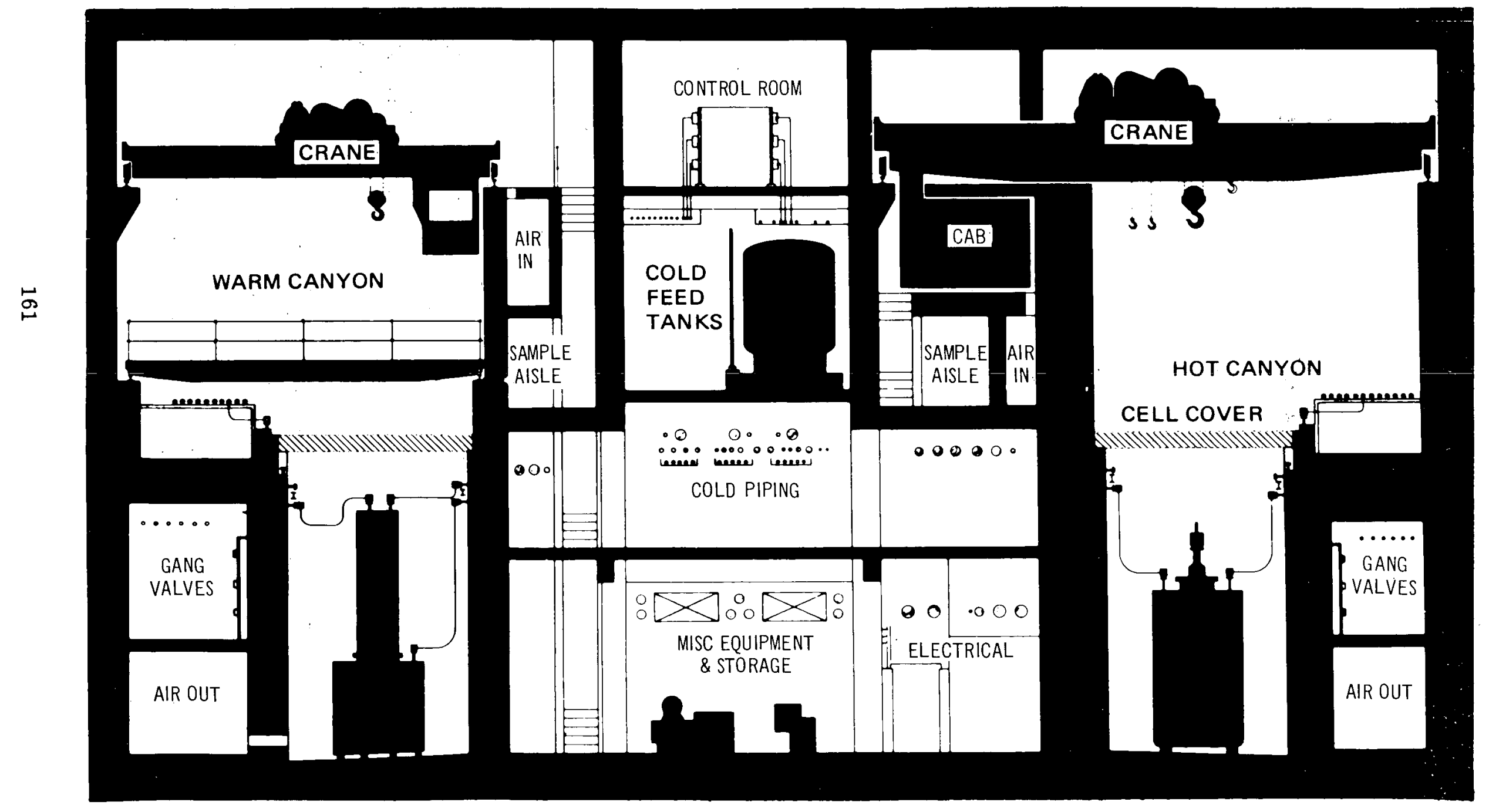




\section{EIGURE 3. SEPARATIONS BUILING HOT CANYON SECTIONS $17 \& 18$}

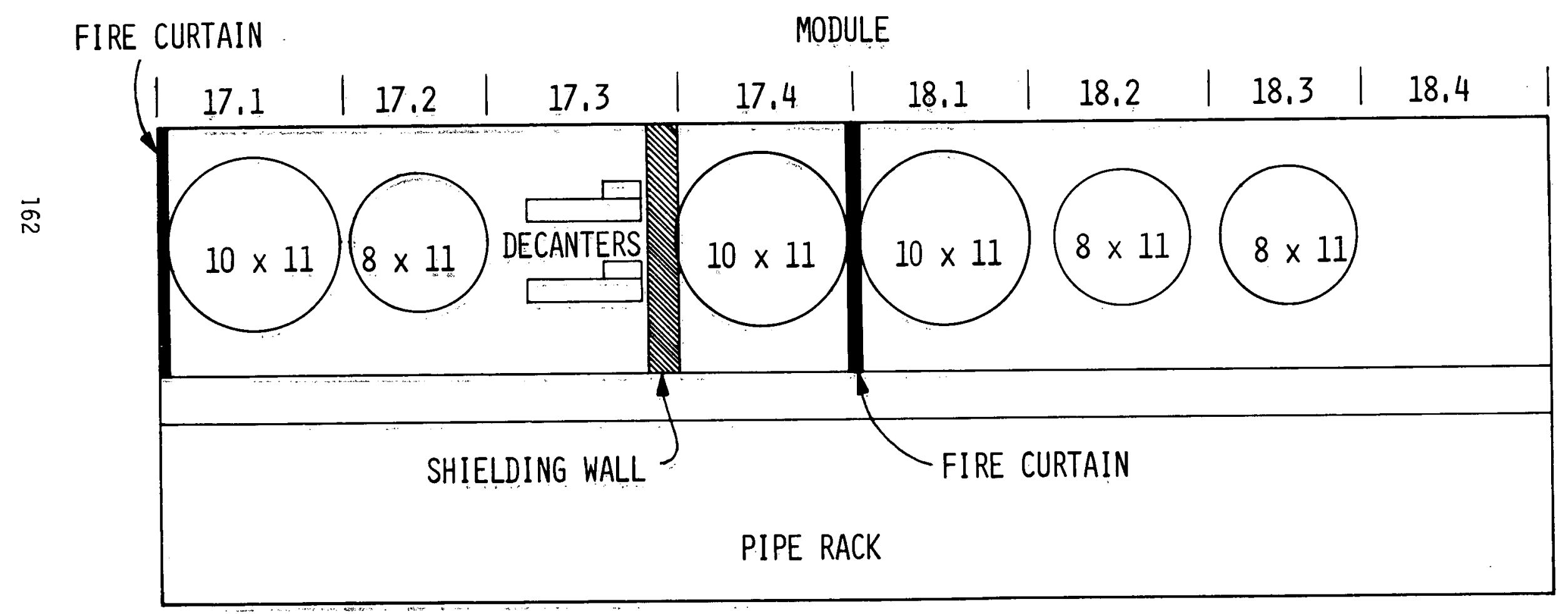




\section{FIGURE 4. DECONTAMINATION SCHEDULE}

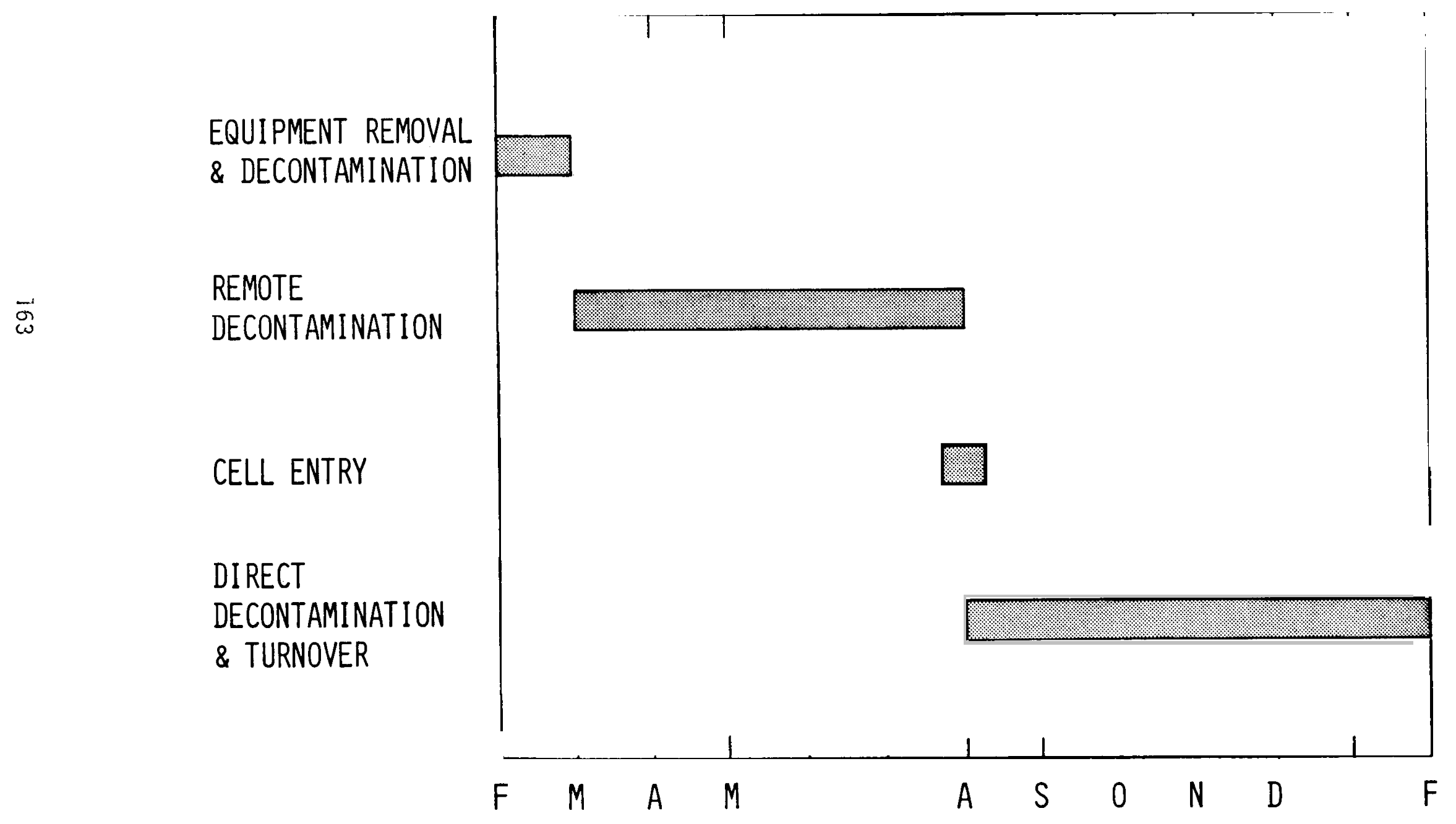




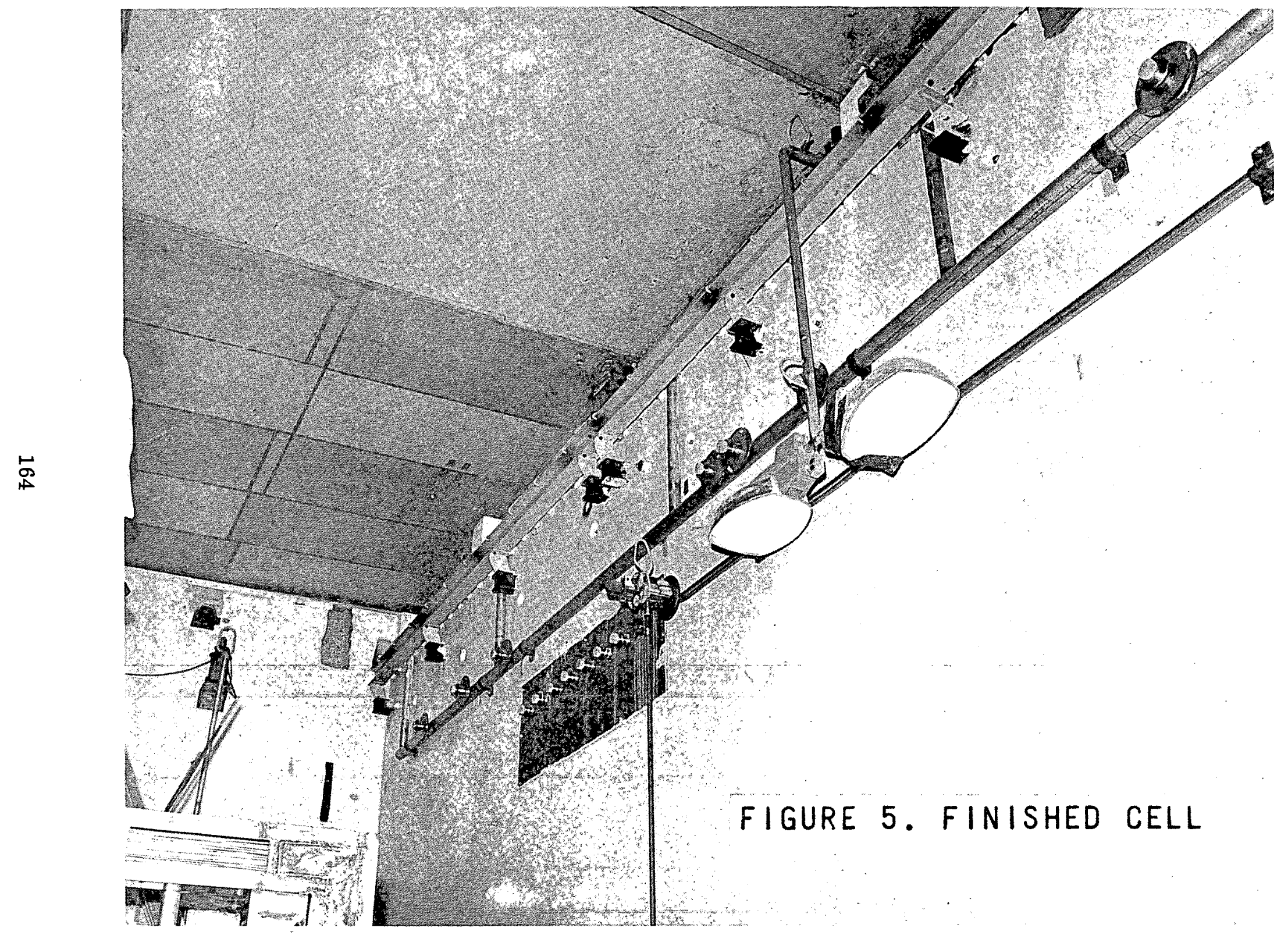




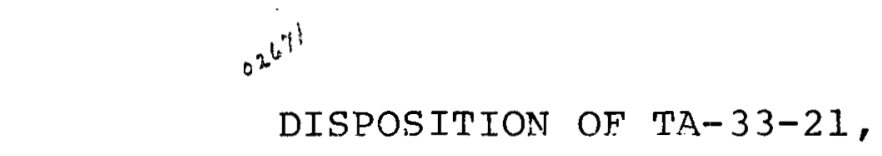

A PLUTONIUM CONTAMINATED EXPERIMENTAL FACILITY

\begin{abstract}
This report discusses the decontamination, demolition and disposal of a plutonium contaminated experimental physics facility which housed physics experiments with plutonium from 1951 until 1960. The results of preliminary decontamination efforts in 1960 are reported along with health physics, waste management, and environmental aspects of final disposition work accomplished during 1974 and 1975 .
\end{abstract}

by

E. J. Cox, R. Garde, A. M. Valentine

of

The Los Alamos Scientific Laboratory*

P. O. Box 1663

Los Alamos, New Mexico

*Work done under the auspices of

The Energy Research and Development Administration

July 21, 1975 
Title

Page No.

1. History . . . . . . . . . . . . 1

2. Description of Facility . . . . . . . 1

3. Decontamination of Buildina 21. . . . . 4

4. Demolition and Disposal . . . . . . 6

5. Health Physics. . . . . . . . . 11

6. Waste Management. . . . . . . . 13

7. Environmental Air Monitoring. . . . . 14

8. Soil Sampling . . . . . . . . . 15

9. Final Site Condition. . . . . . . 16 


\section{History}

The facility described in this report was acquired by the U. S. Atomic Energy Commission in April, 1951, at a cost of $\$ 40,819.00$. During the period from 1951 until 1960, it was used for numerous physics studies, some of which involved plutonium. Most internal surfaces of the building and surfaces of experimental equipment items became contaminated on April 13, 1960, following an accidental release of approximately 300 milligrams of plutonium $(239 \mathrm{Pu})$ oxide powder from an experimental apparatus in the process section of the main building. Soon after this accidental release occurred, preliminary decontamination efforts were initiated. Removal of contaminated equipment items and materials, and repeated washing and painting of surfaces removed and/or fixed the plutonium contamination allowing release of the building for occupancy on May 2, 1960. Due to programmatic changes, the facility was not placed back into service and it remained an excess contaminated facility until October, 1974, at which time final decontamination and demolition work was begun. Final disposition of the facility was achieved in June, 1975. 2. Description of Facility

The facility which is referred to in this report as TA-33-21 was located in Technical Area No. 33 (TA-33). The main building was designated as Building 21 or structure No. TA-33-21 for engineering and maintenance reference. 
TA-33 is a remote technical area located along state Road 4 bordered by National Park Service Land, Indian Land, and by other LASL technical areas. The site, shown in Fig. 1, is approximately $9.6 \mathrm{kilometers}$ southeast of the main Los Alamos Technical Area. TA-33-21 was located approximately 100 meters southwest of the main TA-33 office and Laboratory facilities. It was referred to as the "Cut off Building" in early Laboratory communications and drawings.

In addition to Building 21 , the facility included a small compressor shed, a septic tank, a manhole structure, and several hundred meters of underground drain lines and chain link security fences. These structures, identified in Fig. 2, are:

$\begin{array}{lll}\text { Structure No. } & \text { TA-33-32 } & \text { Septic Tank } \\ \text { Structure No. } & \text { TA-33-55 } & \text { Compressor Building } \\ \text { Structure No. } & \text { TA-33-74 } & \text { Manhole } \\ \text { Structure No. } & \text { TA-33-83 } & \text { Vacuum Pump Base }\end{array}$

As shown in Figs. 3 to 6 , Building 21 was a combination concrete and wooden structure with approximately 100 square meters of floor area. The concrete portion had approximate dimensions of $11 \times 5.4 \times 4.2$ meters and was constructed of 0.2 meter thick monolithic reinforced concrete. It had a poured concrete floor with wire reinforcement. The wooden section had approximate dimensions of $8.7 \times 3.9 \times 3.0$ meters and was constructed of frame with sheetrock paneling on the 
inside and gypsum board siding on the outside; this section was supported on wooden beams. The foundation consisted of concrete piers reinforced with heavy steel bars and was insulated with rock wool. As shown in Fig. 7, Building 21 consisted of six rooms: a counting room, a process room, shower and clothes change areas; a restroom, and a utility room. The counting room was equipped with laboratory benches located around the exterior walls. The process room housed two single gloveboxes and a sink. These rooms were ventilated by two once-through forced air heating systems located in the utility room. There were also several exterior wall exhaust louvers. The building was enclosed in its own perimeter security fence. Building 21 was served by three liquid waste drain systems: 1) a contamination free drain line that served a sink, a floor drain and a safety shower in the counting room; 2) a sanitary sewer system that served restroom and change room lavatories, urinals, and commodes; and 3) a contaminated industrial waste system that served the sink, shower, and glovebox drains in the process room and an adjacent hot change room. The industrial waste system drained to a drain field located approximately 16 meters south of Building 2l. The sanitary sewer system drained to a drop manhole, TA-33-74, which drained to a septic tank, TA-33-32. Overflow from the septic tank surfaced a few 
meters southwest of the septic tank. Figure 8 shows the manhole, a section of the security fence around $\mathrm{TA}-33-21$, and the fenced industrial waste drain field area.

3. Decontamination of Building 21

Following the accidental plutonium release which occurred on April 13, 1960, decontamination efforts were begun to allow personnel occupancy and beneficial use of the building. The general sequence of this decontamination effort was:

1) Removal of most material and equipment items from the process room.

2) Removal of material and equipment from the other rooms.

3) Scrubbing of surfaces in the process room.

4) Sealing of duct openings and outside door from process room and removal of all remaining movable items from process room.

5) Final scrubbing of rooms and equipment surfaces. Decontamination efforts terminated on May 2, 1960. Removable contamination remained on the cracked and buckled linoleum flooring and in inaccessible ducts and cracks. All other surfaces were free of removable contamination. Several small areas of fixed contamination $\left(<400 \mathrm{dpm} / 60 \mathrm{~cm}^{2}\right)$ remained on the west wall of the process room. Surfaces not entirely accessible for decontamination were painted. 
Although the building could be occupied by personnel following this preliminary decontamination effort, it was abandoned due to program redirection. The doors were secured to prevent unauthorized access and the facility became an excess contaminated facility awaiting final disposition.

An extensive survey was conducted on July 18, 1972, to re-establish contamination levels on accessible surfaces in Building 21. Results of this survey are listed in Table 1. No attempt was made to survey inside ducts and drain lines. Results of the July 18, 1972 survey indicated that some recontamination of interior surfaces had occurred since 1960 . There was also evidence that the building was deteriorating structurally making final decontamination and disposal desirable, primarily to prevent accidental plutonium dispersal in the event of a fire or natural disaster.

In October, 1974, final decontamination efforts were begun with special program funding from the ERDA Division of Waste Management and Transportation. The following decontamination efforts were initiated to reduce the potential for plutonium dispersal during subsequent demoliton phases:

1) Removal of gloveboxes, equipment items and miscellaneous materials remaining in Building 21 .

2) Removal of some contaminated air ducts and fixtures.

3) Resealing of duct openings.

4) Scrubbing of floors and bench tops. 
Figure 9 shows the sink unit and a portion of the process room prior to final decontamination. Surface contamination levels following final decontamination work were significantly less than levels measured in 1972 .

During the period from October 1974 until March 1975, final demolition and disposal plans and work orders were developed to accomplish final disposition.

4. Demolition and Disposal

Demolition work started on March 31, 1975 and continued until May 8, 1975. This effort was divided into the following phases:

1) removal of remaining fixtures and equipment items;

2) dismantling and disposal of wooden section of Building 21 which included the process and hot change room;

3) demolition and disposal of concrete section of Building 2I; and

4) removal and disposal of underground drain lines, manhole and septic tank.

To best utilize equipment and manpower, phase four was carried out intermittently throughout the complete operation. The work accomplished during each of the four phases and contamination levels that were encountered are described. 
Phase 1. Removal of Fixture and Equipment Items

Items removed from inside the building consisted of light fixtures, sinks, cabinets, commodes and duct work. Exterior items consisted of exhaust blowers, piping, and light fixtures. The contamination levels detected ranged from several hundred to $100,000 \mathrm{dpm} / 60 \mathrm{~cm}^{2}$. After removal work was completed, the interior wall and floor surfaces were scrubbed and painted to further reduce the potential for plutonium dispersal. This resulted in conditions shown in Fig. 10 .

The furnace, compressor, and other small equipment items located in the utility room were cleaned, painted, dismantled and repainted. This operation produced the highest levels of surface and airborne contamination encountered during the project. The highest surface and airborne contamination levels were $100,000 \mathrm{dpm} / 60 \mathrm{~cm}^{2}$ and $40 \mathrm{x} 10^{-12}$ $\mu \mathrm{Ci} / \mathrm{cm}$, respectively.

All persons engaged in removal work wore full face respirators equipped with ultra-high efficiency filter canisters and anti-contamination clothing.

Phase 2. Removal of Wooden Structures

This phase involved the dismantling and removal of the wooden section of Building 21. This section housed the process and hot change room and was the main source of the remaining contamination. All interior wall paneling, ceiling, flooring and insulation were removed with the 
exterior walls intact to prevent possible contamination release to the atmosphere.

Contamination levels detected ranged from 4,000 dpm/ $60 \mathrm{~cm}^{2}$ under the linoleum to $12,000 \mathrm{dpm} / 60 \mathrm{~cm}^{2}$ on the walls. After removal of the paneling and insulation, the interior surfaces of the remaining walls and floor were repainted. A backhoe was used to remove underground piping and foundations. TA-33-55, the compressor shed, was also removed during this phase of demolition work, leaving conditions shown in Fig. 11.

\section{Phase 3. Removal of Concrete Section}

A large crane equipped with a "wrecking" ball was required for demolition of the concrete section as shown in Fig. 12. All perimeter fencing was removed to allow the equipment to maneuver. After each initial crushing of a portion of the wall and roof, an extensive radiation survey was conducted. Water spray was used for dust and contamination control. No contamination was detected on the debris or the heavy equipment used. The absence of loose contamination allowed use of conventional demolition techniques, thus avoiding high cost and time delay.

During phases 2,3 and 4 , a full set of anti-contamination clothing was required. Full face respirators were used at the discretion of the health physics surveyor in charge. 
On several occasions, demolition was curtailed due to extreme windy conditions.

Phase 4. Removal of Underground Drainlines, Septic Tank and Manhole

As was mentioned earlier, the removal of the underground items were conducted concurrently with the demolition of Building 21 to best utilize manpower and equipment. The uncontaminated lines, i.e., the drainline from the count room and the septic tank system were removed first; no contamination was encountered. These items were easily removed using a backhoe and manual labor.

The tile field which received the industrial wastes from Building 21 was removed last to minimize spreading of contamination. Details of this drain field are shown in Fig. 13. Expectations were that the entire distribution and collection systems as well as the gravel between them would be highly contaminated requiring hand excavation and packaging of the materials. The excavation and removal of the $1.2 \mathrm{~m}$ sections of $10.2 \mathrm{~cm}$ clay pipe began at the out fall in hopes that this would be uncontaminated because wastes entering the field may not have reached this point.

It was soon evident that the entire collection system had never been exposed to contaminated wastes. This fact was verified by monitoring the inside of the pipe and by collecting and measuring soil samples under pipe joints. The 
collection system was removed in a fashion similar to the removal of the two uncontaminated drain systems. A typical trench, after removal of the clay pipe, is shown in Fig. 14.

The next step was the removal of the distribution system. Excavation was begun at the ends most distant from the junction shown in Figs. 13 and 15. All four east-west laterals were removed without encountering any contamination. Contamination was encountered in the north-south lateral of the distribution system. As shown in Fig. 13, approximately $10 \mathrm{~m}$ of trench were contaminated to levels of approximately $80 \mathrm{pCi} / \mathrm{gm}$ gross alpha. Approximately $2.5 \mathrm{~m}^{3}$ of contaminated soil from this trench and all of the clay pipe were sent to the contaminated waste burial ground and buried as nonretrievable waste. Sampling and analyses of the soil will be described in section 8 .

The fact that the contamination in the tile field was not as extensive as expected can probably be explained in this manner: Contamination from the 1960 accidental spill did not enter the field, and volumes of waste from normal operations prior to 1960 were small enough that the wastes did not migrate to very long distances from the entrance to the field.

The demolition portion of this operation required 28 working days and about 1700 manhours of on-site craft and 
health physics manpower. Approximately 200 manhours were required for pre-demolition decontamination work; hence, final disposition consumed a total of about 1900 manhours. No incidents occurred except for an uncontaminated minor scratch on the face of one man which occurred while he was helping dismantle the perimeter fence.

5. Health Physics

A standard operating procedure that established health physics provisions was prepared prior to starting final decontamination and demolition work. Trailer facilities shown in Fig. 16 were located approximately 30 meters east of Building 21. These trailers provided space for health physics monitoring, change rooms, and eating facilities. Provisions established for health physics included:

1) Personnel assigned to work at TA-33-21 were quantitatively fitted with full face respirators and sampled for urinary plutonium before they could work at the site.

2) A complete change into protective anti-contamination clothing was required for workmen and health physics personnel actively engaged in decontamination and demolition work. This included socks, underwear, safety shoes, booties, coveralls, surgeon's cap, gloves, and hard hats. 
3) No personal items such as rings, wrist watches, cigarettes were allowed on personnel engaged in decontamination work.

4) Health physics monitoring was provided continuously and workers were provided film badges even though only background beta-gamma levels existed.

5) All workmen were surveyed for contamination at noon and at the end of the work shift. More frequent surveys were conducted during the final decontamination phase.

6) Nasal smears were taken at the end of each work shift as a minimum.

7) Workmen were required to take showerbaths at the end of the work shift.

8) Any injury was reported to health physics for proper monitoring. .

9) Tools and equipment used in the area were monitored for contamination prior to removal.

10) All dump trucks were monitored for contamination after being loaded at TA-33-21 and after each load was dumped at Area G, TA-54.

11) Daily air samples were collected in work areas during the entire operation.

12) Workers were placed on a routine plutonium urine sampling program to assure post work sampling. 
Minimal airborne and personnel contamination control problems were encountered during final decontamination and demolition phases of the project because prior decontamination efforts in 1960 had removed and/or fixed most of the original plutonium contamination.

Airborne plutonium levels exceeded $2 \times 10^{-12} \mu \mathrm{Ci} / \mathrm{cc}$ in the utility and process rooms on four days during final decontamination work. The highest measured concentration was $40 \times 10^{-12} \mu \mathrm{Ci} / \mathrm{cc}$ which equals the concentration guide for insoluble plutonium. The highest single nasal smear activity was $8 \mathrm{dpm}$ and no contaminated injuries occurred during the job.

6. Waste Management

All structures, fences, and underground tanks and lines at TA-33-21 were removed and disposed of at the LASL's radioactive solid waste disposal site as nonretrievable, $<10 \mathrm{nCi} / \mathrm{g}$, plutonium contaminated solid waste. These waste materials were packaged in different ways depending on size and contamination level to make transport and disposal safe. Contaminated small items were placed in plastic bags and $0.56 \mathrm{~m}^{3}$ cardboard boxes; the bags and boxes were sealed with tape. In addition to the boxed waste, large items and structural materials were taken to the disposal site in covered dump trucks as shown in Fig. 17. Fixing the contamination on large items with several coats of paint allowed 
handling, transport, and disposal without vehicle or personnel contamination problems. Ninety-seven truck loads, or about $450 \mathrm{~m}^{3}$ of contaminated debris were removed from the site. Waste packages and unpackaged items were monitored for plutonium contamination with portable alpha survey instruments prior to removal from the site.

\section{Environmental Air Monitoring}

Environmental monitoring of the demolition operation was conducted with a special on-site air sampling program. Two trailer-mounted, gasoline-powered generators were used to provide electrical power at the site. Each of the generators powered two environmental air samplers. A sampler and a generator can be seen in Fig. 18. The sampler locations are shown in Fig. 19.

The samplers drew air through a 78-mm Microsorban filter with an efficiency of about $99.8 \%$ for $0.3 \mu$ dioctylphthalate (DOP) particles (a standard test aerosol for determining filter efficiency) at a rate of about $70 \mathrm{l} / \mathrm{min}$.

The samples were collected weekly. This schedule was not intended to provide an early detection of a plutonium release, but was to document the magnitude of an accidental release.

Each week's samples were composited for plutonium analyses to determine environmental plutonium levels during the demolition. For comparison, the sampling program was 
begun three weeks prior to start-up and was continued two weeks after completion of the demolition operations. The weekly concentrations of atmospheric ${ }^{239} \mathrm{Pu}$ including the predemolition and post demolition periods are listed in Table 2 .

\section{Soil Sampling and Analyses}

An extensive soil sampling program was effected in the tile field. Samples were collected under pipe joints at intervals of approximately 1.2 meters. The samples were homogenized by mixing in the plastic collection bags. A $100 \times 15 \mathrm{~mm}$ plastic petri dish was filled with soil. The dish and its contents were dried under a heat lamp for five minutes and then allowed to cool. Gross alpha measurements were made on each sample with a ZnS alpha counting system.

Alpha activity levels were considered to be significant if the gross counts were greater than $3 \sigma$ above the approximately 20 counts per $5 \mathrm{~min}$ observed on a background sample of the type of soil found at TA-33-21. The equation used was:

$$
A=1.33(G-20)
$$

where

$$
\begin{aligned}
\mathrm{A}= & \text { alpha activity in } \mathrm{pCi} / \mathrm{gm} \\
1.33= & \text { calibration factor obtained from a } 2 \mathrm{nCi} / \mathrm{gm} \\
& \text { standard } \\
\mathrm{G}= & \text { gross counts for five minutes } \\
20= & \text { background counts for five minutes. }
\end{aligned}
$$


With a gross count of 35 counts/5 min, (just above the $3 \sigma$ level of significance), the significant alpha activity level was $20 \mathrm{pCi} / \mathrm{gm}$.

Ninety percent of the samples (48 out of 53) taken from under clay tile distribution and collection systems contained less than $20 \mathrm{pCi} / \mathrm{gm}$ gross alpha. The remaining five samples, taken from the area where the soil was removed, ranged from 25 to $80 \mathrm{pCi} / \mathrm{gm}$.

Samples taken from the area where soil was removed (after the removal of the contaminated soil) indicated that the remaining soil contained less than 20 pCi/gm gross alpha. Four surface samples collected in the area of TA-33-21 after the demolition but prior to back filling with top soil also contained less than $20 \mathrm{pci} / \mathrm{gm}$ gross alpha activity.

Ten soil samples collected during the removal of the tile field lines were selected for plutonium analyses to confirm the gross alpha measurements made with the zns system. The $\mathrm{Pu}$ concentrations ranged from $0.01 \pm 0.01$ to $0.10 \pm 0.01 \mathrm{pCi} / \mathrm{gm}$ for soil left in place. The highest measured Pu concentration for soil removed for burial was $130 \pm 10 \mathrm{pCi} / \mathrm{gm}$.

9. Final site Condition

The 10 to $15 \mathrm{~cm}$ depression remaining after the removal of Building 21 and its related structures was backfilled with top soil to restore the site to its original contour. The area (approximately $2000 \mathrm{~m}^{2}$ ) was planted in blue gramma and 
stream wheat grasses, and fertilized with ammonium nitrate and super triple phosphate. Figure 20 shows the site following site grading, seeding, and fertilizing operations. 
Table 1

Building TA-33-21 Survey Results 18 July 1972

Maximum Contamination Levels

Direct $\alpha \quad$ Removable $\alpha$

Room

Location

$\left(\mathrm{dpm} / 60 \mathrm{~cm}^{2}\right) \quad\left(\mathrm{dpm} / 100 \mathrm{~cm}^{2}\right)$

Process Room

Outside airlock floor

3,000

90

Process Room

Floor under glovebox

$>40,000$

29,000

Process Room

Water pipe, south wall

2,000

500

Process Room

Floor, center

2,000

180

Process Room

Floor, under sink

1,500

269

Process Room

Floor, under bench

1,000

150

Hot Change Room

Top of door

20,000

160

Hot Change Room

Steam pipes

10,000

110

Hot Change Room

Floor

10,000

550

Locker Room

Light switch

1,000

70

Locker Room

Floor

2,000

90

Restroom

Stearm pipes

1,000

60

Restroom

Floor

1,600

240

Count Room

Floor

1,000

100

Count Room

Flowr

3,000

170

Utility Room

Pipes

36,000

1,000 
Table 2

Environmental Air Sampling Data

\begin{tabular}{cccc} 
Week & \multicolumn{1}{c}{ Status of Project } & $\begin{array}{c}239 \mathrm{Pu} \\
\text { Concentration } \\
\left(10^{-18} \mu \mathrm{Ci} / \mathrm{ml}\right)\end{array}$ & $\begin{array}{c}\text { o } \text { of } \\
\text { ERDA CG** }\end{array}$ \\
$I^{*}$ & Background Air Sampling & $56 \pm 30$ & $<0.01$ \\
2 & Background Air Sampling & $33 \pm 9$ & $<0.01$ \\
3 & Background Air Sampling & $57 \pm 11$ & $<0.01$ \\
4 & Final Building Decontamination & $1821 \pm 66$ & 0.18 \\
5 & Final Building Decontamination & $922 \pm 40$ & 0.09 \\
6 & Building Demolition & $245 \pm 24$ & 0.02 \\
7 & Building Demolition & $70 \pm 12$ & $<0.01$ \\
8 & Building Demolition & $80 \pm 24$ & $<0.01$ \\
9 & Building Demolition & $124 \pm 18$ & 0.01 \\
10 & Background Air Sampling & $58 \pm 8$ & $<0.01$ \\
11 & Background Air Sampling & $58 \pm 8$ & $<0.01$
\end{tabular}

*Sampling began March 5, 1975.

* Concentration guide for uncontrolled area for insoluble $2{ }^{39} \mathrm{Pu}$ in air equals $1 \times 10^{-12} \mu \mathrm{Ci} / \mathrm{ml}$. 
List of Figures

Figure Number

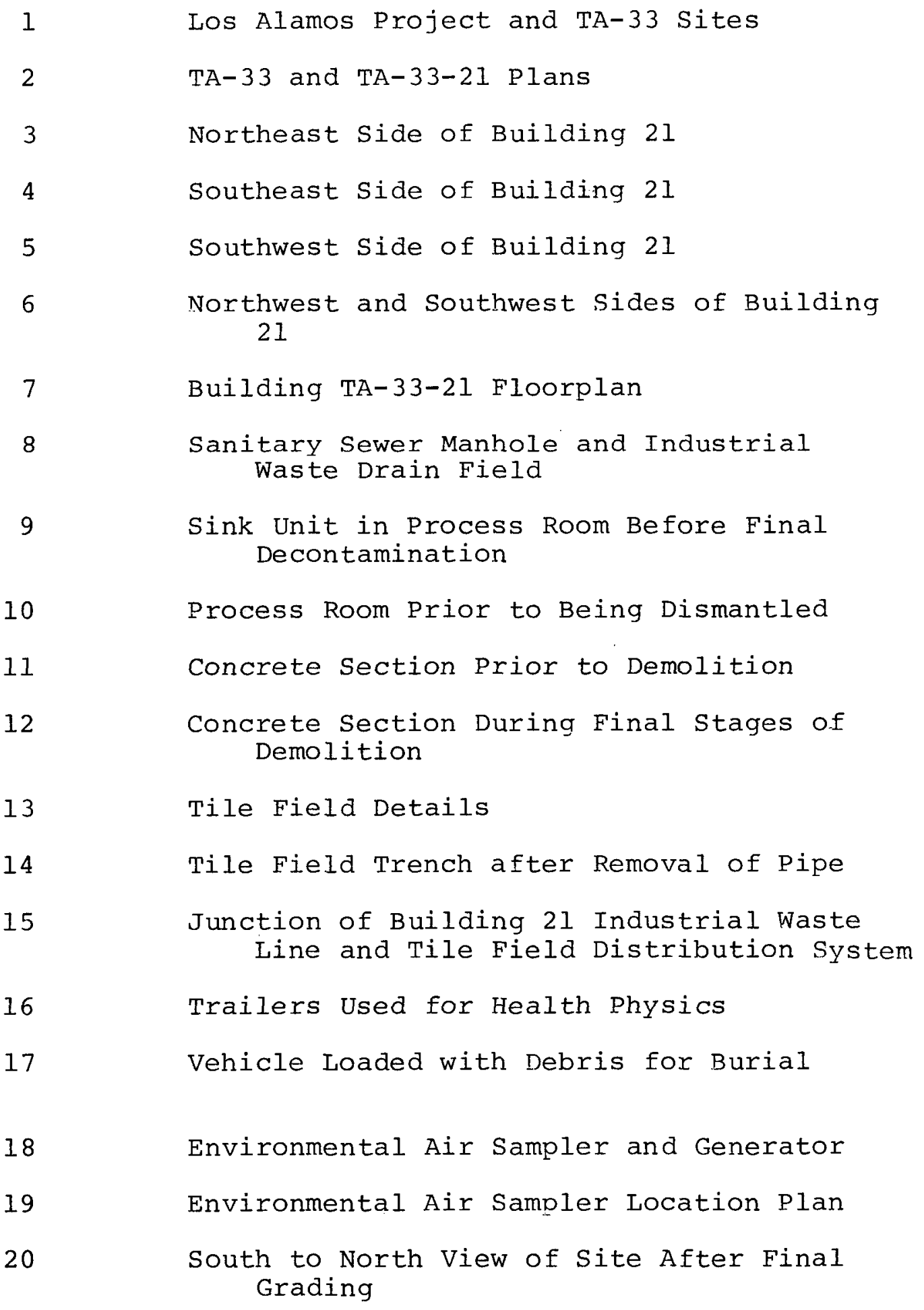




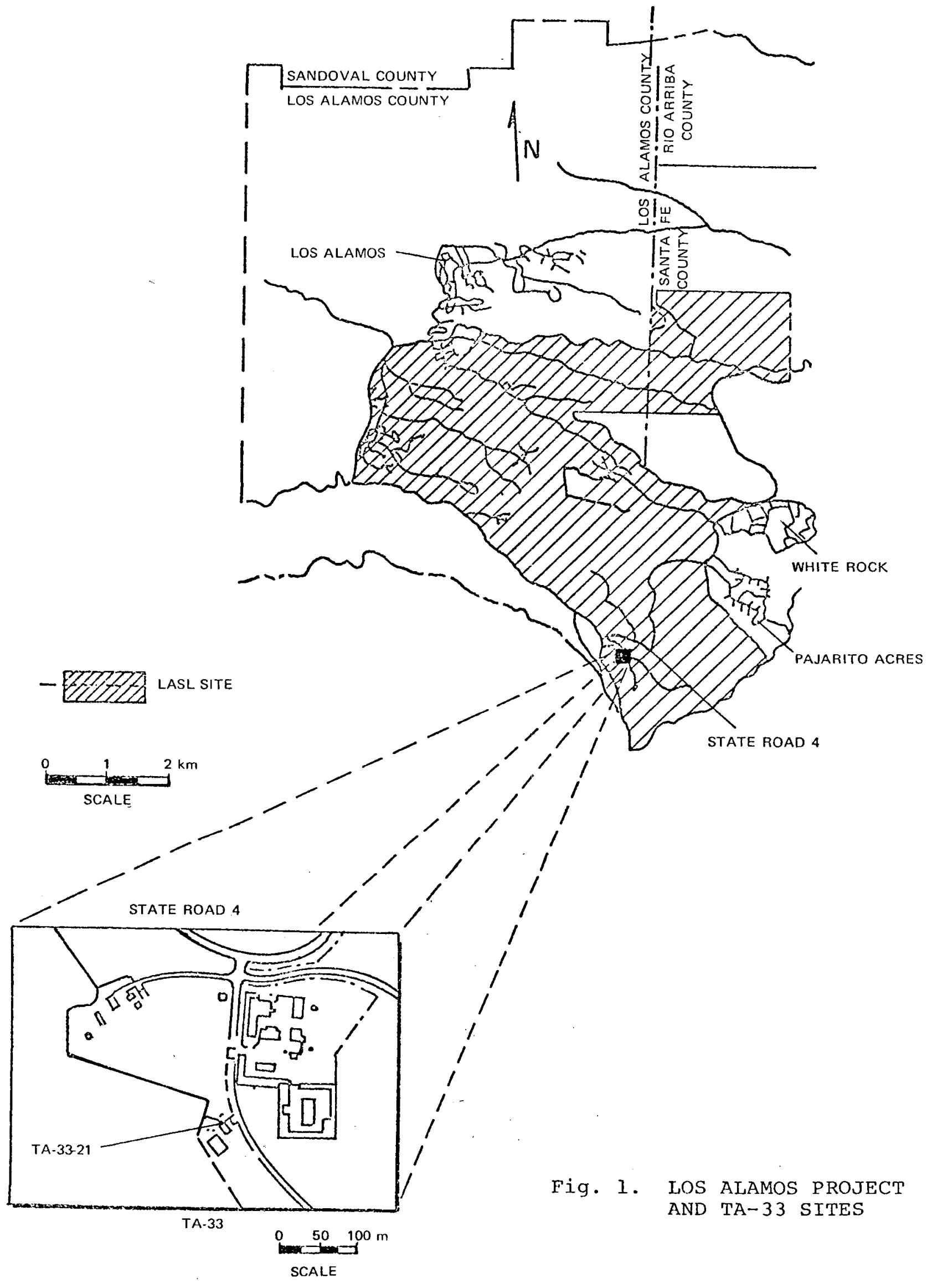




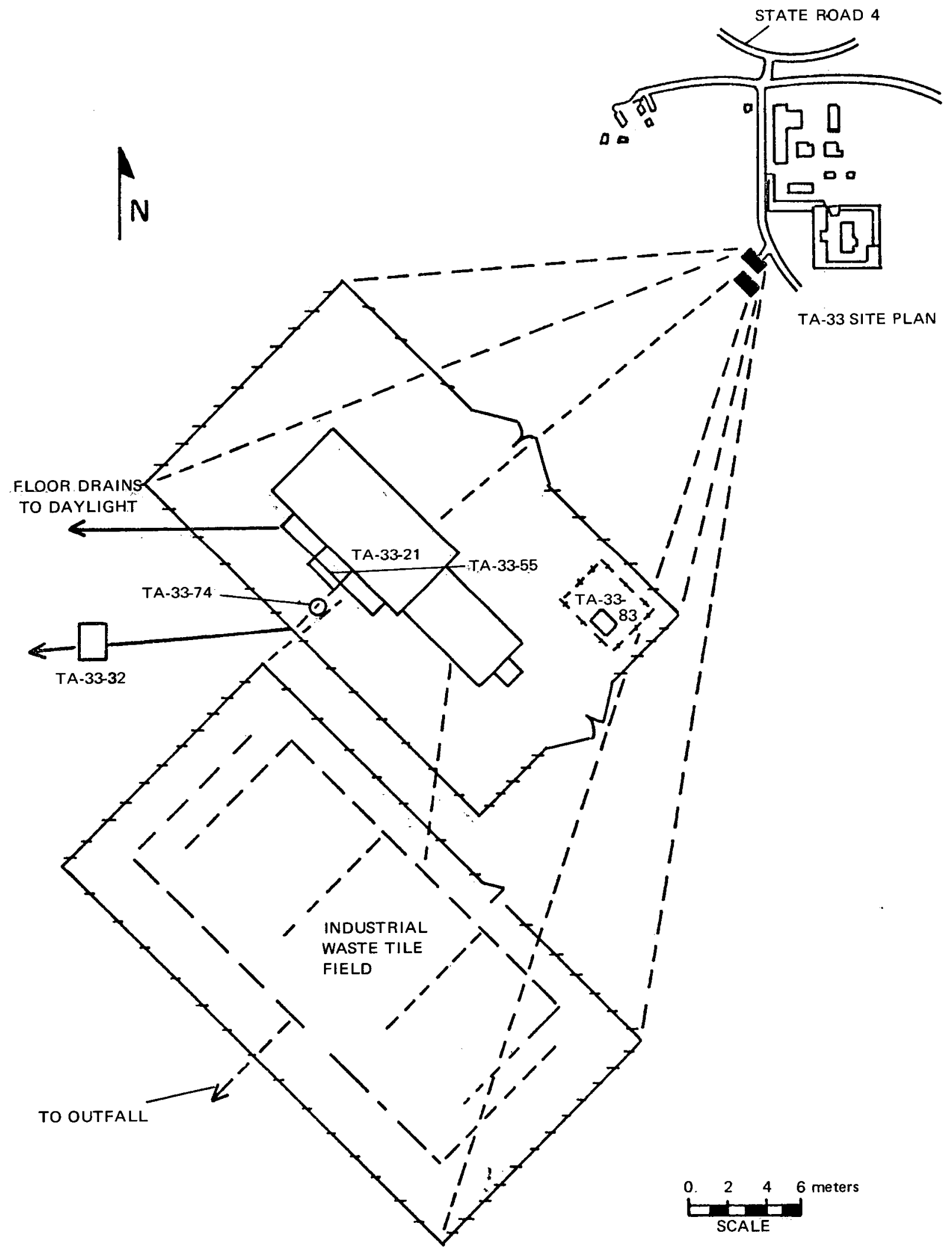

Fi.g. 2. TA-33 AND TA-33-21 PLANS 
Fig. 3. NORTHEAST SIDE OF BUILDING 21

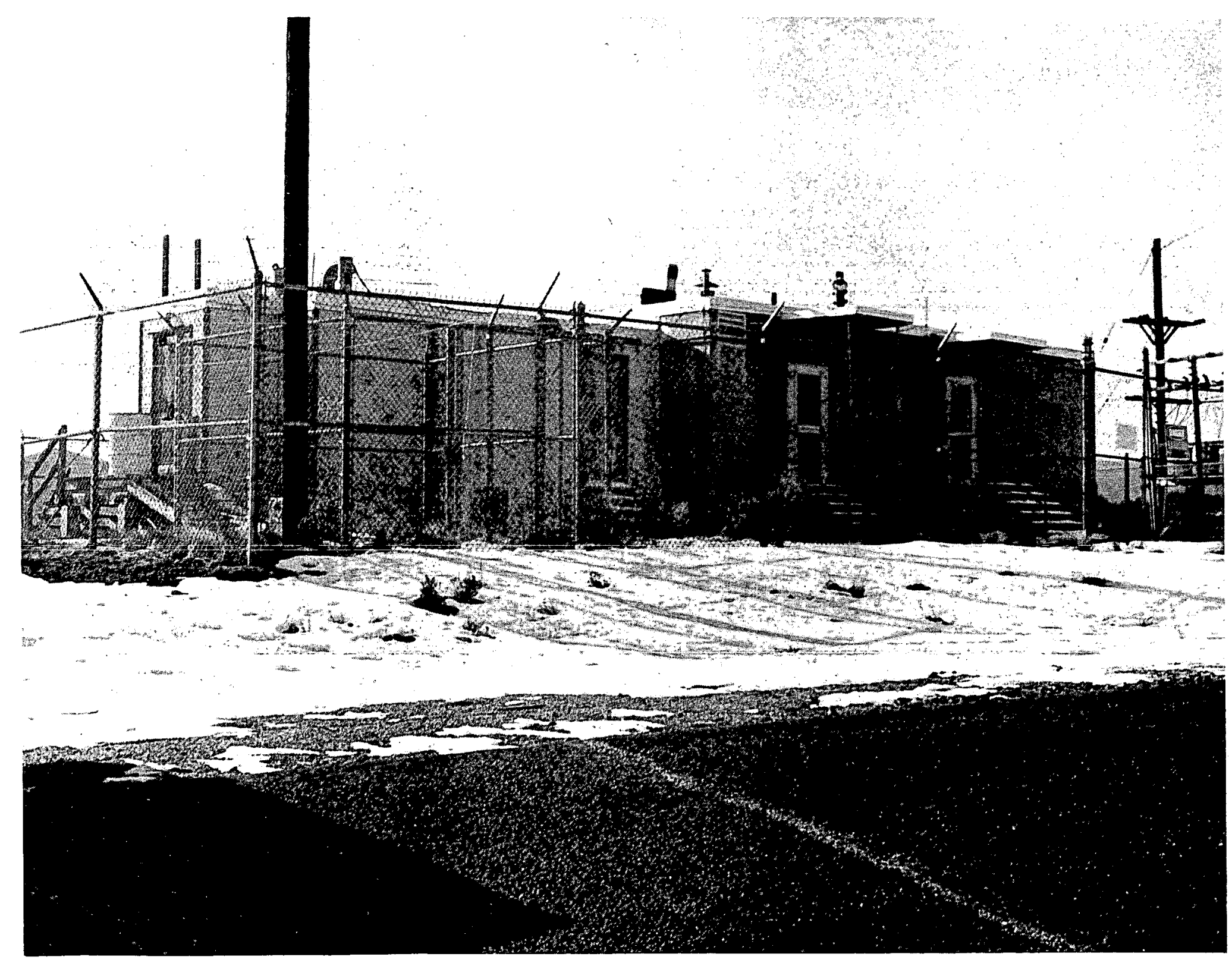


Fig. 4. SOUTHEAST SIDE OF BUILDING 21

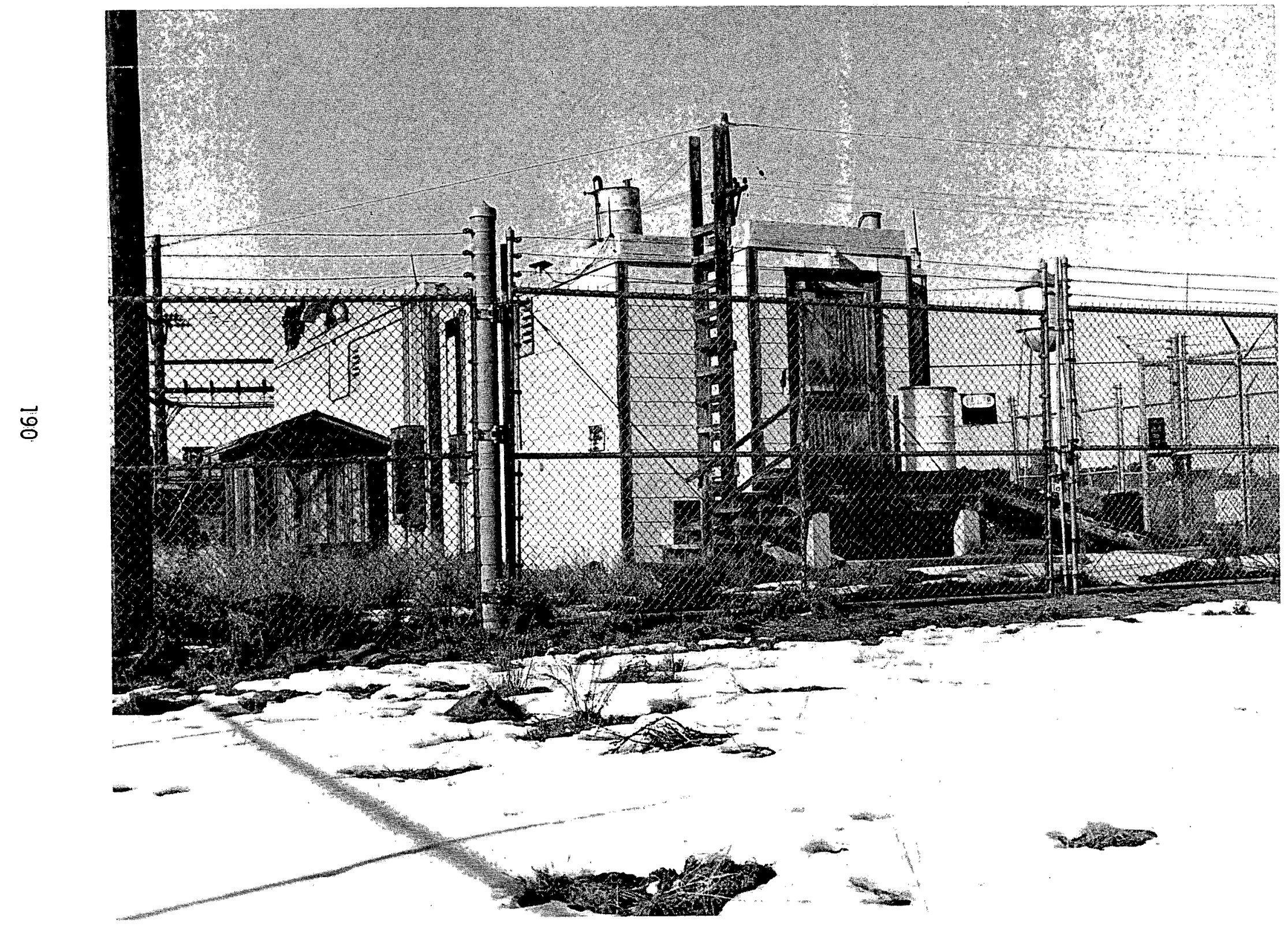


Fig. 5. SOUTHWEST SIDE OF BUILDING 21

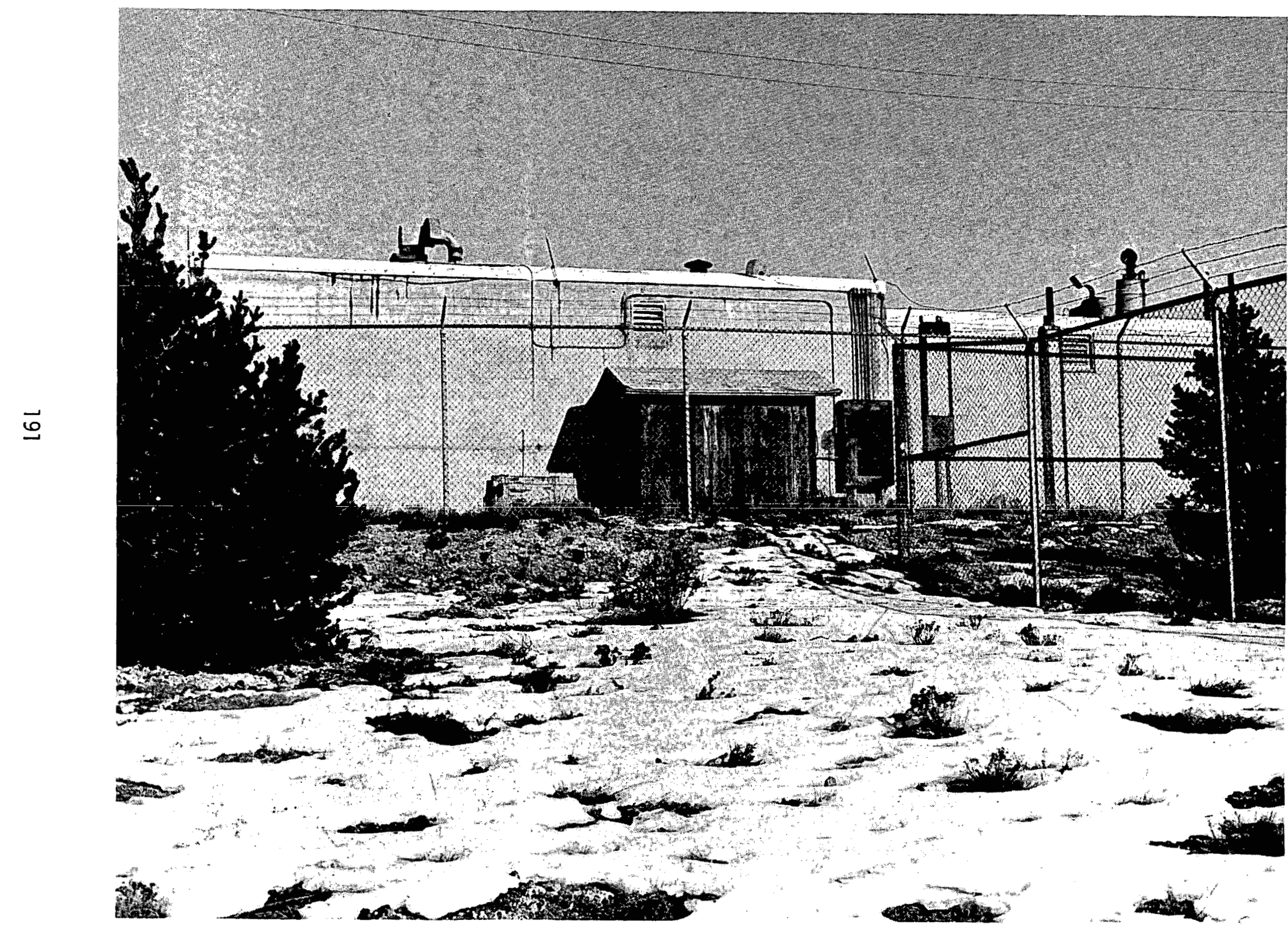


Fig. 6. NORTHWEST AND SOUTHWEST SIDES OF BUILDING 21

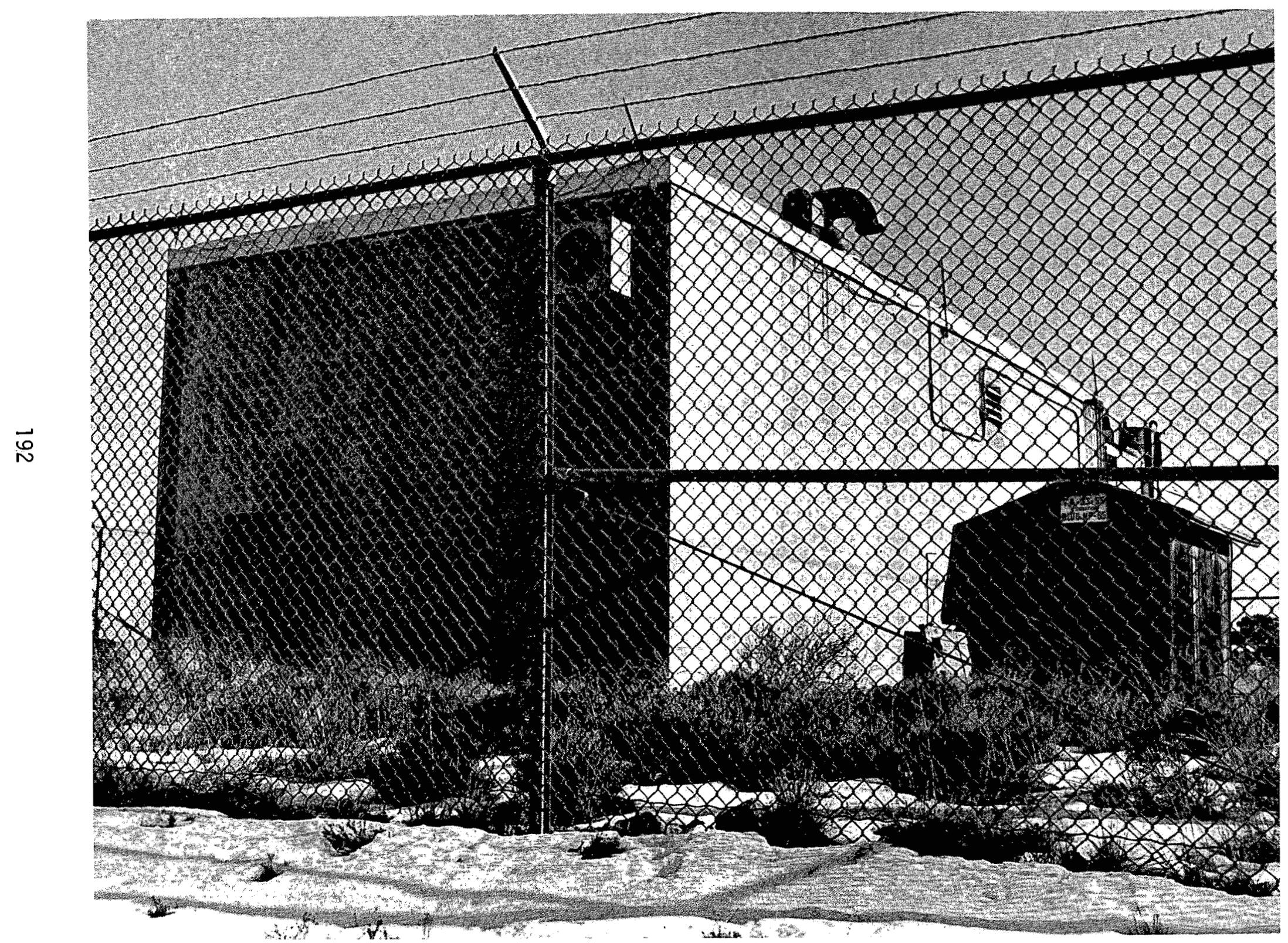

0 


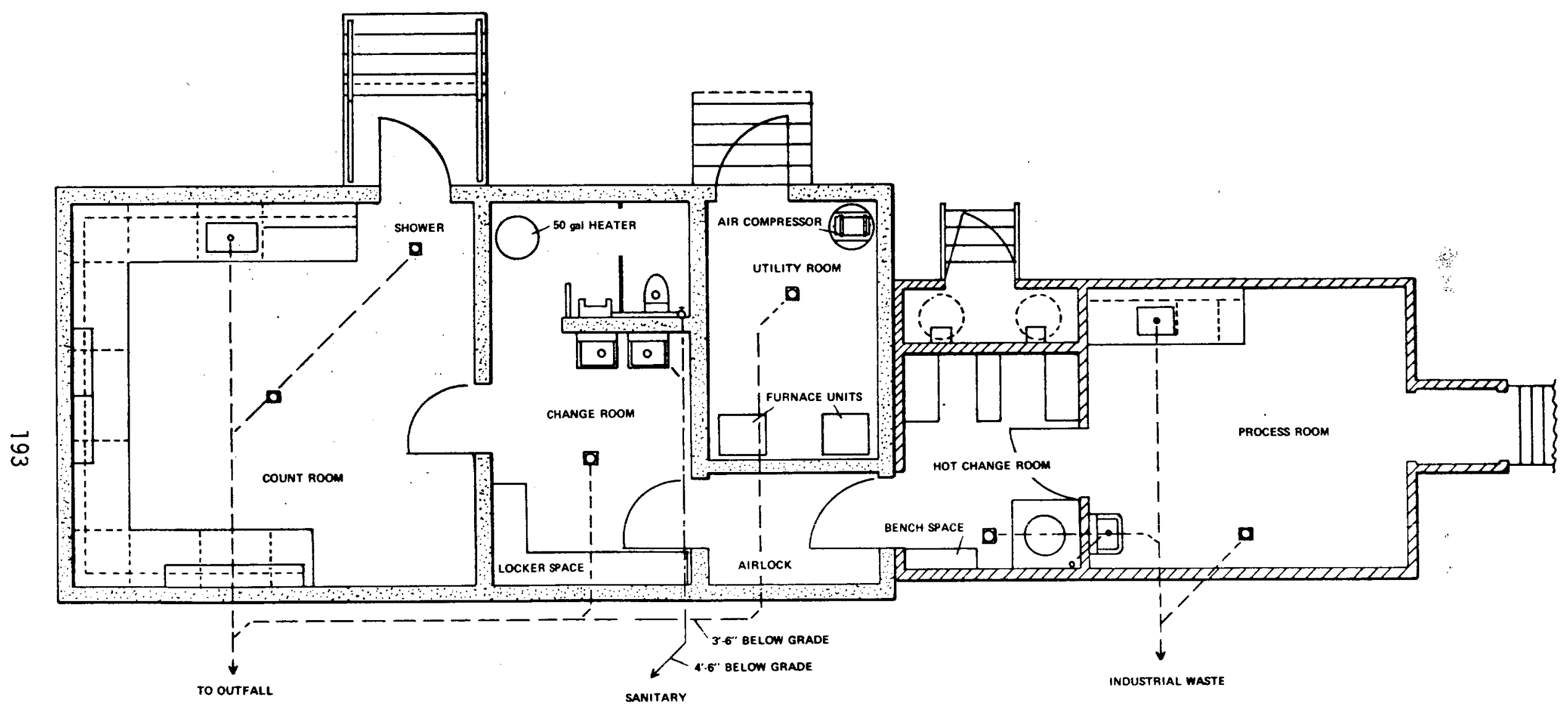

Fig. 7. BUILDING TA-33-21 FLOORPLAN 


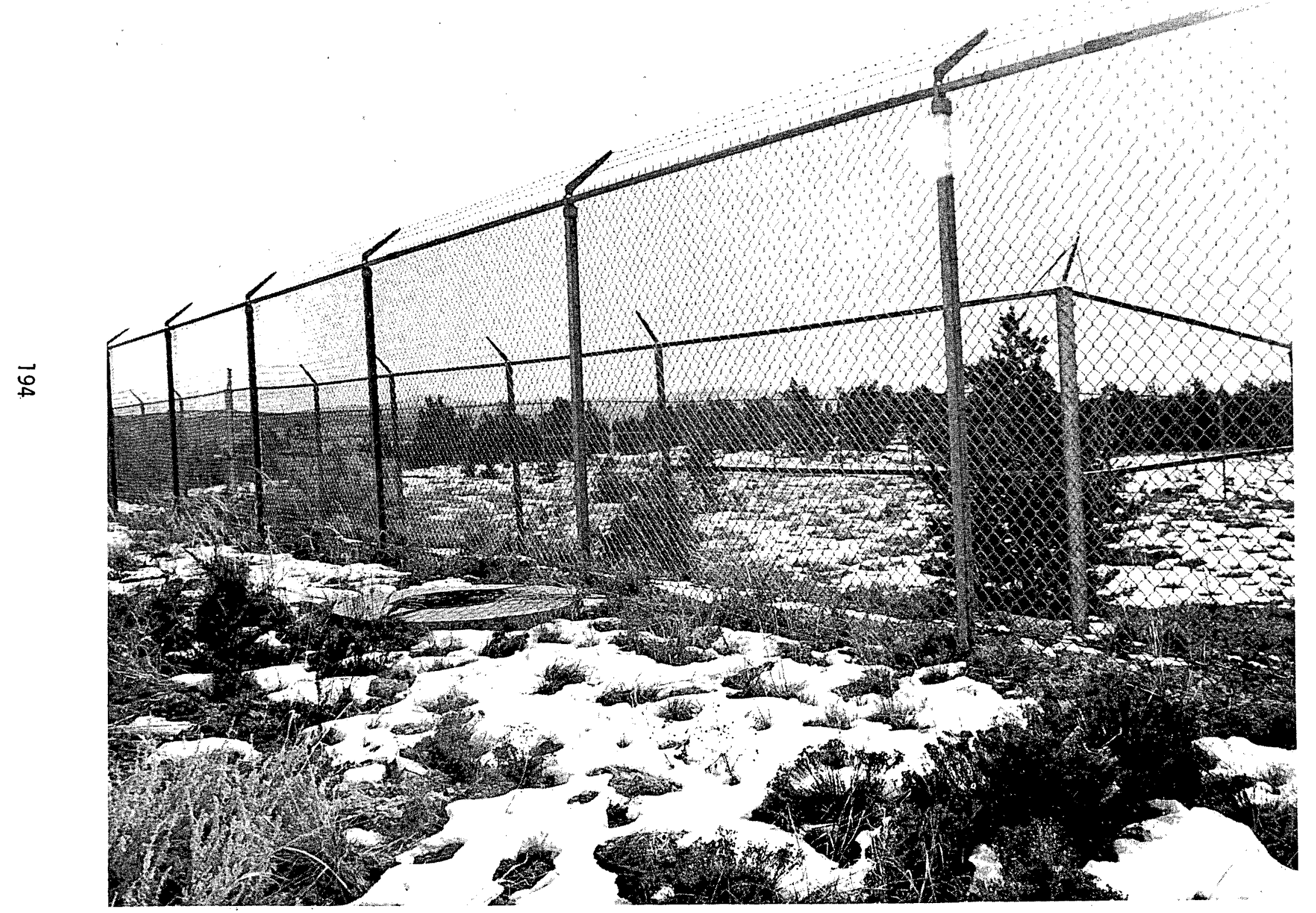


C

Fig. 9. SINK UNIT IN PROCESS ROOM BEFORE FINAL DECONTAMINATION

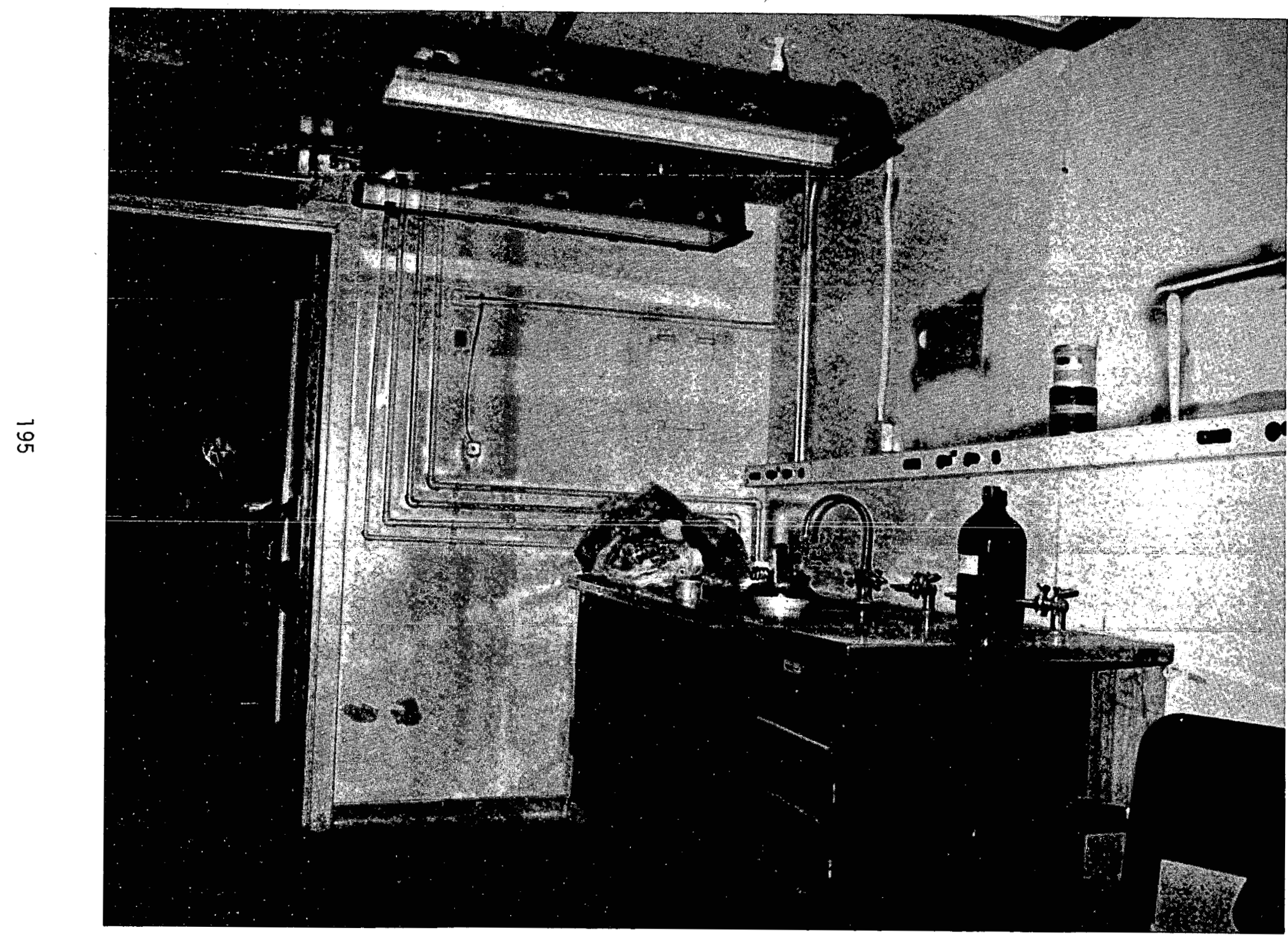


Fig. 10. PROCESS ROOM PRIOR TO BEING DISMANTLED

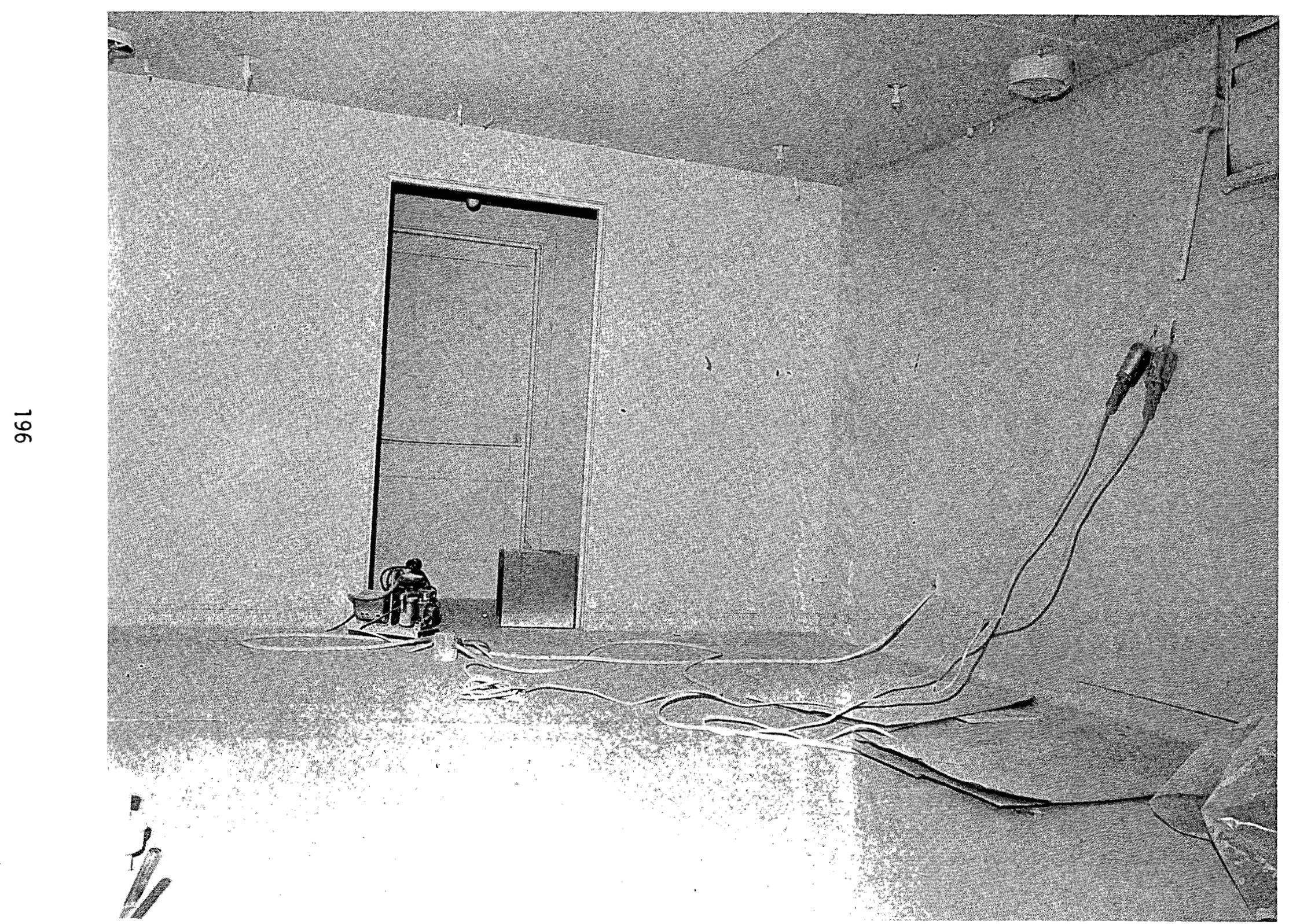

0 


\section{C}

Fig. 11. CONCRETE SECTION PRIOR TO DEMOLITION

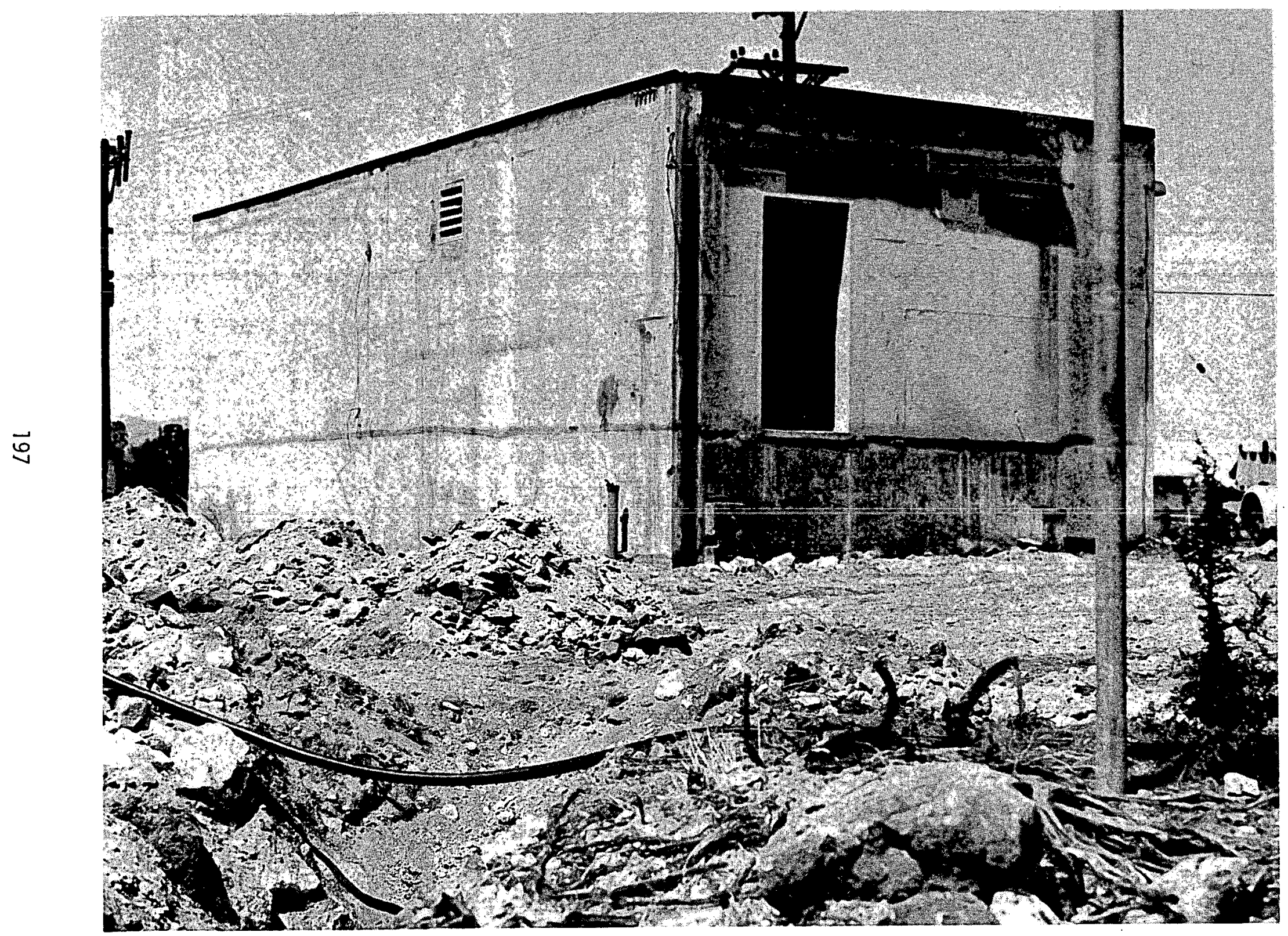


Fig. 12. CONCRETE SECTION DURING FINAL STAGES OF DEMOLITION
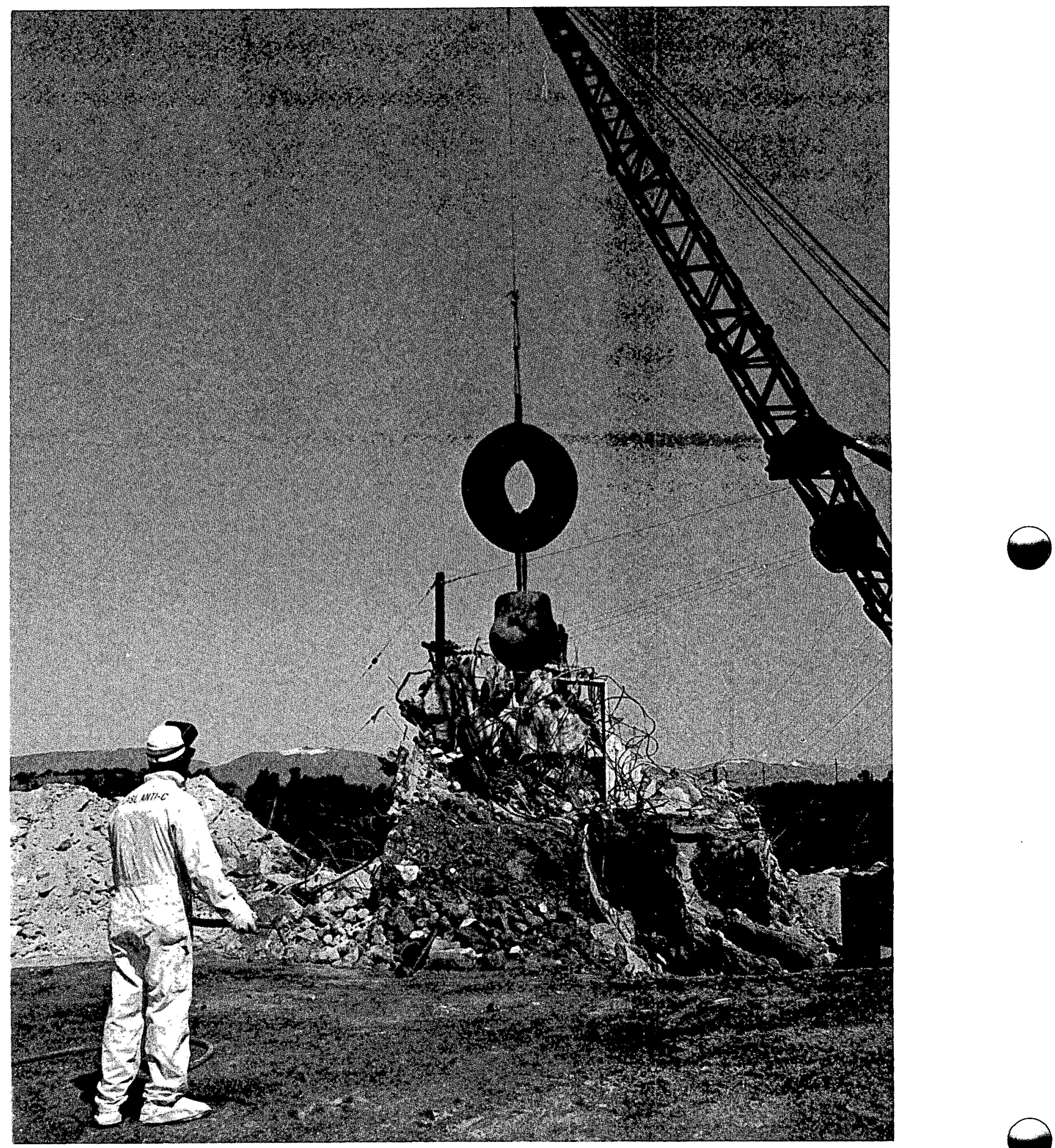

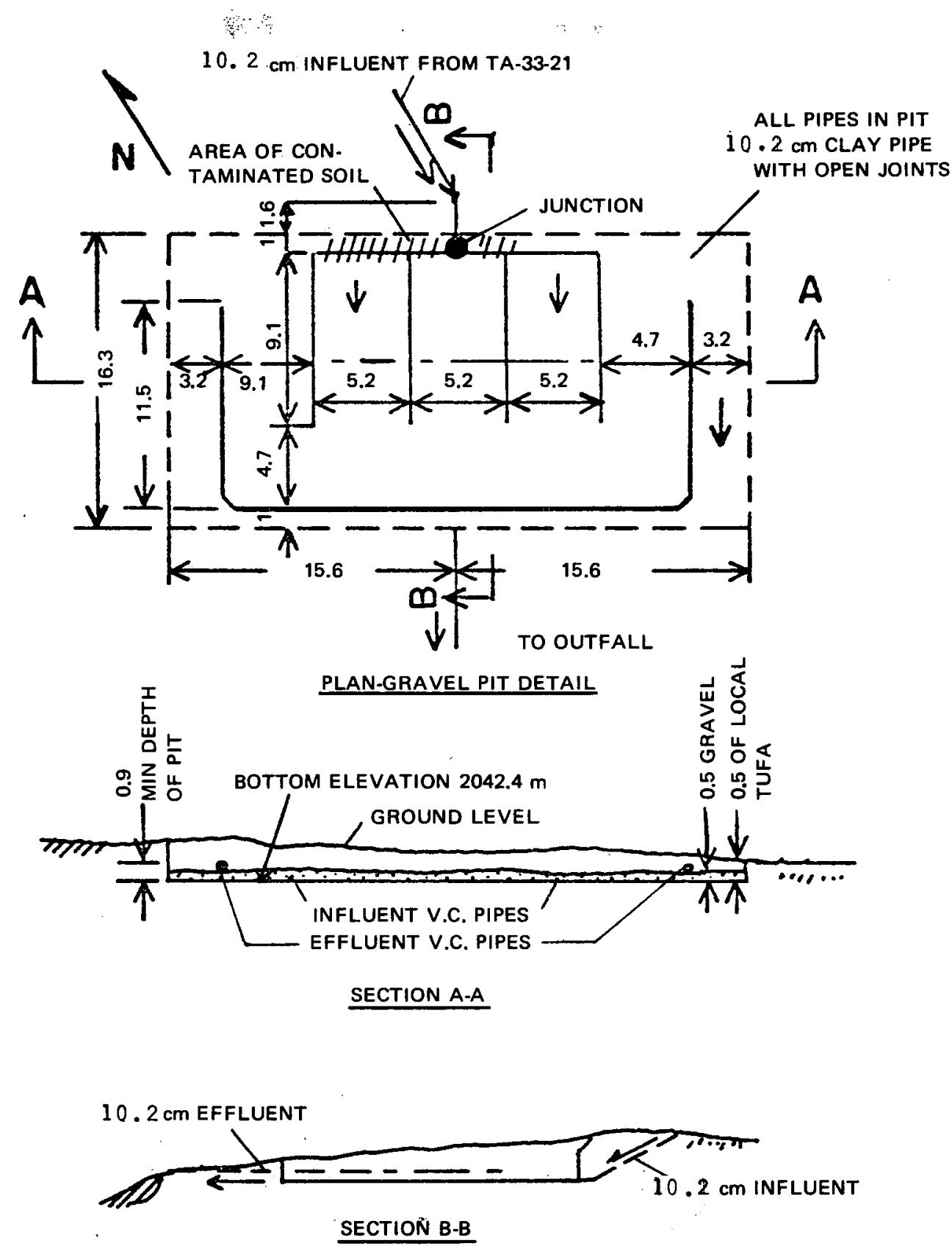

Fig. 13. TILE FIELD DETAILS

All Dimensions in Meters 
Fig. 14. TILE FIELD TRENCH AFTER REMOVAL OF PIPE

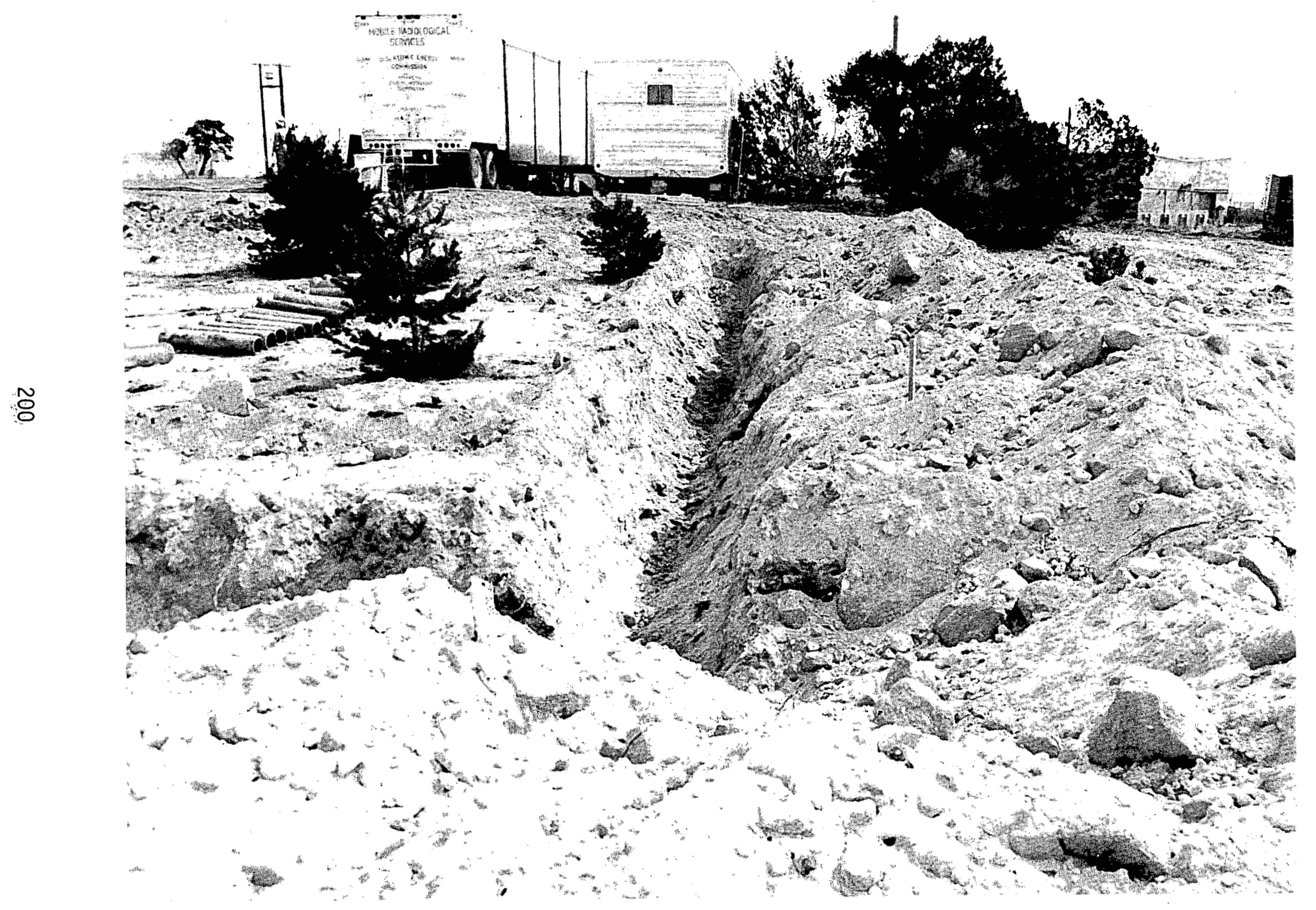



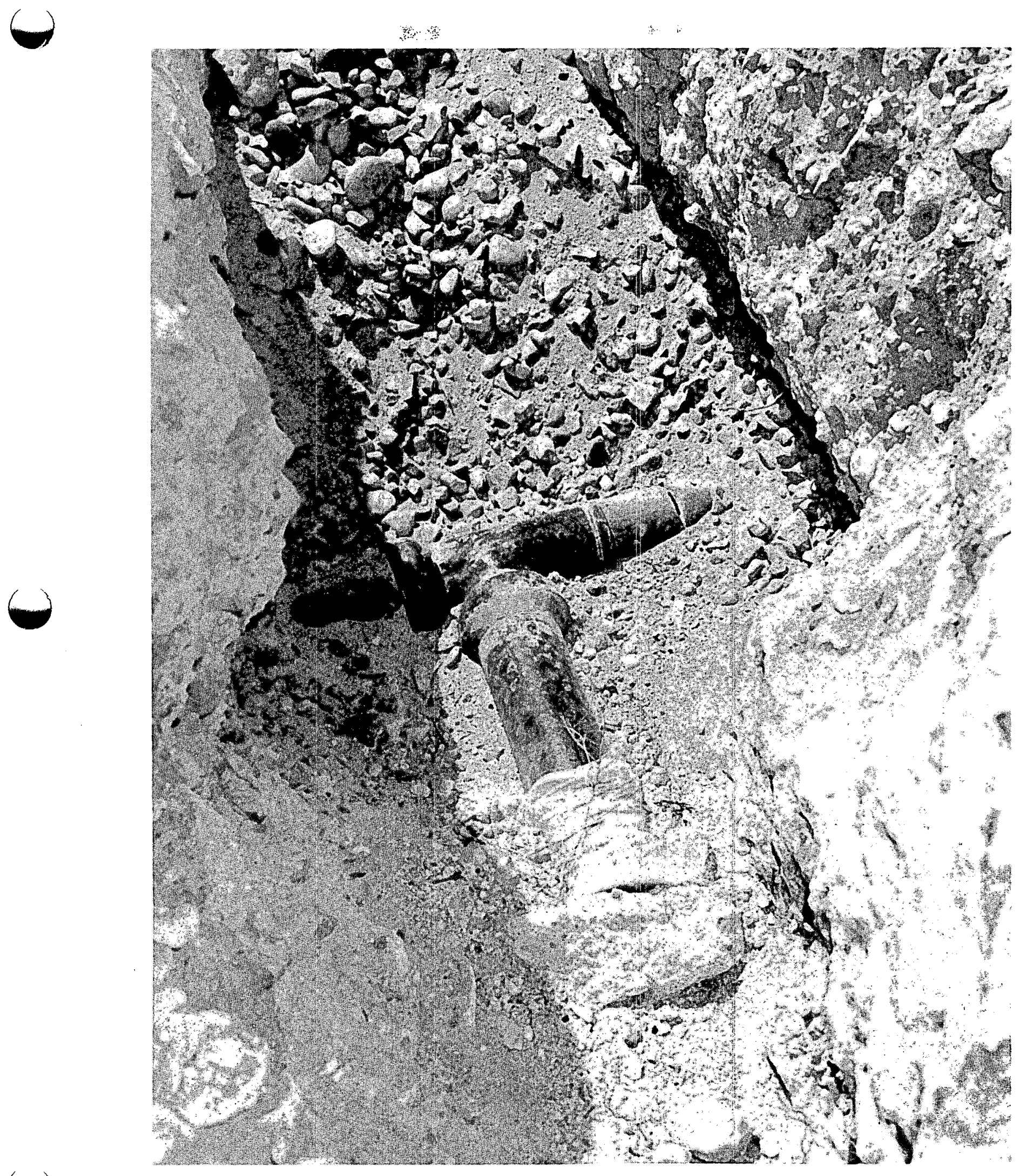

Fig. 15. JUNCTION OF BUILDING 21 INDUSTRIAL WASTE

LINE AND TILE FIELD DISTRIBUTION SYSTEM 
Fig. 16. TRAILERS USED FOR HEALTH PHYSICS

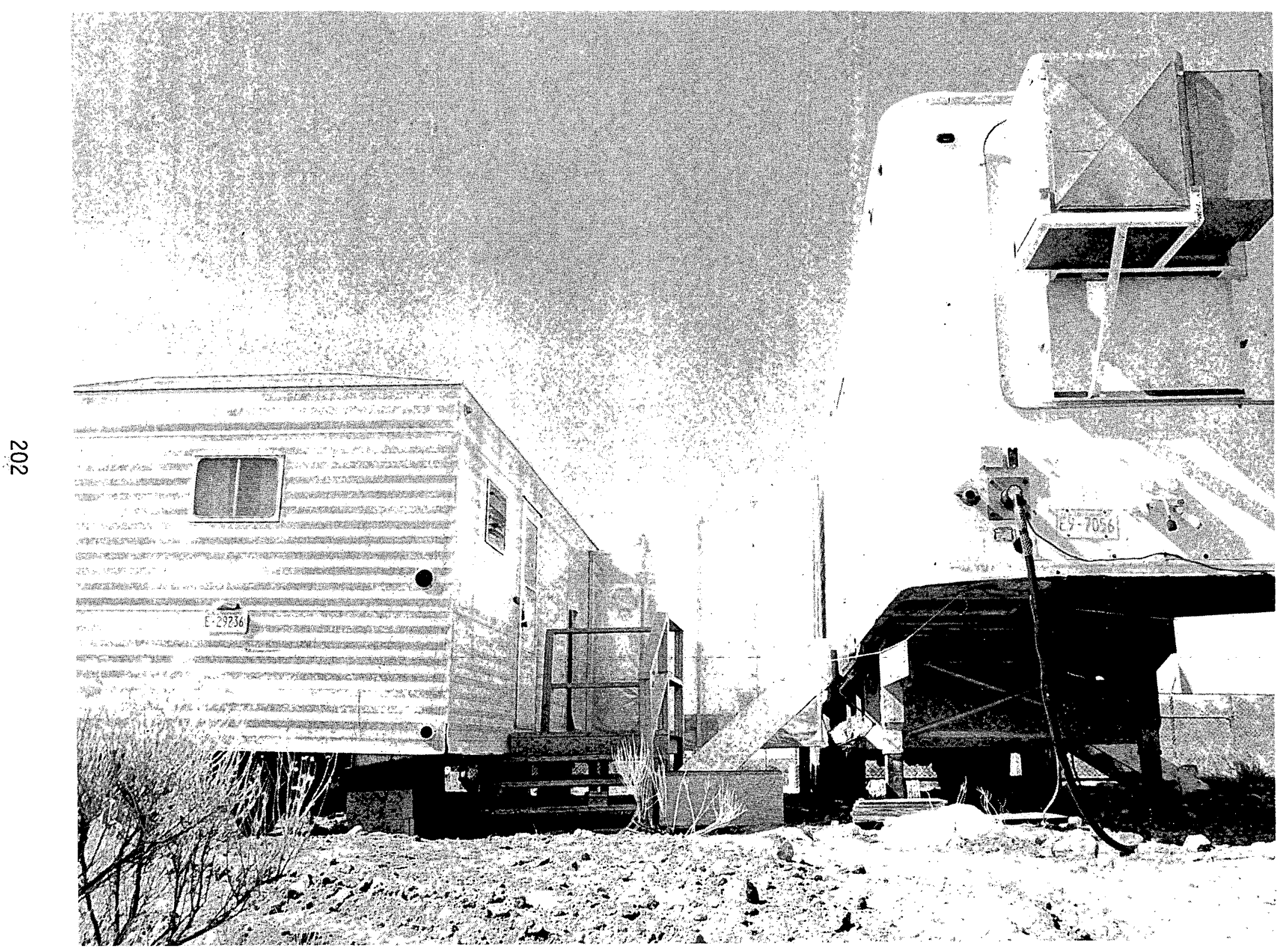

0 


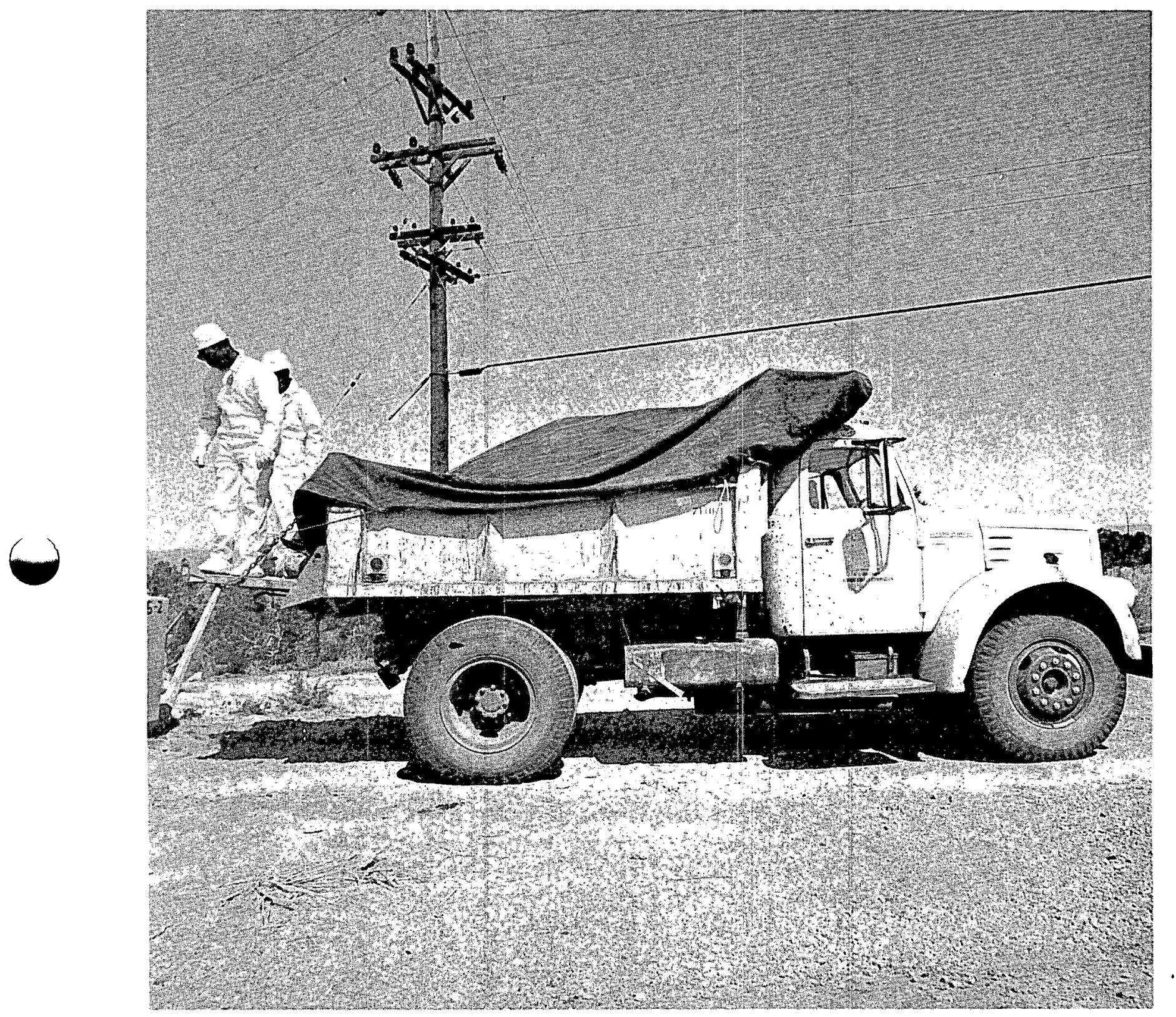

Fig. 17. VEHICLE LOADED WITH DEBRIS FOR BURIAL 
Fig. 18. ENVIRONMENTAL AIR SAMPLER AND GENERATOR

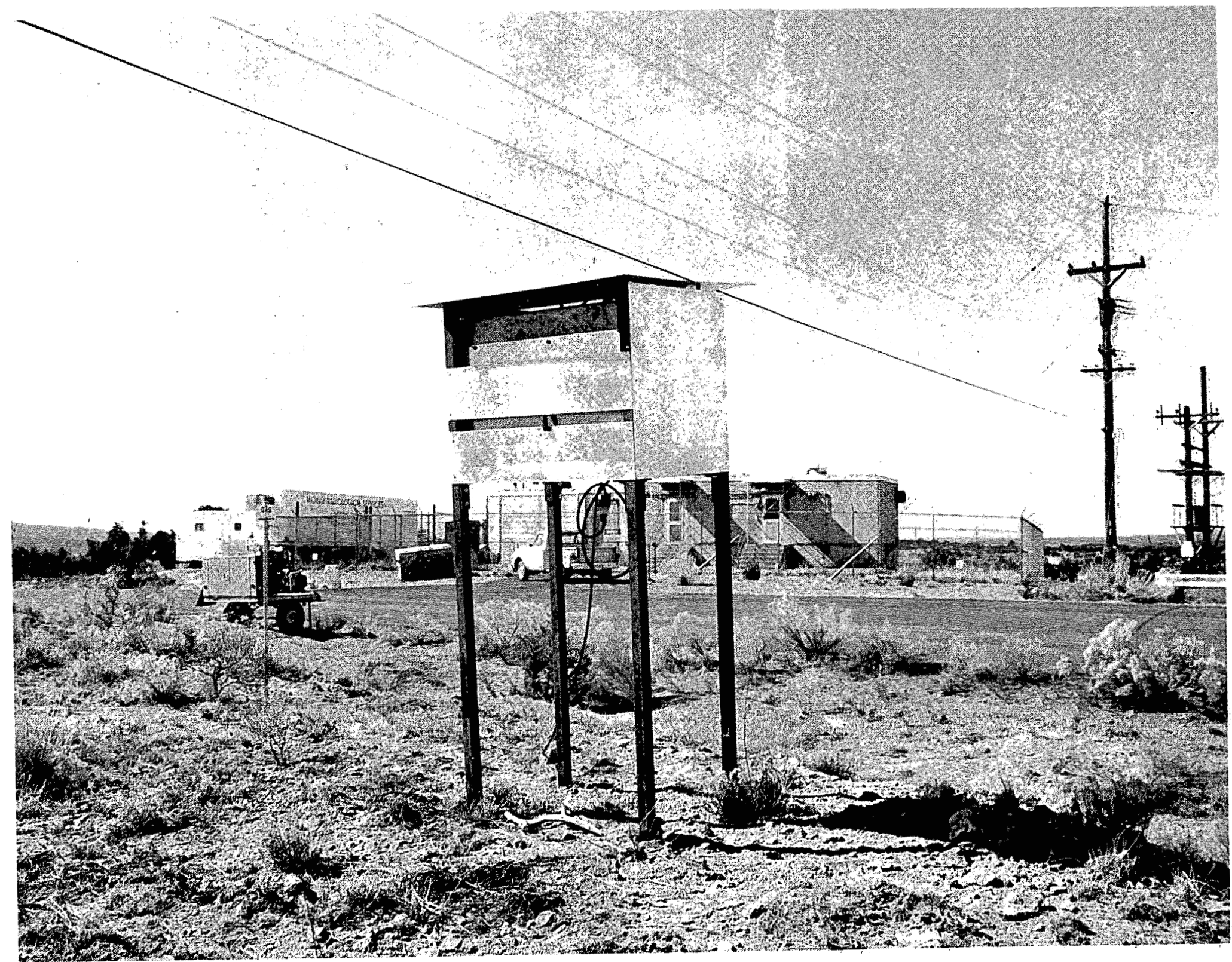




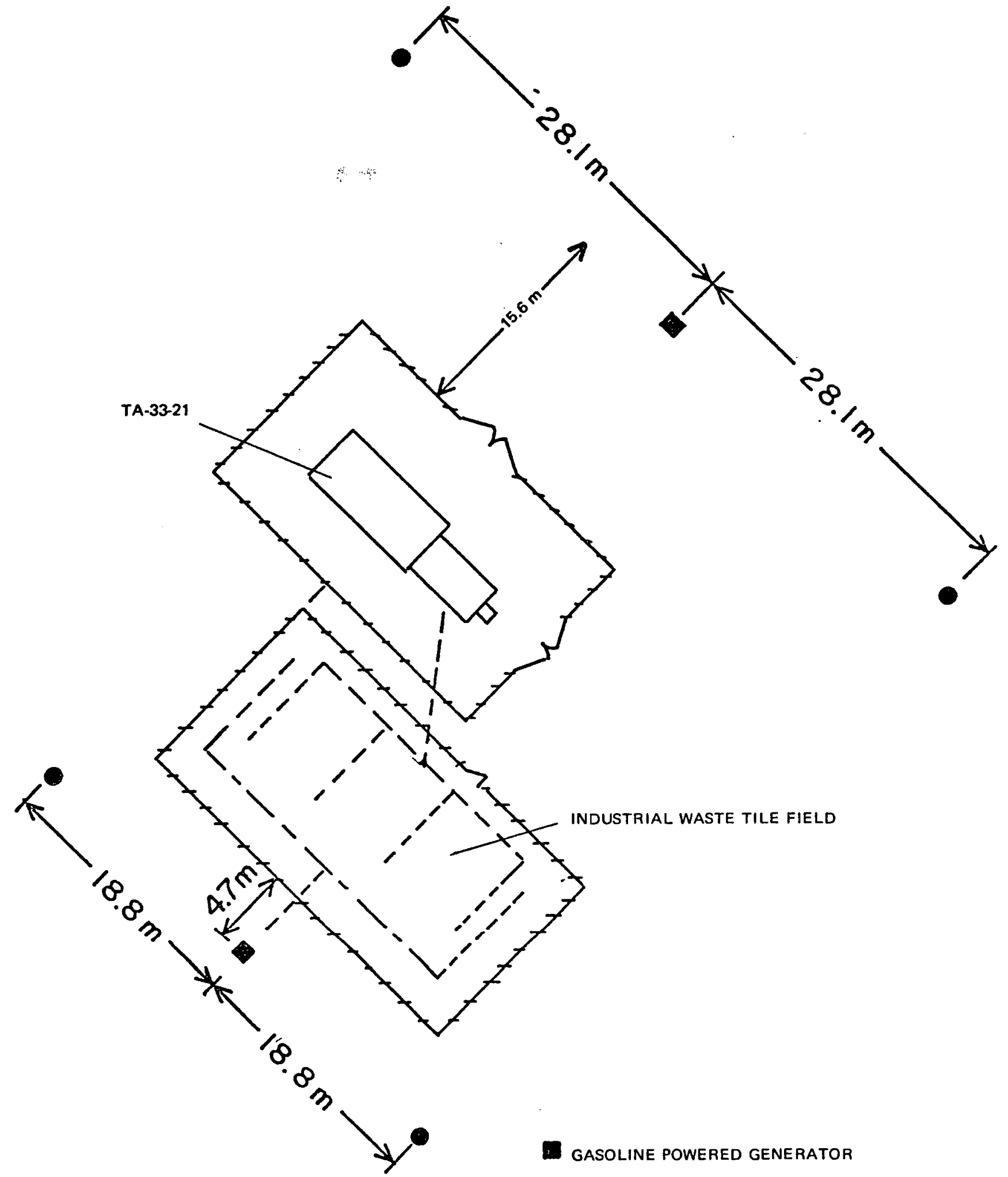

air SAMPLer

Fig. 19 ENVIRONMENTAL AIR

SAMPLER LOCATION PLAN 
Fig. 20. SOUTH TO NORTH VIEW OF SITE AFTER FINAL GRADING

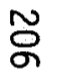
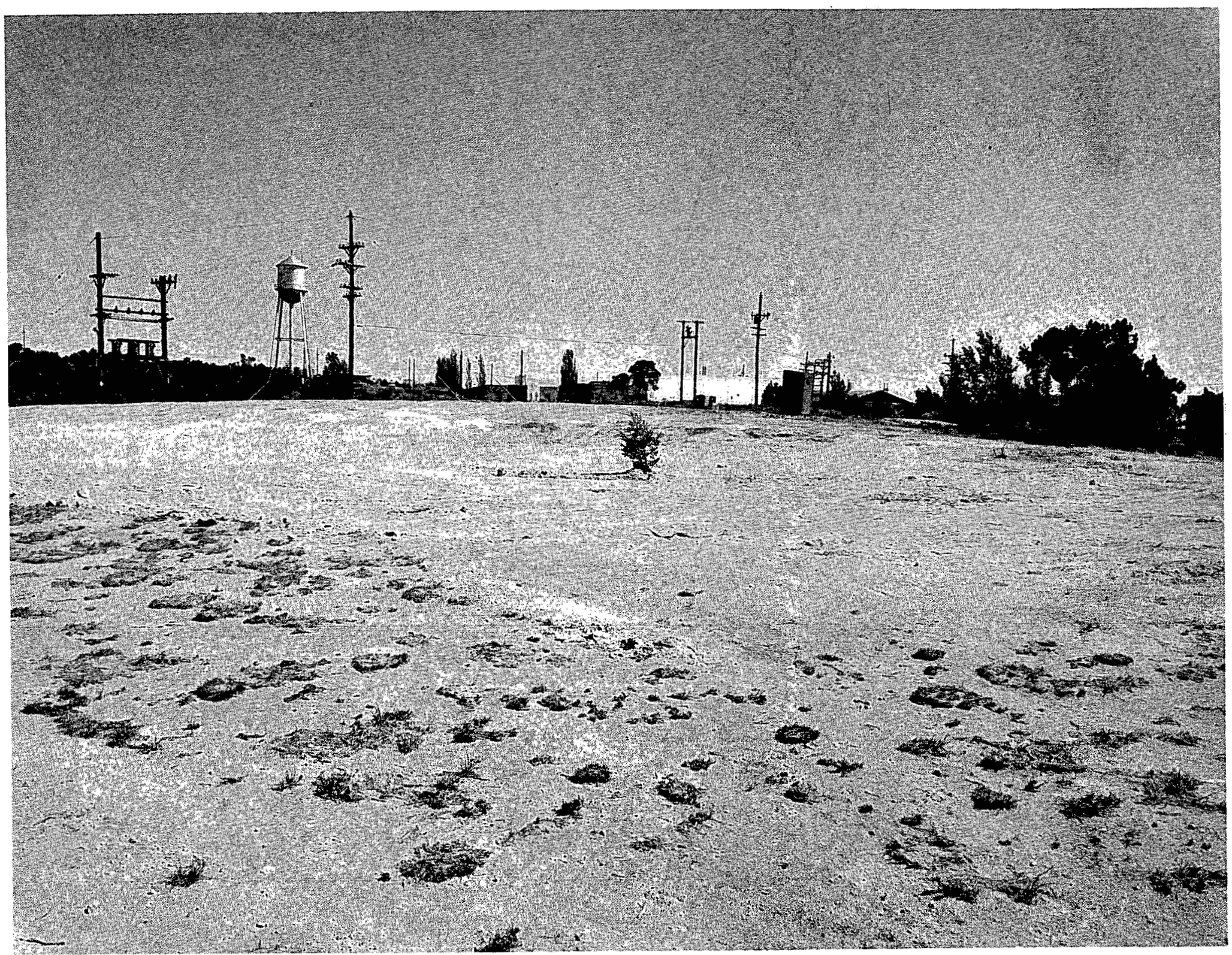


$$
{ }_{20+3}+3^{201}
$$

\title{
SEPARATIONS CANYON DECONTAMINATION FACILITIES
}

\author{
J. H. Hershey \\ $\frac{\text { E. I. du Pont de Nemours and Cg'mpany }}{\text { Savannah River Plant }}$ \\ Aiken, South Carolina 29801
}

\begin{abstract}
Highly radioactive process equipment is decontaminated at the Savannah River Plant in specially equipped areas of the separations canyon buildings so that direct mechanical repairs or alterations can be made. Using these facilities it is possible to decontaminate and repair equipment such as 10 $\times 11-f t$ storage tanks, 8- $\times 8-f t$ batch evaporator pots and columns, 40-in. Bird centrifuges, canyon pumps and agitators, and various canyon piping systems or "jumpers." For example, centrifuge or evaporator pots can be decontaminated and rebuilt for about $60 \%$ of the 1974 replacement cost. The combined facilities can decontaminate and repair 6 to 10 pieces of major equipment per year. Decontamination time varies with type of equipment and radioactivity levels encountered.
\end{abstract}

\section{Discussion}

\section{CURRENT OPERATING PRACTICE}

Highly radioactive process equipment is decontaminated at the Savannah River Plant (SRP) in Separations Department Buildings 221-F and 221-H. Each building has two processing areas known as the hot and warm canyons and a center section that includes space for offices, control rooms, pipe galleries, service areas, etc. (figures 1 and 2). The canyon zones are each about $600 \mathrm{ft}$ long, $15 \mathrm{ft}$ wide, and $25 \mathrm{ft}$ deep below one-foot-thick concrete cell covers. Chemical processing operations involving highly radioactive solutions are performed remotely in stainless steel equipment in both canyons. The center section is shielded from radiation by thick reinforced concrete walls. Process equipment is decontaminated to levels that permit equipment to be moved out of a canyon building for external storage at the SRP storage and burial ground.

Space has been provided in both the hot and warm canyons of Buildings $221-\mathrm{F}$ and $221-\mathrm{H}$ for equipment decontamination and repair work. The hot canyon contains a decontamination cell, a shop, and a swimming pool (essentially a stainless-steel-lined tank built into a canyon module). The warm canyon contains a decontamination cell and shop area, both used for repair activities. A shielded overhead traveling crane is provided in each canyon for remote handling of contaminated equipment. Using these facilities it is possible to decontaminate and repair process equipment such as a 10- $\times 11$-ft canyon storage tank (figure 3), an 8- $\times 8$-ft batch evaporator pot or column (figure 4), a 40-in. Bird centrifuge, a large continuous evaporator and associated reboiler tubes (figures 5 through 8 ), canyon piping systems or jumpers (remotable canyon piping), and miscellaneous pumps and agitators from canyon or waste storage facilities.

Time required for and cost of decontamination and subsequent repairs varies with type of equipment and radioactivity levels encountered. The service history of a failed piece of equipment largely determines radioactivity levels. Failed canyon equipment is stored in canyon cells for as long as is feasible to allow highly radioactive, short half-life isotopes to decay. Most decontamination activities are intermittent operations with work being done when manpower is available and as canyon processing schedules permit. 
Equipment to be decontaminated is moved remotely by an overhead canyon crane to the hot canyon decontamination cell for a series of full-volume flushes with caustic/permanganate and with hydroxylamine sulfate/nitric acid solutions. Personnel do not enter the hot decontamination cell; all solutions are added to or sprayed on vessels remotely. Initial decontamination of a canyon batch evaporator pot, for example, would consist of a full-volume flush with $24,000 \mathrm{lb}$ of $2 \% \mathrm{NaOH} / 2 \% \mathrm{KMnO}_{4}$ solution followed by $24,000 \mathrm{lb}$ of $3 \%$ hydroxylamine sulfate/3\% $\mathrm{HNO}_{3}$ solution. After a series of such flushes the evaporator pot is moved to the hot canyon shop for visual inspection and radiation survey. Chemical flushing during this initial decontamination phase can range from $200,000 \mathrm{lb}$ to $1.4 \mathrm{M} \mathrm{lb}$ of $\mathrm{NaOH} / \mathrm{KMnO}_{4}$ and $\mathrm{HAS} / \mathrm{HNO}_{3}$ solutions. These flushes are disposed of through existing waste processing facilities. A hundred gallons of flush solution generates about one or two gallons of solid waste for permanent storage. The choice of chemicals used for initial decontaminations is limited to those compatible with solutions routinely processed in canyon waste evaporators so that these large volumes of solutions can be evaporated in canyon equipment.

Instead of using full-volume flushes the interior of a process vessel can be decontaminated by spraying heated solutions at 135 psig through a rotating jet assembly held suspended in the vessel by the canyon crane, or mounted on an adaptor flange on the vessel. ${ }^{1}$ The discharge head rotates $360^{\circ}$ in both horizontal and vertical planes. Hydraulic pressure to operate the spray is supplied by a pump on the third level of the center section of the building.

Small equipment such as pumps, agitators, or reboiler tubes can be set in a modified open top 1.0- $\times 11-\mathrm{ft}$ tank and allowed to soak in warm decontaminating solutions. Solutions can be backflushed through pumps using a special canyon jet assembly.

Equipment being decontaminated is periodically moved to the hot canyon shop for radiation survey. If the survey shows radiation to be greater than $500 \mathrm{rads} / \mathrm{hr}$ at $2 \mathrm{ft}$, the equipment is returned to the decontamination cell for additional cleaning. If radiation is less thä $500 \mathrm{rads} / \mathrm{hr}$ at $2 \mathrm{ft}$, the equipment is moved to the swimming pool for second-stage decontamination using detergents as wellas chemicals.

The swimming pool is equipped with a remotely operated manipulator, various steam/spray cleaner units, and a shieldềd work area with viewing windows. ${ }^{23}$ Some direct-contact hand decontamination can be done in this area if radiation exposure levels permit. Solution volumes used for decontamination in this facility are small. Use of detergents or other chemicals incompatible with normal canyon waste solutions is permissible because the waste generated is isolated and processed through a general-purpose evaporator outside the canyon building. Decontamination efforts continue in the swimming pool until the radiation level is reduced to less than $100 \mathrm{mR} / \mathrm{hr}$ body exposure at $1 \mathrm{ft}$.

When radiation is reduced below this level, equipment is moved, using a railroad car and a flat-bed truck, from the hot canyon swimming pool to the warm canyon shop or to the warm canyon decontamination cell for final decontamination and subsequent repair or modification. When moving between the hot and warm canyons, the equipment is either completely wrapped in plastic or placed in a transport box. The external surface of the plastic wrapping or of the transport box must be free of transferable contamination while the equipment is in transit.

Final decontamination may include direct-contact hand cleaning or physical removal of parts or sections that resist decontamination efforts. By these means, and by selective use of lead shielding for isolated high-radiation spots, body exposure rates are reduced to the point that contact maintenance and repair is possible. For repair of a major piece of canyon equipment, the total accumulative radiation exposure to personnel will be about $1 \mathrm{R}$.

1 Tigar Jet Tank Scrubber, Vic Jet; Inc., Narberth, PA

${ }^{2}$ Clayton Hydro-steam Cleaner, Clayton Mfg. Co., E1 Monte; CA

${ }^{3}$ Sellers Hydraulic Jet Cleaner, Sellers Injector Corp., Philadelphia, PA 
Both the warm shop and warm decontamination cell are supplied with breathing air for plastic suit work, power for centrifuge operation, and welding facilities. Both are equipped for functional testing, run-in tests, and layout checks.

\section{HISTORY}

As originally designed, the hot canyon was provided with a decontamination cell, a swimming pool area, and a repair shop. The warm canyon was provided with a decontamination cell and a repair shop. These facilities were intended to operate independently in serving the individual canyons. Canyon equipment was to be decontaminated remotely by external and internal flushes in the decontamination cells to acceptable radiation levels for.transfer to an onsite burial and storage area, or to levels that would permit inspections and minor repairs in the canyon shops. The swimming pool was provided so that equipment could be placed underwater for radiation shielding and the repairs accomplished with special long-handled tools. No major overhaul or repair was originally contemplated; failed major equipment pieces such as centrifuges or evaporator pots were to be decontaminated to acceptable limits for burial or storage and replaced with new equipment.

Deficiencies in the original concept became obvious promptly. Some of the difficulties or deficiencies encountered were as follows:

- The wall-mounted sprays in the decontamination cells proved to be ineffective in reducing contamination levels on external surfaces.

- Underwater repairs in the swimming pool facility were found to be impractical because radioactive materials leached out of equipment into the shielding water and tended to stratify in layers exposing personnel to excessive radiation levels. Manipulation of the long-handled tools was difficult and prolonged repair time.

- Holding or suspending major pieces of equipment underwater proved difficult. Positioning of equipment underwater with canyon cranes was not feasible.

- No shielded observation areas were originally provided. Inspections of failed equipment involved considerable radiation exposure.

- Facilities for removing transferable smearable contamination and for handling alpha-contaminated equipment were inadequate.

- Facilities for repair work were inadequate.

- No provisions were made for handling and repairing pumps, agitators, and miscellaneous small equipment.

It also became apparent that a major repair and modification capability was needed to overcome high replacement costs, long delivery times, and reduce spare part inventories.

\section{MODIFICATIONS TO ORIGINAL FACILITIES}

\section{Decontamination Cells}

In Buildings 221-F and 221- $\mathrm{H}$, the canyon decontamination cells occupy two modules in section 4 of both the hot and warm canyons. These cells are fully stainless steel lined and equipped with trunnion guides and wall connectors for remote installation of canyon equipment. Fixed wall sprays no longer used, are provided in the cell walls for external spraying of vessels. Both cells have concrete covers. A canyon crane removes these covers as necessary and remotely installs equipment in the cells. The hot and warm decontamination cells were essentially identical as originally built. 
The decontamination cells are $22 \mathrm{ft}$ long, $15 \mathrm{ft}$ wide, and $24 \mathrm{ft}$ deep. Original services included: chemical addition lines from third-level tank 5E; 150-psig steam supply for heating solutions and for solution transfers by jet; gang valves for steam supply to jets; cooling water supply; condensate/water-out lines; power supply for agitators and pumps; thermohm connections; liquid level instrumentation; lube lines; sample lines; waste transfer lines; floor spray lines; vessel spray nozzles; and fire water supply lines.

Over the years, the warm decontamination cell has been converted to a direct maintenance/repair facility and only incidental decontamination is performed there. In modifying the warm decontamination cell for direct maintenance, a personnel access door was provided in the south wall of the cell and all chemical addition lines, steam, and water lines were blanked out of service. Other items added or provided include: an electrically-driven one-ton crane; steam and water service for steam cleaning units; breathing air supply for plastic suit work; welding facilities; power supply for operation and run-in of centrifuges; equipment testing capability; layout platforms; additional lighting, and a supply of conditioned air.

\section{Swimming Pool}

The swimming pool is located in section 3 of the hot canyon. The pool is $16 \mathrm{ft}$ wide, $25 \mathrm{ft}$ long, and $23 \mathrm{ft}$ deep, and is fitted with concrete cell covers. The stainless steel liner is about $15 \mathrm{ft}$ high and the observation/work catwalks are about $14 \mathrm{ft}$ above floor level. Catwalks on south and east walls, a movable maintenance platform, two small jib cranes, submerged wall lights, and personnel access from second level were originally provided.

The pool was designed to hold submerged the majority of canyon vessels so that repairs could be made by use of special long-handled tools. Underwater repairs were found to be impractical and the pool is no longer filled with water. It is now used as a secondary decontamination and equipment inspection area. When initial decontamination efforts in the hot decontamination cell have reduced radiation levels to less than $500 \mathrm{rads} / \mathrm{hr}$ at $2 \mathrm{ft}$, equipment is moved into the swimming pool where operators using remotely controlled steam-cleaning lances continue decontaminating until radiation levels are reduced to less than $100 \mathrm{mrads} / \mathrm{hr}$ at $1 \mathrm{ft}$. Decontaminating solutions are made up in third-level tankage and added to or sprayed on equipment being cleaned. Detergent solutions can be made up in a small tank permanently located in a corner of the pool. Accumulated waste solutions are normally transferred to a general-purpose evaporator outside the canyon building. Solutions containing detergents are not compatible with routine waste solutions generated by canyon processing operations.

Modifications of the swimming pool facility include: abandonment of water shielding; installation of breathing air manifolds for plastic suit work; replacement of original jib cranes with two 1-ton electric hoists; removal of the traveling maintenance platform; modification of the south catwalk to serve as a shielded work/observation area with controls for manipulator operation; installation of an air lock for access to east catwalk; installation of a remotely controlled manipulator for a steam-cleaning lance; installation of a high pressure water spray system; and repair and reinforcement of the pool floor to ensure against solutions leaking out of pool area.

\section{Canyon Shops}

Both the hot canyon shop and the warm canyon shop were originally intended for maintenance and repair of contaminated canyon equipment. The shops are located in section 3 of the respective canyons. The hot canyon shop is $15 \mathrm{ft}$ wide, $21 \mathrm{ft}$ long, and approximately $21 \mathrm{ft}$ deep below 3-ft-thick concrete cell covers. The warm canyon shop is $15 \mathrm{ft}$ wide, $24 \mathrm{ft}$ long, and approximately $24 \mathrm{ft}$ deep below 1-ft-thick concrete cell covers. Equipment is remotely positioned in canyon shops with overhead canyon cranes. Personnel enter the hot shop by a stairwell from second level and the warm shop from an air lock in first-level corridor. At $221-\mathrm{H}$, an additional air lock access and observation area for the hot canyon shop has been provided. 
Each shop was originally equipped with breathing air manifolds, electric power outlets, compressed-air hose bibs, flush-mounted wall lights, and safety showers. Both shops have stainless steel floors with built-in sumps for collection of liquid wastes. Accumulated waste solutions are transferred by jet to canyon waste processing stations.

The hot canyon shop is used principally for equipment surveys and inspections following initial decontaminations in the hot decontamination cell. Normally, equipment placed in the hot canyon shop is too radioactive for more than limited direct maintenance or contact decontamination with steam-cleaning units. Some repairs are still done in the hot canyon shop on jumpers, canyon pumps and agitators, and miscellaneous minor equipment.

The warm canyon shop is used routinely for direct maintenance, modification, overhaul, functional checking, mockup, layout, and run-in. Some final decontamination is also performed in the warm canyon shop - direct contact decontamination by hand cleaning and the physical removal of parts or sections that have resisted decontamination efforts.

Modifications to the hot canyon shop include: addition of a chainfall hoist; installation of a Clayton steam-cleaning facility; and added piping to supply flush and decontamination solutions from a third-level tank.

Modifications to the warm canyon shop include: improved welding facilities; power for centrifuge run-in and functional check; two chainfall hoists; observation window in north wall; and provisions for equipment testing and layout.

\section{TYPICAL DECONTAMINATION EXPERIENCE}

The sequence of a decontamination program and the extent of decontamination or repair required varies with each item of canyon equipment handled. A piece of canyon equipment is seldom decontaminated, repaired, and returned to service as a continuous operation. Normally, failed equipment is replaced with an item from the spare equipment inventory. During repair operations it is not unusual to experience delays in obtaining replacement parts. Typical decontamination/repair time, in months, is as follows:

$\begin{array}{lcc} & \text { Decontamination } & \text { Repair/Modification } \\ \text { Centrifuge } & 4 \text { to } 8 & 2 \text { to } 6 \\ 10-\times 11 \text {-ft storage tanks } & 2 & 1 \\ 8-\times 8 \text {-ft evaporator pot } & 3 & 2\end{array}$

Examples

Decontamination of Evaporator Pot in Hot Decontamination Cell. The coils failed in this pot in February 1972 while the pot was in high activity waste service. Full-volume flushes began in January 1973 and continued over a four-month period. There were five hydroxylamine sulfate/nitric acid and three caustic/permanganate flushes - each consisting of about 25,000 lb of solution. The pot was moved in August 1973 to an onsite burial ground for above-ground storage pending final decontamination and coil replacement.

Decontamination of Evaporator Pot in Swimming Pool Decontamination of this pot was performed in the swimming pool because the hot canyon decontamination cell was not available. The pot coils failed in high activity waste service in February 1971. Decontamination took about $3 \frac{1}{2}$ months starting in April 1972, using caustic/permanganate and hydroxylamine sulfate/nitric acid solutions. After a series of full-volume flushes, a number of flushes were made with a rotojet pressurized spray. Some external cleaning was also done with detergents and a Clayton steam-cleaner unit. About $340,000 \mathrm{lb}$ of flush solution was used. In September 1972, the pot was moved to an 
onsite burial ground in a transport box for above-ground storage. At this time radiation levels were $800 \mathrm{mrads} / \mathrm{hr}$ at $1 \mathrm{ft}$ on external surfaces and $2000 \mathrm{mrads} / \mathrm{hr}$ at $1 \mathrm{ft}$ on internal surfaces. Maximum smearable contamination levels on external surfaces was $40,000 \mathrm{c} / \mathrm{m}$ beta-gamma and $1000 \mathrm{~d} / \mathrm{m}$ alpha. The pot was moved to Building 221-F canyon for final decontamination and repair in October 1972. Repairs were completed in March 1973 and the pot was returned to canyon service in April 1974.

Decontamination of De-entrainment Section of Continuous Evaporator. The procedure for remote decontamination of a de-entrainment section of a continuous high activity waste evaporator consists of a series of chemical flushes on various sections of the unit. The first series of flushes are made with hot caustic/permanganate and with hot hydroxylamine sulfate/nitric acid solutions alternately sprayed on the bubble-cap area. These flushes are followed with a hot water flush. Next, a "Tigar Cub" rotojet is used to clean the Hackman hat (feed control area), the internal parts of the de-entrainment area, and the reboiler section (with the bundle removed). When the de-entrainment section is cleaned below the bubble-cap zone, the rotojet is fitted with a flexible hose connection to permit access to this area. A series of chemical flushes followed by a hot water rinse are also made on the external surfaces of the unit. Each flush consists of about $8000 \mathrm{lb}$ of solution; a total of about $224,000 \mathrm{lb}$ is used for the entire decontamination sequence. This usually reduces radiation levels sufficiently to permit transfer of equipment to above-ground storage at an onsite burial ground. Some additional direct decontamination is necessary before modifications and repairs can begin. Since 1960 , six de-entrainment units have been repaired with minimal exposure to repair personnel.

\section{Cost Summary}

The following table shows estimated costs for decontamination and repair of major pieces of canyon equipment in the 221-F/221-H facilities during 1974.

Building 221-F

$\begin{array}{lcc} & \begin{array}{c}\text { Estimated } \\ \text { Replacement } \\ \text { Cost } \\ (\mathbf{1 9 7 4 )}\end{array} & \begin{array}{c}\text { Cost of } \\ \text { Repair and } \\ \text { Decontamination }\end{array} \\ & \$ 200,000 & \$ 118,700 \\ & 58,000 & 15,500 \\ \text { Continuous evaporator } & & \\ \begin{array}{l}\text { Replace coils sealed in tank } \\ \text { Mate new tubesheet to }\end{array} & 125,000 & 82,000 \\ \quad \text { old flange } & 140,000 & 35,000 \\ \text { Canyon pumps (7) } & 8,000 & 6,400 \\ \text { 5-hp agitator } & 50,000 & 14,600 \\ \text { 20-hp agitator (2) Total } & \$ 581,000 & \$ 272,200\end{array}$

a Includes waste storage costs. 
Building 221-H

\begin{tabular}{lccc} 
& $\begin{array}{c}\text { Estimated } \\
\text { Replacement } \\
\text { Cost } \\
(\mathbf{1 9 7 4 )}\end{array}$ & $\begin{array}{c}\text { Cost of } \\
\text { Decontamination }\end{array}$ & \\
& $\$ 45,000$ & $\$ 2,000$ & Cost of Repair \\
Ion exchange column & 200,000 & 60,000 & 500 \\
Centrifuge & 200,000 & 20,000 & 75,000 \\
Centrifuge & 97,000 & 10,000 & 75,000 \\
Install coils in evaporator pot & 35,000 & 5,000 & 45,000 \\
Reinsulate dissolver column & 135,000 & 24,900 & 16,000 \\
Evaporator columns (3) & 80,000 & 10,000 & 60,000 \\
Waste transfer pump & $\$ 792,000$ & $\$ 131,900$ & 16,000 \\
\multicolumn{1}{c}{ Total } & & & $\$ 287,500$
\end{tabular}

a Includes waste storage costs.

This paper was prepared in connection with work under Contract AT(07-2)-1 with the U. S. Energy Research and Development Administration. By acceptance of this paper, the publisher and/or recipient acknowledges the U. S. Government's right to retain a non-exclusive royalty-free license in and to any copyright covering this paper, along with the right to reproduce and to authorize others to reproduce all or any part of the copyrighted paper. 
Figure 1. Separations Building

Figure 2. Separations Building Cross Section

Figure 3. Standard $10 \times 11$-ft Canyon Tank

Figure 4. Modified-Coil Batch Evaporator and Column

Figure 5. Continuous Evaporator 


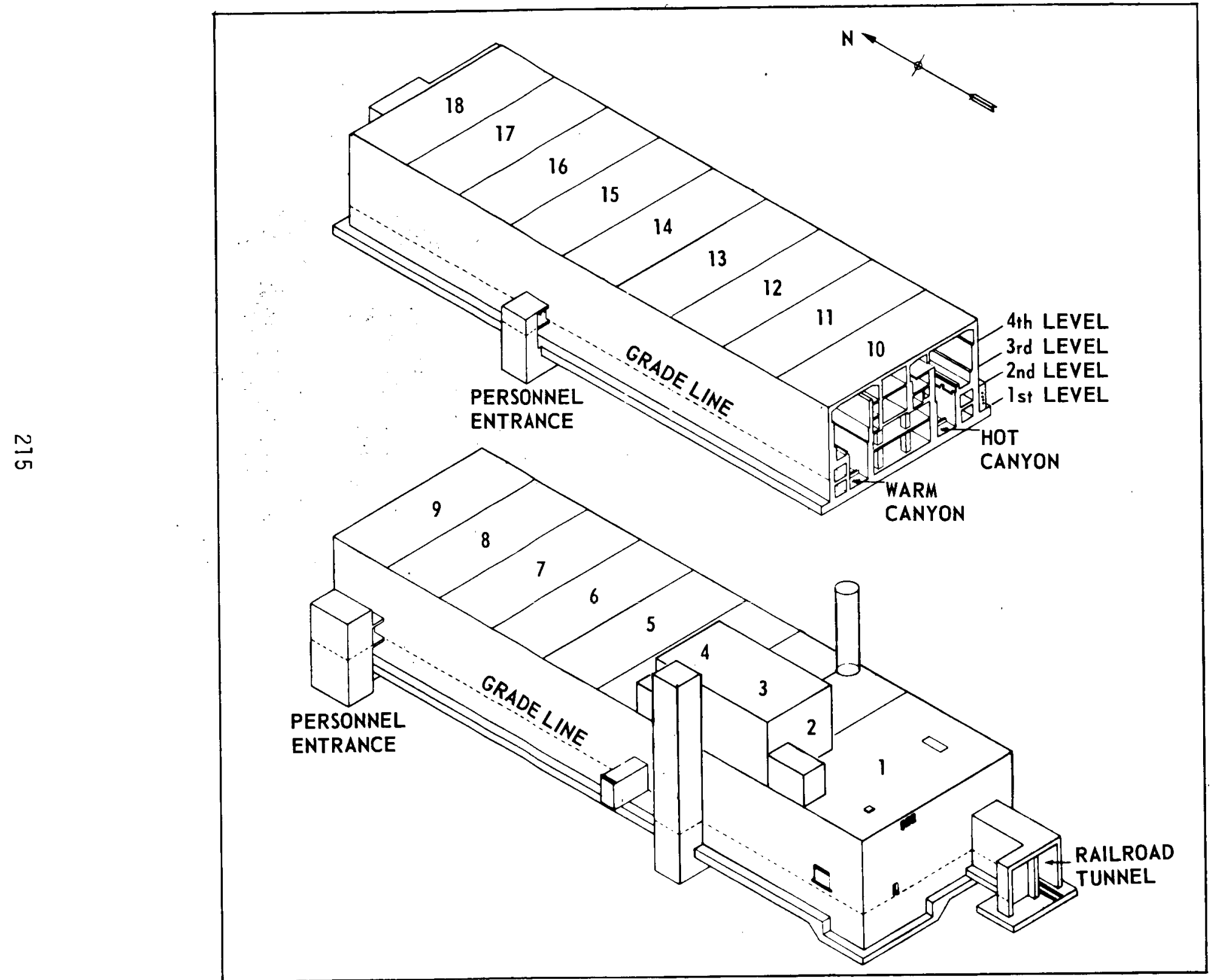

FIGURE 1. SEPARATIONS BUILDING 


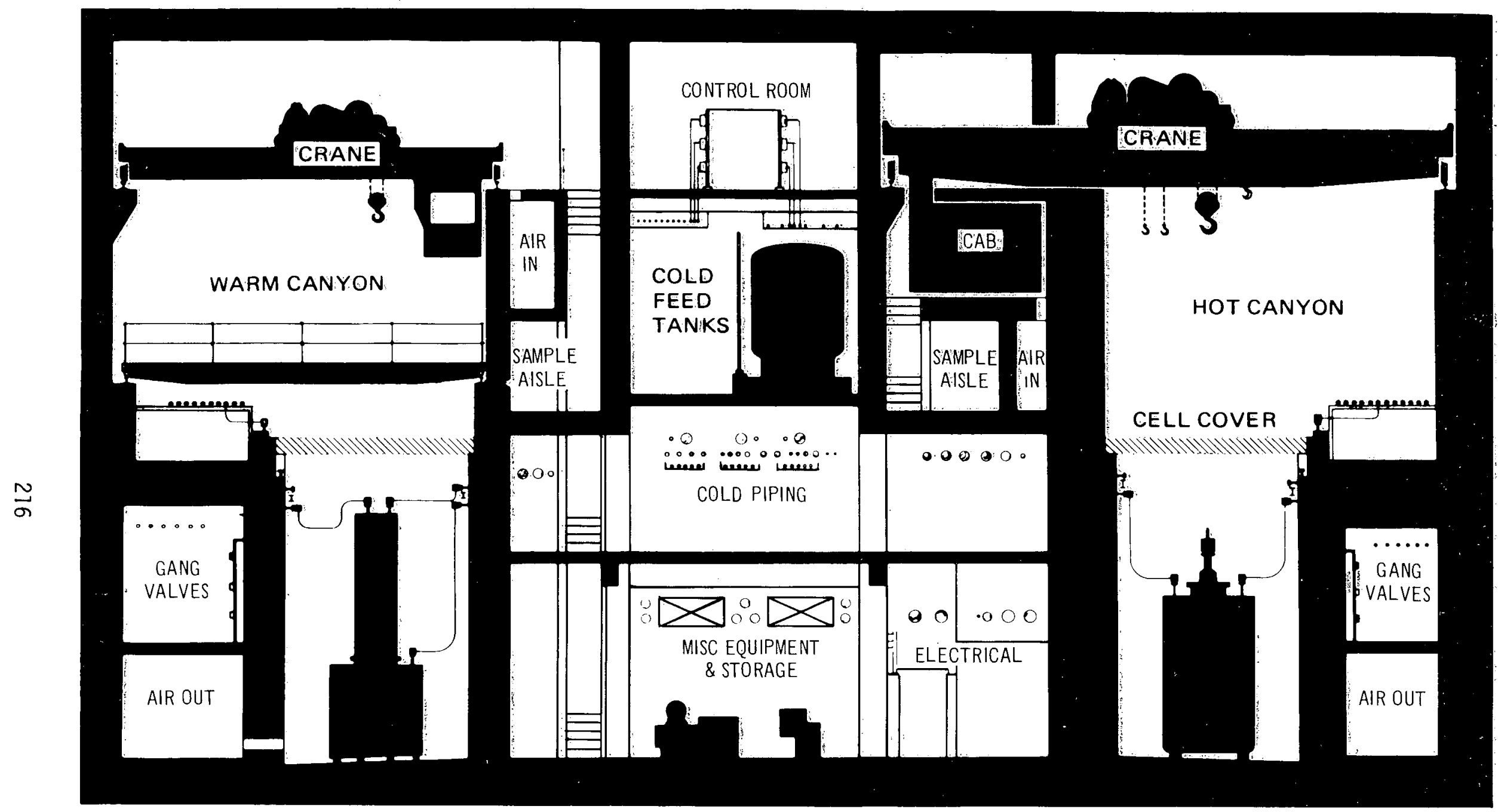

FIGURE 2. SEPARATIONS BUILDING CROSS SECTION. 


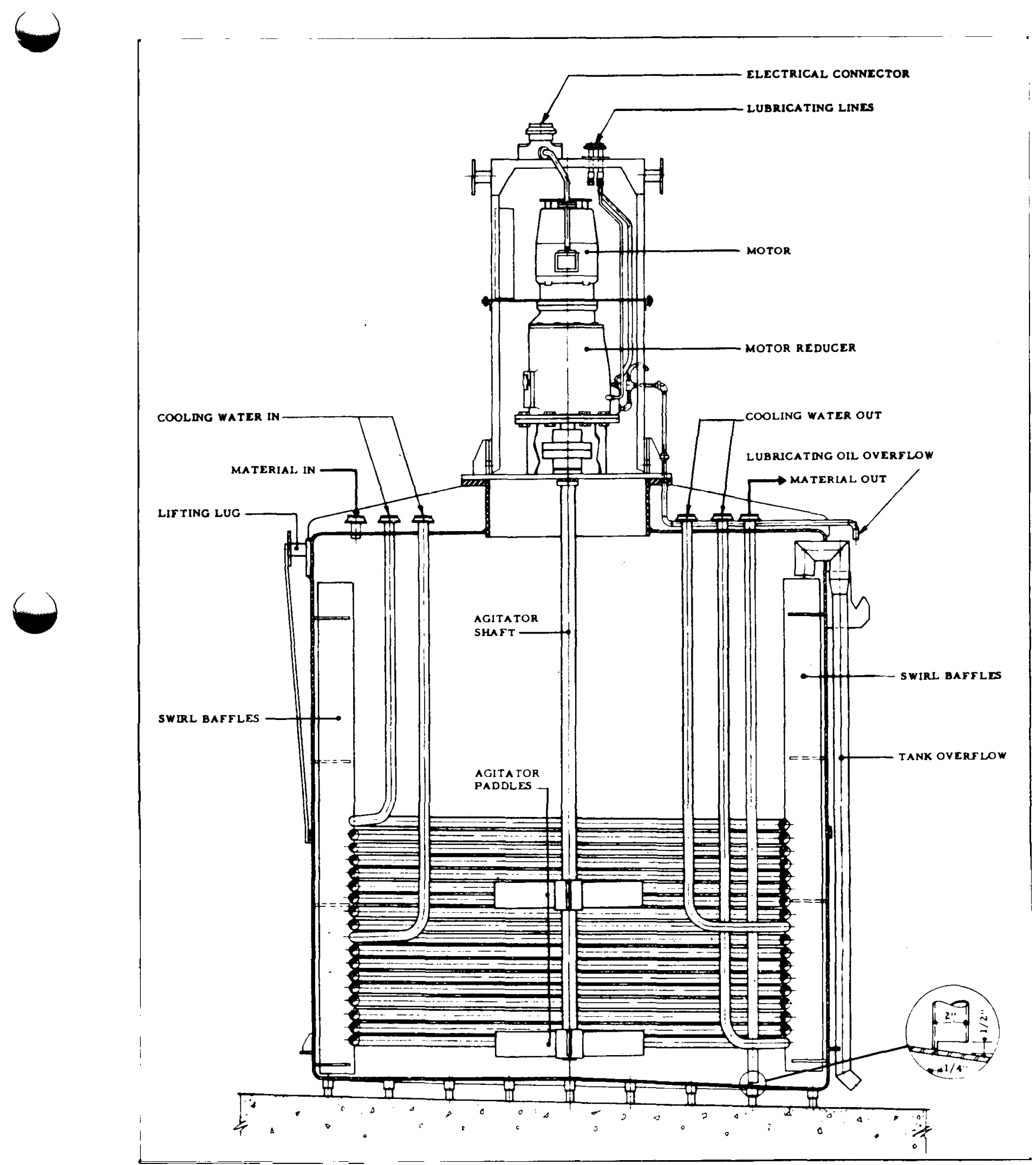

FIGURE 3. STANDARD $10 \times 11 . F T$ CANYON TANK 


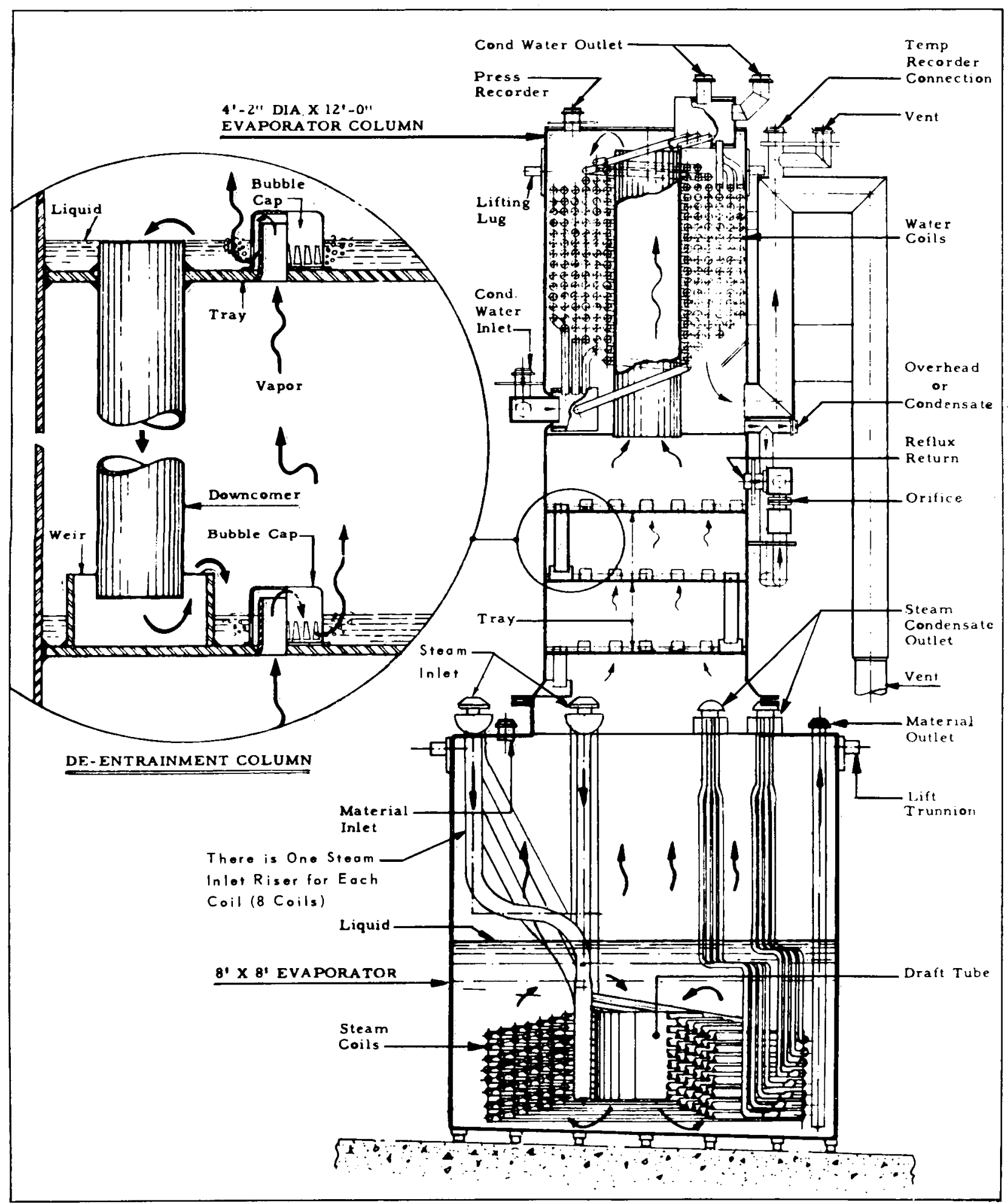

FIGURE 4. MODIFIED-COIL BATCH EVAPORATOR AND COLUMN 


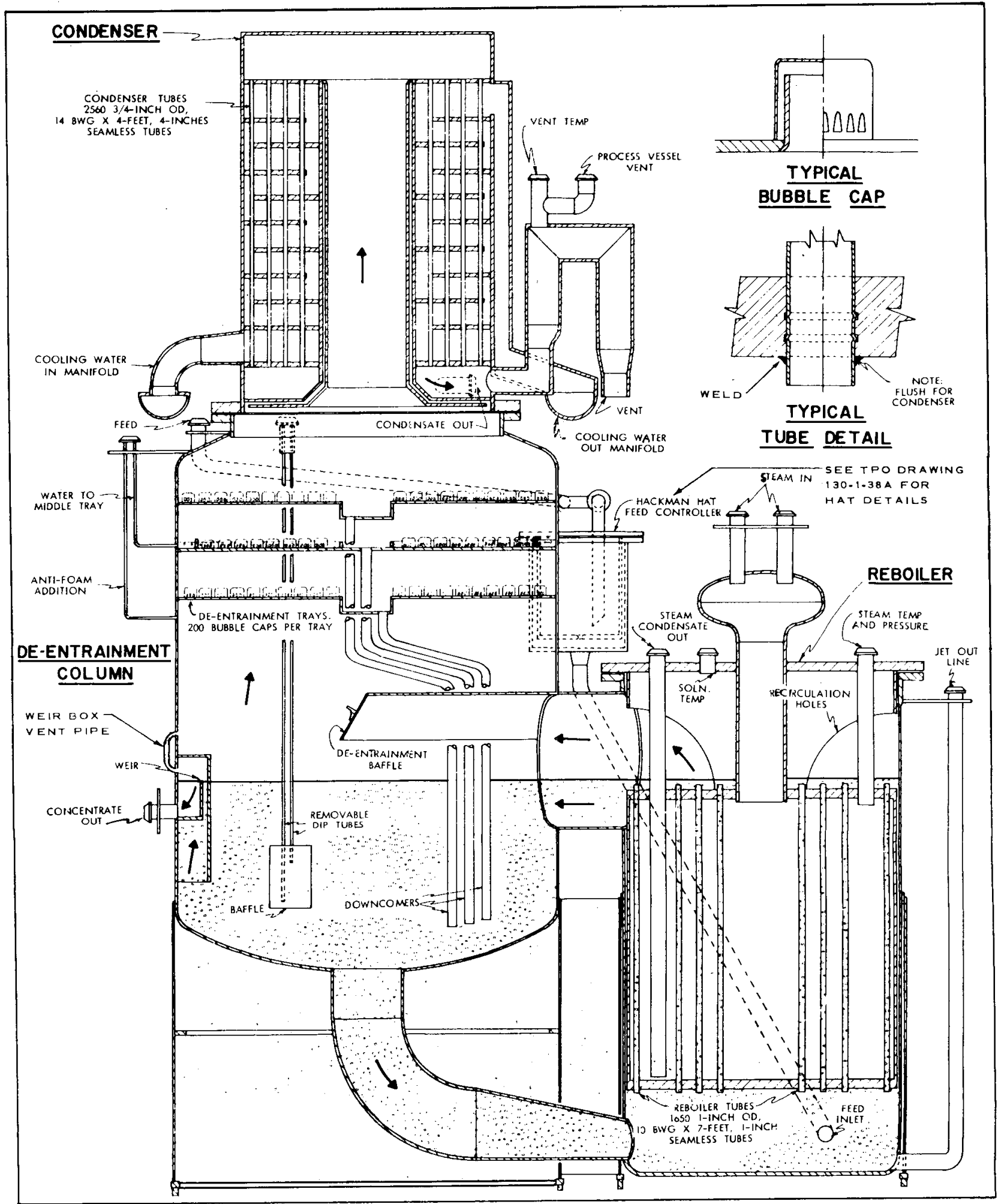

FIGURE 5. CONTINUOUS EVAPORATOR 


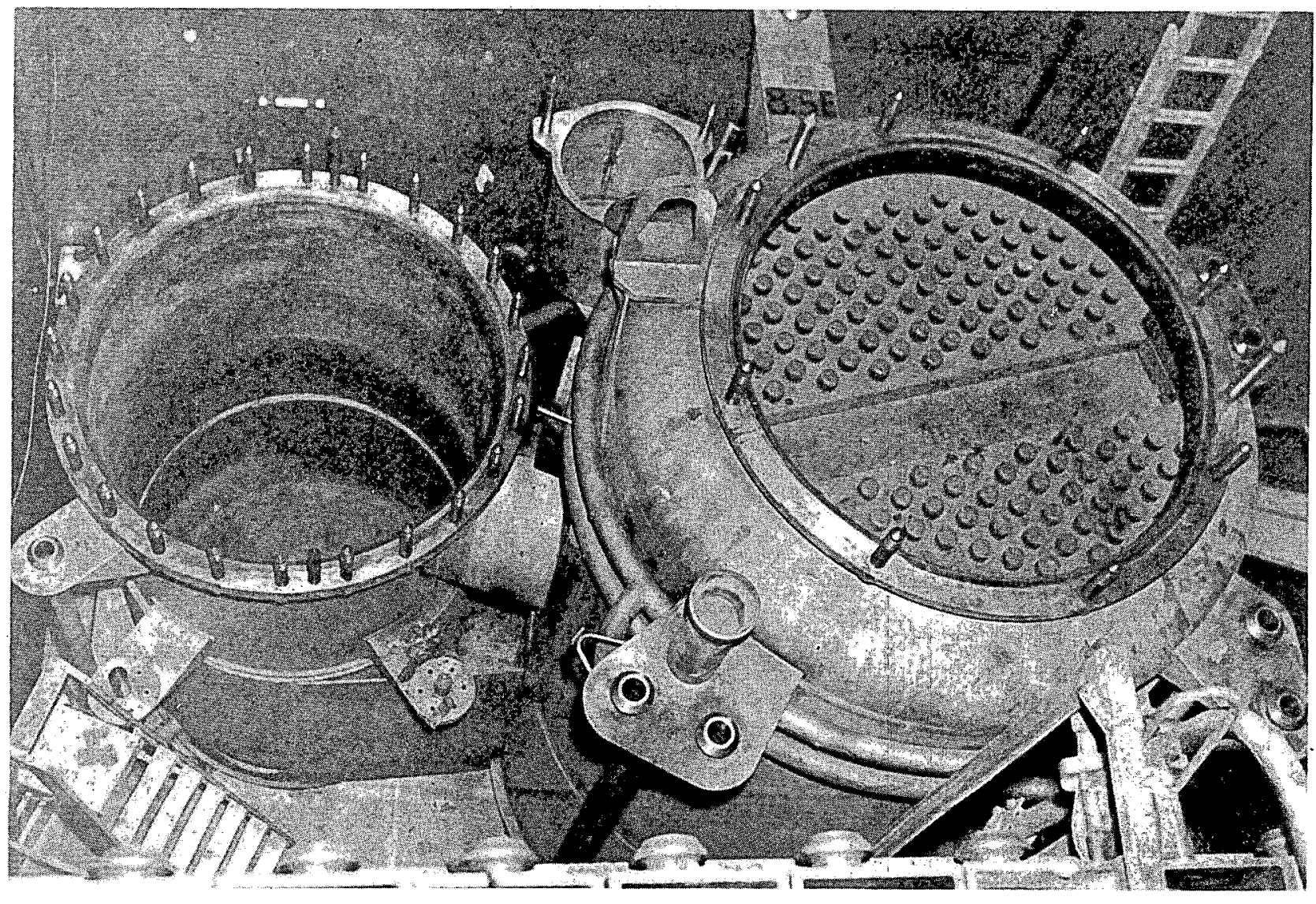

FIGURE 6. CONTINUOUS EVAPORATOR. Condenser column and reboiler tubes removed: DPSPF 10701-6.

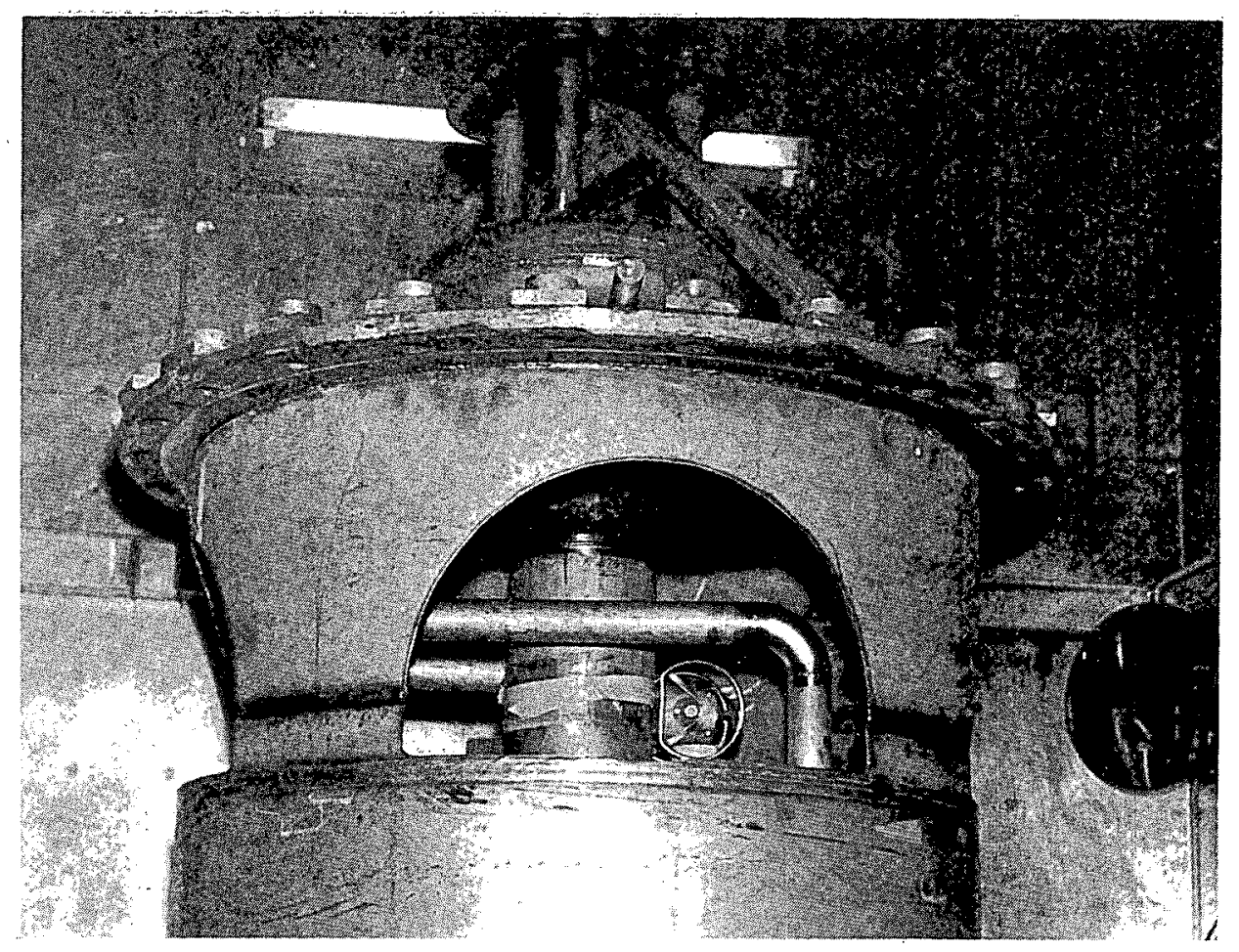

FIGURE 7. SIDE VIEW OF REBOILER SECTION AND STEAM CHEST. DPSPF 15690-2. 


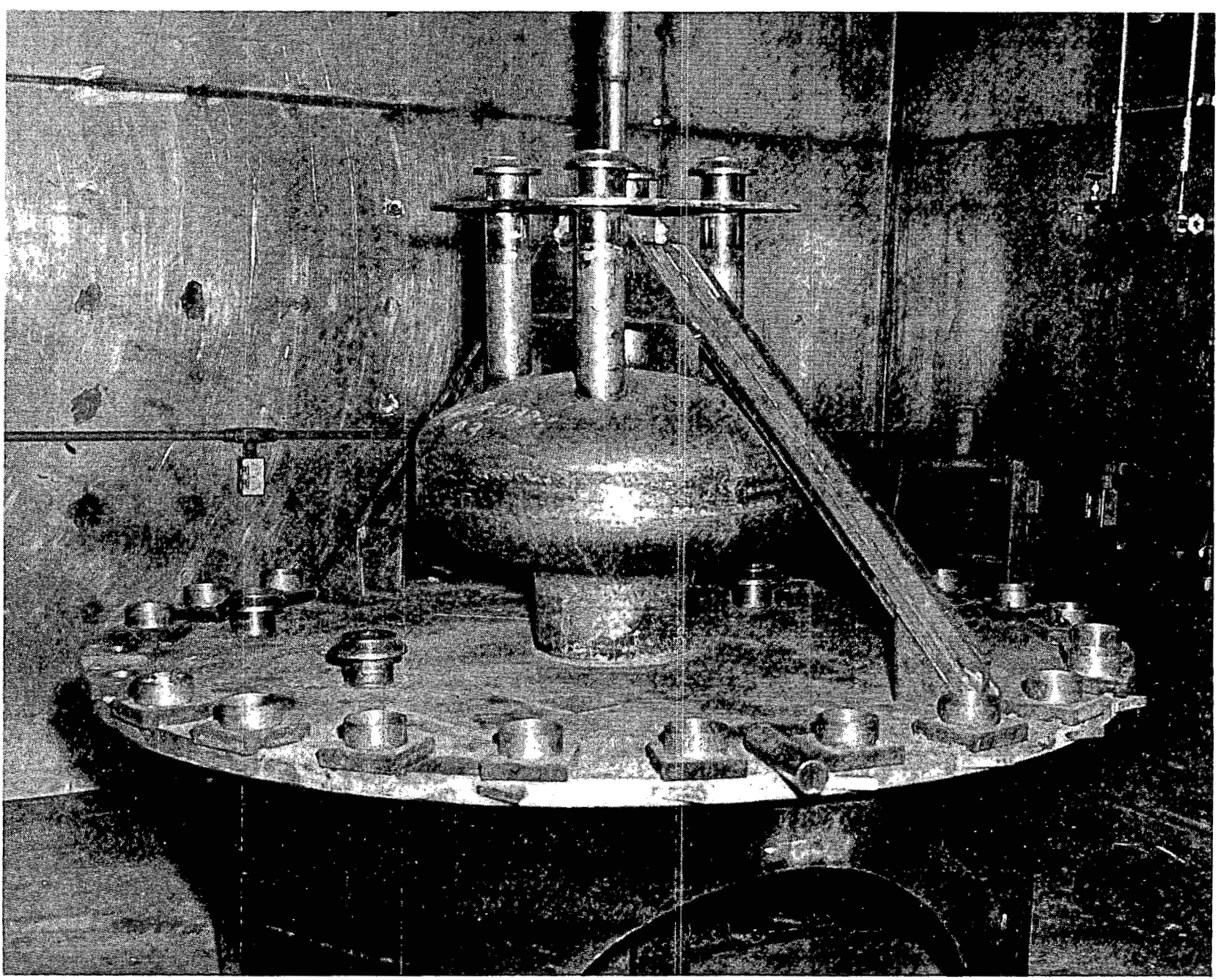

FIGURE 8. STEAM CHEST. Cut from tube bundle section for tubesheet replacement. DPSPF 11966-6. 

$0^{24^{3}}$

A SUMMARY REVIEW OF MOUND LABORATORY'S

EXPERIENCE IN D \& D OF RADIOACTIVE FACILITIES, 1949-1973

J. M. Garner \& W. P. Davis

Mound Labjoratory*

Miamisburg, Ohio, 45342

ABSTRACT

The objective of Mound Laboratory's Decontamination and Decommissioning (D\&D) projects has been the effective termination of radioactive material processing facilities with no significant personnel exposures or environmental releases. This objective must be met with available resources and manpower.

Mound has effectively decontaminated and/or decommissioned four major facilities in the 1949 through 1973 time period. Many minor areas were also decontaminated and/or decommissioned during this period. The major D \& D projects involved the following isotopes: polonium-210, radium-226, actinium227 , and plutonium-238.

To achieve a D \& D status, Mound has employed several control and decontamination techniques such as: "Navy Cocooning", entombment, removal, foaming, bagging, tents, chutes, portable exhausters, dry ice, vents, bubble suits, three-zones,

* Mound Laboratory is operated by Monsanto Research Corporation for the U. S. Energy Research and Development Administration under Contract No. E-33-1-GEN-53. 
fire watches, painting and sealing, in-line cleaning, high pressure water blaster, and chemical cleaning. 
A SUMMARY REVIEW OF MOUND LABORATORY'S EXPERIENCE IN D \& D OF RADIOACTIVE FACILITIES, 1949-1973

J. M. Garner \& W. P. Davis

Introduction

Mound Laboratory has completed four major Decontamination and Decommissioning ( $D \& D$ ) projects of ERDA facilities over the years in addition to several minor D \& D projects.

The four major $D \& D$ projects were:

1. Two polonium-210 processing facilities.

2. A radium-226 and actinium-227 processing and waste disposal facility.

3. A plutonium-238 processing facility.

4. A third polonium-210 processing facility.

The details of these four major projects are described in the following sections.

Polonium-210 Facilities

Units III and IV were used to process polonium-210 from 1944 through 1949. ${ }^{1,2}$ Unit III contained approximately 35,000 ft. ${ }^{2}$ of contaminated floor space and was Decontaminated and Decommissioned from 1949 to 1950 under the direction of AEC/Oak Ridge by conventional scrubbing and removal techniques. The main building was returned to the original owners (the Dayton Board of Education) in 1950. The outer smaller buildings were removed (including footer), and the area was backfilled.

Unit IV was approximately 16,000 ft. ${ }^{2}$. The building was decontaminated as much as possible by conventional scrubbing 
and removal techniques. The structure and footer were then removed, and the area was backfilled. The site was returned to the original owner (the Talbott family) in 1950.

Monitoring included air samples, wipe and direct contamination surveys, water and urine samples. End results of $D \& D$ was N/D (nondetectable) removable alpha and less than $5 \times 10^{3}$ dis/min/100 $\mathrm{cm}^{2}$ fixed alpha $\left(5 \times 10^{4}\right.$ on Unit IV). Followup surveys shows N/D due to the short (138-day) half-life.

Personnel protection included clothing and respiratory (half and full face masks) protection. Clothing was basically twopiece whites, coveralls, gloves, control shoes, shoecovers, and booties.

Radium-226 and Actinium-227 Facility

The "Cave" and associated waste disposal facilities were used to process radium-226 and actinium-227 from 1952 to 1954 . The Cave and associated facilities contained approximately 4,000 ft. ${ }^{2}$ of contaminated floor space and was $D \& D^{\prime} d$ under the direction of the $\mathrm{AEC} / \mathrm{DAO}$ by conventional scrubbing, removal, "Navy Cocooning", and entombment techniques. The D \& D was performed during the 1955 through 1957 time period (equipment in "Navy cocoons" was on hold until 1957) with available manpower. A portion of the Cave structure (where high level material was processed) was entombed in 12 in. of concrete. The remainder of the facility was decontaminated 
to N/D removable and less than $400 \mathrm{dis} / \mathrm{min} / 100 \mathrm{~cm}^{2}$ fixed alpha contamination. This portion is now used for other programs.

Monitoring included air samplers, radon sampling, wipe and direct contamination surveys, gamma surveys, and urine samples .

Personnel protection included clothing and respiration protection (half and full face supplied-air masks, bubble suit). The Mound-Synder supplied-air bubble suit was developed and used on this project.

Plutonium-238 Facility

The SM Facility was used to process plutonium-238 for space programs from 1961 to 1968.

The SM Facility contained approximately $15,000 \mathrm{ft} .{ }^{2}$ of contaminated floor area (585 linear feet of gloveboxes) and was $D \& D^{\prime} d$ under the direction of the AEC/DAO office by employing several control and decontamination techniques such as: removal, foaming, bagging, tents, chutes, portable exhausters, dry ice, vents, bubble suits, three-zones, fire watches, painting and sealing, in-line cleaning, high pressure water blaster, and chemical cleaning. The facility is now awaiting final disposition by ERDA. The $D \& D$ was performed during the 1968 through 1972 time period (work emphasis on later years). 
Monitoring included air samplers, wipe and direct contamination surveys, $\gamma-n$ surveys, soil and water samplers, nosewipes, urine samples, WBC, film badges, etc. The current contamination level inside the facility is less than 10,000 dis/min/ $100 \mathrm{~cm}^{2}$ removable alpha and less than $400,000 \mathrm{dis} / \mathrm{min} / 60 \mathrm{~cm}^{2}$ fixed alpha. (Painting was not used.)

Personnel protection included clothing and respiratory protection. This protection included: two-piece whites, coveralls, two-piece plastic suits, two-piece supplied-air bubble suits, shoecovers, booties, control shoes, head covers, and filtered and supplied-air respiratory protection.

\section{A Third Polonium-210 Facility}

The " $\mathrm{T}$ " facility was used to process polonium-210 for commercial sale and space programs to 1972.

The radioactive processing section was approximately 32,000 $\mathrm{ft} .{ }^{2}$ for two floors (236 linear $\mathrm{ft}$. of gloveboxes) and was $D \& D^{\prime} d$ under the direction of the AEC/DAO office by conventional scrubbing and removal techniques. The $D \& D$ was performed during the 1971 through 1973 time period. The facility is now used for both radioactive and nonradioactive work.

Monitoring included air samples, wipe and direct contamination surveys, $\gamma-n$ surveys, soil and water samplers, urine samples, WBC, film badges, etc. The area was decontaminated 
to N/D removable alpha and N/D fixed. Painting was allowed only on surfaces less than 4,000 dis/min (decayed to N/D by end of project).

Personnel protection included clothing and respiratory (filtered and supplied air) protection.

\section{Special Techniques}

Several techniques were found to be effective in controlling and reducing the spread of contamination during decontamination and decommission work.

- Equipment and structures contaminated with short half-life material were removed for storage at a controlled area until decay had reduced contamination levels to $\mathrm{N} / \mathrm{D}$.

- Sealing equipment and structures were used for containment purposes. The Navy cocooning method was used in the earlier days, but has now been replaced with foaming. Other materials such as asphalt, concrete, and paint can be used on items that are to be discarded or are contaminated with a short half-life material.

- Containment can be achieved by using plastic bags and enclosures. These enclosures were especially helpful when working outside the building.

- Temporary access methods such as a chute improved efficiency.

- Portable exhausters such as Spencer turbines and large industrial vacuum cleaners with absolute filters provided added negative differential to small work areas. 
- The use of dry ice to remove tile minimized the spread of contamination.

- Small respirator filters were used as vents when equipment was foamed.

- The Mound-Synder supplied-air bubble suit provided personnel with maximum respiratory and contamination protection.

- The use of three separate zones of contamination levels proved to be effective in contamination control.

- A 24-hr, seven-days a week, "fire watch" was provided on occasion to increase ability (in addition to automatic alarms) to detect potentially hazardous conditions.

- In-line glovebox cleaning and separation of equipment proved to be very successful. Even high pressure washing can be used if the gloveboxes are not deteriorated.

- A variable high pressure water blaster was used to reduce decontamination time. Wet sandblasting was used on a limited basis because of problems with lines and drains plugging.

- Chemical cleaning such as paint removers and acid solutions also reduced decontamination time. Mechanical paint chippers were used only on a limited basis because they were time consuming.

The exact methods used for $D \& D$ work will depend on an evaluation of several factors: half-life of contaminants, type, specific activity, quantity of contamination, the presence of other radioactive and nonradioactive contaminants, location, and desired end result. 


\section{Summary}

In conclusion, Mound Laboratory has completed four major Decontamination and Decommissioning projects. These projects were accomplished in an effective manner by use of these contamination control techniques, procedures, and decontamination techniques. As a result, there were no significant personnel exposures and no significant impact on the environment as verified by data from the following monitoring programs: stack sampling, on-site and off-site monitoring stations, bioassay sampling, and dosimetry data.

The $D \& D$ projects were also completed with minimum impact on operational resources and manpower. 


\section{REFERENCES}

1. Report No. 3 of Steering Committee for Disposal of Units III and IV, MLM-461, Mound Laboratory, April 17, 1950.

2. Completion Report for Disposal of Unit III, MLM-393, Mound Laboratory, October 31, 1949. 


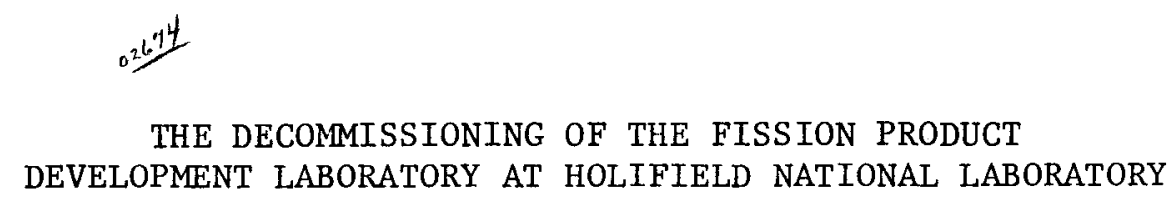

R. W. Schaich

Holifield National Laboratory*

Oak Ridge, Tennessee

\begin{abstract}
The decontamination of the Fission Product Development Laboratory at Holifield National Laboratory was initiated in FY 1975 after 17 years of processing fission product waste streams to produce commercial quantities of ${ }^{90} \mathrm{Sr},{ }^{137} \mathrm{Cs},{ }^{144} \mathrm{Ce}$, and ${ }^{147} \mathrm{Pm}$. The objective of the decommissioning program is the removal of all radiation and contamination areas in the facility to a level which will be compatible with the environment in the foreseeable future.
\end{abstract}

*Operated by Union Carbide Corporation for the Energy Research and Development Administration. 
INTRODUCTION

The fission product research and development work at Holifield National Laboratory (HNL) leading to the construction of the Fission Products Development Laboratory (FPDL) ${ }^{1,2}$ began in 1948 with the investigation of a number of methods for removing long-lived fission products from waste solutions. Fission products were first separated in curie quantities in laboratory glassware using ion-exchange processes. Later, hundred curie quantities were separated in small stainless steel vesse1s. Finally in 1958, the FPDL facility (Fig. 1) went on stream to separate kilocurie amounts of ${ }^{137} \mathrm{Cs},{ }^{90} \mathrm{Sr},{ }^{144} \mathrm{Ce}$, and ${ }^{147} \mathrm{Pm}$ from Redox and Purex type waste streams. This program was successfully demonstrated during the first two years of operation, and kilocurie quantities were made available for worldwide distribution.

With the advent of the AEC's Systems for Nuclear Auxiliary Power (SNAP) and increased demand for ${ }^{137} \mathrm{Cs}$ gamma sources, the requirements for ${ }^{137} \mathrm{Cs},{ }^{144} \mathrm{Ce}$, and ${ }^{90} \mathrm{Sr}$ were increased to a level of megacuries per year. To meet this demand, concentrates of ${ }^{137} \mathrm{Cs},{ }^{90} \mathrm{Sr}$, and ${ }^{144} \mathrm{Ce}$ were shipped from the Hanford Atomic Products Operation (HAPO) to the FPDL for preparation of the fuel compounds used in the SNAP program. The FPDL facility ${ }^{3}$ was modified in 1963 to allow the continuous production of three product streams as follows: 
1. A semi-pure fraction of ${ }^{137} \mathrm{Cs}$ from HAPO was chemically purified at the FPDL ${ }^{4}$ and converted to ${ }^{137} \mathrm{CsCl}$ powder. This powder was cold pressed into pellets which were doubly encapsulated in stainless steel; the capsules were tested for leaks and then shipped to the customer.

2. Purified ${ }^{90} \mathrm{Sr}$ was received from $\mathrm{HAPO}$ and converted to ${ }^{90} \mathrm{Sr}$ titanate. This material was then compacted by vacuum hot press techniques to form a high density pellet. The pellets were encapsulated, usually in Hastelloy "C", and the capsules were tested for leaks and decontaminated before being loaded into a thermoelectric generator for shipment to the customer.

3. A mixed rare earth fraction was received from HAPO; the ${ }^{144} \mathrm{Ce}$ was separated by solvent extraction and converted to ${ }^{144} \mathrm{Ce}$ oxide. The powder was cold pressed and sintered and then sealed in compatible containers for shipment to the customer.

A total of 10.0 megacuries of fission product material was successfully processed at the FPDL during the past decade. During this period, in-cell maintenance requirements were at a minimum and only six cells were decontaminated for the installation of new equipment or repairs to existing equipment. Thus, the decommissioning of 25 individual cells (Fig. 2) highly contaminated with three potent long-lived fission products presented a formidable task for the operating personnel. 
DISCUSSION

The decontamination program at the FPDL was divided into four distinct phases.

I. Removal and encapsulation of ${ }^{90} \mathrm{Sr}$ products.

II. Decontamination of the manipulator cells used for powder preparation.

III. Decontamination of the process cells which contained the vessels and associated piping used in the purification processes.

IV. Decontamination of the tank farm cells and cell ventilation system.

The original FPDL decontamination proposal was to accomplish this effort in two years based on a 3-shift operating crew of 25 chemical operators. Due to a limited budget in FY 1975, the crew was reduced to ten chemical operators. This reduction in personnel drastically reduced the flexibility of rotating personnel on work in radiation zones while maintaining the minimum practical individual radiation exposure. The crew was placed on a day shift schedule and all work assignments were made on the basis of $>75 \%$ remote operations to limit radiation exposure. The initial goals for each cell were to reduce the radiation and contamination level to $<5 \mathrm{R} / \mathrm{hr}$ to allow direct access to the cell for maintenance personnel to remove contaminated equipment to the HNL Solid Waste Storage Area. 
Approximately 500,000 curies of ${ }^{90} \mathrm{Sr}$ titanate powder was stored in the FPDL facility at the beginning of FY 1975. A physical inventory of the powder was made by weighing each batch and determining the ${ }^{90} \mathrm{Sr}$ content calorimetrically on a representative sample from individual batches. The powder was then loaded into stainless steel cans $(25,000$ Ci/can) and sealed with a press fit cap. The inner container was cleaned to a smear level of $<10 \mathrm{mr} / \mathrm{hr}$ and placed into an outer stainless steel container. The outer containers were Tungsten Inert Gas (TIG) welded, leak tested, and cleaned to a smear tolerance of $<10,000 \mathrm{dis} / \mathrm{min}$. The sealed containers were placed in AEC-DOT approved shipping containers and are being held for future customer orders.

\section{DECONTAMINATION OF MANIPULATOR CELLS}

After the removal of the ${ }^{90} \mathrm{Sr}$ products, it was possible to remove all solid waste from nine of the manipulator cells and transfer it to the HIJ Solid Waste Storage Area. A typical manipulator cell and its associated equipment are shown in Fig. 3. The solid waste consisted of glassware, tygon tubing, calorimeters, balances, blenders, graphite die bodies, manipulator-operated tools; ceramic filters, and all equipment that could be disassembled with the manipulators. This material was thoroughly washed in the cell and placed in a plastic-1ined 55-gallon drum. The drum was 
sealed with a standard ring using special tools designed for manipulator operation. The drums were decontaminated in the manipulator cell with high pressure soap spray equipment and then wiped to a smear tolerance of $<1 \mathrm{mr} / \mathrm{hr}$. A total volume of $200 \mathrm{ft}^{3}$ of solid waste was transferred in a shielded drum waste carrier to the HNL Solid Waste Storage Area and lowered into holes for storage.

Large pieces of equipment, such as a vacuum hot press (Fig. 4), were dismantled in the cell with the aid of specially designed tools that could be operated with manipulators. The highly contaminated parts were transferred to the HNL Solid Waste Storage Area. The stainless steel vacuum chambers were cleaned in the cell with high pressure soap solutions and chemicals to remove the insoluble particles of ${ }^{90} \mathrm{SrTiO}_{3}$. The cells were then cleaned using the same techniques by spraying through a 12-in.-diam opening in the top of the cell.

When the radiation level in the cell was reduced to $<10 \mathrm{R} / \mathrm{hr}$, the top blocks were removed and a 3-in. armor plate shield was placed in the cell block opening. This shield was equipped with a 2-in.-thick plexiglass shield approximately $3.5 \mathrm{ft}$ in diameter. Since the remaining contamination in the cell was ${ }^{90} \mathrm{Sr}\left({ }^{137} \mathrm{CsC} 1\right.$ dissolves readily in hot water $)$, the plexiglass was adequate shielding for the soft beta radiation emitting from the cell opening. The shield had various sized holes with removable plugs that would permit the access of high pressure spray equipment to 
reach a large portion of the cell surfaces. The large diameter of the plexiglass allowed excellent line of sight to all areas of the cell.

When the radiation level in the cell was reduced to $<5 \mathrm{R} / \mathrm{hr}$ and the contamination level $<500 \mathrm{mr} / \mathrm{hr}$, the shield was removed and large pieces of equipment were removed from the cell and decontaminated by hand to a level acceptable for reuse. Permanent equipment, (Fig. 5) such as a vessel mounted on the cell wall and its associated piping, was decontaminated during the initial cell clean up work. This was accomplished by flushing the system repeatedly with hot solutions of $1 \underline{\mathrm{N}} \mathrm{HNO}_{3}, 1 \underline{\mathrm{N}} \mathrm{NaOH}$, versene, Turco 4501, oxalic acid, and water flushes between each chemical addition. ${ }^{5}$ Analyses of the decontamination solutions would generally indicate a few millicuries of beta activity after the third cycle of the chemical treatment. If the vessel and piping were reading $<5 \mathrm{R} / \mathrm{hr}$, maintenance personnel would hot rod the piping and the equipment brackets with a carbon graphite-copper clad cutting electrode on a long rod from the top of the cell. The small pieces were removed from the cell by the use of manipulators to transfer the material to the drum waste station. Large vessels ( 100 gal) were lifted through the top of the cell into plywood containers and transferred to the HNL Solid Waste Storage Area for underground storage.

After the removal of piping, conduits, and instrument 1ines, additional hot spots were found that would require decontamination or lead shielding to reduce the cell background to $<1 \mathrm{R} / \mathrm{hr}$ for direct access to the cell. 
As of June 30,1975 , four manipulator cells were decontaminated to a background of $1 \mathrm{R} / \mathrm{hr}$, and direct access for maintenance personnel was approved. The remaining five manipulator cells have a radiation background ranging from $10 \mathrm{R} / \mathrm{hr}$ to $100 \mathrm{R} / \mathrm{hr}$ and are expected to require approximately ten man-years of effort to make them accessible for direct maintenance. Exposure to operating personnel during this period was maintained below the ERDA limits of 5 Rem per year of penetrating dose $\left(D_{C}\right)$ and 15 Rem per year of skin dose $\left(D_{S}\right)$. The skin dose became the controlling factor due to the beta component of ${ }^{90} \mathrm{Sr}$. The ratio of $\mathrm{D}_{\mathrm{S}}: \mathrm{D}_{\mathrm{C}}$ ranged from $5: 1$ to a high of $30: 1$ and limited our ability to decontaminate with open access to the cell. Special shields, tools, and spray systems were required to limit the $D_{S}$ dose to the operator on top of the cell bank.

\section{DECONTAMINATION OF THE PROCESS CELLS}

The decontamination of the nine FPDL process cells (Fig. 6) during FY 1975 was used as a non-exposure operation to balance the work on the manipulator cells involving exposure to personnel. The process cells contain centrifuges and stainless steel vessels for precipitation, evaporation, crystallization, solvent extraction and storage of fission product cuts. This system was operated from panelboards in non-exposure areas. All vessels and approximately $95 \%$ of the transfer lines were operable at the beginning of the decontamination cycle. 
A series of hot chemical flushes similar to those used in the manipulator cells were passed through all of the equipment a total of five times. The final decontamination solution contained less than $100 \mathrm{mCi}$ of beta-gamma activity. This was the expected result since the process system had contained fission products in a chemically soluble form.

During the chemical flushes, all vessels were heated to the boiling point of the solution and the vapor allowed to escape to the vessel off-gas system. The vapor flows through the off-gas lines and then is condensed in the vessel off-gas dehumidifier and chilled scrubber system. After the decontamination solution samples indicated a low level of activity in the process system, the main off-gas header was valved-off and chemical solutions were gravity flowed into the off-gas High Efficiency Particulate Air (HEPA) filter chamber. Since the filter chamber is the highest elevation point in the system, the decontamination solutions filled the vessel off-gas scrubbers, dehumidifiers, and lines and overflowed into the process vessels. The off-gas HEPA filter chamber was decontaminated to $<1 \mathrm{R} / \mathrm{hr}$ and placed in operation with new HEPA filters to contain any residual activity during final phases of decommissioning.

The results of the decontamination of the process system are unknown at this time because removal of the process cell blocks to obtain radiation surveys would involve excessive exposure to personnel. Based on previous decontamination campaigns, the general background in the process cells 
should be $<10 \mathrm{R} / \mathrm{hr}$ with hot spots up to $100 \mathrm{R} / \mathrm{hr}$ on lines that could not be cleaned due to in-cell valve failures. An additional five man-years of operating effort are expected to be required to reduce the nine process cells to a radiation level which will permit the direct access of maintenance personnel to remove the process equipment and piping.

\section{DECONTAMINATION OF TANK FARM CELLS AND CELL VENTILATION SYSTEM}

The final phase in the decommissioning program will consist of decontaminating the process pipe tunnels to the tank farm cells and then decontamination of the four large tank farm cells. All piping and tankage will be removed and the cells cleaned to a low smear tolerance for painting.

The cleaning of the vessels and piping is actually in progress as a11 decontamination solutions from the process vessels and cell floor drains must pass through the tank farm cells on the way to the HNL ILW system. It is estimated that five man-years operating effort will be required to complete this work.

The cell ventilation system will be cleaned as each cell is decontaminated. Each cell has an individual cell ventilation duct and these are high pressure sprayed before cell entries are approved. The decontamination solutions flow down the main ducts to the primary cell 
ventilation filter pit. This pit contains stainless steel Neva Clog roughing filters plus twelve 1000-cfm HEPA filters.

Decontamination of the cell ventilation filter pit is in progress as this time. The filters have been removed and access is available from the upstream side. Due to erosion of the concrete floor on the downstream side of the filters, we have not been successful in entering this area due to the high radiation readings in the concrete. After decontamination, this area will be reconcreted and painted. New HEPA filters will be installed until the completion of the decommissioning program.

The secondary cell ventilation filter house contains nine HEPA filters which can be replaced in an 8-hour period. Some decontamination and painting will be required to place this system in a surveillance mode of operation.

\section{CONCLUSIONS}

The initial phase of the decommissioning of the Fission Product Development Laboratory has been accomplished by reducing the radioactive content in the facility by a factor of $10^{3}$. The intermediate phase of reducing the curie quantities of fission products by an additional factor of $10^{3}$ will require considerable personnel exposure and direct contact 
type of operations. The final phase of shielding and sealing to acceptable levels of radiation and contamination can be accomplished with a minimum of personnel exposure. A substantial monetary investment will be required to allow a complete shutdown of the facility.

\section{ACKNOWLEDGEMENTS}

The author wishes to acknowledge the efforts of R. D. Johnston and F. V. Williams for their contribution to this work. The work described was performed under the auspices of the Energy Research and Development Administration. 


\section{REFERENCES}

1. E. Lamb, H. E. Seagren, and E. E. Beauchamp, Proc. Sec. U.N. Int. Conf. PUAE, 20 (1958) 38.

2. A. F. Rupp, Proc. U.N. Conf. PUAE, 14 (1956) 128.

3. C. L. Ottinger, R. W. Schaich, Hazards Report For Building 3517 Fission Product Development Laboratory, ORNL-TM-753, Oak Ridge National Laboratory (February 1965).

4. R. E. Lewis, T. A. Butler, and E. Lamb, Recovery of ${ }^{137} \mathrm{Cs}$ From Fission-Product Wastes and Transport by an Aluminosilicate Ion Exchanger, ORNL-3765, Oak Ridge National Laboratory (May 1965).

5. W. R. Murphy, C. L. Ottinger, and R. W. Schaich, Fission Product Devezopment Laboratory Operational Procedures, ORNL-TM-850, Oak Ridge National Laboratory (July 1969). 


\section{FIGURES}

1. Fission Product Development Laboratory, Holifield National Laboratory

2. Isometric View Fission Product Development Laboratory

3. Typical FPDL Manipulator Cell

4. Vacuum Hot Press

5. Manipulator Cell Process Equipment

6. Typica1 FPDL Process Cel1. 


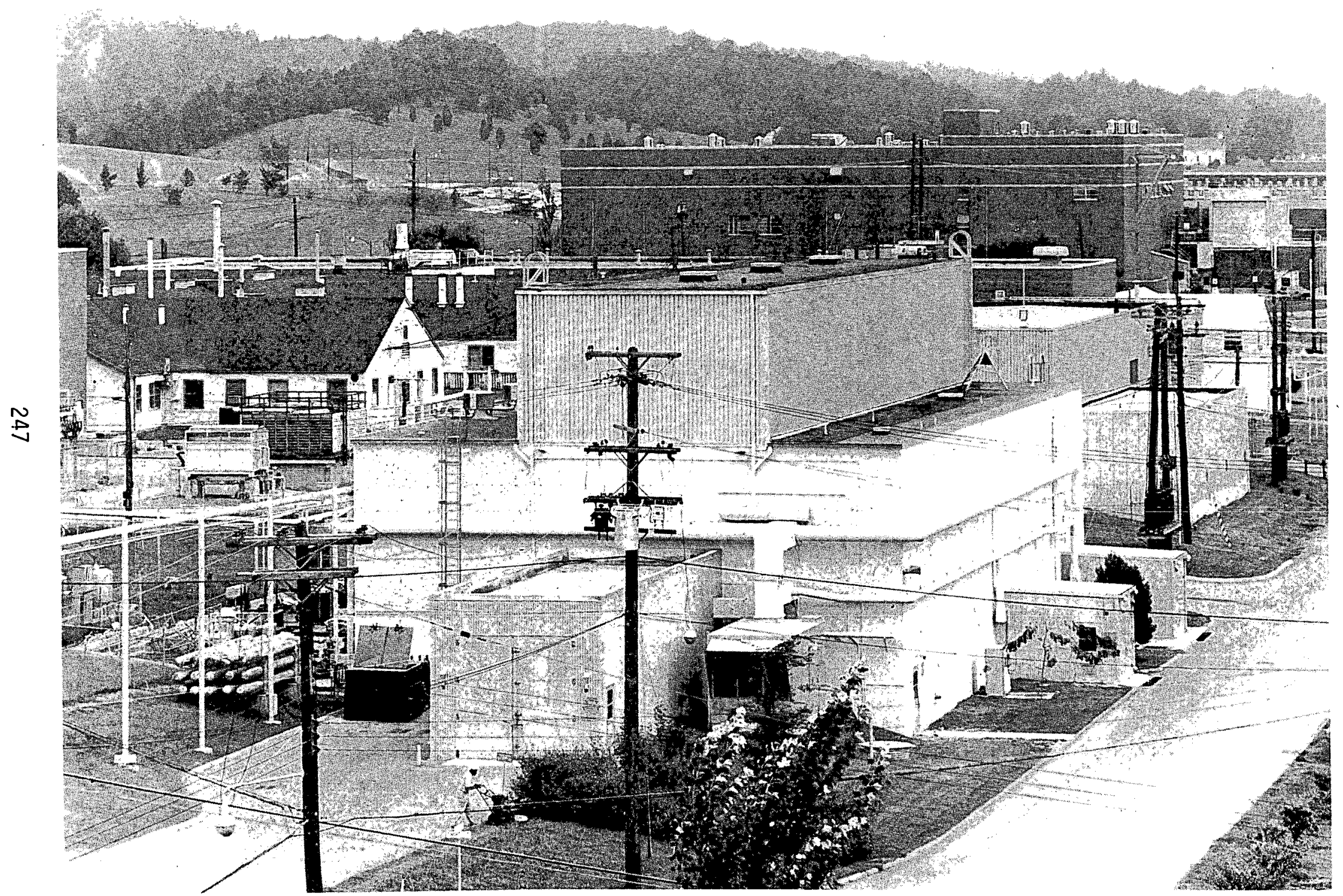

Fig. 1. Fission Product Development Laboratory Holifield National Laboratory 


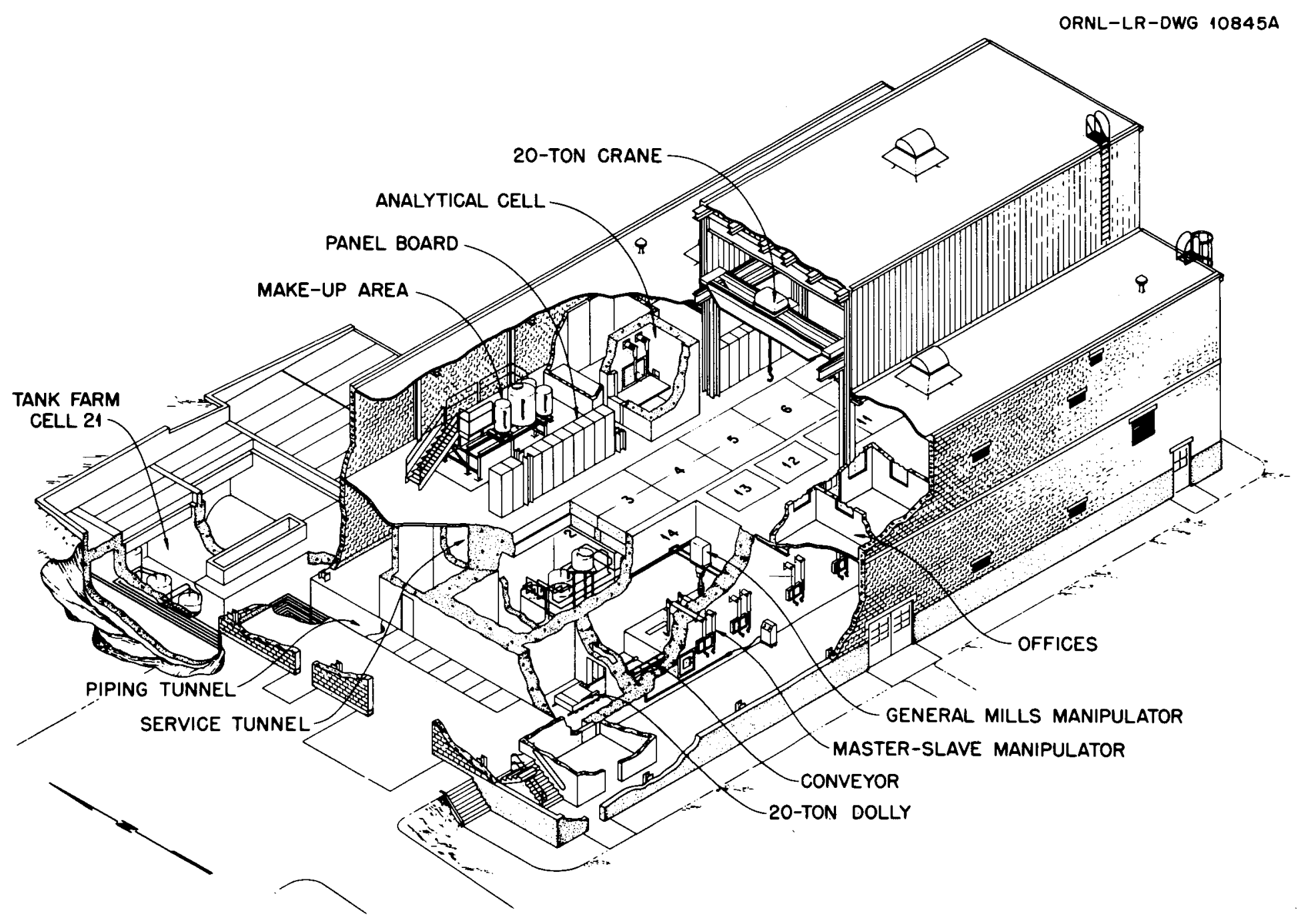

Fig. 2. Isometric View Fission Product Development Laboratory 


\section{C}

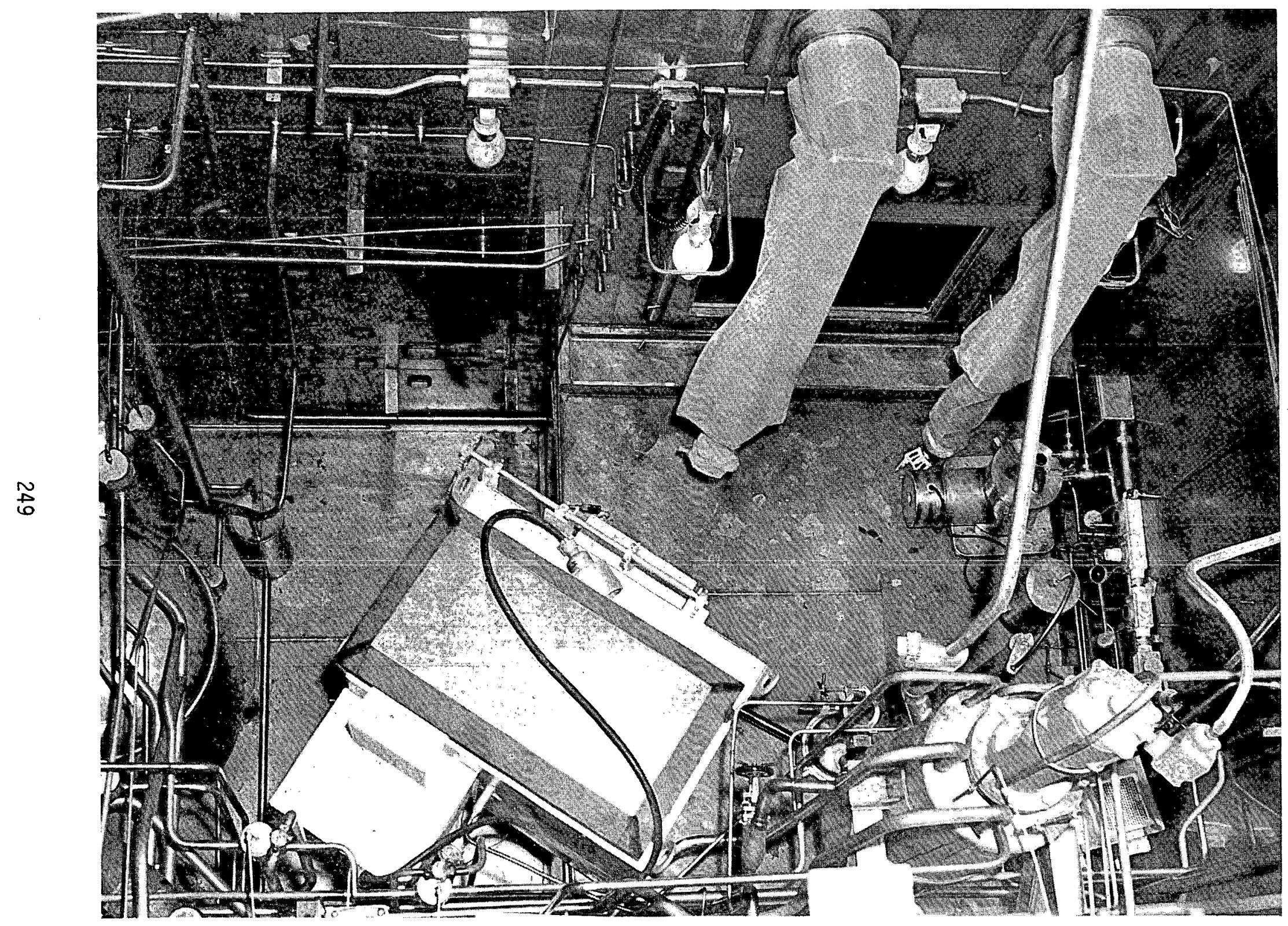

Fig. 3. Typical FPDL Manipulator Cel1 


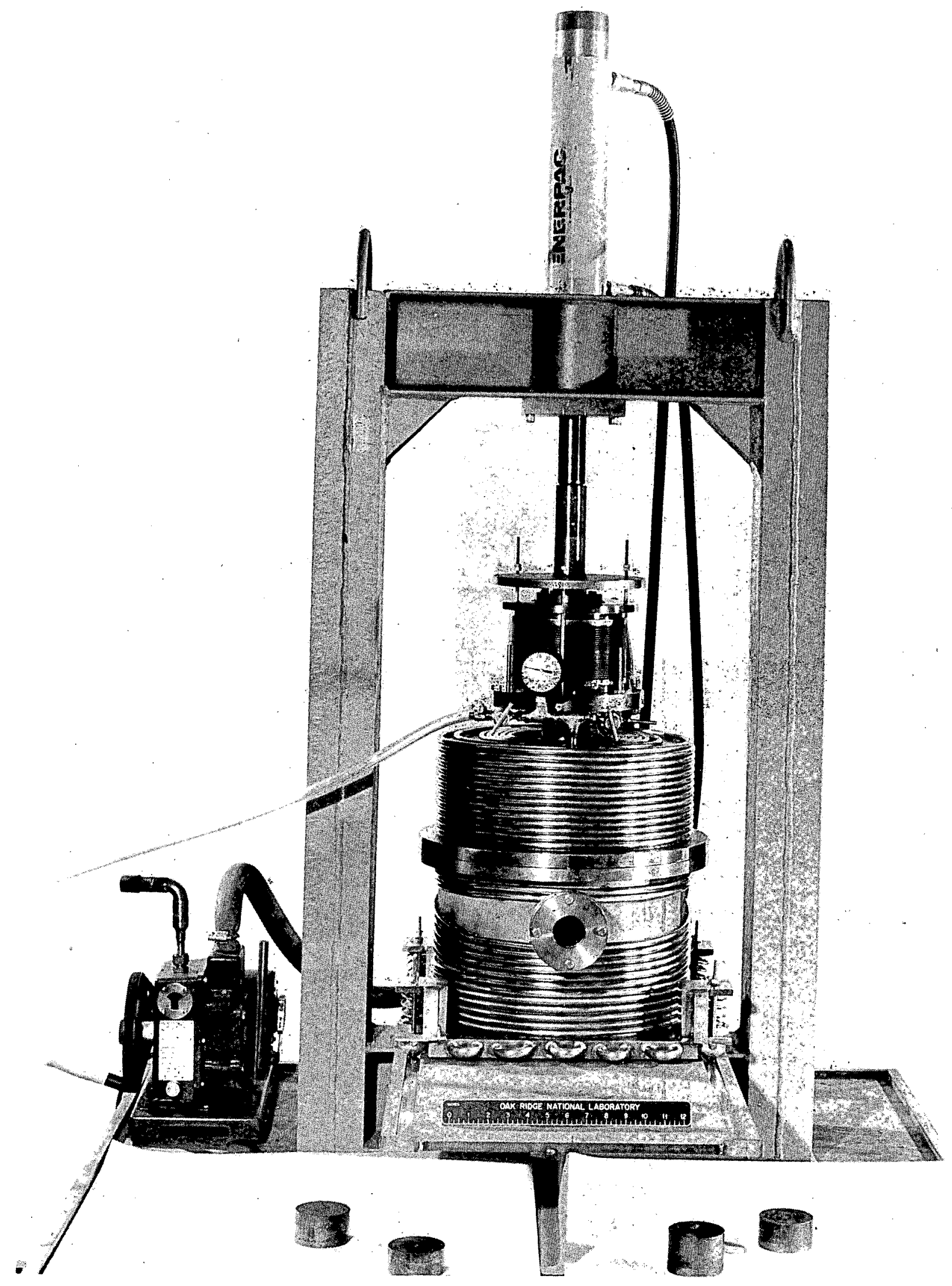

Fig. 4. Vacuum Hot Press 


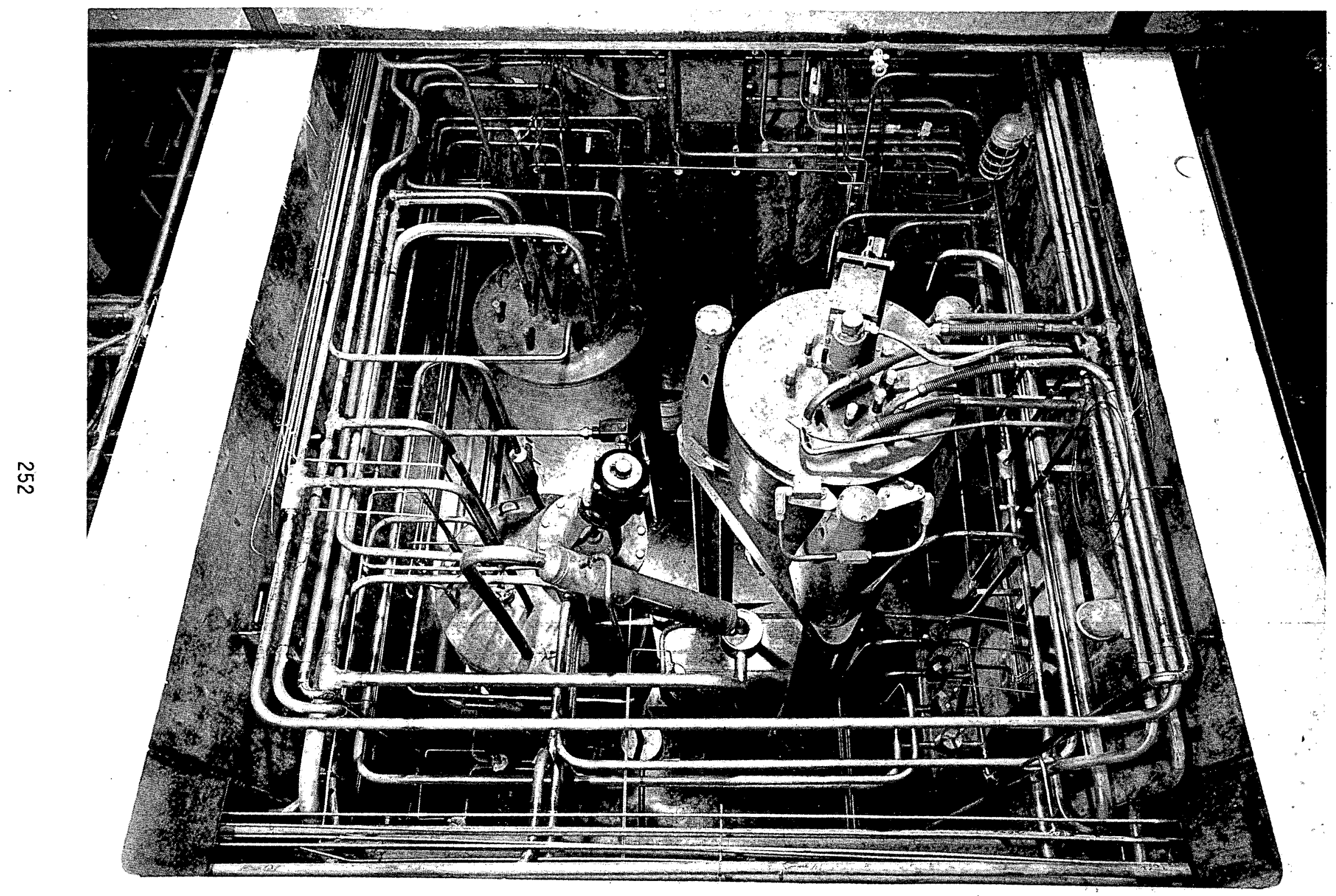

Fig. 6. Typical FPDL Process Cell 


\title{
20205 \\ DECONTAMINATION AND DECOMMISSIONING \\ EXPERIENCE AT EXPERIMENTAL BREEDER \\ REACTOR NO. I
}

\begin{abstract}
This paper discusses the experience obtained from Decontamination and Decommissioning of the Experimental Breeder Reactor No. 1 located at the Idaho Nuclear Engineering Laboratory, Scottsville Idaho. The paper will address the planning, preparation and operations associated with the removal and processing of radioactively contaminated sodium-potassium eutectic alloy (NaK) from the First Experimental Breeder Reactor (EBR-I) facility systems plus the decontamination and decommissioning of same.
\end{abstract}

E. W. Kenda 11

Aerojet Nuclear Corporation

Idaho Falls, Idaho 83401 


\section{INTRODUCTION}

In October 1973, Aerojet Nuclear Company (ANC) initiated the first maneuver involving actual Decontamination and Decommissioning (D\&D) program for EBR-1 facility at the Idaho Nuclear Engineering Laboratory (INEL). The program provided for the removal and processing of the EBR-I alkali metal coolant, the eutectic alloy of sodium and potassium ( $\mathrm{NaK}$ ); the decontamination of all radioactive contaminated portions of the facility, the demolition and removal of those portions which could not be made safe, and relinquishing EBR-I safe for the public use and enjoyment as a Registered National Historic Monument.

This paper presents a portion of the program plan as performed by Aerojet Nuclear Company, assisted by Allied Chemical Corporation (ACC) and Argonne National Laboratories (ANL-West). 


\section{GENERAL DESCRIPTION}

The D\&D of EBR-I is complete, thus marking a first in action taken at INEL to comply with the ERDA directive concerning excessed radioactive contaminated facilities.

Figure 1 locates the EBR-I complex in the southwestern portion of the site and identifies the complex as part of a considerable inventory of excessed INEL facilities which meet the ERDA-D\&D criteria. The facilities which at one time made up the EBR-I complex are shown in Figure 2; however, ancillary structures have been removed from the site leaving two major structures: EBR-I, 601 building which housed the first Experimental Breeder Reactor; and RTF-601 building which contained the ZPR-III, a split table zero power reactor. The split table zero power reactor has been decontaminated and transferred to the EBR-I facility for public display.

The facilities as they appear today are shown in Figure 3.

\section{PURPOSE}

The EBR-I produced the first usable electric energy from nuclear fuel, demonstrated the principle of breeding fuel and proved that the consequence of a core meltdown was not necessarily catastrophic. As a result of these "First in History" demonstrations, the EBR-I was declared a Registered National Historic Monument. The registration ceremonies, over which the late President Johnson presided, were conducted in 1966 as shown in Figure 4. The condition of the facility however, radioactive contamination and hazardous accumulations of NaK, has prevented public access to the Historic Monument. Therefore, the purpose of this program is to provide the EBR-I complex 
safe for the public use and enjoyment, and in a condition acceptable for transfer to the National Park System.

SCOPE OF WORK

The EBR-I has been converted to a safe condition and its physical appearance as an operational reactor facility has been maintained. The building RTF-601 has been decontaminated and the contained ZPR-III reactor structure has been dismantled, decontaminated and transferred from the ZPR-III complex to EBR-I, where it was re-assembled. Plant services required in support of the National Historic Monument, such as the water, fire protection and sanitary systems have been restored and reactivated.

\section{D\&D EXPERIENCE}

The removal and disposal of NaK from the EBR-I primary and secondary coolant systems were considered as major challenges in decontamination of the facility. The primary and secondary NaK coolant systems are shown in Figure 5. The primary system contained 4400 gallons of NaK which was contaminated with $16.2 \mathrm{Ci}$ of $137 \mathrm{Cs}$ residue from the 1955 EBR-I Mark II core meltdown. The NaK was processed in a plant designed, fabricated and installed outside of the EBR-I building.

The secondary system contained 1100 gallons of uncontaminated NaK which was disposed of first over a several day period in order to check out the system, equipment, and procedures.

The NaK disposal process was preceeded by an explosive hazards analysis and evaluation of the eutectic solution of sodium and potassium (NaK) and 
potassium superoxide $\left(\mathrm{KO}_{2}\right)$. This analysis was performed by Cook Associates Inc. in Salt Lake City, Utah. The analysis was to render the following:

(1) determine conditions and properties under which $\mathrm{KO}_{2}$ becomes an explosive hazard, (2) evaluate the explosive parameters of any $\mathrm{XKO}_{2}$ mixture, compound or hazard situation and (3) compare the magnitude of the particular explosive hazards with other well-known explosives in order to evaluate the total hazard potential associated with decontamination of the EBR-I facility.

The results and conclusions obtained from the testing are summarized as follows:

1. Dry $\mathrm{KO}_{2}$ can be mixed at ambient temperature with liquid or solid NaK without an immediate reaction, yet such mixtures will ignite spontaneously (but will not explode) after an induction period (e.g., 18 minutes after a vial of $50 \mathrm{cc}$ of $\mathrm{NaK}$ was ruptured into dry $\mathrm{KO}_{2}$ under a dry argon atmosphere). There is no explosion hazard connected with dry $\mathrm{KO}_{2}-\mathrm{NaK}$ mixtures, but upon ignition they may react, at rates comparable to those occurring in explosions (but with no generation of gas) via a nonexplosive thermite-type, solid-phase burning reaction. Liquid or solid NaK-KO $\mathrm{K}_{2}$ mixtures ignite but do not explode in the "drop-weight" or "impact" test. (By "explosion" is meant a very fast reaction producing high pressure and loud noise. The $\mathrm{NaK}_{-} \mathrm{KO}_{2}$ reaction does not fulfill either the high pressure or loud noise criterion, but it is an extremely fast condensed-phase nonexplosive reaction).

2. NaK and water, of course, react spontaneously and explosively upon contact. However, the rate of pressure development in the NaK-water reaction is relatively slow, as in explosive deflagrations, and a great deal slower than in detonatiors. When NaK was poured into excess water the observed explosion showed an energy release of 
somewhat less than 400 calories per gram of NaK. This compares with roughly 1000 calories per gram for an average high explosive such as TNT. It is about one-third the heat of explosion of nitroglycerin. However, if involved in large quantities, the hydrogen produced in this reaction may be ignited and react explosively with the atmosphere to increase the explosion potential of the NaK-water reaction theoretically to as high as 1380 calories per gram of NaK, comparable to the explosion potential of an equal weight of nitroglycerin.

3. Noisture in $\mathrm{KO}_{2}$ reduces the induction period for spontaneous ignition of mixtures of $\mathrm{NaK}$ and $\mathrm{KO}_{2}$. On the other hand, even when the moisture content is high enough for instantaneous ignition, the $\mathrm{NaK}^{-\mathrm{KO}_{2}}$ mixture still does not explode even though the condensed-phase combustion is extremely rapid and hot (white-hot in air).

4. Mixtures of $\mathrm{KO}_{2}$ and liquid hydrocarbon, e.g., No. 2 fuel oil (FO), can be mixed safely at ambient temperature. (This is not true of all organic compounds, some of which react spontaneously with $\mathrm{KO}_{2}$ at ambient temperature, e.g., acetone). The $\mathrm{KO}_{2}-\mathrm{FO}$ mixture has an auto ignition temperature (i.e., explodes spontaneously) of $207^{\circ} \mathrm{C}$ and is very sensitive to impact and friction. The impact sensitivity of dry $\mathrm{KO}_{2}-\mathrm{FO}$ is comparable to that of PETN, one of the most sensitive of the solid secondary high explosives. The balanced $(91 / 9) \mathrm{KO}_{2}-\mathrm{FO}$ mixture explodes with an incomplete (explosion) energy release with a No. 5 electric blasting cap $(E B C)$, the next size cap smaller than the standard (No. 5) commercial detonator. This mixture detonated with complete energy release with a No. 8 EBC. The ignition hazards of balanced $\mathrm{KO}_{2}-\mathrm{FO}$ is so great that it flashes nonexplosively when initiated with a No. 4 EBC. High explosives are seldom this sensitive to ignition, i.e., they either detonate or else, when the 
cap is too small to produce a detonation, they simply fail completely (Detonations are the fastest and most intense of the explosion reactions. They are orders of magnitude faster and higher in pressure than explosive deflagrations. All detonations are explosions, but explosions are not necessarily detonations).

Balanced (91/9) $\mathrm{KO}_{2}-\mathrm{FO}$ ignited but did not detonate when a vial of NaK was broken into it by a blasting cap.

5. The most important conclusion of this study is that uncontaminated $\mathrm{NaK}-\mathrm{KO}_{2}$ mixtures do not possess an explosion hazard even though they are extremely sensitive to ignition. Explosions in this system referred to in the literature were evidently caused by organic or moisture contamination. Yet even moist $\mathrm{KO}_{2}$ does not explode when it comes into contact with NaK, but upon contact with NaK it will spontaneously and immediately ignite.

6. The $\mathrm{NaK}_{-} \mathrm{KO}_{2}-\mathrm{FO}$ system will ignite spontaneously just like the $\mathrm{NaK}-\mathrm{KO}_{2}$ system. However, the presence of $\mathrm{FO}$ might be expected to cause explosions under some conditions, even though only a nonexplosive reaction was observed in this investigation when a $50 \mathrm{cc}$ vial of NaK caused ignition of about 400 grams of balanced $(91 / 9) \mathrm{KO}_{2}-\mathrm{FO}$.

7. One of the important safeguards against explosion in the EBR-I decontamination project is the fact that the $\mathrm{NaK}_{-} \mathrm{KO}_{2}$ mixture selfignites in a relatively short time even when no moisture is present. Therefore, the only way $\mathrm{KO}_{2}$ could be present in NaK after prolonged storage is to exist at surfaces or interfaces and to be buffered from the NaK by intermediate oxides. And, since the EBR-I NaK systems had Argon cover gas, it is very unlikely that $\mathrm{Ko}_{2}$ would be present in EBR-I in significant amounts. 


\section{NaK PROCESSING}

The NaK in its original form was both a liquid and a potential fire hazard which was not acceptable for storage at the INEL Radioactive Waste Management Complex (RWMC). This situation required the processing of the NaK, converting it to a solid, non-pyrophoric material in order to qualify for storage. Nak processing will be discussed later per the program agenda by Dr. L. C. Lewis.

\section{SYSTEM DECONTAMINATION}

When the greater part of the NaK had been removed from the primary and secondary coolant systems drain tanks, the residual heels, films of NaK and oxides had to be removed to complete the decontamination. The approach taken by Waste Management Projects Branch was to process the residual NaK in the secondary system first to obtain all the data and experience possible prior to processing the primary system, since the secondary was a noncontaminated system. The method used was to inject a moist $\mathrm{N}_{2}$ purge (10:12 psig) through the NaK fill line to the drain tank. When the purge was established and stable (pipe surface was noted to be $100^{\circ} \mathrm{F}$ or less, detected by using templistick markings), water droplets were injected at a rate of 60 drops per minute and maintained at that rate until the audible reaction in the drain tank had ceased or the vent line temperature indicated $400^{\circ} \mathrm{F}$ as noted by the templistick marking which was placed on the pipe prior to starting the reaction. Since an exotherm develops when reacting the $\mathrm{NaK}$, the $\mathrm{N}_{2}$ purge exiting from the drain tank carried the water vapor on through the vent path causing a reaction of the NaK film on the pipes and tanks up stream of the drain tank. To vent the drain tank, the path selected was through the pressurization line into the receiving tank. 
From the receiving tank, the path selected was either through the superheater and steam generator or straight to the flame arrestor outside the building. Both paths were opened in the event that a spike in pressure should occur as it could be easily lowered by the available piping tankage. The rupture disc assembly was removed and valved to give a straight path to the atmosphere. The purging was done on a 24-hour basis; however, the water droplet injection was secured overnight and weekends. When the heat indicator (templistick) and audible activity was no longer detectable, water at $5 \mathrm{gpm}$ was injected into the purge to dilute the caustic in the drain tank. This was done at one minute intervals to verify the NaK reaction was complete. A heat rise of over $100^{\circ} \mathrm{F}$ but less than $200^{\circ} \mathrm{F}$ was noted on the vent line of the drain tank for approximately one hour and there was no audible reaction detected. The water injection was secured after 300 gallons had been delivered to the drain tank. The next injection point was on top of the filter piping where it was known, due to the filter configuration, NaK would exist. The vent path selected for this component was through the pump and receiving tank. There were two paths - either through the pump or through the bottom of the receiving tank-and from there to atmosphere through the same path as noted above for the drain tank. When the reaction was complete in the filter, valving was performed to allow moist $N_{2}$ to travel through the heater, heat exchanger, superheater and steam generator to atmosphere. This 8 psig $\mathrm{N}_{2}$ purge was initiated and left on over a 64 hour period. The caustic water vapor that was discharged to atmosphere through the flame arrestor was visible and fairly steady when the area was secured for the weekend; however, upon returning Monday, there was no visual sign of reaction. Valving was again performed to allow the Moist $\mathrm{N}_{2}$ to flow for one hour through each fin tube cooler and on through 
the economizer to the atmosphere. There was an audible reaction each time another cooler was valved in to accept the moist $\mathrm{N}_{2}$ purge, however, this was no more than you get when slowly opening a cold leg on a steam line. When all the fin tube coolers were purged with moist $\mathrm{N}_{2}$, valving was changed to start a water injection purge through the filter, pump, and to drain tank with no audible reaction noted. We then changed the valving to go through the filter, pump, heater and heat exchanger back to the receiver tank, venting to the atmosphere. When it was evident that water was draining into the receiver tank, the valving was changed to push the water through the superheater, steam generator and economizer. Each time the water made a turn in the piping of these units, audible reaction was detected and the water valve was closed to avoid a stepped reaction, however, the only reaction noted was just at the change in flow direction.

By drilling out a thermo-well for water injection and proper valving, the fin tube coolers were flooded one by one. The reaction was a very smal1, thump and only at the beginning of each fin tube cooler operation. This was felt to be due to a small amount of NaK at the upstream side of the valve. The fin tube coolers were filled with water and drained to receiver tank. The complete secondary system was drained to the drain tank and then the system was completely flooded and drained again. The caustic solution from the drain tank was then moved by pressure to an external holding tank and then transferred to the INEL acid pit. A total of 2,125 gallons of caustic solution was removed from the drain tank.

Prior to initiating the moist $N_{2}$ purge, the primary system required: a modification of the off-gas piping to incorporate filtration, adapters welded to the filter for purging; and the flame arrestor installed. Upon completion 
of the modification, the valving was positioned to initiate a moist $\mathrm{N}_{2}$ purge (10 psi) into the drain tank as well as the EM transfer pump at the base of the drain tank. This purge was started in the morning, remained on overnight and the next morning water droplets were injected into the Moist $\mathrm{N}_{2}$ which increased the reaction rate. This was noted by a rise in temperature of the vent pipe and a boiling type sound. When the temperature returned to ambient, and no sound was detected when injecting the $\mathrm{H}_{2} \mathrm{O}$ at a higher rate, i.e. 20-30 ml/min., the reaction was considered complete. A moist $\mathrm{N}_{2}$ purge line was then attached to a filter. The valving was such that the venting was through the drain, receiving and gravity tanks, then through the filters and flame arrestor to atmosphere. Again, the injection rate and completion was the same as noted on the primary drain tank. It is estimated that each filter had approximately one pint of NaK to be reacted due to the configuration of the filter. The cold trap was valved in next with a moist 8 psi $\mathrm{N}_{2}$ purge left on over the weekend. Upon return on Monday, the water droplets were initiated into the $\mathrm{N}_{2}$ purge and by mid-afternoon, the reaction was complete. It is estimated that approximately 11 gallons of NaK was reacted in the cold trap by this method. A minor problem occured while working the cold trap near the end of the reaction period when the oxides and hyroxides plugged the $7 "$ discharge line. After trying $\mathrm{N}_{2}$ pressure, water and hammering pipe walls, it was necessary to break the flanges and inject a $1 / 4$ " SS tube into the solid plug making a path for water to tunnel. When this was done, the pipe flanges were re-assembled and the discharge lines were cleaned by water flushing. Flushings were, in all cases, drained to the primary drain tank. Prior to processing the NaK in the reactor vessel, a dip tube was installed in the reactor flange for use in removing the reaction 
product after processing. The moist $N_{2}$ purge was then connected to a $1 / 2^{\prime \prime}$ pipe installed in the top of the reactor flange, the purge initiated and all valving was opened on piping to or from the reactor to insure a good vent path. There were approximately 27 gallons of NaK in the bottom of the reactor to be processed. The reactor has two view ports in the top flange which were used to verify the reactor was completely flooded with demineralized water when the reaction was finished. The caustic solution in the reactor was drained to within three feet of the bottom through the primary side of the heat exchanger on down to the primary drain tank. The expansion tank was also flushed while performing the above operation. The reactor vessel was filled twice with demineralized water and then drained to the primary drain tank. A considerable amount of rinsing was performed and by valving and connecting the water line to various attachment points in the system, the direction of flow was controlled to assure all lines had been flushed throughly. Approximately 1500 gallons of demineralized water was pumped to the gravity tank and drained to the drain tank.

The gas purification system, filter trap, and ballast tank were purged with moist $\mathrm{N}_{2}$, then flushed with $\mathrm{H}_{2} \mathrm{O}$ to verify any film or puddle of NaK would be passivated. Upon completion of water flushing of the primary system all valves were opened and system was allowed to drain to the primary drain tank until the NaK process plant was modified and ready for boil-off operations. The NaK process tank required the installation of heaters and the attachment of a vent gas line directly to the filter elements. The boil-off operation required the caustic solution in the primary drain tank to be transferred to the NaK process vessel where boiling down the solution to a $25 \mathrm{M}$ caustic solution would assure a solid waste product 
upon cool down. Eight day shifts were expended on boil-off before a round the clock 8-day operation was initiated. 3,300 gallons of caustic solution were boiled down to a molarity that assured a solid upon cooling $\left(347^{\circ} \mathrm{F}\right)$. The decontamination, decommissioning, and isolation activities were continued throughout the NaK processing operations. The process plant product remained in the reaction vessel as a solid after cool down. All lines were capped or plugged on the vessel to isolate the caustic solid from the atmosphere. The vessel plus all the associated components and piping were contaminated; therefore, the entire NaK processing plant was disassembled, packaged and transferred to the RIWMC.

The approach taken on rooms or areas that had smearable contamination was to generate a grid on all the surfaces and number or letter same. This provided a method for expediting completion and acceptance per criteria requirements of a cell, room or area. The clean-up methods used were manual in most cases. However, a concrete electric chipping hammer was required to remove pieces of concrete that contained impregnated contamination.

The criteria for acceptance was that the facility items and areas must not exceed the contamination levels shown in the following table. 


\begin{tabular}{|c|c|c|c|}
\hline NUCLIDE & AVERAGE & MAXIMUM & REMOVABLE \\
\hline $\begin{array}{l}\text { U-nat, } U-235, \\
U-238 \text { and associated } \\
\text { decay products }\end{array}$ & $\begin{array}{l}5,000 \mathrm{dpm}^{2} \\
\mathrm{a} / 100 \mathrm{~cm}^{2}\end{array}$ & $\begin{array}{l}15,000 \mathrm{dpm} \\
\mathrm{a} / 100 \mathrm{~cm}^{2}\end{array}$ & $\begin{array}{l}1,000 \mathrm{dpm} \\
\mathrm{a} / 100 \mathrm{~cm}^{2}\end{array}$ \\
\hline $\begin{array}{l}\text { TRANSURANICS, } \\
\text { Ra-226, Ra-228 } \\
\text { Th-230, Th-228 } \\
\mathrm{Pa}-231, \mathrm{Ac}-227, \\
\mathrm{I}-125, \mathrm{I}-129\end{array}$ & $\begin{array}{l}100 \mathrm{dpm} / \\
100 \mathrm{~cm}^{2}\end{array}$ & $\begin{array}{l}300 \mathrm{dpm} / \\
100 \mathrm{~cm}^{2}\end{array}$ & $\begin{array}{l}20 \mathrm{dpm} / \\
100 \mathrm{~cm}^{2}\end{array}$ \\
\hline $\begin{array}{l}\text { Th-nat, Th-232 } \\
\text { Sr-90, Ra-223 } \\
\text { Ra-224, U-232, } \\
\text { I-126, I-131, } \\
\text { I-133, }\end{array}$ & $\begin{array}{l}1000 \mathrm{dpm} / \\
100 \mathrm{~cm}^{2}\end{array}$ & $\begin{array}{l}3000 \mathrm{dpm} / \\
100 \mathrm{~cm}^{2}\end{array}$ & $\begin{array}{l}200 \mathrm{dpm} / \\
100 \mathrm{~cm}^{2}\end{array}$ \\
\hline $\begin{array}{l}\text { BETA-GAMMA EMITTERS } \\
\text { (nuclides wi th decay } \\
\text { modes other than } \\
\text { alpha emission or } \\
\text { spontaneous fission) } \\
\text { EXCEPT Sr-90 AND } \\
\text { OTHERS NOTED ABOVE }\end{array}$ & $\begin{array}{l}5000 \mathrm{dpm} \beta-\gamma / \\
100 \mathrm{~cm}^{2}\end{array}$ & $\begin{array}{l}15,000 \mathrm{dpm} \beta-\gamma / \\
100 \mathrm{~cm}^{2}\end{array}$ & $\begin{array}{l}1000 \mathrm{dpm} \beta-\gamma / \\
100 \mathrm{~cm}^{2}\end{array}$ \\
\hline
\end{tabular}

The areas that required isolation were narrowed down to two rooms; the washroom and the conveyor room both located in the basement. The conveyor room had a $25 \mathrm{R} / \mathrm{hr}$ reading at contact that was impractable to remove and the washroom had a $15 \mathrm{mR} / \mathrm{hr}$ reading at contact which would have required extensive removal of load bearing wall surfaces and would have been prohibitively costly to decontaminate. The conveyor room had sodium vapor lights and three observation windows, therefore, tourists could view it 
from the outside and it was considered unnecessary for them to enter the room. These two rooms were sealed up rather than being decontaminated.

There were areas that after chipping or removing concrete required some lead sheeting in the bottom covered by a thin film of polyethylene before filling with grout. This proved very successfut in meeting the required criteria. The contaminated cleaning liquids generated during decontamination were mixed with absorbent materials in an open top 55-gallon drum, sealed when full and transferred to the RWMC. For the most part, the cleaning agents used were: TURC0 4324-OR, METHYL-CHLOROFORM, M-68 cleaning foam and commercial laundry soap. 


\section{SUMMARY OF PROGRAM}

In retrospect, the EBR-I project management activities such as: structuring the task force, personnel training, writing D\&D procedures and producing a Safety Analysis Report, as well as the technical research and development effort, were completed with no major difficulties. The $\mathrm{NaK} / \mathrm{KO}_{2}$ hazards evaluation was successfully completed and provided assurance that the NaK removal operations could proceed without danger of a NaK/KO $\mathrm{K}_{2}$ explosion. The hazard existed only when a third ingredient containing hydrocarbon was present and the EBR-I systems were known to be free of hydrocarbon. The final engineering drawings for the NaK processing equipment were generated by ANC Design Engineering Division. They used the conceptual sketch generated by ACC personnel who were called upon primarily as chemical and instrumentation consultants. The EBR-I facility with the exception of two areas (the conveyer room and washroom, which were isolated), was decommissioned and decontaminated to the level requirements that allows free access by the general public to any area so selected by the National Park Service. The facility was transferred to the National Park Service on June 10, 1975 which allowed for an earlier opening date, then originally scheduled for NPS public tours. 


\section{FIGURES}

1. Idaho Nationa? Engineering Laboratory

2. EBR-I Complex Plan View

3. Photo of EBR-I Complex

4. President Johnson Dedicating EBR-I

5. Simplified Pictorial of EBR-I Coolant Flow 


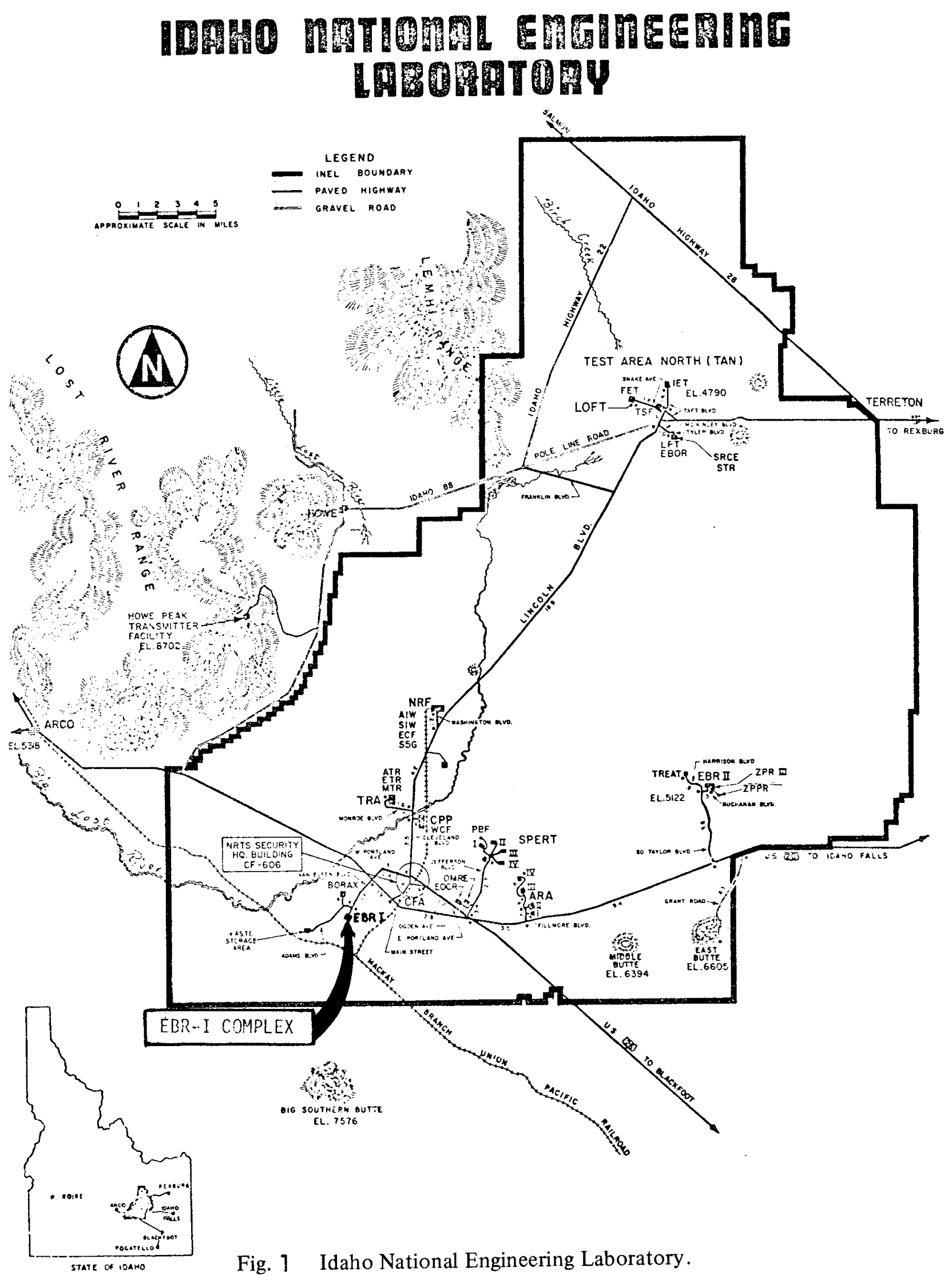


C

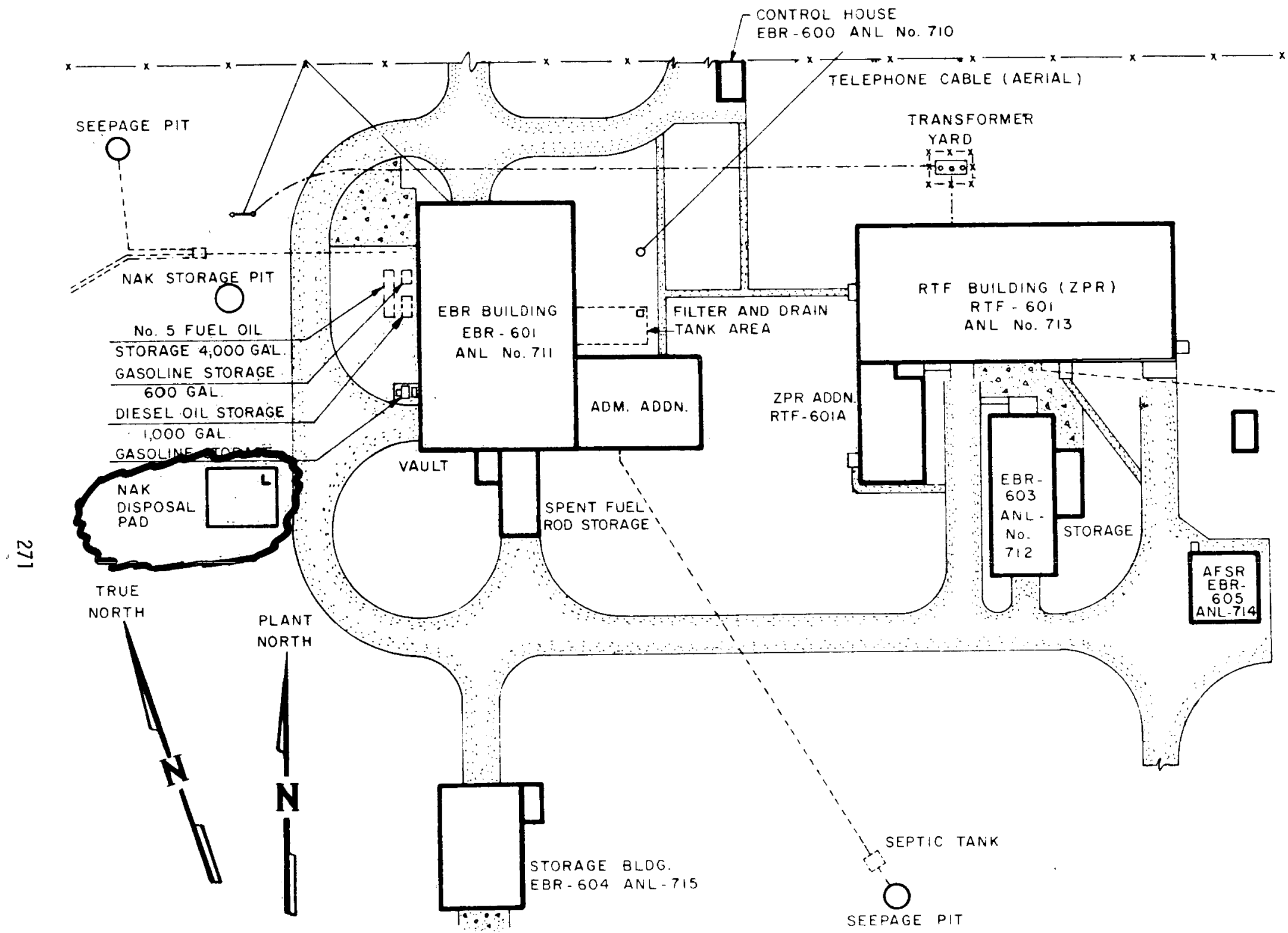

Fig. 2 EBR-I Complex Plan View 


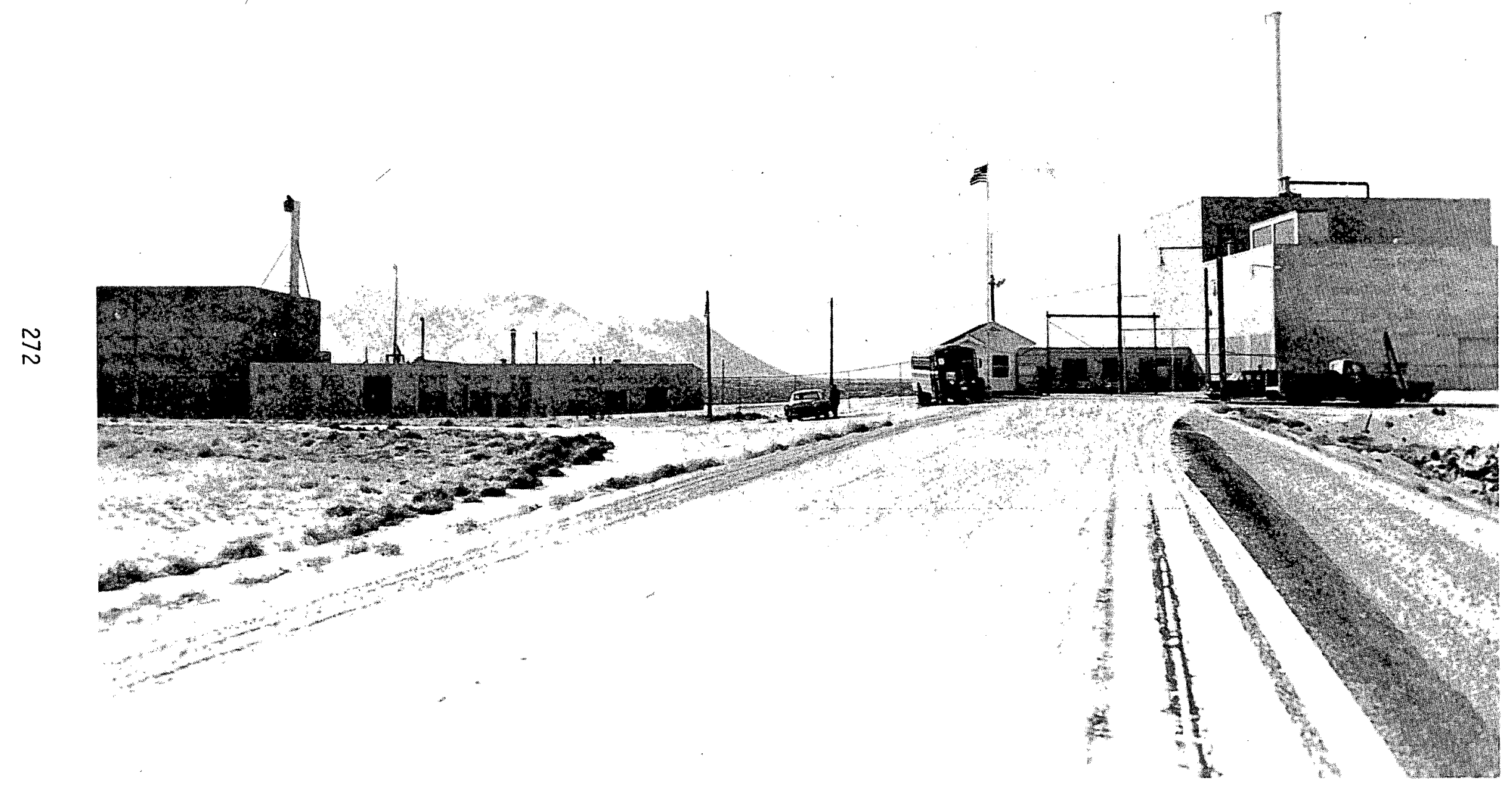

Fig. 3 Photo of EBR-I Complex.

O 


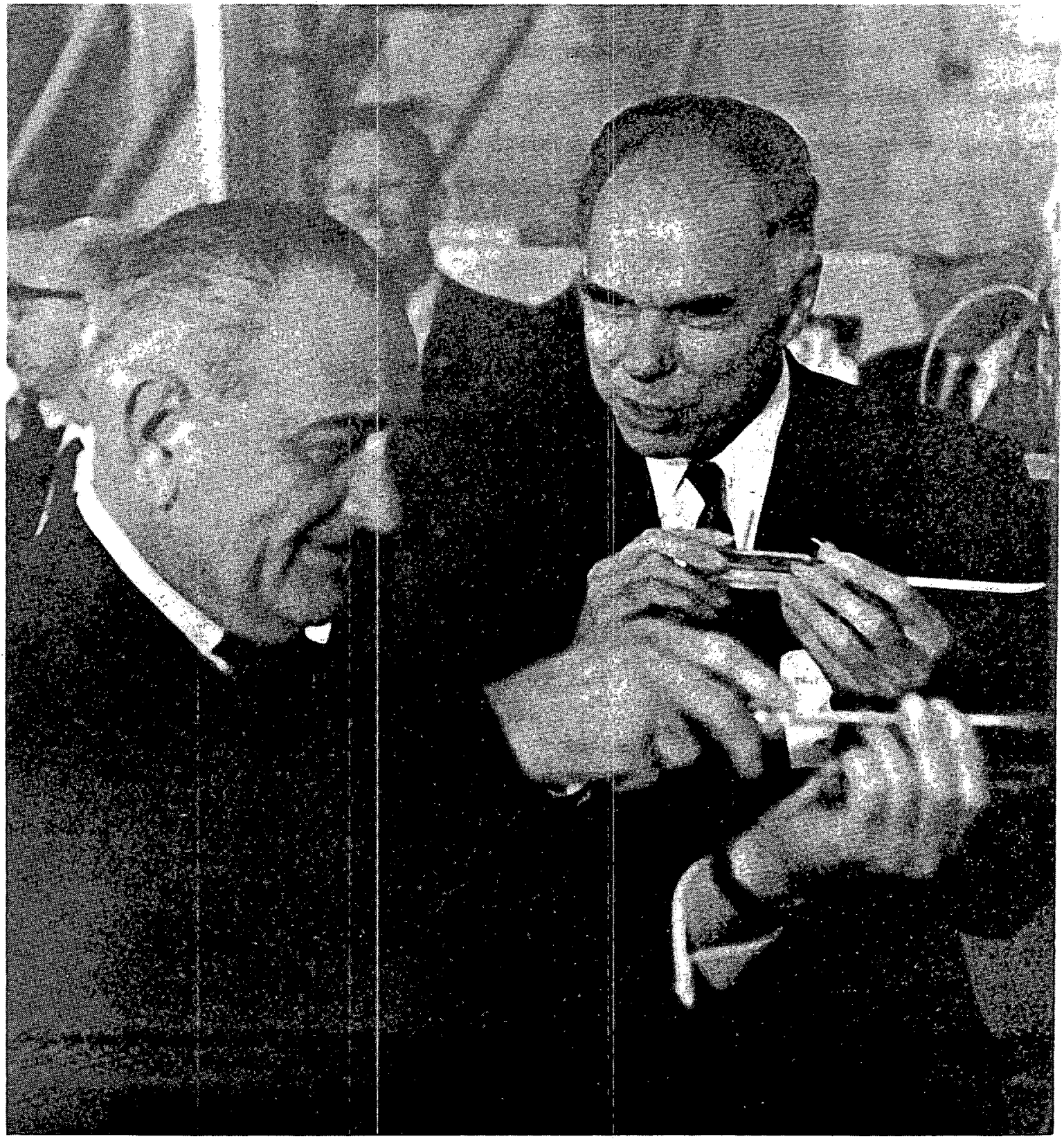

"On this very spot the United States produced the world's first electricity from nuclear energy.,"

President Johnson told more than 15,000 persons who trovelled 50 miles and farther to greet him of the NRTS. Later, he and AEC Chairman Seaborg attached the brass plaque which honors EBR-1 for its technical feats

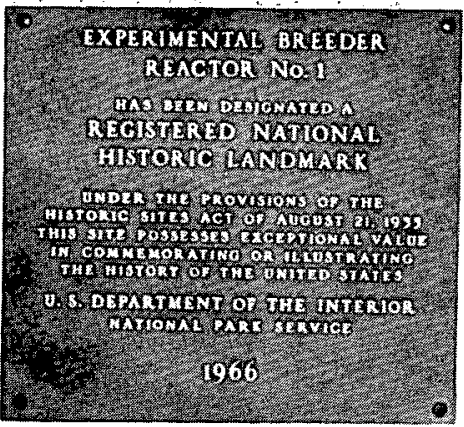

Fig. 4 President Johnson Dedicating EBR-I. 


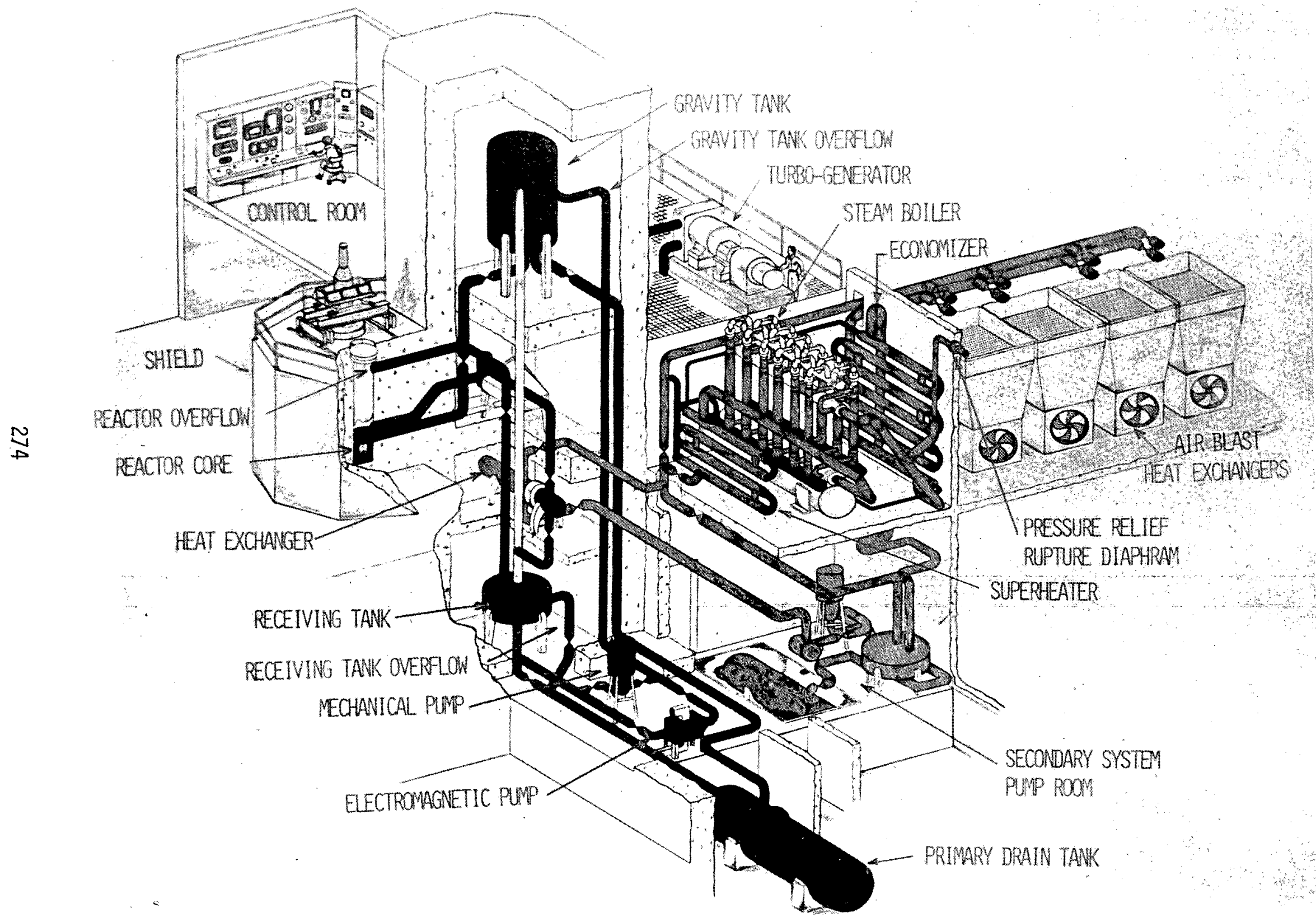

Fig 5 Simplified Rictorial of EBR-I Coolant Flow 

R. R. Hammer
L. C. Lewis

Allied Chemical Corporation

550 Second Street

Idaho Falls, Idaho 83401

\begin{abstract}
Approximately 5500 gallons of fission product - contaminated liquid meta1 coolant (eutectic sodium-potassium alloy - NaK), was removed from the EBR-I reactor system, reacted with caustic solution to produce a solid 25 M potassium hydroxide-sodium hydroxide mixture suitable for storage at the Idaho National Engineering Laboratories RWMC. Considerations that went into the design and operation of the processing unit will be discussed.
\end{abstract}


PROCESSING EBR-I NaK TO PRODUCE A STORABLE SOLID

\section{INTRODUCTION}

Late in 1973, Allied Chemical was asked to develop a process for disposing of the contaminated liquid metal coolant from the EBR-I reactor and the rinsings from the reactor's coolant loops. Several alternative treatment methods for the disposal of the liquid metal (NaK) were considered which included reaction with organic solvents such as alcohols, burning in air, or reaction with steam as well as methods to purify the NaK without changing it from the elemental form.

Several constraints were inherent in the task. These included the natural constraints of handling the relatively hazardous liquid metal safely, the constraint caused by the presence of radioactive fission product contaminants arising from a 1955 core melt down, and finally the constraint of leaving the facility, as closely as possible, in a historically accurate configuration, since it had been designated a National Historical Landmark.

The process concept that was developed was the reaction of the NaK with concentrated aqueous caustic. In this concept, the NaK was transferred from the reactor systems to a pair of feed tanks and then sprayed under pressure into the caustic in the reactor vessel through atomizing nozzles. The finely divided droplets reacted with the water in the aqueous caustic and produced hydrogen and more caustic. The pertinent reactions are:

$$
\begin{gathered}
2 \mathrm{Na}+2 \mathrm{H}_{2} \mathrm{O} \longrightarrow 2 \mathrm{NaOH}+\mathrm{H}_{2} \\
2 \mathrm{~K}+2 \mathrm{H}_{2} \mathrm{O} \longrightarrow 2 \mathrm{KOH}+\mathrm{H}_{2}
\end{gathered}
$$


Quantities and properties of the NaK feed and the caustic product are shown in Table 1.

TABLE 1

NaK PROCESS STATISTICS

Volume of $\mathrm{NaK}$ Reacted

Secondary System:

1100 gallons

Primary System:

4400 gallons

Total 5500 gallons

Radionuclides Processed with the Primary NaK

$137 \mathrm{Cs}$

$16.2 \mathrm{Ci}$

$90 \mathrm{Sr}$

$2.1 \mathrm{mCi}$

No other fission products were detected

Proposed Processing Rate:

120 liters per hour

Projected Caustic Concentration

25 Molar $\left(\mathrm{OH}^{-}\right)$

Boiling Point of Caustic

$\sim 200^{\circ} \mathrm{C}$

Freezing Point of Caustic

$\sim 100^{\circ} \mathrm{C}$

The liquid metal coolant used in EBR-I was the eutectic alloy of sodium and potassium which has a composition of $78 \%$ potassium and $22 \%$ sodium. The freezing point of $\mathrm{NaK}$ is $-12.6{ }^{\circ} \mathrm{C}$. It is chemically more reactive than sodium and has a density and viscosity approximately $90 \%$ that of water. It reacts with water and oxygen to produce various oxides and hydroxides. The thermodynamically stable oxides from complete oxidation by air are sodium peroxide and potassium superoxide both of which are powerful oxidants. The oxides are insoluble in the liquid metal. 
The most desirable product for the disposal process would be an insoluble solid. However, the alkali metals do not conveniently produce insoluble compounds. The best compound for radioactive waste management purposes that can be readily produced is the solid hydroxide. By reacting the NaK in a very concentrated caustic, the rate and violence of the reaction would be much slower since the liquid metal would have to compete with the caustic for water. In addition, the caustic will freeze at a reasonably high temperature. The high concentration of caustic product is required also to avoid stress corrosion cracking of construction materials. Reinoehl and Berry ${ }^{(1)}$ reported that caustic would cause stress corrosion cracking of carbon steel but only in that certain temperaturecomposition region shown in Figure 1 . This region could be avoided by operating at a high concentration of caustic.

The operating concentration chosen was $25 \underline{M}$ hydroxide ion. At this concentration, each mole of hydroxide crystallizes with one mole of water upon cooling. Its freezing point is around $100^{\circ} \mathrm{C}$, and the boiling point is about $200^{\circ} \mathrm{C}$. It is a white deliquescent solid which has a large therma1 contraction upon cooling from the boiling point to the freezing point. The chemical material balance flow sheet for the process is shown in Figure 2.

\section{NaK FEED SYSTEM}

The feed system was used to receive the NaK from the reactor storage vessels and deliver it to the NaK processing system at the proper pressure. All parts of the NaK feed system were constructed of Type 304 or 316 stainless steel which are suitable materials for containing the 
NaK. In order to minimize valve failure and leakage, only bellows sealed valves were used in the NaK feed system.

To avoid the problems inherent to pumps, all NaK transfers were accomplished by pressurizing the tank with nitrogen and withdrawing the NaK through a line that reached the bottom of the vessel. Transfers from the reactor system to the feed tanks were low pressure (15 psi) transfers, while for feeding to the processing system, higher pressures (40 psi) were required.

The two feed tanks have capacities of 328 and 68 gal, respectively. When feeding NaK from a tank it was pressurized to 40 psig to give the proper flow of NaK. When NaK was not being fed from the tank, it was filled by pressurizing the NaK drain tanks in EBR-I while venting the feed tank. To prevent loss of NaK in the event of an overflow, the two feed tanks were vented into a 78 gal NaK feed relief tank.

The NaK on leaving a feed tank passed through one of two filter screens to remove particles larger than the nozzle orifice. The redundant filter screens were installed in an inerted glove box so that they could be replaced quickly if they became plugged, without interrupting the processing of $\mathrm{NaK}$.

Two atomizing spray nozzles were used for injection of NaK. This type of nozzle was found to give the smoothest reaction of NaK with caustic in the pilot plant test. The nozzles were fabricated from Type 304 stainless steel (a nickel plated brass nozzle was used for the processing of the secondary system $\mathrm{NaK}$ ). REACTION VESSEL AND CAUSTIC COLLECTION SYSTEM

The reaction vessel was constructed of carbon steel. It was a tall 
vertical vessel, $15 \mathrm{ft} .2 \mathrm{in}$. from tangent line to tangent line with a 30 in. diameter. The vessel was anchored in the vertical position to three I-beams by turnbuckles.

The two NaK atomization nozzles were mounted in a flange $2 \mathrm{ft}$. above the bottom tangent line, and the water injection nozzle was mounted on a flange 10 in. above the bottom tangent line. Because of the extent of atomization of the $\mathrm{NaK}$, most of the reaction took place at the level that the NaK was sprayed into the vessel.

Caustic product was removed from the reaction vessel through a line leading from the bottom of the vessel. For a safe positive shut off, this drain line had both a remotely- and a manually-operated valve. The outlet of the line was tightly connected to the large hole in a standard 55-gal drum with a HEPA filter attached to the small hole. The depth of caustic product in the drum was indicated by a strip of welders dye check painted the length of the side of the drum. As the hot caustic filled the drum, the dye check burned off the barrel giving an unambiguous level indication as the drum filled. After the drum was full, the caustic drain line was removed and the large hole in the drum sealed with a screw cap. The HEPA filter in the small hole was removed and replaced with a molecular sieve-filled tube so that only dry air could be drawn into the drum while cooling. After the caustic had completely frozen, the molecular sieve tube was removed, and the drum sealed.

\section{INSTRUMENTATION}

Process control instrumentation was relatively simple. Level indication in the reaction vessel was achieved by weighing the vessel and contents with load cells. Pneumatic instruments for level measuring 
were not suitable because of the turbulence. Composition control of the reaction mixture utilized a measurement of the boiling point. An automatic control valve which opened on an increase in the boiling temperature, injected water which diluted the solution in the reaction vessel and reduced the boiling point.

$\mathrm{NaK}$ flow was measured by two electromagnetic flow meters. One flow meter was installed in the line from the drain tanks in the reactor system to the feed tanks. This flowmeter merely indicated that flow of NaK was taking place during the transfer of NaK from the storage tanks in EBR-I to the feed tanks. The other flowmeter was installed between the feed tanks and the injection nozzles. It gave an accurate indication of the volume of $\mathrm{NaK}$ injected. The output from this flowmeter was continuously recorded.

The NaK feed tanks were equipped with electrical level sensing rods. An electrically insulated rod formed a complete circuit when NaK was in contact with it and the walls of the tank. The rods were set at three levels in the tank. The lowest level was indicative that the tank was essentially empty. The second rod was placed to indicate that the tank was filled. The topmost rod served as a redundant fill indicator and warned of impending overflow of the tank into the Nak feed relief tank. All three indicators were fitted with both visual and audible warning devices to indicate when the NaK had reached their control point. Thermocouples were installed at various points in the system to give an indication of the operation of the system. In addition to the several locations in the reactor system, temperature measurements were made in the off-gas system, and on the caustic drain line. 
The off-gas system was directly monitored by condensing a side stream from the main off-gas line down stream from the HEPA filters. The $\mathrm{pH}$ of this condensate was continuously recorded in order to detect sudden changes in the amount of caustic passing the HEPA filters which would signal a breach in the filters. In addition, the gas stream out of this condenser was passed through a constant air monitor (CAM), a hydrogen monitor, and an oxygen monitor.

Al1 inert gas and water lines were equipped with flowmeters and pressure gauges. The flows were balanced to provide sufficient pressure and flow to keep the lines open and the system flushed with nitrogen. PROCESS SUPPORT SYSTEMS

There were several process support systems required for the NaK process plant. The inert gas system was a nitrogen system. The nonreactive nitrogen gas was used to sweep the oxygen from the reaction vessel and the off-gas train as well as to provide an inert atomizing gas at the nozzles and to provide the force to move the NaK. Nitrogen was supplied from a large liquid nitrogen reservoir equipped with a vaporizer. In addition, there was a back-up bottled gas system for an emergency supply.

Water was supplied to the system at two points. The water injection nozzle was located near the bottom of the reaction vessel. A demister installed at the top of the vessel was sprayed with a small stream of water to wash the caustic that was removed by the demister back into the process.

To minimize the amount of chloride in the feed water, which is known to cause or contribute to stress cracking of carbon steel, demineralized 
water was trucked from the Test Reactor Area and stored in a large tank beside the processing system. This water was then pumped from the reservoir as required for the process.

The off-gas train consisted of the demister installed in the top of the reaction vessel, a scrubber to remove most of the entrained caustic, a knockout vessel to remove the entrained liquid from the scrubber, redundant roughing filter/HEPA filter combinations, followed by a flashback arrester and the propane torch at the top of the stack. Caustic solution from the scrubber and from the condensation which occurred between the filters and the top of the stack was recycled into the reaction vessel. After the initial startup of the scrubber unit, the liquid level in the scrubber was maintained by condensation of water from water vapor in the off-gas stream. Excess liquid was recycled to the reaction vessel. The filter boxes were heated to a temperature above the saturation temperature of the off-gas stream to keep them from being breached as the result of condensation increasing the pressure drop across them. The flashback arrester was installed to prevent an explosive mixture of hydrogen and air from causing any damage to the processing system. In order to insure ignition of the hydrogen, a propane torch was installed on top of the stack.

To provide for the possibility of overfilling the feed tanks an overflow tank was provided on the vent line from the feed tanks. When the feed tanks were in use, the valves in the line to the overflow tank and to the EBR-I systems were closed and the feed tank pressurized to $40 \mathrm{psi}$. The atomizing gas pressure was also $40 \mathrm{psi}$. Figure 4 shows the NaK processing unit in operation. 


\section{PROCESS STARTUP}

Because of the possibility that particles of oxide would plug lines and the nozzles, precautions were taken to insure that the lines and vessels were dry and had been swept clear of oxygen. This was accomplished by heating and purging all lines with nitrogen for a day to remove all traces of water. While the purging was taking place, the start-up solution of $14 \underline{M}$ sodium hydroxide was introduced into the vessel through the caustic drain line. Water was added to the scrubber such that any entrained caustic would be removed before the off-gas reached the filters.

OPERATION OF THE NaK DISPOSAL UNIT

A number of conditions had to be met before the NaK could begin flowing to the reaction vessel. These included the oxygen in the offgas system being below the lower explosive limit, temperature on the filters exceeding the maximum expected off-gas temperature, flare torch operating, CAM and $\mathrm{pH}$ meter operating, load cells, flowmeters; and their readout devices operating, tanks filled, and purge and atomizing gas flows at the proper level and pressure. At that point the NaK flow could be started.

No product was removed until the caustic weight in the reaction vessel reached 5000 pounds and the reaction temperature reached $\sim 200^{\circ} \mathrm{C}$. The Nak flow was brought up slowly to the operating rate. It took approximately 24 hours to build the hydroxide level up to the operating level.

During operation, the sound of the reaction was about like an idling internal combustion engine. Some vibration was noted as the result of both the addition of water and of the NaK. The vibration increased as the atomization air flow decreased due to plugging of the nozzle. 
During the entire processing period for the primary system $\mathrm{NaK}$, the $\mathrm{pH}$ of the condensate never exceeded 12 and was rarely above 11.5. Samples of the off-gas and the condensate were periodically taken for chemical analysis. These samples and the $\mathrm{pH}$ readings formed the basis for the release estimates from the off-gas stack of $1.3 \times 10^{-2} \mu \mathrm{Ci} / \mathrm{m}^{3}$ for ${ }^{137} \mathrm{Cs}$ and $1.4 \times 10^{-5} \mu \mathrm{Ci} / \mathrm{m}^{3}$ for ${ }^{90} \mathrm{Sr}$. The stack was located approximately $100 \mathrm{ft}$. from the processing plant which kept the airborne contamination at very low levels in the working areas.

The secondary NaK was used for the feed to the NaK processing plant for an operational check out. Proper values for many of the operating parameters were identified at that time as well as the necessity to install the scrubber/knockout drum system ahead of the HEPA filters. Approximately one hundred gallons of caustic from the cold operation was used as the startup solution for the hot run. Approximately 18 drums of caustic were produced during the processing of the secondary $\mathrm{NaK}$.

The processing of the primary NaK resulted in filling 93 drums of caustic. Some of the process performance statistics are shown in Table 2 . TABLE 2

NaK PROCESS PERFORMANCE STATISTICS

Estimated time for reaction of primary $\mathrm{NaK}$ based

on proposed NaK processing rate 138.8 hours

Actual Elapsed Time 140.9 hours

Reaction Produced:

25 million Kcal of heat equivalent to: 900 gallons gasoline 6100 cubic meters of hydrogen gas equivalent to: 980 standard cylinders 
Average radionuclide releases from off-gas stack:

$137 \mathrm{Cs}: \quad 1.3 \times 10^{-2} \mu \mathrm{Ci} / \mathrm{m}^{3}$

${ }^{90} \mathrm{Sr}: \quad 1.4 \times 10^{-5} \mu \mathrm{Ci} / \mathrm{m}^{3}$

55 gallon barrels of solid caustic produced:

Secondary:

18 barrels

Primary:

93 barrels

CONCENTRATION OF REACTOR SYSTEM RINSINGS

After all the NaK had reacted and the caustic drained from the reaction vessel, one of the original banks of heaters was reinstalled and other external wrap-around heaters were placed on the vessel. It was then used as an evaporator to concentrate the aqueous rinsings from the EBR-I primary coolant system. The rinsings from the EBR-I primary system were accumulated in the old NaK drain/storage tanks at the lowest point in the reactor system. The dilute caustic produced by the reaction of the rinse water with residual $\mathrm{NaK}$ in the system was then transferred into the evaporator vessel along the same route and in the same manner that the NaK was during the NaK processing phase.

In order to effectively evaporate the rinsings, the system was modified by removing the scrubber/knockout drum system and by decreasing the length of piping to the stack such that little condensation would occur in the off-gas line. The flare and the flame arrester had been previously removed for other work in the decommissioning operation.

After all the rinsings had been evaporated, the heaters were turned off and the vessel contents allowed to solidify. All lines to the vessel were cut and capped and the vessel and its contents taken to the 
Radioactive Waste Management Complex. The decommissioning of the processing plant will be discussed in somewhat more detail in the paper by E. W. Kendall presented at this conference.

The success of this operation, the present existence of large quantities of contaminated liquid metal wastes (such as from the Hallam and Fermi reactors and the Sodium Reactor Experiment as well as smaller quantities from reactor experiment loops), and the anticipated large quantities to be generated as the Liquid Metal Fast Breeder Program expands, prompted Allied Chemical to suggest two techniques to deal with these wastes. One proposal for construction of a mobile processing plant was based on the design of the plant described in this paper. It would have the capabilities of treating the liquid metal present at the site and concentrating reactor system rinsings and other aqueous wastes generated during the decontamination/decommissioning of a radiochemically contaminated 1iquid metal facility.

This type of operation is suitable if the quantities of liquid metal are small and the radionuclide contaminants are short-lived. However, because sodium containing wastes do not lend themselves to longterm storage, a second proposal was made to evaluate the technology and to construct a facility which would allow recycle of waste liquid metal back to the liquid metal cooled reactors. The product would be of sufficient purity to be suitable for use in a reactor system with a residual radioactivity due to traces of ${ }^{134} \mathrm{Cs},{ }^{137} \mathrm{Cs}$, and ${ }^{22} \mathrm{Na}$. Implementation of this program would prevent the accumulation of large volumes of liquid metal wastes and the consequent problems and expenses associated with waste management of large volumes of liquid metal or alkali metal based 
aqueous waste as well as assuring a continuing supply of reactor grade liquid metal.

SUMMARY

Numerous constraints on the design, timing, safety, and environmental effects of processing a large volume of radionuclide contaminated liquid metal from the EBR-I reactor were faced and successfully dealt with in converting the 4400 gal of primary NaK and 1100 gal of secondary NaK to a solid caustic. The operation proceeded as planned with minimal environmental effects. 


\section{REFERENCES}

(1) Reinoehl, J. E. and Berry, W. E., Natural Conditions for Caustic Cracking of a Mild Stee1. Corrosion 28, 151-160 (1972). 


\section{FIGURES}

1. Caustic Cracking Zone for Carbon Steel Data from Reinoeh1 and Berry( 1$)$.

2. Material Balance Flowsheet for Processing the EBR-I NaK.

3. Equipment Flowsheet for the EBR-I NaK Conversion Process.

4. Removing a Drum of Caustic Product from the NaK Processing Unit. 


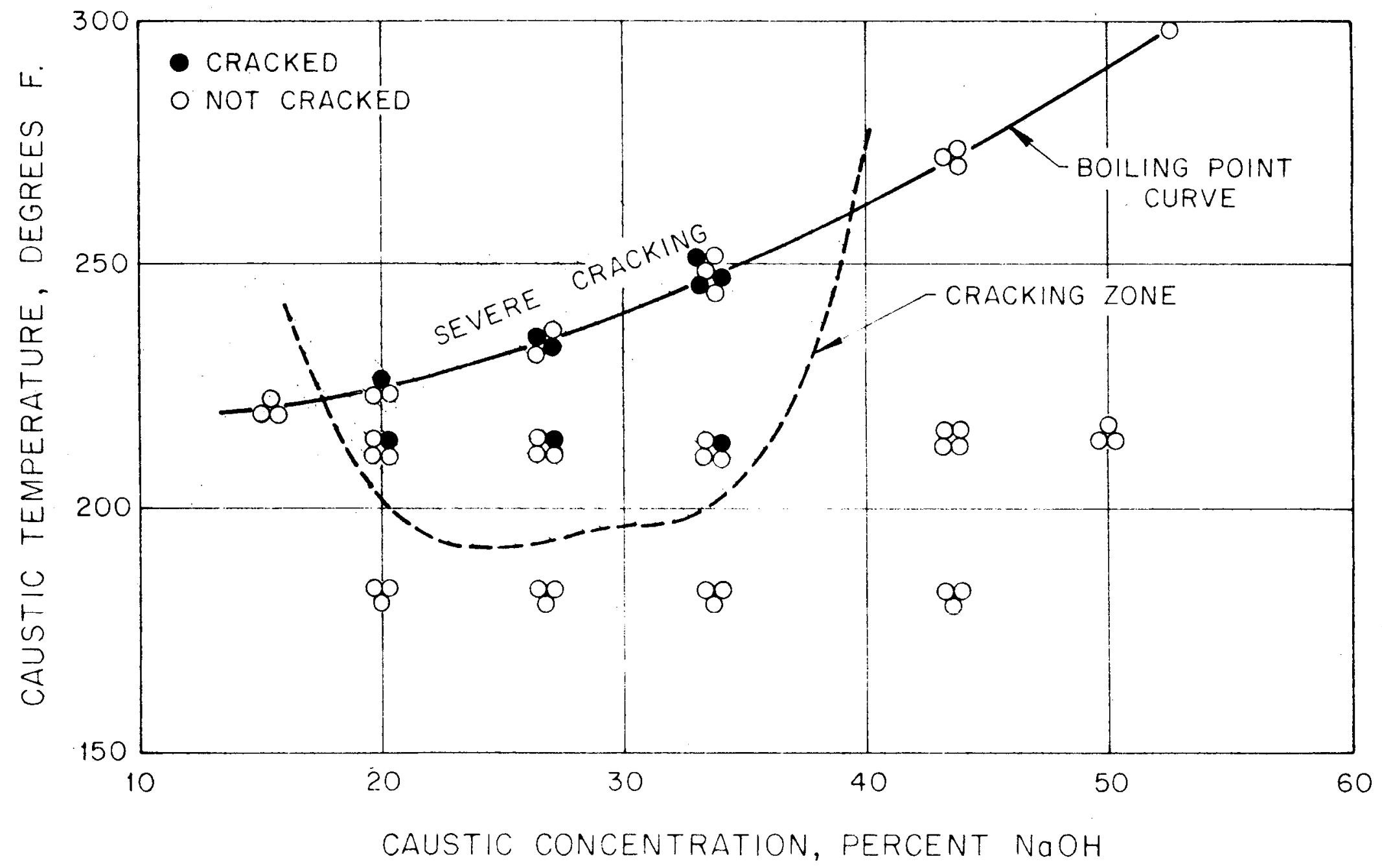

Figure 1. Caustic Cracking Zone for Carbon Steel Data from Reinoeh1 and Berry(1). 


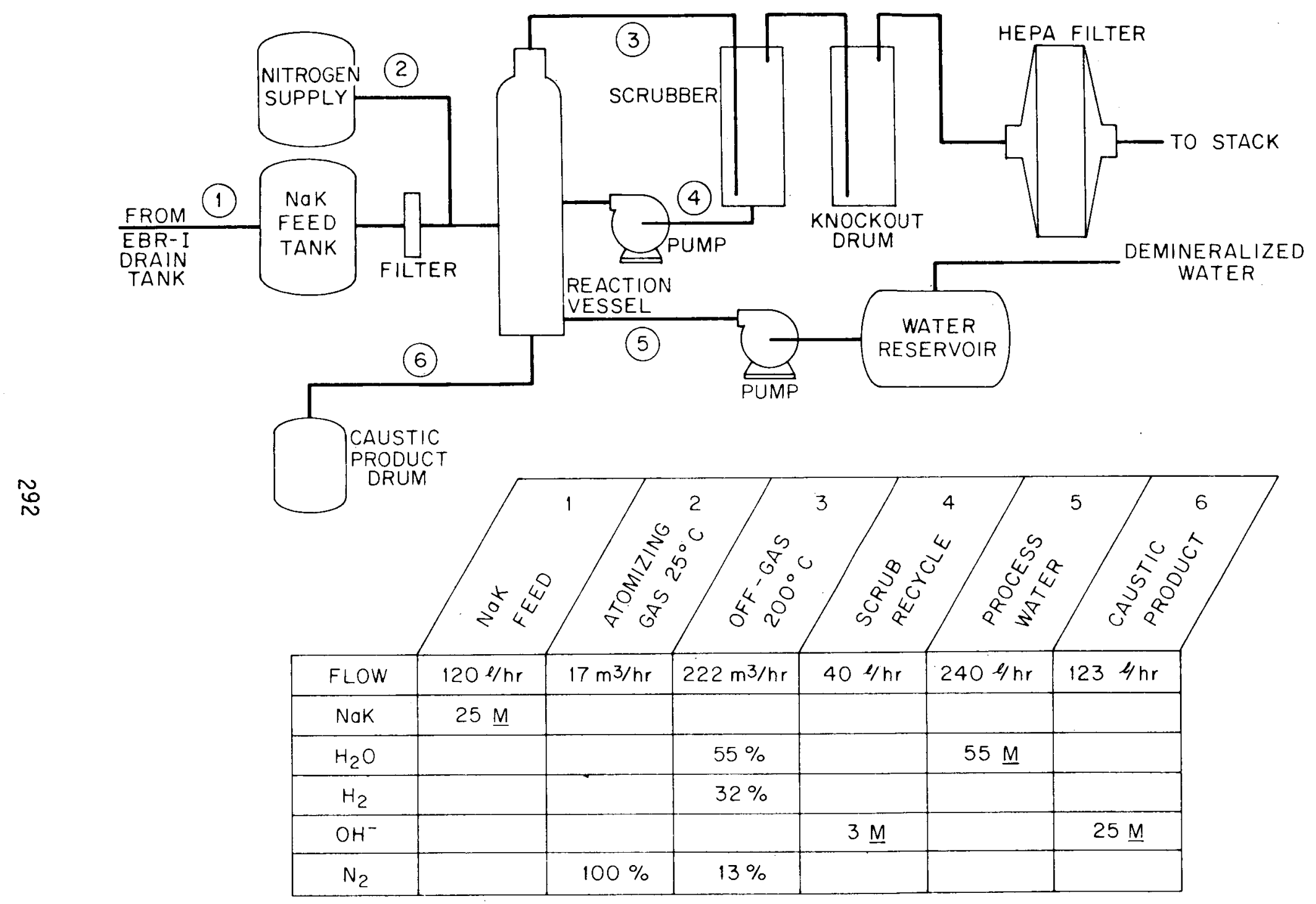

Figure 2. Material Balance Flowsheet for Processing the EBR-I NaK. 


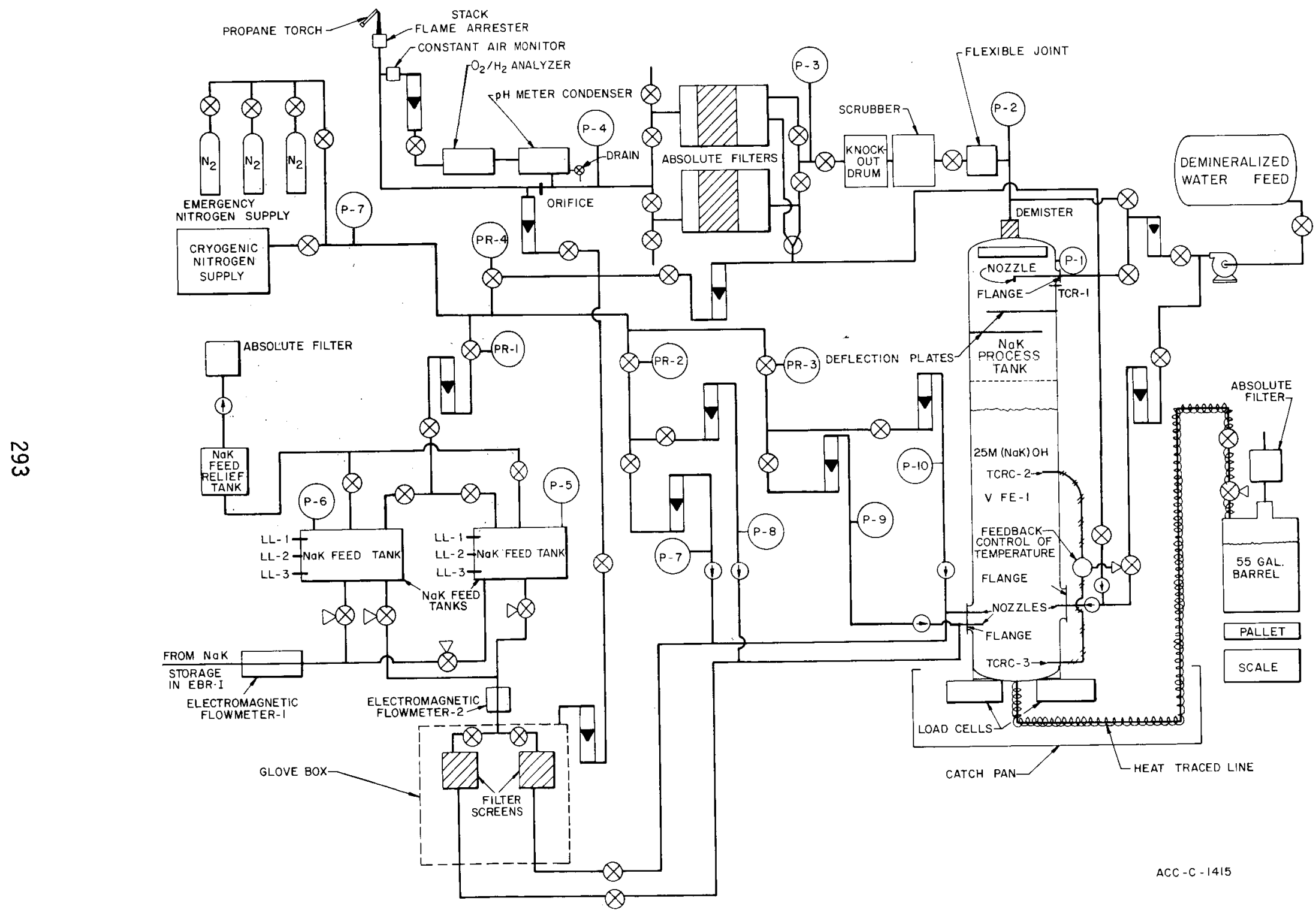

Figure 3. Equipment flowsheet for the EBR-I NaK Conversion Process. 


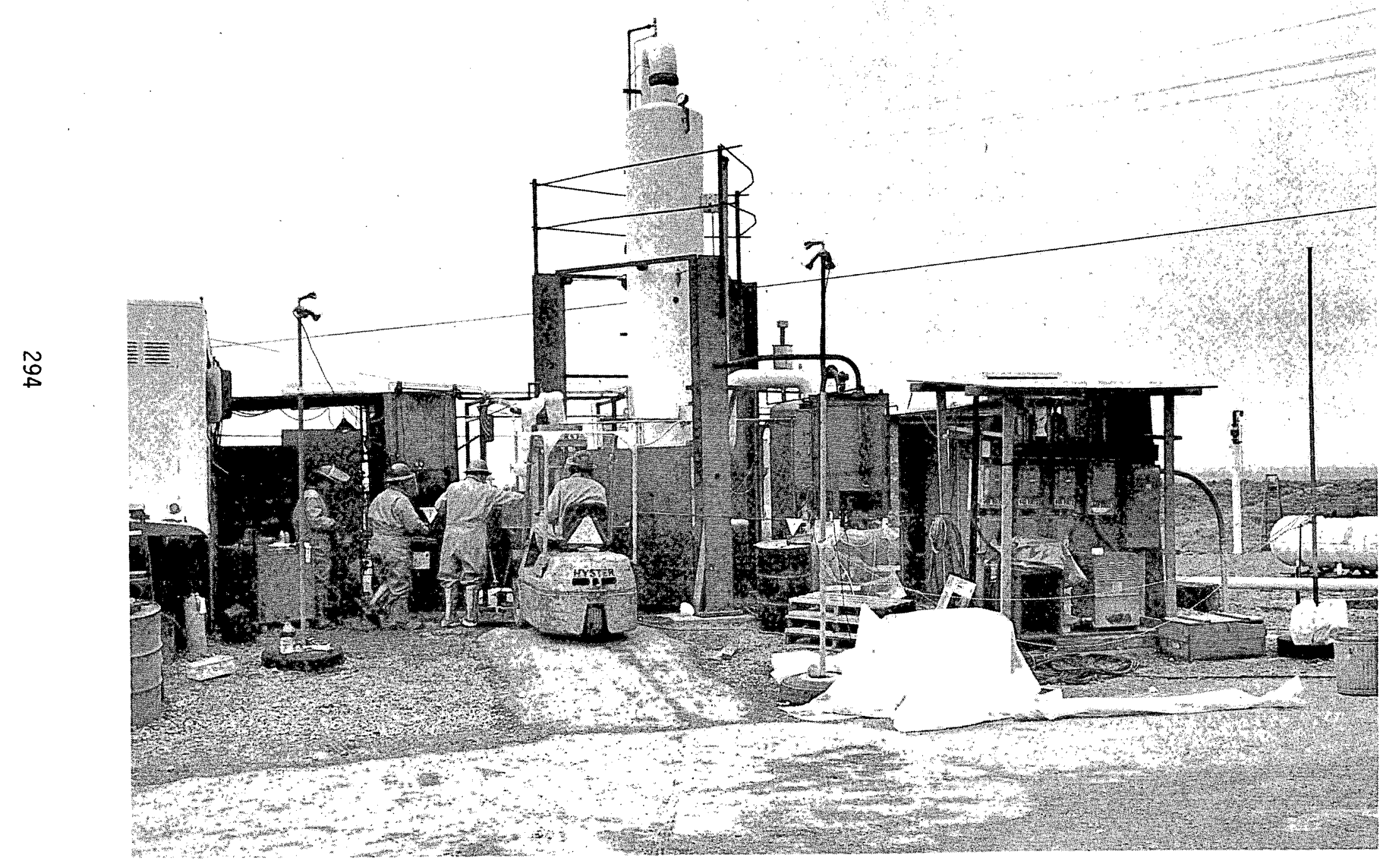

Figure 4. Removing a drum of caustic product from the NaK Processing Unit. 
$0^{2^{679}}$

\title{
DISMANTLING AN ALPHA-CONTAMINATED FACILITY
}

\author{
R. D. Caldwell \\ R. M. Harper
}

E. I. du Pont Co., Savannah River Plant, Aiken, South Carolina 29801

\begin{abstract}
The difficult task of removing large pieces of highly contaminated equipment from an obsolete plutonium-239 facility was completed in a seven-month operation that included structural alteration of the process building. Detailed job planning, job execution and contamination control were major factors in accomplishing the task.
\end{abstract}

\section{INTRODUCTION}

A decision was made to convert an unused plutonium-239 recovery room in a separations building to other use. The room (Figs. 1 and 6), midway between the third and fourth levels of the four-story structure, is approximately $85 \mathrm{ft}$ long, $20 \mathrm{ft}$ wide, and $18 \mathrm{ft}$ high with a partial balcony on one side. It contained:

- one large wet chemistry cabinet enclosing 19 vessels,

- one smaller wet chemistry cabinet enclosing several small vessels,

- five sections of dry chemical cabinets, and

- associated piping, electrical conduit, air ducts, etc. for each cabinet and vessel.

On the balcony were several cold feed tanks and one wet chemistry cabinet containing two process vessels.

Removal was complicated by internal transferable contamination levels up to $10^{8} \mathrm{~d} / \mathrm{m}$ alpha per $\mathrm{ft}^{2}$ and the absence of a route between the room and a loading dock two levels below that could accommodate the large pieces to be moved.

\section{SPECIAL PREPARATIONS}

A series of meetings of production, health physics, and construction personnel produced a four-phase job plan:

Phase I - Remove nonprocess piping and other equipment which is virtually uncontaminated

Phase II - Remove intermediately contaminated equipment $\left(2\right.$ to $3 \times 10^{7} \mathrm{~d} / \mathrm{m}$ alpha per $\mathrm{ft}^{2}$ ) (Transferable contamination determined by paper towel smear)

Phase III - Remove highly contaminated equipment (above $3 \times 10^{7} \mathrm{~d} / \mathrm{m}$ alpha per $\mathrm{ft}^{2}$ ) (Determined as above)

Phase IV - Remove equipment from the balcony.

Equipment contamination required that breathing air-supplied respiratory protection be worn on all but a few jobs. The following additional protective clothing was specified with air-supplied hoods and plastic suits:

With hoods

- 2 pair coveralls

- 2 pair gloves (rubber)

- 3 pair shoe covers (cloth boots, plastic shoe covers, and rubber overshoes as outer pair) 
With plastic suits

- Coveralls

- Gloves

- 3 pair shoe covers (cloth boots, plastic shoe covers under suit, and rubber overshoes as outer pair)

To establish an equipment removal route, an 8 -foot-square hole (Fig. 2) was cut in the floor of the office at the south end of the room and the wall between the office and room was removed. On the level below, the corridor wall was modified to give adequate space under the opening. Walls between the corridor and other affected rooms were removed.

As expected, the additional airflow upward through the floor opening into the old recovery room upset the air balance, pressurizing the room. To solve this problem, the regular air supply to the room was cut off and all available exhaust utilized. A large air lock with doors adequate to permit passage of equipment was constructed in an unused area on the level below to control airflow to the work area. Due to the size of the building and other variables, air control problems could not be accurately forecast. Air balance remained critical throughout the job and the least deviation from control instructions would cause an air reversal. All high efficiency particulate air (HEPA) filters in the exhaust system were replaced prior to start of work.

\section{CONTAMINATION CONTROL}

To prevent spread of contamination, the bag method was used on all duct and process line breaks except those made inside cabinets. (The bag method is the separation of lines, ducts, etc. inside a plastic bag or sleeve that completely encloses the area of the line break then squeezing the bag together between the two separated pieces, taping and cutting at taped area, thereby leaving each end of the break fully covered with plastic.)

The following additional precautions were taken in packaging equipment for delivery to the burial ground:

- Plywood covers were placed over all ventilation duct openings.

- Process pipe openings were sealed with rubber plugs or blank flanges and gaskets.

- Vessel openings were covered with blank flanges and gaskets.

- All contaminated equipment was wrapped in plastic until transferable surface contamination was less than $5000 \mathrm{~d} / \mathrm{m}$ alpha per $\mathrm{ft}^{2}$, then it was removed from the room and placed in special plastic-lined, reinforced 3/4-in. plywood boxes (Fig. 3) to withstand burial in concrete.

- Transferable contamination levels on exterior surfaces of all boxes were less than $500 \mathrm{~d} / \mathrm{m}$ alpha per $\mathrm{ft}^{2}$ before they were shipped to the burial ground.

- Relatively clean equipment with external transferable and/or fixed contamination of less than $500 \mathrm{~d} / \mathrm{m}$ alpha per $\mathrm{ft}^{2}$ was placed in skip pans on the third level. The pans were enclosed with plastic prior to shipment to the burial ground.

\section{Manpower Requirements}

Initially, two Health Physics inspectors were assigned to cover work in the area. As work progressed, a third inspector was required - two inside covering process line breaks and one in the air lock at the south end of the room to check personnel as they exited. A Health Physics supervisor was present at the job site approximately $75 \%$ of the time. 


\section{REMOVAL OF EQUIPMENT}

For several reasons, the concentrated feed cabinet on the west side of the room was first to be removed. This cabinet was the largest and heaviest (approx $3500 \mathrm{lb}$ ) single piece of equipment in the room and served as an excellent test of the method and equipment (triple chain hoist) used to lower items through the 8-foot-square opening to the air lock below. The cabinet was 16 feet long, 5 feet high, and 2 feet wide with top and ends fabricated from laminated lead and iron. The space occupied by this cabinet was needed to provide a clear passage for other equipment to be removed.

After the following preparations the cabinet was moved without incident:

- Cabinet was stripped of all external piping and ductwork.

- Front panel frames were tack-welded to cabinet.

- An angle iron frame with lifting bails was welded around entire cabinet.

- Front panels and duct stub openings were covered with plywood which was strapped to the cabinet with metal bands.

- Cabinet was wrapped in several layers of plastic and tape.

Next to go were the dry chemistry cabinets. After removal of all external piping and ductwork, the cabinets were separated in to three sections using the bag method. Interiors had been previously swept as clean as possible. All waste had been removed and heavy equipment in cabinets had been secured in place; then all interior surfaces were sprayed with "Krylon" (a clear plastic) to fix any loose contamination. All openings (glove ports, bag ports, etc.) were covered with $3 / 4$-inch plywood and banded. The cabinets were covered with plastic and tape before they were lowered to the air lock on the level below. All equipment in the air lock was resurveyed by Health Physics before it was moved to the loading dock and placed on trucks for shipment to the burial ground.

The large wet chemistry cabinet, containing 19 vessels and associated piping, required extensive preparation. It was 60 feet long, 5 feet wide, and 7 feet high with three high hats approximately 6-feet high. A large plastic containment hut with air lock was erected around the cabinet (Figs. 4 \& 5). The sumps were cleaned and the piping removed by removing cabinet panels (maximum of three at one time) and physically entering the cabinet. All interior surfaces were spray-painted with a water base latex paint using a low pressure sprayer to fix the contamination. Water-base paint was selected because of the large quantity needed and because of the explosion potential in spray propellants. Panels were replaced with plastic taped to the cabinet frame. This was necessary to control the airflow. Cabinet framework and ends were then cut away, leaving the vessels in place over the sump pans. Airflow had to be continuously adjusted during this work. The vessels were rigged on chainfalls suspended from the ceiling and extended down through the roof of the hut to the cabinet area. The vessels were disconnected from all bracings and mounts and moved from the sump area. While still suspended on the chainfalls, vessels were wrapped in plastic and taped until transferable contamination on the outer covering measured less than $5000 \mathrm{~d} / \mathrm{m}$ alpha per $\mathrm{ft}^{2}$. The vessels were placed on a cart, removed from the hut through the air lock, and lowered to special made-to-order boxes in the air lock below. Actual removal of the large wet chemistry cabinet framework and the vessels required only eleven working days other than preparation time. The concrete around the edges of the sump pans was removed with jackhammers. The pans were cut into five sections, wrapped, and removed following the same procedures used for the vessels. At one stage of this job, airflow into the hut was practically lost. Maximum contamination spread to the hut surfaces during the work was $3.5 \times 10^{6} \mathrm{~d} / \mathrm{m}$ alpha per $\mathrm{ft}^{2}$. The containment hut was cleaned and removed.

The small wet chemistry cabinet on the balcony was cleaned and painted in the same manner as the large wet chemistry cabinets. Panels, framework, piping, and vessels were removed following the same procedures outlined for the large cabinets except that no containment hut was employed.

The remaining cold piping, cold feed vessels, ductwork, and electrical conduit was removed. This 
essentially completed the work except for cleanup and refinishing of the room (Fig. 6).

A survey of the room before final cleanup established these transferable contamination levels:

- walls, less than 1000 to $10,000 \mathrm{~d} / \mathrm{m}$ alpha per $\mathrm{ft}^{2}$

- floor, 2000 to $3000 \mathrm{~d} / \mathrm{m}$ alpha per $\mathrm{ft}^{2}$

- overhead piping and cuts left in place, 1000 to $50,000 \mathrm{~d} / \mathrm{m}$ alpha per $\mathrm{ft}^{2}$

- light fixtures, $2 \times 10^{5} \mathrm{~d} / \mathrm{m}$ alpha per $\mathrm{ft}^{2}$

The room was cleaned until transferable contamination was less than $1000 \mathrm{~d} / \mathrm{m}$. Floor tile was taken up and fixed contamination removed by chipping. The floor was regrouted and the room repainted.

\section{SURFACE AND AIRBORNE ALPHA CONTAMINATION EXPERIENCE}

Transferable contamination on the room floor did not exceed $40,000 \mathrm{~d} / \mathrm{m}$ alpha per $\mathrm{ft}^{2}$ and was generally less than $5000 \mathrm{~d} / \mathrm{m}$ alpha per $\mathrm{ft}^{2}$. Air-supplied respiratory protection was worn at all times in the room so the contamination level was not considered serious but was kept as low as possible. Airborne alpha contamination ranged from $5 \times 10^{12} \mu \mathrm{Ci} / \mathrm{cm}^{3}$ to $50 \times 1 \sigma^{-12} \mu \mathrm{Ci} / \mathrm{cm}^{3}$ except for two incidents: air activity reached approximately $1500 \times 10^{-12} \mu \mathrm{Ci} / \mathrm{cm}^{3}$ in one and greater than $2000 \times 1 \sigma^{12} \mu \mathrm{Ci} / \mathrm{cm}^{3}$ in the other. (RCG $=2 \times 1 \sigma^{12} \mu \mathrm{Ci} \mathrm{Pu} / \mathrm{cm}^{3}$ air)

The one instance in which activity exceeded $2000 \times 10^{-12} \mu \mathrm{Ci}$ occurred while the sump pans were being removed inside the containment hut. Use of a jackhammer to remove concre te produced considerable airborne concrete dust. The sou theast corner of the old dissolver sump had been jacked or pried from its supports and was being cut along the seam with a power saw equipped with an abrasive blade. Airflow into the hut was low but thought to be adequate. There were eight men in the hut and one man in the air lock. When the high level was revealed by air samples, work in the hut was halted. Plastic suits were removed at the entrance to the hut air lock and a breathing air hood was then worn from the hut to the room exit. All personnel were asked to submit nasal smears because of the dust on the plastic suits. Three of the nine persons showed positive alpha nasal contamination levels and were administered a chelating agent and a cathartic by Medical personnel. All nine were counted on the whole body counter and submitted bioassay samples. The persons having nasal contamination had confirmed plutonium assimilations less than 5\% MPBB. No skin contamination was detected.

There were no indications that nasal contamination occurred while plastic suits were being worn. Apparently contamination occurred while suits were being removed. A survey of the inner surfaces of the suits (after the fact) showed no contamination but outer surfaces were contaminated to $10^{5} \mathrm{~d} / \mathrm{m}$ transferable alpha per $\mathrm{ft}^{2}$ and were heavily covered with concrete dust. Had suits been wiped down with a wet towel before removal, contamination would probably have been avoided.

\section{SUMMARY}

In the seven months required to complete the job, 415 six-mil and 60 twelve-mil air-supplied plastic suits were used along with approximately 2900 air-supplied hoods. The 12 -mil suits were worn for entry of the wet chemistry cabinets. Two thousand man-hours of Health Physics inspector coverage and 700 man-hours of Health Physics supervisory time were required. Excellent radiation protection in all phases of the job resulted from extensive preplanning and the continuing cooperation of Health Physics, Production, and Construction personnel. 
Figure 1. Plutonium-239 Recovery Room at Beginning of Equipment Removal Project. West wall at left.

Figure 2. $8 \times 8$-ft Hole in Floor of Adjoining Office. Opening ras made to provide an evacuation route throurn the level below.

Figure 3. Specially Constructed Burial Boxes. Sides of 3/4-inch plywood reinforced to withstand burial in concrete.

Figure 4. Exterior of Plastic Containment Hut with Airlock Portion in Foreground

Figure 5. Interior of Plastic Containment Hut. Wrapped and partially removed vessel in background.

Figure 6. Plutonium-239 Recovery Room at Conclusion of Equipment Removal Project 


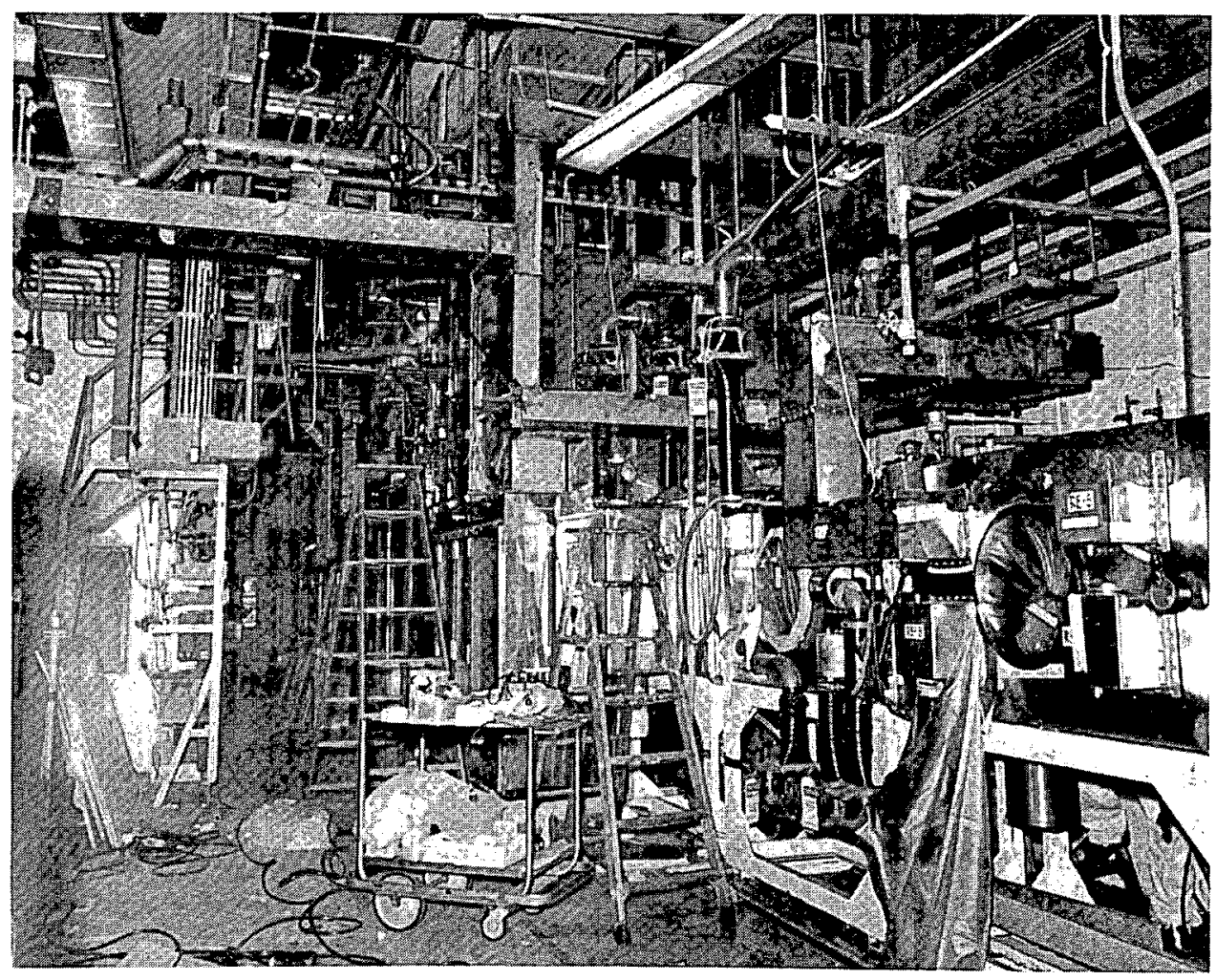

Fig. 1. Plutonium-239 recovery room of beginning of equipment removal project. West wall at left.

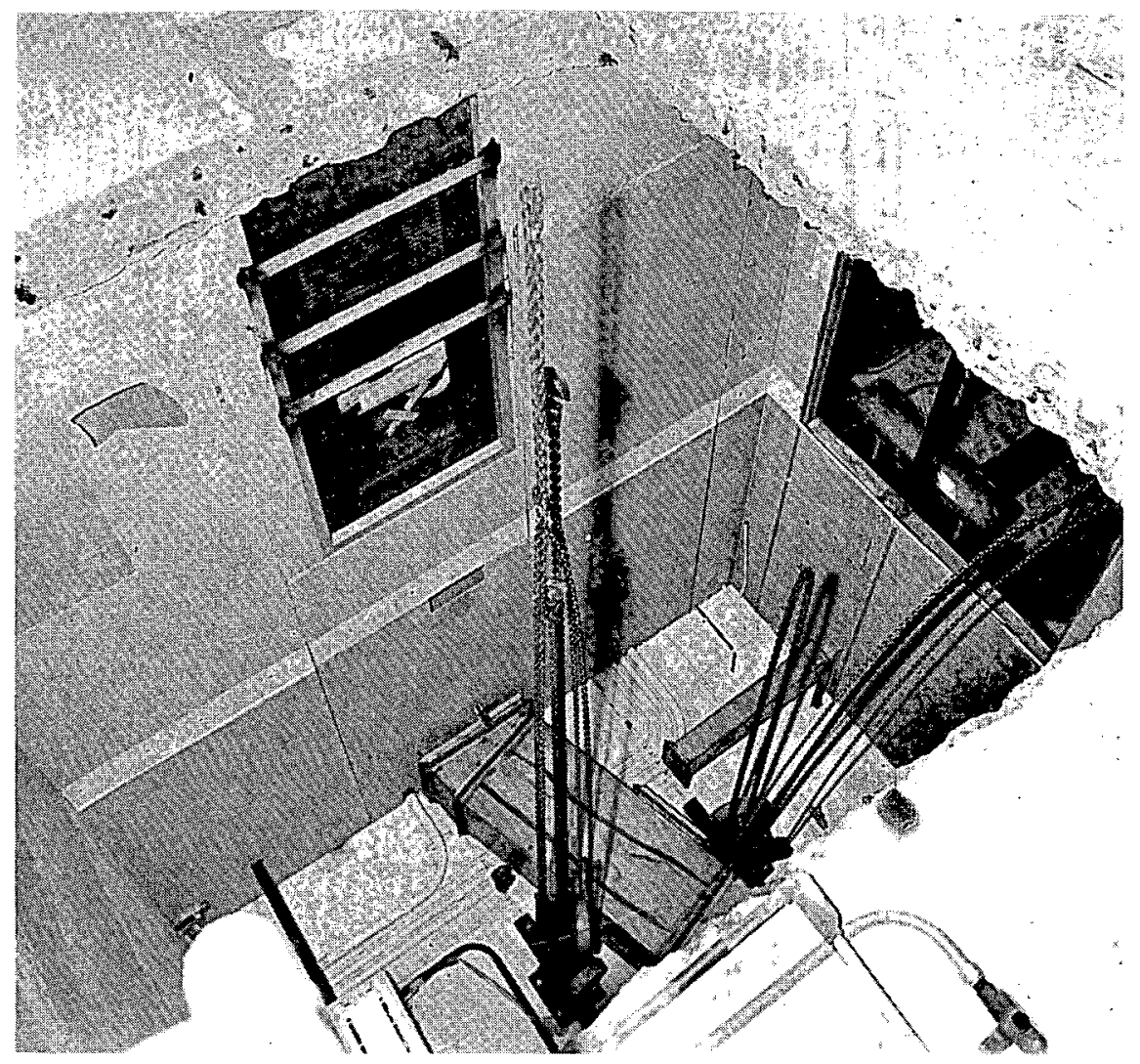

Fig. 2. $8 \times 8 . \mathrm{ft}$ hole in floor of adjoining office. Opening was mode to provide an evacuation route through the level below. 


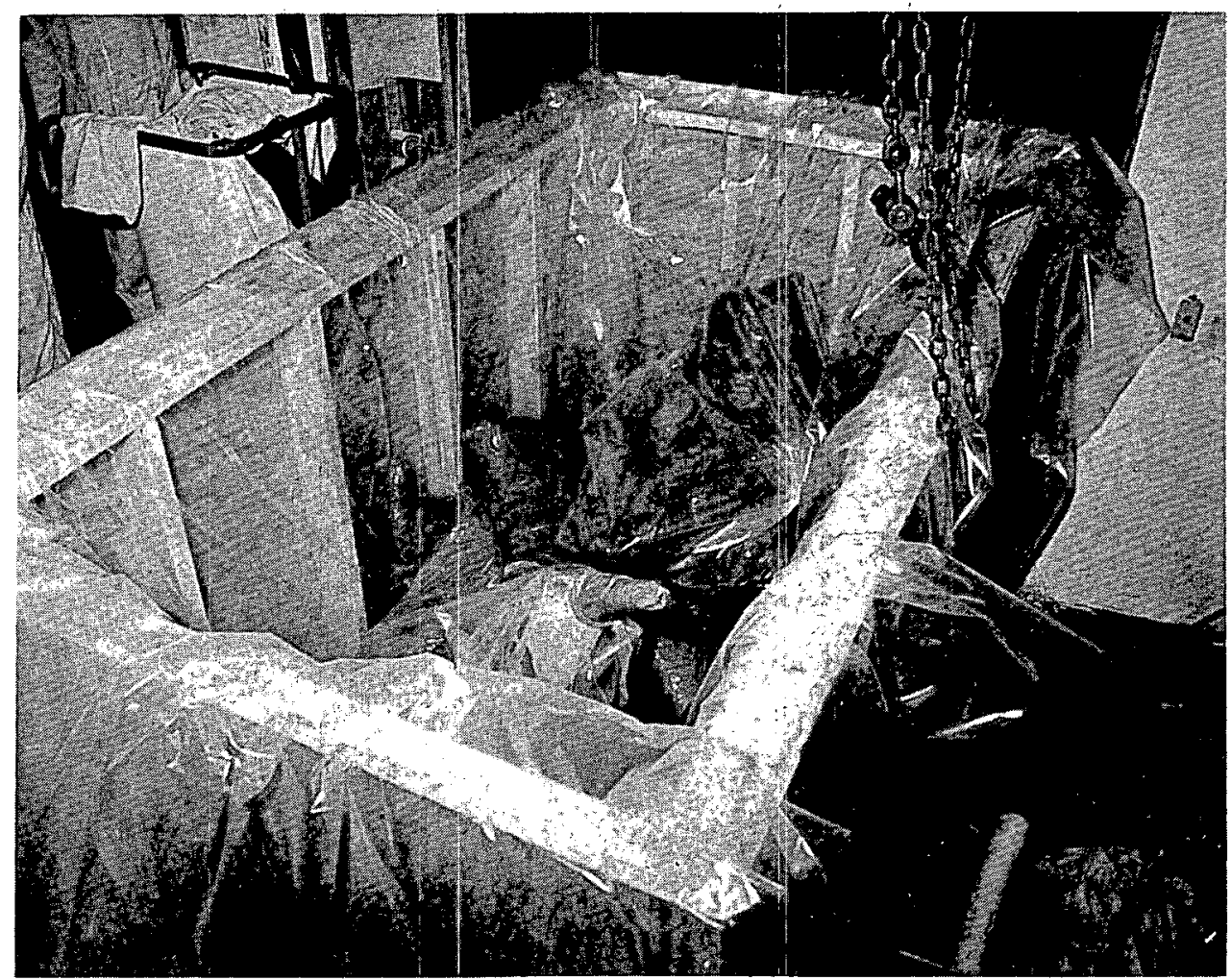

Fig. 3. Specially constructed burial boxes. Sides of $3 / 4$-inch plywood reinforced to withstand burial in concrete.

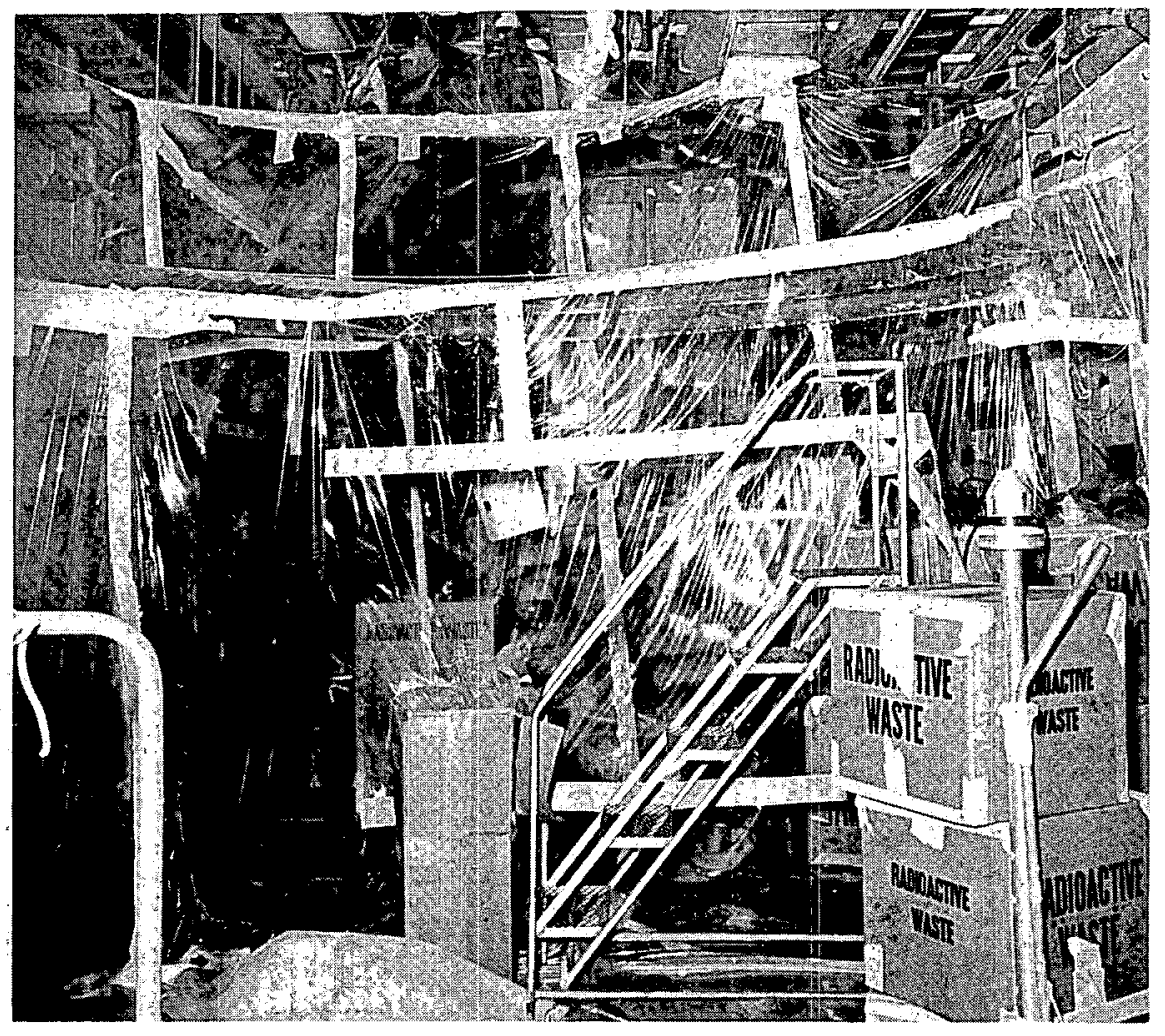

Fig. 4. Exterior of plastic containment hut with airlock portion in foreground. 


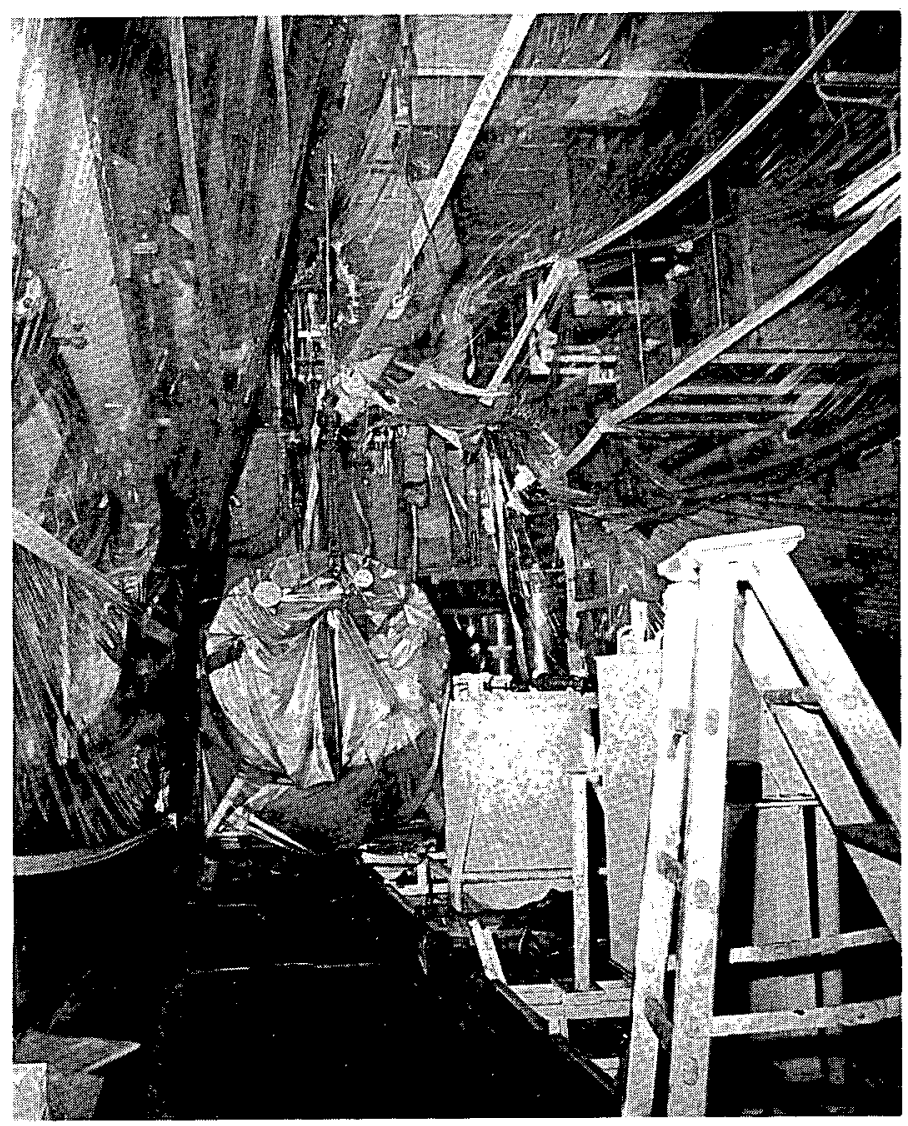

Fig. 5. Interior of plastic containment hut. Wrapped and partially removed vessel in background.

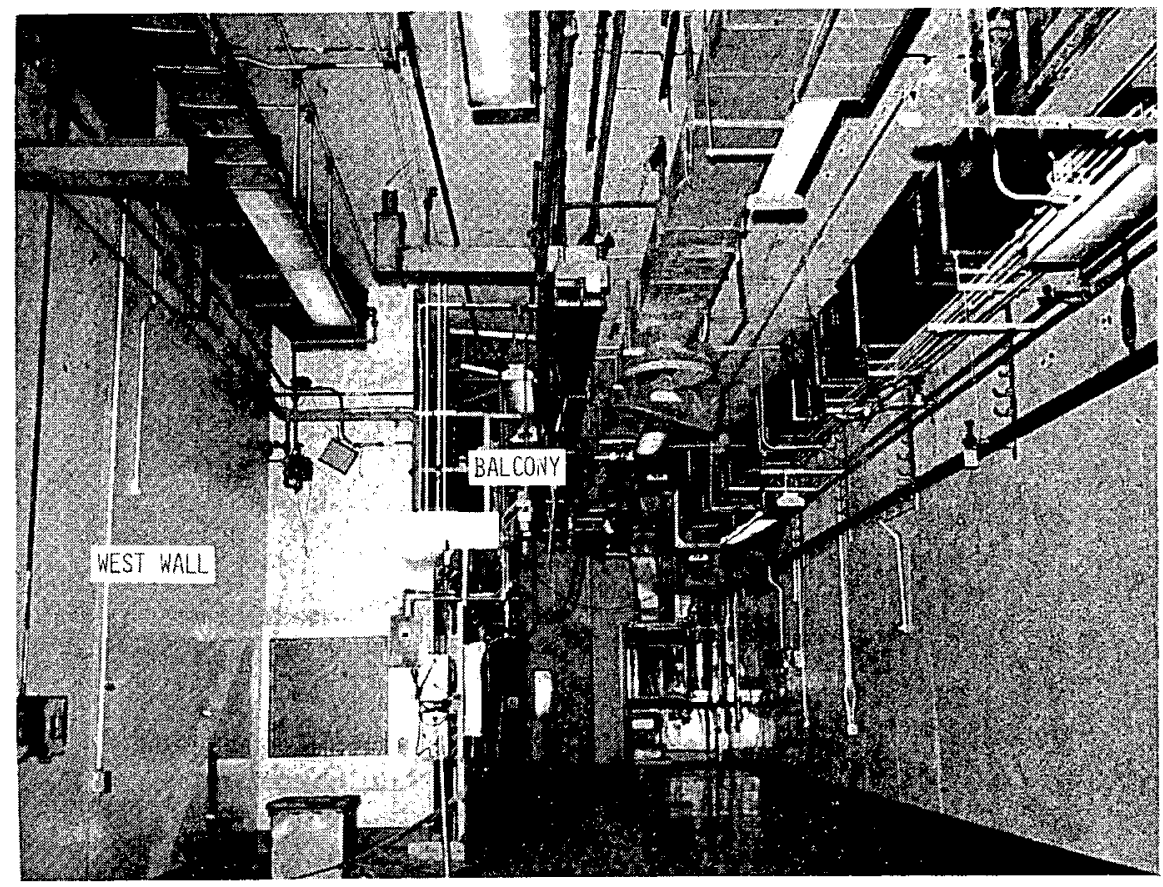

Fig. 6. Plutonium-239 recovery room at conclusion of equipment removal project. 


\title{
$0^{26^{18^{8}}}$ \\ DEMOLITION OF BUILDING 12, AN OLD PLUTONIUM FILTER FACILITY
}

by

\author{
E. L. Christensen, R. Garde, and A. M. Valentine
}

\begin{abstract}
This report discusses the decommissioning and disposal of a plutoniumcontaminated ai $x$ filter facility that provided ventilation for the main plutonfum processing plant at Los Alamos from 1945 until 1973. The health physics, waste management, and environmental aspects of the demolition are also discussed.
\end{abstract}

\section{HISTORY}

A plutonium processing facility was built in Los Alamos in 1944, on what is now known as DP Mesa. The urgency at that time dictated that the facility be built as rapidly as possible, incorporating all the best construction ideas but using only those materials that were readily avallable.

The process buildings were constructed with sheet metal on 1.22-m-high concrete wainscoting. Plaster, on metal laths over metal studs, was used to give a smooth interior surface.

The buildings were ventilated with a $60000-\mathrm{m}^{3} / \mathrm{min}-$ capacity central air exhaust system. This system handled air from rooms and fuine hoods, sparging of dissolvers, and venting of solution tanks. At that time exhausting air from the glove boxes was not believed necessary. Several years later the decision was made to vent these work enclosures. The air was exhausted, without being filtered, through the room air exhaust system, Particulates were removed from the exhaust air by electrostat1c precipitron units backed up by a single bank of AmerIcan Air Filter Company Type PL-24 filters. This system was considered the best available for air clean-up at that time.
The filter bullding, designated Building 12, was completed and put into service in.May 1945. It continued in service for room and process air until July 1, 1959. That year another system was installed for the process air, and afterward only room air was handled in Building 12. Building 12 continued in service until February 1973, when new room air filtration systems were completed, one for each of the process buildings.

\section{DESCRIPTION OF FACILITY}

The site plan (Fig. 1) shows the relationship of the process buildings to the filter building. The finished site is shown in Fig. 2. The filter butlding is on the left. Air from the rooms was exhausted from floor level, up vertical ducts through the roof, then to ducts mounted parallel to the roof, to the collector duct on the peak of the roof. All the ductwork was galvanized steel. In those ducts that handled chemical fumes, corrosion began Immediately, and small holes formed within a few years. Corrosion products and dirt drawn through the holes in the ductwork were deposited in the plenum of the filter building. 
The floor plan of Building 12 is shown in Fyg. 3. The floor area for that portion housing the filters and prectpitron units was $30.8 \mathrm{~m}$ by $19.5 \mathrm{~m}$. The intake plenum was a trapezoidal area $23.5 \mathrm{~m}$ wide at its longest base, $7.6 \mathrm{~m}$ wide where the air entered the building, and $18.9 \mathrm{~m}$ from that point to the rectangular portion of the building.

The precipitron units and filter banks were built in five sections. Each section had two large doors that could be lowered to isolate the area while filters were being changed or while work was being done on the precipitron unit. Access to the isolated section was by ladder from the second story of the building. The second story housed the doors when they were in the ratsed position.

Figure 4 shows a side view of the building; and Fig. 5 , a side view of the filter and blower area, shows the positions of the electrostatic precipitron units, the PL-24 filter bank, the common blower plenum, the exhaust blowers, and the doors used to isolate the sections. A front view of the bullding is shown in Fig. 6 .

The construction of Building 12 was constrained by the materials avallable at that time. The concrete foundation was made deeper and thicker because reinforcing steel was in short supply. The wall studs and floor and roof beams were wood. They were covered with two layers of gypsum board to give a smooth interior surface. This construction actually helped prevent the spread of contamination during demolition. Construction details will be discussed in Sec. IV.

\section{DECONTAMINATION OF FACILITY}

In 1960 the interior of the plenum and the largest portion of the air ducts were cleaned. About $3000 \mathrm{~kg}$ of dirt were removed from the building during this first cleaning operation, including several hundred pounds of sand that had been used in sandblasting plutonium parts. Samples of dirt removed were analyzed and showed a plutanium content ranging from 0.001 to $0.05 \mathrm{wt} \%$. The data indicated that this dirt, which was packed in two 0.3-mm-thick plastic bags and placed in steel drums for burial, conta!ned about $600 \mathrm{~g}$ of plutonium $\left(93.5 \%{ }^{239} \mathrm{Pu}\right.$, $6 \%{ }^{240} \mathrm{Pu}$, and $0.5 \%{ }^{241} \mathrm{Pu}$ ). The prectpitron units were disassembled, removed from the bullding, wrapped in several layers of plastic, and packed in plywood crates for burial.

Over the next few years the building was cleaned several times. Each time the final operation was to wipe down the entire floor with wet rags. Immediately after this cleaning, the floor would have a swipe count of only a few hundred disintegrations per mimute, but the di rect count was still > $100000 \mathrm{dis} / \min$ per $60 \mathrm{~cm}^{2}$. All the cracks, such as expansion joints, had a swipe count of $>100000 \mathrm{dis} / \mathrm{min}$.

\section{DEMOLITION OF BUILDING 12}

A proposed procedure for the demolition of the building was prepared by a member of the Engineering group and a member of the Plutonium Processing group. Their report was submitted for approval to the Demolition Committee, which was composed of representatives from the Los Alamos Scientific Laboratory (LASL) and from the contractor that would do the demolition. The names of the groups represented are shown in Table $I$. Demolition work was started using this approved procedure; but as work progressed, conditions were sometimes encountered that necessitated a change in procedure. Therefore, the Committee met every week to hear progress reports on the demolition and to review proposals for any change in the procedure.

TABLE I

DE PARTMENTS RE PRESENTED ON DEMOLITION COMMITTEE

Plutonium Processing

Health Physics Environmental Studies

Fire Safety Industrial Sa fety

Waste Management

Engineering Planning Engineering Estimating

Transportation Engineering Maintenance Contractor for Demolition 
The first step in the demolition was removal of the ductwork leading to Bullding 12. This work was started. in June 1972 and was completed in February 1973. As ductwork was removed and air supply was reduced, blowers in Building 12 were shut down. When the third blower was shut down, a partition was built in the blower plenum so that blower No. 4 and filter No. 5 could provide ventilation for the bulling. The position of the partition is shown in Fig. 3 at point No. 8.

A change room was built on the east side of the building, adjacent to the air lock and access door shown in Fig. 3. Here, the workers were suited up, including a fitting and testing of full face masks.

An initial cleaning was done by chemical technicians assisted by janitors, and the final cleaning just before painting was done by janitors and laborers. The painter was kept on duty during the entire period of demolition to paint freshly exposed surfaces. After the walls, ceilIngs, and partitions had been cleaned with water spray, the floors were wiped with wet rags. Again, the contamination could be reduced only to the levels discussed earlier. Then, water-base paint was applied with a spray gun. After several applications, nearly all exposed areas in the building no longer had any swipe or direct count. However, if any paint peeled off the surface, the direct count would reappear and the area had to be wiped with wet rags and repainted. As expected, all expansion joints still had large amounts of solids that soaked in with water from previous cleaning operations.

At this stage blowers Nos. 1, 2, and 3, were idle. Air was being drawn down the stacks, through the filters In bays 1 through 4 in reverse flow, through the filters In bay 5 in the normal manner, and exhausted through blower No. 4. With this air flow helping to control contamination, removal of stacks 1,2 , and 3 was begun. The roof and walls around the blowers for these three stacks were removed by lifting on a cable wrapped around ceiling beams. The roof was constructed with the beams ending at the middle of the brick wall separating the blower room from the blower plenum. Thus, the beams could be lifted off this dividing wall without exposing the contaminated blower plenum.
After the blower room roof (except for a section over blower No. 4 and another section over the electrical panels) was removed, work was started on removing the stacks. Figure 7 shows a rigger being raised to the top of the first $15,2-\mathrm{m}(50-\mathrm{ft})$ stack to attach a lifting collar. The stacks had a square base that was slipped over a slightly smaller male fitting on the blower to provide the air seal. This joint had been taped and painted to make it air tight. The stack was removed by cutting the tape, cutting some external supports (which were not contaminated), and lifting the stack off the blower with a crane. The bottom of the stack and the opening of the blower were immediately covered with preassembled sheets of plywood. The stack was then placed on a lowboy, the ends were sealed with metal plates, and the stack was wrapped in plastic for hauling to the burial site. Fygure 8 shows the blower room after the first three stacks were removed.

The next step was to remove all the filters in banks 1 through 4. As shown in Fig. 9, each bank contained 63 filters, each 0.67 by $0.67 \mathrm{~m}$ by $0.22 \mathrm{~m}$ ( $2 \mathrm{ft}$ by $2 \mathrm{ft}$ by $8 \mathrm{in.}$ ). The filters were lifted out of the frame and put in plastic bags, carried to the access door of the change room, and slipped into another bag held by two laborers. This outer bag was checked for external contamination so that the package could either be rebagged or could be safely carried through the change room to plywood boxes for burial.

Next, the filter frames were cleaned and painted. Disassembling the filter rack, which had been made by rivetting open-end metal boxes together, required either sawing the frames into pieces or driving a wedge between them so that the rivets would pop loose. The latter method was found to be faster and was used to remove the 252 frames in filter bays 1 through 4 . The frames were taken from the building and crated, using the same method that was used for the filters.

The laborers then began disassembling the precipitron frames. These frames were $1.22 \mathrm{~m}$ wide, $0.61 \mathrm{~m}$ deep, $4.27 \mathrm{~m} \mathrm{high}$, and weighed $275 \mathrm{~kg}$. As soon as a frame was unbolted, it was lowered to the floor with a chain hoist, then cleaned, painted, and placed on rollers 
to be moved to an access door of the exhaust blower plenum area (FYg. 3 ). There, a final coat of paint was applied before the frame was rolled through the door onto a large plastic sheeting. The frame was wrapped in plastic, loaded onto a truck, and hauled to the burial site. Figures 10, 11, and 12 give vlews of various stages of this operation.

Sprinkler pipes and electrical conduit and process lines leading to the oll baths on the precipitron units were removed, cut with hacksaws into $2.5-\mathrm{m}$ lengths, painted, wrapped in plastic, and passed through access doors to be crated for burial.

Similar techniques were used for the large doors that Isolated the filter sections. The doors were $1.6-\mathrm{cm}$ (5/8-in.) plywood mounted on a 10-cm channel Iron frame. Each bay had two doors $5.2 \mathrm{~m}$ wide, one $3.1 \mathrm{~m}$ high and the other $4.3 \mathrm{~m}$ high.

Except for the filters in bay 5, the building was empty and was considered ready for removal of the interior surfaces of the walls, floor, and ceiling.

The construction details indicated that the contamInation of walls and ceiling might be restricted to the first layer of material. As shown in Fig. 13, the roof was made of two layers of wood beams, $5 \mathrm{~cm}$ by $20 \mathrm{~cm}$ ( 2 in. by 8 in.), supported by metal I beams. The beams were covered with two layers of gypsum boand and a $0.3-$ $\mathrm{cm}$ layer of transite. The final layer was a hot tar and roofing paper application. The celling was two layers of gypsum board covered by a fabric called "Walltex." A 1.6-mm-thick metal nailing strip was used to prevent the nalls from pulling through the gypsum board when the plenum was operating at its lower air pressure. After the metal strips were pulled from the ceiling, the surface fabric layer, covered with several coats of paint, was easily pulled off leaving a nearly contaminationfree surface.

Figure 14 shows construction of the walls and floor. The walls were made of two layers of gypsum board nailed to the inside of the $5-\mathrm{cm}$ by $20-\mathrm{cm}$ studs. Here, too, the gypsum board could be pulled off without contaminatIng the studs, All exposed surfaces were immediately covered with a coat of paint to seal porous surfaces.
The wall and floor function consisted of overlapping layers of gypsum board, expansion joint material, and gunnite. This construction had prevented the sill from becoming contaminated; and by removing the expansion joint material along with a strip of the gunnite, the stll was exposed free of contamination. The remaining gunnite was coated with paint until all of the contamination was covered. It remained on the floor for removal with the foundation.

At this time samples of the soil under the floor were taken and analyzed for gross alpha activity. The results, discussed in Sec. VIII., showed that the soll was contaminated in certain areas and would have to be removed to leave a clean site.

Demolition of the plenum could now be completed using power equipment to tear down the roof and walls In a normal manner. The appearance of the intake plenum's interior is shown in Fig. 15, and the appearance of the area that housed the precipitrons and filters is shown in Fig. 16.

In the penthouse area the interior wall covering was removed without spreading contamination to the wall studs. The floor, however, was built of $5-\mathrm{cm}$ by $10-\mathrm{cm}$ tongue and groove boards, and the cracks between the boards were filled with contaminated dirt, which could not be fixed, even with several coats of paint. Therefore, all the floor boards were pried loose and painted individually to fix the contamination. These interior floor boards and the gypsum wallboard were packed in plywood boxes, then banded and sealed and hauled to the burial site. The interior, after removal of floor and interfor surface of the walls of the penthouse, is shown in Fig. 17.

The external siding was made of paperboard nalled to the $5-\mathrm{cm}$ by $20-\mathrm{cm}$ studs covered with corrugated asbestos siding. The asbestos siding was removed, monitored for alpha contamination, and hauled to the LASL waste disposal site. Figure 18 shows the building after the siding was removed. Because no alpha contamination was found on the siding, it was hauled to the disposal site in an open truck.

After the exhaust plenum, blower plenum, precipitron area, and the penthouse area had been stripped, 
cleaned, and painted as discussed earlier, a survey for alpha contamination showed that all contamination was fixed, except for the soil under the floor and in the expansion joints in the concrete floor.

The steel columns that held the ten large doors could not be dismantled without cutting torches. Because of the fire danger from wooden construction in the area it was decided to leave the steel standing and tear down the building around the steel. After all combustible material was removed, the steel was cut up and hauled to the disposal site. The removal of the steel is discussed later in this section.

The interior was stripped and cleaned as much as possible. The next step was to shut down the last blower and to remove the last bank of filters. Because this would leave the building without any ventilation, a $300-\mathrm{m}^{3} / \mathrm{min}$ blower and HEPA filter were installed.

While blower No. 4 was still running, and before the new blower was started, the filters were coated with water-base spray paint to fix the dust and contamination. Just as the filters began to plug, the large blower was shut off and the $300-\mathrm{m}^{3} / \mathrm{min}$ blower was started.

The filters and frames were then removed, using the same technique as for the others. After bay 5 was stripped and cleaned, the building was surveyed again for alpha contamination. When all loose contamination and detachable items were removed and all areas were painted at least three times to cover impregnated contamination, the decision was made that the remainder of the building could be safely torn down and loaded onto trucks with equipment working from the outside.

Because no contamination could be detected on the remaining portions of the walls, it was decided to pull the penthouse over with a cable as if it were a normal building being razed. This was done, exposing the steel beam door supports. Figures 19 and 20 show the building with most of the penthouse gone. As portions were pulled down, the long boards were cut into $2.5-\mathrm{m}$ sections with chain saws. The pieces were checked for contamination and then loaded into a dump truck fitted with plywood sides, canvas top, and rear flap. Only rarely was any contamination found, and when it was the area was immediately painted.

The remainder of the walls and ceiling of the blower room, which never had been contaminated, were broken apart and loaded onto a truck with a payloader. The concrete foundations were broken loose with a bulldozer and loaded onto the dump truck.

After the work on the penthouse and blower room was completed, work was started on the intake plenum. The roof was pulled down with cables, and the debris was hand-loaded into the covered truck. Then the walls were pushed over, dismantled, and loaded. Figure 21 shows this area after one of the walls was pushed over. When this work was completed, the building was reduced to the brick and steel remaining in the precipitron area and the floor of the intake plenum area.

The next stage was to tear out the intake plenum floor with a payloader. The foundation was extensive, as shown in Fig. 22. The concrete at the point where the external foundation intersects with the internal foundations was often $46 \mathrm{~cm}$ thick. The foumdation was $1.52 \mathrm{~m}$ deep, and because some of the soil inside was contaminated, the decision was made to have the equipment dig deep enough to go beneath the foundation and to load foundation, soil, and floor at the same time. Figure 23 shows the equipment in the process of removing the plenum floor area. When that was completed the building was reduced to the steel, brick and concrete shown in Fig. 24.

An attempt was made to pull some of the steel down with a cable and in the process to break some bolts and rivets so that the individual beams could be loaded onto the truck. Unfortunately, the construction was such that when the bulldozer pulled on a piece of steel at the end of the building, the whole steel assembly toppled over and became the tangled mess shown in Fig. 25. The steel then had to be cut apart with cutting torches and loaded onto an open dump truck with a cranc. Figures 26, 27, and 28 show various stages of this operation.

After the steel was cleared away, only the concrete floor and foundations in the precipitron and filter remained ( $\mathrm{F}$ 'ig. 28). The only contaminated areas on the floor 
slabs were the edges that had been in contact with the expansion joints, and these areas were immediately painted. A bulldozer (Fig. 29) was used to lift the floor slabs and push them to an area where the payloader could load them onto a dump truck. Then the bulldozer was used to loosen and break the foundation into pieces small enough to load. Most of the foundation was 15 to $20 \mathrm{~cm}$ thick and $1.5 \mathrm{~m}$ deep. However, one plece of the foundation was nearly $75 \mathrm{~cm}$ wide, $1.5 \mathrm{~m}$ deep, and $30 \mathrm{~m}$ long. Efforts to break this foundation into small chunks with the bulldozer proved fruitless. Therefore, this 30-m piece of foundation had to be weakened by drilling a series of holes as a perforation line. Part of this perforation line is shown in Fig. 30. The bulldozer was then able to break this foundation into pieces small enough to be lifted onto the truck. Figure 31 shows the removal of the last concrete and dirt from the site.

The final task was to remove the drain pipe that led from the precipitron and filter area to a tile field. The tile field had been removed several years earlier, but the plugged drain line remained in place. Workers engaged in removing the drain line are shown in Fig. 32. Although this cast iron drain line had been embedded in the soll for nearly $30 \mathrm{yr}$, corrosion had penetrated less than $0.16 \mathrm{~cm}(<1 / 16 \mathrm{in}$.).

After the drain line was removed, the trench and the area that had been occupied by the building were surveyed for alpha contamination. When no alpha contamination was detected, soil samples were taken for analyses, the area was backfilled with dirt until the original ground contour was restored, and native grasses were planted as a ground cover. Figure 33 shows the area after completion of the backfilling operation.

The demolition work was started in February and completed in July 1973, at a total cost of approximately $\$ 160000$. Craftsmen employed on this project were riggers, painters, laborers, equipment operators, truck drivers, carpenters, and electricians.

\section{HEALTH PHYSICS}

Personnel assigned to do the demolition were inexperienced in dealing with plutonium contamination. However, they were provided with formal health physics instruction and with day-to-day instructions from the plutonium plant supervisor and from health physics technictans who were present during all phases of the project. All workers also participated in a full face respirator fitting and testing program. Full face respirators equipped with high-efficiency particulate fllters were the standard respiratory protection during all phases of demolition involving loose contamination. During prior decontamination work in 1960, supplied air suits were used.

Demolition workers were provided protective (anticontamination) clothing for work in the area. For work inside the building, workers were double-suited with coveralls, booties, a cap and hood, gloves, and underwear (Fig. 34). Disposable paper coveralls, hoods, and plastic booties were used for outerwear. The outer garments were overlapped and taped together, and openings in the coveralls were taped shut. This clothing provided adequate protection against worker contamination during the demolition, and no personnel decontamination beyond normal showering and washing procedures was required.

Air in the working area was sampled by drawing It through $\mathrm{HV}-70$ filter paper at the nominal rate of $0.56 \mathrm{~m}^{3} / \mathrm{min}$. The paper was removed and counted dally for alpha activity to provide a record of the workers' exposure to air contamination. On four occasions the alr-borne plutonium concentraticn exceeded $2000 \times 10^{-12}$ $\mu \mathrm{Ci} / \mathrm{m} \ell$, but during most of the remaining work days the concentration generally ranged from 50 to $150 \times 10^{-12}$ $\mu \mathrm{Ci} / \mathrm{m} \ell$ with some as low as $2 \times 10^{-12} \mu \mathrm{Ci} / \mathrm{m} \ell$.

All personnel working on the project were provided with monthly beta-gamma and neutron film badges to record external radiation exposures. The highest monthly recorded exposure was $40 \mathrm{mrem}$. All workers were surveyed for alpha contamination before leaving the area, and nose swipes were collected after work requiring 
respiratory protective equipment. The frequency of these monitoring practices varied somewhat with the assigned task and level of contamination involved. A few cases of hand contamination occurred; however, all were decontaminated by normal showering and washing methods. Of 1195 nose swipes collected only four were $>10 \mathrm{dis} / \mathrm{min}$ alpha; of these $85 \mathrm{dis} / \mathrm{min}$ was the highest single result. Workers submitted urine samples for plutonium analysis at the beginning and completion of the job. Most workers were given plutonium chest counts at job completion. No measurable plutonium body or lung burdens were indicated by the results of the urinalysis and chest counting programs. One minor injury occurred during the job. The wound, caused by a nail puncture, was monitored by alpha and x-ray monitoring techniques and found to be free of plutonium contamination.

\section{WASTE MANAGEMENT}

Waste materials were packaged in different ways depending on size and contamination level to make transport and disposal safe. Small items and highly contaminated larger items that could be reduced in size were placed in plastic-lined $0.56-\mathrm{m}^{3}$ cardboard boxes. The bags were sealed with tape to prevent leaks during disposal. Approximately 1320 cardboard boxes were filled with waste and buried at LASL's solid radioactive waste disposal site, about $9 \mathrm{~km}$ from the demolition site. The location of this site is shown in Fig. 33. Larger items, such as filters, filter frames, gypsum board pieces, and metal trim, were wrapped in plastic and placed in 69 plastic-lined plywood crates ( 1.2 by 1.2 by $2.4 \mathrm{~m}$ ) for burial at the disposal site. In addition to the boxed and crated waste, approximately $1200 \mathrm{~m}^{3}$ of contaminated transite, doors, lumber, pipes, roofing materials, and metals were taken to the disposal site in covered dump trucks. Fixing the contamination on large items with several coats of paint allowed for handling, transport, and disposal without vehicle or personnel contamination problems. In addition to the waste already mentioned, approximately $400 \mathrm{~m}^{3}$ of concrete, dirt, and large metal items were buried in a disposal site located at TA-21, $300 \mathrm{~m}$ from the building site.
All waste packages and unpackaged items were monitored for plutonium contamination with portable alpha survey instruments. The waste was buried as nonretrievable, $<10 \mathrm{nCi} / \mathrm{g}$ plutonium waste. The wastes that contained $>10 \mathrm{nCi} / \mathrm{g}$ plutonfum had been placed in retrievable storage during decontamination, before actual demolition.

Trucks, loaders, and bulldozers used to load or transport contaminated materials were monitored during the job and decontaminated as necessary. The equipment did not become highly contaminated, and washing with cold water was sufficient to reduce contamination levels to less than $100 \mathrm{dis} / \mathrm{min}$ per $60 \mathrm{~cm}^{2}$.

During the 109 days required for the demolition work and site clean-up, a total of 235 man-days of health physics technician effort were required for personnel and miscellaneous monitoring.

\section{ENVIRONMENTAL AIR MONITORING}

The Los Alamos Scientific Laboratory Environmental Studies Group monitored the environmental impact of the demolition operation with its routine air sampling network and a special on-site sampling program. The routine air sampling network, consisting of 36 sampling stations was supplemented with two additional stations to more adequately encircle the demolition site. The positioning of the supplemental samplers was limited somewhat by avallability of electrical power and access to the equipment. The location of these sampling stations (with the exception of the Santa Fe, Espanola, and Pojoaque stations) and of the demolition site are shown in Fig. 35 .

The samples drew air through a 78-mm Microsorban filter with an efficiency of about $99.8 \%$ for $0.3-\mu \mathrm{m}$ dioctyl phthalate (DOP) particles (a standard test aerosol for determining filter efficiency) at either $70 \mathrm{l} / \mathrm{min}$ or 200 $\ell / \mathrm{min}$. The two different rates were due to replacing the $70-\ell / \mathrm{min}$ pumps with higher capacity pumps that require less maintenance.

The 38 samples were collected weekly. This schedule was not intended to provide an early detection of a plutonium release but to help document the magnitude of an accidental relcase. Meteorological data were available 
for TA-21 during the entire operation and could have been used if a high gross alpha concentration had been detected at any of the sampling stations. Because no concentration of any significance was detected, it was not necessary to use the data to determine the pollution source.

The samples were handled routinely; they were counted after a 1-day decay period and then recounted after approximately a 10-day decay period to allow for the decay of natural radon and thoron daughters. During the demolition both measurements were observed and compared to background levels to detect any abnormal concentrations. An attempt was made to compare these 10-day measurement data to the corresponding data for 17 weeks of 1972 to eliminate seasonal background variathons. However, the data for those weeks in 1972 were influenced by fallout from a Chinese Nuclear Test and no meaningful comparison was possible. Instead, the data were compared to the 1972 averages. These data are presented in Table $\Pi$ and indicate that if plutonium was released to the environment during demolition, it was minimal and had no detectable impact on the overall gross alpha background levels in the area.

Air monitoring in the immediate vicinity of the structure was added to provide an early detection of a release of radioactivity. If such a release had been detected the operation would have been curtailed until more protective demolition measures could be used. These samples (location of samplers shown in Fig. 36) were collected daily. Because of mechanical failures, a variety of sampling devices and rates were used. On April 4, 1973, at the start of the sampling operation, the network consisted of four Staplex "Hi-Volume" samplers. They sampled through 76-mm-diam Microsorban paper (simllar to the filter media for the weekly samples) at a rate of approximately $0.37 \mathrm{~m}^{3} / \mathrm{min}$. Two of the samplers were located near bulldings and used line power; the other two were driven by gasoline-powered generators.

By the end of April three of the samplers had been changed to use $100-\mathrm{mm}$ Microsorban filters to increase the flow rate and reduce pump heating. The flow increased to approximately $0.52 \mathrm{~m}^{3} / \mathrm{min}$. These samplers were located, as shown in Fig. 36, so that they could be operated on line power and were used throughout the remain- der of the sampling period. The fourth sampling station was abandoned because the others would give adequate coverage. The samplers were not centered around the building but instead, around the center of the demolition activity, where releases of contamination were more likely to occur.

The filters were first counted by Health Physics persomnel within an hour after collection for early detection of a release. Two weeks later, after allowing for decay, they were counted by Environmental Studies personnel. The average and maximum gross alpha concentration values for the second measurement are compared in Table III to AEC Manual Chapter 0524, Concentration Guides for Uncontrolled Areas. All of the gross alpha activity was assumed to be insoluble ${ }^{239} \mathrm{Pu}$ for comparison to applicable concentration guides. The highest $24-\mathrm{h}$ concentration at any on-site sampler $\left(8.7 \times 10^{-13} \mu \mathrm{Ci} / \mathrm{m} \ell\right.$

TABLE II

GENERAL SURVEILLANCE ATR MONTORING RESULTS

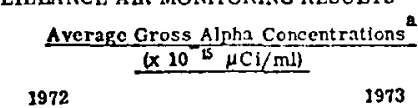

\begin{tabular}{|c|c|c|c|c|c|c|c|c|c|}
\hline \multirow{2}{*}{$\begin{array}{l}\text { Station } \\
\text { Number } \\
\text { Off sitc }\end{array}$} & \multicolumn{2}{|c|}{ Coordinates } & 1972 & \multicolumn{3}{|c|}{1972} & \multicolumn{3}{|c|}{1973} \\
\hline & & & & & & & & & \\
\hline 1 & N220 & E220 & $1.8 \pm 2.2$ & 2.0 & \pm 0 & 0.6 & 1.2 & - & 0.6 \\
\hline 2 & $\mathrm{~N} 220$ & E300 & $2.3 \pm 2.6$ & 1.9 & \pm 0 & 0.6 & 0.8 & \pm & 0.4 \\
\hline 3 & $\mathrm{~N} 200$ & $\mathbf{E} 380$ & $1.7 \pm 2.4$ & 1.7 & \pm 0 & 0.6 & 1.4 & \pm & 1.0 \\
\hline 4 & N180 & E130 & $1.5 \pm 1.6$ & 1.6 & \pm 0 & 0.4 & 1.0 & \pm & 0.6 \\
\hline 5 & $\mathrm{~N} 170$ & E 20 & $2.2 \pm 2.8$ & 1.6 & \pm 0 & 0.6 & 1.2 & \pm & 0.8 \\
\hline 6 & N160 & E 60 & $2.2 \pm 2.6$ & 1.5 & \pm 0 & 0.6 & 1.3 & \pm & 1.0 \\
\hline 7 & N150 & $E 490$ & $1.7 \pm 1.8$ & 1.7 & \pm 0 & 0.4 & 1.4 & \pm & 0.8 \\
\hline 8 & $\mathrm{~N} 140$ & E130 & $1.5 \pm 2.2$ & 1.7 & \pm 0 & 0.6 & 1.3 & $*$ & 1.0 \\
\hline 9 & N130 & E 20 & $1.8 \pm 2.2$ & 1.6 & \pm 0 & 0.6 & 1.5 & \pm & 0.8 \\
\hline 10 & N110 & $E 90$ & $2.0 \pm 2.6$ & 1.6 & \pm 0 & 0.6 & 1.3 & \pm & 0.6 \\
\hline 11 & s 90 & E390 & $1.8 \pm 2.2$ & 1.6 & \pm 0 & 0.6 & 1.4 & \pm & 0.6 \\
\hline 12 & 5210 & E370 & $1.5 \pm 2.4$ & 1.3 & \pm 0 & 0.6 & 0.9 & \pm & 0.6 \\
\hline 13 & S270 & E.190 & $1.0 \pm 1.0$ & 1.5 & \pm 0 & 0.4 & 1.3 & \pm & 0.8 \\
\hline 14 & & - & $3.3 \bullet 2.8$ & 2.1 & \pm 1 & 1.0 & 1.5 & \pm & 1.0 \\
\hline 15 & & - & - & & - & & 1.2 & \pm & 1.2 \\
\hline 16 & & - & $3.3 \pm 4.2$ & 2.0 & \pm 0 & 0.8 & 0.8 & \pm & 1.0 \\
\hline \multicolumn{10}{|c|}{ Perimeter } \\
\hline 17 & N110 & E160 & $2.7 \bullet 3.6$ & 1.9 & \pm 0 & 0.8 & 0.8 & \pm & 0.6 \\
\hline 18 & N110 & E260 & $1.3=2.0$ & 1.6 & $\neq 0$ & 0.8 & 1.0 & \pm & 0.8 \\
\hline 19 & N100 & E 20 & $1.9 \pm 2.4$ & 1.5 & $\neq 0$ & 0.6 & 1.4 & \pm & 1.2 \\
\hline 20 & N100 & E110 & $1.8 \pm 2.8$ & 1.4 & \pm 0 & 0.6 & 1.0 & $t$ & 0.6 \\
\hline 21 & N 80 & $E 10$ & $1.7 \pm 2.8$ & 1.5 & \pm 0 & 0.6 & 1.2 & \pm & 0.6 \\
\hline 22 & N 30 & E310 & $1.8 \pm 2.8$ & 1.5 & \pm 0 & 0.6 & 0.8 & \pm & 0.4 \\
\hline 23 & S 80 & 90 & $2.2 \pm 2.4$ & 1.5 & \pm 0 & 0.6 & 1.1 & \pm & 0.8 \\
\hline 24 & $\mathbf{s} 100$ & E 40 & $1.6 \pm 1.8$ & 1.5 & \pm 0 & 0.6 & 0.8 & \pm & 0.6 \\
\hline 25 & $\$ 100$ & E300 & $2.1 \pm 2.2$ & 1.6 & \pm 0 & 0.6 & 1.1 & * & 0.6 \\
\hline 26 & $\mathbf{8 2 7 0}$ & 1.200 & $1.9 \pm 2.0$ & & - & & 1.3 & $\bullet$ & 0.8 \\
\hline \multicolumn{10}{|l|}{ On-Site } \\
\hline 27 & N 90 & E 170 & $1.6 \pm 1.8$ & 1.3 & \pm 0 & 0.4 & 0.8 & \pm & 0.1 \\
\hline 28 & N 60 & E: 180 & $3.0 \pm 4.4$ & 2.2 & \pm 0 & 0.8 & 1.0 & \pm & 0.1 \\
\hline 29 & N 10 & E 20 & $1.9 \pm 3.2$ & 1.5 & \pm 0 & 0.6 & 1.0 & \pm & 0.6 \\
\hline 90 & N 20 & E.170 & $2.6 \pm 4.2$ & 1.6 & \pm 0 & 0.4 & 1.0 & \pm & 0.6 \\
\hline 31 & s 30 & W 10 & $1.3 \pm 2.2$ & 1.1 & -0 & 0.4 & 1.1 & \pm & 0.8 \\
\hline 32 & 330 & E 190 & $1.8 \pm 2.0$ & 1.5 & \pm 0 & 0.4 & 1.7 & \pm & 1.2 \\
\hline 33 & 550 & Fic0 & $1.5 \pm 1.4$ & 1.1 & \pm 0 & 0.4 & 0.8 & \pm & 0.4 \\
\hline 34 & s 60 & E 10 & $1.1 \pm 1.4$ & 1.2 & \pm 0 & 0.4 & 1.1 & \pm & 0,6 \\
\hline 35 & 870 & L. 80 & $1.5 \pm 1.8$ & 1.3 & \pm 0 & 0.4 & 0,8 & \pm & 0.6 \\
\hline 36 & S2so & E230 & $3.3 \pm 5.4$ & 1.0 & \pm 1 & 1.2 & 1.1 & \pm & 1.0 \\
\hline 37 & N 20 & E:110 & - & & - & & 1.1 & \pm & 0.8 \\
\hline 38 & N 70 & F115 & - & & - & & 1.1 & \pm & 1.0 \\
\hline
\end{tabular}


TABLE III

ON-SITE (TA-21) GROSS ALPHA CONCENTRATIONS IN AIR

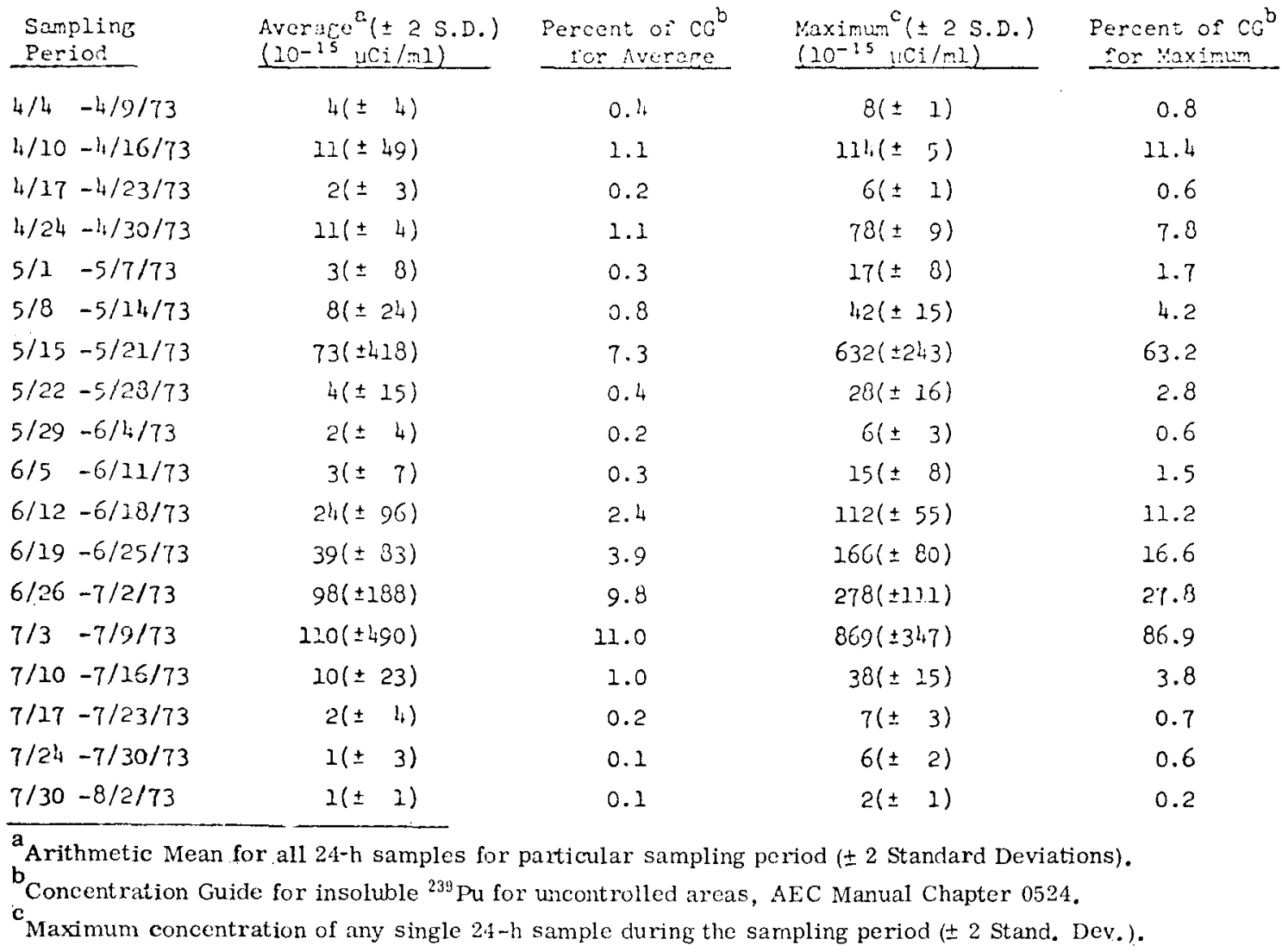

on July 5) was $87 \%$ of the $\left(1 \times 10^{-12}-\mu \mathrm{Ci} / \mathrm{m} \ell\right)$ concentration guide for insoluble ${ }^{239} \mathrm{Pu}$ in controlled areas.

Air exhausted by the ventilation blower was sampled by drawing it through HV -70 filter paper at the nominal rate of $0.56 \mathrm{~m}^{3} / \mathrm{min}$. The filter papers were measured daily for gross alpha activity. Data indicated that 1371 $\mu \mathrm{Ci}$ of plutonium were released through the blower between February and May 1973.

\section{SOIL SAMPLING}

As was mentioned in Sec. IV., water from clean-up operations escaped the building through expansion joints in the concrete floor. For this reason, the concrete was broken and surface and core samples of dirt were collected at suspect locations to determine the magnitude and depth of contamination. The surface samples were collected with a spoon from the top entincter of soil, and the core samples were collected by driving a $2.54-\mathrm{cm}-$ diam polyvinyl chloride (PVC) pipe into the soil with a hammer. The sample locations and the gross alpha concentrations at those locations are shown in Fig. 37 and Table IV, respectively. The data confirmed expectations that some soil underneath the building would be contaminated.

After the building and approximately $30 \mathrm{~cm}$ of soil were removed, an attempt was made to survey the remaining $2-\mathrm{m}$ depression with a low-cnergy $\mathrm{x}$-ray detector. The results of the survey were meaningless, however, because the instrument readings were influenced by radioactive materials stored in a nearby building. Therefore, soil core samples were collected at the locations shown in Fig. 38. Samples collected at points 4, 5, and 6 (near the centerline of the building) were divided into the listed segments to determine variation in 
TADIF V

TABLE $\mathbf{N}$

\begin{tabular}{|c|c|c|c|c|c|}
\hline Bart: & mples & & Con & o Bample & \\
\hline $\begin{array}{l}\text { Bemple } \\
\text { Locatton }\end{array}$ & 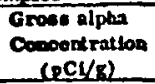 & $\begin{array}{l}\text { Eample " } \\
\text { Locatlon" }\end{array}$ & $\begin{array}{r}\text { Dopkl } \\
\operatorname{ser} \\
10\end{array}$ & $\begin{array}{l}\text { Irom } \\
\text { Ince } \\
\text { in) }\end{array}$ & $\begin{array}{l}\text { Cross alpha } \\
\text { Concentration } \\
\text { (PC1/g) }\end{array}$ \\
\hline & 67 & & - & -2.6 & 36 \\
\hline & 21 & & 6.4 & -8.0 & 9 \\
\hline & 17 & - & 18.1 & -16.2 & 6 \\
\hline & 108 & & $\bullet$ & -2.8 & 10 \\
\hline & 207 & & 0.4 & -8.0 & 1 \\
\hline & $\mathbf{m}$ & & - & -2.6 & 108000 \\
\hline & 4 & - & 0.4 & -8.0 & 4653 \\
\hline & 211 & - & $\mathbf{2 8 . 7}$ & -15.2 & 722 \\
\hline & & ш & 20.4 & -87.0 & 446 \\
\hline & & & - & -2.5 & 30 \\
\hline & & & 0.4 & -8.0 & 4 \\
\hline & & 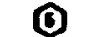 & & $-8,8$ & 23 \\
\hline & & & 0.4 & -8.0 & 10 \\
\hline & & * & $\mathbf{2 . 1}$ & -18.8 & 21 \\
\hline & & & 90.8 & -22.0 & 20 \\
\hline
\end{tabular}

Sop Figure 32 for bocation.

contamination with depth. Samples from the other loca-

Hons were analyzed as single samples. Runoff from a rainshower the previous night that had formed a puddle at the northeast side of the depression was also sampled; Its gross alpha concent ration was less than the minimum detection IImit of $4 \times 8^{-8} \mu \mathrm{Cl} / \ell$.

To arrive at a quick estimate of contamination levels and also minimize the number of plutonium analyses, gross alpha measurements were made on all the samples by leaching the samples with actd and analyzing the leachate. The gross alpha concentrations were used to select samples for plutonium analyses that would include the maximum and minimum gross alpha concentrations and several concentrations within the range. The plutonium data are shown in Table $\mathrm{V}$.
PLUTONIUM IN SOIL SAMPLES TAKEN FROM CLEAKED SI'J'

\begin{tabular}{|c|c|c|c|c|}
\hline \multirow{2}{*}{$\frac{\text { 8ampling Station }}{1}$} & $\begin{array}{l}\text { Dopth from Surface } \\
\text { (om) }\end{array}$ & $\begin{array}{r}{ }^{238} \mathrm{Pu} \\
(\mathrm{mCl} / \mathrm{E})\end{array}$ & \multicolumn{2}{|c|}{$\begin{array}{l}239 \text { ir } \\
(\mathrm{nC} 1 / \mathrm{g})\end{array}$} \\
\hline & $0-20.9$ & $0.3 \pm 0.08$ & 25.7 & $\pm 1,1$ \\
\hline 2 & $0-24.0$ & - & & - \\
\hline 3 & $0-22.2$ & - & & - \\
\hline \multirow[t]{3}{*}{4} & $\dot{0}-2.5$ & $0.4 \pm 0.07$ & 28.9 & \pm 1.2 \\
\hline & $8.5-7.6$ & - & & - \\
\hline & $7.6-22.8$ & - & & - \\
\hline \multirow[t]{4}{*}{8} & $0-2.5$ & - & & - \\
\hline & $2.8-7.6$ & $0.0 \pm 0.1$ & 42.5 & \pm 1.6 \\
\hline & $7.6-12.7$ & $0.7 \pm 0.1$ & 70.0 & 2.6 \\
\hline & $12.7-33.0$ & $0.22 \pm 0.01$ & 4.3 & \pm 0.2 \\
\hline \multirow[t]{3}{*}{6} & $0-2.5$ & - & & - \\
\hline & $2.5-7.6$ & - & & - \\
\hline & $1.6-15.2$ & $0.3 \neq 0.04$ & 30.0 & \pm 1.1 \\
\hline 7 & $0=16.6$ & 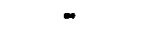 & & - \\
\hline 8 & $0-16.5$ & - & & - \\
\hline \multirow[t]{2}{*}{$\bullet$} & $0-17.8$ & $0.4 \pm 0.08$ & 50.7 & \pm 2.3 \\
\hline & Fnl dirt & $0.03 \pm 0.01$ & 1.3 & \pm 0.1 \\
\hline
\end{tabular}

Qce Fig. 38 for location.

IX. FINAL SITE CONDITION

The depression was fllled wth soll from a previous excavation of a trench approxdmately $300 \mathrm{~m}$ due east of the Building 12 site. A composite sample of this fill dirt contained $0.03 \pm 0.01 \mathrm{pCl} / \mathrm{g}^{238} \mathrm{pu}$ and $1.300 .1 \mathrm{pCl} / \mathrm{g}$ ${ }^{239} \mathrm{Pu}$. The site was graded to Its original natural contour, and the area was seeded with native grasses. The site, after grading and seeding, is shown in Fig. 33. 


\section{FIGURES}

1. General Tayout of DP Site West

2. View of plutonium processing facility

3. Floor plan of building DP-12

4. Side view of building 12

5. Side view of blower and filter area

6. Front view of Building 12

7. Preparing to remove stack No. 1

8. Blower room after removal of stacks Nos. 1,2 and 3

9. View of filter banks in 1945

10. Precipitron frame being rolled onto plastic sheeting

11. Precipitron frame being wrapped in plastic, ready for loading

12. Precipitron frame ready for hauling to disposal site

13. Details of roof construction

14. Details of floor and wall construction

15. Intake plenum after stripping and painting

16. Precipitron and filter area after stripping and painting

17. Interior of penthouse area after stripping and painting

18. Building 12 after corrugated siding had been removed from intake plenum wall

19. Ground-level view of penthouse area after removal of most of the walls and roof

20. Roof-level view of penthouse area, after removal of most of the walls and roof

21. Intake plenum after east wall was pulled down

22. Foundation for intake plenum

23. Removal of intake plenum floor

24. Precipitron and filter area after blower room and intake plenum were removed

25. Appearance of structural steel after attempt to pull down individual pieces

26. Cutting steel beams with welding torch

27. Loading steel beams onto truck for disposal

28. Precipitron area after most of the steel had been removed

29. Bulldozer removing concrete floor in precipitron area

30. Part of concrete foundation

31. Removing the last concrete and dirt 


\section{FIGURES (Cont.)}

32. Removing drain line

33. View of site after completion of demolition

34. Worker suited for demolition work

35. Location of demolition site and air sampling stations

36. On-site (TA-21) air sampler locations

37. Locations of soil samples taken underneath intake plenum

38. Locations of soil samples taken from cleared site 


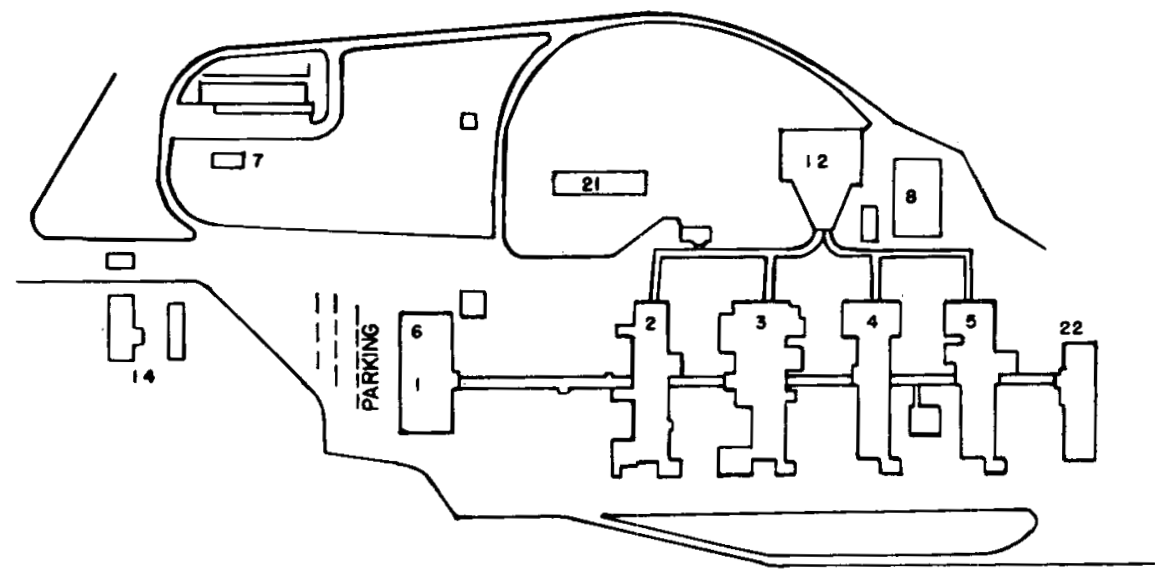

BUILDINGS

1. OFFICES O CHANGE ROOMS

2. ETHER EXTRACTION

3. OXALATE PRECIPITATION

4. FLUORINATION OF OXALATE

5. METAL PREPARATION a FABRICATION

6-11. PLANT SERVICES

12. FILTER BUILDING

13-22. PLANT SERVICES

F1g. 1. General layout of DP Site West.

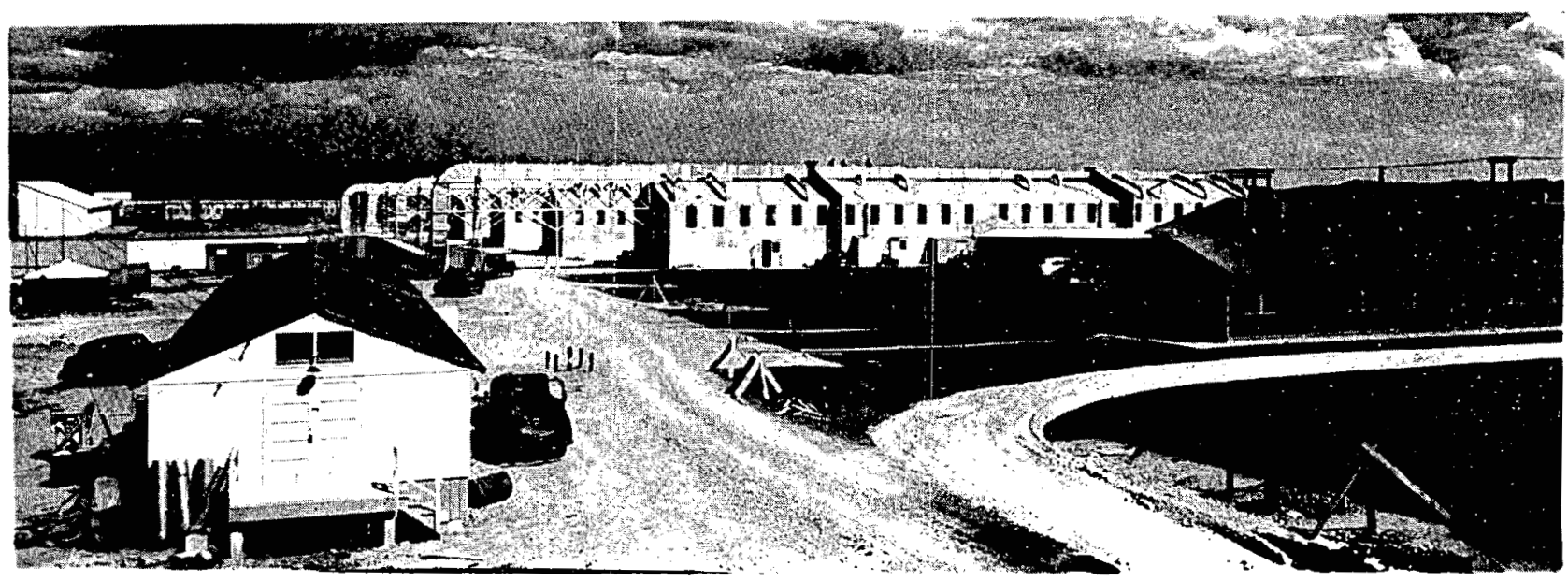

Fig. 2. View of plutonium processing facility.

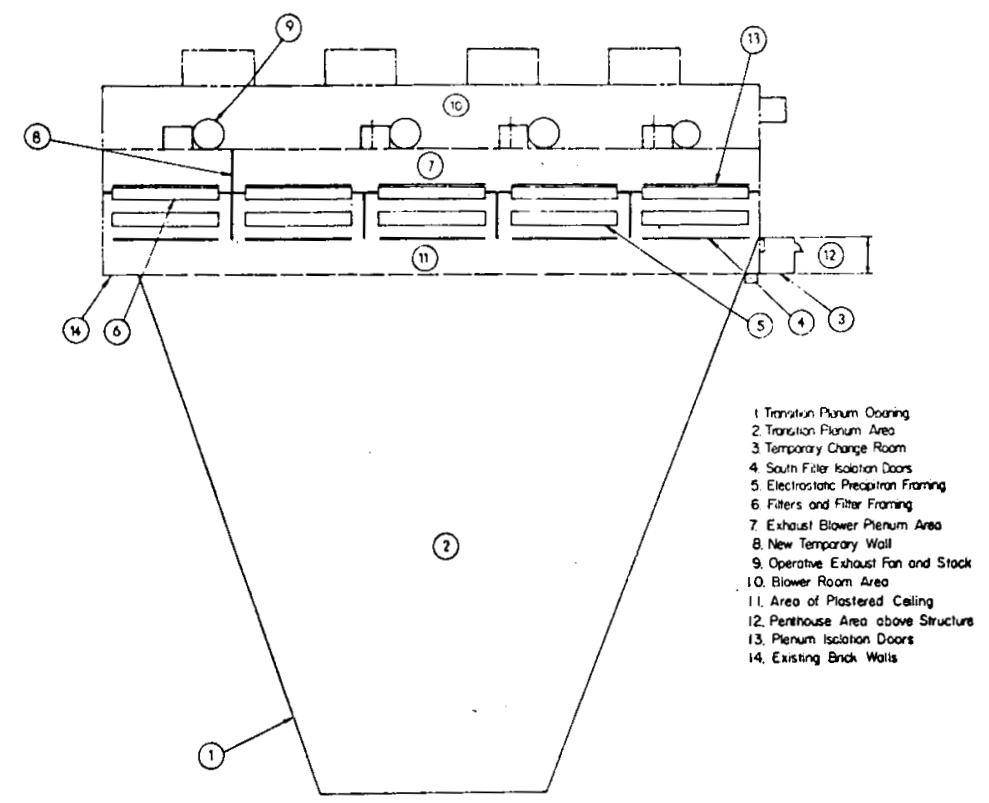

Fig. 3. Floor Plan of Building DP-12. 


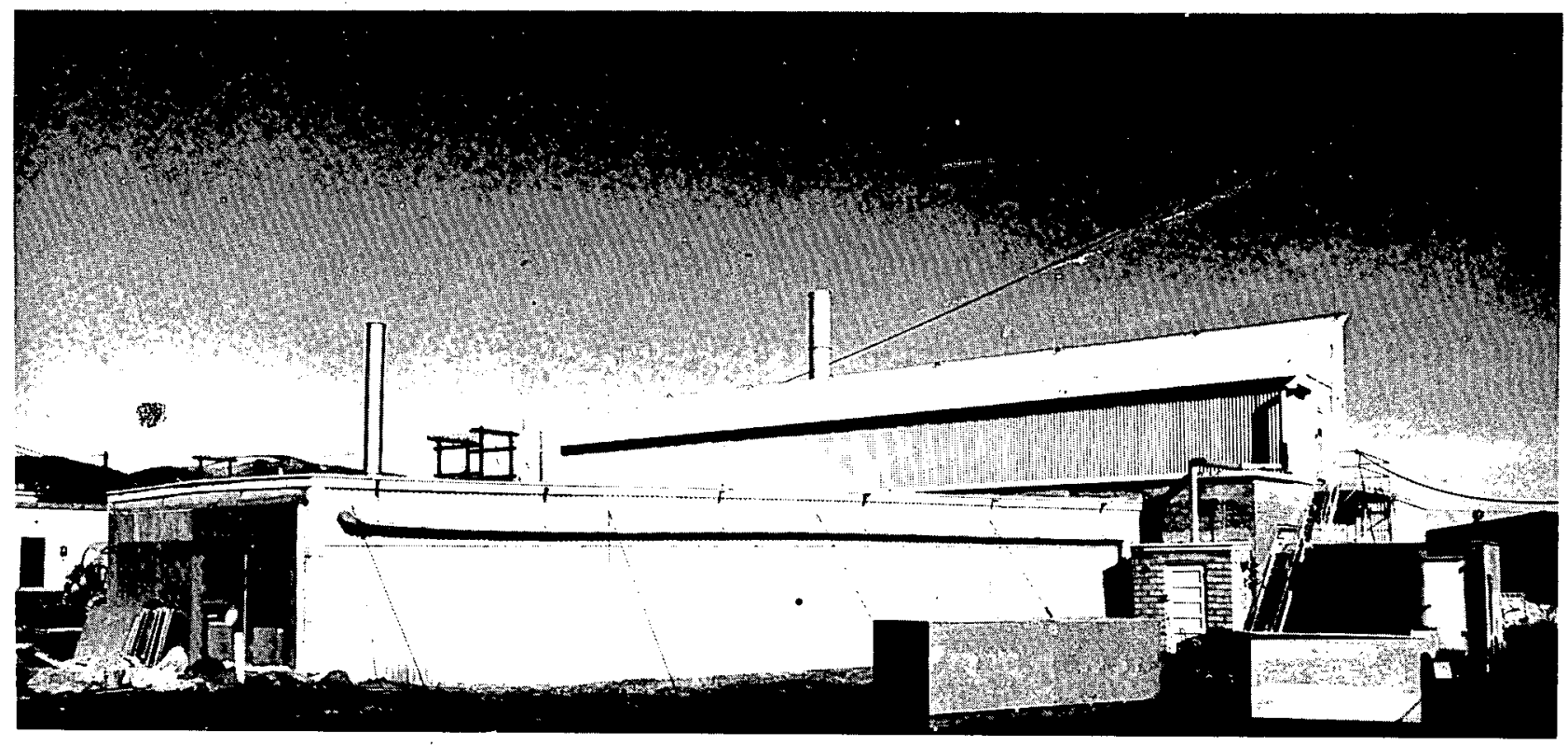

Fig. 4. Side view of Building 12 .

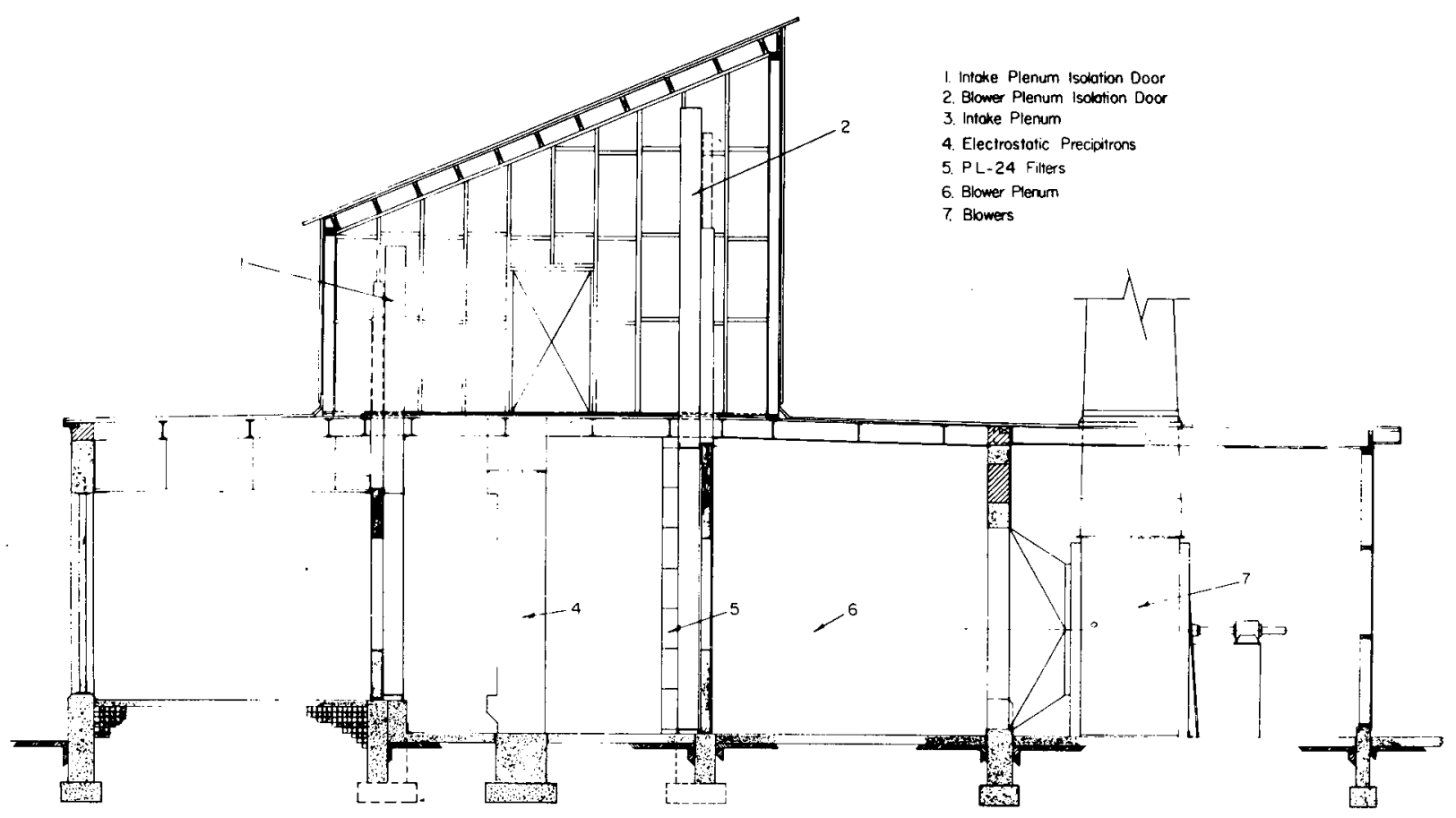

Fig. 5. Side view of blower and filter area. 


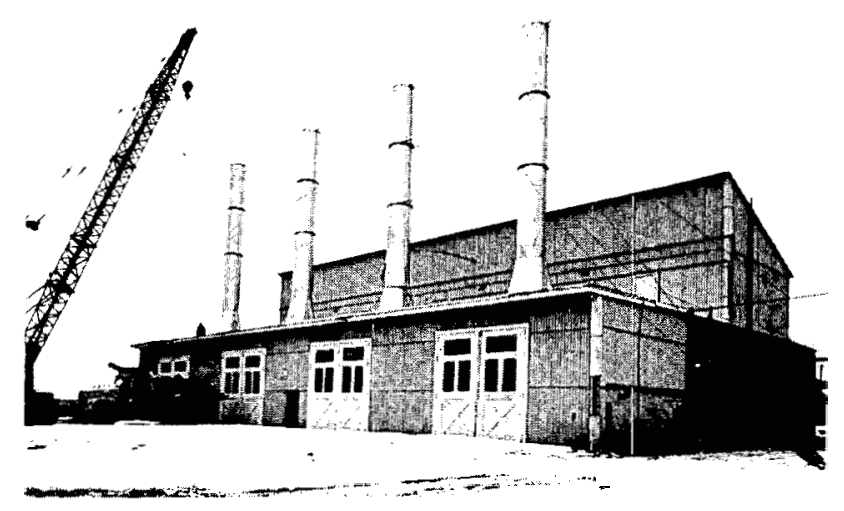

Fig. 6. Front view of Building 12.

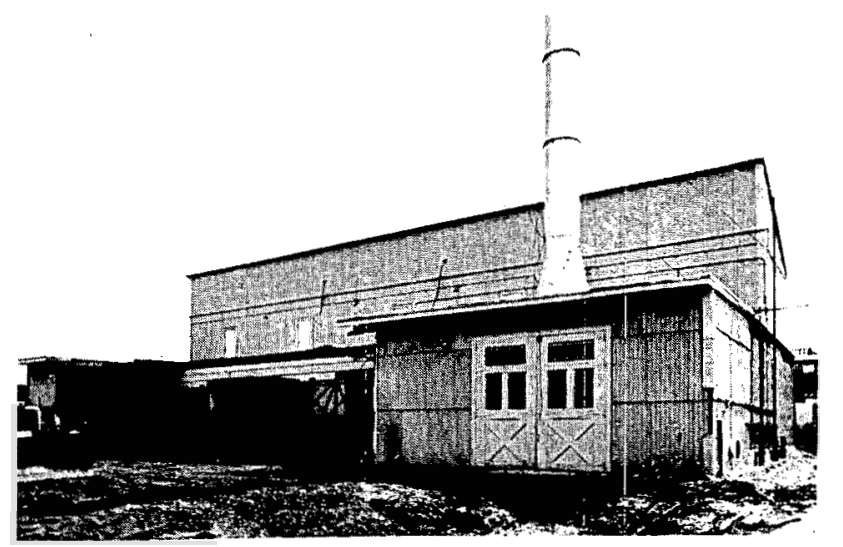

Fig. 8. Blower room after removal of stacks Nos. 1, 2, and 3 .

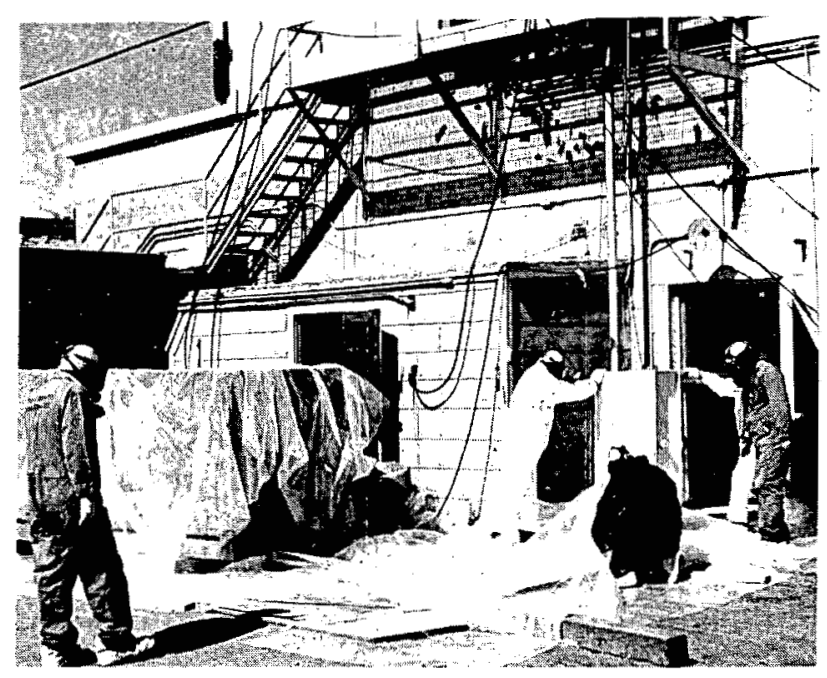

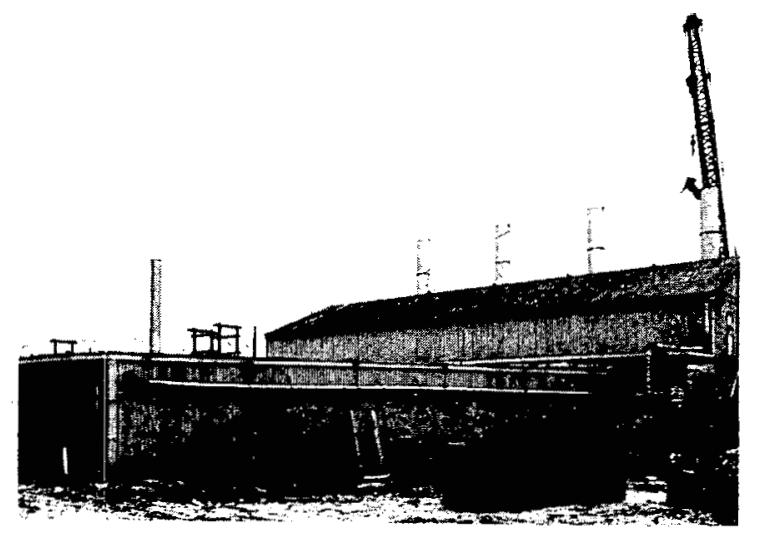

Fig. 7. Preparing to remove stack No. 1.

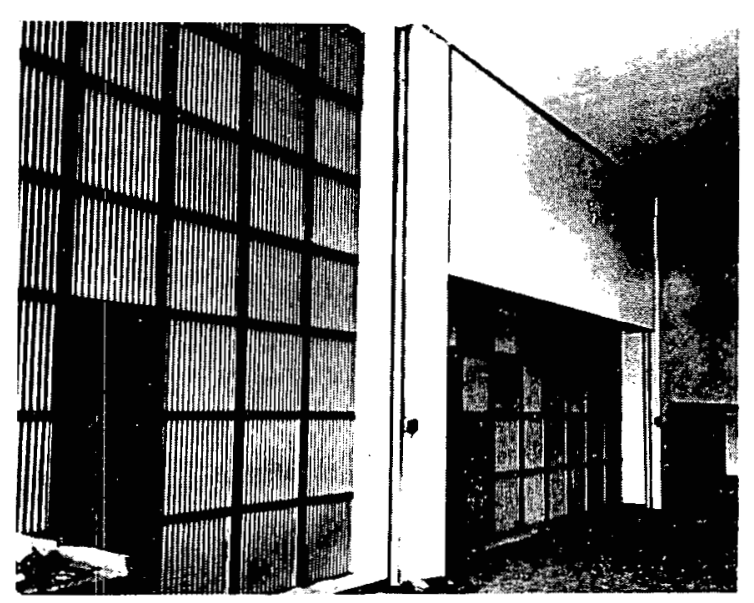

Fig. 9. View of filter banks in 1945.

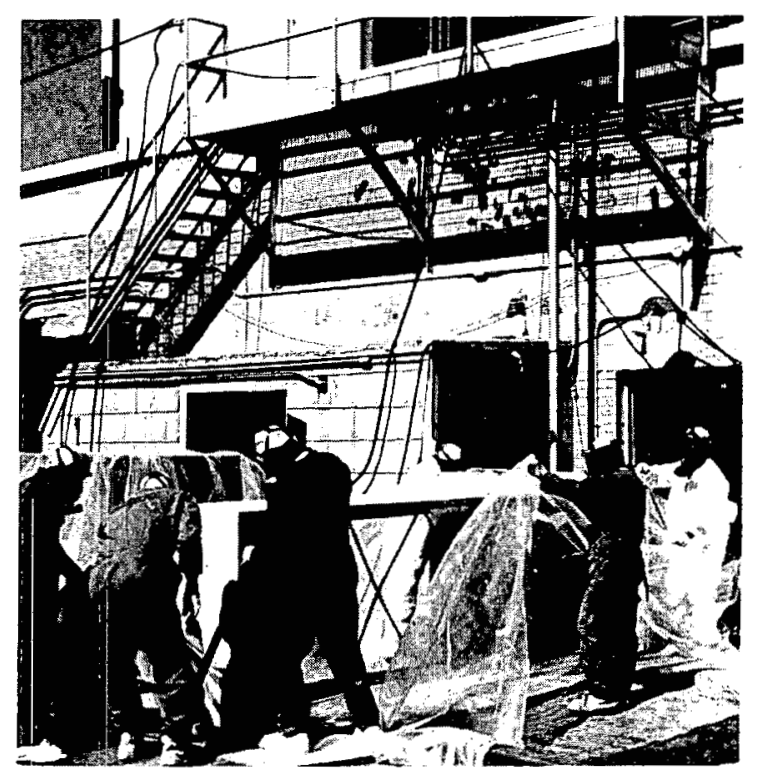

Fig. 11. Precipitron frame being wrapped in plastic, ready for loading. 


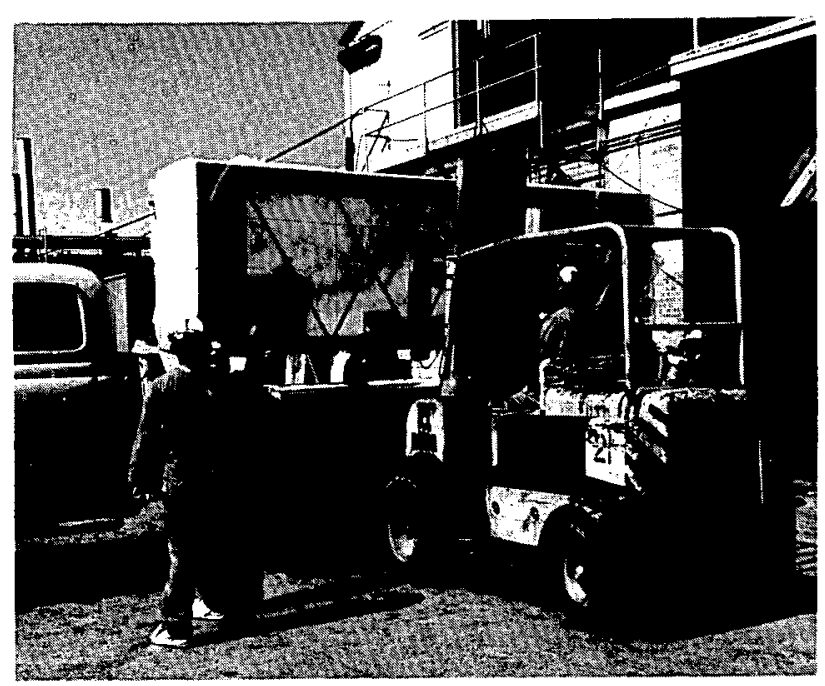

F1g. 12. Precipitron frame ready for hauling to disposal site.

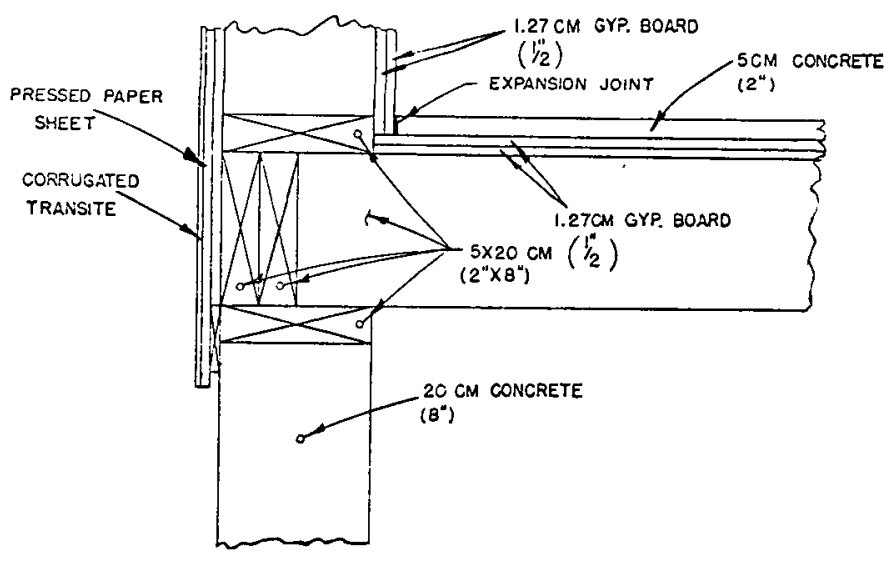

Fig. 14. Details of floor and wall construction.

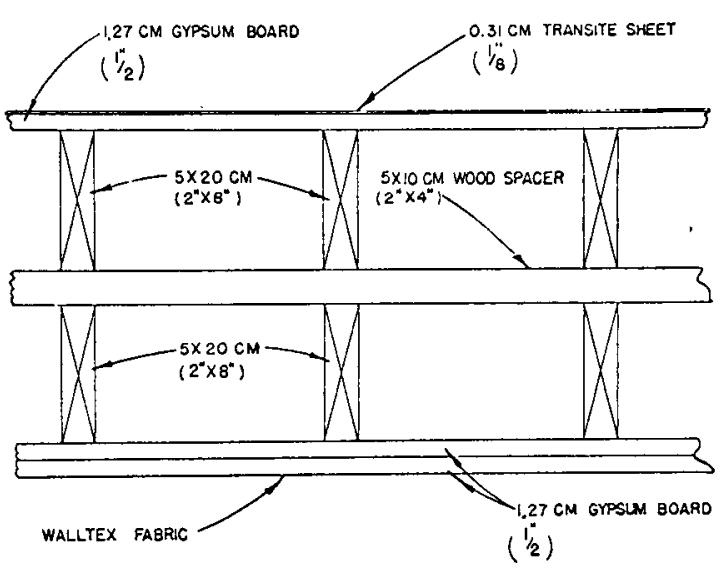

Fig. 13. Details of roof construction.

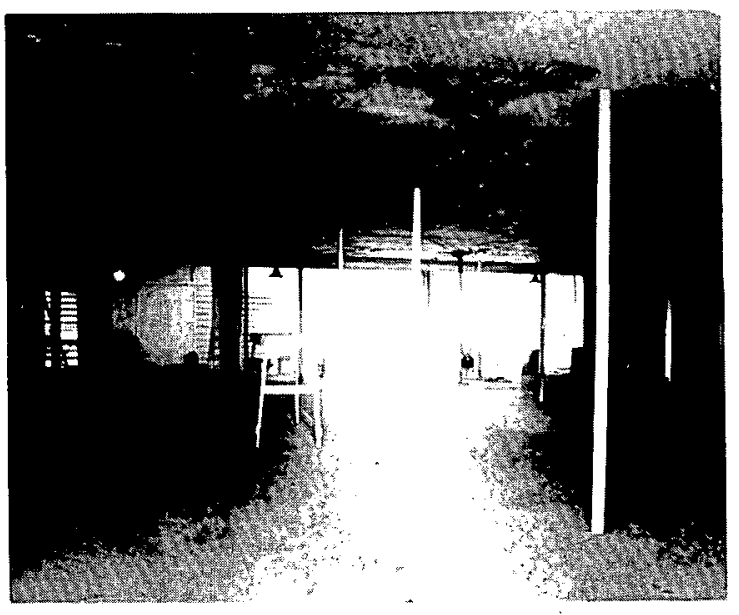

Fig. 15. Intake plenum after stripping and painting.

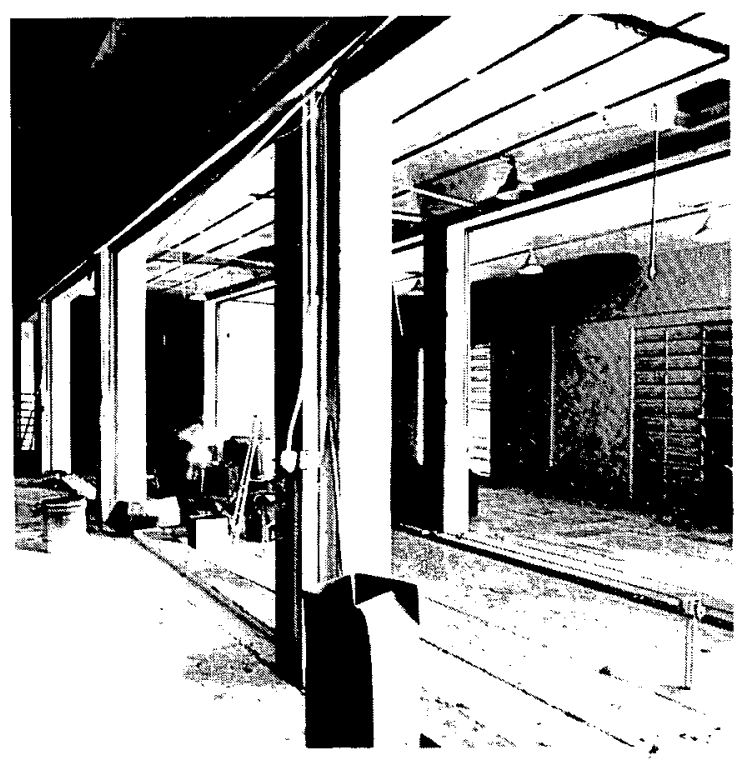

Fig. 16. Precipitron and filter area after stripping and painting. 


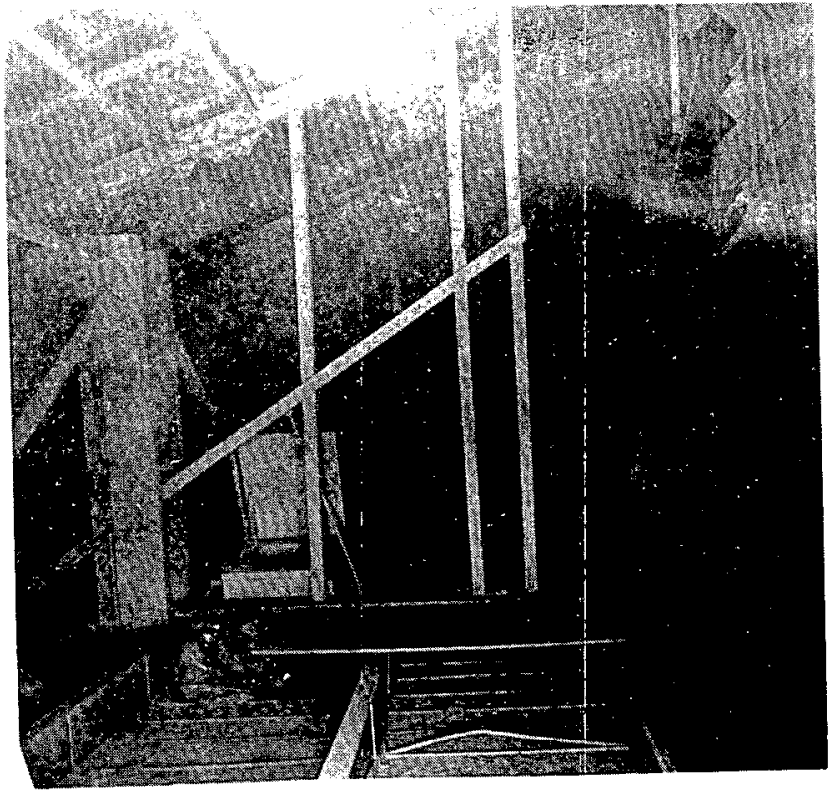

Fig. 17. Interior of penthouse area after stripping and painting.

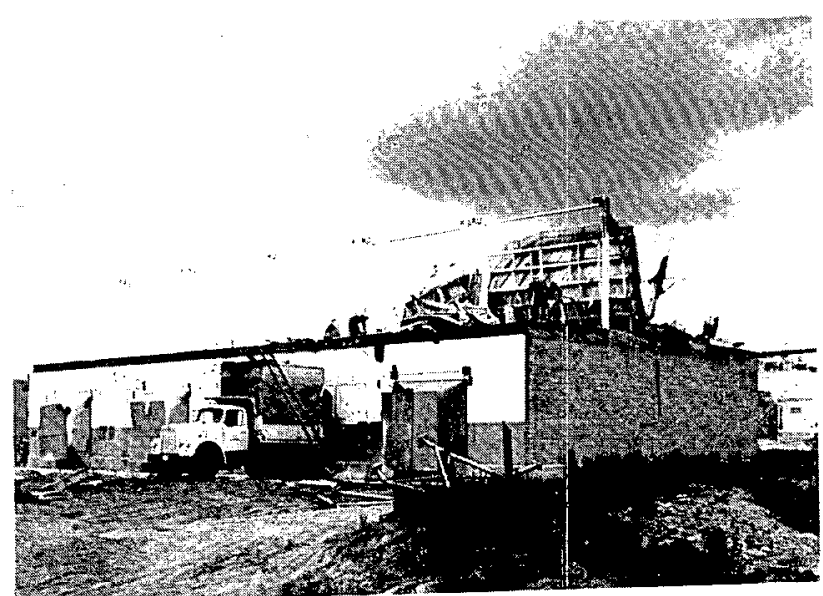

Fig. 19. Ground-Ievel view of penthouse area after removal of most of the walls and roof.
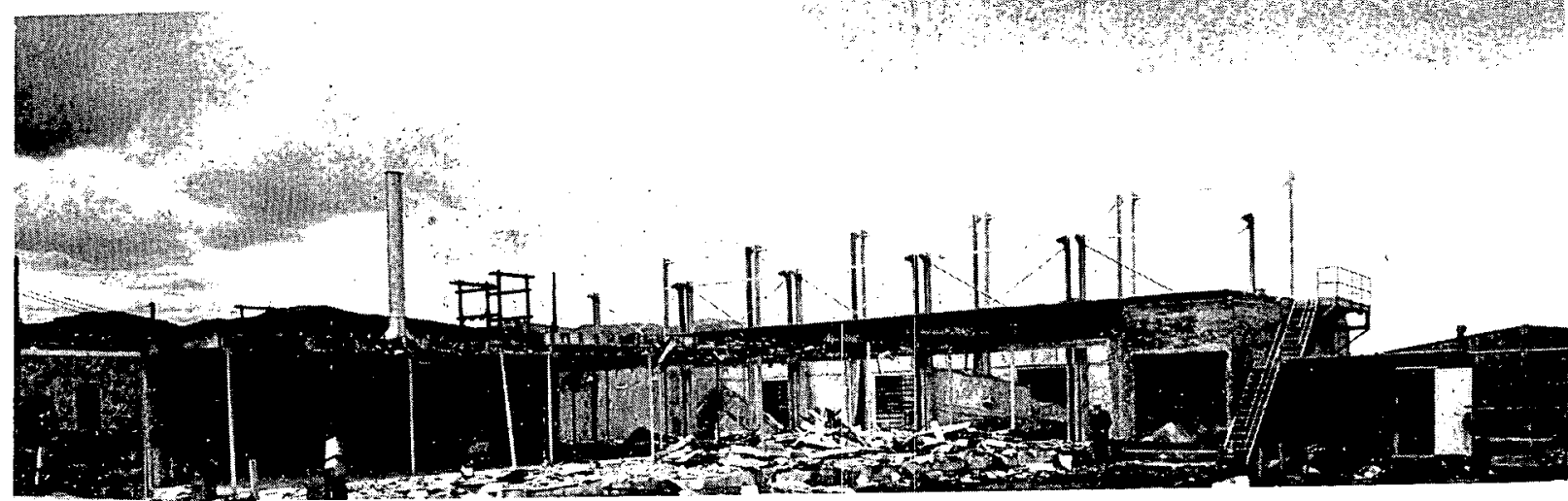

Fig. 21. Intake plenum after east wall was pulled down.

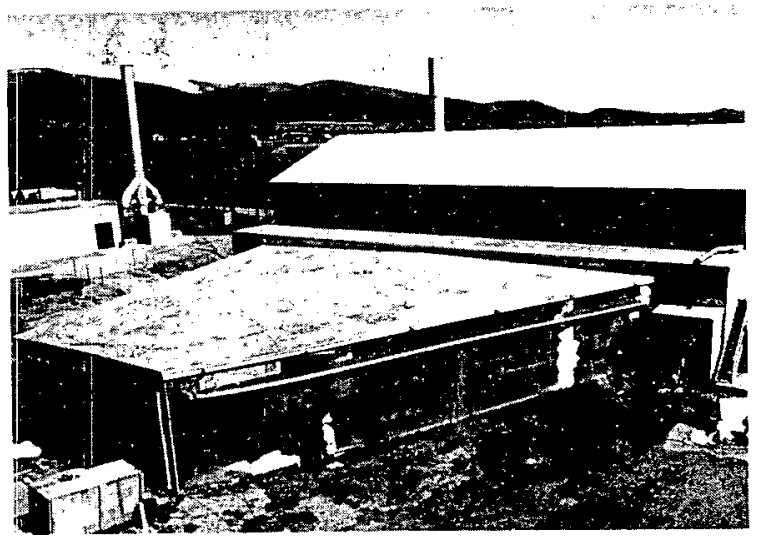
had been removed from intake plenum wall.

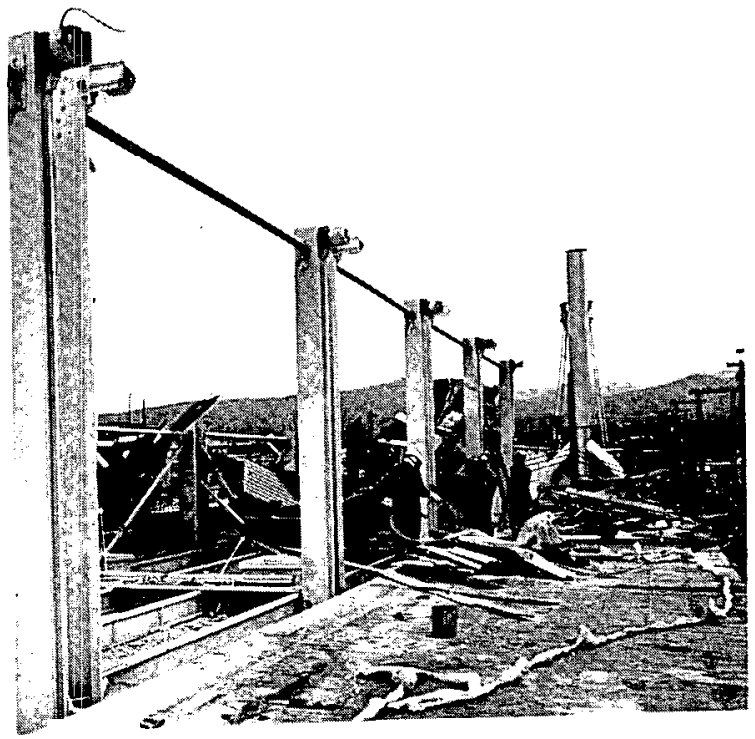

Fig. 20. Roof-level view of penthouse area, after removal of most of the walls and roof.

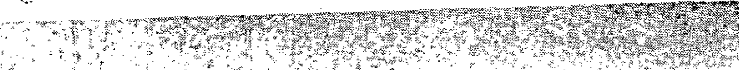

Fig. 18. Building 12 after corrugated siding 

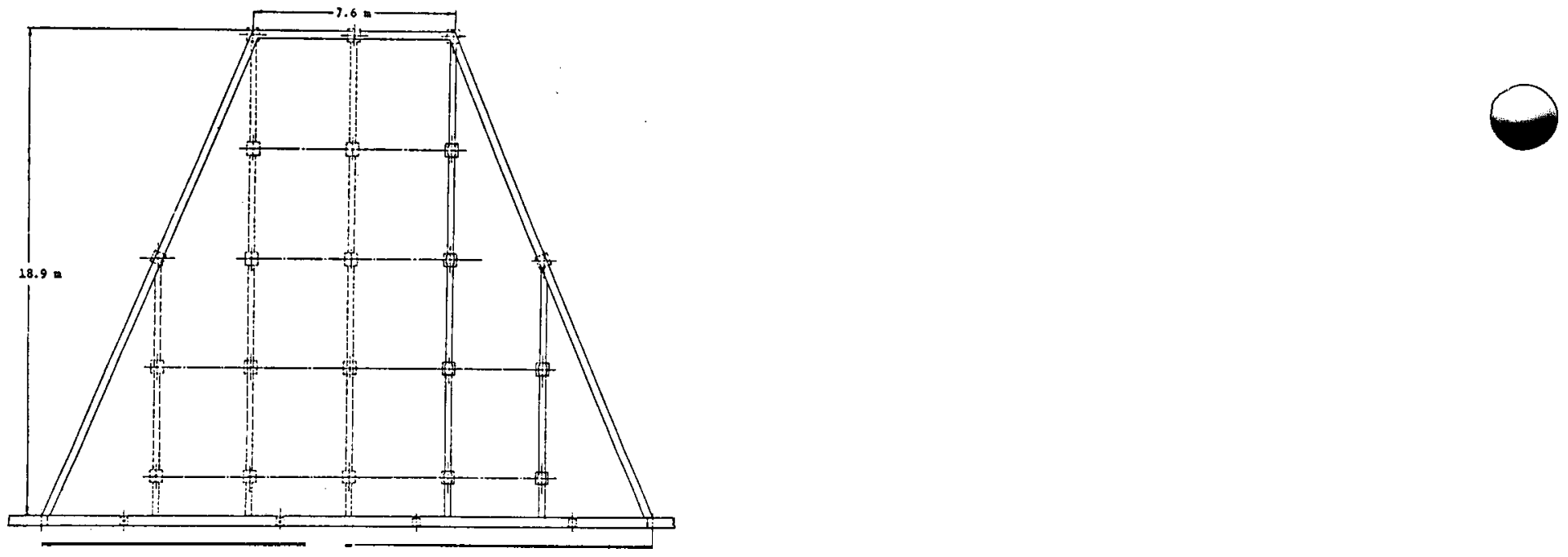

F18. 22. Foundation for intake plenum.

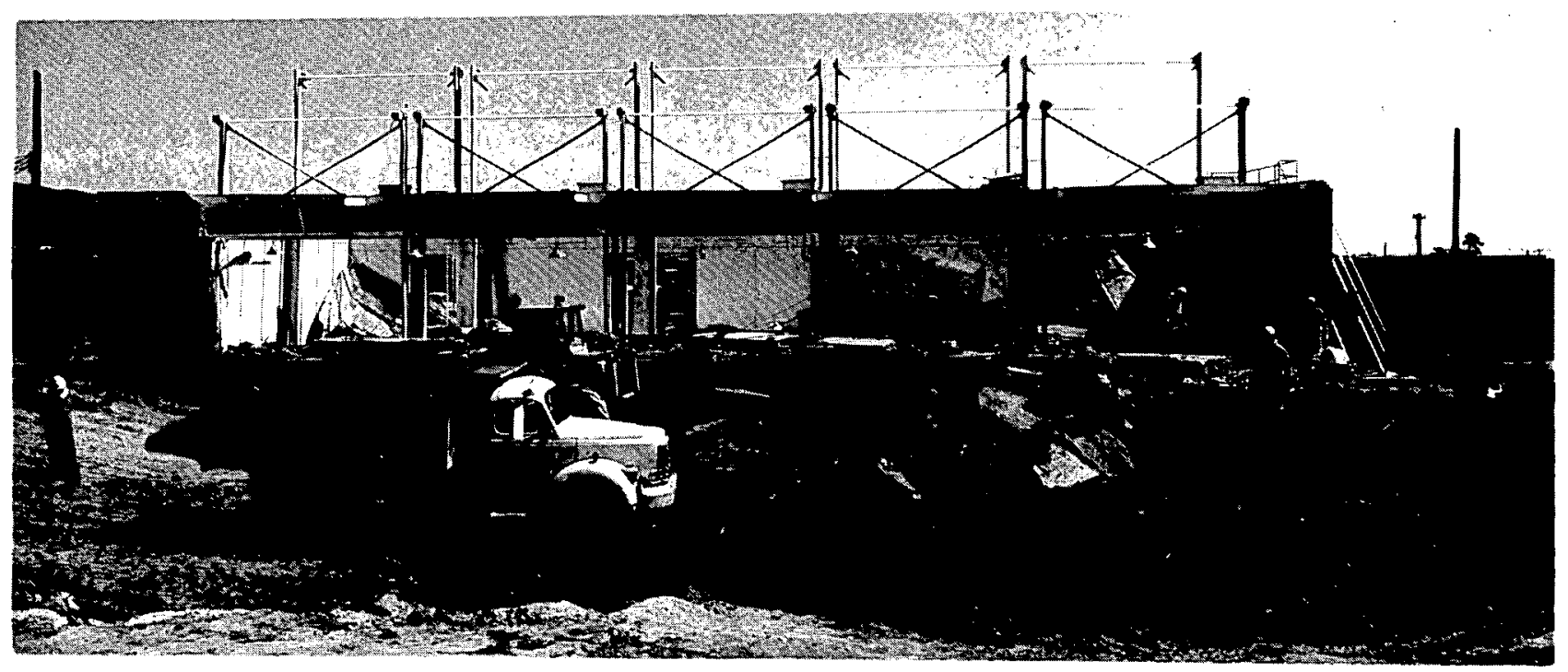

F1g. 23. Removal of intake plenum floor.

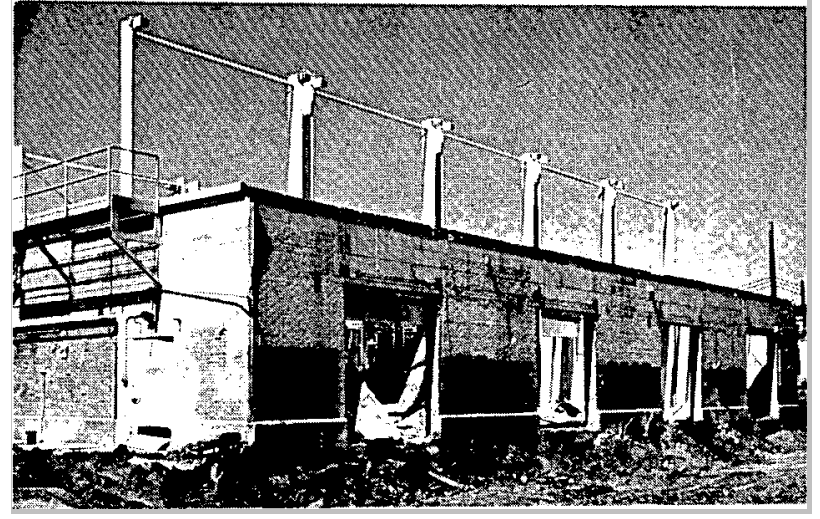

Fig. 24. Precip1tron and filter area after blower room and intake plenum were removed.

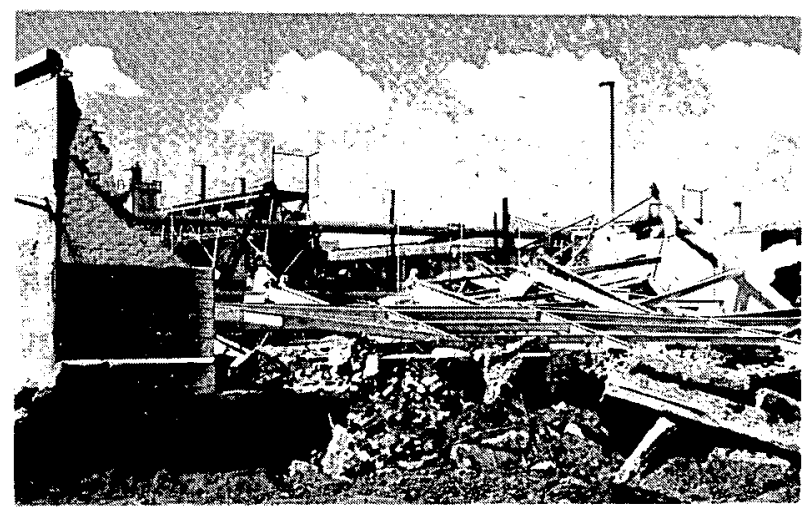

F18. 25. Appearance of structural steel after attempt to pull down Individual pleces. 


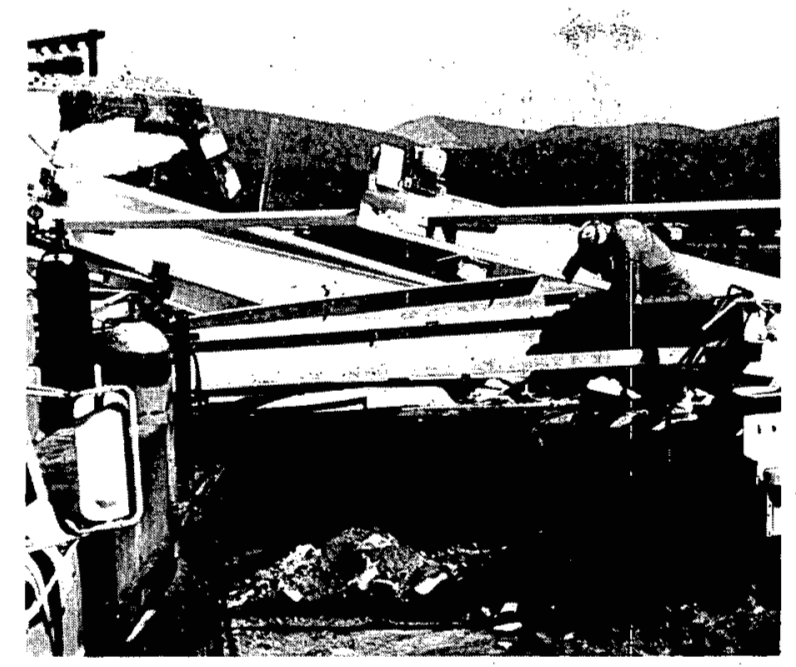

Fig. 26. Cutting steel beams with welding torch.

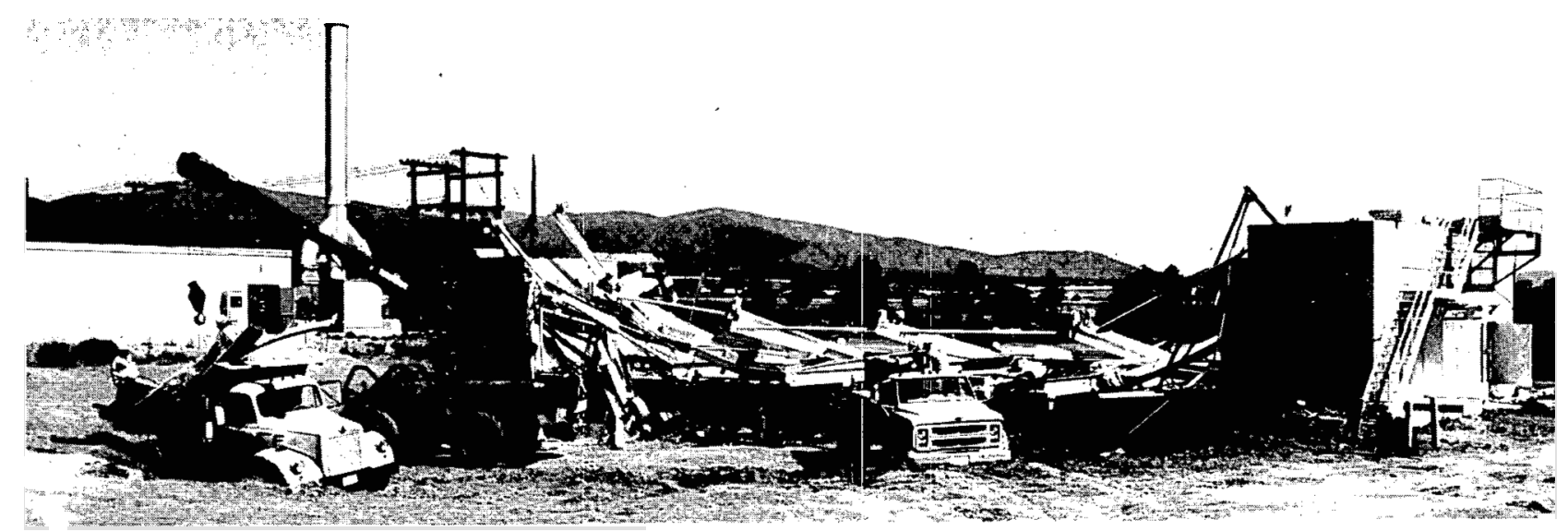

Fig. 27. Loading steel beams onto truck for disposal.

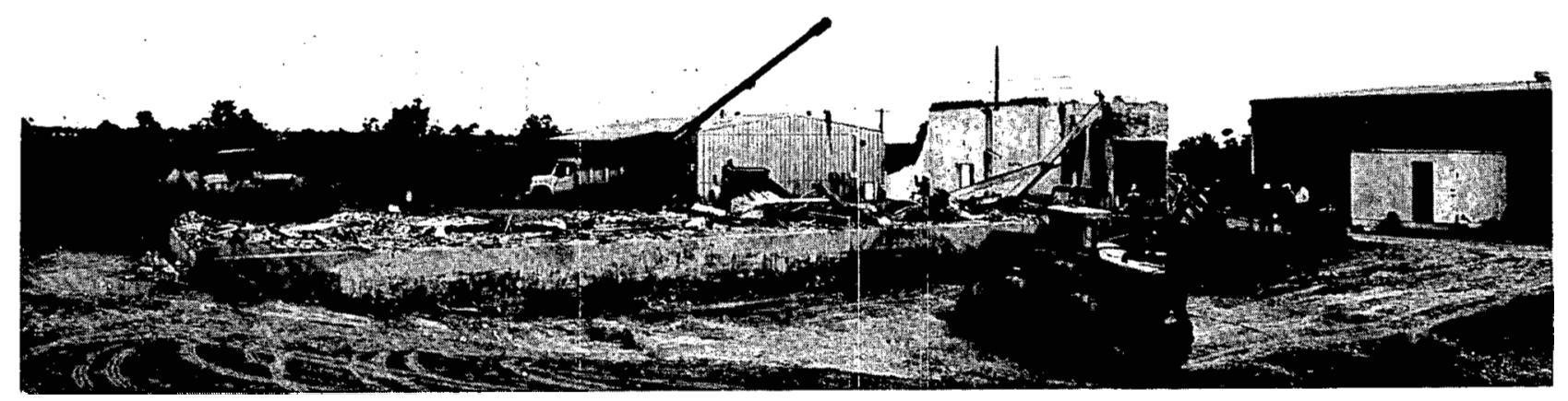

Fig: 28. Precipitron area after most of the steel had been removed. 


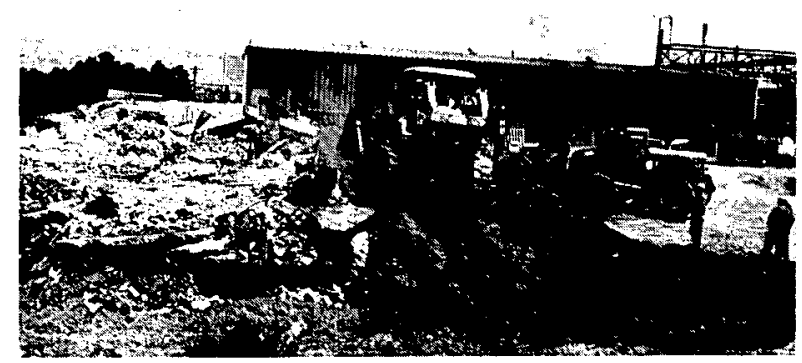

Fig. 29. Bulldozer removing concrete floor in precipitron area.

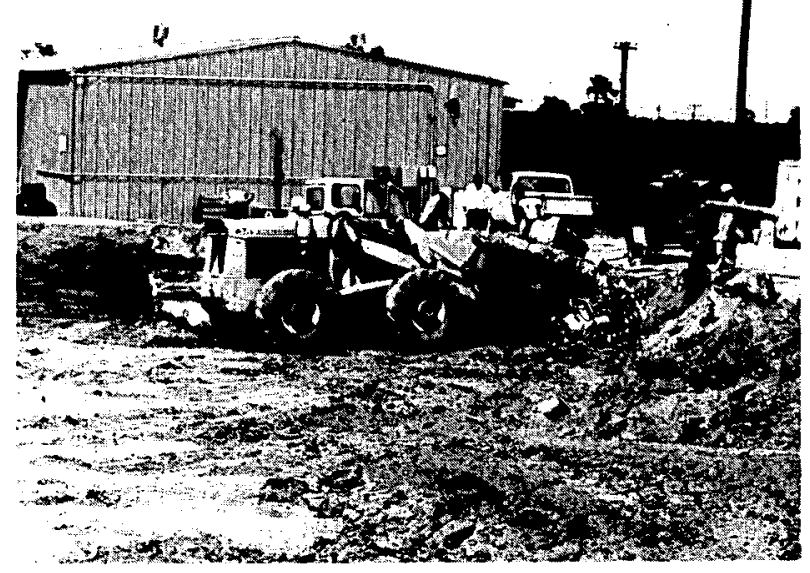

Fig. 31. Removing the last concrete and dirt.

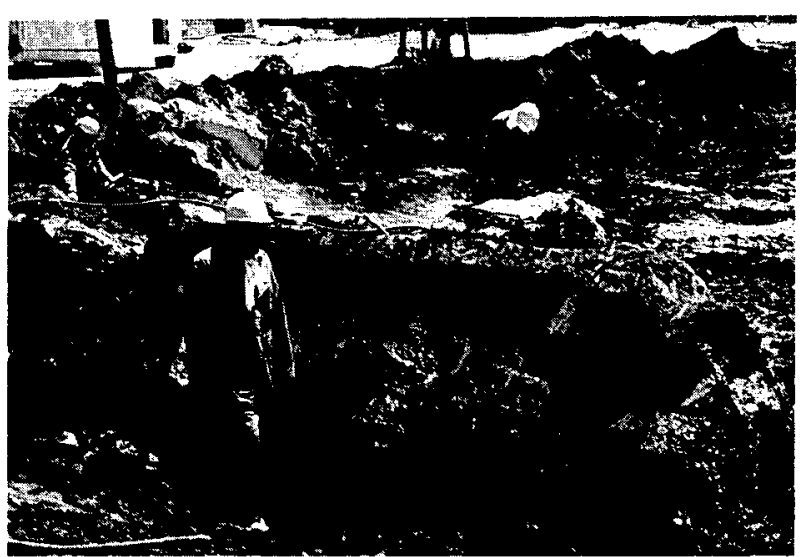

Fig. 30. Part of concrete foundation.

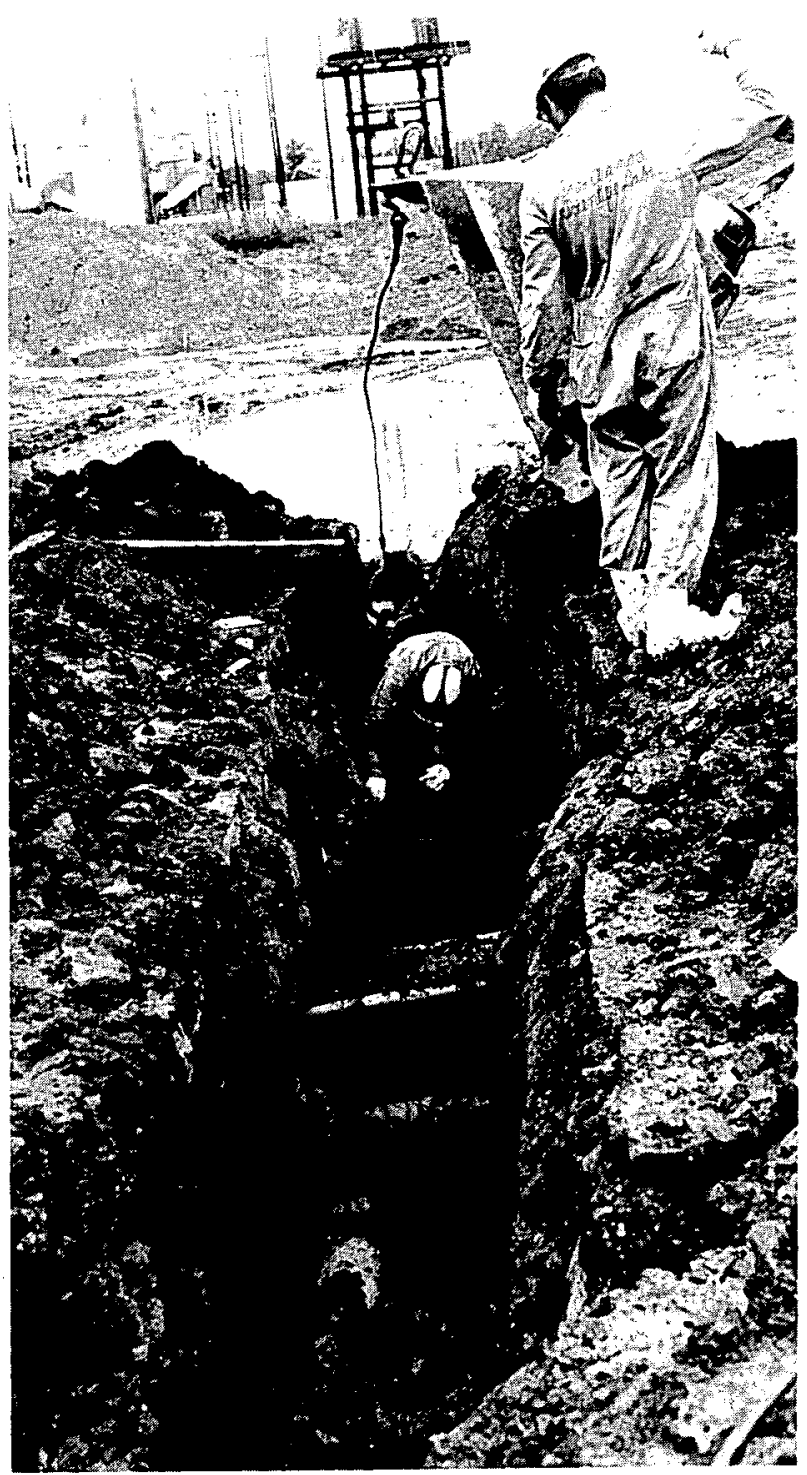

Fig. 32. Removing drain line. 


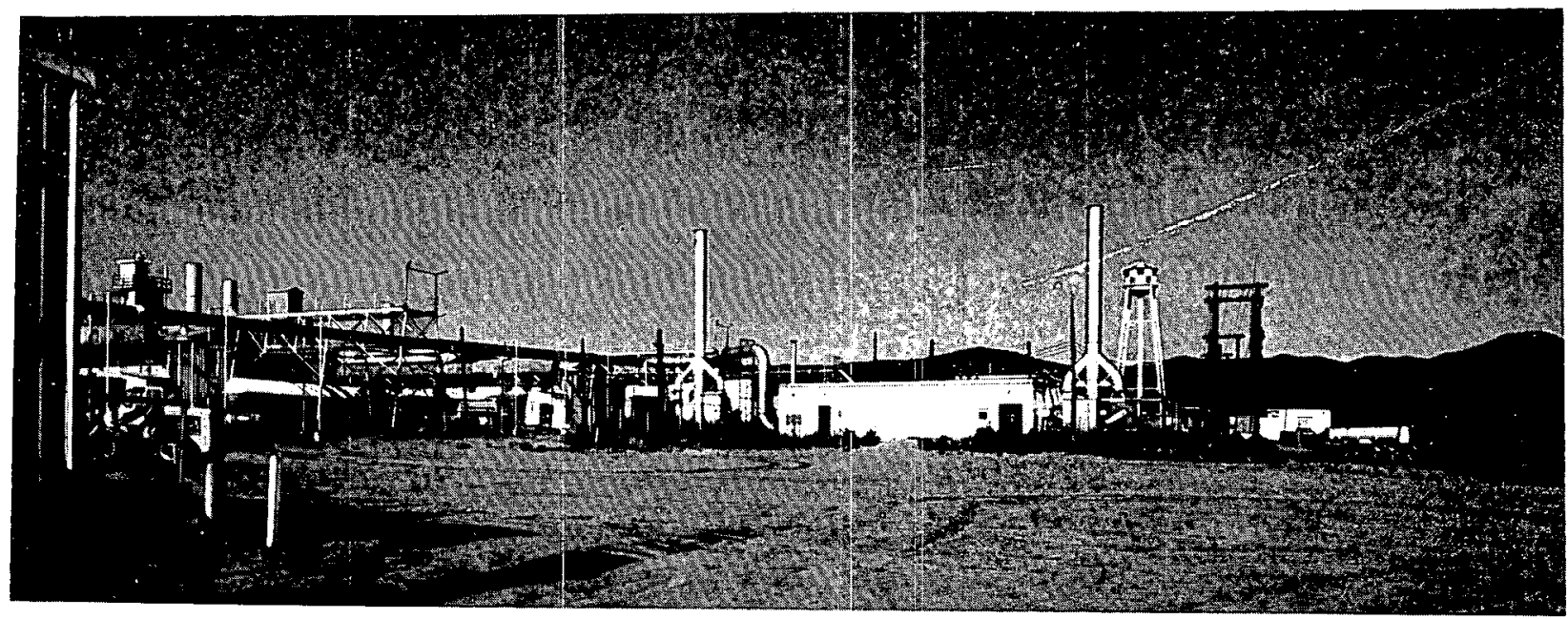

Fig. 33. View of site after completion of demolition.
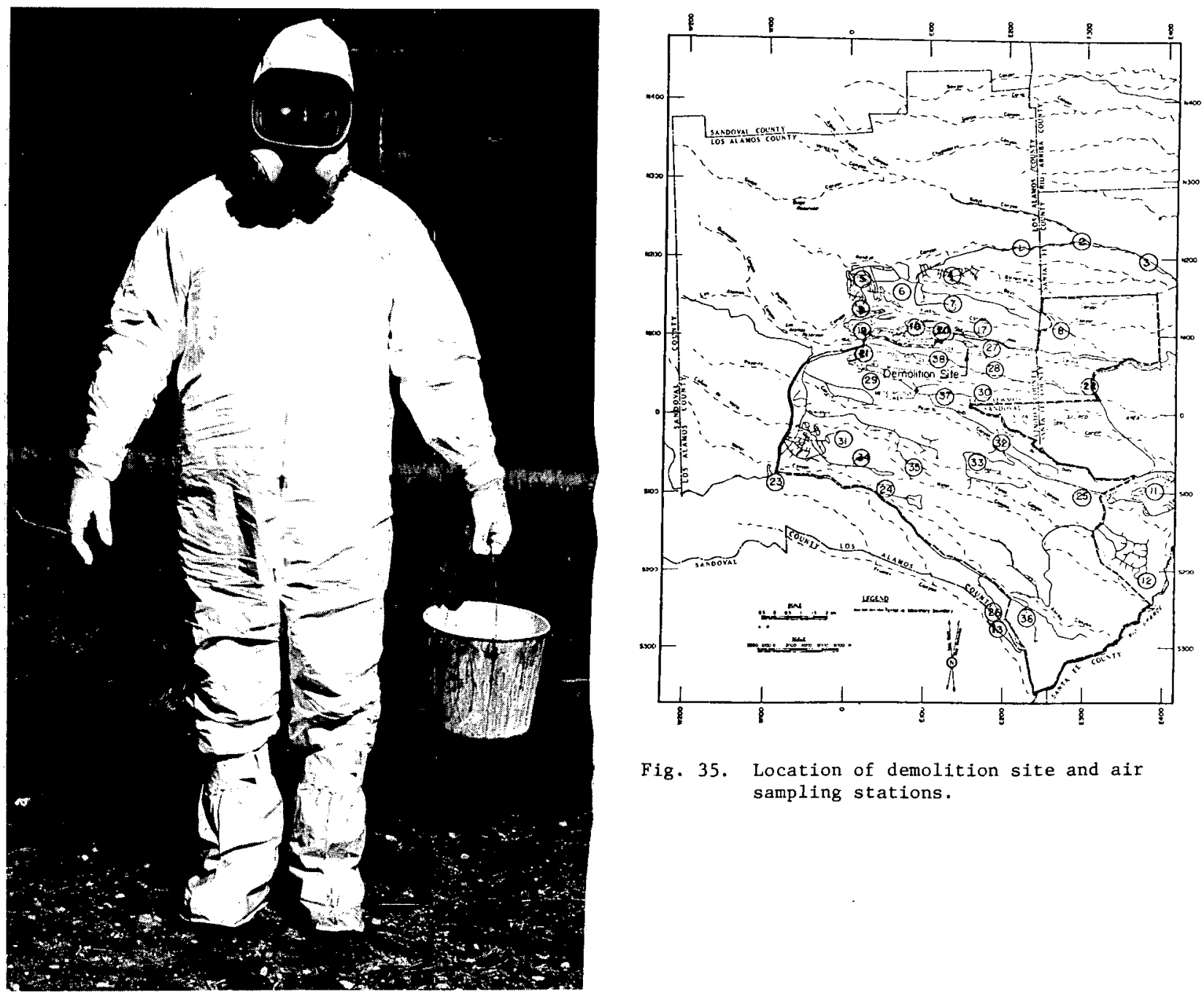

Fig. 35. Location of demolition site and air sampling stations.

Fig. 34. Worker suited for demolition work. 


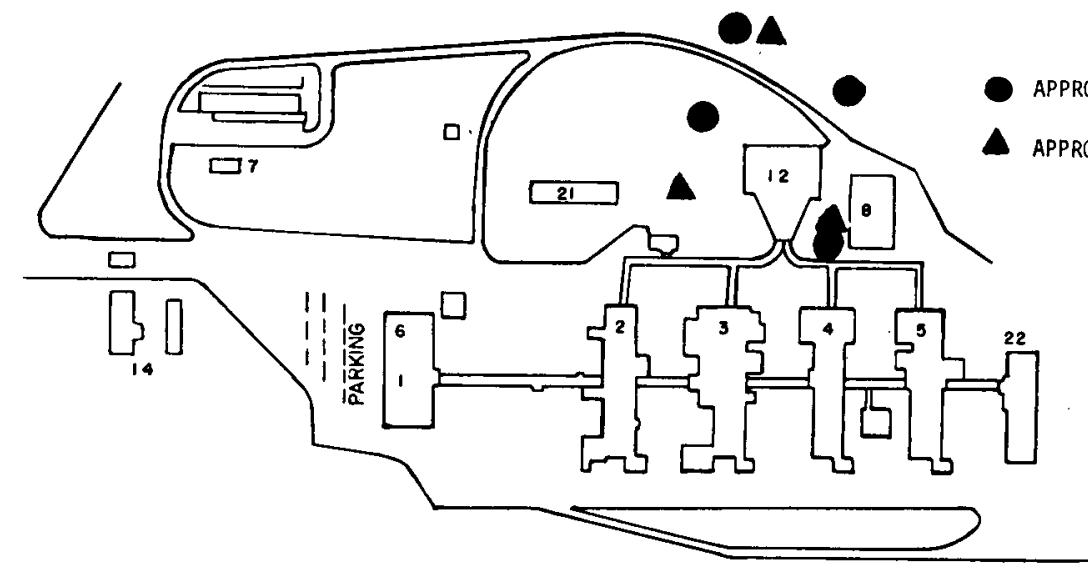

PPROXIMATE LOCATION OF INITIAL SAMPLING NETWORK

APPROXIMATE LOCATION OF FINAL SAMPLING NETWORK

Fig. 36. On-site (TA-21) air sampler locations.

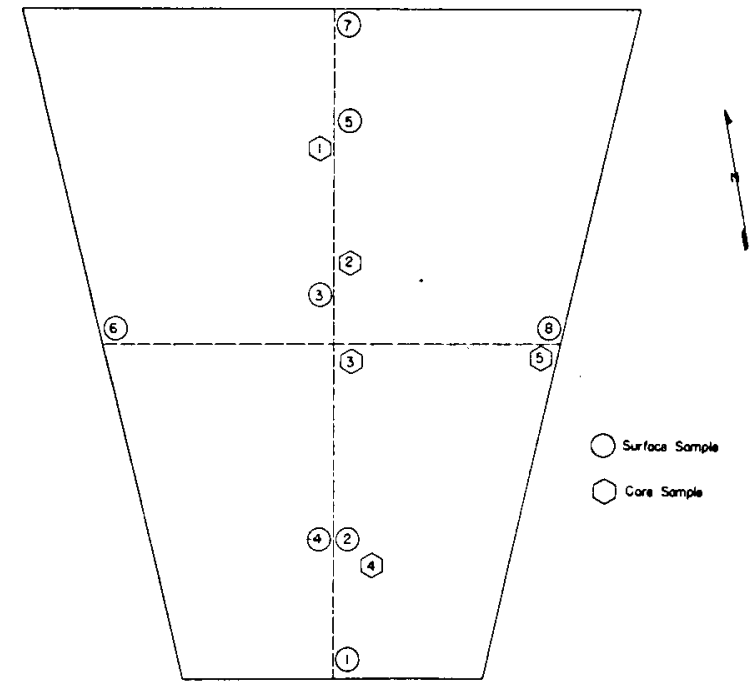

Fig. 37. Locations of soil samples taken underneath intake plenum.

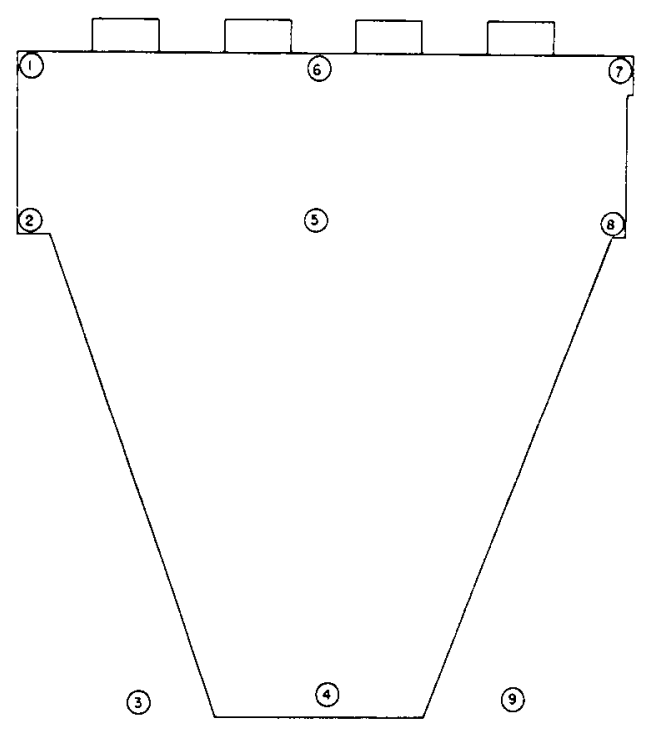

Fig. 38. Locations of soil samples taken from cleared site.

JJ : $373(130)$ 


\begin{tabular}{c}
$0^{2^{699}}$ \\
PROGRAM PLAN \\
FOR \\
DECONTAMINATION AND DECOMMISSIONING \\
THE \\
MATERIALS TESTING REACTOR \\
AT THE INEL \\
\hline
\end{tabular}

ABSTRACT

This paper discusses a program plan developed for the dismantling of the Materials Testing Reactor located in the Testing Reactor Area (TRA) of the Idaho National Engineering Laboratory. Included in the discussion are: The scope of work, dismantling problems resulting from the nature of construction of the MTR and a program plan for physically dismantling the reactor.

Thomas F. Jones

Aerojet Nuclear Corporation

Idaho Falls, Idaho 83401 


\section{SUMMARY OF PROGRAM STATUS}

Program plans for the overall dismantling of the Materials Testing Reactor Complex are still in the development stage. A general program plan has been prepared but will have to be expanded upon following the final decisions on all demolition techniques to be utilized. Cost, practicality, and radiation exposure potential will have to be considered prior to selecting the D\&D methods to be utilized. Preliminary cost estimates have been prepared but will have to be expanded upon to reflect the complications inherent in a contaminated and irradiated facility. Basic tooling designs are being developed, but exotic tool selection and procurement is precluded until decisions on demolition techniques have been finalized. 
The Materials Testing Reactor (MTR) is included on the list of facilities to be decontaminated and decommissioned (D\&D) at the Idaho National Engineering Laboratory (INEL). The Materials Testing Reactor actually consists of a number of interrelated facilities such as the MTR structure, the process water facility, the air discharge system including the stack, the two plug storage enclosures, and all interrelated primary and secondary reactor utility supply and discharge systems. This report deals only with the main reactor structure contained within the MTR 603 reactor building.

The MTR was a high flux, light water cooled reactor having the primary function of advancing reactor development for military and peace-time applications. It was designed to gain more information about radiation effects on construction materials, graphite fission product cross sections as related to the problem of breeding gain in power reactor work, and isotope production by second and third order neutron capture. This basic research was used to obtain physical, chemical, biological and engineering data.

The MTR achieved initial criticality in March of 1952 and reached ful 1 power in May, 1952. The power was increased to 40 mega watts in 1955 and operated primarily at that level until its final shutdown in 1970. Prior to the final shutdown, the reactor had accumulated 178,810 MWD of operating output. 
The main Materials Testing Reactor structure considered in this report is a 34 foot square facility centrally located in the MTR 603 reactor building. The main biological structure extends 24 feet above the main floor and 16 feet below it. The outer portion of the structure is high density concrete enclosed by a steel liner. In-bedded in this concrete are the structural supports, air ducting, water systems, reactor vessels and numerous experiment penetrations. Directly around the reactor core area is a graphite ball zone which in turn is surrounded by a solid graphite section approximately 14 foot square by 9 foot high. Enclosing the graphite on all sides are two 4 inch thick carbon steel plates which serve as thermal shields.

The entire reactor main structure including all of the aforementioned components will have to be dismantled and removed to appropriate storage areas. All precautions must be taken to insure that the MTR D\&D work does not adversely affect the existing operating facilities at the Test Reactor area. Every effort will be made to retain the integrity of the MTR 603 building so that it can be remodeled for future use. 
D\&D PROBLEMS

The MTR has many dismantling problems not present in most conventional power reactors. Of major consideration is the proximity and interrelated nature of the two operating test reactors at TRA. Total isolation of all MTR Systems that might adversely affect the operation of ETR or ATR must be insured. Any use of explosives will require studies to limit ground shock and air blast problems.

The presence of graphite both in solid form and balls near the core lattice poses some interesting problems. In the dismantling process, the carbon dust must be contained both to insure that nuisance dust levels do not exceed industrial hygiene limits and that carbon fourteen $\left({ }^{14} \mathrm{C}\right)$ emissions stay within the AECM 0524 guide concentrations. Although ${ }^{14} \mathrm{C}$ is not anticipated to be a problem according to calculations, an analysis of the graphite balls will be required to substantiate the actual maximum levels of ${ }^{14} \mathrm{C}$ that will be received.

Combustibility of the graphite balls and dust in either dismantling with plasma cutters or explosives must be considered. This problem is complicated by the Wigner Effect, the increase in stored energy in crystiline lattices due to neutron bombardment, which in effect lowered the combustion temperature of the graphite balls for self-sustained combustion from $820^{\circ} \mathrm{C}$ to $750{ }^{\circ} \mathrm{C}$. Removal of the graphite balls and spraying the resultant cavity with a non-flamable fixative prior to the addition of an external heat source will eliminate this problem to a great extent.

Other problems of limited scope are the numerous experiment penetrations into the biological structure, the interlacing of utility systems through the concrete, the remote location of the canal, and the contamination problems resulting from numerous past fission breaks. Many of these problems are counter balanced by the location of a contaminated storage site at the INEL and by the number of trained personnel available to call upon if the need arises. 
For planning purposes, the dismantling of the Materials Testing Reactor structure has been divided into two major tasks, each having a number of work packages under them. Task I consists of preliminary preparation work including the removal of some easily retrievable components. Task II deals primarily with the general demolition. Final decontamination and building renovation will not be dealt with in this report. The following listing shows the various work packages in their task groupings:

TASK I :

W.P. 1. Remove In-Tank components

W.P. 2. Remove Graphite Pebble Shielding

W.P. 3. Remove Reactor Vessel Tanks Band C

W.P. 4. General Preparation and Isolation

TASK II:

W.P. 1. Prepare Sub-Pile Room

W.P. 2. Remove Vessel Tank $D$ and Top Section of E Tank

W.P. 3. Remove Reactor Vessel Tanks $A$ and the Remainder of $E$

W.P. 4. Removal of Experiment Penetration Inserts

W.P. 5. Stage Demolition of the Biological Shielding

Prior to the physical removal of any portion of the MTR, a program plan must be developed and approved for the specific task being considered. Included in this plan will be the technical planning, health and safety requirements, equipment requirements, schedules, and cost estimates.

Detailed sequencing proceedures will have to be developed to insure that the $D \& D$ problems are 1 imited to the greatest extent possible.

The over-all planning of work can be diminished by removing various reactor components in stages. After removing the core components and retrievable in-tank items, an exact radiation mapping can be obtained to determine what methods are to be ultimately utilized to remove the imbedded tanks. Samples taken during the removal of the graphite pebbles will indicate whether or not carbon fourteen is going to pose a problem. 
The removal of the in-tank components can be accomplished in approximately four months at a current operating cost of $\$ 100,000$. The work involves

tool fabrication and removal of the following:

A-Tank Extension

Existing Experiment Tubes

Thermocouple Ring

Inner Shielding Ring

Spider Support Ring

Loose Components Adjacent to Core

Upper Support Casting

Skirt Plates

Beryllium Reflector Components

Lower Assembly Grid

Lower Guide Grid

Shock Absorbers

Monitor Tubes

Components having cross sectional dimensions three inches by three inches or less can be discharged to the canal through the discharge chute.

Larger items will have to be removed over the top of the reactor in transfer casks. Personnel shielding during removal operations will be provided by maintaining a maximum practical water level in the reactor vessel.

Work package two of Task I covers the removal of the araphite pebble shielding. These balls will be dumped into plastic lined steel barrels through the two pebble discharge chutes in the reactor basement. Dust emissions during discharge will be controlled by utilizing a double containment bag out system and by providing a negative pressure at the discharge nozzle with the existing reactor air system.

Following the in-tank component removal and the graphite pebble discharge, the reactor vessel water level can be lowered for the removal of the B-Tank and the C-Tank. The B-Tank is a 2' 2" high 345 stainless steel vessel having an outside diameter smaller than the inside diameter of the A-Tank. After unbolting it from both the A-Tank and the C-Tank, the entire $B-T a n k$ section can be removed through the top of the reactor vessel. The B-Tank will have a reading of about 400 millirem per hour, thus allowing 
it to be sealed at both ends and then transported as its own shipping container.

The C-Tank is an aluminum-25 structure having a height of $4^{\prime} 3 \frac{11}{2}$ and an outside diameter equal to that of the B-Tank. After unbolting it from the D-Tank, it can also be removed through the A-Tank as one unit. Radiation should be insignificant but contamination on the outer portion of the tank may pose a problem because of the tanks interface with the graphite balls. Again the vessel could serve as its own shipping container by placing it in a Nucon sleeve.

General preparation consists of terminating existing electrical, instrumentation and mechanical service systems to the reactor and biological shield. Temporary services as required for the D\&D activities will be installed. Components adjacent to the reactor structure but not vital to reactor dismantling will be removed. Al1 contaminated and irradiated trash items stored in the canal will be hauled to the RWMC for disposal. Filtering systems will be installed in the air exhaust system as required to minimize the spread of contamination.

Existing accesses to MTR-603 will be sealed and a manway access installed to provide isolation of the work area. The reactor structure may be siesmically isolated from the ground floor to minimize interference with adjacent operations as a result of blasting.

By modifying the sub-pile room, the rubble of demolition can be dropped through the reactor vessel cavity into containers at the MTR basement floor level. The filled containers can then be sealed, wheeled out of the subpile room to the north, lifted through a hatchway in the floor, placed on a truck, and hauled to the Radioactive Waste Management Complex for disposal. Sub-pile room modification consists of filling in the canal under the reactor structure after decontamination, removing the canal parapet walls, repairing the sub-pile room floor, and making a new equipment access door in the north wall to permit transfer of the debris containers.

Numerous experiment liner attachments were built into the D-Tank. The six horizontal beam penetrations consist of $6^{\prime \prime}$ diameter thimbles made out of 
extruded aluminum. The tank is also pierced by two bars containing the pneumatic rabbit holes ( $H R-1$ and $H R-2)$ and by the horizontal through hole facility (HT-1). Horizontal rabbit tubes (HR-3 and HR-4), horizontal graphite facilities ( $H G-5, H G-6$, and $H G-9$ ), and six down beam liners are also attached to sockets on the outside of the tank. A remotely operated plasma-arc torch or explosive internal pipe cutters will be used to separate these attachments from the D-Tank.

The D-Tank constructed out of aluminum-25 and the upper portion of E-Tank, a stainless steel 304L vessel, will be removed down to a horizontal plane just above the top of the upper thermal shield. Explosive shape charges or a plasma-arc torch will be used to section the tanks.

The A-Tank, a 304-L stainless steel vessel, is firmly imbedded in the biological shield. In addition to being entirely surrounded by high density concrete, it has four large fins protruding into the biological structure on the NE, NW, SE and SW sides. There is also a large imbedded steel shielding ring surrounding the top of the A-Tank. Two 24" process water lines enter the A-Tank from the north and the south.

The lower two-thirds of the E-Tank is also firmly imbedded in the biological shield. It is penetrated by the two 24 " process water lines on its south and north sides. Attached to it are four 2" thick imbedded ribs on its NE, NW, SE and SW sides. The 4" thick lower thermal shield ring and a 4" thick lower flange are welded to the outside of the E-Tank wal1. The E-Tank proper is a 2" thick 304-L stainless steel vessel.

The exact method to be utilized in removing the imbedded portions of these tanks has not been determined at this time. Possible considerations are as follows:

1. Explosive Cutting

2. Milling Exposed Portions of Tank

3. Plasma-Arc Sectioning

4. Removal of Tank Sections following Removal of Surrounding Biological shield 
The bottom plug will have been removed prior to the removal of the $A$ and $E$ Tanks. For removal, it can be attached to the overhead crane by two existing eyebolts, unbolted from the bottom, and then lowered.

The MTR Reactor biological structure is interlaced with 105 various experiment penetrations. Of these, 30 are horizontal penetrations, 69 are vertical and 6 are downbeam penetrations on a 30 degree slant. The bulk of these penetrations have inserts in them in the form of imbedded chambers. Prior to dismantling the biological shielding around the reactor vessels, it would be advisable to remove as many of the chambers as is economically and physically feasible. By removing these chambers, a great deal of the contamination build-up in the penetrations can be removed, thus limiting the contamination control problems inherent in the demolition of a reactor structure.

The demolition of the biological shielding includes sectioning and removing of all imbedded structural supports, piping, conduit, thermal shields, experiment liners, air ducting, permanent graphite blocks, and the high density barytes concrete shield. The stage demolition will progress from the top downward and from the reactor vessel center line outward.

Stage I:

Top of structure at 120' 6" elevation to $115^{\prime} 0^{\prime \prime}$ elevation except outer steel shell to be removed at Stage $V$.

Stage II:

$115^{\prime} 0^{\prime \prime}$ elevation to $107 \cdot 0^{\prime \prime}$ elevation

Top Thermal shield plates

Permanent graphite blocks

Stage III

$107^{\prime} 0^{\prime \prime}$ elevation to $95^{\prime} 0^{\prime \prime}$ elevation

Remaining thermal shield plates

Stage IV:

$95^{\prime} 0^{\prime \prime}$ elevation to sub-pile room ceiling

Stage $V$ :

Sub-pile room ceiling to floor (el. $79^{\prime} 10^{\prime \prime}$ )

Outer steel shell 


\section{LIST OF FIGURES}

1. Idaho Nationa] Engineering Laboratory

2. Test Reactor Area

3. MTR Reactor Structure

4. MTR Reactor Vertical Cross Section

5. Reactor Structure N-S Center

6. Reactor Structure E-W Center

7. Reactor Structure Horizontal Cross Section at Reactor Center Line

8. Reactor Tanks and Internals, Top Plan with Plug Removed.

9. Reactor Air Flow Schematic 


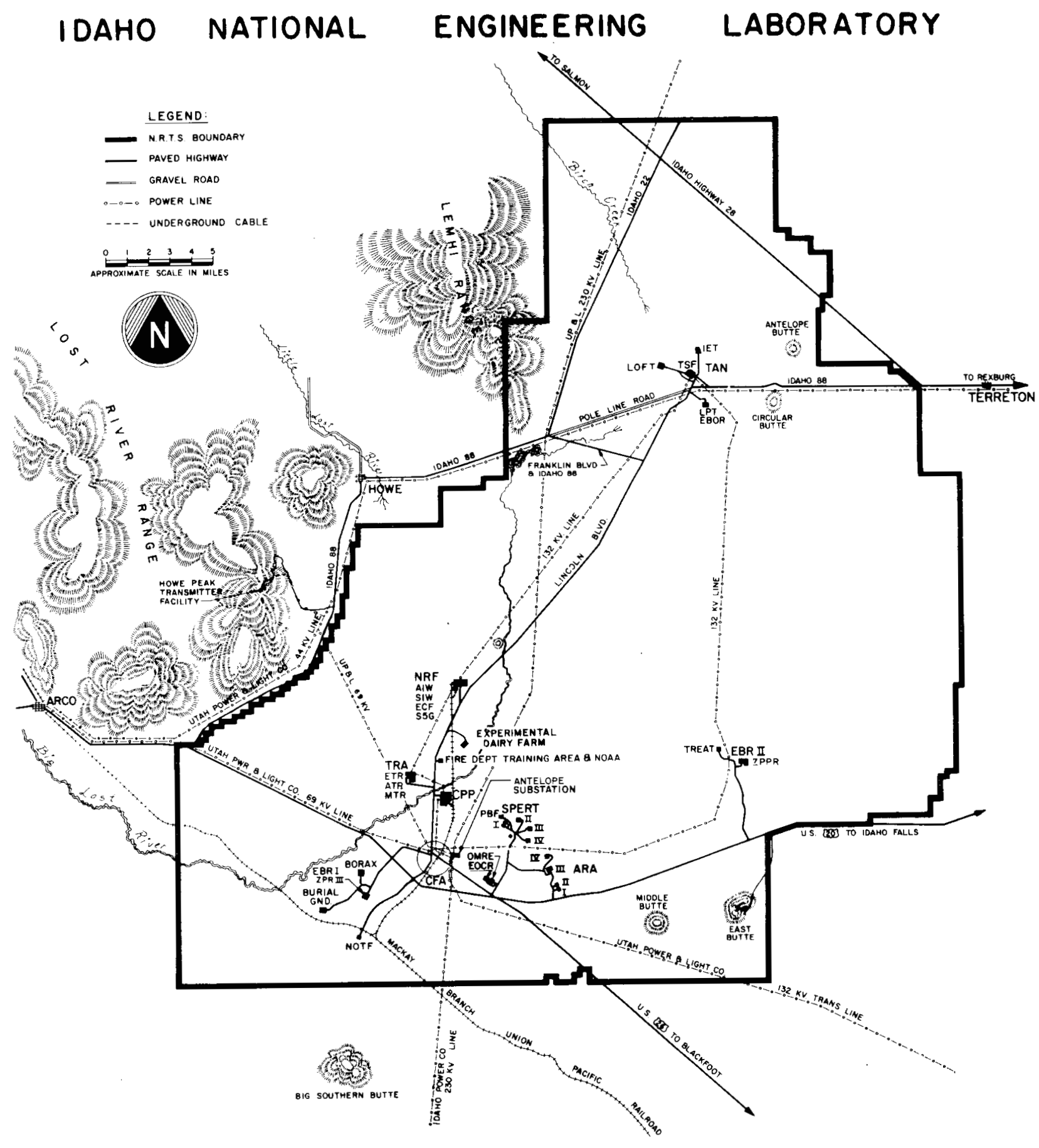

FIGURE I 


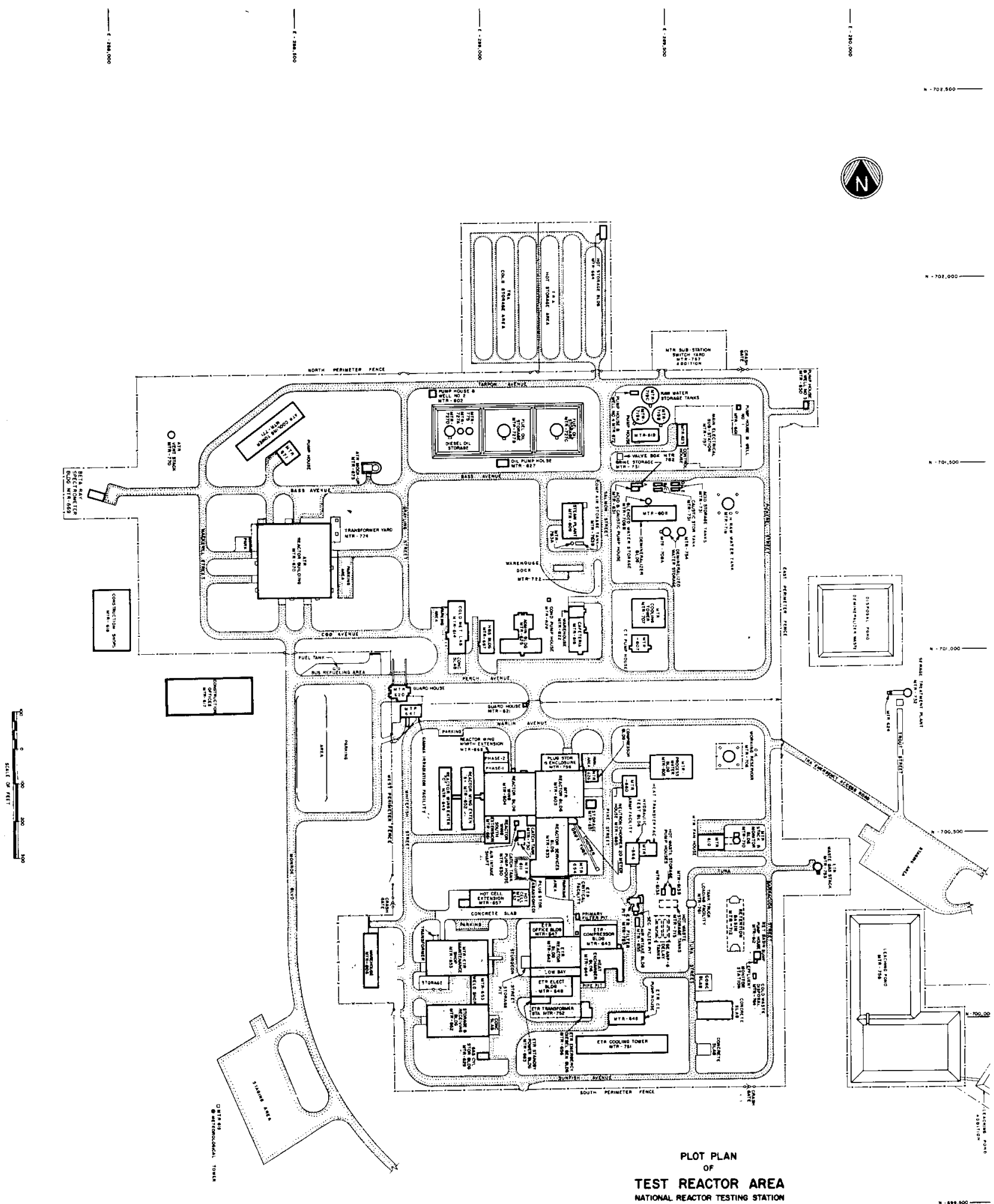

FIGURE 2 


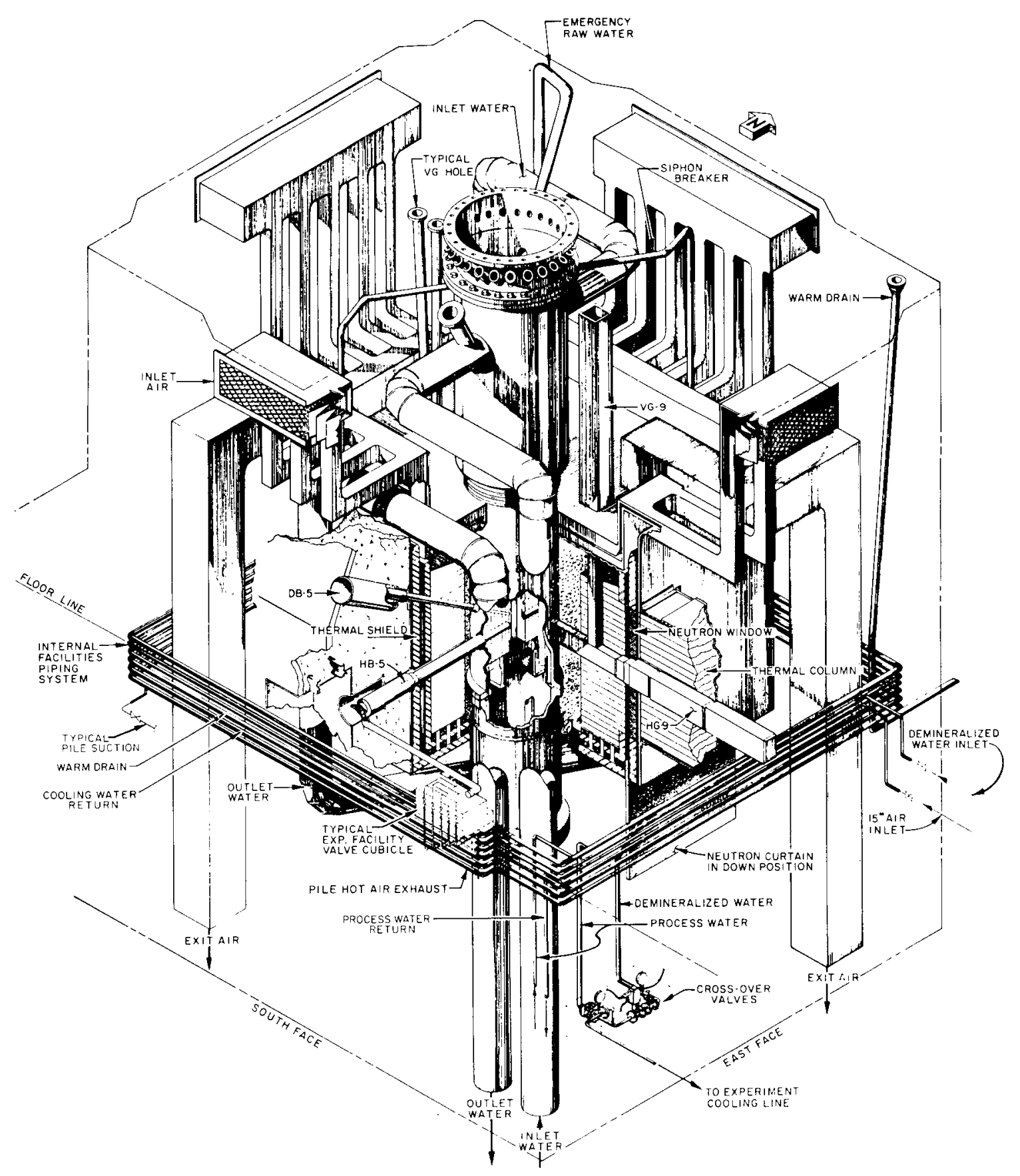

FIGURE 3 MTR REACTOR STRUCTURE 


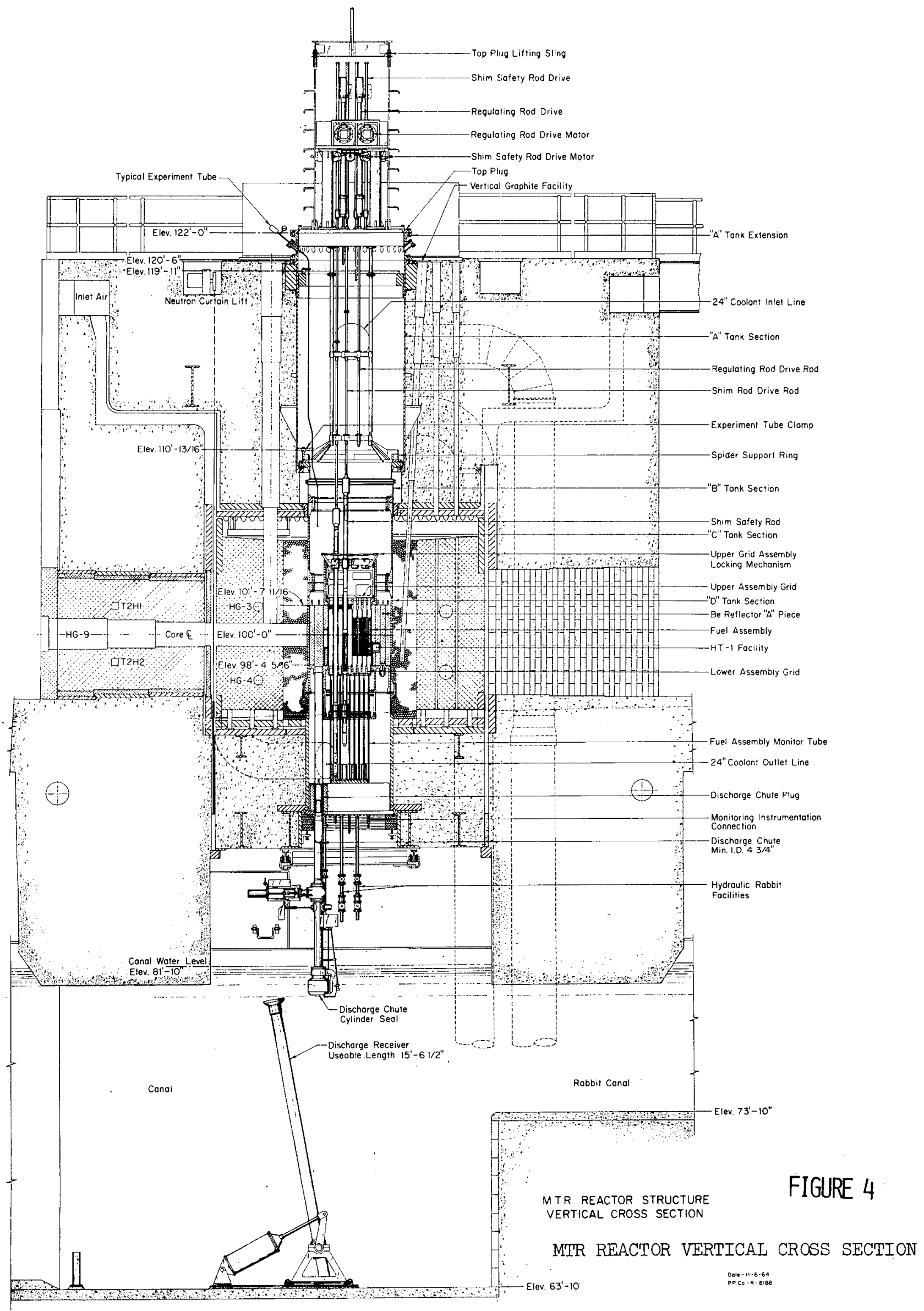




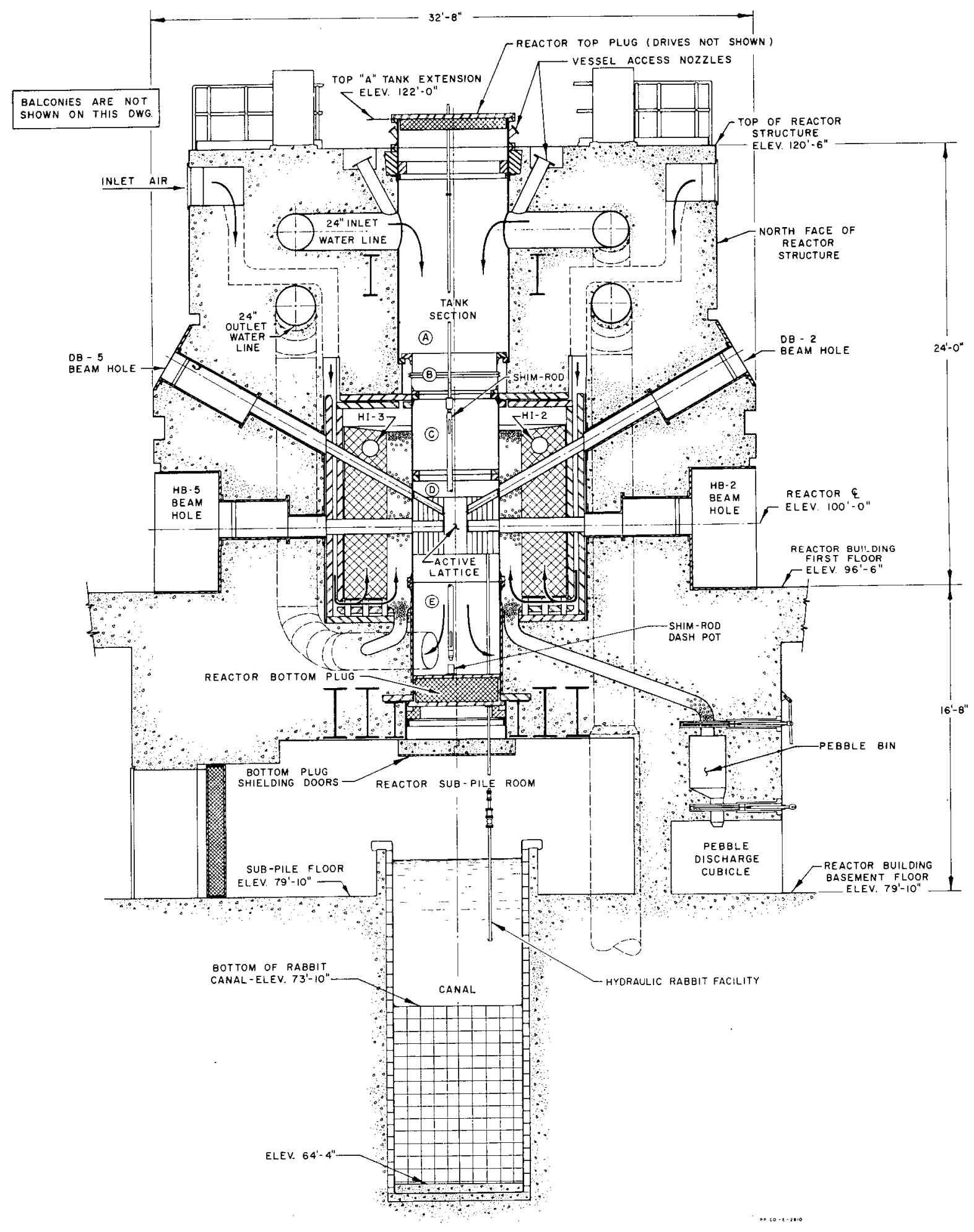

FIGURE 5 REACTOR STRUCIURE N-S CENTER 


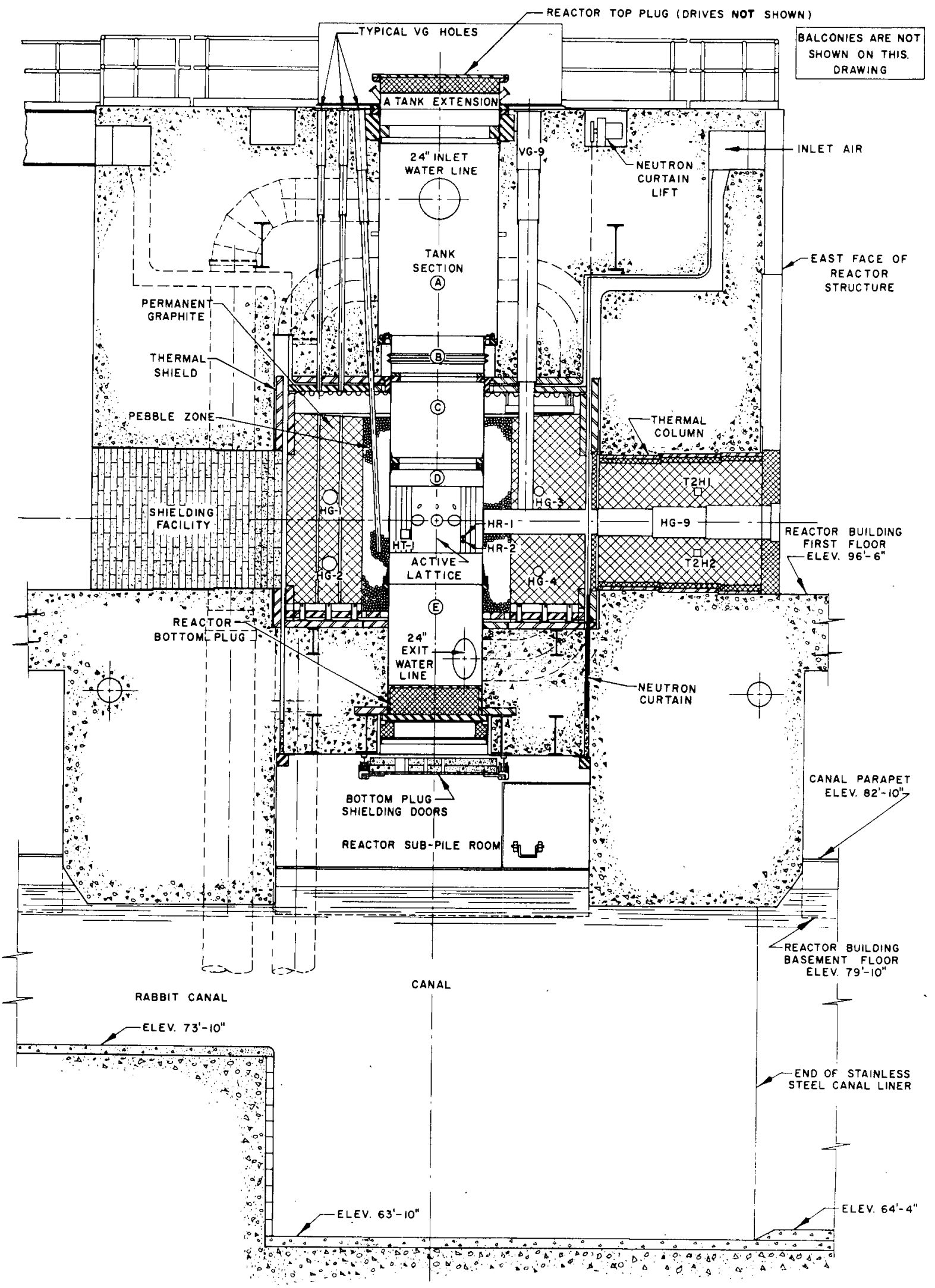

FIGURE 6 REACTOR STRUCTURE E-W CENTER 


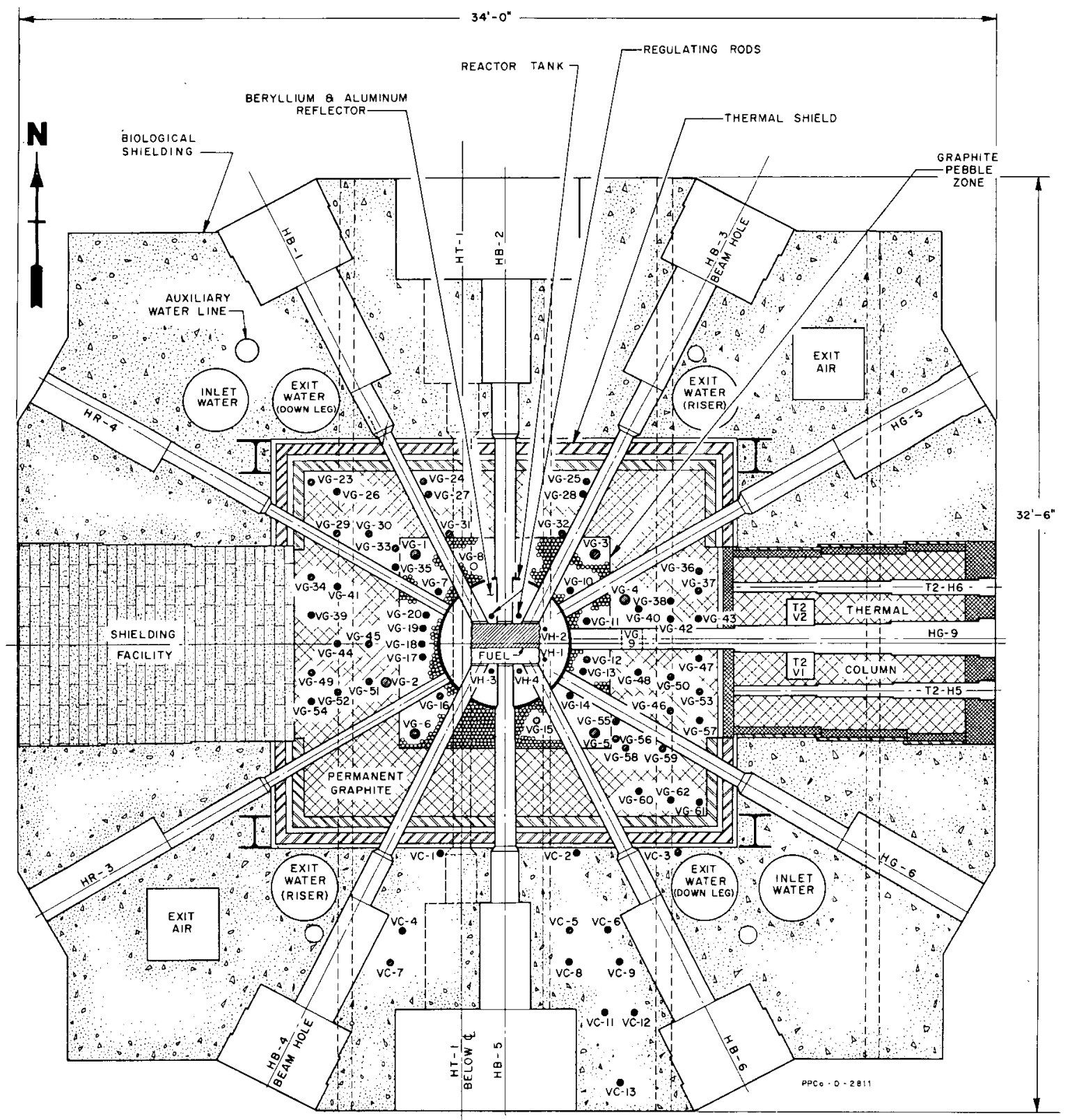

FIGURE 7 MTR REACTOR STRUCTURE HORIZONTAL CROSS SECTION AT REACTOR CENTERLINE 


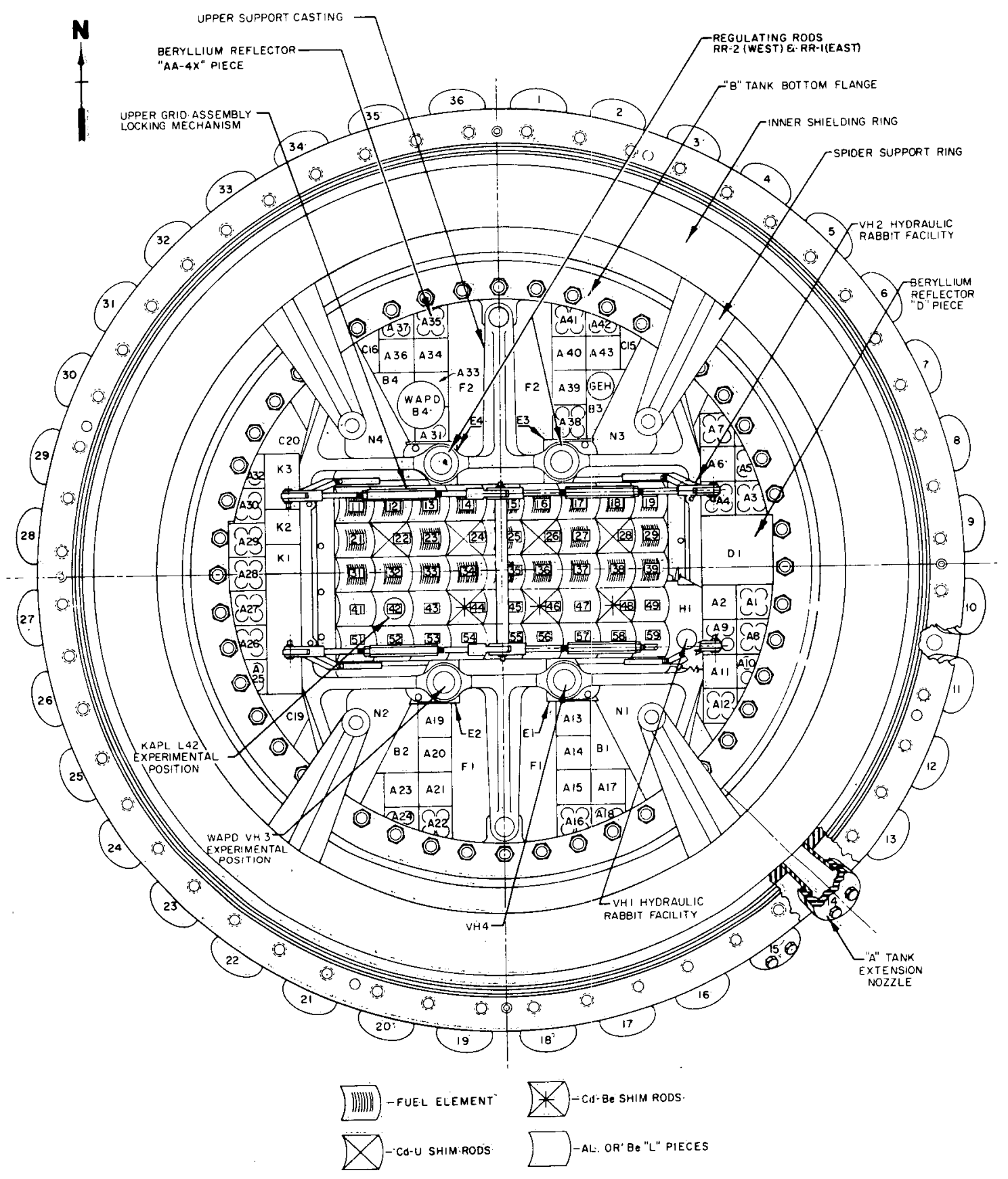

FIGURE 8 MTR REACTOR TANKS AND INTERNALS, TOP PLAN WITH TOP PLUG REMOVED 


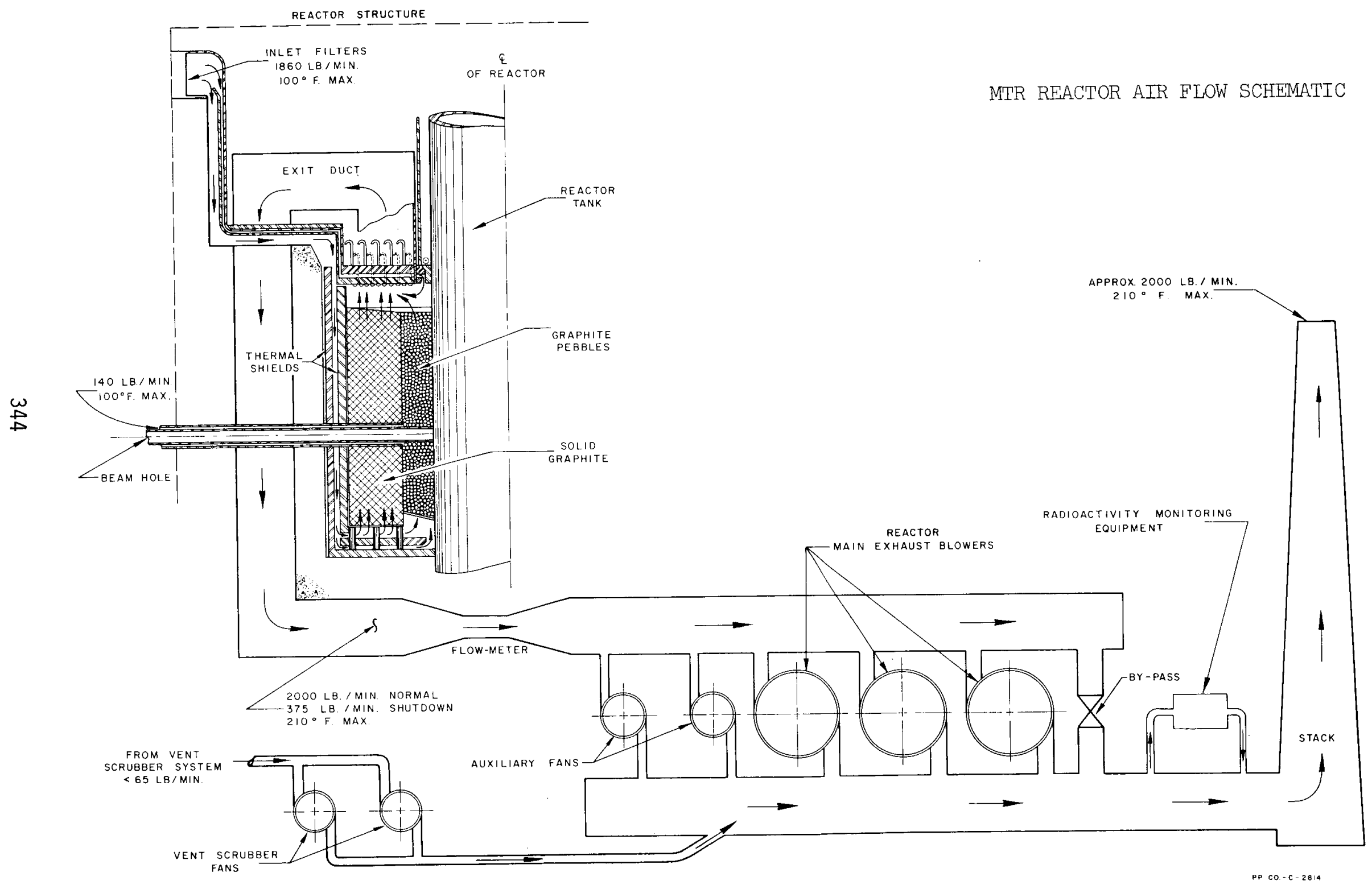

FIGURE 9 
PNL STUDIES OF D\&D AT HANFORD

K. M. Harmon, Manager

Hanford Waste Management Programs Battelle, Pacific Northwest Laboratories Richland, Washington 99352

\author{
August 1975
}

For presentation at

ERDA CONFERENCE ON DECONTAMINATION AND DECOMMISSIONING (D\&D) OF ERDA FACILITIES August 19-21, 1975

Idaho Falls, Idaho

This paper is based on work performed under U.S. Energy Research \& Development Administration Contract No. E (45-1)-1830 


\section{PNL STUDIES OF D\&D AT HANFORD}

K. M. Harmon

\section{INTRODUCTION}

The Hanford Reservation in the State of Washington was selected in 1943 by the United States Army Corps of Engineers as the location for reactor and chemical separation facilities for the production and purification of plutonium. The years since 1943 have seen the construction, use and retirement of graphite-moderated reactors, several generations of chemical processing plants, facilities ancillary to the production plants, laboratories, and a large number of ground sites used for the disposal or storage of contaminated equipment and solid or liquid wastes. In consequence, the decontamination and decommissioning (D\&D) of retired, contaminated facilities at Hanford offers a great engineering and economic challenge.

\section{HANFORD RESERVATION}

The Hanford site (Figure 1) measures 570 square miles or 365,000 acres. The reactor facilities are located along the Columbia River in what is known as the 100 Areas. The reactor fuel processing and waste management facilities are in the 200 Areas which are on a plateau about 7 miles from 
the river and about 200 feet higher in elevation than the 100 Areas. The 300 Area, just north of Richland, contains the reactor fuel manufacturing facilities and the research and development laboratories. A few miles north of the 300 Area, the FFTF and WPPSS Hanford No. 2 reactors are under construction.

A representative section of a typical Hanford reactor area, $100 \mathrm{~B}-\mathrm{C}$, is shown in Figure 2. Of major concern in the D\&D program are 1) the reactor building with its ancillary recirculating gas and ventilation systems and 2) the retention basin system used for return of reactor coolant water to the river.

Major features of the chemical processing areas are diagrammed in Figure 3 . These areas include five chemical processing plants and one semi-works, a plutonium purification and fabrication plant, extensive facilities for the storage and handling of high-level liquid and solid wastes, laboratories, and many contaminated burial grounds, cribs, ditches and ponds. The semi-works and some of the plants and laboratories have been retired. 0.thers are held on stand-by or have been converted to uses supporting the waste management program. Many of the contaninated soil sites have been retired. 
D\&D AT HANFORD

For a number of years, Hanford has been the site of varied D\&D-related activities. Some $i$ dea of the scope may be gained from figure 4. The UNI characterization of the retired 100 Areas involves taking and analyzing samples from many locations (soils, filters, reactor cores, etc.) to improve the knowledge of radionuclide inventories. AEC/ ERDA, ARHCO, PNL and UNI have long been concerned with the migration of contamination through soil and with development of techniques for stabilizing soils against wind erosion, plant and animal incursion, and downward movement of radionuclides to the water table. PNL maintains an active investigation of the part that plant and animal life and nonbiological environmental forces play in the transport of radioactivity into the Hanford environs. PNL is studying safety and cost factors in decommissioning fuel cycle facilities for NRC and has started a study of methods for characterizing solid waste burial grounds. ARHCO has active programs to demonstrate the recovery of plutonium from ground disposal sites and to study techniques for dismantling and consolidating contaminated equipment and facilities. Consideration is also being given to the possible recovery and disposal of fission products from cribs, burial grounds, etc.

The PNL study, D\&D at Hanford, was started in June, 1974, with the objectives stated in Figure 5. 


\section{Task 1.}

The first task, to establish methods, costs and priorities for D\&D at Hanford, has been approached in the following manner:

1. An annotated bibliography of over 400 D\&D references has been prepared and issued as a formal BNWL report.*

2. The contaminated facilities at Hanford have been categorized into the eleven groupings shown in Figure 6. The following comments about some of these classes might help provide and idea of the magnitude of the D\&D problem at Hanford.

- Contaminated Liquid Disposal Sites.

These include surface ponds or ditches and underground structures called cribs. As of September, 1974, a total of 177 cribs had been provided in the 200 Areas for disposal of intermediate-level liquid waste. Of these, 144 are now deactivated, eight were not used, ten are in standby, and 15 are in current use. There are also 30 surface ponds or ditches in the 200 Areas used for disposal of cooling water.

\footnotetext{
ॠW. E. Sande, M. S. Hanson, R. L. Mckeever and H. D. Freeman, "Decontamination and Decommissioning of Nuclear Facilities A Literature Search," BNWL-1917, Pacific Northwest Laboratories, Richland, WA (1975).
} 
been discharged to 30 surface ponds or ditches. About 360 acres of 1 and have been used for these disposal operations, with about 180 acres currently in use. Cribs, ditches, and ponds are located in the 100 and 200 Areas in large numbers.

- Contaminated Solids Storage and Burial Sites. As of September, 1974, more than five million cubic feet of contaminated dry solids had been buried in the 100 Areas, 200 Areas and near the 300 Area. Initialiy, transuranic waste received special packaging for containment, but was not buried for 20 year recovery. Since May 1970, transuranic waste is packaged in sealed metal containers, segregated from other waste, and placed in special burial trenches to permit recovery in the original packaged condition.

\section{- Fuel Storage Basins.}

Each reactor has its fuel storage basin, and three additional basins were constructed on the 200 Areas plateau. Most of them were left with water in them on retirement. Some were filled with clean soil to prevent spread of contamination. 


\section{- Reactors}

Nine reactors were built for plutonium production.

Only N-Reactor, designed also for power production, is still operating. The other eight are retired or on stand-by.

- Reactor Retention Bas in Systems.

Each single-purpose reactor was cooled by oncethrough flow of water from the Columbia River. Effluent water passed through large-diameter steel or concrete pipe to a retention basin and thence back to the river. Some of the basins are concrete, some are mild steel. The concrete basins leaked and contaminated adjacent soil. All have had at least a foot or two of clean soil added to prevent spread of contamination. The systems include several linear miles of contaminated buried pipe-line.

3. As many as five possible alternatives were identified for treatment of each category of facilities. The alternatives under consideration are shown in Figure 7. 
Procedures considered applicable to each alternative were described, and consideration was given to the volumes of contaminated waste that would be generated and to methods of waste disposition.

4. The following cases were selected for evaluation of over-all D\&D strategy at Hanford:

- Complete cleanup of retired ERDA facilities

- Cleanup of the areas near the Columbia River and dedication of the 200 Areas for long-term nuclear use including storage or burial of radioactive wastes. Wastes removed from the 100 and 300 Areas would be relocated to the 200 Areas.

- Dedication of the entire reservation for nuclear uses.

5. Preliminary cost estimates will be made for several scenarios based on the above cases, safety implications will be reviewed, and priorities will be established for the various scenarios. We anticipate that selected scenarios will then be subjected to more extensive evaluations of hazards and costs. 
Task 2.

Under the second task, to provide the detailed planning for a specific D\&D demonstration, we have selected a relatively small building which is highly contaminated. This facility, the 233-S Building, is adjacent to the Redox Plant and was used for concentration of the plutonium product from Redox. Some of the principal features of the 233-S Building are outlined in Figure 8 . Our best estimate of the plutonium inventory in the hood is that it does not exceed $1.5 \mathrm{~kg}$. This value was arrived at by placing metal discs at various places on the outside of the hood and determining the induced activity in the discs. The activity appears to be localized in or near one of the process vessels.

Much of the interior of the building was contaminated as a result of a violent chemical reaction in one of the process vessels, which breached the hood and caused a fire. The facility was cleaned of gross contamination, painted and returned to service for a few years. The facility was retired from production service in 1967. Continued survei1lance and maintenance of the ventilation system are necessary, and entry to the building is made only under carefully monitored and controlled conditions. 
In early planning, we identified the disposition alternatives listed in Figure 9. Because a major objective of the program is to learn as much as we can about D\&D technology for this type of facility, we are basing our detailed procedures on the fifth alternative--to strip the facility, decontaminate it as far as practical, and dismantle the structure. The operations will be phased, however, to permit stopping with the building structure intact should that be desirable. The six phases, or activities, of the demonstration are listed in Figure 10. Activity IV, to be conducted after the process hood is cleaned out, provides for in-hood testing on actual plant equipment and structures of a variety of decontamination and size reduction procedures. We plan to conduct at least limited testing of advanced technology also in Activities II, III, and V. We also expect to document the various activities thoroughly, to provide a complete record of events and results.

SUMMARY

In summary, the PNL D\&D at-Hanford program involves 1) the preparation of a long-term plan for a systematic approach to the extensive and varied problems of decommissioning retired facilities at Hanford; and 2) a D\&D demonstration project, the decommissioning of a grossly-contaminated plutonium processing facility. 


\section{LIST OF FIGURES}

Figure 1. Hanford Area Map

Figure 2. Section of 100 B-C Reactor Areas

Figure 3. Separations Areas (200-E, 200-W, 200-N)

Figure 4. D\&D-Related Programs at Hanford

Figure 5. Disposition ( $D \& D$ ) of Retired Contaminated Facilities at Hanford

Figure 6. Categories of Contaminated Facilities and Soil Sites

Figure 7. Disposition Alternatives

Figure 8. Task 2: D\&D Demonstration Project (233-S, Plutonium Concentration Bldg.)

Figure 9. Task 2: D\&D of 233-S

(Disposition Alternatives)

Figure 10. Major Activities: D\&D of 233-S Building 


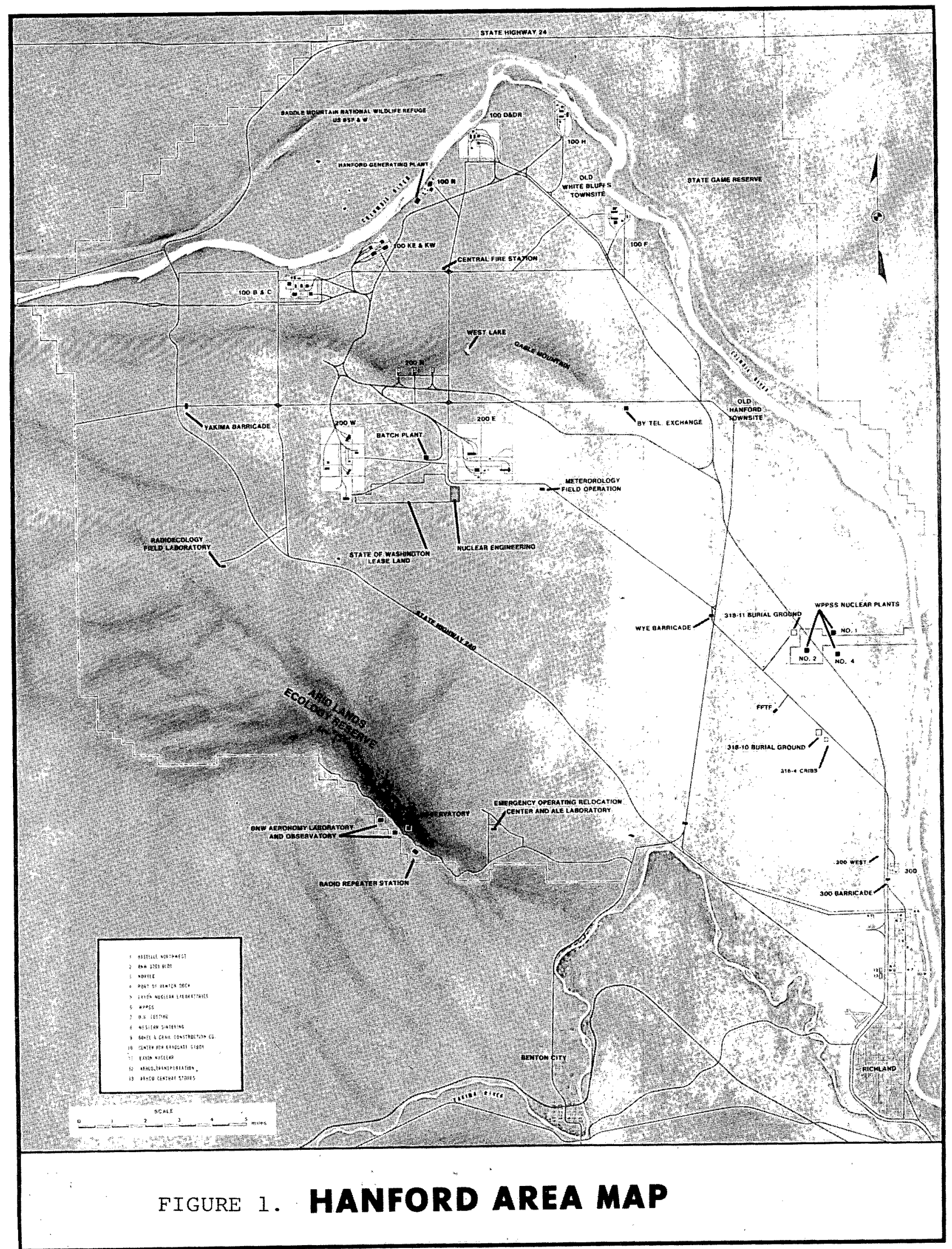

$\ominus$
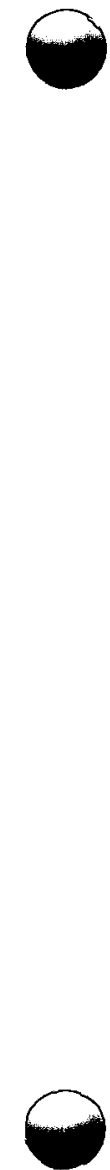


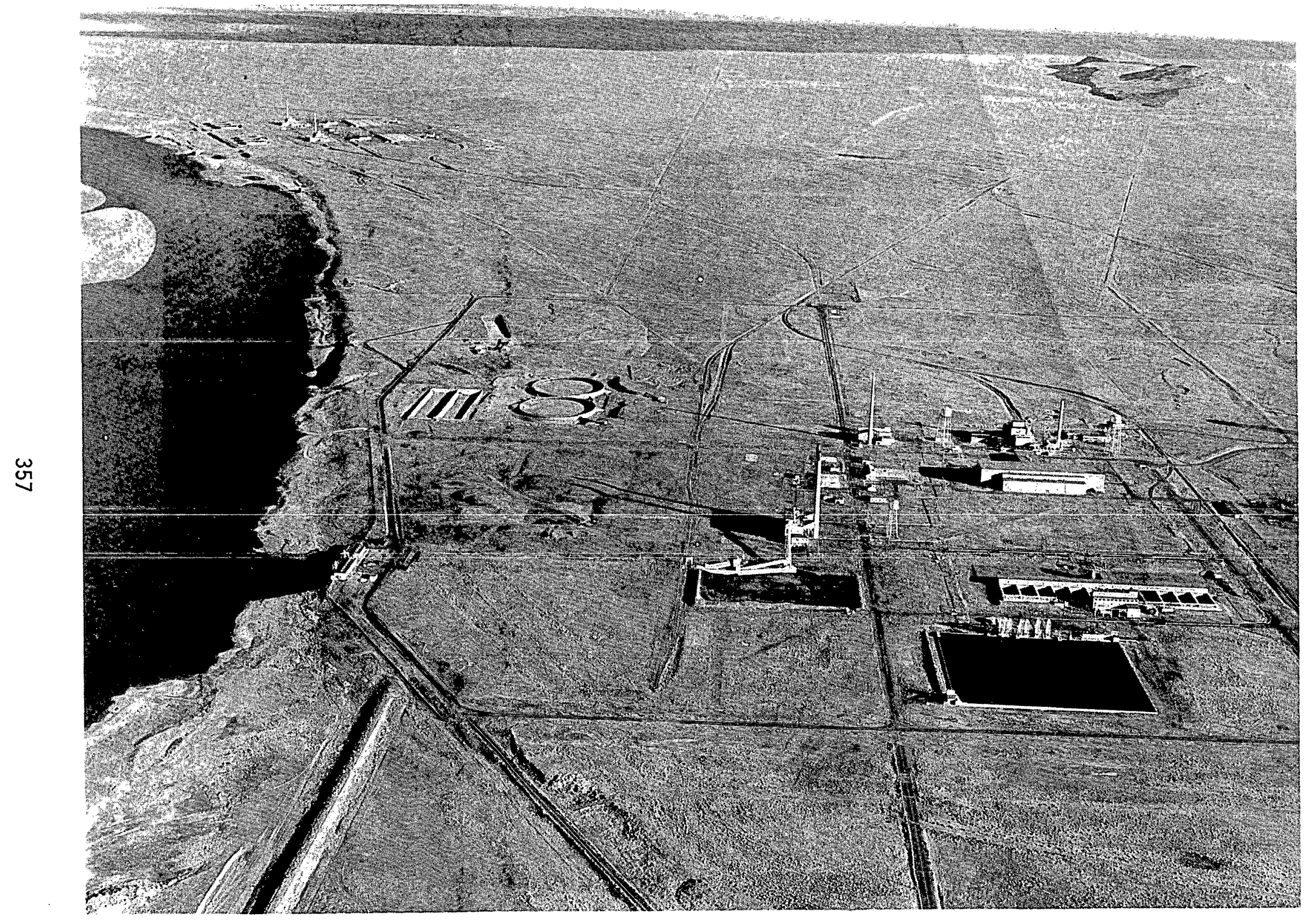

FIGURE 2. SECTIONS OF 100 B-C REACTOR AREAS 


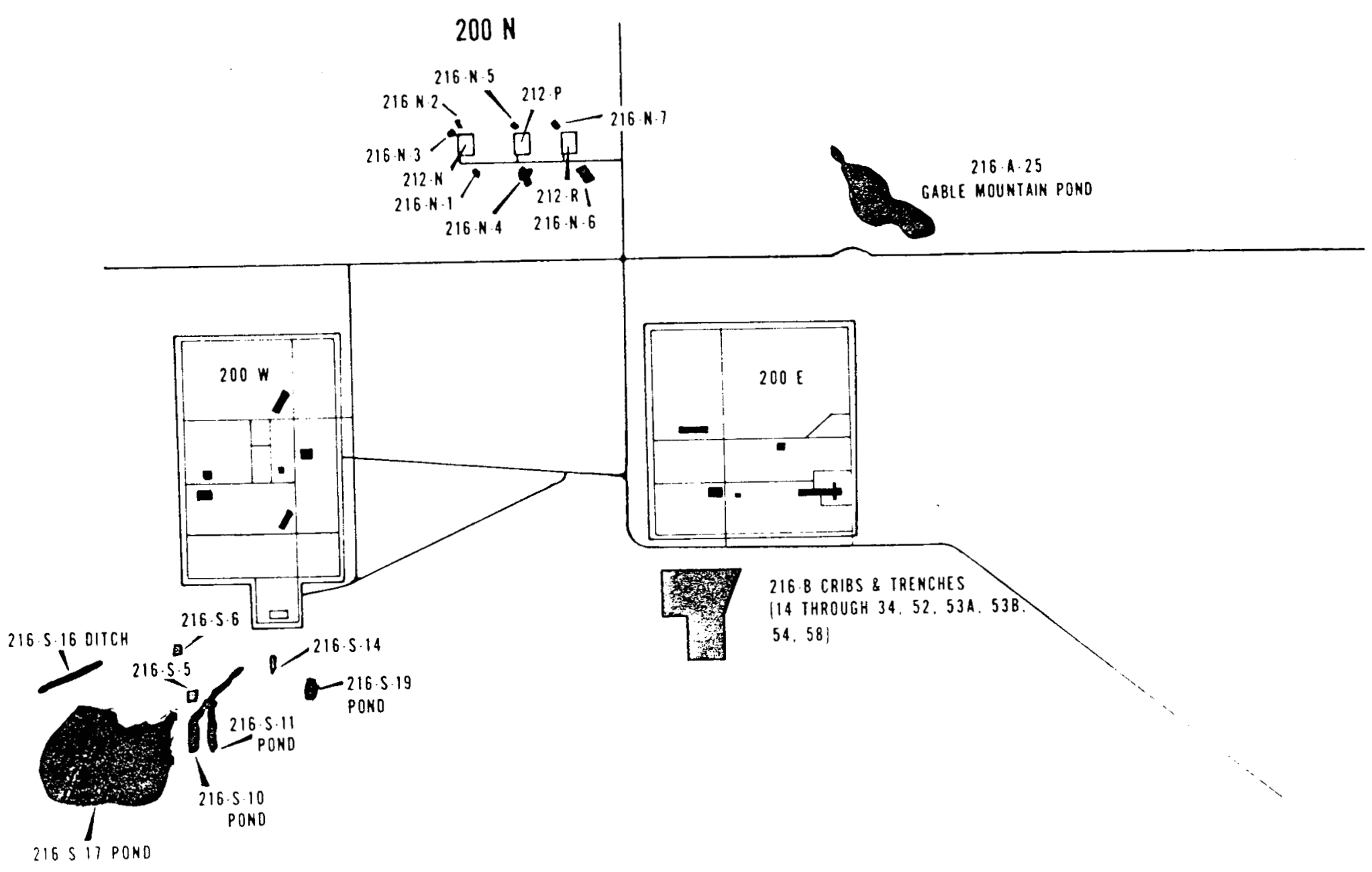

FIGURE 3. SEPARATIONS AREAS (200-E, 200-W, 200-N) 


\section{D\&D - RELATED PROGRAMS AT HANFORD}

1. RADIOLOGICAL CHARACTERIZATION OF THE RETIRED 100 AREAS (UNI)

2. TRANSPORT OF RADIONUCLIDES THROUGH SOIL, AIR, GROUNDWATER \& BIOTA (ARHCO, PNL, UNI)

3. STABILIZATION OF CONTAMINATED SOILS (ARHCO, PNL, UNI)

4. DEVELOPMENT OF SAFETY AND COST OF DECOMMISSIONING FUEL CYCLE FACILITIES (REGS-PNL)

5. EQUIPMENT AND FACILITIES DECOMMISSIONING (ARHCO)

6. CHARACTERIZATION OF 300-WYE AND NORTH BURIAL GROUND (PNL)

7. DISPOSITION (D\&D) OF RETIRED CONTAMINATED FACILITIES AT HANFORD (PNL) 


\section{DISPOSITION (D\&D) OF RETIRED CONTAMINATED}

FACILITIES AT HANFORD

OBJECTIVES FOR FY1975-76

- ESTABLISH METHODS, COSTS, PRIORITIES FOR D\&D OF RETIRED, CONTAMINATED FACILITIES AT HANFORD (TASK 1)

- FoRMUlate PLANS For a SPECIFIC D\&D PROJECT TARGETED TO START IN FY1976 (TASK 2)

- IDENTIFY R AND D NEEDED FOR D\&D PROJECTS. 


\section{CATEGORIES OF CONTAMINATED FACILITIES} AND SOIL SITES

1. CONTAMINATED LIQUID DISPOSAL SITES

2. CONTAMINATED SOLIDS STORAGE AND BURIAL SITES

3. FUEL PROCESSING FACILITIES

4. FUEL STORAGE BASINS

5. GAS \& EXHAUST AIR SYSTEMS (REACTORS)

6. LABORATORIES

7. REACTORS

8. RETENTION BASIN SYSTEMS

9. TRANSURANIC FACILITIES

10. URANIUM FACILITIES

11. WASTE MANAGEMENT FACILITIES 


\section{DISPOSITION ALTERNATIVES}

1. SHORT-TERM MAINTENANCE AND SURVEILLANCE (PENDING FUTURE DEVELOPMENTS)

2. PREPARATION FOR LONG-TERM MAINTENANCE AND SURVEILLANCE (PENDING DECAY OF SHORT-LIVED NUCLIDES)

3. STABILIZATION IN PLACE (ENTOMBMENT)

4. DECONTAMINATION TO LOWEST PRACTICAL LEVEL

5. DISMANTLING AND REMOVAL 


\section{TASK 2: D\&D DEMONSTRATION PROJECT} (233-S, PLUTONIUM CONCENTRATION BLDG.)

- STRUCTURE: $\quad 85^{\prime} \times 37^{\prime} \times 32^{\prime}$; CONCRETE \& METAL WALLS

- EQUIPMENT: PLEXIGLASS PROCESS HOOD CRITICALLY-SAFE VESSELS \& PIPING

- contamination:

- BETWEEN 1 AND 3 Kg PLUTONIUM IN HOOD

- AS HIGH AS 800,000 D/M SMEARABLE CONTAMINATION OUTSIDE HOOD. 
FIGURE 9

TASK 2: D\&D OF 233-S

\section{DISPOSITION ALTERNATIVES}

MAINTAIN AS IS

ENCLOSE IN CONCRETE SHELL

ENTOMB (ENCASE \& FILL)

STRIP INTERIOR \& DECONTAM.*

DISMANTLE FACILITY*

* preferRed alternatives 
MAJOR ACTIVITIES: D\&D OF 233-S BUILDING

ACTIVITY I.DETAILED CHARACTERIZATION OF THE FACILITY ACTIVITY II.SITE PREPARATION

ACTIVITY III.DISMANTLING AND REMOVAL OF PROCESS EQUIPMENT

ACTIVITY IV.IN-CELL TEST PROGRAM

ACTIVITY V.FINAL DECONTAMINATION

ACTIVITY VI.DEMOLITION 
0

$\theta$

$\ominus$ 


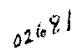 \\ DESIGN FEATURES FOR DECONTAMINATION \\ IN NEW PLUTONIUM FACILITIES
}

\author{
by \\ Kenneth J. Freiberg \\ $\&$ \\ Charles G. Haynes
}

August 1975

RFP -2428

\begin{abstract}
Rockwel1 International6 Atomics International Division, Operates the
Rocky Flats Plant as a Prime Contractor to the U.S. Energy Research \& Development Administration under Contract Number E(29-2)3533.
\end{abstract}


Because radioactive contamination can not only make a place unfit for its intended use, but also can expose operating personnel and the public to significant health hazards, design criteria have been established for preventing and controlling contamination, and methods have been developed for removing contamination if necessary.

ERDA has developed design criteria intended to assure that contamination can be prevented or controlled in its facilities, and that the facilities ultimately can be decommissioned to a safe status. ERDA's "General Design Criteria" (ERDA Manual Appendix 6301, Part II) was utilized in developing the design of the new Plutonium Recovery and Waste Treatment Facility at Rocky Flats Plant, Golden, Colorado.

Specifically, the General Design Criteria directs that:

1. Design of critical areas shall incorporate measures to simplify decontamination.

2. The building shall be designed to facilitate decontamination for decommissioning.

3. Ancillary equipment shall be located in areas that are least likely to become contaminated.

A primary design goal for the new Facility is to confine radioactive materials during normal operations and design-basis accident conditions. Hence, in the new Facility, the primary goal with respect to contamination is designing the structure and equipment to keep the radioactive 
materials confined within the areas where they are supposed to be. This is where the most effective decontamination savings are real ized.

However, since it is impossible, from a practical point of view, to prevent some contamination, design features are incorporated that make it easier to remove the contamination during useful life of the Facility, and when it is decommissioned.

Specific features for preventing, containing, controlling, and removing contamination in the Plutonium Recovery and Waste Treatment Facility are outlined below.

Design Features For Contamination Containment

\section{Structure}

The building is constructed from reinforced concrete and designed with tornado and seismic considerations. As the expected structure life will exceed the process life, the ability to decomission the facility becomes apparent.

\section{A. Compartmentalization}

Compartmentalization provides for physical separation of various production and support processes. Each compartment is also isolated by ventilation design. 


\section{B. Air Locks}

Air locks isolate areas both physically and by ventilation. Air lock doors are separated so that it is impossible for one person to open both doors simultaneously.

\section{Sealed Penetrations}

All penetrations, such as process piping, ductwork, conduit, etc., through any walls, floors, and ceilings are sealed to prevent contamination movement from one area to another. Condujit is internally sealed to further limit spread of radioactive materials.

D. Pneumatic Stack Closure Valves

These valves are on each ventilation discharge point to provide protection against the high negative pressures of tornadic winds. They also provide the capability of complete shutdown and isolation of the facility in case of a major incident.

E. Canyons

The canyons remove process equipment from a glovebox-type operation. As most contamination incidents in our present 
facility are glove failures, this will reduce the number of incidents as well as lessen the exposure potential. The canyons isolate the process equipment physically and by ventilation and operated remotely. Access into the canyons for maintenance purposes is through air locks with submarine-type doors.

F. Remote and Shielded Storage

All in-process material is stored and most solid material transfer is through a computer controlled stacker-retreiver that is glovebox accessible from most process areas. This vault eliminates glovebox storage and reduces material handling thereby minimizing contamination incidents.

G. Curbs

The curbs are two-inch high concrete dams located at critical points in and around the process area. They are for the purpose of restricting liquid movements, primarily fire sprinkler water, from one area to another. The two-inch height is dictated by criticality considerations. 


\section{Ventilation}

A primary function of the ventilation system is to assist in the containment of contaminates and to control the spread of contamination if it escapes from its confines. This is accomplished by some of the following.

\section{A. Four Separate Zones}

The ventilation system is designed to direct the flow of air from the area of least contamination to the area of greatest contamination. The areas are broken dwon into four separate zones, each separated physically as well as by pressure differentials created by the ventilation system.

\section{B. Adequate Air Flow}

The rates of air changes are dictated by the need to control contamination, to control dust in certain operations and to prevent the buildup of radioactive material within gloveboxes. The air change or flow rates are:

$\begin{array}{lr}\text { Gloveboxes } & 30 \text { changes/hour } \\ \text { Hoods } & 150 \text { feet/minute } \\ \text { Downdraft Tables } & 200 \text { feet/minute } \\ \text { Submarine Doors } & 75 \text { feet/minute } \\ \text { Work Areas } & 15 \text { changes/hour }\end{array}$


The work area change-rate has evolved from experience and from testing performed at Rocky Flats using various air change rates. The fewer air changes per hour, the larger the area of contamination spread.

Proper location of work area exhaust ducts also minimizes contamination spread. Ducts located floor level draw air away from breathing zones as well as reducing spread. The ducts are placed under the gloveboxes and around the perimeter of the room.

\section{HEPA Eiltration and Scrubbers}

The filter plenums are designed such that, in case of an accident and loss of one stage of filtration, contamination will be contained within the building. The room air plenums have two stages of filtration and the process plenums have four. The plenums have a spearate air lock to each stage with submarine doors. The scrubbers, primarily for removal of chemical pollutants, are also quite effective for removal and containment of particulate contamination.

\section{Gloveboxes}

Design advancements is gloveboxes have been minimal for many years. Some new thoughts incorporated into the gloveboxes for the new facility are: 


\section{A. Remote Operations}

Many operations are remotely controlled even though they are in gloveboxes. This reduces man-hours in the gloves and lessens the number of incidents due to glove failures.

B. Spacing and Location

Each glovebox is designed around its particular piece of equipment; therefore, the glovebox is neither too small and cramped nor too large as to make areas inaccessible. This feature reduces excessive stress on the glovebox and helps prevent glove failures.

C. Inline HEPA Filtration

The inline filters consisting of a HEPA filter and a roughing filter at the exhaust point in the glovebox prevents buildup of residual contamination in the HVAC ductwork. This is a nuclear safety consideration as well as contamination control.

D. Elimination of Air Locks on Gloveboxes

Air locks were eliminated as they presented contamination control problems. Most equipment enters or leaves the glovebox 
over a downdraft table. The downdrafts are contained within separate metal rooms in the work area.

E. Elimination of Bag-Ports

Chemical recovery of Plutonium created many problems for the common bagging method. To eliminate this procedure, pneumatic transfer, gravity feed, the stacker-retriever and a double-port transfer device are being utilized. The double-port device is a device where a container can be easily attached to or removed from special glovebox ports located throughout the building.

F. Enclosure of Criticality Drains

The existing criticality drains overflow from the glovebox to the floor and are a constant source of contamination. The new design has each drain piped to critically safe holding tanks. There are separate drain systems because of chemical imcompatability of some processes. This entire system is continuously monitored by level alarms.

G. Dust Control

Dust-generating equipment will be enclosed and ventilated within the glovebox to minimize buildup of material. 
Cyclone separators are also utilized. The lesser amounts of loose material decreases the scope of any incident.

\section{H. Pneumatic Transfer}

The transfer of liquids and fines by pneumatic methods within double contained piping minimizes other methods of material handling, thereby decreasing the potential for an incident.

I. Double Containment and Welded Pipe

The most common problem with process piping systems is leakage at the flanges. Most flanges external to gloveboxes and canyons were eliminated. In addition, most process piping is double contained utilizing cyrogenic type piping in process areas. Cyrogenic piping is sloped so that plutonium solutions drain back to the glovebox.

IV. Fire Protection

Quickly extinguishing a fire involving contaminated materials will not only reduce fire damage but decrease the area of contamination. Overheat detectors with remote alarms and fire sprinklers are required for rapid response and control. Most sprinklers are heat activated, both on and off, to prevent accumulation of 
excessive amounts of fire water. Water from sprinkler systems protecting the filter plenums is collected in a critically safe holding tank. Holding ponds have been provided in case of a massive incident that requires volumes of water greater than the capacity of the tanks.

V. Health Physics Selective Air Monitor System

The primary function of the continuous air monitors is to warn personnel of airborne contamination. As the air monitors are remotely alarmed to the guard shack as well as the Health Physics Office, contamination surveillance is provided during off hours, and in unmanned areas. They have been known to detect a smoldering fire before the overheat detection system.

Design Features For Decontamination

\section{Structures}

Several features were incorporated in the basic structure to facilitate decontamination. Some of those are listed below.

\section{A. Smooth Clean Surfaces}

The concrete finish is specified so that all pits, protrusions, cracks, etc., are minimized. Any cracks in the walls are sealed by epoxy injection. 
B. Accessible Surfaces

All surfaces are designed so that they are accessible for decontamination. Concrete inserts for hanger support are replaced by steel plates.

C. Water Proofing

The exterior of the structure is waterproofed to prevent out-leakage of contaminated liquids or in-leakage of sub-surface water.

\section{Surface Finishes}

The finish on all surfaces, including equipment, was evaluated so that a good decontaminatible finish would be available.

\section{A. Floors}

Additional water proofing is applied to the concrete floors to prevent liquid movement from one level to another. Over the water proofing a re-inforced 4-inch thick concrete cover is poured. All edges and corners are coved to make them accessible. All seams are filled. Several coats of an epoxy and aggregate finish is applied. The epoxy is 90 mils thick and is resistant to most process chemicals. 


\section{B. Walls and Ceilings}

The concrete is finished to a smooth surface, then given a treatment to fill small pits and voids. A primer coat is then applied followed by 3 coats of epoxy with a total thickness of $8 \mathrm{mils}$. Experience has shown that light colors are easier to decontaminate, therefore, they are applied to all surfaces.

\section{Metal \& Equipment Surfaces}

A high gloss epoxy or enamel is applied to all equipment in the process area to assure decontaminatibility. Electrical equipment that must be in the area is sealed, suppiy air ducted to them with HEPA filtered outlets. This is to pressurize the cabinet to prevent internal contamination to equipment that is uncleanable. The supply air also cools the equipment.

III. Gloveboxes

Several additional features were incorporated in the glovebox design to facilitate contamination removal.

A. All corners and edges are rounded for accessibility and to prevent material buildup. All seams are welded, flanges are 
held to minimum. The gloveboxes are spaced so that all surfaces are accessible. Epoxy is applied to all lead shielded gloveboxes. All seams in the lead are epoxy filled to assist decontamination and to prevent contaminates from getting behind the shielding. Neutron shielded gloveboxes are double walled and water filled. This eliminates the contamination traps associated with external shielding.

\section{General}

A. Piping Held to a Minimum

Remote chemical operations generally dictate large quantities of conduit as well as process piping. By relocating that which does not have to pass thru a process area, some of the more difficult decontamination work is reduced.

\section{B. Pre-filtration}

Pre-filtration is utilized on room air ductwork as well as the glovebox exhaust. Roughing filters reduce contamination levels withing the ductwork. They also lessen the accumulation of lint which can be a fire hazard. 
C. Control Rooms

Control rooms remove people and equipment from the process area. They isolate delicate equipment that cannot be effectively decontaminated.

D. No Threaded Rod

Threaded rod, unistrut and concrete inserts are standard items in the construction industry, but they are difficult to decontaminate and present safety hazards when decontamination is attempted. Fully threaded rod and unistrut have been replaced by square tubing and angle iron weided to steel plates in the concrete, which replaces the standard concrete inserts.

E. Spacing

All equipment should be spaced so that all surfaces are available for decontamination. HVAC duct work will be separated to provide access. If space is not available the inaccessible area will be enclosed. All piping and conduit witl be separated so that it can be wiped down. Large equipment is located so that it is accessible from all sides. 


\section{F. Ventilation and Compartmentalization}

A primary function of a ventilation system is to decontaminate building air. Proper location of ductwork aids in surface decontamination efforts. Room air exhaust ducts are located away from entry doors to prevent direct entrance into areas of highest contamination levels. Supply air ducting is located in the attic area with sealed penetrations thru the ceiling. A HEPA filter acts as a diffuser for the supply air and prevents possible entry of contamination into the ductwork. Generally each compartment has its own ventilation system to further isolate them.

Decommissioning of a facility can only be accomplished by decontamination of that facility. Any aids to decontamination that can be incorporated into the design of the building and equipment will facilitate that goal. Probably the most important aids are proper spacing and accessibility associated with good surface finishes. 


\author{
$0268 \%$ \\ WASTE MANAGEMENT AND SAFETY \\ CONSIDERATIONS FOR FUTURE LASL \\ $D \& D$ PROJECTS
}

\begin{abstract}
Currently excess contaminated facilities at the Los Alamos Scientific Laboratory are described along with associated Decontamination and Decommissioning waste management and safety considerations. Waste management and safety considerations are also briefly described for the removal and disposal of plutonium contaminated gloveboses and equipment items in the LASL plutonium facility since the facility will be decontaminated when current operations are transferred to a new facility and for both past and future upgrading of the exhaust air filter system in a chemistry metallurgy research facility.
\end{abstract}

by

A. M. Valentine and J. L. Warren

of

The Los Alamos Scientific Laboratory*

P. O. Box 1663

Los Alamos, New Mexico

*Work done under the auspices of

The Energy Research and Development Administration

July, 1975 
TABLE OF CONTENTS

1. Introduction

2. Excess Contaminated Facilities and Equipment Items

3. Contaminated Facilities and Equipment Items Expected to Become Excess

4. Summary 


\section{WASTE MANAGEMENT AND SAFETY CONSIDERATIONS \\ FOR FUTURE LASL D \& D PROJECTS}

\section{Introduction}

Several excess facilities at the LASL are contaminated with radioactive materials to an extent they cannot be occupied without health physics control and cannot be beneficially used in their present conditior. Similarly, facilities, equipment items and numerous miscelianeous tanks, pits and pipe Iines have been or are expected to be declared excess due to reorientation of research prograris, the termination of certain projects, and/or constructior of new facilities. In many instances, these excess facilities have accumulated over the past years because of a continuing need to commit operating funds to more airect support of vital research programs.

Safety considerations always have been paramount both in identifying a need for and in the accomplishment of Decontamination and Decommissioning (D\&D) type projects at the LASI. waste management considerations and planning, although important to the overall project completion, have been handled with relative ease of accomplishment owing to the rather basic approach of burial of the resulting debris in an approved onsite solid radioactive waste burial site. More recently as a consequence of the nature of pending projects, and the issuance of ERDA-MC-0511, considerably more complicated waste handing and disposal concerns related to these projected D \& D activities 
are being identified. Specific problem areas include:

(1) providing packaging, handling, and storage for large bulky items

(2) providing the means for decontamination and/or size reduction of large bulky items of waste for both burial and storage

(3) safety of personnel during accomplishment of these more extensive required waste management activities

(4) means of assay to determine quantity of TRUcontamination present

(5) containment of tritium contamination

Presently the LASL is in the earty planning stages on $D \& D$ projects involving several contaminated facilities. Trese facilities and related waste management and safety concerns are discussed.

2. Excess Contaminated Facilities and Equipment Items Listed in Table 1 are the major excess contaminated facilities and equipment items that have been identified at LASL. Some of these excess contaminated facilities and equipment items represent significant potential sources of radioactive material which may be accidentally dispersec in the event of a fire or other destructive occurrence. One facility which was abandoned in 1974, releases a few thousand curies of tritium per year to the atmosphere because the exhaust ventilation system must continue in operation to protect 
TABLE I

\section{LISTING OF EXCESS CONTAMINATED FACILITIES \\ AND MAJOR EQUIPMENT ITEMS AT IASE}

NOMENCIATURE

1. Water Boiler Reactor

Equipment

2. Filter Building and

Equipment

3. Incinerator Facility

4. UHTREX Reactor Facility

5. Tritium Gloveboxes

6. Air Washer and Equipment Ra-La Liquid Waste Tanks

7. LAMPRE Reactor Vessel

8. LAPRE II Reactor Vessel

9. Liquid Waste Tanks

10. Sodium Storage Tanks

11. Misc. Abandoned Pits, Tanks and Lines
LOCATION

$\mathrm{TA}-2, \mathrm{Bldgs.} 1$ (Rm 123),

$19,32,48$ and 62 .

TA-21, Bldg. 153

$\mathrm{TA}-42$

$\mathrm{TA}-52$

TA-35, Bldg. 2, Rm A-12,

$A-12 A$ and $A-12 B$

TA-35, Bldgs. 6, 7, and

10

TA-35, Bldg. 2, Rm L

TA-35, Under TA-0-585

Trailer

$\mathrm{TA}-35, \mathrm{Bldg} \cdot 37,38,39$

and 40

$\mathrm{TA}-35-43$ 
personnel working in the adjacent laboratory facilities. The presence of these contaminated facilities also hamper and in some cases prevent beneficial use of other associated building and land spaces.

The Water Boiler Reactor was a low power homogeneous reactor fueled with enriched uranyl nitrate solution. The fuel was contained in a stainless steel sphere with volume of approximately 13 liters. The uranyl nitrate fuel was removed in 1974. The reactor vessel with its associated recombiner and plumbing is contained in a concrete, grapinte-Iined biological shield structure that has an approximate volume of $73 \mathrm{~m}^{3}$. The reactor_and its biological shield structure and control room is housed in a frame building approximately $18 \mathrm{~m}$ $\times 18 \mathrm{~m} \times 8 \mathrm{~m}$. Gaseous effluents from the reactor were released via a small double encased stainless steel line which exited the reactor enclosure undergound and proceeded to an underground concrete chamber. This chamber contains several purns and tanks. The line passed through this chamber and on to an aboveground concrete valve house. Fron the valve house, the effluent line entered a condensing trap and two delay tanks before terminating at a stack. The delay tanks are stainless steel and have volumes of approximately $3 \mathrm{~m}^{3}$.

Radiation surveys indicate radiation levels in excess of $50 \mathrm{R} / \mathrm{h}$ at the reactor vessel surface primarily from induced ${ }^{60}$ Co activity. The stack line, underground chamber, valve house and delay tanks have contact radiation levels as high as 
$40 \mathrm{R} / \mathrm{h}$. The primary concern with this disposal will be personnel exposure control during removal, packaging and transport to LASL radioactive solid waste disposal site. Because of the presence of high gamma radiation levels from the reactor components, any significant size reduction will be extremely difficult without special shielded and/or remote facilities.

Not connected with the reactor, but in the same general area, and no longer being used, is a septic tank. This tank is contaminated with fission products and has an approximate volume of $8 \mathrm{~m}^{3}$.

The Filter Building and Equipment items are located at the DP-East site and about $15 \mathrm{~m}$ from an operating facility. This filter building is a two story frame and masonary structure with 300 square meters of floor area on the ground floor and 84 square meters on the second story. The building was used for cleaning the exhaust air from buildings at DP-East from the late forties until March, 1970. The building contains several lineal meters of metal ducts, and associated plenums, filter housings, two blowers, and two stacks. Dismantling this facility to effect size reduction paxticularly of the plenums, ducts and other bulky pieces is needed to minimize the volume of contaminated waste that must be disposed of on site.

The primary radioactive contaminant in this facility is $227 \mathrm{Ac}$ and its daughters. Precleaning after shutdown removed most of the contamination in those parts of the bujlding which 
could be decontaminated without dismantling. However, unmeasured quantities of radioactive contamination remain on inaccessible surfaces in the duct work, plenums, blowers and stacks. TRU-retrievable packaging is not of concern in this project, and a similar facility was decommissioned in 1973 by LASI. The Incinerator Facility is located approximately $120 \mathrm{~m}$ west of Pecos Drive immediately north of TA-55, the new LASL plutonium facility which is under construction. The incinerator is acjacent to a control office building which contains about 185 scyare meters of floor space. This building houses the office, change room, sorting area, and entrance ports to the incinerator. Associated equipment items include blowers, cyclones, separators and other air cleaning devices, two large storage tanks plus drain lines, a septic tank and drain field. Preliminary decommissioning work accomplished in 1975 resulted in the removal of walls inside the control office building and removal of most equipment items except the incinerator and its associated liquid tanks.

Internal surfaces of the incinerator, liquid waste tanks, drain lines, and air cleaning devices are contaminated with plutonium. While levels are thought to be sufficiently low to allow disposal as nonretrievable waste, accurate assay of the major contaminated areas of many of these items will be almost impossible. Many of the removable equipment and facility components are bulky by nature and will lend themselves to considerable size reduction if facilities to effect this were 
available. Additional handling associated with size reduction efforts would pose an increased worker exposure risk, however. The Tritium Glovebox line is located in the basement of an operating facility. This glovebox line is a comination of gloveboxes and hoods interconnected directly or by transitions. The gloveboxes and hoods have a combined length of approximately 25 meters and are constructed of steel frame with glass or plastic windows. Some of the glovebox and hood sections were assembled in place because movement after final assembly was not possible. The line was constructed in a walled-ff portion of an existing basement. It was necessary to excavate and remove a portion of the exterior basement wall to get some of the associated large equipment items in to the basement. The wall was then rebuilt and area back-filled with soil. At present, in and around the gloveboxes and hoods, there are numerous vacuum pumps, utility lines and exhaust ducts. Flso in the main room there are conventional laboratory cabirets and benches. An adjacent room houses the electrodryer and its associated pumps and lines. Exhaust room ventilation, the glovebox and the hood ventilation is provided by an exhaust blower and stack system separate from the main building exhaust system. This system is not equipped with effluent treatment systems for tritium removal; hence a few thousand curies of tritium is reIeased per annum.

It is estimated that there are some $10^{4}-10^{5} \mathrm{Ci}$ of residual tritium contamination in the electrodryer system, and between 
2000 and $10000 \mathrm{Ci}$ of tritium in the glovebox line itself. Spraying the walls of the gloveboxes and hoods with asphalt followed by sectioning and packaging the systems for burial has been suggested as one possible disposal and containment means. However, recent investigations of tritium waste disposal at the primary IASL burial site indicate that the past use of asphalt has been almost, if not totally, ineffective in containing the tritium in the waste. In an object as large as this glovebox chain, the capability of applying an effective asphalt coating also must be questioned. Additional study of means of application, adherence, and effectiveness of such a coating should be carried out prior to initiation of this project. Means of assuring safe handling and containment of the tritiated water in the dryer system are not expected to pose as great a problem, since these systems are contained in heavy metal tanks.

The Exhaust Air Washers and several Ra-La Liquid Waste Tanks are located east of the main laboratory office building at Ten Site, an occupied area. These large systems received contaminated exhaust air and liquid wastes from the main facility at Ten Site and are contaminated with fission products, primarily ${ }^{90} \mathrm{Sr}$ and ${ }^{137} \mathrm{Co}$, and low levels of TRU materials. The components of these systems are large metal and/or concrete structures and it will be extremely difficult to effect size reduction prior to disposal without significant additional worker risk. 
There are several other equipment items in and around these facilities that could be eliminated such as the old purphouse and several smaller liquid waste tanks.

The UFTREX Reactor Facility is located south of Puye Road approximately $300 \mathrm{~m}$ east of Pajarito Road. This reactor was a ̧as cooled research reactor which was operated at hiç temperatures. It utilized enriched uranium impregnated in graphite rods for fuel elements. In addition to the reactor are numerous large equipment items such as heat exchangers: gas clean-up systems, pumps, filters and stack. The irradiated fuel elements have been removed, however, and undetermined quantity of fuel fragments remain in the graphite lirer of the reactor vessel along with a ${ }^{238} \mathrm{pu}$ neutron source.

Both waste management and safety considerations regarding the future disposition of this facility indicate that it may be best to leave the reactor vessel in place, removing only the associated contaminated reactor hardware from the facility. Other possible uses for the UHTREX facility are being proposed, some of which (e.g. LASL High-Temperature Helium Test Loop Facility) make use of much of the existing facility equipment while leaving the reactor vessel in place. Obviously such future applications of these facilities is most advantageous from the waste management standpoint when compared to complete facility decommissioning.

The LAMPRE Reactor Vessel is located in the main labora- 
tory office building at Ten Site. The LAYPRE reactor was defueled in the mid-1960's leaving a vessel which has approximate dimensions of $6 \mathrm{~m}$ long and $0.6 \mathrm{~m}$ diareter. The vessel is steel and most of the associated cooling pipes and control apparatus have been removed. The vessel is setting upright in a basement room which opens into a hict bag ground level room. The top of the vessel is shielded $2 y$ graphite and lead bricks. Radiation surveys indicate radiation levels of $25 \mathrm{R} / \mathrm{h}$ at the top support yoke and $\sim 200 \mathrm{R} / \mathrm{h}$ immediately above the vessel surface.

It is estimated that $50-100 \mathrm{gms}$ of $239 \mathrm{pu}$ remain in the vessel cooling coils; consequently remova: of the $\mathrm{Pu}$ or packaging for 20-year storage must be considered. The size, gamma radiation levels, and present locations of the LAPRE reactor and associated contaminated hardware will make handling and packaging most difficult. If at all possible a cutting of the $6 \mathrm{~m}$ long core vessel into three (or more) smaller sections followed by packaging into shielded containers, or removal of the $\mathrm{Pu}$, should be effected.

The LAPRE II Reactor Vessel is located below ground level at Ten site. The LAPRE II reactor was an experimental reactor used for early liguid metal reactor experiments. The reactor was defueled in 1959 and all associated equipment except the vessel and fuel storage tank were removed later in 1959. The vessel is covered with dirt and a layer of black top and a trailer is positioned on the black top directly above the 
vessel location.

The vessel is approximately $1.8 \mathrm{~m}$ in diameter and $3 \mathrm{~m}$ long and is constructed of stainless steel and with a gold lining. Radiation levels are not significantly above background in the area adjacent to where the vessel is located. Justification for removal of the vessel would be to facilitate a general area clean-up and to consolidate the location of all buried radioactive residues. However, in the present location, little of any direct hazard is present, and perhaps leaving the LAPRE II reactor vessel in place is the most desirable from both the waste management and safety standpoint.

The four (4) Liquid Waste Treatment Tanks located at Ten Site are about $1.8 \mathrm{~m}$ in diameter and $3 \mathrm{~m}$ deep. The tops of these tanks are at ground level and two of the tanks house ion exchange columns. The other two tanks provide regenerator and flocculator storage capacities. The drain lines, ion exchange columns, pumps, and various liquid piping systems associated with these tanks would be removed. Undetermined levels of fission products including ${ }^{90} \mathrm{Sr}$ exist on the inside surface of these tanks, ion exchange columns and pipes. The penetrating radiation associated with these tanks and systems will make handling and packaging difficult. Since the systems do not contain plutonium there will be no need to package and treat the resulting waste as TRU-waste.

Two Sodium Storage Tanks are located several hundred yards south of the main laboratory office building at Ten site 
and on the edge of a small canyon. These underground double walled stainless steel tanks are $12-15 \mathrm{~cm}$ ID and about $40 \mathrm{~m}$ long. The tanks are approximately $0.6 \mathrm{~m}$ apart and the tops are near ground level. They each contain approximately 115150 liters of sodium which is contaminated with some fission and activation product activities, and probably some ${ }^{239} \mathrm{Pu}$. The pumps, lines and exposed tops of the tanks are housed in a small shed. The sodium transfer pipes leading to the tanks have been removed. Radiation levels at surface of the tank range from 5-10 $\mathrm{m} / \mathrm{hr}$.

Concern has been raised regarding the presence of these tanks. However, removal and the associated handling to dispose of elsewhere likely may not be worth the associated risks and costs. Chemical treatment or controlled reaction of sodium need investigation. Also, the possibility of leaving the tanks in place while significantly modifying the surface cover and facilities is a viable alternative. Miscellaneous Contaminated Waste Disposal Pits, Tanks and Iines have been abandoned in place on and around LASL site. These items are listed in Table II and disposition will for the most part consist of removal and on-site disposal of contaminated items followed by restoration of land area. No major waste management concerns are foreseen in such cleanup operations except for the large volumes of waste generated. 
TABLE II

MISCELLANEOUS CONTAMINATED PITS, TANKS, AND LINES

A. Underground pits used for liquid disposal:

1. Near TA-21-164

2. Unmarked: Between $T A-21-2$ and $T A-21-3$, liquids from Hanford container washing operation

3. Unmarked: TA-21-0 (dismantled laundry) between TA-21-14 and Waste Disposal Area $B$

4. At $T A-49$

B. Septic Tanks and Sumps: TA-2, TA-2I, TA-33, TA-41, TA-42, TA-46 (WA-61, 69, \& 70)

C. Underground contaminated drain lines:

1. TA-3-700 to ULR-3.3 manhole

2. ULR-33 to ULR-35 manhole

3. HRL to ULR-35

4. ULR-35 to $\mathrm{N}$ side Trinity Drive

5. Under Canyon Rd. near Diamond Drive

6. ULR-2 to $\mathrm{N}$ side Central Avenue

7. Under Rose St. near Central Ave.

8. Under Canyon Rd. near Central Ave.

9. TA-48-1 to ULR-149

10. Miscellaneous lines at $T A-21$

11. Dirt bunkers (4) at TA-15-44, 45, e, and I-J firing points

12. Underground chamber TA-33-29
Principle Radionuclides

Ro, $\mathrm{Ac}, \mathrm{Ra}$

$\mathrm{Pu}$

Pu, U

$\mathrm{Pu}$

$\mathrm{Pu}, \mathrm{U}, \mathrm{T}$

$\mathrm{Pu}, \mathrm{U}, \mathrm{FF}$

$\mathrm{Pu}, \mathrm{U}, \mathrm{FP}$

$\mathrm{Pu}, \mathrm{FP}$

$\mathrm{Pu}, U$, FP

$P U, U, F P$

$\mathrm{Pu}, \mathrm{U}$

$\mathrm{Pu}, \mathrm{U}$

$\mathrm{Pu}, \mathrm{U}$

Pu, U, FP

$\mathrm{Pu}, \mathrm{Am}, \mathrm{U}$

U

Po 
3. Contaminated Facilities and Equipment Items Expected to Become Excess

Construction of new facilities and effluent treatment systems upgrading projects are expected to cause several major equipment items to become excess in the next 2-3 years. Since these items are contaminated with TRU materials special planning is needed. These items and associated waste management and safety considerations are described in the following paragraphs.

The presently operational LASL Plutonium Facility commonly referred to as DP-West, has been operational since 1945. Oper-' ations at this facility will be relocated in a new plutonium facility which is currently under construction. Once operations have moved to the new site, extensive cleanup, decontamination and quite possibly some complete facility decommissioning is planned at the abandoned facility. Although the primary decision has not yet been made regarding the extent to which the LASL DP-West Pu-facility will be decommissioned, very large volumes of solid TRU waste are anticipated. These cleanup efforts likely will begin in late FY77 or FY78.

Much of this waste will be TRU-retrievable. Presently it is acknowledge that all gloveboxes and associated equipment in the recovery area will require removal. This amounts to approximately 100 lineal meters of glovebox line measuring approximately $2.5 \mathrm{~m}$ high by $1.5 \mathrm{~m}$ wide. In other Pu-processing areas,additional gloveboxes will require removal as 
TRU-waste while some can be cleaned and moved into the new facility. Additional waste to be generated includes ductwork, wall plaster, contaminated soil from utility tunnels, equipment and possibly the process air filter building. A total waste volume is expected to range from $2000-3000 \mathrm{~m}^{3}$ in this project.

Means to decontaminate and/or prepare the highly contaminated glovebox lines for 20-year storage are a major concern in tre planning for this operation. Three alternatives have, thus far, been identified, these being:

1) providing a size reduction and decontamination facility to facilitate packaging of gloveboxes into standard sized crates.

2) package glovebox lines into oversized boxes, as is required for individual components.

3) seal all openings in glovebox lines and use the glovebox itself as the contajnment.

In light of current accepted ERDA-contractor practices, the first option is the most desirable; however, it is also the most costly. In the long term, assuming eventual removal of all TRU-wastes from the IASL to a centralized repository, the accomplishment of this option would be the most economical as well as the safest approach in light of the future handing, decontamination size reduction, and packaging efforts that may be requirea. Many other large-sized components in the 
facility will require eventual size reduction, while not at this time being suitable for the other options because of their construction, contamination, etc. Overall, the option 1 indicated likely is the most desirable from the waste management standpoint. As such, funding, planning, and implementation are required.

In 1973, major modification to the air filter system in three wings of a chemistry metallurgy research facility was initiated. This facility houses varied fission product, TRU and $U$ research and development activities ir: a total of 6 independent but interconnected wings. A total of 48 sections of filter plenum were generated as waste, the largest section measuring approximately $5.5 \mathrm{~m} \times 5.5 \mathrm{~m} \times 3.5 \mathrm{~m}(6$ pieces this size). The approximate total waste volume was $1700 \mathrm{~m}^{3}(60000$ $\left.\mathrm{ft}^{3}\right)$. Assay of several sections of the plenum indicated that the two pieces at the "head end" were likely in excess of 10 $\mathrm{nCi} / \mathrm{g}$ for ${ }^{239} \mathrm{Pu}$ (also $100 \mathrm{nCi} / \mathrm{g}$ for ${ }^{238} \mathrm{Pu}$ ) and required retrievable storage. Several other pieces "down stream" were measured at or about the retrievable limits; however, the error in measurement being $\pm 100 \%$ or more made this determination very questionable, and it was subsequently decided to bury these pieces. Nevertheless, there are at the LASL waste disposal/ storage area eight (8) pieces of this plenum which are felt to require 20-year storage for which there is no presently acceptable means of handling or storage. Furthermore, the possibility of easy decontamination at this time has been removed 
because of treatment each piece received at the time of removal from the building; to facilitate the safe handling of each piece and transport to the interior surface to "fix" the contamination. Decontamination at the time of removal was not accomplished because of the difficulty and cost of the operation.

Presently anticipated air filter system modifications, will result in the removal of four additional plenum systems from 2 wings, a few sections of which could be retrievable under the current $10 \mathrm{nCi} / \mathrm{g}$ standard. Total volume of waste anticipated is approximately $1130 \mathrm{~m}^{3}\left(40000 \mathrm{ft}^{3}\right)$. This volume, as with the earlier sections, is about $75 \%$ void space. While current LASL programs attempt to reduce current operational waste volumes by a few to 10 s of cubic meters per month, the existing program can have little if any impact on this large waste volume. Providing necessary means of waste size reduction is a major waste management problem to this future project.

\section{Summary}

Major D\& D type projects currently identified at the Los Alamos Scientific Laboratory will have major impacts on volumes of radioactive solid wastes generated in coming years. Means of effecting volume reduction and decontamination of much of this waste will be essential to the proper execution of waste management programs. In particular, $50 \%$ or more of the anticipated TRU-retrievable waste to be generated in the next 4-5 years 
may result from $D$ \& $D$ operations. Most of this will be comprised of highly contaminated equipment, glovebox lines, and components of air cleaning systems. Size reduction and/or decontamination will be required to effect the proper and safe handling, packaging, and disposal or storage of retrievable TRU wastes.

Several other identified D \& D type projects at the LASI. will require considercble adaitional study to determine safe means of accomplishment. On the other hand, such study may identify modification: to $D$ \& $D$ planning which indicate alternative uses for all or portions of existing facilities, or that the facility is best entombed at its present location, with or without some modifications. 


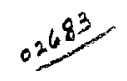

THE HOT FUEL EXAMINATION FACILITY/SOUTH

\author{
REFURBISEMMENT PROGRAM
}

L. Larsen

Argonne National Laboratory

C. C. Miles

Argonne National Laboratory

\title{
ABSTRACT
}

The Hot Fuel Examination Facility/South has been in continuous service since 1964. With the exception of a two-month air cell shutdown in 1969, all maintenance and repair has been done either remotely or by the removal of components from the cells for repair or replacement. The point has now been reached where extensive overhaul is required, and a major shutdown of the facility is planned.

During the facility shutdown, the in-cell equipment will be removed from the cells. The cells will be decontaminated, cell windows and lighting will be modified, and remote-handling equipment will be improved. When the cells and cell equipment have been cleaned and modified, the facility will be retumed to service in support of the LMFBR program . 
Argonne National Laboratory-West is located 36 miles west of Idaho Falls at the Idaho National Engineering Laboratory. There are four major facilities at ANL-West; these are the Transient Reactor Test Facility (TREAT), the Zero Power Plutonium Reactor (ZPPR), Experimental Breeder Reactor (EBR-II), and the Hot Fuel Examination Facility (HFEF).

The TREAT reactor is used for experimental verification of fuel failure thresholds and failure mechanism resulting from accidents. Reactor transient overpower and loss-of-coolant experiments are carried out within self-contained loops in TREAT to provide the basis for modeling the course of such events.

The major component of the Laboratory's reactor physics program is ZPPR, which provides valuable information about the behavior of proposed fast reactor designs. ZPPR is the nation's largest fast reactor critical assembly and the only zero-power reactor in the world large enough to permit plutonium-fueled mockups of the large breeder reactors that are envisioned as central power stations in the 1990s and beyond.

The major experimental facility in the LMFBR Program is EBR-II, which was designed by Argonne and built at ANL-W. As the nation's only operating fast breeder reactor, EBR-II is the primary irradiation test facility for fuels, materials, and components in the LMFBR safety program.

The HFEF complex consists of two hot cell facilities. HFEF/South, originally called the Fuel Cycle Facility (FCF), was placed in operation in 1962 and HFEF/North was placed in operation in April, 1975. These 
two facilities provide a heavily-shielded, highly-automated system for examining and analyzing irradiated fuels and materials experiments and tests. HFEF also provides major support for the LMFBR safety program. Two general types of examinations are currently performed at the HFEF complex; the se are interim nondestructive examinations of irradiated fuels and structural specimens that may later return to the reactor, and nondestructive and destructive examinations after final irradiation. These examinations furnish valuable information on the performance of candidate LMFBR fuels and materials in an environment of intense fast neutron radiation, heat, and flowing sodium in the core of a fast breeder reactor.

The completion and activation of HFEF/N in April, 1975 has made it possible to implement a program to shut down and refurbish the $\mathrm{HFEF} / \mathrm{S}$ facility. Work now being performed at HFEF/S will be temporarily transferred to $\mathrm{HFEF} / \mathrm{N}$ for the time required to perform the refurbishment work in $\mathrm{HFEF} / \mathrm{S}$.

This paper presents the features of a refurbishment program for $\mathrm{HFEF} / \mathrm{S}$; these features can be described in four categories: deactivation, decontamination, equipment and facility repair, and reactivation. We are currently in the early stages of the deactivation program.

$\mathrm{HFEF} / \mathrm{S}$ is made up of two connected shielded cells and support facilities housed in a $22,500-\mathrm{ft}^{2}$ building. The building is attached to the EBR-II containment shell on the eastem quadrant of its circumference. The cells are constructed of 5-ft-thick, high-density concrete walls and a 4-ft-thick concrete roof. 
The rectangular-shaped air cell has nine lead-glass windows. Interior lighting is furnished by mercury-vapor lamps that provide an intensity of approximately 150 foot-candles of in-cell illumination at the work level. One 5-ton bridge crane, two electro mechanical (E-M) manipulators and 18 master-slave manipulators constitute the remotehandling equipment for operations and maintenance within the air cell. The floor, walls, and ceiling of the cell are concrete with an epoxy enamel surface finish.

The argon cell, which has the shape of a 16-sided regular polygon, has 14 lead-glass shielding windows at its outer perimeter. Interior lighting is also fumished by mercury-vapor lamps with the same lighting intensity as those in the air cell. There are two 5 -ton bridge cranes, six E-M manipulators, and 18 master-slave manipulators in the argon cell. In addition to the work stations outside the outer perimeter of the polygon, there is a viewing and operating room inside the polygon with 5-ft-thick concrete walls which has eight shielding-window locations. The interior surface of the cell is lined with a steel liner to provide a fully sealed cell for the containment of inert argon gas. The surface of the steel liner has been zinc coated and then shot peened to provide a diffused light reflecting surface.

EBR-II and HFEF/S were designed and built by Argonne National Laboratory and placed in operation in 1963 to develop and demonstrate an LMFBR Pilot Plant, including production of electricity and pyrochemical fuel reprocessing system for uranium-fission EBR-II driver fuel. From 1964 to 1968 approximately 40,000 fuel pins were processed. 
The source of spent fuel for this reprocessing program was EBR-II, which operated (and continues to operate) as a power-producing (20MW electrical) fast breeder reactor. Irradiated fuel subassemblies were transferred from the reactor to the HFEF/S air cell in an interbuilding cask. In the air cell, the fuel elements were removed from the subassemblies in preparation for transferring to the argon cell. The fuel elements were then transferred to the argon cell where the remote fuel reprocessing activity was performed. The reprocessing operation consisted of removing the fuel cladding, chopping the fuel pins to short lengths, and melt-refining these pieces to remove the fission products. The slag from the refining process was then treated to remove the small amount of trapped uranium.

This latter process caused much of the contamination that is presently distributed throughout the argon cell. The major part of this contamination is ${ }^{137} \mathrm{Cs},{ }^{144} \mathrm{Ce},{ }^{235} \mathrm{U}$, and ${ }^{239} \mathrm{Pu}$. The fission products ${ }^{137} \mathrm{Cs}$ and ${ }^{144} \mathrm{Ce}$, which are present in very low mass, account for most of the beta and gamma radiation. Also contributing to the beta and gamma radiation are very small amounts of other long-lived fission products such as ${ }^{106} \mathrm{Ru}$ and ${ }^{90} \mathrm{Sr}$ and some very small amounts of long-lived activation products such as ${ }^{58} \mathrm{Co},{ }^{60} \mathrm{Co}$, and ${ }^{54} \mathrm{Mn}$. The ${ }^{239} \mathrm{Pu}$ in the cell comprises only $\sim 0.5 \%$ of the fissile material believed to be present in the cell. However, because it is very active, ${ }^{239} \mathrm{Pu}$ contributes over $90 \%$ of the alpha activity. 
From 1968 until the present, the cells have been used as a conventional hot cell facility for the examination of irradiated specimens and materials from EBR-II, TREAT, and other reactors .

Except for a two-month shutdown of the air cell in 1969, HFEF/S has been in continuous service. With the exception of this one shutdown, which was required to repair the overhead in-cell handling equipment, all maintenance and repair has been done remotely or by the removal of components from the cell for repair or replacement. Although this maintenance has kept the cells in operation, a point has now been reached where extensive overhaul is required, and the facility must be shut down to accomplish this refurbishment work. During the shutdown of the facility, the in-cell equipment will be removed from the cells. The cells will be entered and decontaminated, the cell windows and lighting will be modified, and the remote-handling equipment will be improved. When the cells and cell equipment have been cleaned and modified, the facility will be retumed to service to support the LMFBR Program by providing a backup for and supplement to the new HFEF/N facility.

The major unknowns in the refurbishment plan at this time are (1) the level of radiation expected in the argon cell after all fuel and equipment have been removed, and (2) how effectively these levels can be reduced by the use of remote decontamination methods prior to actual personnel entry into the cell for contact decontamination and refurbishment operations . 


\section{PRE-SHUTDOWN TEST PROGRAM}

A program for remote decontamination tests has been established to provide information on these unknowns. The goal of the remote decontamination tests is to determine the amount and types of contamination present, the radiation levels associated with each type, and the best method for the removal of the contamination.

As a basis for the test program, we have separated the contamination present into three general types: free, adherent, and fixed.

1. Free Contamination: that which is easily removed by vacuuming, flowing water, or dry wiping with cloth.

2. Adherent Contamination: that which can be removed only by vigorous wiping and scrubbing using detergent or complexing solutions.

3. Fixed Contamination: that which is mechanically or chemically bonded into the surface and can be removed only by removing the surface.

In order to obtain this information as quickly as possible, the decontamination test program is to be accomplished while the HFEF/S cells are still in operation. Obtaining this information prior to the shutdown will provide time to work out the details of the actual remote decontamination. To evaluate the effectiveness of the remote decontamination tests, a method for taking radiation readings on selected cell surface areas must be used. 
Remote radiation readings will be accomplished using a Jordan "Rad Gun." The Jordan "Rad Gun" was chosen because it has a very wide range. In three separate scales it covers from $0.01 \mathrm{millirems} / \mathrm{hr}$ to $10,000 \mathrm{rems} / \mathrm{hr}$. A wide range was deemed necessary because we expect that there will be a great variation in intensities of radiation. We will want to measure not only high-level radiation, but will also want to measure moderate and low-level radiation from partially decontaminated surfaces in the presence of high background radiation. To do this we have built a shield around the "Rad Gun" which attenuates gamma radiation by a factor of $\sim 10^{6}$ from all directions except one.

The shielded "Rad Gun" assembly weighs about 2,000 lb and therefore must be transported and positioned by means of one of the 5 -ton capacity in-cell bridge cranes. A lifting bale has been provided to lock the shield for obtaining readings on either a horizontal or vertical silrface. Placing the instrument against the cell surfaces will give directional radiation readings and will give us an indication of the amount and location of contamination in the cells. By the use of these data, selected areas in the cell will be decontaminated and resurveyed to obtain information on the effectiveness of the decontamination methods.

Using a remotely operated vacuum cleaner with a special attachment for collecting the free contamination on a filter paper, test areas will be vacuumed. The filter paper will then be transferred to the chemistry laboratory and analyzed for uranium and other radioisotopes. After being vacuumed, each test area will be resurveyed to measure the reduction of 
radiation and hence obtain a decontamination factor for each vacuum treatment. This decontamination factor will thus be tied to a definite amount and kind of material.

Using cloth pads soaked in a cleaning solution, the test location will be remotely cleaned. After this wiping operation, the test pads will be analyzed for the type and quantity of radioisotopes, and the test patch area will again be surveyed with the Jordan "Rad Gun." This will establish the decontamination factor for wiping or scrubbing off adherent contamination and will tie it to a definite amount and kind of material removed.

If radiation levels indicate that contamination still exists in the test areas, a controlled acid etching process will be used to remove the fixed contamination. The solution selected for the initial work is a sulfamic acid solution which will lift the zinc plating and the fixed contamination embedded in the zinc. The solution will be collected and analyzed as before for type and quantity of radioisotopes.

In summary, the results of the quantitative and qualitative analysis and the gamma surveys made on each test location after each test will tie the material removed to the radiation measured and establish a decontamination factor for each process. These data will also allow us to make a proper estimate of the amount of uranium we can expect to collect in the overall decontamination to in sure criticality safety during the waste collection and disposal. 


\section{REMOTE DECONTAMINATION TEST PROGRAM}

The remote decontamination procedure for the argon cell will rely heavily upon the results of the decontamination tests. Also, data on contamination levels in the argon cell are now being gathered from the equipment currently being removed and will supplement data collected during our remote decontamination tests.

Planning for the air cell can confidently be based on similar work carried out in 1969. During a two-month period in 1969, the HFEF/S air cell was shut down for remote cleanup, direct cleanup, crane repair, manipulator repair, and miscellaneous work. Upon completion of remote cleanup of the cell, radiation levels at window locations ranged from $150 \mathrm{mR} / \mathrm{hr}$ to $280 \mathrm{mR} / \mathrm{hr}$. After contact cleanup was completed, personnel exposures produced by in-cell radiation sources were between $12 \mathrm{mR} / \mathrm{hr}$ and $50 \mathrm{mR} / \mathrm{hr}$. Because the argon cell has never been entered, no comparable data are available.

After the facility is shut down, the remaining equipment will be removed, decontaminated, boxed and stored for maintenance or disposal. To reduce the time required for equipment removal from the argon cell, the argon atmosphere will be released from the cell as early as possible. This argon gas (which contains a small quantity of Krypton-85) will be discharged to the atmosphere under carefully controlled and monitored conditions in order to maintain safe environmental-release conditions.

The goal of the remote decontamination is to reduce the in-cell general radiation levels to $\sim 100 \mathrm{mR} / \mathrm{hr}$ before cell entry. Provided that the remote testing indicates the method to be useful, the first step will 
be to vacuum all cell interior surfaces using remotely operated vacuum cleaners while periodically measuring the radiation with the shielded "Rad Gun." This will be followed by a wash-down with damp or wet cloths and cleaning solutions. We expect that these two operations will be quite successful in decontaminating the walls, ceiling, and other exposed surfaces.

We also expect substantial success in decontaminating most of the floor areas using these two methods. However, on the floor and perhaps on some vertical surfaces, we probably will find localized hot spots, and perhaps general areas where the contamination has been ground in and is mechanically bonded to the cell structure. At that time a decision will be made whether to pursue additional remote cleaning techniques or to remotely install shielding over those areas which would prevent cell entry by personnel.

\section{CONTACT DECONTAMINATION}

When we have met our goal of reducing the general radiation background, the cells will be entered and direct contact decontamination will begin. Personnel entry into the air cell will be through an existing cell access door; entry into the argon cell will be made through one window location, which is now set up as a periscope viewing station. Anticontamination change rooms will be constructed adjacent to the transfer station.

The initial entries into the cells will be made by ANL personnel, especially trained in health physics operations, to perform direct 
radiation and air-monitor surveys and to establish other cell conditions relating to safety in subsequent operations.

Once safe working conditions have been established, the initial cleanup work will be performed by ANL personnel to remove hot areas in an attempt to quickly reduce the general cell radiation levels. Reducing radiation levels in this manner will permit the general contact decontamination, which it is planned will be done by a subcontractor using a minimum of personnel. The decontamination goal will be to reduce the radiation levels for safe entry of personnel for extended work periods without the necessity for breathing protection.

The dire ct decontamination techniques will be generally the same as those used for remote decontamination; other methods, if found useful and more practical when having direct access to the contaminated surfaces, will also be used. Once the decontamination goal has been reached, repair of the cells and replacement and repair of the cell equipment will begin.

\section{WASTE MANAGEMENT .}

During the course of the Refurbishment Program, large quantities of solid radioactive waste and obsolete contaminated equipment will be removed from the cells. Much of this material will be buried in the INEL nuclear burial ground. The equipment will be partially decontaminated, wrapped, boxed, and buried according to provisions for disposal of such material as defined in the Argonne-West Health and Safety Manual and ERDA-ID requirements . 
The radioactive liquid wastes generated during the shutdown will be processed through the ANL-W Liquid Suspect Waste Processing System. The quantity of liquid to be processed j.s not expected to be greater than the capacity of the existing process equipment. The total quantity of radioactive waste to be disposed of has been estimated and factored into the overall ANL-West disposal program for 1975 and 1976 .

\section{PERSONNEL TRAINING AND SAFETY}

There is obviously a potential for industrial safety hazards during a project of this nature; personnel will work at heights up to 20 feet, work in confined spaces, hoist heavy equipment, and perform abrasive and chemical cleaning. The hazards of this type of work are clearly recognized, and appropriate controls will be established as covered in the Argonne-West Health and Safety Manual.

Personnel safety will be of utmost concem during the HFEF/S Refurbishment Project. All work will be done under safety controls which insure that personnel are not subjected to unsafe working conditions from either industrial or radiological hazards.

All personnel working in radiation fields and with radioactively contaminated materials shall be properly trained for this work. Many of the technicians and craft personnel who are to accomplish the decontamination and equipment repair are now qualified radiation workers who have been trained in accordance with the ANL-W Radiation Worker Training Program. Other personnel who have not received this training will be trained before working with radioactive materials. Detailed work 
procedures and radiation work permits will be issued and approved by Radiological Engineering prior to the start of any work.

\section{REACTIVATION}

Following the completion of the HFEF/S refurbishment and after all equipment has been requalified, the facility will be returned to service in support of the LMFBR program. The mission of the refurbished facility will be to back up and complement $\mathrm{HFEF} / \mathrm{N}$ for interim nondestructive examinations of LMFBR experimental irradiations. Included in this mission will be the provisions for interim storage of experimental capsules and elements in an inert-gas environment. 
Title:

PREPARATIONS FOR DECONTAMINATION \& DISPOSITION

OF THE SODIUM REACTOR EXPERIMENT (SRE) AND

OTHER ERDA FACILITIES AT AI

Authors: W. F. Heine

Program Manager

D\&D Program

A. W. Graves

Project Manager, Engineering

D\&D Program

Atomics International

8900 De Soto Avenue

Canoga Park, California 91304

Abstract: The Atomics International (AI) Decontamination and Disposition (D\&D) of Facilities Program for the Sodium Reactor Experiment (SRE) and other ERDAowned, AI-operated, radioactive facilities is described. The program objective along with a description of each of the subject facilities is presented. A description of the organizational structure within AI supporting the D\&D program is given. The elements of planning required to prepare for the D\&D task are detailed, including the requirements for cost and schedule control. The D\&D progress to date and the future plans are presented. The available technology utilized in the program is described. 
PREPARATIONS FOR THE D\&D OF THE SODIUM REACTOR EXPERIMENT

(SRE) AND OTHER ERDA FACILITIES AT

ATOMICS INTERNATIONAL

\section{A. PROGRAM OBJECTIVE}

There are eight inactive, ERDA-owned nuclear facilities at the Atomics International (AI) Santa Susana Nuclear Development Laboratory included in the Decontamination \& Disposition of Facilities (D\&D) Program. These facilities include completed reactor experiments, hot cave facilities, and waste disposal facilities which contain extensive amounts of radioactive materials in the form of activated or contaminated structures and components. These facilities are: Sodium Reactor Experiment (SRE), Building 003 Hot Cave, Kinetic Experiments Water Boiler (KEWB), Shield Test Irradiation Reactor (STIR), SNAP Experimental Reactor (SER) Facility, SNAP Experimental Test Facility (SETF), SNAP 8 Ground Prototype Facility (SGPTF), and the Radioactive Materials Disposal Facility (RMDF).

The principal objective of the AI D\&D Program is the decontamination and dismantling of the above facilities, with funding from ERDA Division of Waste Management and Transportation, culminating in the release of the facilities from all requirements for radiological control, licensing or monitoring, and the placing of the facilities into a condition acceptable for unrestricted use. The D\&D effort will take five years to accomplish, beginning with GFY 1975.

An additional program objective requires that the SRE Cores I and II fuel, presently stored at the RMDF, be declad, cleaned of NaK bonding in the AI Hot Laboratory, and shipped to Savannah River for reprocessing. 


\section{B. FACILITIES BACKGROUND DATA}

SRE--The SRE is a 20-Mwt sodium-cooled, graphite moderated thermal reactor. The core, moderator, reflector, and support structures are contained in a $\frac{1}{4}$-in.-thick, stainless-stee] vessel liner within a $1 \frac{1}{2}$-in.-thick, stainless-steel reactor vessel, which is surrounded concentrically by $5 \frac{1}{2}-i n$.-thick steel thermal shielding, $\frac{1}{4}-i n$-thick steel outer vessel, 1-ft-thick insulation, $\frac{1}{4}$-in.-thick steel cavity liner, and 4 -ft-thick high density concrete biological shielding. Primary sodium heat transfer circuits carried the heat generated in the reactor to a secondary circuit through sodium-to-sodium heat exchangers. The secondary sodium carried the heat to airblast heat exchangers or to a steam generator.

The SRE and associated auxiliary facilities have been "stored in place" since the SRE-PEP program was terminated in GFY 1968. The facility was maintained in this condition pending approval of funding and plans for complete dismantling.

SRE Fuel Decladding--The irradiated fuel from SRE cores I and II has been stored in the irradiated fuel storage vault at the RMDF since it was removed from the SRE reactor (1959 for Core I and 1964 for core II). Because the fuel is bonded to the cladding with liquid metal (NaK), it cannot be reprocessed without special head-end, pre-reprocessing treatment which is currently not available at the Division of Production Savannah River reprocessing plant. The decladding of the fuel and removal of the NaK bonding, which is being performed at the AI Hot Laboratory, will place the fuel in an acceptable condition for reprocessing at the Savannah River Reprocessing Plant. 
Hot Cave--The Building 003 hot cave was a high-density concrete, steel, and lead shielded remote handling facility containing two hot cells, complete with manipulator systems, and a transfer tunne1. The hot cave had been inactive since the close out of the SNAP Program in GFY 1973. Prior to that time, it had been used for the analys is of SNAP fuel burnup samples. The inner surfaces were grossly contaminated with mixed fission products. Dismantling of this facility was completed by Atomics International during GFY 1975.

KEWB--The KEWB reactor was a homogeneous-fueled, graphitereflected reactor used for power transient studies. The reactor facility had been "stored in place" since the KEWB program was terminated in GFY 1967. The fuel was removed from the fuel storage tank and shipped to a recovery plant in GFY 1969. Radioactive components remaining in the facility were the reactor core vessel, the fuel handling system, the reflector assembly, all waste handling systems, and a number of other contaminated or activated components. Dismantling of this facility was also completed by Atomics International in GFY 1975.

STIR--The Shield Test Irradiation Reactor was a 1-Mwt, pooltype reactor which operated with a highly enriched core consisting of 20 MTR-type fuel elements. The reactor was used throughout the SNAP Program to test shielding materials for SNAP power systems, and was defueled and partially dismantled during the closeout of the SNAP Program in GFY 1973. There remain at the facility a number of activated and contaminated structures, including: (1) the core structure, (2) the reactor pool tank, (3) the concrete biological shielding, (4) the thermal column, and (5) the fuel storage cells. 
SER--Two SNAP reactors, S2ER and S8ER, were operated over several years in a below-grade reactor containment vessel in the SER facility. Following completion of respective operating tests, the reactors were removed intact and transferred to the AI Hot Laboratory for disassembly and examination. There remain at the facility, extensive high level activated and contaminated materials, including steel containment vessels and concrete biological shielding, most of which are below grade.

SETF--The SETF was used as a facility for the operating endurance test of the SNAP $10 F 53$ reactor. The reactor was operated in a vacuum vessel contained in a below-grade test vau1t, and was subsequently removed intact and transferred to the AI Hot Laboratory for disassembly and examination. Activated components and structures remaining in the facility include the SNAP 1OFS3 vacuum vessel, the test vault liners, and the concrete biological shielding.

SGPTF--The SGPTF was designed for endurance testing of the SNAP 8 Development Reactor. The reactor was operated for more than a year at power levels of up to 1 Mwt. Following completion of the test in GFY 1970, the reactor was removed intact and transferred to the AI Hot Laboratory for disassembly and examination. There remain at the facility extensive below-grade activated structures, including steel containment vessels and vacuum ducts, high density concrete biological shielding, and sand fill.

RMDF--The Radioactive Material Disposal Facility (RMDF) is a facility devoted to radioactive waste process and storage. It includes an irradiated fuel and high-level waste storage vault, a waste compaction and packaging building, a component decontamination building, and liquid waste storage tanks. Extensive fission product and activation product contamination exists in the waste handling systems. 


\section{PROGRAM ORGANIZATION}

AI has placed sufficient emphasis on the decommissioning activities to establish a full Program Office with a Program Manager directing the activities of a staff of Project Managers and Project Engineers. The decommissioning activities are recognized by AI as an integral phase in the overall development of nuclear energy, and AI intends to provide this service to the industry. The overall divisional management organization at Atomics International is shown in Figure 1.

The D\&D Program Manager, who reports to the Director, Fue] and Test Facility Programs (Figure 2), has overall programmatic responsibility for all efforts associated with the decontamination and disposition of ERDA facilities at the Santa Susana Field Test Laboratory.

An Engineering Project Manager reports directly to the Program Manager. This project manager is responsible for the engineering efforts associated with the D\&D Program, including the development of Activity Requirements, Test Plans, and Operating Procedures associated with the design and development of special tooling and containers. The development and coordination of the program documentation and Activity Network Schedules are also the responsibility of this Project Manager. Project engineers assist the Engineering Project Manager within specific areas of the D\&D engineering.

A Dismantling Activities Project Manager reports directly to the Program Manager. This Project Manager is responsible for the development of Dismantling Plans, Activity Requirements, Detailed Working Procedures, and the physical dismantling activities being performed by AI, Rocketdyne, and subcontractor personnel. Project engineers established for major dismantling tasks within this project, will also report to this Project Manager. 


\section{PROGRAM PLANNING}

The overall schedule for the D\&D Program, Figure 3, was established by determining the optimum sequence for dismantiing the various facilities according to degree of hazard potential, program utilization of existing facilities, cost effectiveness, funding limitations, and special planning and tooling development requirements. Several general activity categories were identified to provide sufficient detail for the overall program activity schedule and to establish a common base for developing the more detailed individual facility Activity Network Schedules and Dismantling Plans. The general categories were identified as: (1) program management, (2) planning, (3) tooling and equipment, (4) decontamination and dismantiing, (5) waste disposal, (6) radiological survey, and (7) documentation. All of the efforts involved in the D\&D Program fall into one of these categories.

A Dismantling Plan is prepared and approved for each of the facilities prior to commencing the dismantling efforts. The plan defines the scope of the dismantling effort, provides a brief description of the facility and background data, expands upon the specific applications of the general activity categories listed above, and identifies the major tasks which require the preparation of separate Activity Requirements documentation.

Activity Requirements are written for each of the major tasks involved in each of the facilities. The Activity Requirements define the scope, proposed methods and sequence for accomplishing the task, tooling requirements, overall health and safety requirements, and technical guidelines for the preparation of the Detailed Working Procedures. 
Detailed Working Procedures are written where required to supplement existing approved in-house working procedures. These procedures describe the details of the decontamination and dismantling operations, the associated radiation safety and industrial hygiene requirements, the use of special tooling, and any special handling requirements.

The following paragraphs describe the details of the generai activity categories listed above which are used in developing the activity network schedules for the overall D\&D Program; in preparing the detailed schedules and manpower estimates for the individual facilities; and in preparing the specific Dismantling Plans.

Program Management--The program management activity includes the efforts involved in directing the overall performance of the program objectives; interfacing with the appropriate offices of ERDA, internal AI management, and outside suppliers and contractors; obtaining the services of the internal functional organizations, and monitoring the subsequent performance; and performing administration support functions such as reproductions, data management, cost monitoring, schedule monitoring, and purchasing activities.

Planning--The planning activity includes the efforts required to develop and prepare the overall D\&D Program Plan, the Quality Assurance Plan, the Operational Safety Plan (including occupational and radiological safety requirements), and a Training Plan; establish schedules and projected costs for each facility; and prepare the Dismantling Plans, Activity Requirements, and Detailed Working Procedures for each facility. Figure 4 presents the document tree for the D\&D Program. 
Tooling and Equipment Design and Fabrication--The tooling activities involve the establishment of the functional and operational requirements for tooling and equipment to support the decontamination and dismantling operations; the preparation of detailed designs for tooling and equipment not available off-theshelf; the fabrication and/or procurement of the identified tooling and equipment; the design, fabrication, and operation of a mockup facility, where required for remote operational checkout; checkout operations; and development of operational parameters for remote tooling and equipment in the mockup facility. The SRE will require the greatest tooling effort. A remote manipulator system will be utilized to cut up the reactor vessels. The manipulator system will be submerged under water as necessitated by the requirements for radiation shielding. A vessel mockup will be used to develop and check out the remote manipulator operating parameters prior to installation in the SRE. The ORNL manipulator design used for the Elk River dismantling program has been modified by AI Engineering to meet the SRE geometry requirements and material requirements; e.g., the system will be fabricated from stainless steel rather than carbon steel for ease of decontamination. The vessel mockup facility was designed by $A I$ and was constructed by an outside contractor in an existing building at AI. An existing manipulator control console was obtained from ORNL and modified for added versatility of operation. The remaining facilities in the D\&D Program will require less extensive tooling. The two SNAP 8 test facilities (SER and SGPTF) will require some remote tooling for dismantling the vessels, which will be an adaptation of the SRE tooling.

Decontamination and Dismantling--This activity involves all the effort associated with the actual decontamination and dismantling of equipment, hardware, systems, and facilities. This activity does not include the processing, packaging, shipping, or 
burial of the radioactive waste, which is a separate activity category. Each of the facilities require substantial decontamination prior to and in conjunction with the dismantling operations. The Detailed Working Procedures for each facility identify the extent of required decontamination operations expected for those activities involving activated or contaminated materials and/or equipment. AI personnel trained in radioactive material handling perform all tasks involving high-level radioactive material. AI personnel, or specially qualified contractor personnel supervised by AI personnel, are used to handle lowlevel radioactive material and other hazardous materials.

Contractor personnel are utilized as much as possible to remove nonradioactive materials, especially where the salvage value of the material partialiy defrays the removal costs. Demolition contractors will be used extensively in the concrete removal activities.

Waste Disposal--This activity involves efforts associated with the preparing, packaging, and shipping for burial of radioactive waste generated in the D\&D Program. Special shipping containers meeting NRC and Department of Transportation requirements will be fabricated, obtained on loan, or rented from commercial sources. The overall D\&D Program radioactive waste disposal effort is coordinated by the RMDF to minimize the overall shipping and burial costs. ERDA equipment that is not contaminated or has been decontaminated is processed through the equipment utilization system. Salvage material is made available to the outside contractors in fair consideration for operating costs on a bid basis. Noncontaminated scrap is disposed of in land fill sites. 
Radiological Survey--Initial radiological surveys are made in each facility to provide input to the planning efforts. Continuous radiological surveillance is performed at each facility for personnel and environmental safety, to determine the extent of decontamination required and to segregate waste. A final radiological survey will be made at each facility at the conclusion of the dismantling activity to certify that the site meets the established limits for unrestricted access.

Documentation--A11 documents generated in support of the planning and engineering activities will have release and revision control according to the requirements of an Engineering Release Plan of Action. The Quality Assurance, and Health, Safety, and Radiation Services records for the Program will be maintained for permanent traceability. Photographic documentation will be used for tracing progress, recording pertinent developments, future informational or training aids, and for historical purposes. A final report will be written for each facility to document: the effort, schedule, and costs expended as compared to the original estimates; any special problems encountered and the methods used for resolution; any tooling or process developments that would be useful to future programs; and the final radiological status of the site. The levels of radioactivity remaining after the D\&D process will be certified, and approval for release for unrestricted use will be obtained from ERDA, with concurrence by $A I$ and California Bureau of Radiological Health. These approvals will be included in the final report.

\section{E. PROGRAM COST AND SCHEDULE CONTROL}

Budgetary cost estimates were developed by the preparation of detailed manloaded activity networks. Equipment, material, subcontract, consultant, and other direct expenses associated with an activity were also estimated to determine the total 
forecast activity costs. An internal monthly cost report and cost analysis is prepared utilizing AI's computerized cost reporting system as a means of monitoring actual costs vs forecast at each of the general activity levels. These expenditures, along with the physical progress of the activities, are compared to the forecasts and the results of the comparison are transmitted to ERDA in the monthly progress report for the D\&D Program.

\section{F. PROGRESS AND PLANS TO DATE}

SRE--Tasks completed during GFY 1975 included the preparation of the SRE Dismantling Plan; drumming of the primary sodium; removal of the airblast heat exchangers, kerosene cooling system, and gallery cooling system; removal of some secondary sodium components and piping external to the reactor building; design completion and fabrication initiation of the rotating mast manipulator for vessel cutup and the SRE vessel mockup facility; and initial operation of the plasma arc cutting system in a small scale underwater cutting tank for cutting parameter development. The schematic representation of the plasma arc cutting development system is shown in Figure 5 .

Activity Requirements and Detailed Working Procedures will be prepared as required for the duration of the D\&D task on the SRE. Mockup operations for the vessel cutup remote tooling will be accomplished during GFY 1976. Operating parameters for the cutup and removal of the vessel internals, core tank liner, core tank, thermal rings, outer tank, insulation, and cavity liner will be developed. Also during GFY 1976, the residual sodium in the reactor and primary piping will be reacted, the primary system piping and the secondary system sodium piping inside the building will be dismantled, the portable hot cell will be dismantled, work will begin on removing the storage and wash cells, 
and special one-way shipping and burial containers will be designed and procured. The storage and wash cells, the reactor vessel internals, and the waste tanks and lines will be removed during GFY 1977.

The remote removal of the reactor vessels, the cavity liner, and biological concrete shielding will be completed during GFY 1978. Also, during this period the moderator handling machine will be dismantled, the retention pond will be removed, the building structures will be razed or repaired, and the site will be backfilled as required.

SRE Fuel Decladding--Preparations and initial operations for decladding and cleaning the NaK from SRE Cores I and II fuel were accomplished in GFY 1975. The preparations included safety studies; planning; tooling design, fabrication, and testing; intrasite transfer cask selection and preparation; setup of hot cell operations, tooling, and processing arrangements in the AI Hot Laboratory; design of shipping canisters for fuel slugs; design of waste containers; and arrangements for shipping casks and inserts. Following completion of the preparations, the first three Core I fuel storage containers were transferred from the RMDF to the AI Hot Laboratory where the actual decladding, cleaning, and repackaging was performed. During GFY 1976, the cleaned and repackaged Core I and II fuel will be returned to the RMDF in shipping canisters, from where it will be shipped to the Savannah River Reprocessing Plant.

Building 003 Hot Cave--The Dismantling Plan and Detailed Working Procedures were prepared for the Hot Cave, and, subsequent to the approval of the Plan by ERDA, decontamination and dismantling was completed during GFY 1975. The dismantling included removal of the Hot Cave, the integral cave and the building exhaust and liquid radioactive waste systems, and extensive floor excavation. 
KEWB--The Dismantling Plan and Detailed Working Procedures were prepared for the KEWB facility, and, subsequent to approval of the PIan by ERDA, the decontamination and dismantling was completed during GFY 1975. The KEWB dismantling included removal of the core vessel and all contaminated components, dismantling of the reactor and support buildings, excavation of the waste tanks, and backfilling and regrading of the area.

STIR--Preparation of the Dismantling Plan was completed in GFY 1975. Preparation of the Activity Requirements for the STIR will be accomplished during the first half of GFY 1976. Subject to the approval of the Plan, dismantling the fuel storage wells, heat exchanger, cooling system, shield carriage system, core structure, thermal column, activated vessel, activated concrete, exhaust system, and liquid waste systems will be completed during GFY 1976.

SER--The SER Dismantling Plan, Activity Requirements, and Detailed Working Procedures will be written and approved during GFY 1977. The tooling design, fabrication, development, and checkout will occur during GFY 1978. The actual dismantling operations will extend through the first quarter of GFY 1979.

The major effort in the SER dismantling activity will be the removal of the activated steel reactor containment vessel and the biological shielding, all located below grade. The concrete was poured around the vessel and attached cooling coils, leaving a steel-lined, activated, concrete monolith below grade. Tooling will be required to excavate the structure with some shielding required: The choice of entry from the inside or outside of the structure remains to be determined. The metal building enclosing the facility will be demolished. 
SETF--The SETF Dismantling Plans, Activity Requirements, and Detailed Working Procedures will be written during early GFY 1978. A minimal tooling effort will be required, and the tooling and dismantling operations will be accomplished during the second half of the year.

The effort in SETF will consist mainly of removing and disposing of the activated SNAP 1.OFS3 vacuum vessel located in one of the vaults, removing the test vault aluminum liners, excavating some of the adjacent concrete biological shielding, and possibly removing portions of the exhaust and liquid waste holdup systems.

SGPTF--The SGPTF Dismantling Plan, Activity Requirements, and Detailed Working Procedures will be prepared during GFY 1978. The tooling effort and dismantling operations will extend through GFY 1979.

Extensive below-grade activated structures remain in the SGPTF, including steel containment vessels and vacuum lines, concrete biological shielding, and sand fill.

RMDF--The RMDF Dismantling Plan, Activity Requirements, and Detailed Working Procedures will be written during GFY 1978. The tooling effort and dismantling operations will extend through GFY 1979.

\section{G. AVAILABLE TECHNOLOGY}

A modification of the remote manipulator-plasma arc system design, developed by Oak Ridge National Laboratory (ORNL) for the Elk River Reactor dismantling, is being used by AI for the SRE vessel cutup. The design was modified by AI Engineering as required to fit the SRE Requirements. Fabrication of the system 
is now underway in the AI manufacturing shops. Following completion of the manufacturing, the AI Remote Technology Unit will check out the system in the SRE vessel mockup facility and establish parameters for the actual cutting of the SRE vessels. Extensive remote tooling expertise exists at Atomics International from experience gained on the SRE, Hallam, Piqua, and SNAP reactor programs.

Explosive demolition techniques similar to those used for the Elk River Reactor Dismantling Program will also be utilized on this program to remove concrete structures. Additionaliy, commercially available remote techniques for piping and component removal will be utilized wherever possible; e.g., underwater explosive pipe cutting used in offshore drilling operations. 


\section{LIST OF FIGURES}

Figure 1. A.I. Divisional Organization Chart.

Figure 2. Fuel and Test Facility Program Organization Chart.

Figure 3. Overall Schedule for D\&D Program.

Figure 4. A.I. D\&D Document Tree.

Figure 5. SRE Vessel Mockup Facility. 


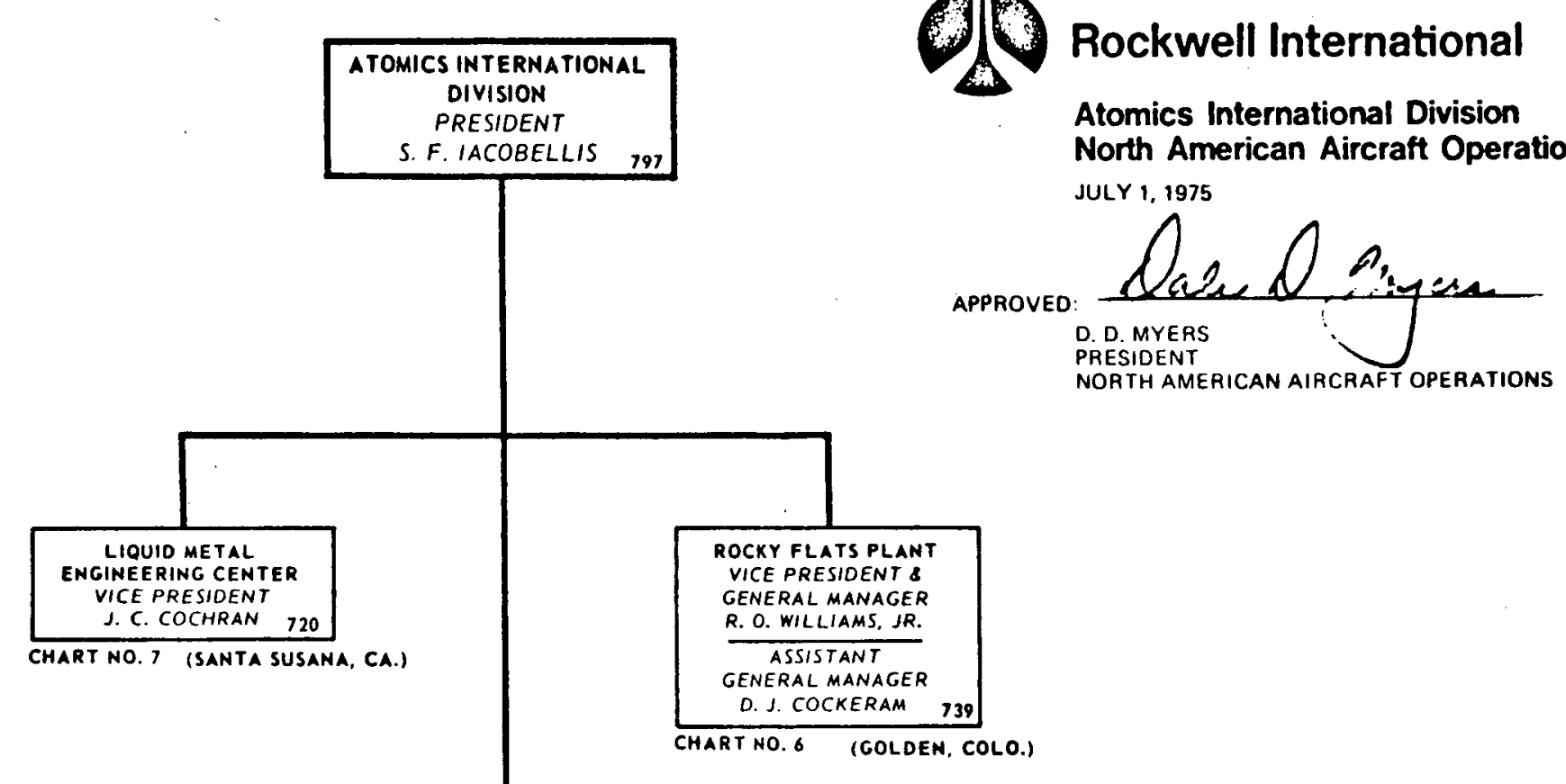

$\underset{p}{\stackrel{\leftrightarrow}{p}}$
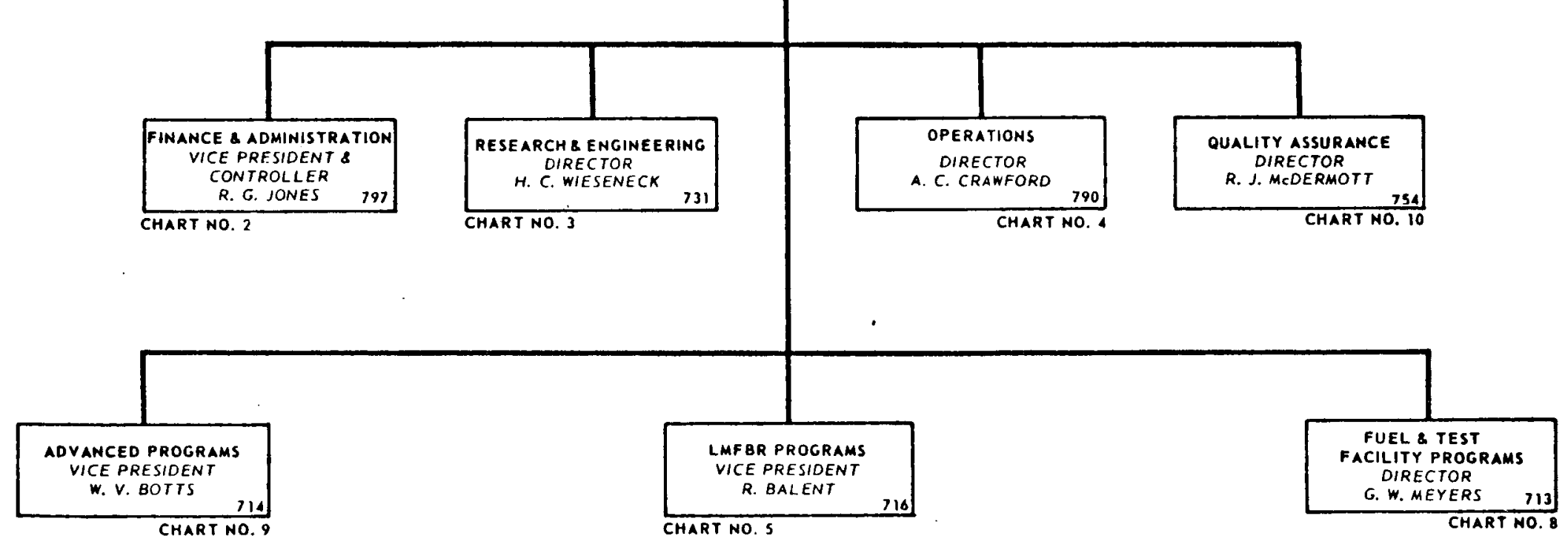
90 Rockwell hrematonal

Atomica International Division

FUEL \& TEST FACILITY PROGRAMS

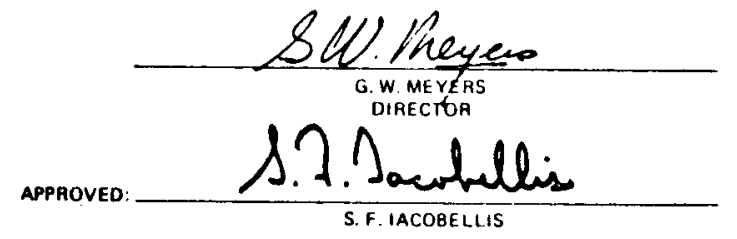

$\underset{\omega}{\stackrel{\leftrightarrow}{\omega}}$

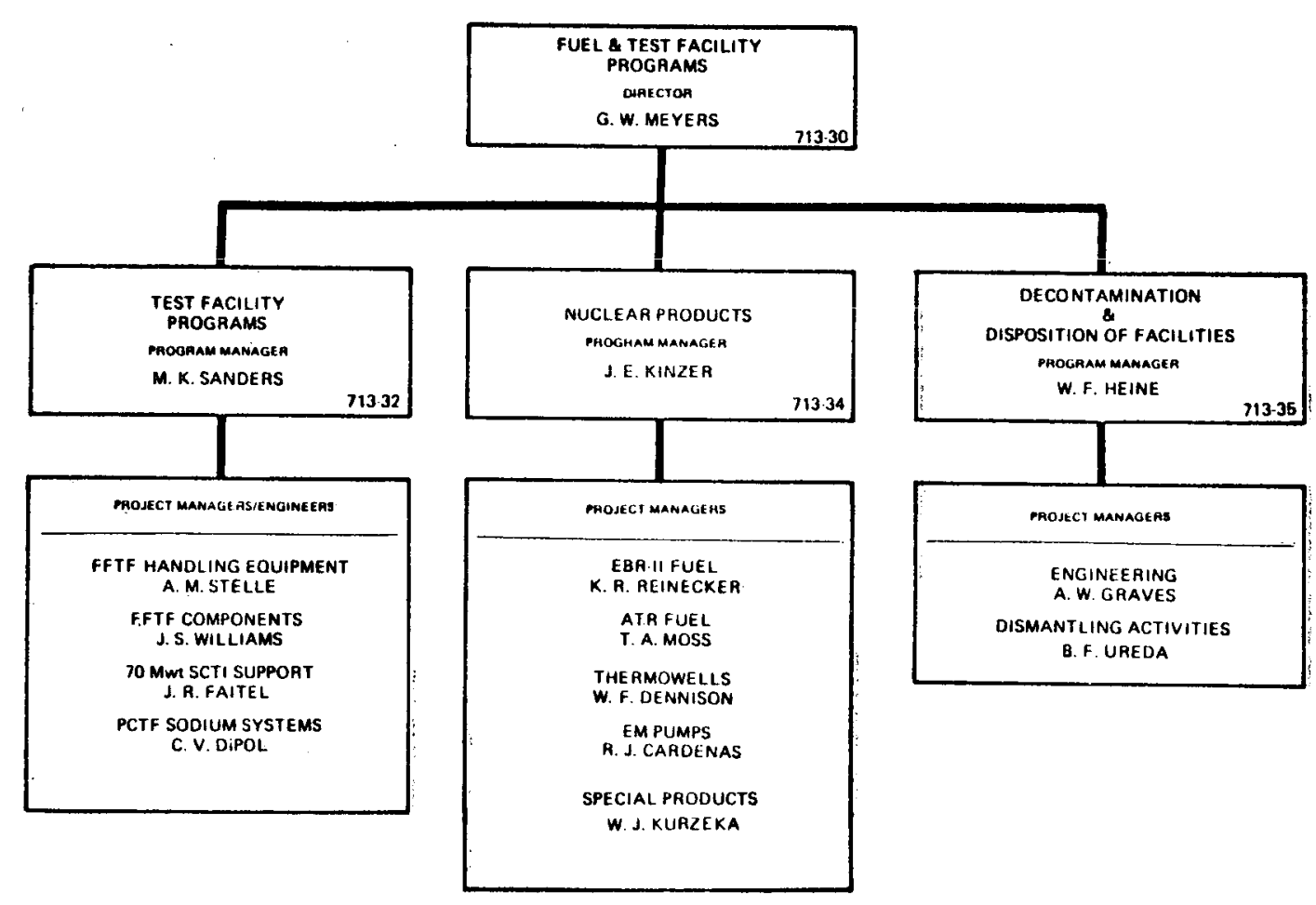




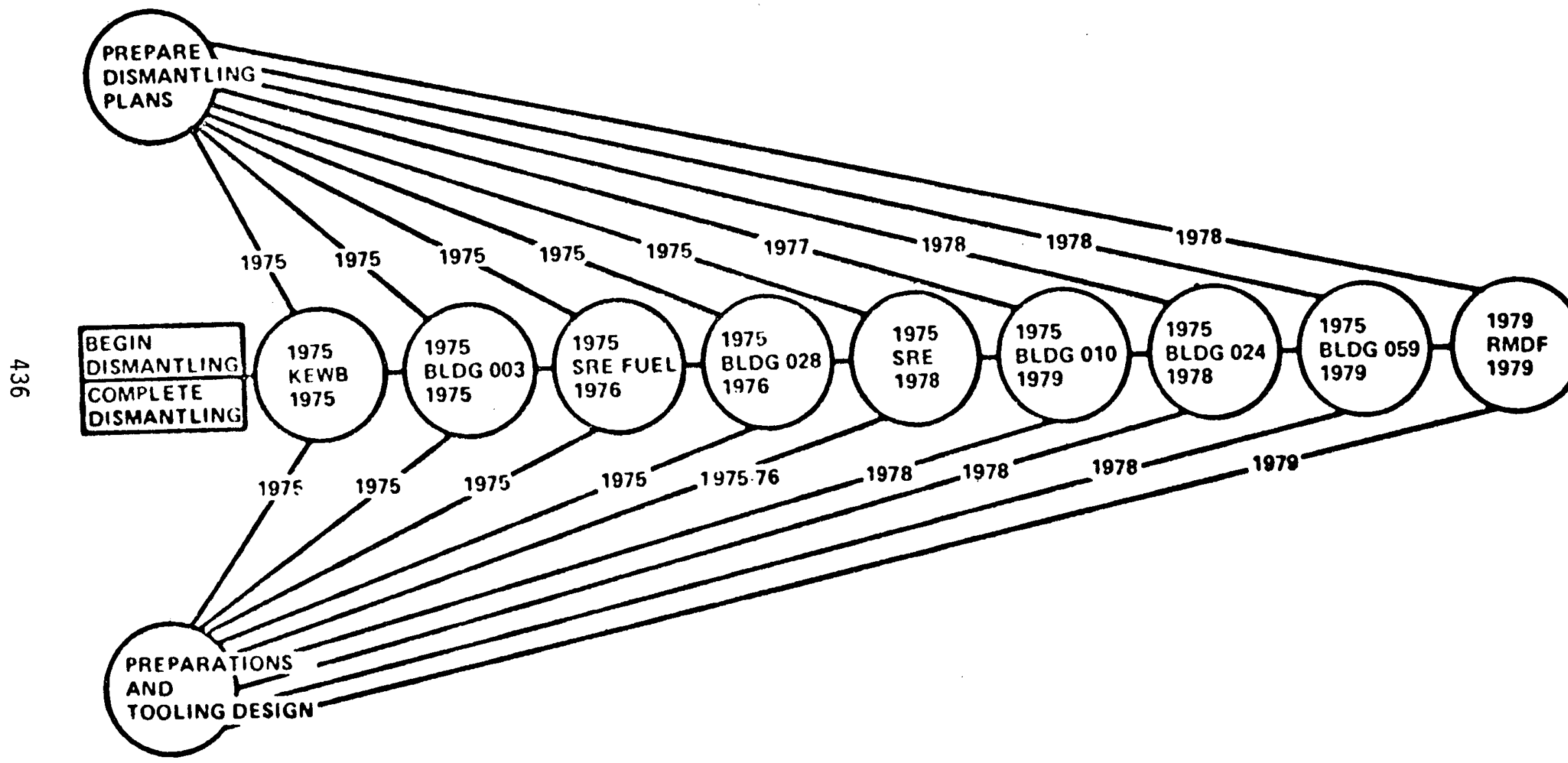


Figure 4
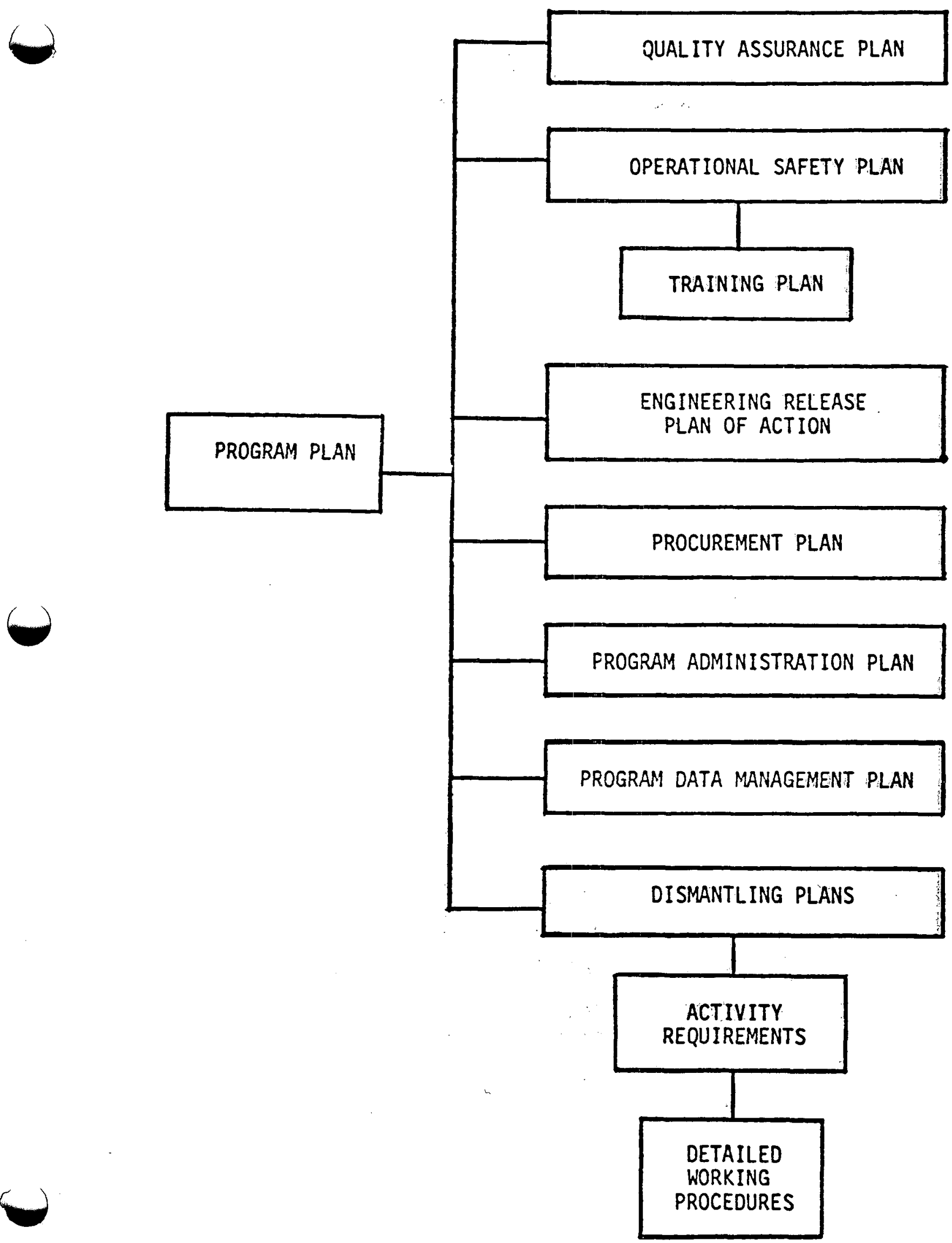
Figure 5
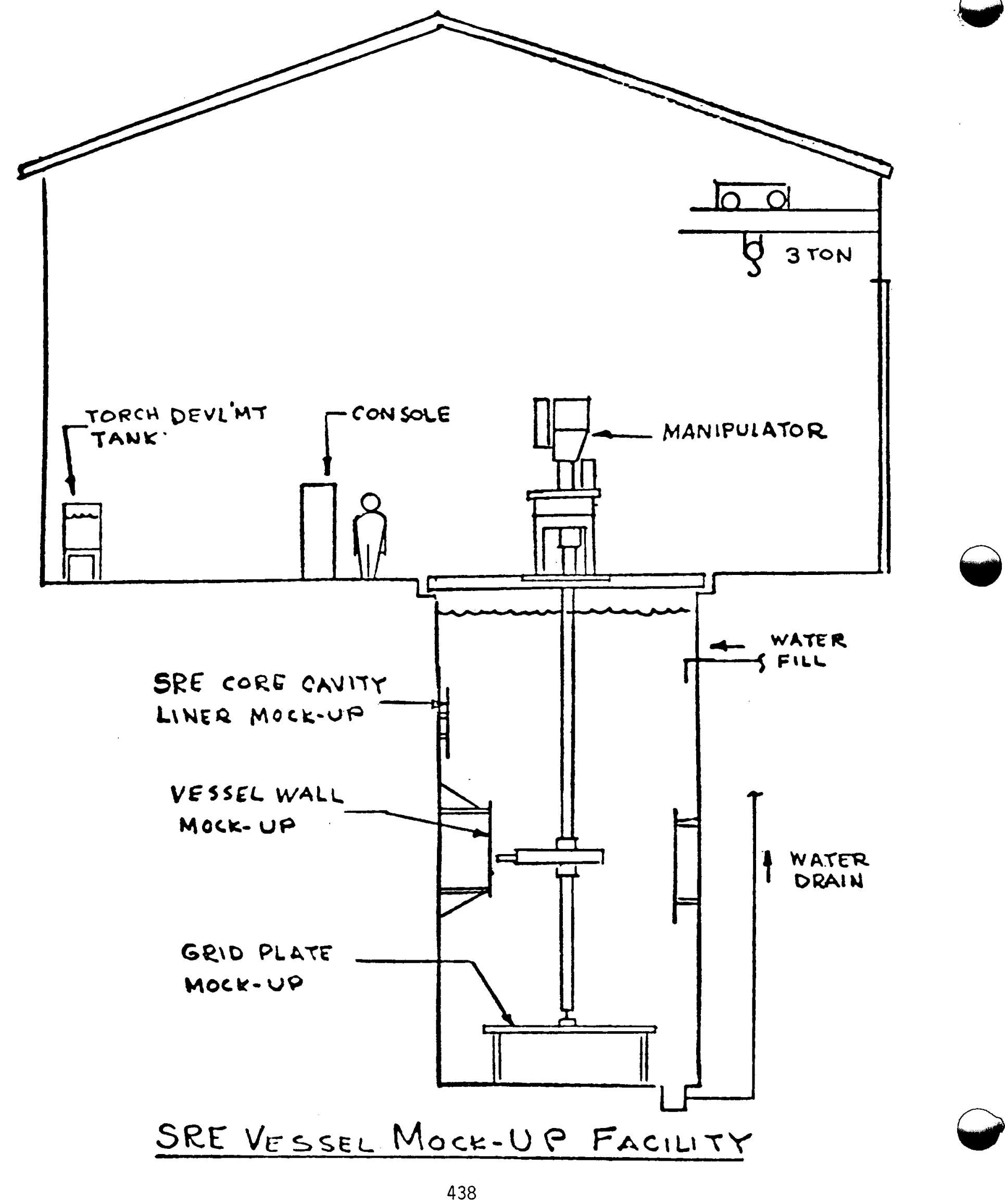
A DECOMMISSIONING PLAN

FOR THE HEAVY WATER COMPONENTS TEST REACTOR

by

\section{F. R. Field}

Savannah River Laboratory

E. I. du Pont de Nemours \& Co.

Aiken, South Carolina 29801

A Paper for Presentation at the Conference on Decontomination and Decommissioning of ERDA Facilities

Idaho Falls, Idaho

August 19-21, 1975

and for publication in the Proceedings

This paper was prepared in connection with work under Contract No. AT (07-2)-1 with the U. S. Energy Research and Development Administration. By acceptance of this paper, the publisher and/or recipient acknowledges the U. S. Government's right to retain a nonexclusive, royalty-free license in and to any copyright covering this paper, along with the right to reproduce and to authorize others to reproduce all or part of the copyrighted paper. 
A DECOMMISSIONING PLAN

FOR THE HEAVY WATER COMPONENTS TEST REACTOR

by

F. R. Field

Savannah River Laboratory

E. I. du Pont de Nemours \& Co.

Aiken, South Carolina 29801

\section{ABSTRACT}

Three alternatives to decommission the Heavy Water Components Test Reactor (HWCTR) have been analyzed. The major elements of the alternatives are shown in Table 1 . No final choice has been made between alternatives, and all are feasible. The Protective Confinement approach is advantageous as long as current activities onsite require limited access by the general public, and because excellent confinement of the residual activity $\left(2.3 \times 10^{4}\right.$ curies $)$ is provided by in situ dry storage as the radiation from ${ }^{60} \mathrm{Co}$ diminishes. Entombment provides the most-secure confinement of the activity at some increased cost; in 35 years, the activity will decay to $2 \times 10^{3}$ curies and consist primarily of ${ }^{6} \mathrm{Ni}$. Dismantling HWCTR has no apparent advantages, other than a demonstration at the Savannah River site, because of the long-term commitment to safeguarding radioactive material; the relative cost is high.

Selection of a plan for decommissioning will depend on criteria that are presently being formulated within ERDA and other regulatory bodies.

The information contained in this article was developed during the course of work under Contract No. AT(07-2)-1 with the U. S. Energy Research and Development Adminstration. 
HWCTR HISTORY

Before discussing the alternatives used to develop decommissioning plans for HWCTR, some background information on the purpose for building the reactor will be given.

The Heavy Water Components Test Reactor (HWCTR) was a test reactor used to develop candidate fuel designs for heavy water power reactors. The nominal reactor power of $50 \mathrm{MW}_{\mathrm{t}}$ was dissipated to the atmosphere; the total HWCTR exposure was 13,900 MWD. The general plan of the site is shown in Figure 1, and the appearance of the site during operation is shown in Figure 2.

The reactor hydraulic system operated at $1200 \mathrm{psig}$ and $250^{\circ} \mathrm{C}$. The reactor vessel was made of 3 - to 5 -inch-thick carbon steel clad with stainless steel; the external hydraulic system was carbon steel only. Two test loops isolated from the primary hydraulic system were provided for special test conditions. Arrangement of the equipment within the containment building is shown by models in Figures 3, 4, and 5. These models were used in building construction and also during the decommissioning studies.

After HWCTR was shut down in December 1964, the fuel assemblies and the startup source were removed from the site. Safety rods and control rods were delatched from their drives and fully inserted into the reactor vessel. Heavy water was drained from the reactor, and the system was dried. The reactor was maintained in a standby status for about one year and then retired in place. Since that time, surveillance has been provided 
by personnel from an adjacent site. Access to HWCTR is controlled by the locked fences surrounding the site.

\section{PREPARATION OF A DECOMMISSIONING PLAN}

A six-step procedure was followed to prepare a decommissioning plan for HWCTR:

- Assemble a task force to develop alternatives.

- Study guidelines and precedents in comparable efforts and propose criteria for the current effort.

- Define the residual activity.

- Define alternatives; characterize feasibility, cost, and residual risk to public.

- Assess the alternatives using the criteria.

- Determine a course to be followed considering constraints and plans for the site.

\section{TASK FORCE PERSONNEL}

To assemble the information needed to evaluate alternatives for decommissioning HWCTR, seven senior employees with varied backgrounds were assigned to the effort (Table 2). The services of Du Pont Engineering Department, which designed and built HWCTR, were used to estimate capital costs for the decommissioning options. Laboratory services onsite were used for more-extensive radiological analyses of HWCTR samples than could be attained by field surveys. Three members of the task force, who had been assigned at the HWCTR site during operations recovered records, reviewed 
construction techniques, and outlined special operating occurrences relevant to decommissioning modes.

\section{OBJECTIVES AND CRITERIA}

The three alternatives identified for decommissioning the HWCTR facility and the objective to be achieved through each alternative are listed in Table 3.

The criteria used to evaluate the merits of the alternatives are:

Radiation Impact. Acceptably low probability of release of the HWCTR activity to the environment for normal and unlikely occurrences.

Land Area Commitment. The acreage committed both to confine the activity and to monitor and control water runoff. Cost. Decommissioning capital cost and operating cost for surveillance after decommissioning. Certainty and Finality. The resolution of current decommissioning steps must take into account radioactive decay, retrievability, and site equipment reactivation.

Aesthetics. Appearance of the site.

\section{RESIDUAL ACTIVITY}

The definition of the residual activity at the HWCTR site was divided into three tasks: defining the activity in the reactor system (exclusive of the reactor vessel), defining the induced 
activity in the reactor vessel and shield, and determining the radiation emitted by the equipment so that working conditions could be estimated for removal operations.

\section{Reactor System Activity}

The current inventory of activity was defined inside the reactor vessel and in the exterior circulating system. In HWCTR, the logical point of division between these two systems is where stainless-steel-lined pipe stubs are welded to the carbon steel piping system (primarily 10-inch-diameter pipes, steam generators, and pumps). The carbon steel portion of the system was coated with an adherent magnetite film; a sidestream from the major system was circulated through a purification system (filters and deionizers) made of stainless steel. Corrosion product deposits and small amounts of adsorbed activity from fuel failures cause the residual radiation in the carbon steel, or external, portion of the system. Activity levels and distribution in the system are shown in Table 4. The amount of activity in the external system is less than $0.01 \%$ of the total and, therefore, is not a controlling factor in design of a method to provide long-term confinement of the residual activity at the HWCTR site.

The transuranium (TRU) activity in the main system is from failure of two experimental fuel assemblies; the calculated total release was $5 \mathrm{~g}$ of uranium and $4 \mathrm{mg}$ of plutonium. One failure also occurred in the liquid loop and released an additional $5 \mathrm{~g}$ of uranium that was confined to the 1oop. The other test loop (boiling loop) 
never contained a test assembly. Further studies are being made on small samples of pipe that were cut from the piping systems so that laboratory analysis techniques (rather than field surveys) could be used to characterize the small amounts of activity in the carbon steel portion of the system.

Induced Activity in Reactor Vessel and Shields

The major source of residual activity is induced activity in the HWCTR vessel (the stainless-steel-lined portion of the reactor system inside the biological shield). The calculated activities of the reactor components within the vessel boundary are listed in Table 5. The principal activities are ${ }^{55} \mathrm{Fe},{ }^{60} \mathrm{Co}$, and ${ }^{63} \mathrm{Ni}$. However, as shown in Figure 6, after 30 to 50 years, the only induced activity remaining will be ${ }^{63} \mathrm{Ni}$, and radiation levels in the reactor components will be minimal.

The concrete biological shields surrounding the reactor vessel contain trace amounts of ${ }^{59} \mathrm{Co}(100 \mathrm{ppm})$; reinforcing rods and steel shot (assumed to contain $1000 \mathrm{ppm}$ of ${ }^{59} \mathrm{Co}$ ) were also used in the shield structures. All shielding and rods within $3 \mathrm{ft}$ of the reactor vessel would have to be removed to reduce site activity to the level applied in the Elk River dismantlement if the assumption of $100 \mathrm{ppm}{ }^{59} \mathrm{Co}$ in the concrete is correct. Three separate types of shield would be involved in the HWCTR case. The quantity of concrete shielding to be removed is uncertain because impurity levels of ${ }^{59}$ Co vary over a wide range. 


\section{External Radiation}

Radiation levels near the HWCTR system are generally less than $3 \mathrm{mR} / \mathrm{hr}$. The residual radiation is attributed to small deposits of corrosion products with induced activity (chiefly ${ }^{60} \mathrm{Co}$ ). Work on the reactor system equipment (excluding the reactor vesse1) will only involve breathing protection for tritium if lines are opened, or for particulates if cutting or welding is done. Radiation emitted by the reactor vessel is not extremely high $(1-2 \mathrm{R} / \mathrm{hr}$ at a distance of $2 \mathrm{ft}$ ) because of the shielding provided by the vessel walls; radiation intensities inside the vessel in the range of $100-200 \mathrm{R} / \mathrm{hr}$ from the thermal shield would be encountered if parts of the vessel exterior were removed (reactor top or main coolant nozzle).

\section{ALTERNATIVES}

The steps taken with the major equipment are compared in Table 6 for the three options for decommissioning HWCTR: Dismantlement, Entombment, and Protective Confinement.

\section{SAFETY ASSESSMENT}

With HWCTR shutdown and the nuclear fuel removed, only two mechanisms for public sector dose are postulated: direct exposure onsite and transport offsite via water. Direct exposure is currently prevented by physical security of both the HWCTR site and SRP site. Water transport of corrosion products from the thermal shield to the plant streams and then offsite is a long-term risk. 
The risk analysis is made with many conservatisms. The dose criteria are based on 30 -mrem bone dose associated with drinking water ingestion of ${ }^{63} \mathrm{Ni}$ (the major isotope remaining after 50 years). Even postulating highly improbable events that cause failure of protective vaults in the next 20 years, more than 100 years would be required for water first to reach the reactor vessel and then to seep to the site creeks. The analyses are summarized in Table 7.

The probability estimates for immersion of the vessel reflect the higher water table in the burial ground (10 to $20 \mathrm{ft}$ below the bottom of a trench). At the HWCTR site, the water table is $30 \mathrm{ft}$ below the bottom of the building and therefore more than $50 \mathrm{ft}$ below the reactor vessel. In addition, the barriers to water penetration differ. In the Protective Confinement case, water must corrode through the carbon steel piping before the vessel internals will start to corrode. In the Entombment case, water must penetrate at least one-quarter inch of stainless steel before reaching the vessel internals. A mechanism for transport of the corrosion products into the ground water is assumed to be similar in all cases, but no credit for soil removal effects are included. Thus the concentration of activity in the creek largely reflects the differences in dilution and decay of ${ }^{63} \mathrm{Ni}$.

\section{SITE CONSIDERATIONS}

The Savannah River site is shown in Figure 7. If HWCTR is dismantled, the activity is relocated from $U$ area to the site 
burial ground. Rainwater runoff and ground water flow in the vicinity of the burial ground reaches either Upper Three Runs Creek or Four Mile Creek Therefore, if the HWCTR vessel were transferred to the burial ground, long-term surveillance of the nearest creek would be involved. However as shown in Figure 7, with the activity remaining at the present site, Upper Three Runs Creek would still be the first creek to be affected by the postulated activity transport if activity somehow escaped the confinement provided by the HWCTR system. Long-term plans for the SRP burial grounds will probably involve commitment of a caretaker crew for perhaps 100 years. Such a crew might easily provide surveillance for the nearby HWCTR site if the alternatives of either Entombment or Protective Confinement were chosen.

\section{PROGRAM}

Alternatives for decommissioning HWCTR are described in a plan document that has been forwarded to ERDA for appropriate review. Each alternative has been assessed using the criteria (Table 1); major conclusions are shown in Table 8 .

When funding is provided to decommission HWCTR, a final design and analysis will be required. The decommissioning plan for the HWCTR site will be integrated into longer-range planning for other radioactive sites on the Savannah River Plant. 
TABLE 1

Summary of Decommissioning Options

\section{Dismantlement}

Remove all radioactive equipment to burial ground

Radiation Exposure

Accidental to Public

Planned Occupational ${ }^{a}$

Land Area, acres

HWCTR.

Burial Ground

Water Rights, acres

Capital Cost, $\$$ millions $b$

Annual Cost, \$

Flexibility

Aes thetics

\section{Unlikely}

Some

0

\section{$\cdot 2$}

Burial site to creeks (al ready needed)

5

$<100$

Best

Best

\section{Entombment}

Relocate above-grade equipment to burial ground, and fill

building with concrete

Extremely unlikely

Less

1.5

0.2

From 0 to 90 (HWCTR to creek)

1

1500

Poor

Good
Protective Confinement

Repair dome, seal

building, and seal

piping system

Very unlikely

Leas $t$

1.5

0

90

(HWCTR to creek)

$<0.5$

3000

Good

Least attractive

a. An estimate of the man-rem involved will be given when the paper is presented.

b. Costs given are approximations; better cost estimates will be given when the paper is presented. Burial costs are included where incurred but no cost for land or water rights is included. 
TABLE 2

HWCTR Decommissioning Task Force

\begin{tabular}{|c|c|c|c|}
\hline No. & Education & Site Experience & Function \\
\hline 1 & Physics & Nuclear Physics ${ }^{a}$ & $\begin{array}{l}\text { Flux, exposure, and induced } \\
\text { activities }\end{array}$ \\
\hline 1 & Math & Health Physics & $\begin{array}{l}\text { Surveys of HWCTR facilities, } \\
\text { decontamination requirements }\end{array}$ \\
\hline 1 & Chemical Engineer & Long-Range Planning & Coordinate planning and analyses \\
\hline 1 & Chemical Engineer & Reactor Engineering $\left.{ }^{\alpha}\right\}$ & \multirow{2}{*}{$\begin{array}{l}\text { Develop engineering steps for } \\
\text { alternatives, make safety studies }\end{array}$} \\
\hline 1 & Nuclear Engineer & Reactor Engineering $\int$ & \\
\hline $1^{b}$ & Chemist & Environmental Studies & $\begin{array}{l}\text { Apply environmental and } \\
\text { site guidelines }\end{array}$ \\
\hline $1^{b}$ & Nuclear Engineer & Separations Engineering ${ }^{a}$ & Plant liaison \\
\hline
\end{tabular}

a. Assigned to HIWCTR during period of reactor operation.

$b$. Part-time members of the task force.

TABLE 3

objectives

Azternative

objective

Dismantlement

Restore the $U$ site to a condition suitable for releasa to the general public. Relocate HWCTR radioactivity to the burial ground.

Entombment

Secure the activity remaining

in the HWCTR facility so that release

to the environment is extremely improbable

until decay renders it harmless.

Protective Confinement Confine activity at the HWCTR site in dry storage while decay proceeds for the foreseeable future. 
TABLE 4

Circulating System Activity Inventory ${ }^{\alpha}$

$\frac{\text { Activity, } \mathrm{Ci}}{\text { Transuranium Fission Products }{ }^{60} \mathrm{Co}}$

Main System $2 \times 10^{-4} \quad<10^{-4} \quad \sim 0.5$

Loops

$\begin{array}{llll}\text { Liquid } & 2 \times 10^{-4} & <10^{-4} & <0.1 \\ \text { Boiling } & 4 \times 10^{-4} & <10^{-4} & \sim 0.3\end{array}$

a. $<0.01 \%$ of total HWCTR activity.

TABLE 5

Activity of Reactor Components

Thermal Shield

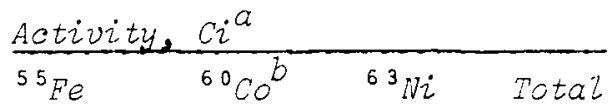

Monitor Pin Plate

$\begin{array}{rrrr}10,800 & 8800 & 2400 & 22,000 \\ 390 & 320 & 90 & 800 \\ 380 & 230 & 10 & 620 \\ 1100 & \frac{80}{9430} & \frac{20}{2520} & \frac{200}{23,620}\end{array}$

a. July 1,1975 .

b. From the $1000 \mathrm{ppm}{ }^{59} \mathrm{Co}$ impurity assumed. in steels. 
TABLE 6

Equipment Disposition

HWCTR

Equipment

Zero leve 1

equipment

Reactor vessel

Nozzles from

reactor vessel

Below-grade

piping and

equipment

Concrete shields

around reactor

vesse 1, including

reinforcing rods

Containment

shell

Auxiliary

buildings

Dismantlement
Remove process
piping to
burial ground
Remove to
burial ground

Cap for

transport to

burial ground

Remove to

burial ground

Remove to

burial ground

Remove

Remove
Entombment

Relocate some

be low grade;

move remainder

to burial ground

Case in concrete

Cap with

stainless steel

Encase in

concrete

Include in

tomb

Remove

Paint

Protective

Confinement

Leave in place

Leave in place

Not required

Leave in place; cap any

temporary seals

No action needed

Remove

Leave in place

\section{TABLE 7}

Risk Comparison

$\begin{array}{lllll} & \text { Relative } & \begin{array}{l}\text { Relative } \\ \text { Consequence }\end{array} & & \begin{array}{l}\text { Minimum Time } \\ \text { for Activity }\end{array} \\ \text { Arobability } & \text { of Activity in } & \text { Relative } & \text { Transport to } \\ \text { Altemative } & \text { of Immersion } & \text { Creek Water } & \text { Risk } & \text { Creek, yr } \\ \text { Dismantlement } & 1 & 10^{-1} & 10^{-1} & 300 \\ \text { Entombment } & 10^{-2} & 10^{-2} & 10^{-4} & 300 \\ \text { Protective Confinement } & 10^{-1} & 1^{\alpha} & 10^{-1} & 100\end{array}$

a. Estimated dose from drinking water corresponds to $30 \times 10^{-3} \mathrm{mrem}$. 


\section{TABLE 8}

$\begin{array}{lll}\begin{array}{l}\text { Comparison of Alternatives } \\ \text { Aztemative }\end{array} & \begin{array}{l}\text { Major Advantage } \\ \text { Demonstration of } \\ \text { cleared site }\end{array} & \begin{array}{l}\text { Major Disadvantage } \\ \text { Entombment }\end{array} \\ \begin{array}{l}\text { Maximum security } \\ \text { of activity }\end{array} \quad \text { Low flexibility } \\ \text { Protective Confinement } & \begin{array}{l}\text { Lowest cost } \\ \text { Good confinement } \\ \text { and flexibility } \\ \text { under current plant } \\ \text { status }\end{array} & \\ & \end{array}$




\section{FIGURE CAPTIONS}

FIGURE 1 U-Area Building Arrangement

FIGURE 2 HWCTR Containment Dome and Auxiliary Buildings

FIGURE 3 HWCTR Model - Reactor and Below-Grade Equipment

FIGURE 4 HWCTR Model - Other Half of Below-Grade Equipment

FIGURE 5 HWCTR Model - Above-Grade Equipment

FIGURE 6 Activity Decay of Reactor Vessel Components

FIGURE 7 Savannah River Plant Site 


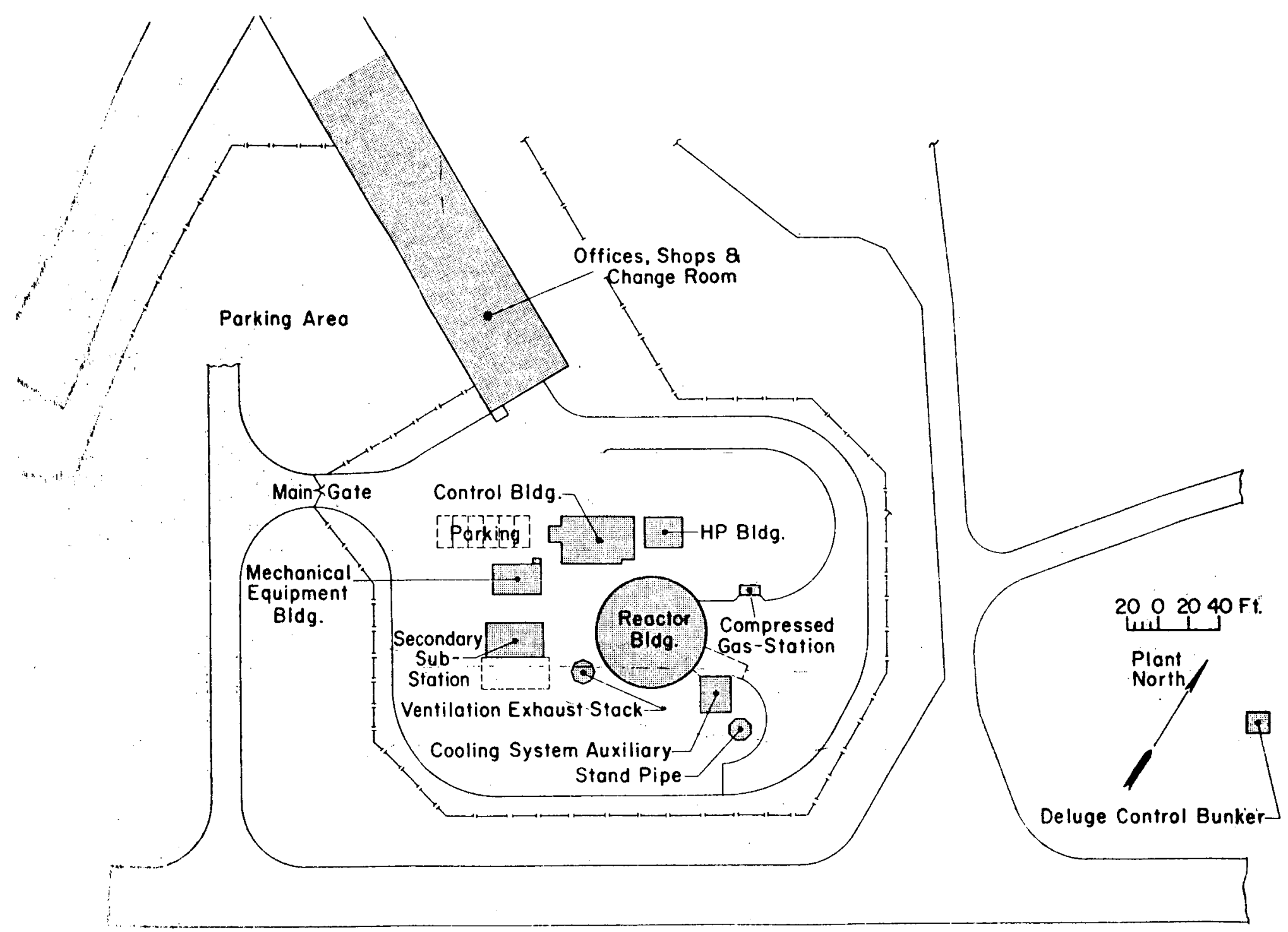

FIGURE 1 U-Area Building Arrangement 


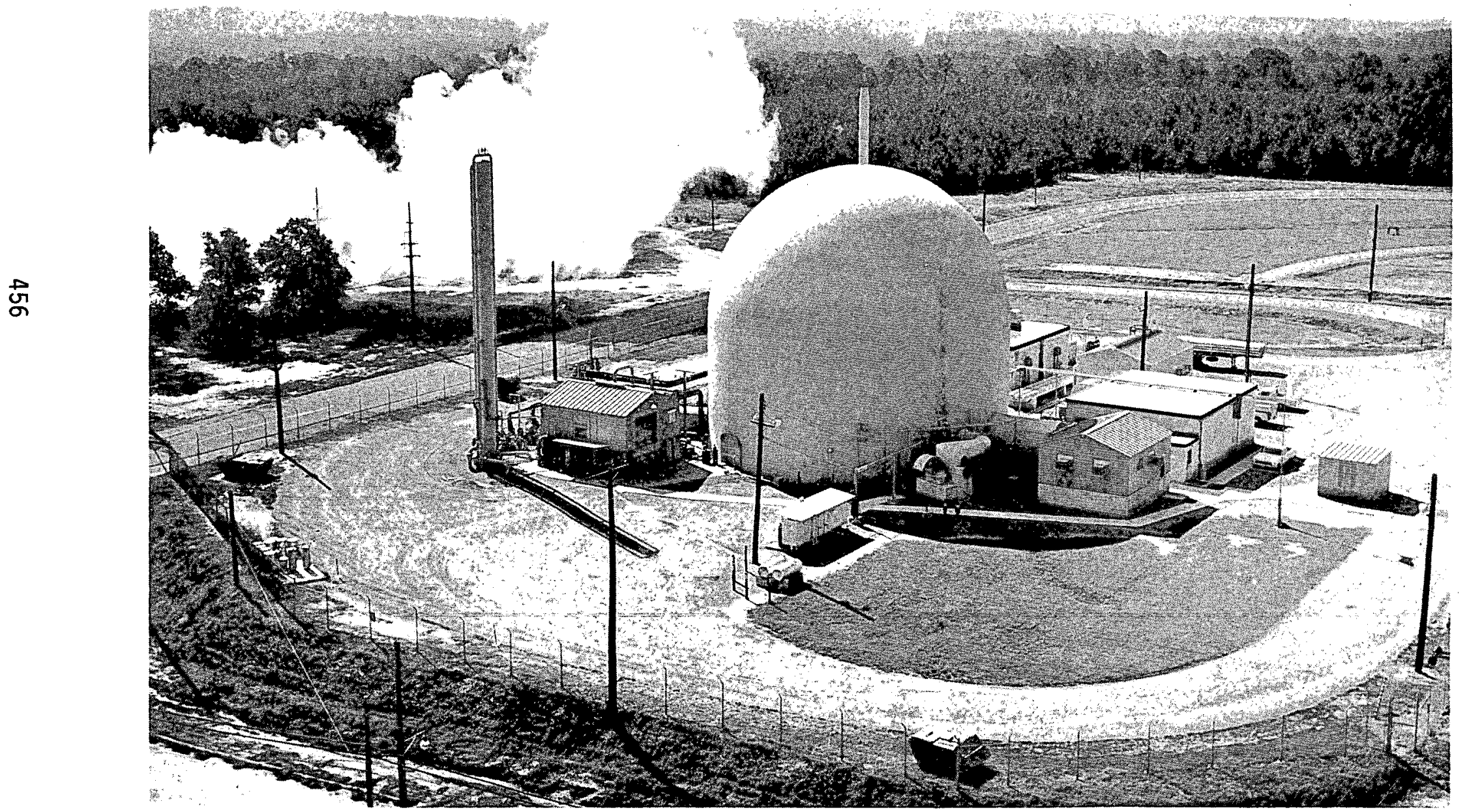

FIGURE 2 HWCTR Containment Dome and Auxiliary Buildings 


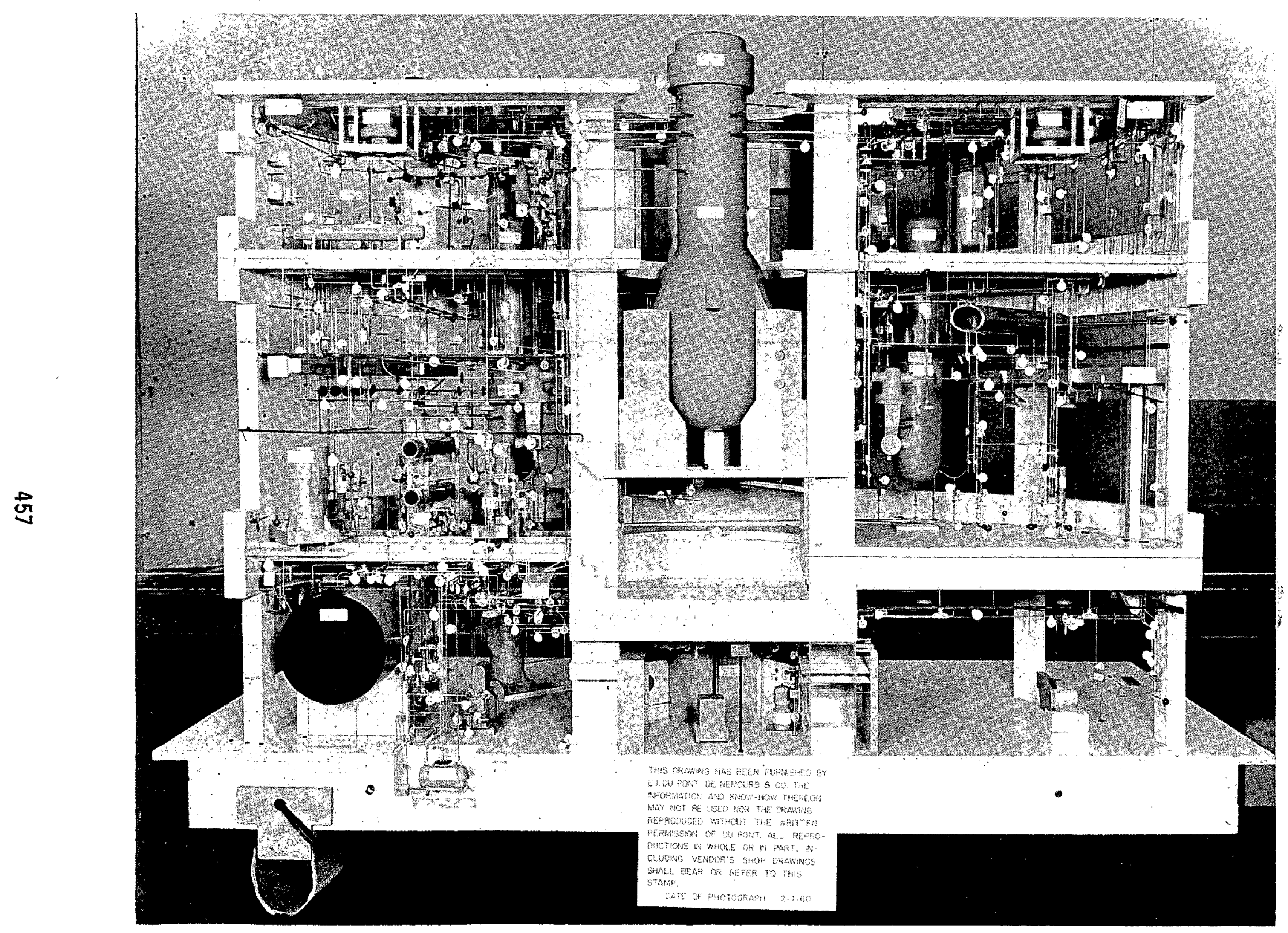

FIGURE 3 HWCTR Mode 1 - Reactor and Below-Grade Equipment 


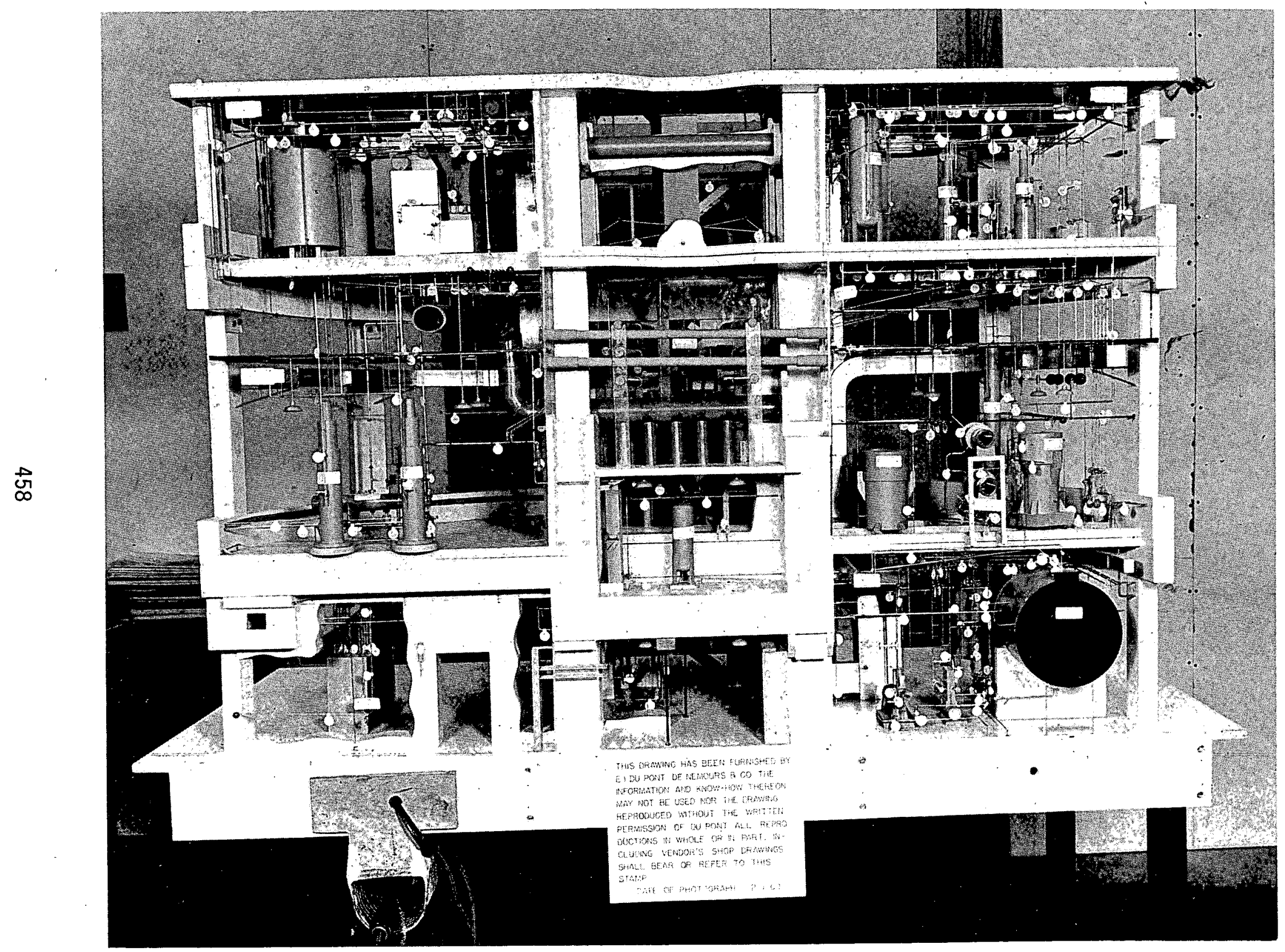

FIGURE 4 HWCTR Model - Other Half of Below-Grade Equipment 
C

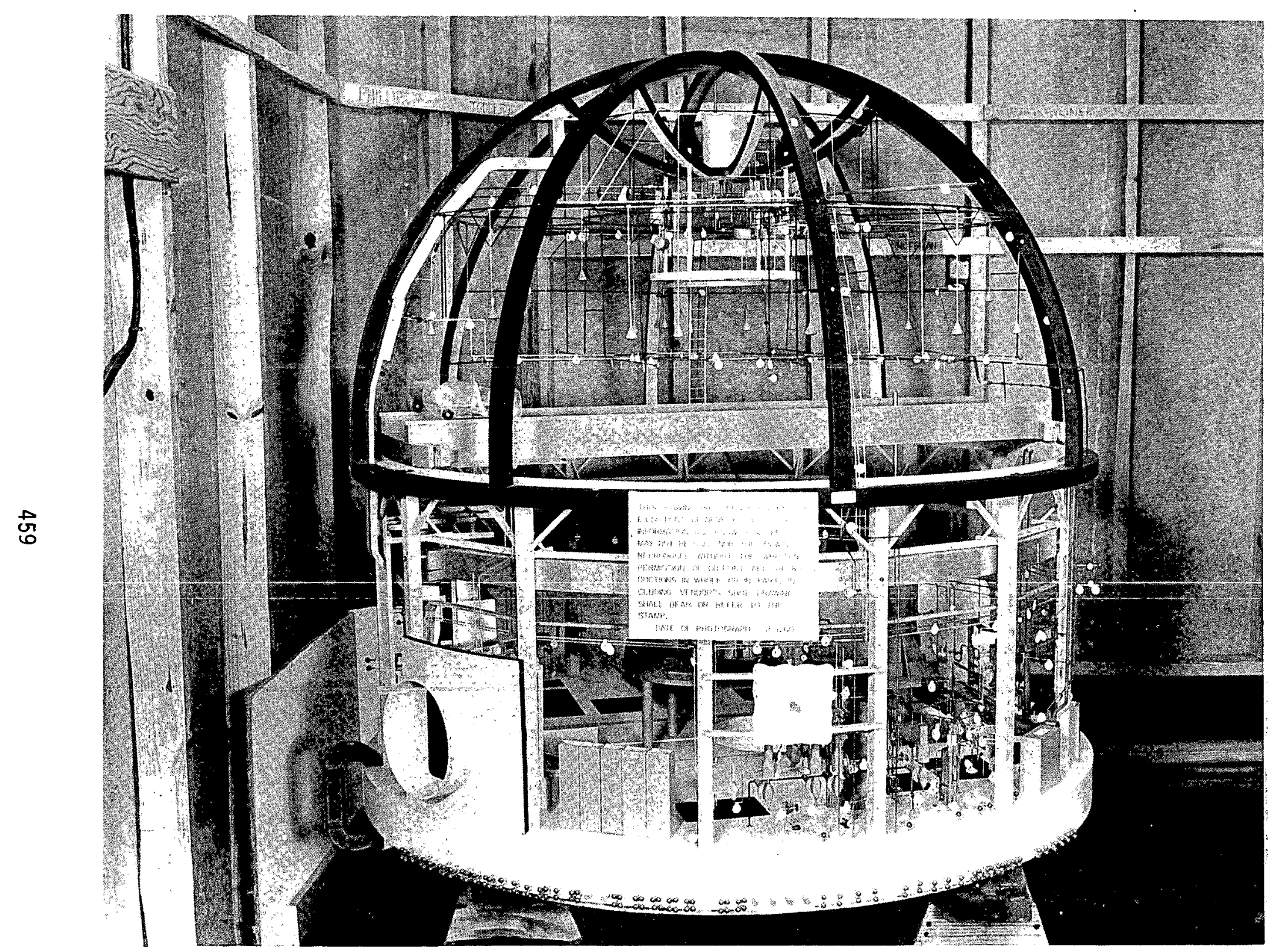




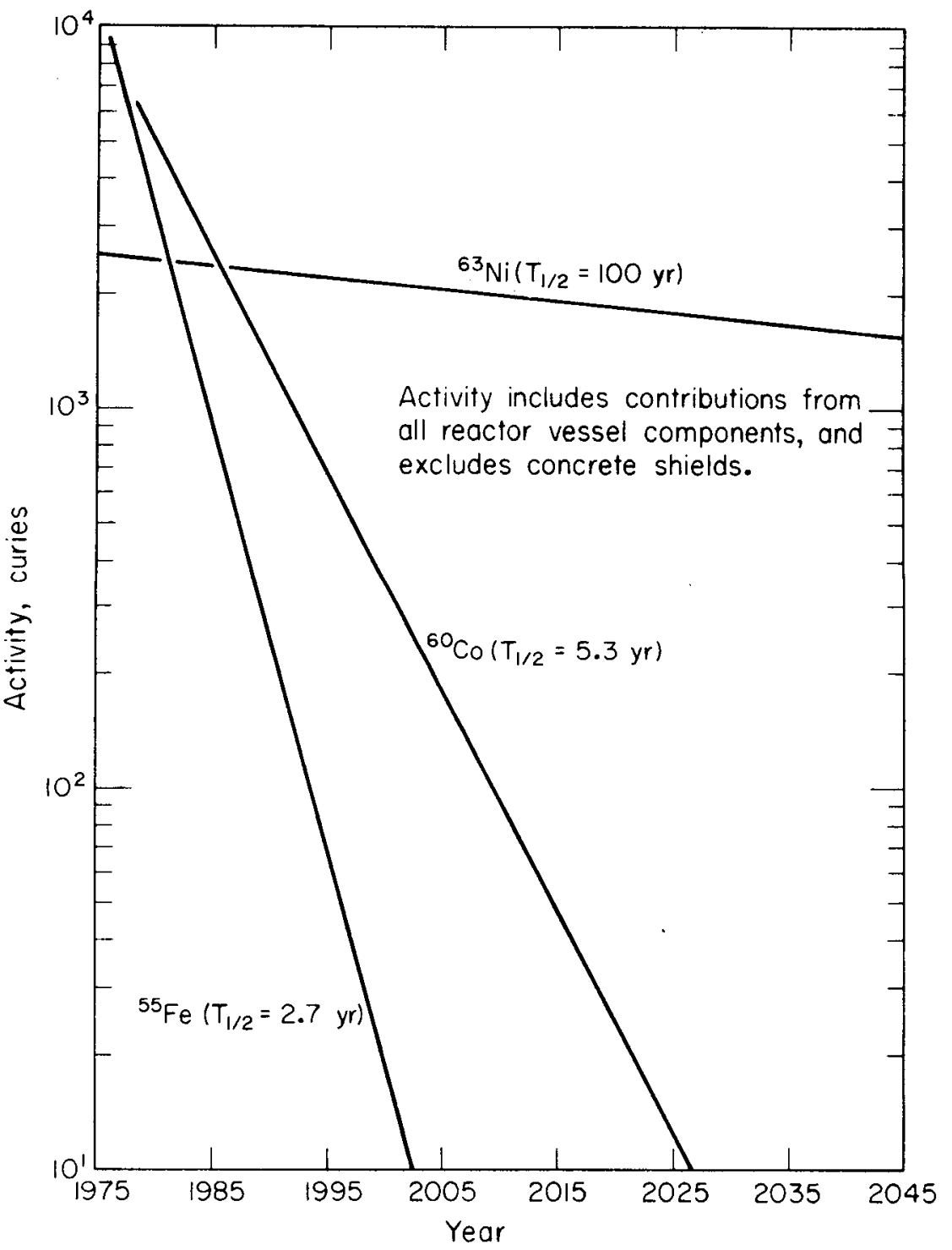

FIGURE 6 Activity Decay of Reactor Vessel Components 


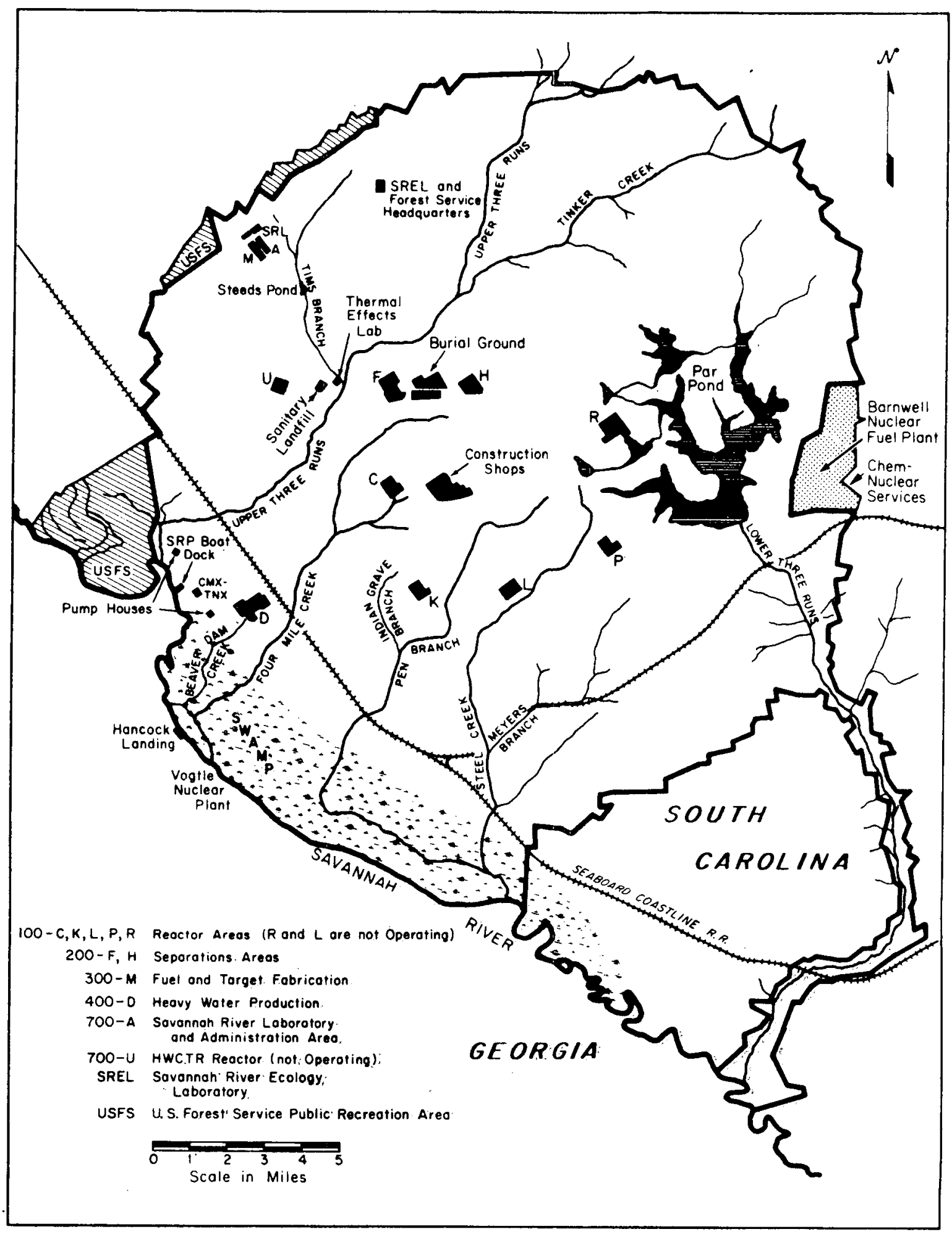

FIGURE 7 Savannah River Plant Site 


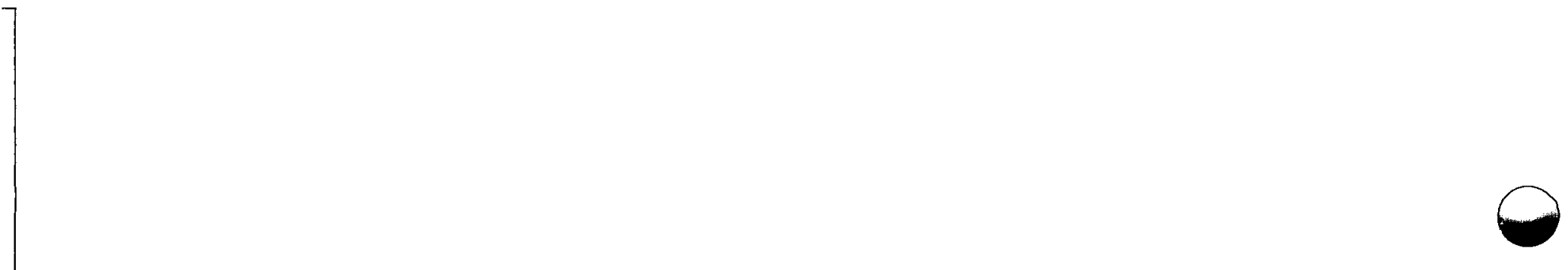

$\theta$

$\theta$ 
$0^{-288^{6}}$

SUMMARY REPORT OF SOIL REMOVAL

PRELIMINARY EXCAVATIONS

Report No. ES-389-75-171

by: C. E. Wickland

Rockwel1 International

Rocky Flats Division

P.0. Box 464

Golden, Colorado 80401

Ju1y, 1975

Key Words

FRP coating

Monitoring

Soil

Waste Management 
SUMMARY REPORT OF SOIL REMOVAL

PRELIMINARY EXCAVATIONS

\section{SUMMARY}

This report discusses a proposed technique to remove small areas, $<2,000 \mathrm{~m}^{2}$, of contaminated soil and the results of an actual excavation. Based on the results of a trial excavation in uncontaminated soil and an excavation of two trenches in contaminated soil, it is concluded that the techniques described are a satisfactory means of contaminated soil removal. It can be done safely with a release of airborne plutonium a factor of 10 or more below the Environmental Protection Administration (EPA) limit. 


\section{INTRODUCTION}

The removal of approximately $2,000 \mathrm{~m}^{2}$ of ${ }^{239} \mathrm{Pu}$ contaminated soil was planned for the summer of 1975 at Rocky Flats. Contamination levels were from 5,000 to $22,000 \mathrm{~d} / \mathrm{m} / \mathrm{g}$. An environmental assess ment was prepared covering the project. Waste Management was assigned the responsibility of preparing a plan to do the soil removal and do the actual excavation. The plan describes in detail the equipment and supplies to be used, personnel requirements, air monitoring plan, technique for soil removal, and packaging requirements.

One stipulation in the plan was to perform a practice excavation on uncontaminated soil simulating all aspects of the procedure to be followed when removing contaminated soil. This report is a summary of that trial excavation which was performed on May 5, 1975. Photos are included which illustrate some of the equipment and techniques used.

Also included in this report are the results of an excavation of contaminated soil by representatives of Health and Safety Laboratory (HASL). Two trenches, approximately $5^{\prime} \times 3^{\prime} \times 2^{\prime}$, were dug in the contaminated zone with the aid of Rocky Flats personnel utilizing the techniques employed in the trial run. 
III. UNCONTAMINATED SOIL REMOVAL, TRIAL EXCAVATION

A. Equipment used:

1. Mobile trailer, $10^{\prime} \times 60^{\prime}$

2. Portable shed, $8^{\prime} \times 16^{\prime}$, equipped with $400 \mathrm{cfm}$ air mover and 8" HEPA filter

3. Water spray can

4. Shovels and picks

5. Wheelbarrow

6. Waste box, $4^{\prime} \times 4^{\prime} \times 7^{\prime}$

7. Plastic bags

8. Plywood walkway

9. Staplex $40 \mathrm{cfm}$ hi volume portable air sampler with micro solvent filter

10. Portable air sampler, 2 cfm

11. Johnson scintillation counter

\section{B. Excavation Description}

The trial excavation was performed on May 5, 1975. The weather was dry and the wind velocity was greater than 15 miles per hour from a southerly direction. The wind conditions would have precluded an excavation of contaminated soil but were considered inconsequential to the trial run. A11 other details of the specified plan were adhered to. 
The portable shed was placed in an uncontaminated area and staked down. A staplex hi-volume air sampler was placed approximately 20 feet downwind from the shed. A $2 \mathrm{cfm}$ air sampler was placed in the shed. The air mover was turned on to provide a slight negative pressure in the shed. This resulted in air flow into the doorway exhausting through a fiberglass prefilter, $8^{\prime \prime}$ HEPA filter, and the air mover filter bag.

Two decontamination workers, clothed in white coveralls, booties, cap and rubber surgeon gloves, performed the actual excavation. Wearing respirators, the 2 workers and a Health Physics monitor entered the shed. The soil was stabilized by sprinkling with water. Excavation was begun at an extreme corner from the entrance. The soil was shoveled into a plastic-lined metal container which contained a plastic bag. Approximately one cubic foot of soil was placed in the plastic bag. The bag was then closed, taped and removed from the metal container. The monitor checked the exterior of the bag for alpha activity. After determining that the bag was uncontaminated, it was passed through the doorway to a worker who placed the bag in a wheelbarrow. Filled bags were transported to and placed in a standard waste box. A standard waste box 
is a $4^{\prime} \times 4^{\prime} \times 7^{\prime}$ plywood box coated with fiberglass reinforced plastic (FRP), lined with fiberboard and two (2) plastic liners, and containing 50\# of absorbent spread over the bottom.

After excavating 3 bags of soil the trial run was terminated. According to the plan, this procedure would be repeated until contamination levels of the soil were reduced to below the detection level of the FIDLER probe, $250 \mathrm{~d} / \mathrm{m} / \mathrm{g}$.

The filter paper on the hi-volume air monitor was analyzed for ${ }^{239} \mathrm{Pu}$. The results were $0.00004 \mathrm{pCi} / \mathrm{m}^{3}$. This compares with background due to fallout and natural radiation of approximately $0.00003 \mathrm{pCi} / \mathrm{m}^{3}$. The Environmental Protection Administration (EPA) allowable limit for the general population for plutonium in air is $0.02 \mathrm{pCi} / \mathrm{m}^{3}$.

\section{HEALTH AND SAFETY LABORATORY (HASL) EXCAVATION}

On May 13 and 14, 1975, representatives from HASL with the aid of Rocky Flats personnel, excavated two trenches in the contaminated area utilizing the techniques employed in the trial run. Stabilizing the soil was not required because the work was done 
following a day of rain which dampened the ground sufficiently to minimize any dust production. The purpose of the Health and Safety Laboratory (HASL) excavation was to take core samples at varying depths to determine a profile of the plutonium migration in soil.

The contaminated soil from these excavations was packaged per the plan, but placed in 55-gallon drums instead of fiberglass reinforced plastic (FRP) coated waste boxes. The soil contained a specific activity of less than $10 \mathrm{nCi} / \mathrm{g}$ of Pu. Eight drums of contaminated soil were removed from the two trenches. Photos were also taken of these excavations. Analysis of the filter paper on the hi-volume air monitor showed $0.00258 \mathrm{pCi} / \mathrm{m}^{3}$ of ${ }^{239} \mathrm{Pu}$. Results from the $2 \mathrm{cfm}$ air sampler located in the shed indicated total alpha activity of $0.09 \mathrm{pCi} / \mathrm{m}^{3}$ on May 13 and $0.002 \mathrm{pCi} / \mathrm{m}^{3}$ on May 14. These results compare with allowable limits in a work area of $4.05 \mathrm{pCi} / \mathrm{m}^{3}$ for insoluble $\mathrm{Pu}$ and $1.98 \mathrm{pCi} / \mathrm{m}^{3}$ for soluble Pu. A comparison of these results with those of the trial excavation in uncontaminated soil indicate a small amount of plutonium became airborne due either to personnel activities in the area and/or the actual excavation. The levels released were well below established limits. 


\section{DESCRIPTION OF PHOTOS}

1. Westward View of Rocky Flats Plant

2. Planned Soil Removal Sites

3. Plutonium Concentrations $(\mathrm{d} / \mathrm{m} / \mathrm{g})$

4. Anemometer to measure wind velocity and direction

5. Trailer $10^{\prime} \times 60^{\prime}$ for storage of equipment and supplies, a1so used as a clothes change area. Tank in foreground to supply water for stabilizing soil

6. Portable shed $8^{\prime} \times 16^{\prime}$ with portable air mover and $8^{\prime \prime}$ HEPA filter. Shed is anchored to prevent capsizing in the wind. Plywood walkway with wheelbarrow and standard fiberglass reinforced plastic (FRP) coated wastebox to left

7. Temporary anchoring technique

8. Sky hook to relocate portable shed with crane

9. Appare1 worn by decon workers, coveralls, booties covered with plastic, cap, surgeon's gloves and respirator

10. Radiation monitor using FIDLER probe to determine alpha activity of the soil

11. Fiberglass prefilter inside shed 
12. Stabilizing the soil with water

13. Shoveling soil into plastic bag in plastic lined container

14. Closing and sealing bag with tape

15. Checking for contamination on exterior of bag with portable alpha detector

16. Placing bag in wheelbarrow

17. Placing 50\# of absorbent material in bottom of fiberglass reinforced plastic (FRP) coated waste box

18. Placing plastic bag of dirt in standard fiberglass reinforced plastic (FRP) coated waste box lined with fiberboard and two 0.006 " polyethelene liners

19. Monitoring personnel for contamination with portable alpha detector

20. Monitoring personnel for contamination with portable alpha detector

21. Monitoring personnel for contamination with portable alpha detector

22. Scintillation counter to determine activity on portable air sampler filter paper

23. Set up for Health and Safety Laboratory (HASL) excavation of contaminated soil 
24. Excavating contaminated soil. Note portable $2 \mathrm{cfm}$ air sampler in background

25. No alpha activity detected on rock removed from trench

26. Monitoring plastic bag of contaminated soil with portable alpha detector

27. Air sample results

28. Air sample results 


\section{C}

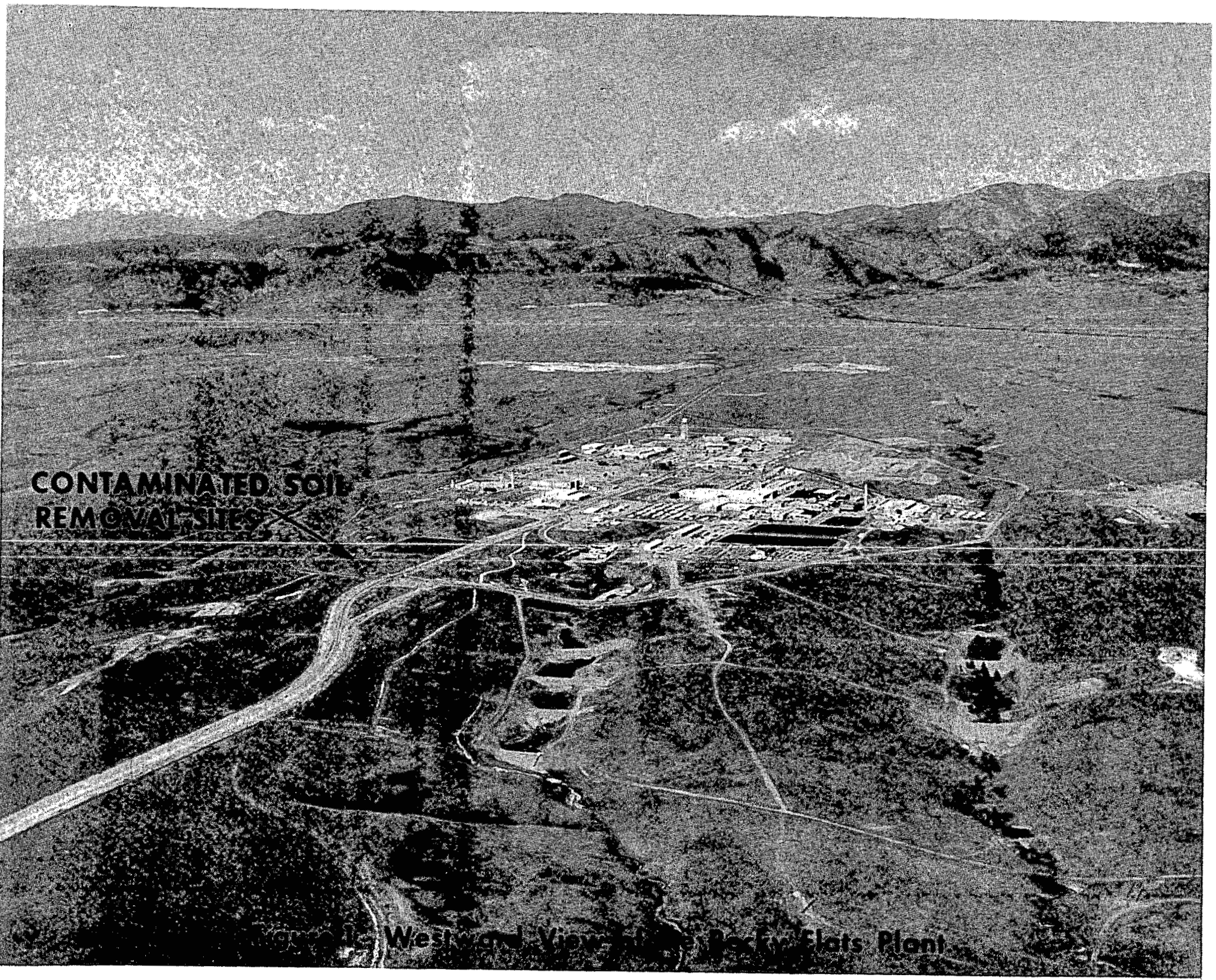




\section{3-AREA}

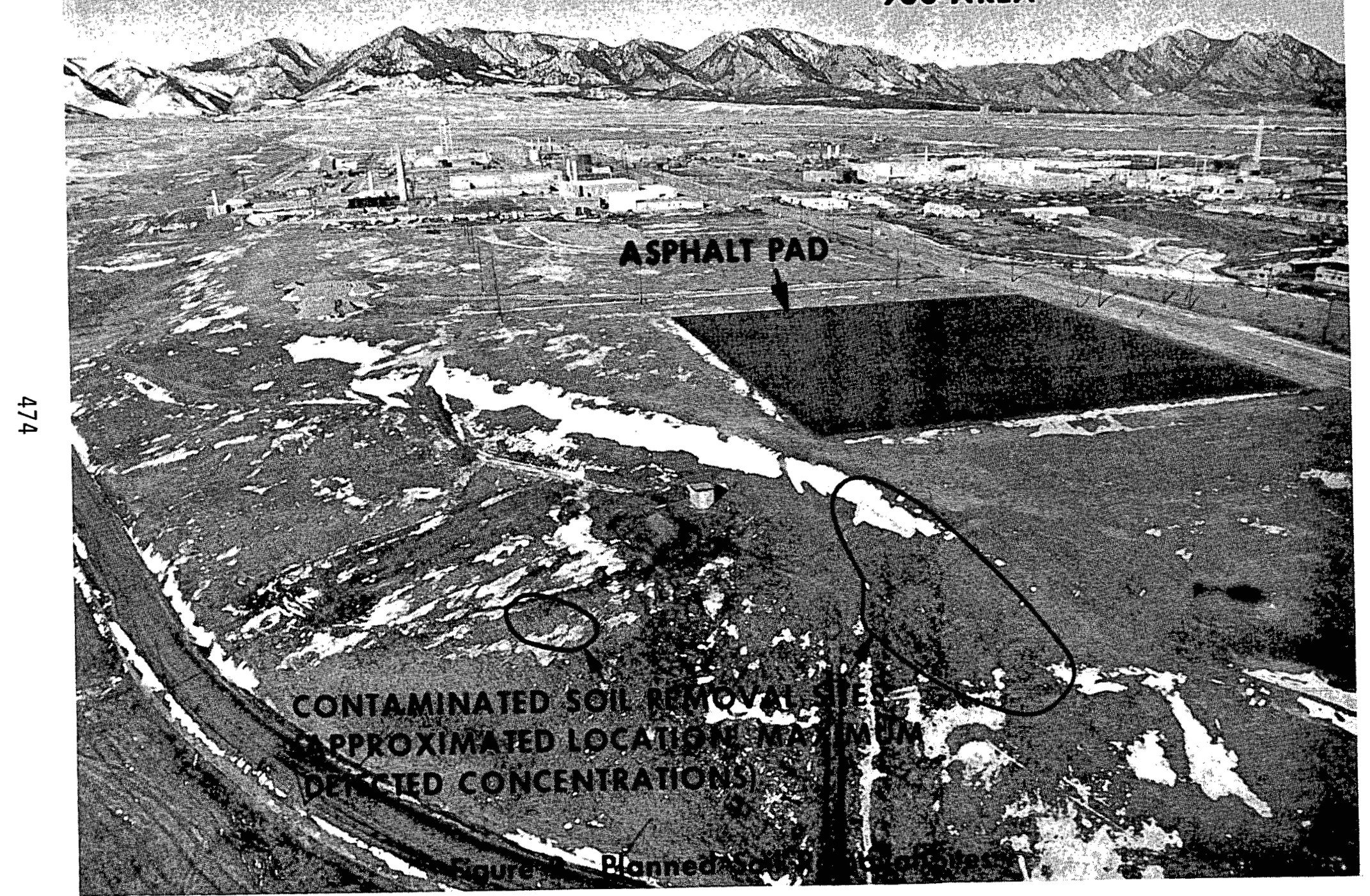




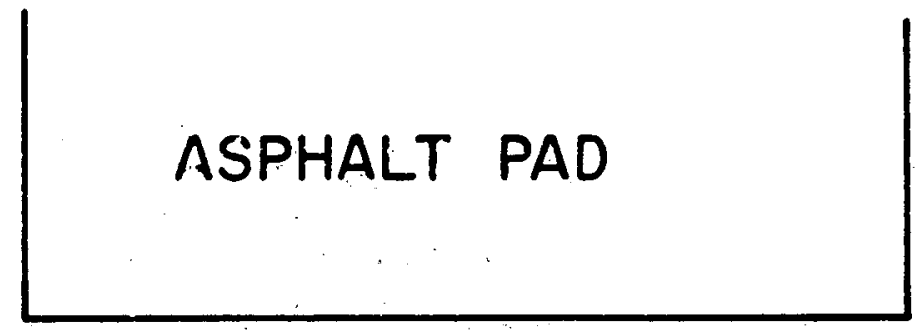

$+100 \mathrm{ft} \rightarrow$

(30-metres)

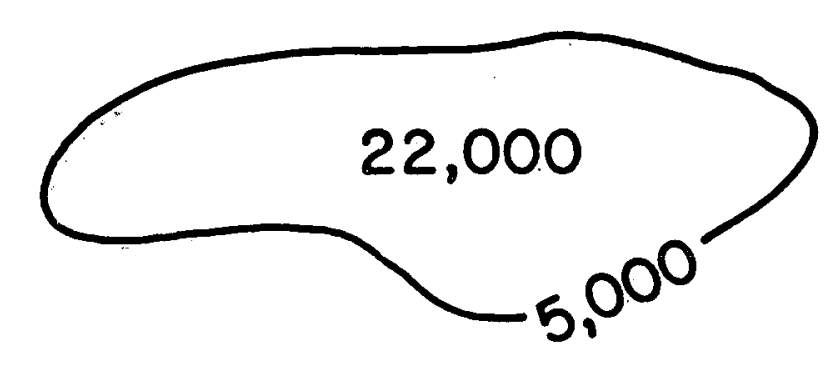

जu

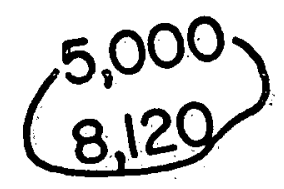

FIGURE 3. PLUTONIUM CONCENTRATIONS (D/M/G) 


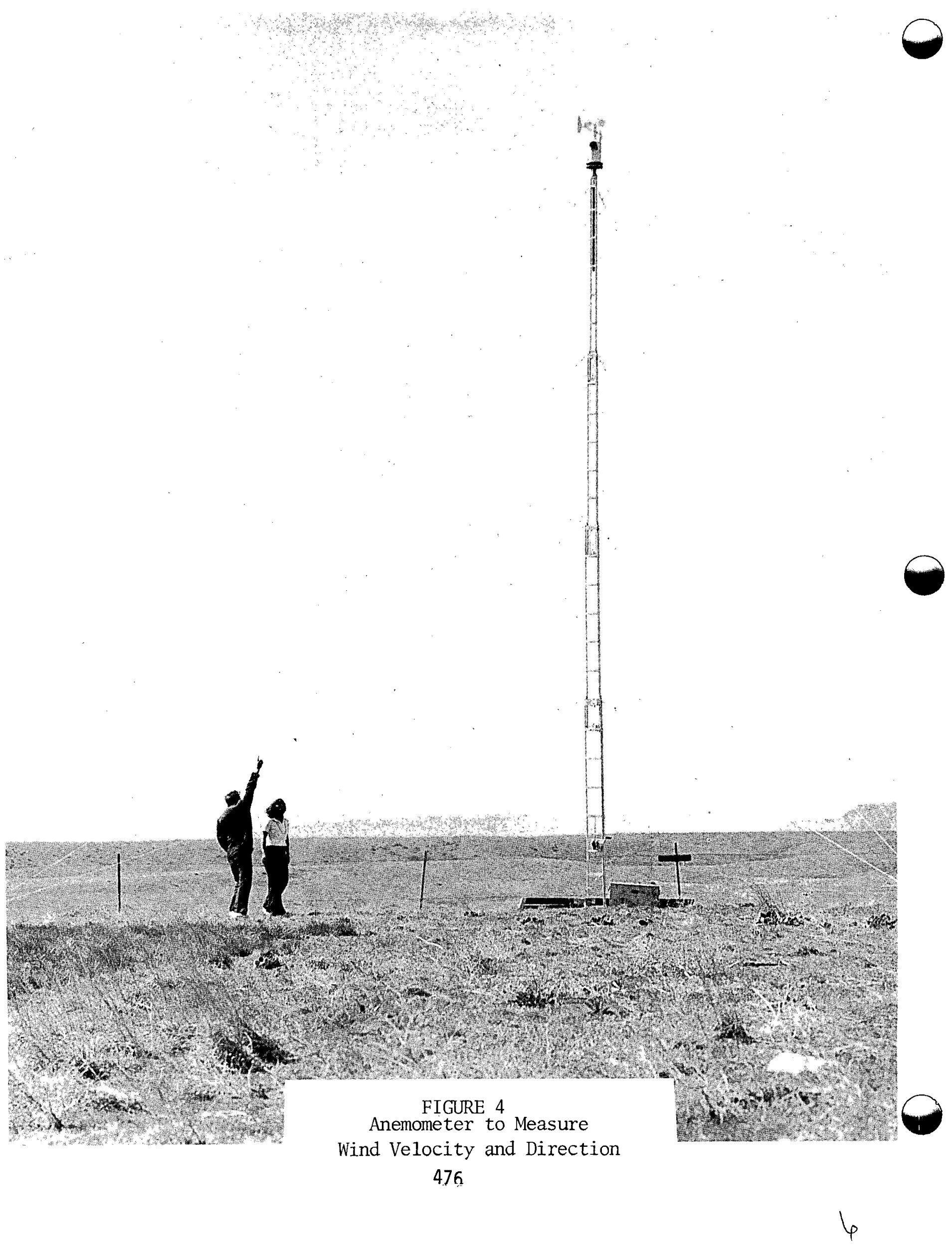




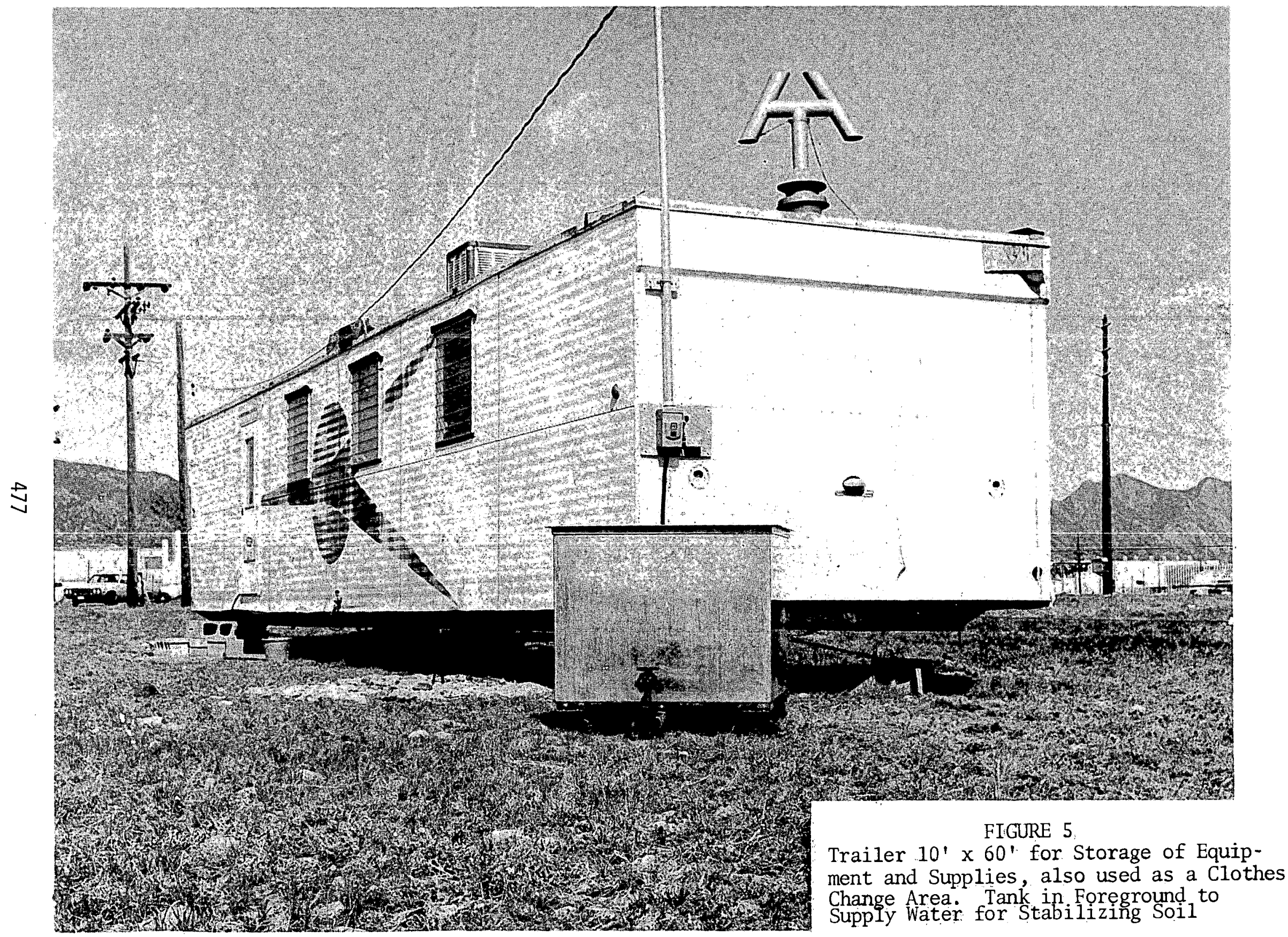




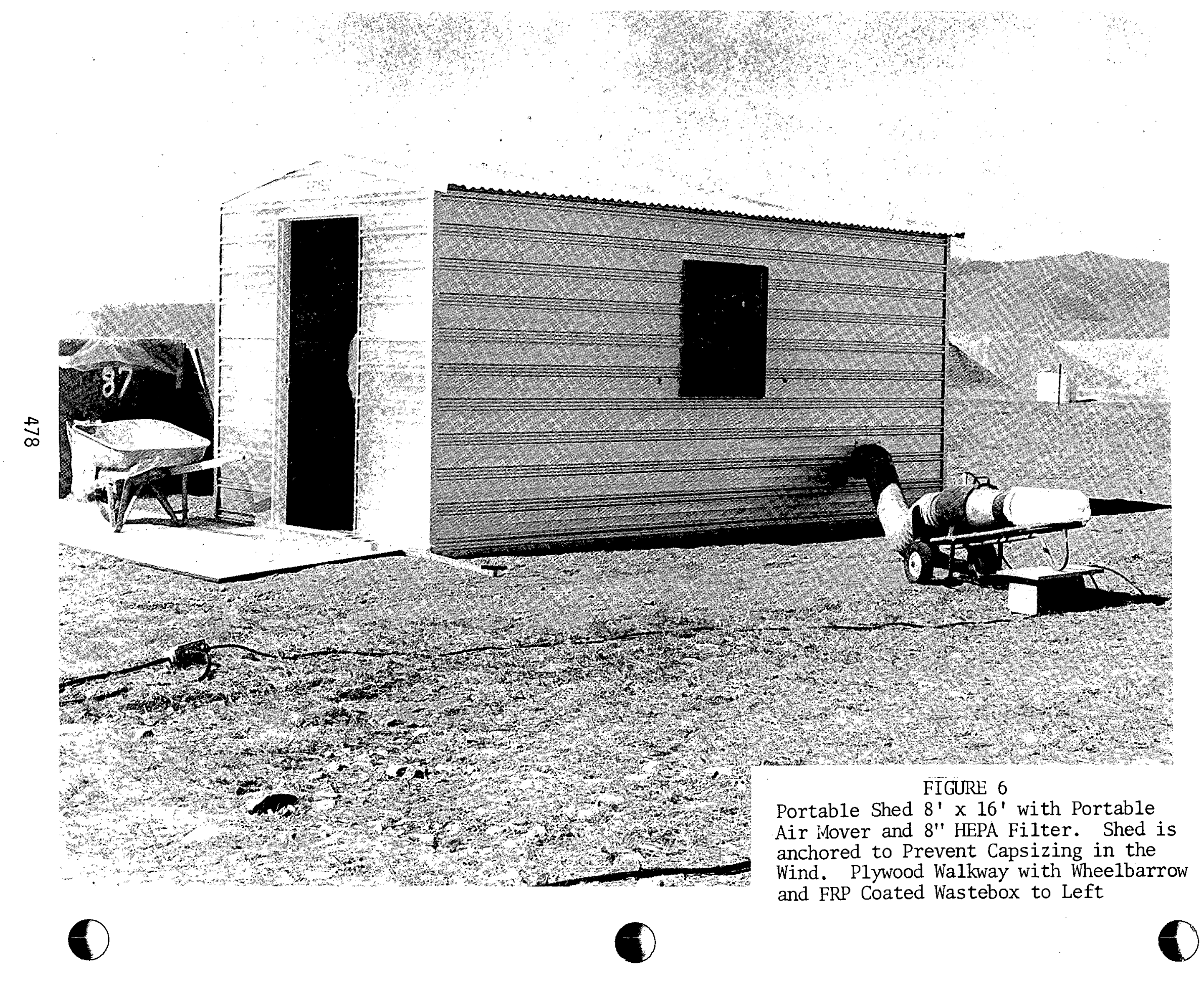


(1)

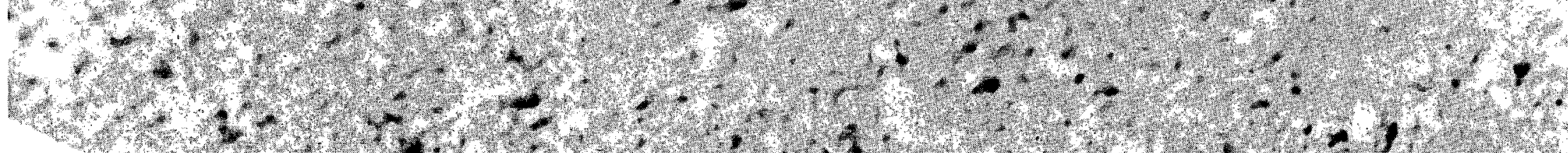
H. -

\section{s.

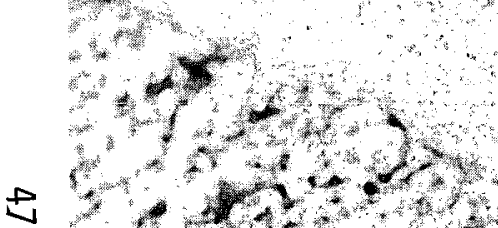

(4)

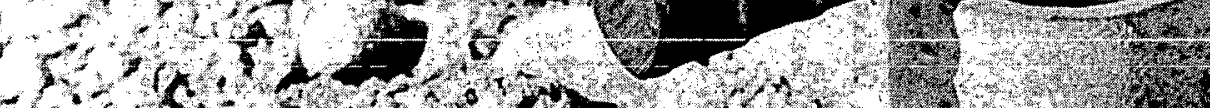

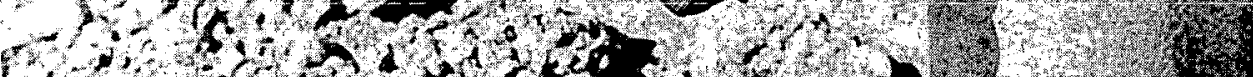

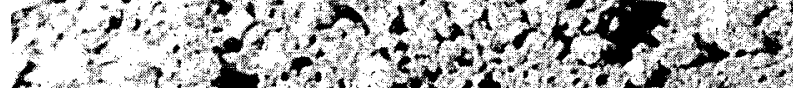

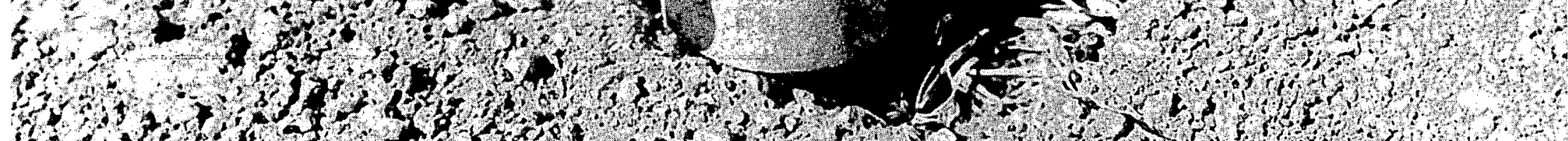

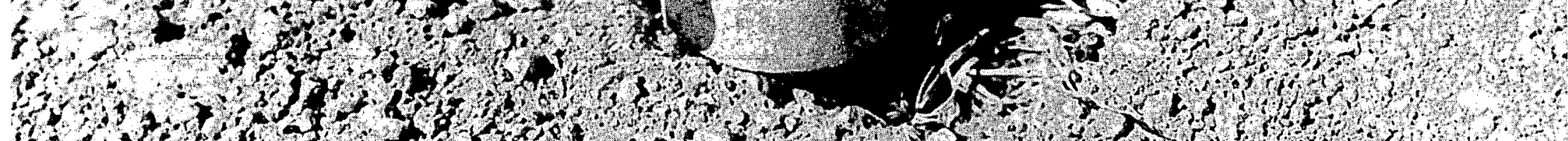

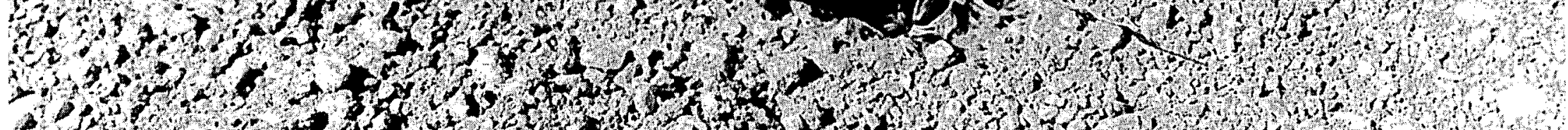

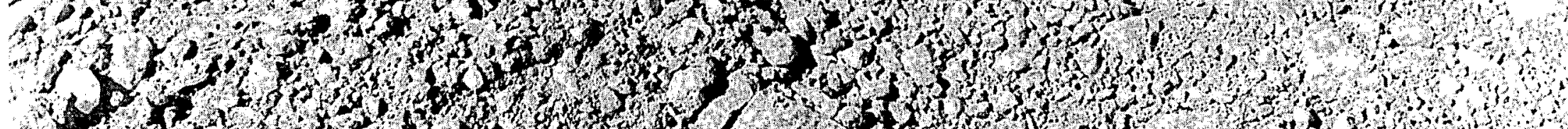

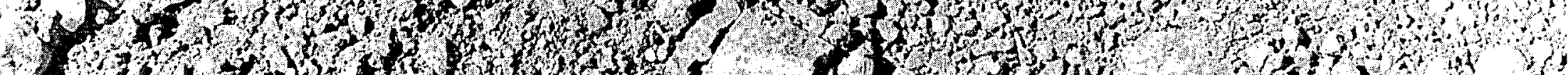

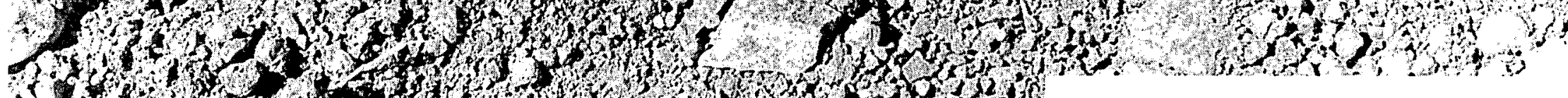

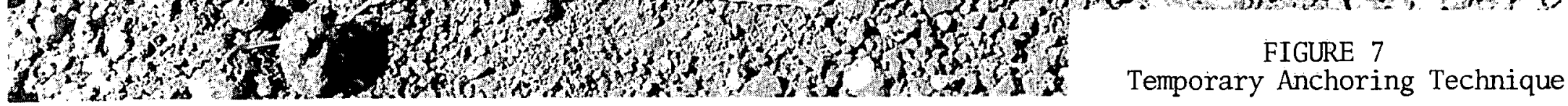




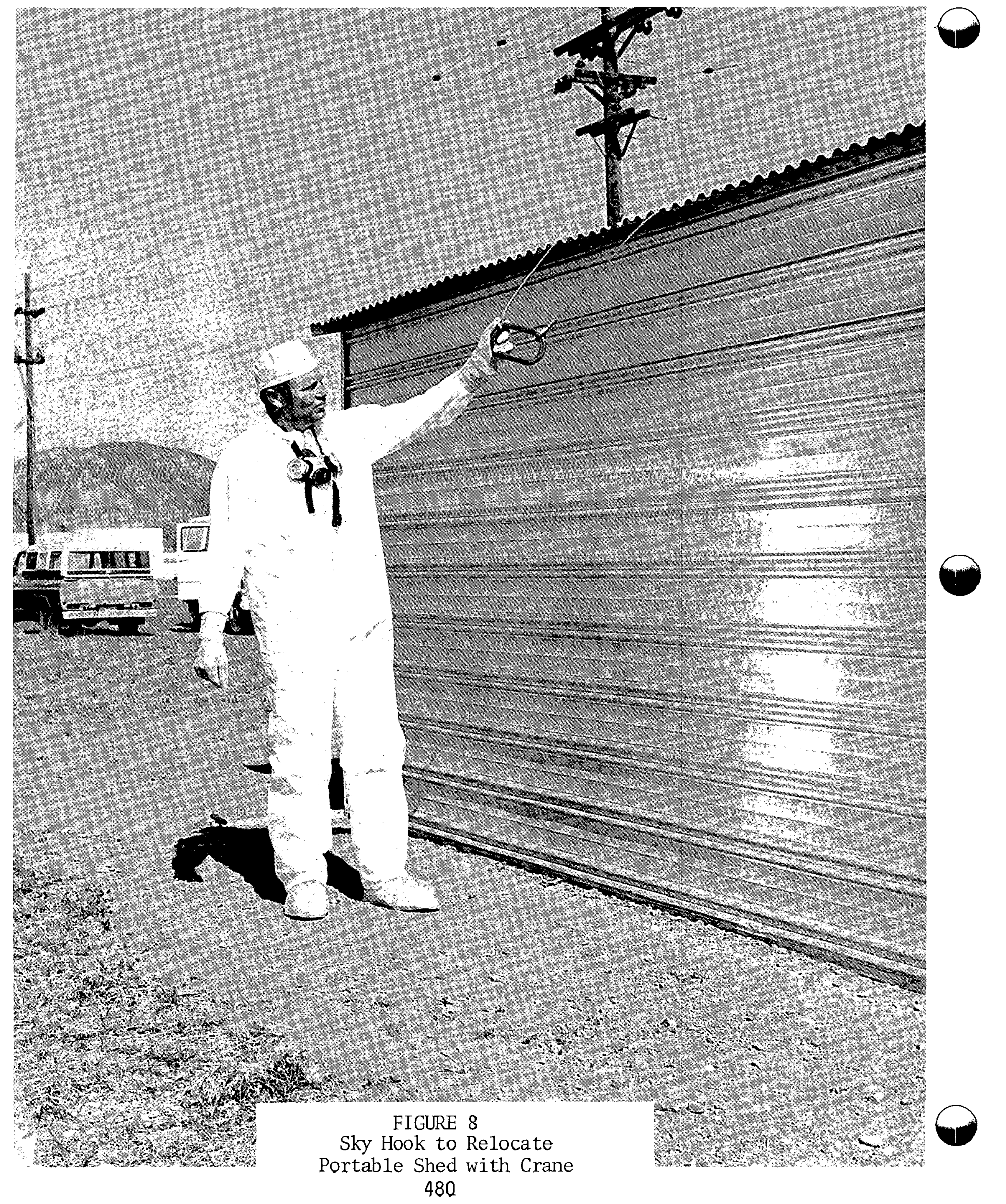




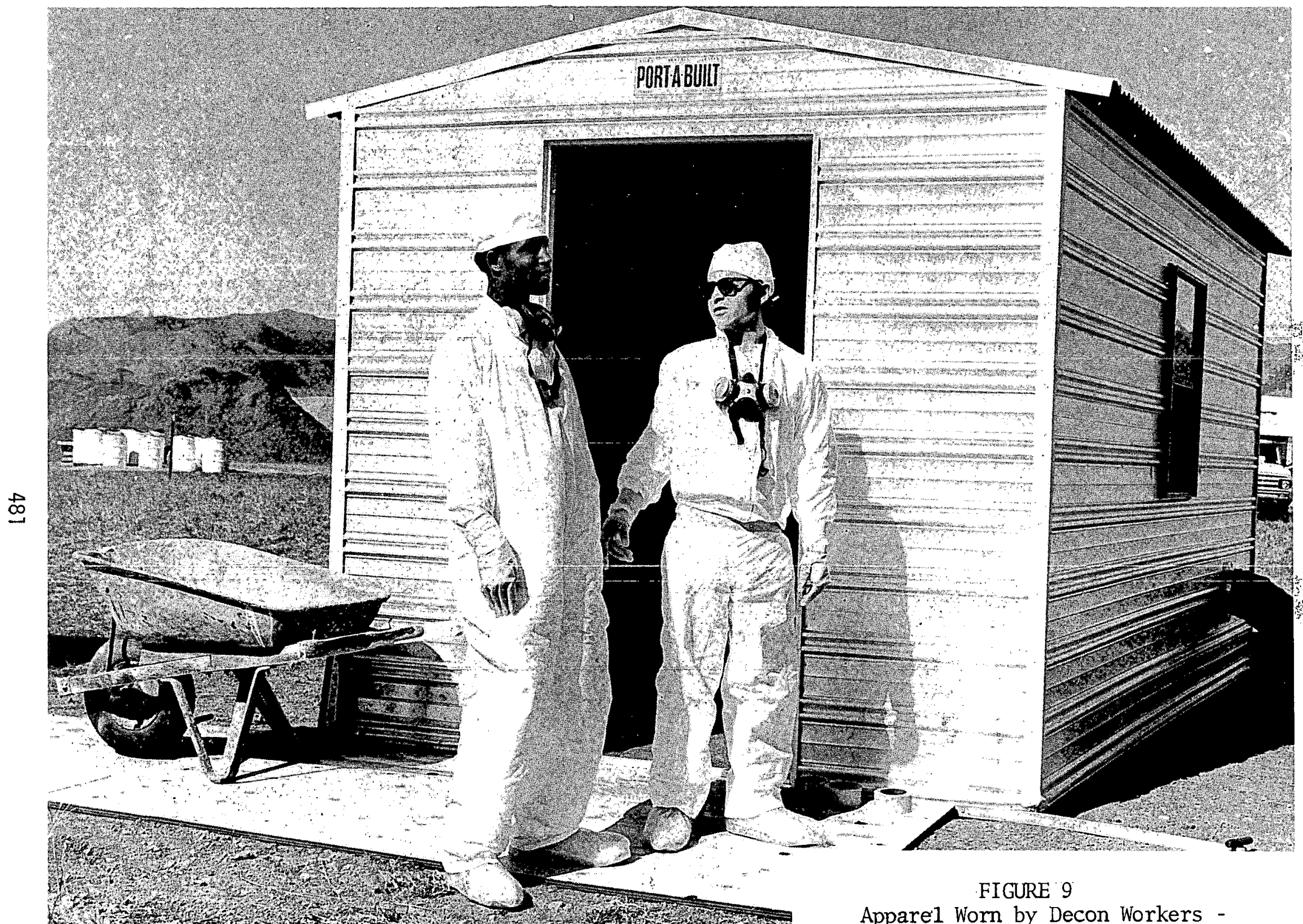




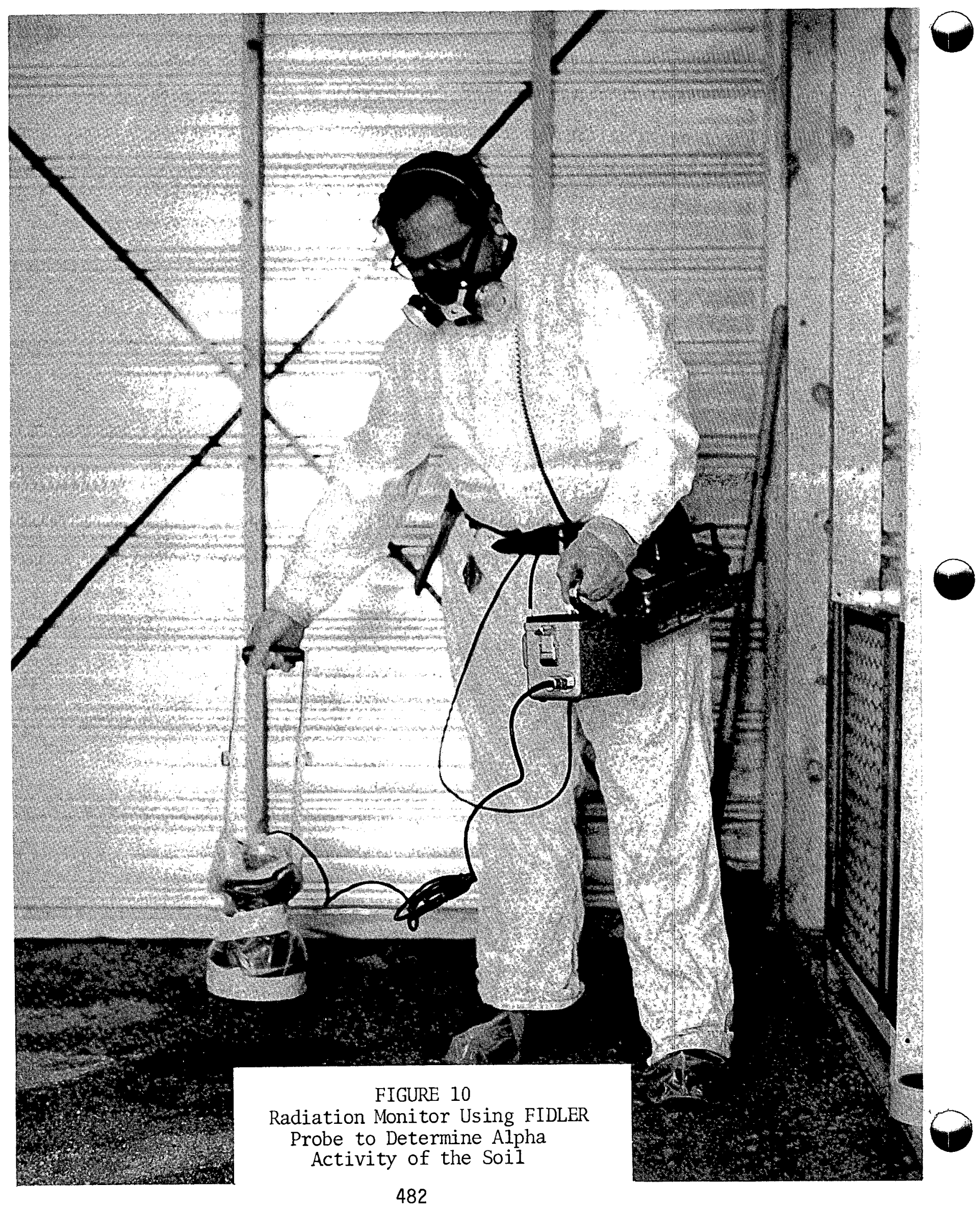




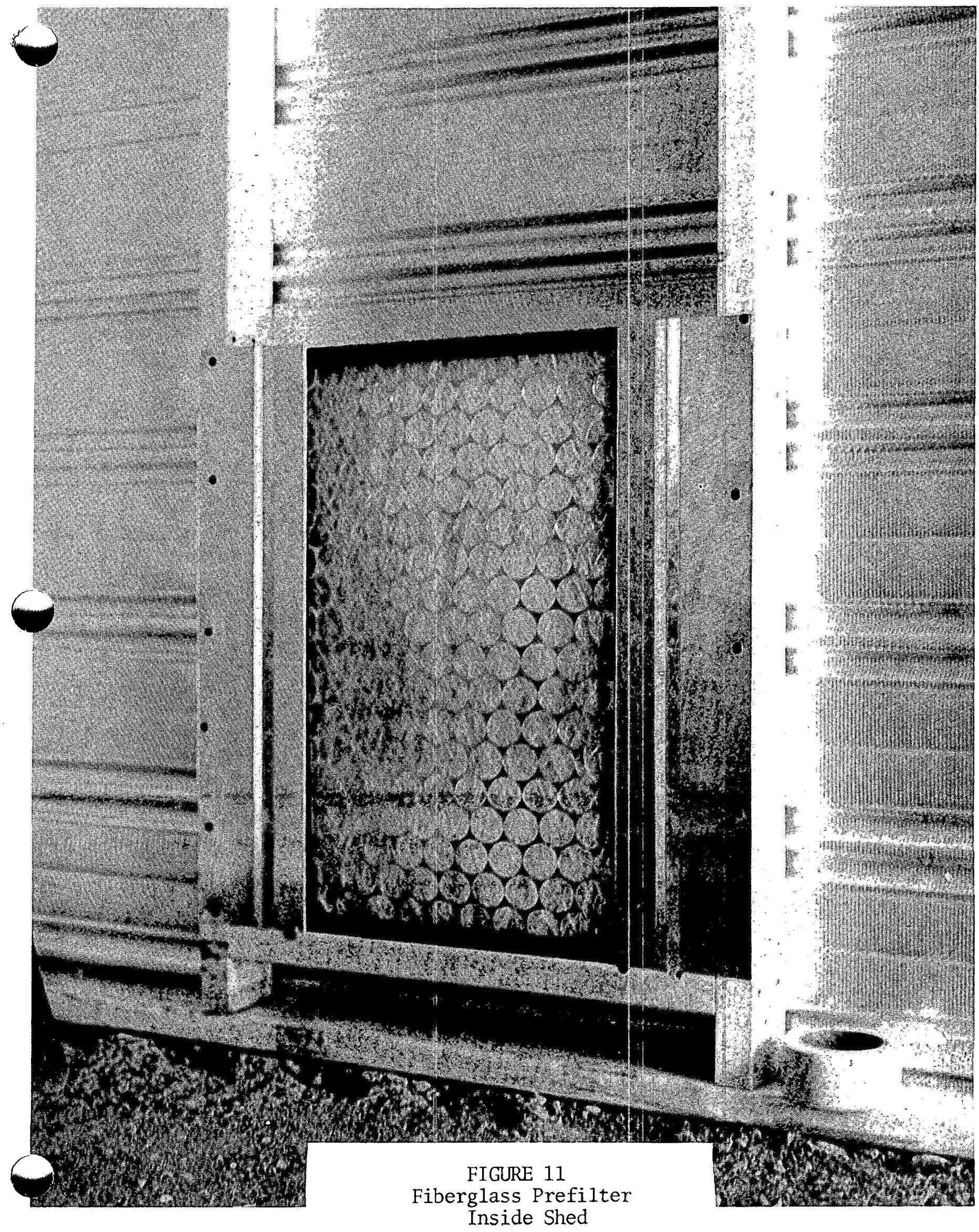




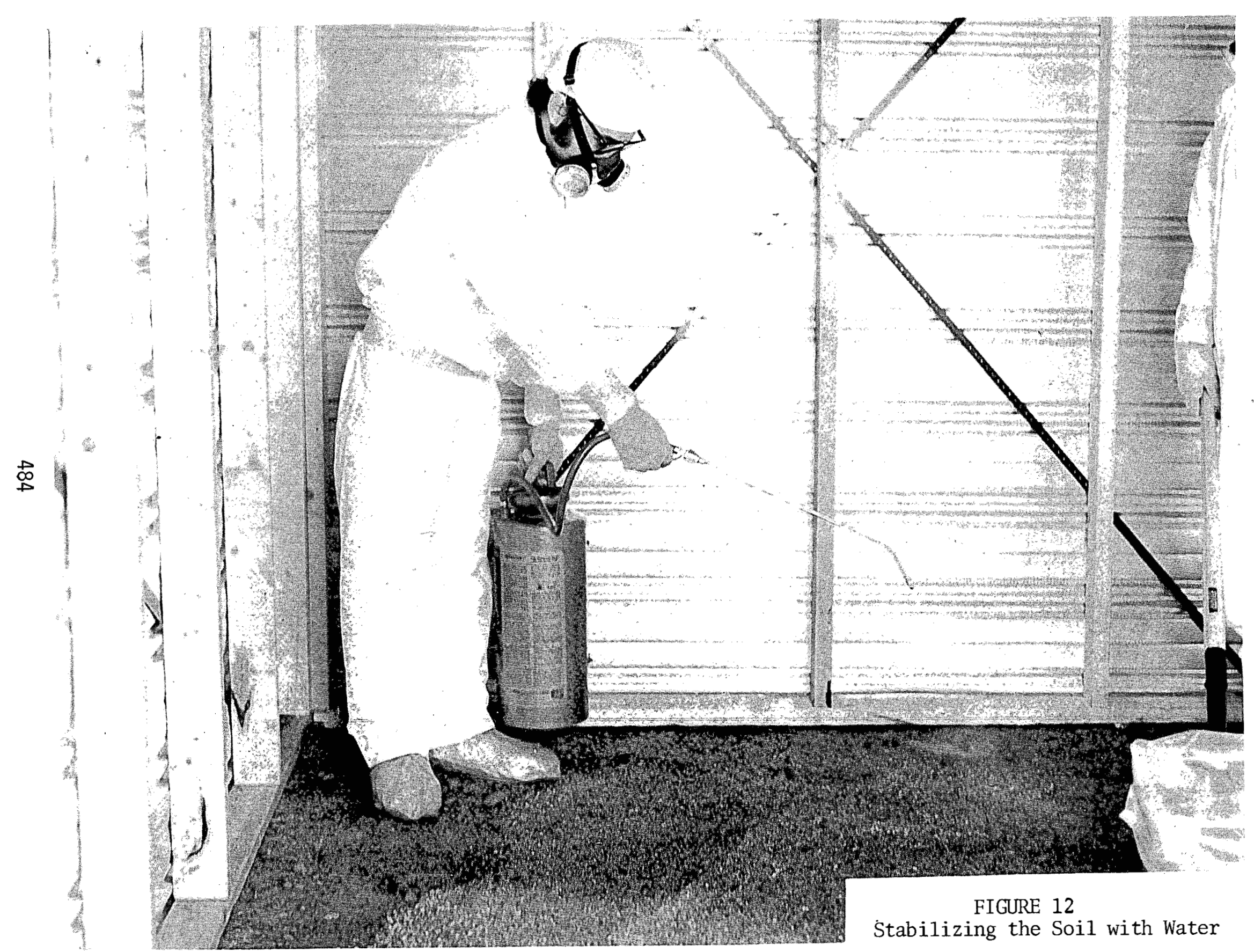




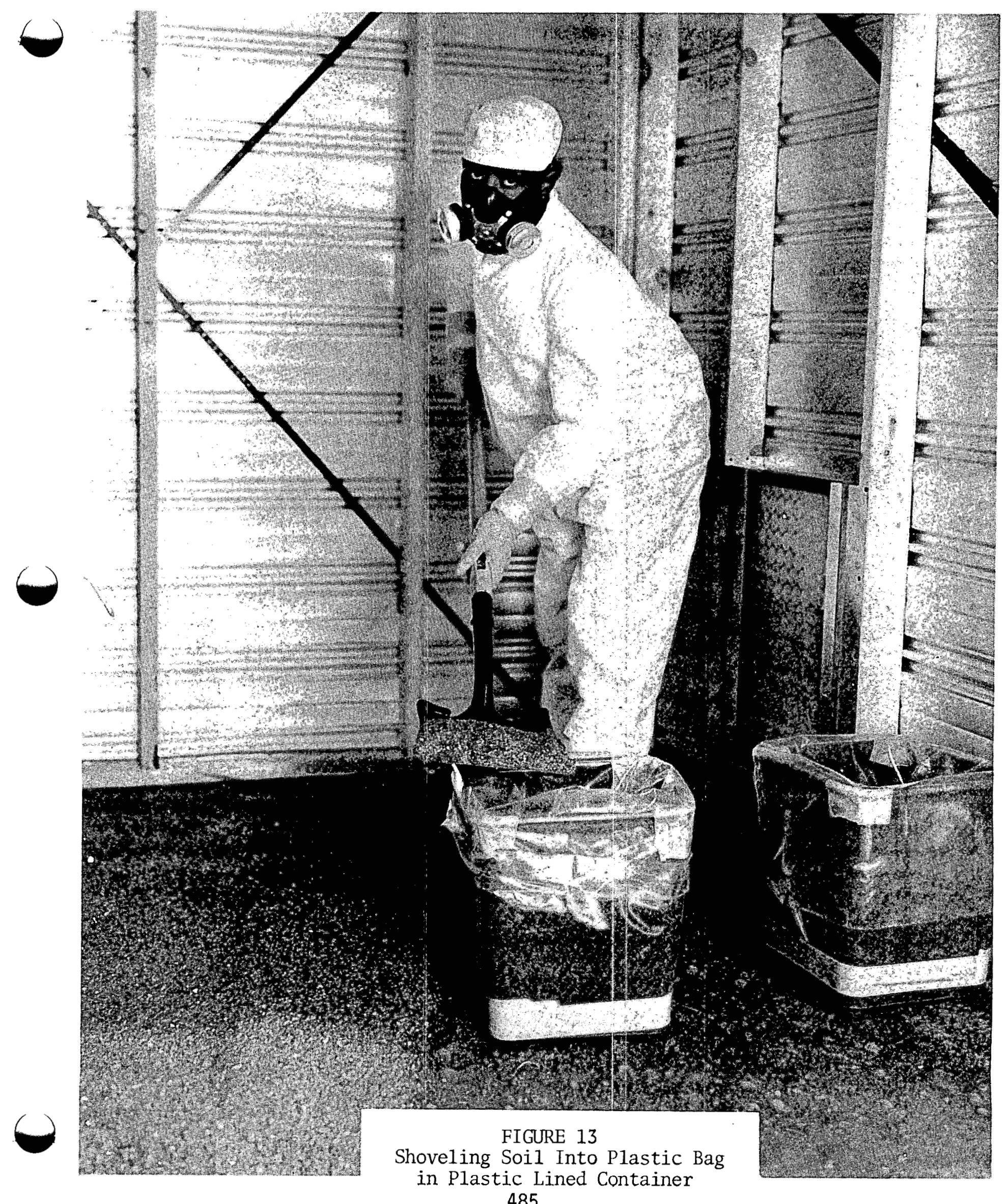




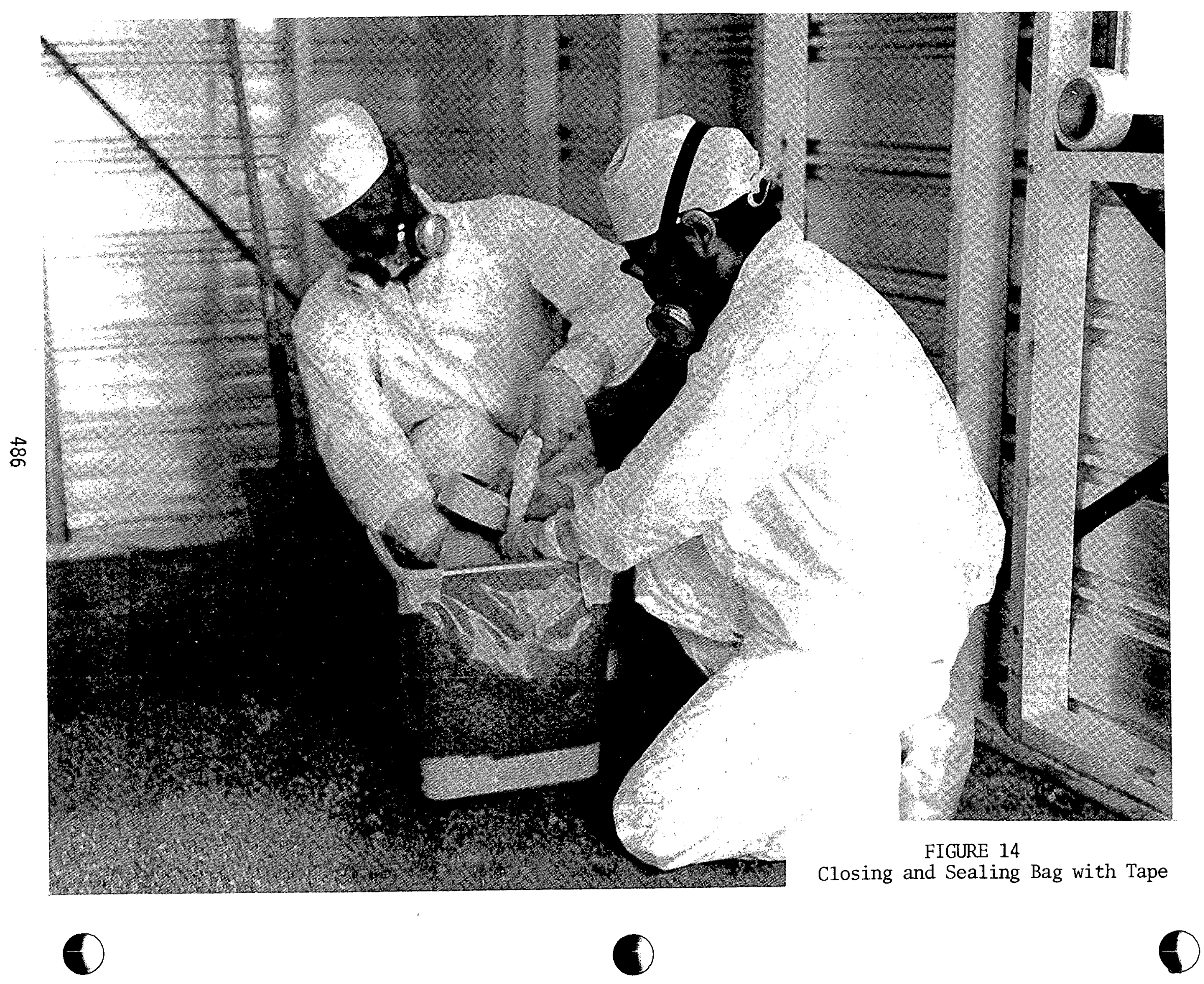




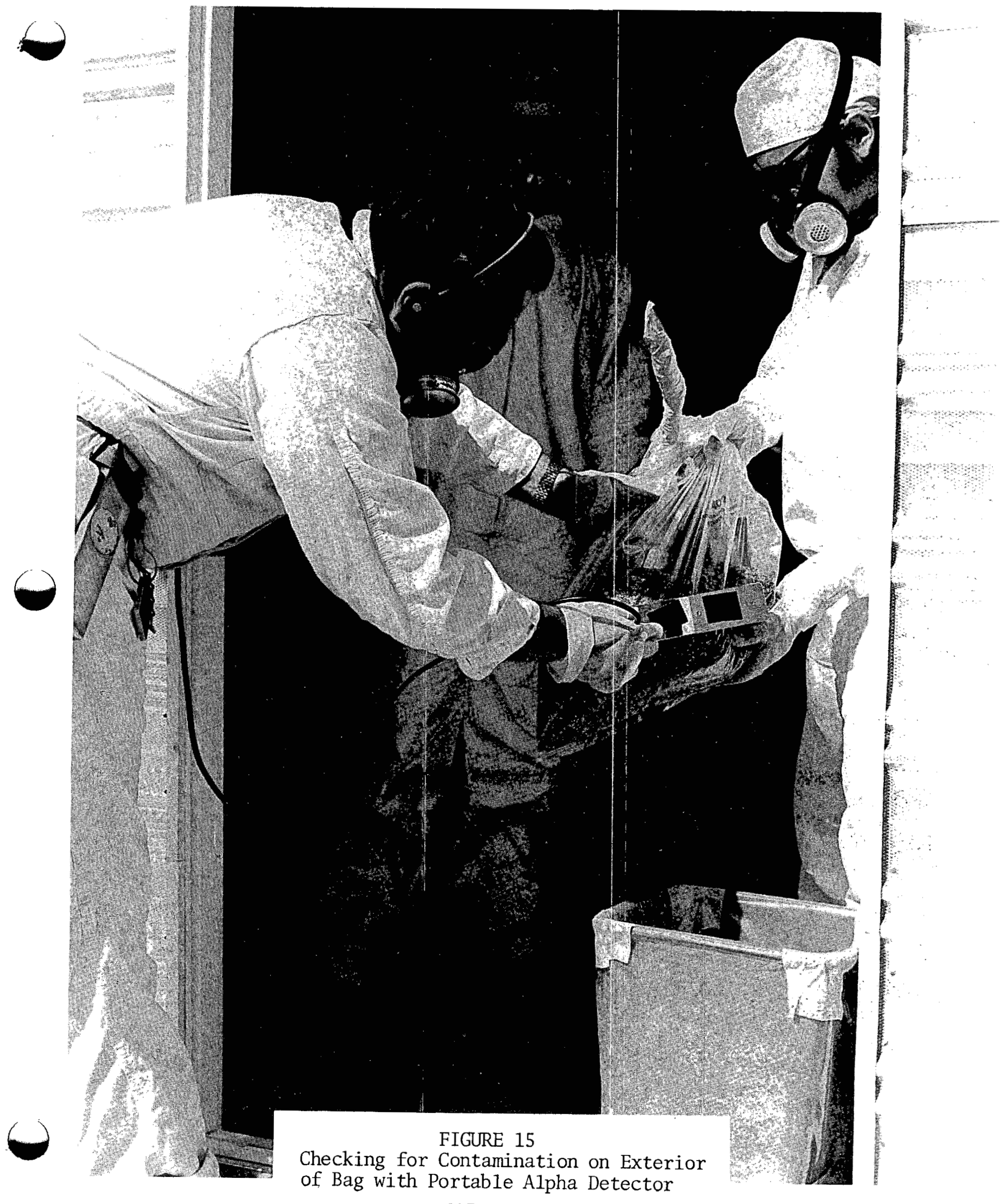




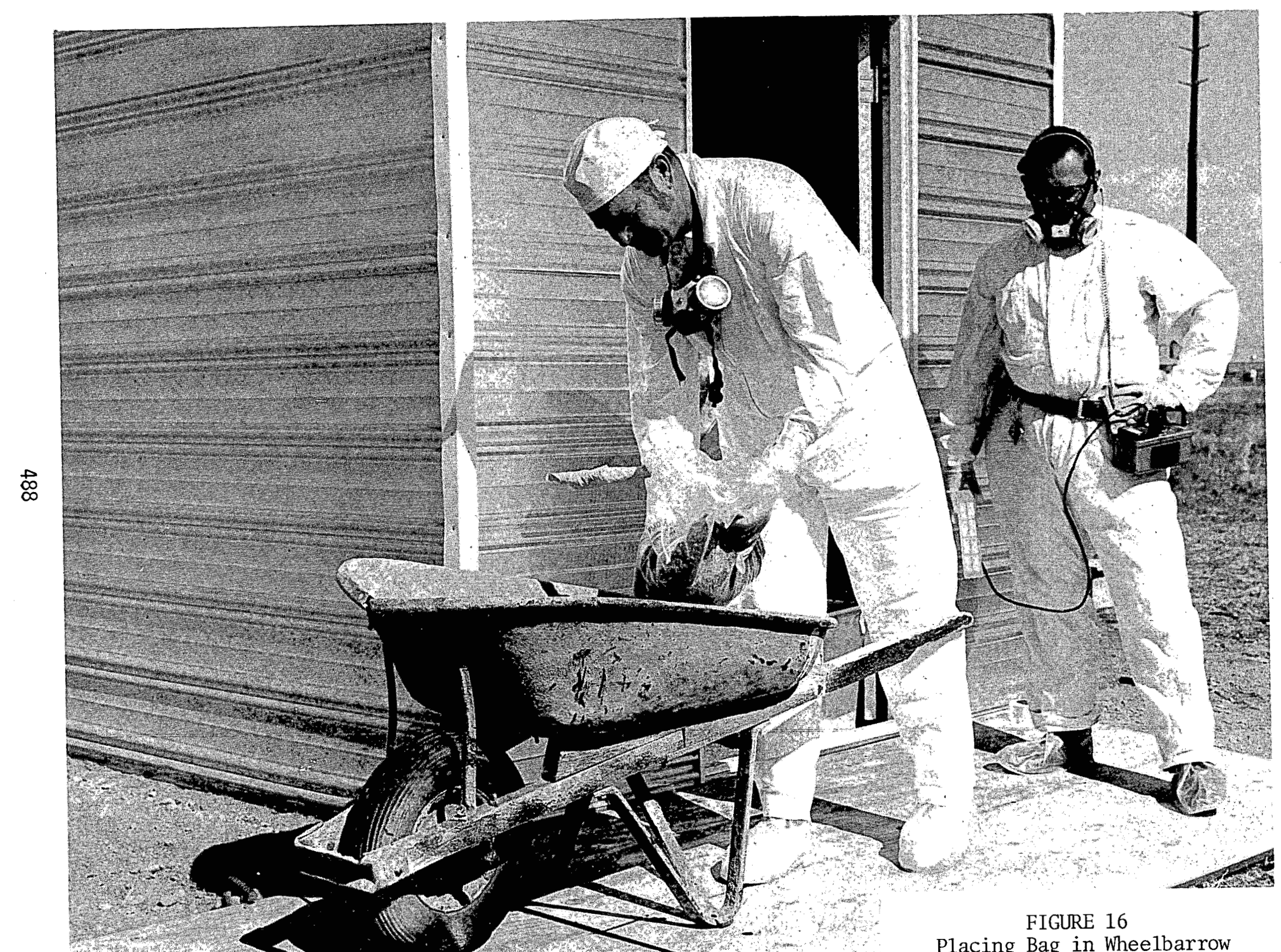

0 


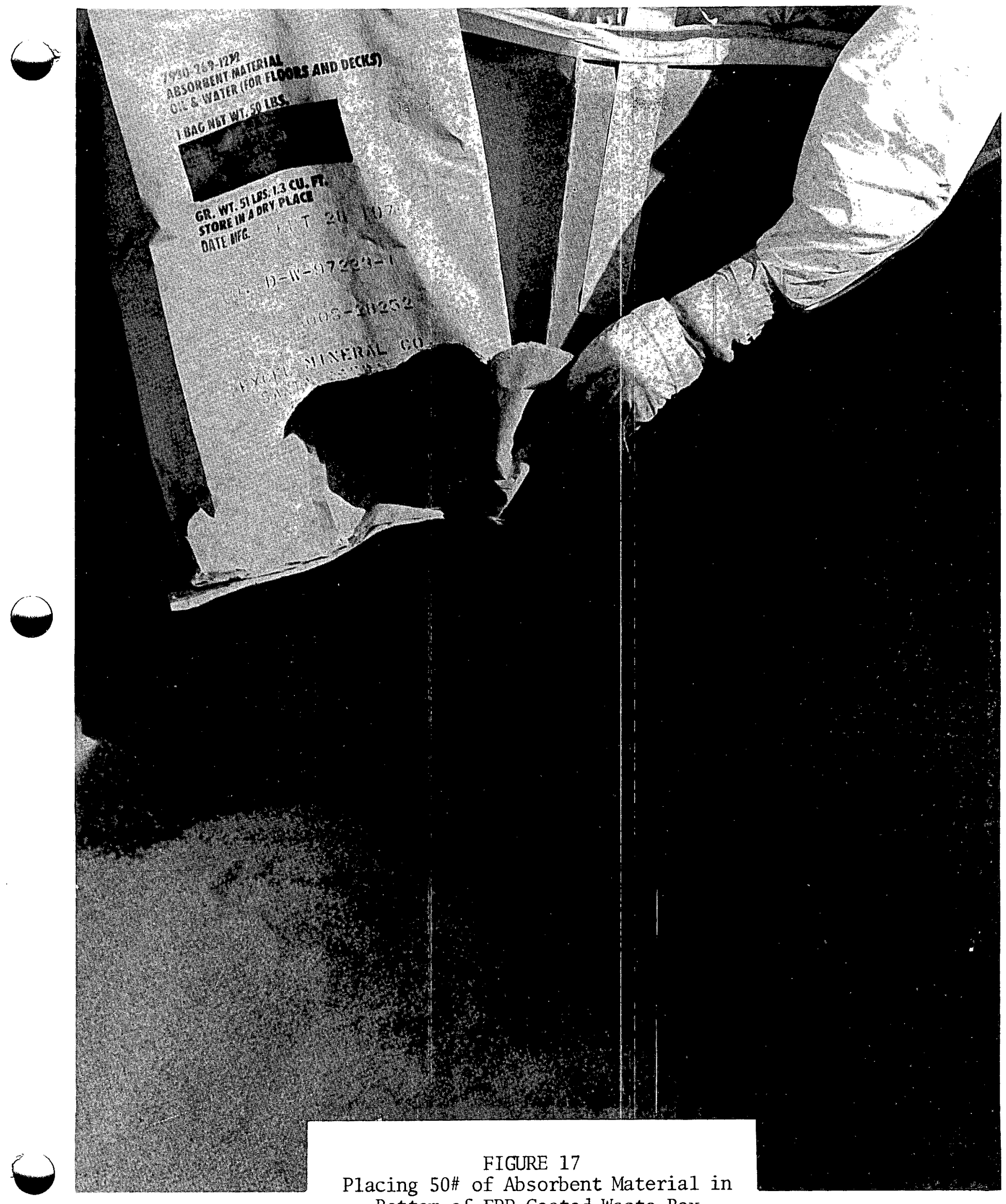
Bottom of FRP Coated Waste Box 


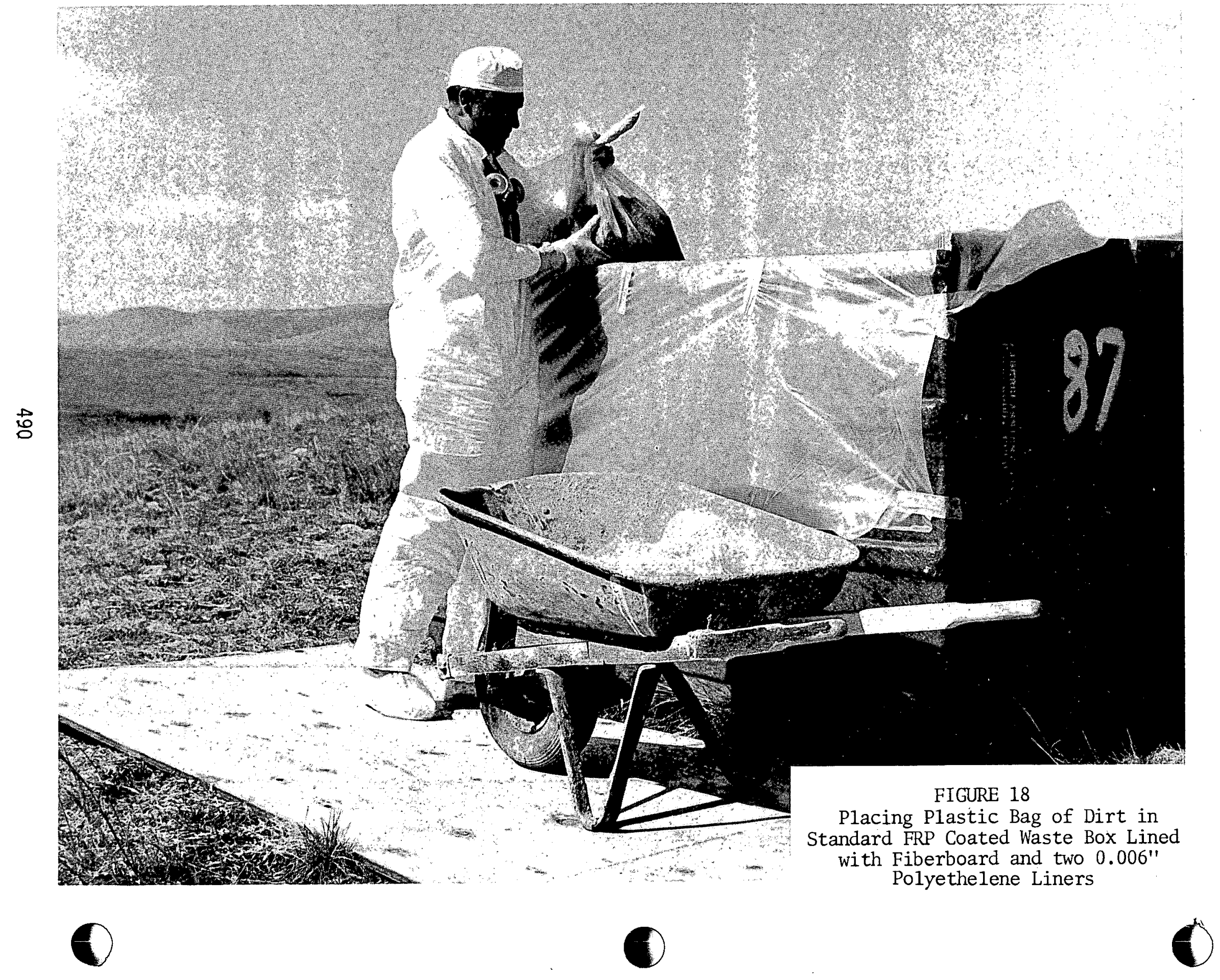




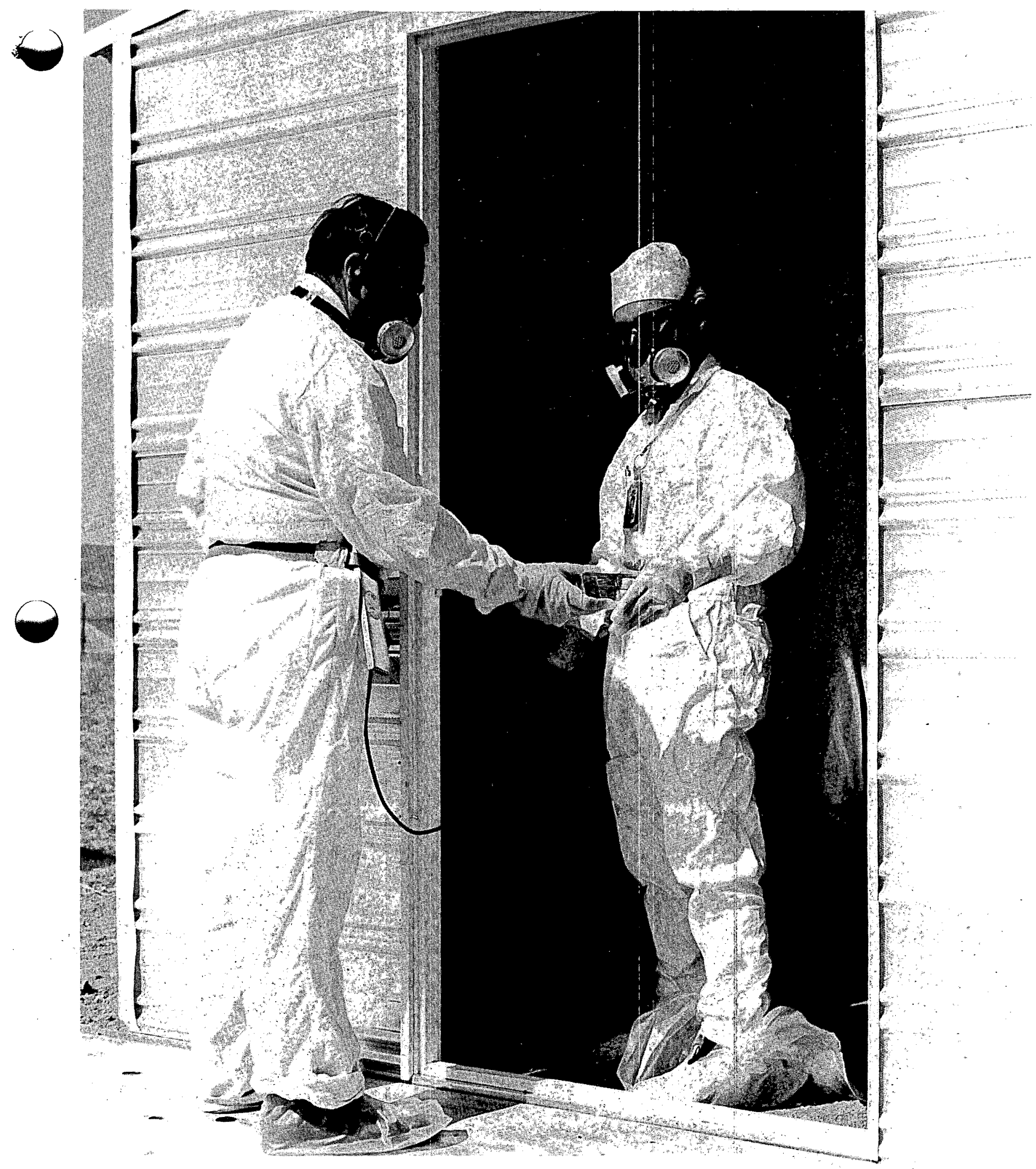

FIGURE 19

Monitoring Personnel for Contamination with Portable Alpha Detector 


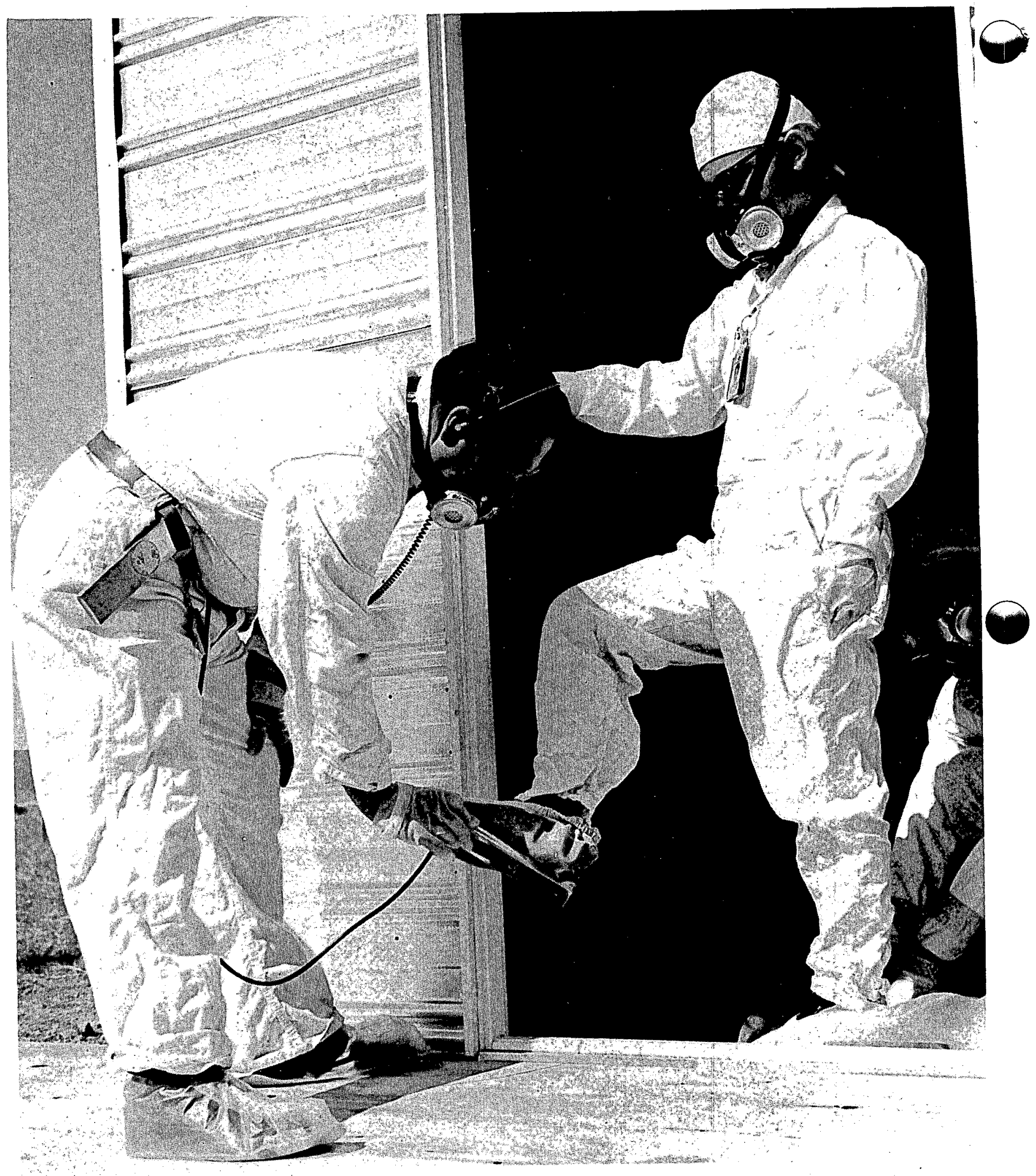

FIGURE 20

Monitoring Personnel for Contamination with Portable Alpha Detector 

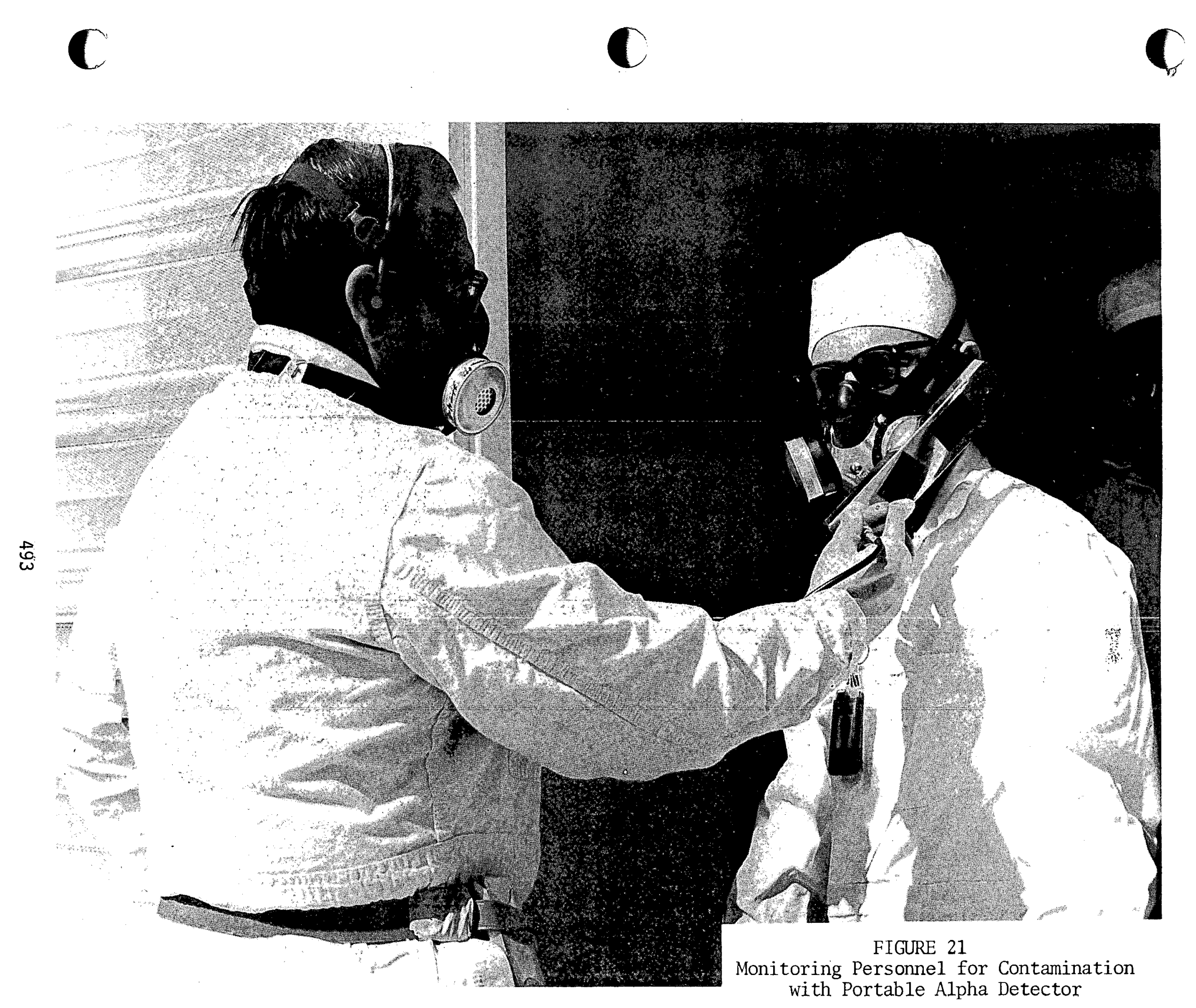


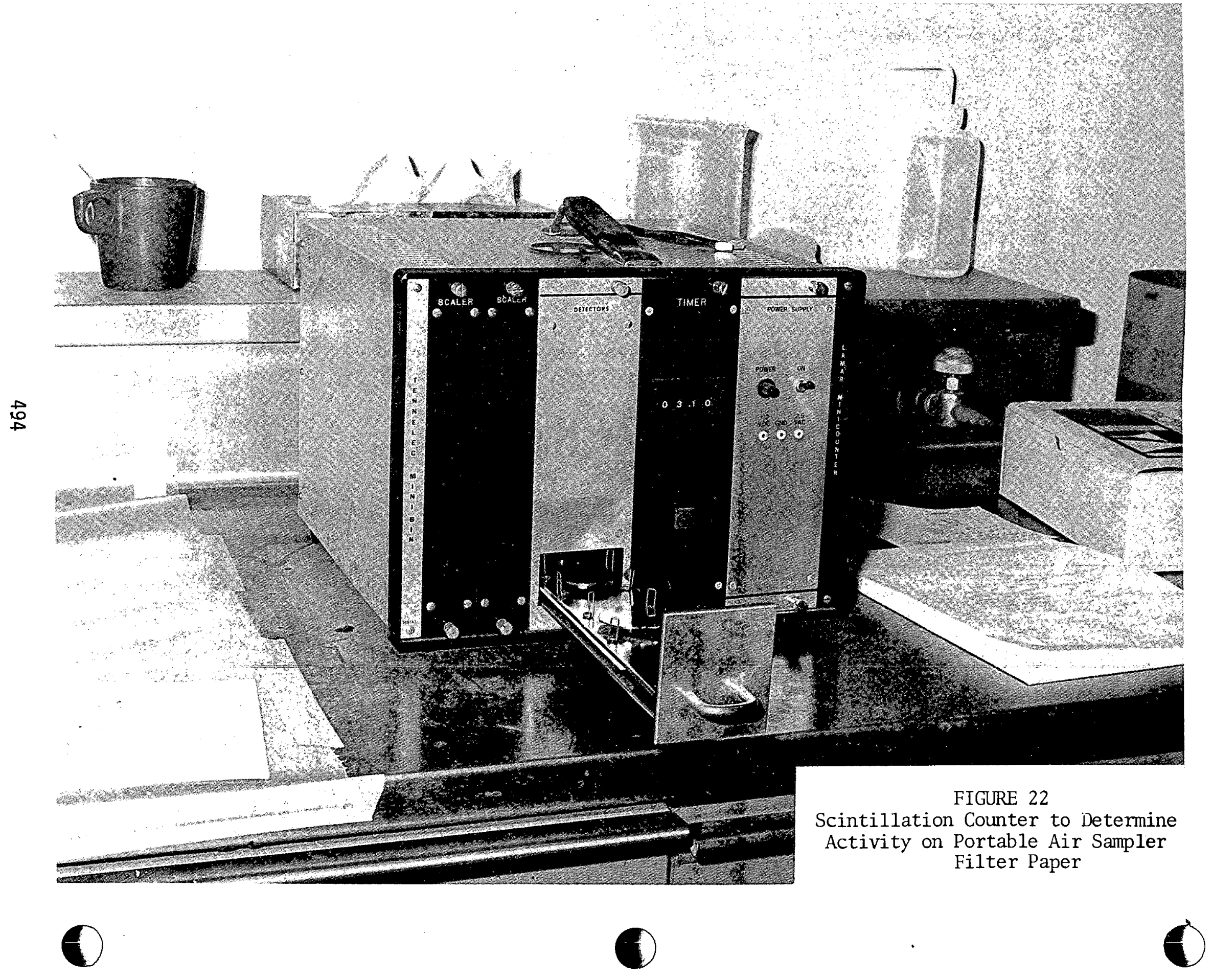




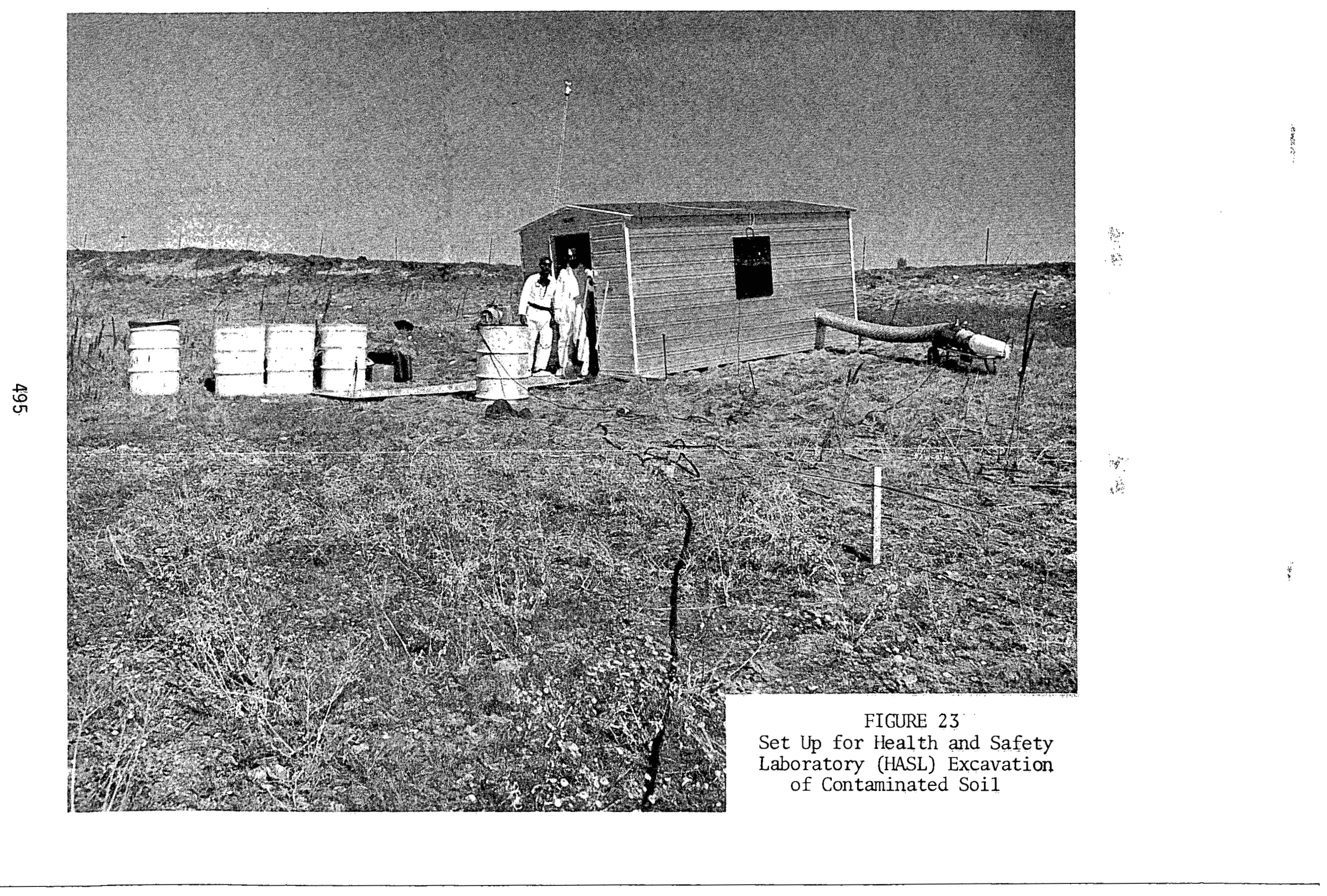



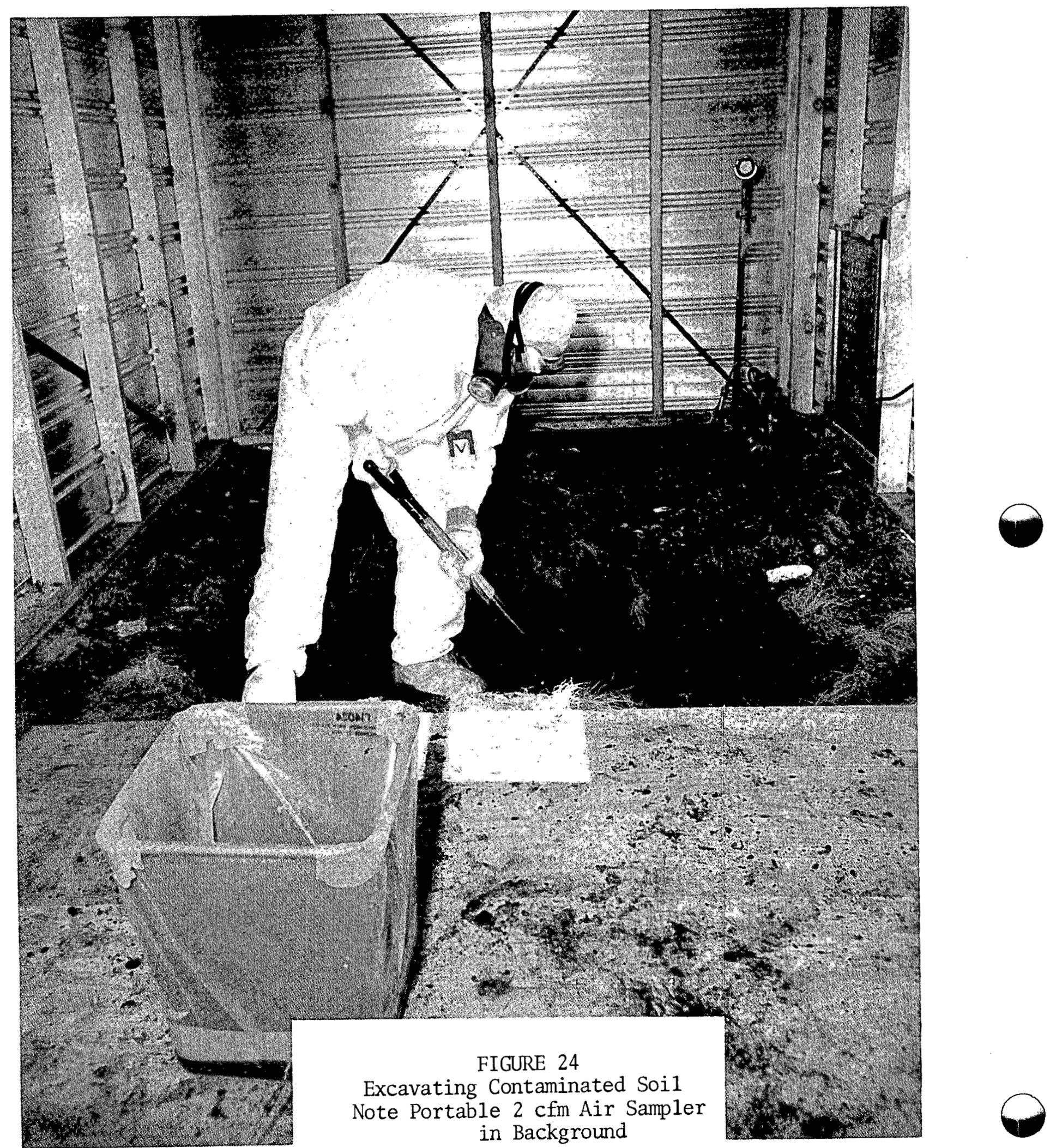


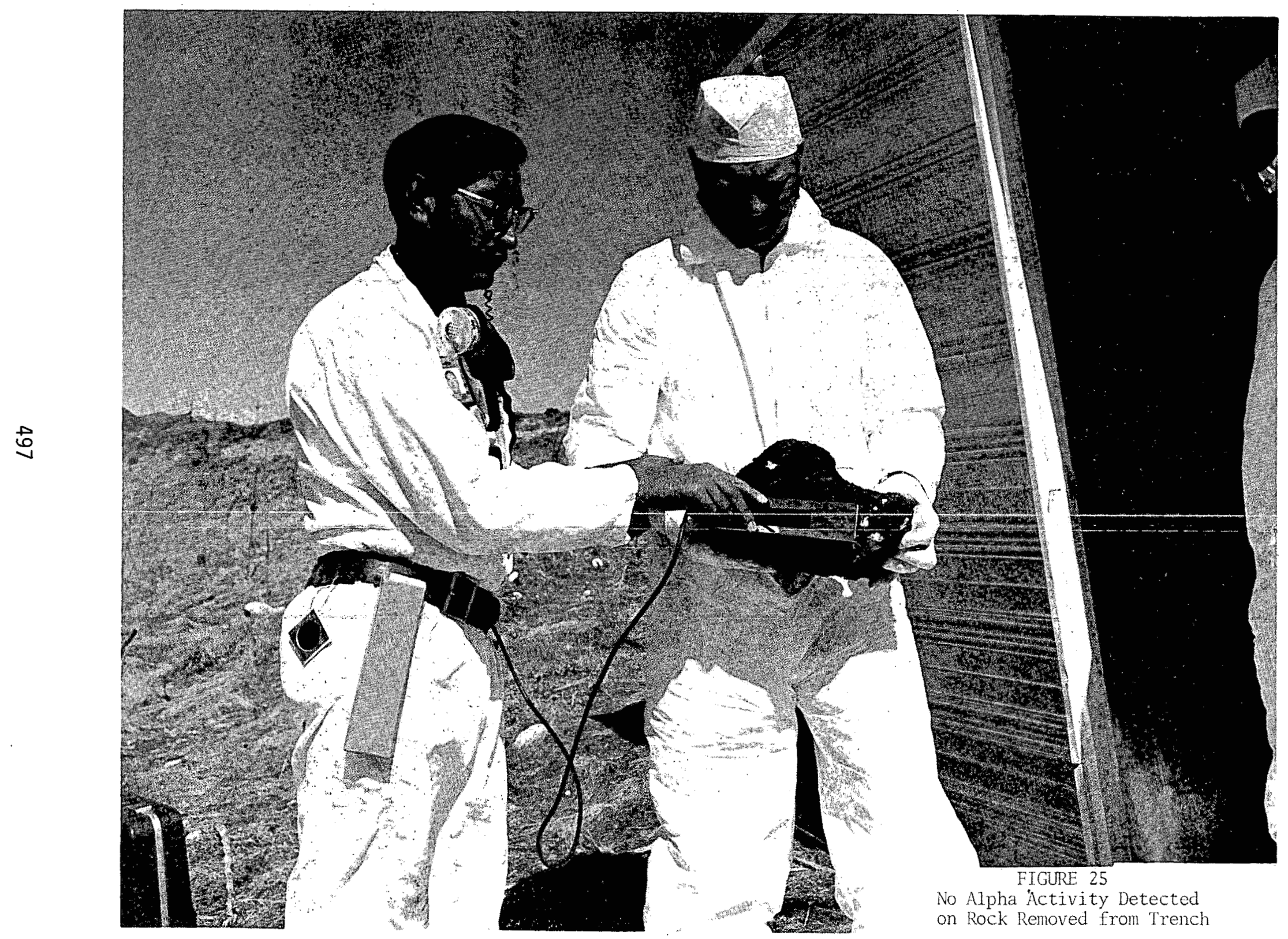




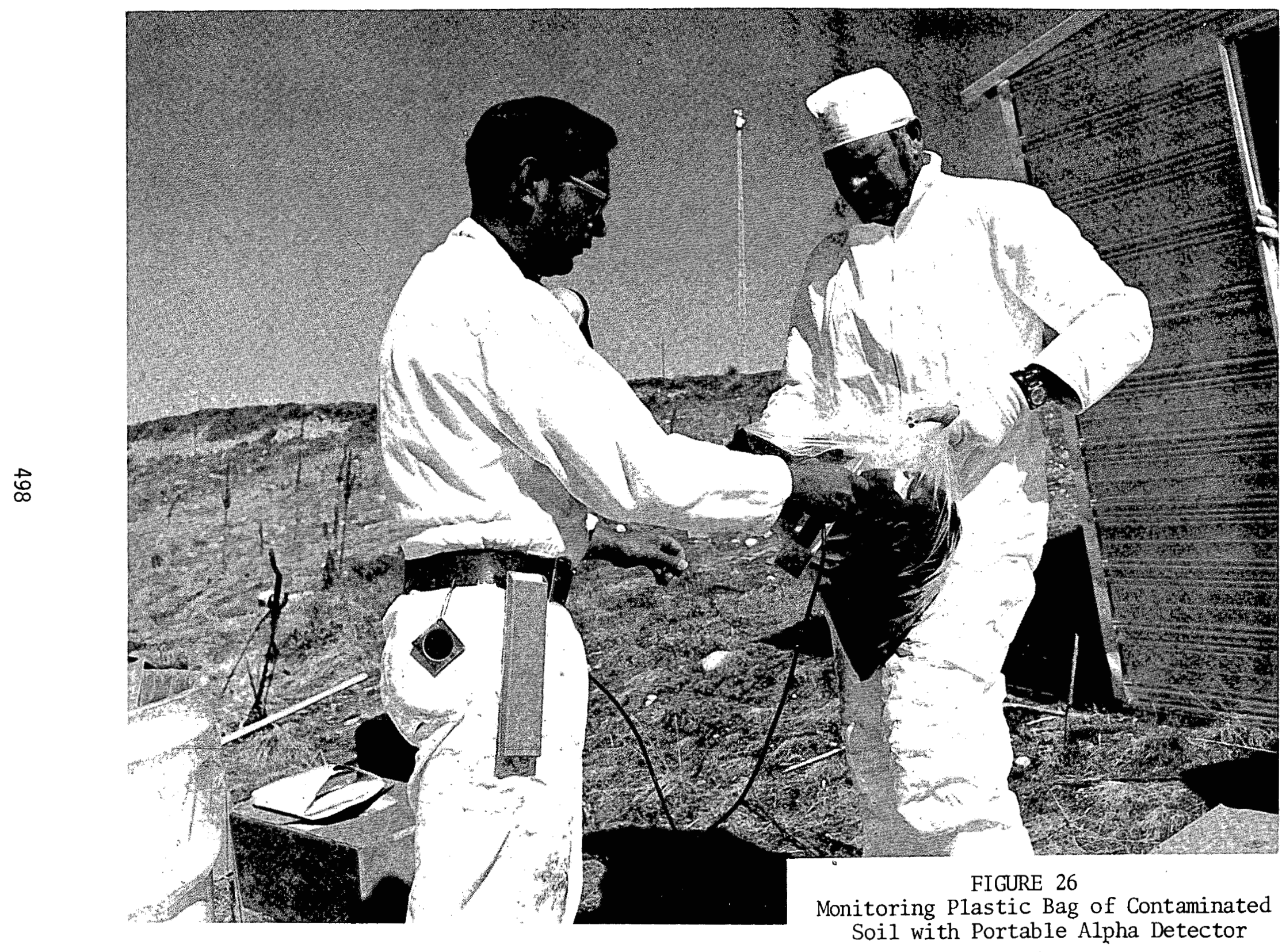

0 


\section{AIR SAPLE RESULTS}

\begin{tabular}{|c|c|}
\hline UND & $0,00003, P C$ \\
\hline & 0.02 \\
\hline
\end{tabular}

\section{HI-VOL AIR SAPLER 20 FEET DOANIRD FROM EXCAVATIQN: \\ TRIAL RUN \\ 0,00004: PCI/M3 Pu \\ HASL RUN \\ $0.00258 \mathrm{PCI} / \mathrm{M} 3 \mathrm{Pu}$}

FIGURE 27

Air Sample Results 
AIR SAMPLE RESULTS

ROCKY FLATS LIMIT

WITHIN WORK AREA

HASL RUN

2 CFM AIR SAMPLER

IN SHED $\begin{array}{lccc}\text { INSOLUBLE } & -40.5 & \mathrm{pCi} / \mathrm{m}^{3} \mathrm{Pu} \\ \text { SOLUBLE } & - & 1.98 & \mathrm{pCi} / \mathrm{m}^{3} \mathrm{Pu}\end{array}$

MAY $13-0.09 \mathrm{pCi} / \mathrm{m}^{3} \mathrm{Pu}$

MAY $14-0.002 \mathrm{pCi} / \mathrm{m}^{3} \mathrm{Pu}$ 


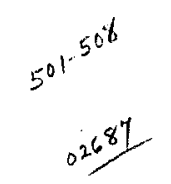

DISPOSAL OF PERSONAL PROPERTY FROM

ERDA FACILITIES BEING DECOMMISSIONED

Prepared by John D. French

Division of Procurement

U. S. Energy Research and Development Administration

August 20, 1975

\section{INTRODUCTION}

Recently, much has been said about Decontamination and

Decommissioning or "D\&D" of ERDA facilities. This is a 2-D

approach. There is another "D" which is closely allied with the $2 \mathrm{D}^{\prime} \mathrm{s}$, because decontamination and decommissioning of a factlity cannot be completed without it. That "D" is for "Disposal of Property." One cannot say that a facility is decontaminated and ready for decommissioning until all the movable property is removed from that facility or otherwise disposed of. So, it is suggested that a $\underline{3-D}$ approach be taken on facilities which are to be decommissioned.

The purpose of this paper is to point out problem areas which should be considered early in planning the decommissioning of a facility.

The property which must be disposed of is termed Personal Property. Persona1 Property means:

A. Property which is Government-owned or rented or leased from commercial sources in the custody of ERDA or its cost-type or fixed-price contractors or subcontractors, including 
vendors, fabricators, and research and development contractors; and is

B. Property of any kind or type except real property, records, special source materials, which includes source materials and special nuclear material and those other materials such as defined in Section II of the Atomic Energy Act of 1954, as amended.

For all practical purposes, personal property is everything except real estate, which includes the buildings and utilities, records, and nuclear materials. It includes paper and pencils, these projectors, tables, nails, closed circuit TV, manipulators, railroad locomotives, cars, etc.

What is the magnitude of this disposal job? We11, two examples might indicate the size of the problem. The Elk River Reactor had about 400 pieces of equipment (each costing $\$ 300$ or more) to dispose of with a total acquisition value of about $\$ 117,000$. It required about one year to properly dispose of this property.

At the NRDS in Nevada, the station was closed in July 1973. There were several thousand pieces of movable equipment with a total acquisition value of about $\$ 32$ million, plus about $\$ 2$ million in stores inventory. P1ant facilities amounted to about $\$ 89$ million. The disposal is still underway with completion estimated in two to three years. 
How does the property disposal task impact on decontamination and decommissioning? There are many racks of instrumentation used in reactors and other operating facilities with several miles of cabling, standby generators, compressed gas systems, pumps, etc., all of which may be contaminated to some degree. A11 of this property must be removed, checked for contamination, and the rooms holding the property must be rechecked again after the property is removed. The coordination problem here between the disposa1 and decontamination staffs is tremendous.

\section{RESPONSIBILITIES}

Who is responsible for these disposal actions? The responsibility for (1) developing policies and programs for the decontamination and decommissioning of excess facilities, equipment, and land, and (2) for review of proposed field office D\&D plans and provides advice and assistance (0153-022) is assigned to the Division of Environnental Control Technology (formerly WMT).

The Director of Procurement is responsible for the policies and general procedures for disposal of excess personal property.

Who does the actual work? Generally, the field office which had administrative control of the facility and the operating contractor wi11 be responsible for the disposal, decontamination, and decommissioning. 


\section{REGULATIONS}

The regulations covering the disposal of property within ERDA are the Federal Property Management Regulations (FPMR) issued by the General Services Administration (GSA), Parts 101-43, 44, and 45, and the ERDA Property Management Instructions (ERDA-PMI), Parts 109-43, 44, 45, and of these particularly Part 45, which deals with disposal of contaminated property. It is not suggested that decontamination personnel familiarize themselves with these regulations, because each ERDA office or contractor has a property management organization. It is sufficient to know that the disposal must be conducted in a certain manner according to published regulations.

IV. DISPOSAL

Who gets first crack at the property? What's the order for claiming the goodies?

Definitely ERDA organizations get first chance, then other Government agencies, finally Health, Education and Welfare associated groups such as schools, states, etc., through donations. If no one wants it, then it goes on sale.

V. PROBLEM AREAS TO BE CONSIDERED IN PLANNING FUTURE PROGRAMS

\section{A. Funding}

The dismantling and removal of equipment, moving, describing, listing, and distribution of lists of available property to a11 organizations requires manpower and equipment, both of 
which require funding. If no funds, or inadequate funds, are provided for the dismantling and disposal work, then a service charge generally of a certain percentage, say 5 to $10 \%$ of the acquisition cost of the property must be charged the requestor of the property to cover the disposal costs. Such a service charge decreases interest in the property and it takes longer to get rid of the property. This ends up costing the Government more. Adequate funds must be included in the D\&D plan.

B. Problems Immediately Prior to Closedown

Frequently, as a program comes to an end, the operating budget decreases, people are looking for work, and morale and efficiency is going down. Property records also suffer and good property records are almost a requirement for disposal or a new physical inventory after closedown will be required. This is costly and time consuming.

Also, immediately prior to closedown, property starts disappearing as employees begin their own disposal program, particularly of sensitive items. Sensitive items are those with high personal appeal or which can be readily sold, such as cameras, hand tools, portable electric tools, and pocket: calculators.

\section{Security}

Again, prior to closedown, all keys to doors and cabinets should be placed under control. A practical security plan 
should be considered; a practical plan because guard costs may amount to more than the property is worth. For example, in Nevada a 24 -hour guard post costs about $\$ 100,000$ a year.

\section{Centralization of Records}

A11 plant records, as-built drawings, site plans, and equipment and plant operating manuals should be brought together at one location and kept under close control, because they will be invaluable during $D \& D$.

E. Need for Knowledgeable Technical Personnel

Plans should be made to budget for and retain through, the disposal process one or two of the "old-timers" who know the facilities, who know where the equipment is located, which units of equipment go together to make up a system, what is the history of certain major units, etc. It is suggested, if necessary, that these individuals be hired in order to retain their knowledge.

\section{F. Priorities}

Program priorities should be established as to which program gets first chance at the property. The field office which will be responsible for the $D \& D$ should know these priorities as early as possible. This will reduce traffic to the facility, confusion, and arguments as to who got their tag on the equipment first. 
G. Contaminated Property

Make plans for the identification of and disposal of contaminated property.

H. Property Required for D\&D

Equipment will be required for decontamination and disposal of property, such as trucks, fork lifts, manipulators, Rad-Safe clothing and supplies, etc. Where will all this be obtained? At Elk River, the AEC had to buy a few pieces of equipment, but obtained a lot as excess from other locations.

I. GSA Interface

Early in the process, GSA should be apprised of the disposal and efforts coordinated with them. Genera1ly, they are happy for ERDA to do the disposal if they are kept informed and receive copies of the paperwork. This is primarily a property function rather than planning.

\section{J. Leased Facilities}

When operating in leased facilities, try to always have the provision that ERDA can abandon the facilities and property. If not in the original agreement, modifications are sometimes possible, such as at Hattiesburg, Mississippi, where certain facilities were abandoned at a considerable savings to the Government. 
VI. SUMMARY

In summary, it should be recognized that the property disposal

must be accomplished, as does decontamination, in accordance with certain rules. One just can't walk away and leave the property.

Disposal requires careful planning, time, effort, and money. 


\section{ACC}

1. L. K. Aldrich

2. N. A. Chipman

3. M. P. Hales

4. R. R. Hammer

5. D. K. Jenson

6. J. E. Johnson

7. W. B. Kerr

8. L. C. Lewis

9. A. G. McGuire

10. D. R. Michaud

11. R. A. Schiffern

12. C. M. Slansky

13. M. Valentine

\section{AGNS}

1. R. Ruest

\section{AIR FORCE}

1. H. Piltingsrud

$\underline{A I}$

1. W. F. Heine

2. A. W. Graves

3. R. B. Hunter

ANC

1. B. Baldwin

2. D. C. Card

3. J. C. Commander

4. S. D. Dixon

5. W. C. Francis

6. R. C. Green

7. D. P. Halls:

8. W. W. Hickman

9. T. F. Jones

10. E. W. Kenda 11

11. B. C. Lunis

12. P. J. Macbeth

13. D. E. Michels

14. K. Latham

15. R. B. Ringer
ANL-E

1. H. A. Flaugher

2. T. Gerding

3. H. J. Howe

4. W. H. Kline

5. B. J. Koprowski

ANL-W

1. R. A. Kifer

2. L. Larsen

3. J. P. Madison

4. K. Mansfield

5. C. C. Miles

7. R. B7umberg

2. C. E. Easterly

3. H. B. Graham

4. D. G. Jacobs

5. R. A. Robinson

6. R. W. Schaich

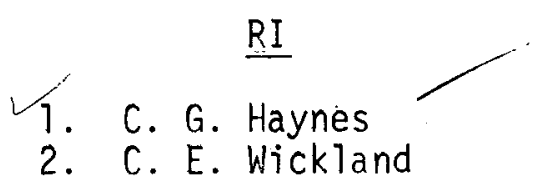

SANDIA

1. J. C. Russell

$\underline{S R L}$

1. E. L. Albenesius

2. F. R. Field

3. E. B. Sheldon 
SRP

1. R. D. Caldwell

2. J. H. Hershey

3. E. 0. Kiger

4. P. R. Moore

STAFCO

1. G. A. Freund

TWO HARBORS, Mn.

1. K. Anderson

U of CALIF. - LIVERMORE

1. J. J. Baranda

2. C. King

UNI I

1. J. J. Dorian

2. J. F. Nemec

WESTINGHOUSE HANFORD

1. M. B. Nelson

2. D. Colburn

\section{FLUOR CORP}

1. H. W. Kellar

$\underline{G A}$

1. S. Strausberg

KMNC

1. B. J. Buntz

KAPL

1. B. Knapp $\checkmark$ LASL

1. F. Cox

2. E. Christensen

3. J. L. Desilets

4. W. D. McNeese

5. R. Nance

6. J. L. Warren

$\checkmark 7$. A. Valentine

MRC

1. W. P. Davis

2. W. R. Harris

$\underline{N L}$

1. W. E. Shaw

$\underline{\mathrm{NRC}}$

1. B. Baker

2. P. Frickson

3. G. Lear

4. T. D. Murphey

5. C. Neilson

6. T. R. Horkinger

NUS

1. B. J. Reckman

ARMY PM-CHEM DEMIL

1. J. C. Adams

2. G. J. Niedermeyer

ARHCO

1. M. K. Bayless

2. R. E. Smith

$\underline{\text { ATCOR }}$

1. J. W. Jones

2. E. C. Holman 
$\underline{B N L}$

1. L. C. Emma

$\underline{B P N L}$

1. H. T. Fullam

2. K. M. Harmon

3. C. E. Jenkins

4. D. Waite

CATALYTIC, INC.

7. R. D. Bryson

2. J. V. Iacono

COM-ED

1. W. Worden

DOW.

1. M. Snyder

$\underline{E I}$

1. V.F. Baston

2. J. N. McFee

3. S. J. Winston

\section{EPA}

1. C. B. Smith

\section{ERDA-ID}

1. J. Barry

2. C.W. Bills

3. J. R. Horan

4. R. Nelison

5. W. N. Sato

6. G. Wehmann
ERDA-CH

1. R. Clinaman

2. B. I. Davis

3. C. Jierree

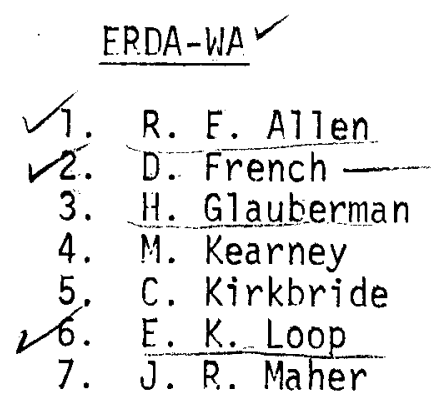

ERDA-OR

1. W. T. Thornton

2. 0. J. Turmelle

ERDA-NV

1. B. W. Church

2.. P. J. Mudra

3. J. Smits

4. C. P. Bromley

ERDA-SR

1. M. G. O'Rear

2. D. E. Skinner

ERDA-SF

1. L. Lanni

ERDA-RF

1. J. R. Thomas 


\section{D\&D CONFERENCE ATTENDEES (Cont.)}

\section{ERDA-ALO}

1. W. P. Armstrong

2. N. H. Mackay

3. A. J. Radosevich

4. G. Werkema

\section{ERDA-RL}

1. M. J. Zamorski

\section{ERDA-LA00}

1. W. Crismon 


\section{External}

27 - Technical Information Center - Oak Ridge, Tennessee

111 - Special External

\section{Interna]}

1. - Chicago Patent Group - ERDA 9800 South Cass Avenue Argonne, Illinois 60439

3. A. T. Morphew, Classification and Technical Information Officer: ERDA-ID. Idaho Falls, Idaho 83401

35 - Special Internal

14 - INEL Technical Library 